ORLANDO MARTINI DE OLIVEIRA

\title{
ESTUDO SOBRE A RESISTÊNCIA AO CISALHAMENTO DE UM SOLO RESIDUAL COMPACTADO NÃO SATURADO
}

\author{
Tese apresentada à Escola Politécnica da \\ Universidade de São Paulo para a obtenção do \\ título de Doutor em Engenharia.
}

- São Paulo -

2004 
ORLANDO MARTINI DE OLIVEIRA

\title{
ESTUDO SOBRE A RESISTÊNCIA AO CISALHAMENTO DE UM SOLO RESIDUAL COMPACTADO NÃO SATURADO
}

\author{
Tese apresentada à Escola Politécnica da \\ Universidade de São Paulo para a obtenção do \\ título de Doutor em Engenharia.
}

Área de concentração:

Engenharia de Solos

Orientador:

Prof. Doutor Fernando A M. Marinho

- São Paulo -

2004 


\section{FICHA CATALOGRÀFICA}

Oliveira, Orlando Martini de

Estudo sobre a resistência ao cisalhamento de um solo residual compactado não saturado / O. M. Oliveira - São Paulo, 2004

$330 \mathrm{p}$.

Tese (doutorado) - Escola Politécnica da Universidade de São Paulo - Departamento de Engenharia de Estruturas e Fundações.

1. Resistência ao Cisalhamento 2. Solos não saturados 3.Tensiômetro de alta capacidade I. Universidade de São Paulo. Escola Politécnica. Departamento de engenharia de Estruturas Fundações II.t. 
Dedicatória

À minha esposa e aos meus pais pelo constante incentivo, paciência e confiança. 


\section{AGRADECIMENTOS}

Aos professores da pós-graduação cujos ensinamentos foram fundamentais para a minha formação como engenheiro geotécnico.

Ao professor Carlos Pinto pelo seu interesse e disponibilidade em cooperar em todos os momentos em que foi solicitado.

Ao professor Massao pela revisão de parte desta tese.

Aos professores José Maria e Jucá, da UFPE, por meio dos quais pude ingressar na pós-graduação da Escola Politécnica.

Aos amigos da pós-graduação pela agradável presença e amizade.

Aos amigos e técnicos do laboratório, Joaquim e Antônio, pela cooperação e auxílio na parte experimental desta pesquisa.

Um agradecimento especial ao professor Fernando Marinho, por ter me concedido a possibilidade de realizar esta pesquisa, por ter acreditado na minha capacitação, pelo incentivo, orientação e presença constante em todos os momentos.

Ao CNPq pelo suporte financeiro. 


\section{SUMÁRIO}

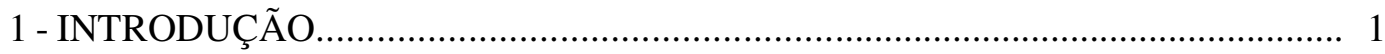

1.1 - Importância dos estudos em solos não saturados............................................ 1

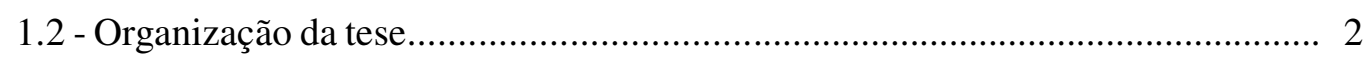

2 - REVISÃO BIBLIOGRÁFICA................................................................ 5

2.1 - Equações para a previsão da resistência ao cisalhamento dos solos não

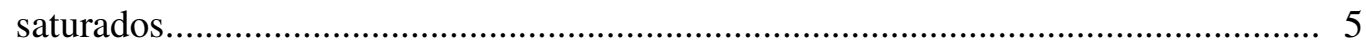

2.1.1 - Equação Proposta por Bishop (1959)........................................................ 6

2.1.2 - Equação proposta por Fredlund, Morgenstern e Widger (1978)................. 19

2.1.3 - Comparação entre as equações de resistência ao cisalhamento propostas por Bishop (1959) e Fredlund et al (1978).................................................... 23

2.2 - Características dos solos compactados........................................................ 26

2.2.1 - Estrutura dos corpos de prova moldados para a obtenção da curva de

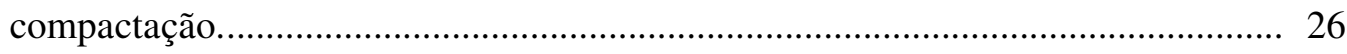

2.2.2 - Formação de agregações de partículas no processo de compactação........... 29

2.2.3 - Características de expansão e contração em função da variação do teor de umidade.

2.2.4 - Variação da estrutura de poros do corpo de prova após o umedecimento ou secagem.

2.2.5 - Sucção dos corpos de prova moldados na curva de compactação 38

2.2.6 - Influência da compactação nos valores da resistência ao cisalhamento e deformação axial.

2.3 - Equações da curva de retenção e principais aspectos que interferem no seu formato 46

2.3.1 - Definição de alguns aspectos da curva de retenção 46

2.3.2 - Principais equações para representar a curva de retenção. 50

2.3.3 - Fatores que afetam a curva de retenção. 55

2.4 - Modelos de previsão da resistência em função da curva de retenção............... 64

2.4.1 - Relação entre a curva de retenção e a resistência ao cisalhamento. 64 
2.4.2 - Modelo de previsão da resistência ao cisalhamento proposto por

Vanapalli et al (1996).

2.4.3 - Modelo de previsão da resistência ao cisalhamento proposto por Khalili e Khabbaz (1998).

\section{3 - DESCRIÇÃO DOS EQUIPAMENTOS UTILIZADOS E PROCEDIMENTOS} PARA A CALIBRAÇÃO DO PAPEL FITRO...................................................... 75

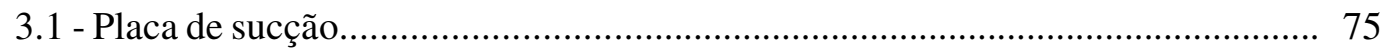

3.1.1 - Saturação da pedra porosa................................................................. 76

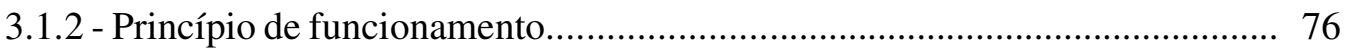

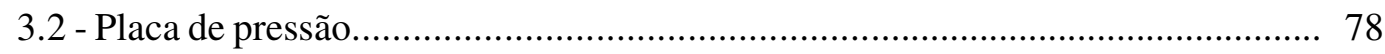

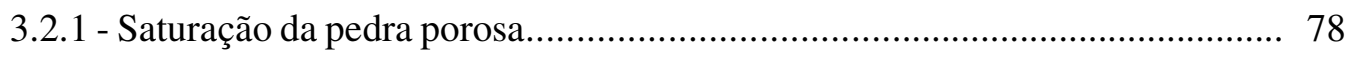

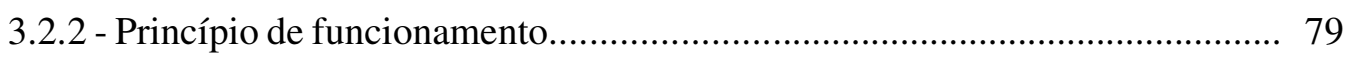

3.3 - Tensiômetro de alta capacidade ................................................................. 79

3.3.1 - Princípio de funcionamento.................................................................. 80

3.3.2 - Saturação e calibração.............................................................................. 81

3.4 - Célula de cisalhamento com tensiômetro na base ............................................ 83

3.5 - Molde tripartido utilizado para moldagem dos corpos de prova....................... 85

3.6 - Prensa do tipo Bishop Wesley utilizada nos ensaios triaxais saturados ........... 86

3.7 - Procedimentos utilizados para a calibração do papel filtro.............................. 87

3.7.1 - Equipamentos e métodos para se gerar sucção..................................... 88

3.7.2 - Fatores importantes da calibração.......................................................... 89

3.7.3 - Algumas calibrações propostas................................................................. 91

\section{4 - CARACTERIZAÇÃO DO SOLO E PROGRAMAÇÃO DOS ENSAIOS DE}

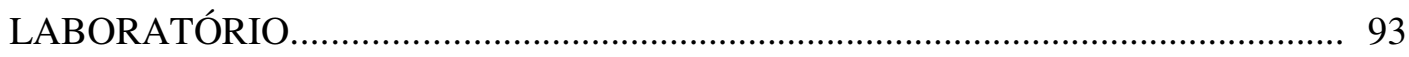

4.1 - Aspectos geológicos regionais...................................................................... 93

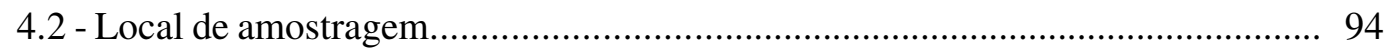

4.3 - Retirada da amostra e armazenamento......................................................... 94

4.4. - Ensaios de caracterização.......................................................................... 95

4.5 - Determinação da curva de compactação.......................................................... 97

4.6 - Definição dos pontos de estudo e programação dos ensaios............................. 98 
4.7 - Curvas de retenção e principais objetivos de sua determinação

4.8 - Procedimentos utilizados para a determinação das curvas de retenção dos corpos de prova compactados estaticamente.

4.8.1 - Moldagem dos corpos de prova e preparação para o ensaio

4.8.2 - Utilização da placa de sucção 107

4.8.3 - Utilização da placa de pressão. 108

4.8.4 - Utilização do papel filtro. 109

4.9 - Procedimentos utilizados na obtenção da curva de retenção dos corpos de prova compactados dinamicamente.

4.9.1 - Moldagem dos corpos de prova e preparação para o ensaio

4.9.2 - Utilização do papel filtro na determinação da curva de retenção dos corpos de prova compactados dinamicamente.

4.10 - Procedimentos utilizados na determinação da curva de retenção da lama....... 113

4.10.1 - Preparação das amostras e moldagem dos corpos de prova..................... 113

4.10.2 - Procedimentos da utilização na placa de sucção e de pressão.................. 114

4.11 - Ensaios de resistência ao cisalhamento.

4.11.1 - Moldagem dos corpos de prova e trajetórias de umidade utilizadas em sua preparação para realização dos ensaios

4.11.2 - Preparação dos corpos de prova e procedimentos utilizados nos ensaios de resistência ao cisalhamento.

\section{5 - APRESENTAÇÃO E DISCUSSÃO DOS RESULTADOS DA CURVA DE}

5.1 - Critério adotado para a estabilização da sucção na placa de sucção e de pressão

5.2 - Resultados dos ensaios da curva de retenção.

5.2.1 - Curvas de retenção determinadas sem confinamento utilizando corpos de prova compactados estaticamente.

5.2.2 - Curvas de retenção determinadas com confinamento utilizando corpos de prova compactados estaticamente na umidade ótima. 
5.2.3 - Curvas de retenção determinadas sem confinamento utilizando corpos de prova compactados dinamicamente nos pontos de estudo.

5.2.4 - Curva de retenção dos corpos de prova moldados para a obtenção da curva de compactação

5.2.5 - Curva de retenção da lama.................................................................. 150

5.3 - Aspectos relacionados à histerese .................................................................. 154

5.4 - Efeito do tipo de compactação na curva de retenção..................................... 157

5.5 - Aplicação da equação de ajuste proposta por Fredlund e Xing (1994) aos valores experimentais da curva de retenção.......................................................... 160

5.6 - Variação da sucção de entrada de ar............................................................. 166

6 - RESULTADOS DOS ENSAIOS DE RESISTÊNCIA AO CISALHAMENTO..... 171

6.1 - Resultados dos ensaios de compressão simples........................................... 171

6.1.1 - Ensaios com deformação controlada realizados em corpos de prova que foram umedecidos ou secados (trajetórias 3 e 4) ............................................... 174

6.1.2 - Ensaios com deformação controlada realizados em corpos de prova que foram saturados e secados (trajetória 5).

6.1.3 - Ensaios com carregamento controlado realizados em corpos de prova que foram umedecidos ou secados (trajetória 3 e 4 ).

6.1.4 - Efeito da velocidade de cisalhamento dos corpos de prova nos ensaios realizados com deformação controlada.

6.2 - Resultados dos ensaios triaxiais saturados.

6.2.1 - Ensaios triaxiais CAU realizados com tensão controlada.

6.2.2 - Ensaios triaxiais CD realizados com carregamento controlado. 200

6.3 - Resultados dos ensaios triaxiais CW não saturados. 205

\section{7 - ASPECTOS RELACIONADOS ÀS MEDIÇÕES DAS SUCÇÕES OBTIDAS} COM O TENSIÔMETRO, O PAPEL FILTRO E A PLACA DE PRESSÃO.............. 219

7.1 - Influência da pasta na medição da sucção utilizando o tensiômetro................. 219

7.2 - Estudo do tempo de equilíbrio das sucções determinadas com o tensiômetro 227

7.3 - Determinação da equação de calibração do papel filtro................................. 231 
7.5 - Relação entre os valores das sucções determinadas com a placa de pressão, papel filtro e o tensiômetro

8 - ANÁLISE DOS ENSAIOS DE RESISTÊNCIA............................................. 247

8.1 - Análise dos ensaios de compressão simples.................................................... 247

8.1.1 - Considerações sobre as relações definidas pelo grau de saturação e a sucção dos corpos de prova após a etapa de preparação e na ruptura.

8.1.2 - Influência das trajetórias de umidade nos valores nos valores de resistência ao cisalhamento

8.2 - Análise dos resultados dos ensaios triaxiais não saturados

8.2.1 - Aspectos relacionados à etapa de preparação e confinamento dos corpos de prova.

8.2.2 - Análise das trajetórias de tensões.

8.2.3 - Análise das variações de sucção dos corpos de prova durante a etapa de cisalhamento

8.3 - Definição dos parâmetros efetivos obtidos dos ensaios triaxiais saturados.

8.4 - Obtenção das equações de ajuste para a relação definida entre q e a sucção do corpo de prova na ruptura

8.5 - Definição das equações das superfícies de ruptura.

8.6 - Aplicação dos modelos propostos por Vanapalli et al (1996) e Khalili e Khabbaz (1998).

9 - CONCLUSÕES E RECOMENDAÇÕES PARA FUTURAS PESQUISAS.......... 301

9.1 - Aspectos relacionados às curvas de retenção.................................................. 301

9.2 - Aspectos relacionados à resistência ao cisalhamento...................................... 303

9.3 - Recomendações para futuras pesquisas....................................................... 306

10 - REFERÊNCIAS BIBLIOGRÁFICAS........................................................ 309

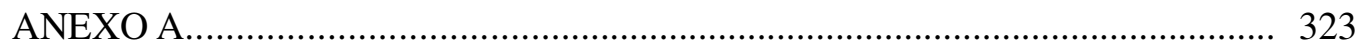

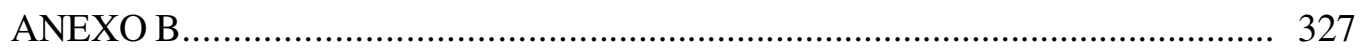




\section{LISTA DE FIGURAS}

\section{CAPÍTULO 2}

Figura 2.1 -Resultados de ensaios triaxiais não drenados realizados em amostras argilosas (clay shale) compactadas (Bishop et al 1960)

Figura 2.2 - Determinação do valor de $\chi$ para ensaios triaxiais realizados com umidade constante e diferentes pressões confinantes (Bishop et al 1960).

Figura 2.3 - Resultados dos testes triaxiais não confinados realizados em corpos de prova (Bolder clay) compactados com diferentes umidades (Bishop et al 1960).

Figura 2.4 - Método para se calcular o valor de $\chi$ em ensaios triaxiais não confinados $\left(\mathrm{u}_{\mathrm{a}}=\sigma_{3}\right)($ Bishop et al 1960)

Figura 2.5 - Determinação do valor de $\chi$ para o solo siltoso, obtido de ensaios triaxiais com sucção controlada realizados na condição drenada e a umidade constante (Bishop e Donald, 1961)

Figura 2.6 - Ensaio de adensamento (Breahead silt) com incremento de sucção (Bishop e Donald, 1961)

Figura 2.7 - Variação de $\chi$ em função do grau de saturação obtido para um solo siltoso (Breahead silt) (Bishop e Donald, 1961)

Figura 2.8 - Variação do índice de vazios devido ao acréscimo de sucção (Jennings e Burland, 1962).

Figura 2.9 - Variação dos valores de $\chi$ em função do grau de saturação obtidos para diferentes tipos de solos (Jennings e Burland, 1962).

Figura 2.10 - Variação volumétrica da estrutura do solo em função de um mesmo incremento de carregamento externo (partes (a) e(b)) e de sucção (Partes (c) e (d)). (Jennings e Burland, 1962).

Figura 2.11 - Variáveis de estado de tensão aplicadas a um elemento de solo não saturado. (Fredlund e Morgenstern, 1977) 
Figura 2.12 - Verificação da sucção e da tensão confinante como variáveis de estado de tensão. (Bishop; Blight, 1963)

Figura 2.13 - Representação da equação de Fredlund et al (1978) para resistência ao cisalhamento baseada no critério de Mohr e Coulomb.

Figura 2.14 - Comparação do efeito da sucção na resistência ao cisalhamento utilizando as propostas de Bishop (1959) e Fredlund et al (1978) (Fredlund e Rahardjo, 1993).

Figura 2.15 - Resultados de ensaios triaxiais realizados em corpos de prova compactados com teor de umidade de 11.6\% (Bishop e Blight, 1963).

Figura 2.16 - Variação da estrutura do solo na compactação (Lambe, 1958).

Figura 2.17 - Variação da agregação de partículas em função do grau de saturação na compactação (Toll, 2000)

Figura 2.18 - Distribuição de volume de poros em função do diâmetro (Delage et al, 1996).

Figura 2.19 - Imagem de microscopia eletrônica de varredura obtida de amostra compactada no ramo seco, mostrando a formação de agregações (Delage et al, 1996).

Figura 2.20 - Resultado do ensaio de intrusão de mercúrio realizado em amostras compactadas dinamicamente (Proctor Normal) em diferentes pontos da curva de compactação (Ahmed et al, 1974).

Figura 2.21 - Resultado do ensaio de intrusão de mercúrio realizado em amostras compactadas no ramo seco utilizando diferentes métodos de compactação (Ahmed et al, 1974)

Figura 2.22 - Valores da contração axial apresentada por corpos de prova compactados no ramo seco e no ramo úmido (Seed e Chan, 1959).....

Figura 2.23 - Valores da pressão de expansão correspondentes a corpos de prova moldados ao longo da curva de compactação (Seed e Chan, 1959).

Figura 2.24 - Valores da pressão de expansão obtidos de corpos de prova compactados estaticamente na curva de compactação (Khattab et al, 2002).....

Figura 2.25 - Distribuição de poros de um mesmo solo moldado no ramo úmido após atingir diferentes valores sucções (Simms e Yanful, 2001). 
Figura 2.26 - Valores das sucções iniciais dos corpos de prova compactados ao longo da curva de compactação (Olson e Langfelder, 1965).

Figura 2.27 - Curvas de mesma sucção obtida de um silte de baixa plasticidade compactado estaticamente (Suriol et al, 2002).

Figura 2.28 - Curvas de compactação e de mesmo valor de sucção de um solo residual de gnaisse (Marinho e Stuermer, 2000)

Figura 2.29 - Resultados dos ensaio não drenados realizados em uma caolinita compactada ao longo da curva de compactação (Seed e Chan, 1959).

Figura 2.30 - Resultados dos ensaios triaxiais não drenados (UU) realizados em corpos de prova saturados, compactados em pontos distintos da curva de compactação (Seed e Chan, 1959).

Figura 2.31 - Comparação entre os resultados dos ensaios triaxiais saturados CU realizados em corpos de prova compactados no ramo seco e no ramo úmido (Seed e Chan, 1959)

Figura 2.32 - Penetração da interface ar água no interior do solo em função do aumento de sucção (Fredlund e Rahardjo, 1993).....

Figura 2.33 - Principais feições da curva de retenção (Fredlund e Xing, 1994).

Figura 2.34 - Determinação gráfica dos parâmetros utilizados para calcular os valores de a, n e m (Fredlund; Xing 1994).

Figura 2.35 - Influência do parâmetro a na curva de retenção (Fredlund e Xing, 1994).

Figura 2.36 - Influência do parâmetro n na curva de retenção (Fredlund e Xing, 1994).

Figura 2.37 - Influência do parâmetro m na curva de retenção (Fredlund e Xing, 1994).

Figura 2.38 - Representação esquemática de curvas de retenção para diferentes tipos de solo (Vanapalli, 1994).

Figura 2.39 - Comparação entre as curvas de retenção obtidas de amostras compactadas com diferentes umidades (Vanapalli et al, 1999).

Figura 2.40 - Procedimentos para se simular uma pressão confinante de $100 \mathrm{kPa}$ (Vanapalli, 1994). 
Figura 2.41 - Variação do valor da sucção referente à entrada de ar para um solo argiloso compactado estaticamente no ramo seco e submetido a diferentes pressões de confinamento (Vanapalli et al, 1999)

Figura 2.42 - Variação do valor da sucção referente à entrada de ar para um solo argiloso compactado estaticamente no ramo úmido e submetido a diferentes pressões de confinamento (Vanapalli et al, 1999).

Figura 2.43 - Curvas de retenção obtidas em ciclos de secagem e umedecimento (Croney, 1952)

Figura 2.44 - Variação dos teores de umidades para um mesmo valor de sucção em função de ciclos de secagem e umedecimento (Dineen e Ridley, 1999).

Figura 2.45 - Relação entre a resistência a compressão simples e a sucção total obtida para um solo siltoso (Nishimura e Fredlund, 2002).

Figura 2.46 - Relação entre a resistência a compressão simples e a sucção total obtida para um caolim (Nishimura e Fredlund 2002).

Figura 2.47 - Relação entre a resistência ao cisalhamento e a curva de retenção (Fredlund et al, 1995)....

Figura 2.48 - Regiões em que se divide a curva de retenção em função da dessaturação (Vanapalli (1994) modificado de White et al (1970)).

Figura 2.49 - Redução da área de água em função das diferentes regiões de dessaturação (Vanapalli, 1994).............................................................................. 66

Figura 2.50 - Relação entre o IP e o parâmetro k (Vanapalli e Fredlund, 2000)...... 68

Figura 2.51 - Ajuste de $\kappa$ aos valores experimentais obtidos em ensaios de cisalhamento direto com sucção controlada (Vanapalli et al, 1996)........................ 70

Figura 2.52 - Determinação gráfica do valor de $\chi$ (khalili e khabbaz, 1998)............ 71

Figura 2.53 - Relação entre $\chi$ e a sucção matricial (khalili e khabbaz 1998)............ 72

Figura 2.54 - Variação de $\chi$ em função da sucção normalizada em relação à entrada de ar (Khalili e Khabbaz, 1998). 


\section{CAPÍTULO 3}

Figura 3.1 - Esquema da placa de sucção......................................................... 76

Figura 3.2 - Equipamento utilizado para o ensaio da placa de sucção (sem escala).. 77

Figura 3.3 - Detalhes da placa de pressão........................................................... 78

Figura 3.4 - Representação esquemática do tensiômetro.......................................... 80

Figura 3.5 - Equipamento utilizado na saturação do tensiômetro............................. 82

Figura 3.6 - Resposta do tensiômetro a ciclos de pressão hidrostática (Kuwajima, 2000).

Figura 3.7. - Esquema da célula de cisalhamento utilizada nos ensaios triaxiais CD saturado e CW não saturado

Figura 3.8 - Representação esquemática do ensaio triaxial realizado com carregamento controlado................................................................................... 85

Figura 3.9 - Esquema do ensaio triaxial realizado na prensa Bishop Wesley......... 87

Figura 3.10 - Algumas calibrações propostas para o papel filtro Whatman $n^{0} 42$ (Marinho, 1994)

\section{CAPÍTULO 4}

Figura 4.1 - Visão geral do talude de onde foram retiradas as amostras de solo

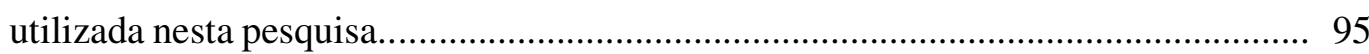

Figura 4.2 - Curva Granulométrica do solo residual de gnaisse.............................. 96

Figura 4.3 - Classificação do solo residual de gnaisse na carta de plasticidade........ 97

Figura 4.4 - Curva de compactação do solo residual de gnaisse............................. 98

Figura 4.5 - Localização dos pontos de estudo na curva de compactação................ 99

Figura 4.6 - Ensaios a serem realizados em cada condição de moldagem................ 101

Figura 4.7 - Curvas de retenção obtidas por compactação estática.......................... 104

Figura 4.8 - Resultados dos ensaios de adensamento dos corpos de prova utilizados para a determinação das curvas de retenção submetidas a diferentes pressões confinantes 
Figura 4.9 - Representação esquemática das diferentes trajetórias de umidade impostas aos corpos de prova na etapa de preparação para os ensaios de resistência ao cisalhamento.

\section{CAPÍTULO 5}

Figura 5.1 - Variação da umidade dos corpos de prova CRO1, CRO2 e CRO3 ao serem submetidos na placa de pressão a uma sucção de $200 \mathrm{kPa}$.

Figura 5.2 - Variação da umidade relativa em função da sucção

Figura 5.3 - Variação da umidade do corpo de prova quando submetido a um determinado valor de sucção na placa de pressão.

Figura 5.4 - Curvas de retenção determinadas sem confinamento utilizando corpos de prova compactados estaticamente nos pontos de estudo (O, S e U).

Figura 5.5 - Variação do índice de vazios em função da umidade gravimétrica e do grau de saturação.

Figura 5.6 - Imagens de microscopia eletrônica de varredura obtidas de corpos de prova moldados na curva de compactação (x4000)

Figura 5.7 - Imagem de microscopia eletrônica de varredura obtida do corpo de prova moldado no ramo seco (x2000)

Figura 5.8 - Imagem de microscopia eletrônica de varredura obtida do corpo de prova moldado no ramo úmido (x8000)

Figura 5.9 - Relação entre os teores de umidade (gravimétrico e volumétrico), grau de saturação, índice de vazios e a sucção dos corpos de prova compactados estaticamente nos pontos de estudo $(\mathrm{O}, \mathrm{S}$ e $\mathrm{U})$

Figura 5.10 - Curvas de retenção dos corpos de prova compactados na umidade ótima e submetidos a diferentes pressões de confinamento.

Figura 5.11 - Curva de retenção em função da umidade gravimétrica obtidas em corpos de prova compactados na umidade ótima e submetidos a diferentes pressões de confinamento.

Figura 5.12 - Variação do índice de vazios em função do teor de umidade e do grau de saturação dos corpos de prova compactados na umidade ótima. 
Figura 5.13 - Relação entre os teores de umidade (gravimétrico e volumétrico), grau de saturação, índice de vazios e a sucção dos corpos de prova moldados estaticamente na umidade ótima e submetidos a diferentes pressões confinantes.....

Figura 5.14 - Curvas de retenção dos corpos de prova compactados dinamicamente nos pontos de estudo $(\mathrm{O}, \mathrm{S}$ e $\mathrm{U})$

Figura 5.15 - Variação do índice de vazios em função da umidade gravimétrica e do grau de saturação das curvas de retenção obtidas por compactação dinâmica......

Figura 5.16 - Relações entre os teores de umidade (gravimétrico e volumétrico), grau de saturação, índice de vazios e a sucção dos corpos de prova compactados estaticamente nos três pontos de estudo $(\mathrm{O}, \mathrm{S}$ e U).

Figura 5.17 - Curvas de retenção obtidas dos corpos de prova moldados para a obtenção da curva de compactação

Figura 5.18 - Sucções iniciais dos corpos de prova compactados para a obtenção da curva de compactação

Figura 5.19 - Curvas de retenção dos corpos de prova moldados com a consistência de lama

Figura 5.20 - Variação do índice de vazios da lama em função do teor de umidade e do grau de saturação

Figura 5.21 - Relações entre os teores de umidade (gravimétrico e volumétrico), grau de saturação, índice de vazios e a sucção dos corpos de prova moldados com a consistência de lama.

Figura 5.22 - Curvas de retenção do corpo de prova compactado estaticamente na umidade ótima, obtidas por secagem e umedecimento (Ponto O)

Figura 5.23 - Curvas de retenção do corpo de prova compactado estaticamente no ramo seco, obtidas por secagem e umedecimento (Ponto $\mathrm{S}$ ).

Figura 5.24 - Curvas de retenção do corpo de prova compactada estaticamente no ramo úmido, obtidas por secagem e umedecimento (Ponto $\mathrm{U}$ ).

Figura 5.25 - Variação do índice de vazios, em função do teor de umidade e do grau de saturação, obtida durante a secagem e o umedecimento dos corpos de prova compactados estaticamente nos três pontos de estudo $(\mathrm{O}, \mathrm{S}$ e U).

Figura 5.26 - Comparação entre as curvas de retenção obtidas em corpos de prova moldados na umidade ótima por compactação estática e dinâmica (Ponto O) 
Figura 5.27 - Comparação entre as curvas de retenção obtidas em corpos de prova moldados no ramo seco por compactação estática e dinâmica (Ponto S).

Figura 5.28 - Comparação entre as curvas de retenção obtidas em corpos de prova moldados no ramo úmido por compactação estática e dinâmica (Ponto U)

Figura 5.29 - Variação do índice de vazios, em função do teor de umidade e do grau de saturação, dos corpos de prova moldados por compactação estática e dinâmica nos pontos de estudo $(\mathrm{O}, \mathrm{S}$ e $\mathrm{U})$.

Figura 5.30 - Ajuste aos pontos experimentais da curva de retenção definida sem confinamento utilizando o corpo de prova compactado estaticamente na umidade ótima (CRO1).

Figura 5.31 - Ajuste aos pontos experimentais da curva de retenção definida sem confinamento utilizando o corpo de prova compactado estaticamente no ramo seco (CRS1)

Figura 5.32 - Ajuste aos pontos experimentais da curva de retenção definida sem confinamento utilizando o corpo de prova compactado estaticamente no ramo úmido (CRU1)

Figura 5.33 - Ajuste aos pontos experimentais da curva de retenção definida com confinamento de $100 \mathrm{kPa}$ utilizando o corpo de prova compactado estaticamente na umidade ótima (CRO2).

Figura 5.34 - Ajuste aos pontos experimentais da curva de retenção definida com confinamento de $200 \mathrm{kPa}$ utilizando d corpo de prova compactado estaticamente na umidade ótima $(\mathrm{CRO} 3)$

Figura 5.35 - Ajuste aos pontos experimentais da curva de retenção definida com confinamento de $300 \mathrm{kPa}$ utilizando o corpo de prova compactado estaticamente na umidade ótima (CRO4)

Figura 5.36 - Ajuste aos pontos experimentais da curva de retenção da lama formada como o solo que passa na peneira $\mathrm{n} \stackrel{0}{ } 10$.

Figura 5.37 - Ajuste aos pontos experimentais da curva de retenção da lama formada com o solo que passa na peneira $\mathrm{n} \stackrel{0}{ } 40$

Figura 5.38 - Determinação da entrada de ar das curvas de retenção dos corpos de prova moldados na umidade ótima. 
Figura 5.39 - Determinação da entrada de ar das curvas de retenção dos corpos de prova moldados no ramo seco, ramo úmido e com a consistência de lama

Figura 5.40 - Relações entre a entrada de ar e a tensão confinante obtidas para os ensaios desta pesquisa e encontrados na literatura.

\section{CAPÍTULO 6}

Figura 6.1 - Resultados dos ensaios de compressão simples realizados com deformação controlada em corpos de prova compactados na umidade ótima (Ponto O)

Figura 6.2 - Resultados dos ensaios de compressão simples realizados com deformação controlada em corpos de prova compactados no ramo seco (Ponto S)... 179 Figura 6.3 - Resultados dos ensaios de compressão simples realizados com deformação controlada em corpos de prova compactados no ramo úmido (Ponto U)

Figura 6.4 - Resultados dos ensaios de compressão simples realizados com deformação controlada utilizando corpos de prova compactados na umidade ótima e preparados por secagem ou umedecimento (ponto $\mathrm{O}$ )

Figura 6.5 - Resultados dos ensaios de compressão simples realizados com deformação controlada utilizando corpos de prova compactados no ramo seco e preparados por secagem ou umedecimento (ponto $S$ )

Figura 6.6 - Resultados dos ensaios de compressão simples realizados com deformação controlada utilizando corpos de prova compactados no ramo úmido e preparados por secagem ou umedecimento (ponto $U$ )

Figura 6.7 - Resultados dos ensaios de compressão simples realizados com deformação controlada utilizando corpos de prova compactados na umidade ótima e preparados por saturação e secagem (ponto $\mathrm{O}$ )

Figura 6.8 - Resultados dos ensaios de compressão simples realizados com deformação controlada utilizando corpos de prova compactados no ramo seco e preparados por saturação e secagem (ponto $S$ ). 
Figura 6.9 - Resultados dos ensaios de compressão simples realizados com deformação controlada utilizando corpos de prova compactados no ramo úmido e preparados por saturação e secagem 2(ponto $U$ )

Figura 6.10 - Resultados dos ensaios de compressão simples realizados com carregamento controlado utilizando corpos de prova compactados na umidade ótima e preparados por umedecimento ou secagem (ponto $\mathrm{O}$ ).

Figura 6.11 - Resultados dos ensaios de compressão simples realizados com carregamento controlado utilizando corpos de prova compactados no ramo seco e preparados por umedecimento ou secagem (ponto $S$ )

Figura 6.12 - Resultados dos ensaios de compressão simples realizados com carregamento controlado utilizando corpos de prova compactados no ramo úmido e preparados por umedecimento ou secagem (ponto U).

Figura 6.13 - Variação da leitura do tensiômetro em função do tempo para um ensaio de compressão simples realizado com carregamento controlado (ponto $\mathrm{O}$ )...

Figura 6.14 - Ensaios de compressão simples realizados com diferentes velocidades de cisalhamento e com medição da variação da sucção.

Figura 6.15 - Resultados da tensão desviadora e da poro pressão em função da deformação axial, obtidos dos ensaios triaxiais CAU (ponto O)

Figura 6.16 - Resultados da tensão desviadora e da poro pressão em função da deformação axial, obtidos dos ensaios triaxiais CAU (ponto $\mathrm{S}$ )

Figura 6.17 - Resultados da tensão desviadora e da poro pressão em função da deformação axial, obtidos dos ensaios triaxiais CAU (ponto U)

Figura 6.18 - Resultados da tensão desviadora normalizada e da poro pressão em função da deformação axial, obtidos dos ensaios triaxiais CAU (ponto $\mathrm{O}$ )

Figura 6.19 - Resultados da tensão desviadora normalizada e da poro pressão em função da deformação axial, obtidos dos ensaios triaxiais CAU (ponto S)

Figura 6.20 - Resultados da tensão desviadora normalizada e da poro pressão em função da deformação axial, obtidos dos ensaios triaxiais CAU (ponto U)...

Figura 6.21 - Resultados dos ensaios triaxiais CD realizados com carregamento controlado, utilizando corpos de prova compactados na umidade ótima (Ponto O).. 202 
Figura 6.22 - Variação da poro pressão em função do tempo, medida com o tensiômetro no ensaio triaxial $\mathrm{CD}$, realizado com carregamento controlado e pressão confinante de $50 \mathrm{kPa}$ (Ponto $\mathrm{O}$ )

Figura 6.23 - Variação da poro pressão em função do tempo medida, com o tensiômetro no ensaio triaxial $\mathrm{CD}$, realizado com carregamento controlado e pressão confinante de $100 \mathrm{kPa}$ (Ponto O)

Figura 6.24 - Variação da poro pressão em função do tempo medida, com o tensiômetro no ensaio triaxial $\mathrm{CD}$, realizado com carregamento controlado e pressão confinante de $200 \mathrm{kPa}$ (Ponto O).

Figura 6.25 - Variação da sucção determinada com o tensiômetro durante a realização de um ensaio triaxial $\mathrm{CW}$ não saturado.

Figura 6.26 - Resultados dos ensaios triaxiais CW não saturados obtidos dos corpos de prova compactados na umidade ótima e ensaiados com confinamento de $50 \mathrm{kPa}$

Figura 6.27 - Resultados dos ensaios triaxiais CW não saturados obtidos dos corpos de prova compactados na umidade ótima e ensaiados com confinamento de $100 \mathrm{kPa}$.

Figura 6.28 - Resultados dos ensaios triaxiais CW não saturados obtidos dos corpos de prova compactados na umidade ótima e ensaiados com confinamento de $300 \mathrm{kPa}$

Figura 6.29 - Resultados dos ensaios triaxiais CW não saturados obtidos dos corpos de prova compactados no ramo seco e ensaiados com confinamento de $50 \mathrm{kPa}$

Figura 6.30 - Resultados dos ensaios triaxiais CW não saturados obtidos dos corpos de prova compactados no ramo seco e ensaiados com confinamento de $100 \mathrm{kPa}$

Figura 6.31 - Resultados dos ensaios triaxiais CW não saturados obtidos dos corpos de prova compactados no ramo seco e ensaiados com confinamento de $200 \mathrm{kPa}$

Figura 6.32 - Resultados dos ensaios triaxiais CW não saturados obtidos dos corpos de prova compactados no ramo seco e ensaiados com confinamento de $300 \mathrm{kPa}$ 
Figura 6.33 - Resultados dos ensaios triaxiais CW não saturados obtidos dos corpos de prova compactados no ramo úmido e ensaiados com confinamento de $50 \mathrm{kPa}$

Figura 6.34 - Resultados dos ensaios triaxiais CW não saturados obtidos dos corpos de prova compactados no ramo úmido e ensaiados com confinamento de $100 \mathrm{kPa}$

Figura 6.35 - Resultados dos ensaios triaxiais CW não saturados obtidos dos corpos de prova compactados no ramo úmido e ensaiados com confinamento de $200 \mathrm{kPa}$

Figura 6.36 - Resultados dos ensaios triaxiais CW não saturados obtidos dos corpos de prova compactados no ramo úmido e ensaiados com confinamento de $300 \mathrm{kPa}$

\section{CAPÍTULO 7}

Figura 7.1 - Medição da variação do valor da sucção em função do teor de umidade da pasta e do incremento de carregamento, obtida de um corpo de prova compactado na umidade ótima (teste $\mathrm{n}^{\mathrm{o}} 1$ ).

Figura 7.2 - Medição da sucção do corpo de prova do teste $n^{0} 1$ utilizando pastas com diferentes teores de umidade.

Figura 7.3 - Medição da variação do valor da sucção em função do teor de umidade da pasta e do incremento de carregamento, obtida de um corpo de prova compactado na umidade ótima e posteriormente umedecido (teste $\mathrm{n}^{\mathrm{o}} 2$ ).

Figura 7.4 - Medição da sucção do corpo de prova do teste $\mathrm{n}^{\mathrm{o}} 2$ utilizando pastas com diferentes teores de umidade. ...

Figura 7.5 - Medição da variação do valor da sucção em função do teor de umidade da pasta e do incremento de carregamento, obtida de um corpo de prova compactado na umidade ótima e posteriormente submetido à secagem (teste $\mathrm{n}^{\mathrm{o}} 3$ ).. 226 Figura 7.6 - Medição da sucção do corpo de prova do teste $n^{0} 3$ utilizando pastas com diferentes teores de umidade. 
Figura 7.7 - Resultados das medições das sucções iniciais dos corpos de prova compactados na umidade ótima e utilizados nos ensaios triaxiais $\mathrm{CW}$ não saturados

Figura 7.8 - Resultados das medições das sucções iniciais dos corpos de prova compactados no ramo seco e utilizados nos ensaios triaxiais CW não saturados.....

Figura 7.9 - Resultados das medições das sucções iniciais dos corpos de prova compactados no ramo úmido e utilizados nos ensaios triaxiais CW não saturados... 229 Figura 7.10 - Resultados das medições das sucções dos corpos de prova utilizados na determinação da curva de retenção da lama preparada com o solo que passa na peneira $\mathrm{n}^{\mathrm{o}} 10$.

Figura 7.11 - Resultados das medições das sucções dos corpos de prova utilizados na determinação da curva de retenção da lama preparada com o solo que passa na peneira $\mathrm{n}^{\mathrm{o}} 40$

Figura 7.12 - Variação do tempo de equilíbrio das medições das sucções dos corpos de prova em função das condições de moldagem e do nível de sucção.

Figura 7.13 - Valores experimentais dos ensaios e representação da equação de calibração encontrada para o lote 920071 ....

Figura 7.14 - Resultados experimentais da curva de retenção utilizando-se, para o trecho determinado com o papel filtro, a calibração obtida para lote 920071 e a equação proposta por Chandler et al (1992).

Figura 7.15 - Valores das sucções medidas com o tensiômetro em relação a sucção obtida com o papel filtro e a sucção imposta na placa de pressão (ponto O)

Figura 7.16 - Valores das sucções medidas com o tensiômetro em relação a sucção obtida com o papel filtro e imposta na placa de pressão (ponto $S$ )

Figura 7.17 - Valores das sucções medidas com o tensiômetro em relação a sucção obtida com o papel filtro e imposta na placa de pressão (ponto U)

Figura 7.18 - Relação entre os valores das sucções impostas na placa de pressão e medida com o tensiômetro, utilizando os resultados da curva de retenção da lama.. Figura 7.19 - Apresentação de todos os resultados experimentais das relações definidas entre os valores de sucção impostas na placa de pressão e medidas pelo tensiômetro e papel filtro 


\section{CAPÍTULO 8}

Figura 8.1 - Valores do grau de saturação e da sucção dos corpos de prova após a etapa de preparação para realização dos ensaios de compressão simples (Ponto O). 249 Figura 8.2 - Valores do grau de saturação e da sucção dos corpos de prova após a etapa de preparação para realização dos ensaios de compressão simples (Ponto S).. 249 Figura 8.3 - Valores do grau de saturação e da sucção dos corpos de prova após a etapa de preparação para realização dos ensaios de compressão simples (Ponto U). 250 Figura 8.4 - Valores das sucções iniciais e na ruptura em função do teor de umidade obtidos dos corpos de prova moldados na umidade ótima e ensaiados em compressão simples (Ponto O)

Figura 8.5 - Valores das sucções iniciais e na ruptura em função do teor de umidade obtidos dos corpos de prova moldados no ramo seco e ensaiados em compressão simples (Ponto $\mathrm{S}$ ).

Figura 8.6 - Valores das sucções iniciais e na ruptura em função do teor de umidade obtidos dos corpos de prova moldados no ramo úmido e ensaiados em compressão simples (Ponto U)

Figura 8.7 - (a) - Representação esquemática das trajetórias de tensão e (b) envoltória de ruptura dos ensaios de compressão simples

Figura 8.8 - Resultados dos ensaios de compressão simples realizados nos corpos de prova compactados na umidade ótima (ponto $\mathrm{O}$ ).

Figura 8.9 - Resultados dos ensaios de compressão simples realizados nos corpos de prova compactados na umidade ótima e com sucção inicial inferior a $150 \mathrm{kPa}$... 255 Figura 8.10 - Resultados dos ensaios de compressão simples realizados nos corpos de prova compactados no ramo seco (ponto $S$ ).

Figura 8.11 - Resultados dos ensaios de compressão simples realizados nos corpos de prova compactados no seco e com sucções iniciais inferiores a $100 \mathrm{kPa}$ (ponto S).

Figura 8.12 - Resultados dos ensaios de compressão simples realizados nos corpos de prova compactados no ramo úmido (ponto $U$ ) 
Figura 8.13 - Resultados dos ensaios de compressão simples realizados nos corpos de prova compactados no ramo úmido e com sucções iniciais inferiores a $150 \mathrm{kPa}$ (ponto $\mathrm{U}$ )

Figura 8.14 - Representação esquemática das etapas seguidas pelos corpos de prova nos ensaios triaxiais não saturados $(\mathrm{CW})$

Figura 8.15 - Trajetória da variação da sucção durante a etapa de preparação e aplicação da pressão confinante dos corpos de prova utilizados nos ensaios triaxiais $\mathrm{CW}$ não saturados (ponto $\mathrm{O}$ )

Figura 8.16 - Trajetória da variação da sucção durante a etapa de preparação e aplicação da pressão confinante dos corpos de prova utilizados nos ensaios triaxiais CW não saturados (ponto $S$ ).

Figura 8.17 - Trajetória da variação da sucção durante a etapa de preparação e aplicação da pressão confinante dos corpos de prova utilizados nos ensaios triaxiais CW não saturados (ponto $U$ )

Figura 8.18 - Trajetórias de tensões dos ensaios triaxiais $\mathrm{CW}$ não saturados realizados em corpos de prova compactados na umidade ótima (Ponto $\mathrm{O}$ )

Figura 8.19 - Trajetórias de tensões dos ensaios triaxiais CW não saturados realizados em corpos de prova compactados no ramo seco (Ponto S).

Figura 8.20 - Trajetórias de tensões dos ensaios triaxiais CW não saturados realizados em corpos de prova compactados no ramo úmido (Ponto $\mathrm{U}$ )

Figura 8.21 - Valores das sucções após confinamento e na ruptura obtidos dos ensaios triaxiais CW não saturados realizados em corpos de prova compactados na umidade ótima.

Figura 8.22 - Valores das sucções após confinamento e na ruptura obtidos dos ensaios triaxiais $\mathrm{CW}$ não saturados realizados em corpos de prova compactados no ramo seco.

Figura 8.23 - Valores das sucções após confinamento e na ruptura obtidos dos ensaios triaxiais CW não saturados realizados em corpos de prova compactados no ramo úmido.

Figura 8.24 - Resultado dos ensaios triaxiais CAU realizados com tensão controlada utilizando corpos de prova compactados na umidade ótima (Ponto O)... 271 
Figura 8.25 - Trajetórias de tensão dos ensaios triaxiais CAU realizados com tensão controlada utilizando corpos de prova compactados na umidade ótima (ponto O)

Figura 8.26 - Resultado dos ensaios triaxiais CAU realizados com tensão controlada utilizando corpos de prova compactados no ramo seco (ponto $\mathrm{S}$ ).

Figura 8.27 - Trajetórias de tensão dos ensaios triaxiais CAU realizados com tensão controlada utilizando corpos de prova compactados no ramo seco (ponto S) 272 Figura 8.28 - Resultado dos ensaios triaxiais CAU realizados com tensão controlada utilizando corpos de prova compactados no ramo úmido (ponto U)....... 273 Figura 8.29 - Trajetórias de tensões dos ensaios triaxiais CAU realizados com tensão controlada utilizando corpos de prova compactados no ramo úmido (ponto $\mathrm{U})$.

Figura 8.30 - Resultado dos ensaios triaxiais CD realizados com carregamento controlado utilizando corpos de prova compactados na umidade ótima (ponto O)... 274 Figura 8.31 - Trajetórias de tensões dos ensaios triaxiais CD realizados com carregamento controlado utilizando corpos de prova compactados na umidade ótima (ponto $\mathrm{O}$ ).

Figura 8.32 - Ajuste obtidos para os ensaios triaxiais saturados e não saturados realizados em corpos de prova compactados na umidade ótima (ponto $\mathrm{O}$ ) 278

Figura 8.33 - Ajuste obtidos para os ensaios triaxiais não saturados realizados em corpos de prova compactados no ramo seco (ponto $S$ )

Figura 8.34 - Ajuste obtidos para os ensaios triaxiais não saturados realizados em corpos de prova compactados no ramo úmido (ponto $\mathrm{U}$ )

Figura 8.35 - Comparação dos ajustes obtidos para os resultados dos ensaios triaxiais $\mathrm{CW}$ não saturados realizados em corpos de prova compactados na umidade ótima, ramo seco e ramo úmido.

Figura 8.36 - Representação da projeção da envoltória dos ensaios de compressão simples para o valor de p igual a zero.

Figura 8.37 - Representação esquemática das equações utilizadas para a determinação das superfícies de ruptura.

Figura 8.38 - Representação da superfície de ruptura correspondente às condições de moldagem na umidade ótima. 
Figura 8.39 - Representação da superfície de ruptura correspondente às condições de moldagem no ramo seco.

Figura 8.40 - Representação da superfície de ruptura correspondente às condições de moldagem ramo úmido.

Figura 8.41 - Aplicação do modelo proposto por Vanapalli et al (1996) aos ensaios realizados na umidade ótima (Ponto $\mathrm{O}$ )

Figura 8.42 - Aplicação do modelo proposto por Vanapalli et al (1996) aos ensaios realizados no ramo seco (Ponto $S$ ).

Figura 8.43 - Aplicação do modelo proposto por Vanapalli et al (1996) aos ensaios realizados no ramo úmido (Ponto $\mathrm{U}$ ).

Figura 8.44 - Relação entre $\kappa$ e o valor do índice de plasticidade proposta por Vanapalli e Fredlund (2000).

Figura 8.45 - Projeção dos ajustes e dos resultados experimentais juntamente com a envoltória de ruptura obtida dos ensaios triaxias saturados (ponto O).....

Figura 8.46 - Projeção dos ajustes e dos resultados experimentais juntamente com a envoltória de ruptura obtida dos ensaios triaxias saturados (ponto $S$ ).

Figura 8.47 - Projeção dos ajustes e dos resultados experimentais juntamente com a envoltória de ruptura obtida dos ensaios triaxias saturados (ponto $\mathrm{U}$ ).

Figura 8.48 - Relação entre o parâmetro $\chi$ e a sucção do tensiômetro na ruptura.......

Figura 8.49 - Relação entre o parâmetro $\chi$ e a sucção do tensiômetro na ruptura normalizada em relação à sucção referente ao início da entrada de ar.

Figura 8.50 - Aplicação do modelo proposto por Khalili e Khabbaz (1998) utilizando diferentes relações entre o valor de $\chi$. e a sucção do corpo de prova (Ponto O)

Figura 8.51 - Aplicação do modelo proposto por Khalili e Khabbaz (1998) utilizando diferentes relações entre o valor de $\chi$. e a sucção do corpo de prova (Ponto S)

Figura 8.52 - Aplicação do modelo proposto por Khalili e Khabbaz (1998) utilizando diferentes relações entre o valor de $\chi$ e a sucção do corpo de prova (Ponto U) 


\section{LISTA DE TABELAS}

\section{CAPÍTULO 2}

Tabela 2.1 - Principais equações para representar a curva de retenção. 50

\section{CAPÍTULO 3}

Tabela 3.1 - Procedimentos que podem ser utilizados para a calibração do papel filtro (Marinho, 1994) 88

Tabela 3.2 - Tempo de equilíbrio sugerido para medição da sucção utilizando soluções de $\mathrm{NaCl}$ (Marinho, 1994) 90

\section{CAPÍTULO 4}

Tabela 4.1 - Resultados dos ensaios de caracterização............................................. 96

Tabela 4.2 - Pontos de estudo com as respectivas condições de moldagem............. 99

Tabela 4.3 - Resumo dos aspectos que serão abordados nesta pesquisa................... 100

Tabela 4.4 - Tipos de curva de retenção determinadas nos pontos de estudo............ 102

Tabela 4.5 - Condições iniciais de moldagem dos corpos de prova utilizados para a determinação das curvas de retenção determinadas por compactação estática.......... 104

Tabela 4.6 - Dados dos corpos de prova utilizados para a determinação das curvas de retenção obtidas por compactação estática, após os procedimentos de saturação. 104 Tabela 4.7 - Dados finais da preparação dos corpos de prova utilizados na determinação das curvas de retenção submetidas a diferentes pressões confinantes. 106 Tabela 4.8 - Dados das variações volumétricas dos corpos de prova ao serem saturados por aspersão de água destilada............................................................. 106

Tabela 4.9 - Dados iniciais de moldagem dos corpos de prova compactados dinamicamente nas condições dos pontos de estudo $(\mathrm{O}, \mathrm{S}$ e $\mathrm{U}) \ldots \ldots \ldots \ldots \ldots \ldots \ldots \ldots \ldots \ldots . . . . . . . . . . . . .111$ Tabela 4.10 - Dados dos corpos de prova compactados dinamicamente nas condições dos pontos de estudo após a etapa de saturação $(\mathrm{O}, \mathrm{S}$ e U). 
Tabela 4.11 - Dados iniciais de moldagem dos corpos de prova obtidos na determinação da curva de compactação.

Tabela 4.12 - Dados referentes à variação volumétrica dos corpos de prova, compactados dinamicamente, após saturação.

Tabela 4.13 - Quantidade de corpos de prova ensaiados em compressão simples com as trajetórias de umidade impostas em sua preparação

Tabela 4.14 - Envoltórias de ruptura obtidas nos ensaios de compressão simples e objetivos de sua obtenção.

Tabela 4.15 - Dados iniciais dos corpos de prova utilizados nos ensaios triaxiais CAU realizados com medição da poro pressão.

Tabela 4.16 - Dados de moldagem dos corpos de prova utilizados nos ensaios triaxias $\mathrm{CD}$.

Tabela 4.17 - Dados dos corpos de prova utilizados no ensaio triaxiais CD após saturação

Tabela 4.18 - Tipos de ensaios triaxiais CAU e CD saturados e objetivos de sua realização.

Tabela 4.19 - Quantidade de corpos de prova utilizados nos ensaios triaxiais CW não saturados

Tabela 4.20 - Objetivos da realização dos ensaios triaxiais não saturados. 126

\section{CAPÍTULO 5}

Tabela 5.1 - Resultados experimentais das curvas de retenção determinadas sem confinamento, obtidas dos corpos de prova compactados estaticamente nos pontos de estudo

Tabela 5.2 - Resultados experimentais das curvas de retenção dos corpos de prova compactados estaticamente na umidade ótima e submetidos a diferentes pressões de confinamento.

Tabela 5.3 - Resultados experimentais das curvas de retenção dos corpos de prova compactados dinamicamente nos pontos de estudo $(\mathrm{O}, \mathrm{S}$ e $\mathrm{U})$ 
Tabela 5.4 - Resultados experimentas das curvas de retenção dos corpos de prova moldados com a consistência de lama

Tabela 5.5 - Valores obtidos da curva de retenção em função do grau de saturação, utilizados para aplicação da equação proposta por Fredlund e Xing (1994).

Tabela 5.6 - Valores iniciais dos parâmetros da equação proposta por Fredlund e Xing (1994), utilizados no ajuste das curvas de retenção

Tabela 5.7 - Parâmetros de ajuste da curva de retenção ao se utilizar a equação de Fredlund e Xing (1994).

Tabela 5.8 - Valores da sucção de entrada de ar em função das condições de moldagem e da pressão de confinamento aplicada aos corpos de prova

\section{CAPÍTULO 6}

Tabela 6.1 - Tipos de ensaios de compressão simples e resultados obtidos para a condição de moldagem na umidade ótima.

Tabela 6.2 - Tipos de ensaios de compressão simples e resultados obtidos para a condição de moldagem no ramo seco.

Tabela 6.3 - Tipos de ensaios de compressão simples e de resultados obtidos para a condição de moldagem no ramo úmido

Tabela 6.4 - Condições iniciais de moldagem, preparação dos corpos de prova e resultados dos ensaios de compressão simples realizados com deformação controlada (Ponto O)

Tabela 6.5 - Condições iniciais de moldagem, preparação dos corpos de prova e resultados dos ensaios de compressão simples realizados com deformação controlada (Ponto S)

Tabela 6.6 - Condições iniciais de moldagem, preparação dos corpos de prova e resultados dos ensaios de compressão simples realizados com deformação controlada (Ponto U)

Tabela 6.7 - Condições iniciais de moldagem, preparação por saturação e secagem e resultados dos ensaios de compressão simples realizados com deformação controlada nos três pontos de estudo $(\mathrm{O}, \mathrm{S}$ e $\mathrm{U})$ 
Tabela 6.8 - Condições iniciais de moldagem, preparação por umedecimento ou secagem e resultados dos ensaios de compressão simples realizados com carregamento controlado nos três pontos de estudo.

Tabela 6.9 - Dados de moldagem e resultados dos ensaios de compressão simples dos corpos de prova moldados na umidade ótima e ensaiados com diferentes teores de umidade e velocidades de cisalhamento.

Tabela 6.10 - Resultados dos ensaios triaxias CAU realizados com tensão controlada nos três pontos de estudo.

Tabela 6.11 - Dados dos corpos de prova utilizados nos ensaios triaxias CD, após moldagem, após saturação e aplicação da tensão confinante (Ponto O).

Tabela 6.12 - Resultados dos ensaios triaixias CD realizados com carregamento controlado, utilizando corpos de prova compactados na umidade ótima (ponto O)... 202 Tabela 6.13 - Condições iniciais de moldagem, preparação por umedecimento ou secagem e resultados dos ensaios triaxias CW não saturados realizados com carregamento controlado, utilzando corpos de prova compactados na umidade ótima (Ponto O)

Tabela 6.14 - Condições iniciais de moldagem, preparação por umedecimento ou secagem e resultados dos ensaios triaxias $\mathrm{CW}$ não saturados realizados com carregamento controlado, utilizando corpos de prova compactados no ramo seco (Ponto S)

Tabela 6.15 - Condições iniciais de moldagem, preparação por umedecimento ou secagem e resultados dos ensaios triaxias CW não saturados realizados com carregamento controlado, utilizando corpos de prova compactados no ramo úmido (Ponto U)

\section{CAPÍTULO 7}

Tabela 7.1 - Dados iniciais do corpo de prova compactado na umidade ótima e utilizado para a realização dos testes da medição da sucção com tensiômetro........ 220 Tabela 7.2 - Equipamentos e sucções aplicadas na calibração do papel filtro........ 232 Tabela 7.3 - Resultados das calibrações realizadas para o lote de papel utilizado nesta pesquisa..................................................... 236 
Tabela 7.4 - Resultados das calibrações realizadas para os outros lotes

Tabela 7.5 - Comparação das diferentes técnicas utilizadas na determinação das sucções iniciais dos corpos de prova..................................... 239

Tabela 7.6 - Resultados dos valores das sucções obtidas com o papel filtro e o tensiômetro, utilizando um corpo de prova moldado na umidade ótima.

\section{CAPÍTULO 8}

Tabela 8.1 - Localização das tabelas e itens dos resultados dos ensaios de compressão simples

Tabela 8.2- Parâmetros efetivos obtidos dos ensaios triaxiais saturados.

Tabela 8.3 - Equações dos ajustes obtidos para os resultados dos ensaios triaxiais CW não saturados realizados em corpos de prova moldados na umidade ótima........ 278 Tabela 8.4 - Equações dos ajustes obtidos para resultados dos ensaios triaxiais CW não saturados realizados em corpos de prova moldados no ramo seco

Tabela 8.5 - Equações dos ajustes obtidos para os resultados dos ensaios triaxiais CW não saturados realizados em corpos de prova moldados no ramo úmido.

Tabela 8.6 - Valores dos parâmetros efetivos correspondente aos ajustes dos resultados de ensaios $\mathrm{CW}$ não saturados.

Tabela 8.7 - Intercessão das superfícies de ruptura com o plano definido por q

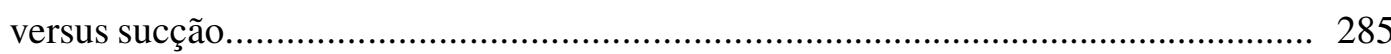

Tabela 8.8 - Equações utilizadas para a definição das superfícies de ruptura............ 286

Tabela 8.9 - Valores das sucções correspondentes ao início da entrada de ar em função da condição de moldagem e da tensão confinante aplicada nos ensaios 


\section{LISTA DE SÍMBOLOS}

\section{Alfabeto latino}

a - parâmetro relacionado à sucção de entrada de ar na equação de Fredlund e Xing (1994).

$\mathrm{a}_{\mathrm{w}}$ - área de água normalizada

$\mathrm{A}_{\mathrm{dw}}$ - área de água correspondente a um determinado grau de saturação

$\mathrm{A}_{\mathrm{tw}}$ - área de água correspondente à saturação

$\mathrm{c}^{\prime}$ - intercepto de coesão efetiva

d - intercepto de coesão obtida do gráfico de q versus $p$

$\mathrm{E}_{\mathrm{tg}}$ - módulo de deformabilidade tangente

e - índice de vazios

IP - índice de plasticidade

m - parâmetro relacionado à curva de retenção na equação de Fredlund e Xing (1994).

$\mathrm{n}$ - porosidade e parâmetro relacionado ao formato da curva de retenção na equação de Fredlund e Xing (1994).

$\mathrm{p}$ - valor da máxima ordenada do círculo de Mohr dado por $\left(\sigma_{1}+\sigma_{3}\right) / 2$

$\mathrm{q}$ - tensão desviadora dividida por dois dada por $\left(\sigma_{1}-\sigma_{3}\right) / 2$

$\mathrm{RH}$ - umidade relativa

S - grau de saturação

$\mathrm{u}_{\mathrm{a}}$ - poro pressão do ar

$\left(\mathrm{u}_{\mathrm{a}}-\mathrm{u}_{\mathrm{w}}\right)$ - sucção matricial

$\mathrm{u}^{*}$ - poro pressão equivalente

$\left(u_{a}-u_{w}\right)_{b}$ - valor da sucção correspondente a entrada de ar

$\mathrm{u}_{\mathrm{f}}$ - poro pressão na ruptura

$\mathrm{u}_{\mathrm{w}}$ - poro pressão da água

$\mathrm{w}$ - teor de umidade gravimétrica

$\mathrm{w}_{1}$ - limite de liquidez

$\mathrm{w}_{\mathrm{p}}-$ limite de plasticidade 


\section{Alfabelto grego}

$\beta$ - valor do ângulo de atrito obtido em termos de $q$ versus $p$

$\beta^{b}$ - razão do incremento da resistência em função da sucção em termos de q versus $p$

$\chi$ - parâmetro função do grau de saturação

$\Delta \mathrm{v}$ - variação volumétrica

$\Delta \mathrm{u}_{\mathrm{f}}$ - variação da poro pressão na ruptura

$\varepsilon_{\mathrm{f}}$ - deformação axial na ruptura

$\phi '$ - ângulo de atrito efetivo

$\phi^{\mathrm{b}}$ - ângulo relacionado a razão do incremento da resistência em função da sucção

К - parâmetro de forma

$\Theta$ - relação entre a umidade volumétrica e a umidade volumétrica na saturação $\left(\theta / \theta_{\mathrm{s}}\right)$.

$\theta_{\mathrm{r}}$-umidade volumétrica residual

$\theta_{\mathrm{s}}$ - umidade volumétrica na saturação

$\theta_{\mathrm{w}}$ - umidade volumétrica

$\rho_{d}$ - densidade seca

$\rho$ - densidade úmida

$\sigma$ - tensão normal total

$\sigma^{\prime}$ - tensão norma efetiva

$\sigma_{1}-$ tensão principal maior

$\sigma_{3}-$ tensão principal menor

$\tau$ - tensão cisalhante

$\psi_{\mathrm{b}}$ - Sucção correspondente a entrada de ar

$\psi_{\mathrm{m}}$ - Sucção matricial 


\section{RESUMO}

O principal enfoque deste estudo é investigar alguns aspectos da resistência ao cisalhamento e as propriedades de retenção de água de um solo residual compactado no estado não saturado. Foi utilizado um solo residual de gnaisse retirado do campo experimental de geotecnia da Universidade de São Paulo. Com base na curva de compactação foram escolhidos três pontos de moldagem para o estudo, estando os mesmos associados à umidade ótima, ao ramo seco e ao ramo úmido. Foram realizadas algumas series de ensaios triaxiais sob condições saturadas (CAU e CD), e um grande número de ensaios triaxiais não saturados com teor de umidade constante $(\mathrm{CW})$. Os ensaios triaxiais $\mathrm{CW}$ não saturados, foram feitos com medição de sucção utilizando um tensiômetro de alta capacidade (TAC) colocado na base do corpo de prova. Estudos específicos relacionados com a técnica de medição de sucção com o uso do TAC foram feitos. Com os resultados dos ensaios de resistência foram obtidas, para diferentes pressões confinantes, as variações dos valores da resistência ao cisalhamento (q) em função da sucção. Estas relações permitiram a definição das superfícies de ruptura para as três condições de moldagem. Foram investigados também aspectos relativos à forma de carregamento, a velocidade de carregamento, o tipo de compactação e a trajetória de umedecimento. São apresentados detalhes de como a resistência do solo é afetada por estas variáveis. O estudo define os procedimentos para obtenção das superfícies de resistência do solo no estado não saturado, com o uso de ensaios de compressão simples, feitos com medição de sucção durante o ensaio, e com a envoltória do solo saturado. As curvas de retenção do solo foram obtidas sob diversas condições de moldagem e umedecimento, e utilizado as técnicas de translação de eixos, placa de sucção, tensiômetro e papel filtro. Estas curvas foram utilizadas como ferramenta para se verificar a aplicabilidade dos modelos de previsão de resistência propostos por Vanapalli et al (1996) e Khalili e Khabbaz (1998), ao solo estudado. 
The main focus of this study is to investigate some aspects of the shear strength and water retention properties of a compacted residual soil, under unsaturated condition. A residual of gneiss obtained from the geotechnical experimental site of the University of São Paulo was used. Based on the compaction curve three molding conditions were adopted for the study: one associated with the optimum water content, and two others located at the dry side and wet side of the compaction curve. A series of triaxial tests were performed under saturated conditions (CAU and $\mathrm{CD}$ ), and a great number of triaxial tests under unsaturated conditions at constant water content $(\mathrm{CW})$. The $\mathrm{CW}$ tests were performed with suction measurement using a high capacity tensiometer (HCT) placed at the base of the sample. Investigations were carried out associated with the use of the CHT. Based on the shear strength tests performed under different confining pressure the relation between shear strength and suction were determined. With this relation it was possible to define the shear surface for the three molding conditions. It were also investigated aspects related with type of loading, speed of the test, type of compaction and moisture path after compaction. It is presented details on how the shear strength is affected by these parameters. The study defines a procedure to obtain the shear surface of an unsaturated soil using unconfining tests, with suction measurement and using the shear envelope obtained at saturated condition. The retention curves were obtained at different molding conditions, following distinct moisture path. The retention curves were determined using axis translation technique, suction plate, filter paper and tensiometer. The retention curves were used as a tool to evaluate the applicability of the models presented by Vanapalli et al (1996) and Khalili and Khabbaz (1998) to infer the shear strength of the residual soil studied. 


\section{1 - INTRODUÇÃO}

\section{1 - Importância dos estudos em solos não saturados}

Uma grande parte da superfície da terra encontra-se em regiões áridas, onde a evaporação excede as precipitações anuais. Em torno de $60 \%$ da população mundial vive nesta região. No interior do solo a água acima do nível freático apresenta pressão negativa, o que aumenta a força normal entre as partículas do solo. Estas forças de contato entre as partículas atuam como um confinamento interno. Quando estas forças excedem a pressão confinante lateral, a superfície passa a apresentar fissuras (Fredlund e Rahardjo, 1993). Quando ocorre a precipitação de chuva, a poro pressão da água aumenta tendendo a apresentar valores positivos. Nestes ciclos de umedecimento e secagem os solos apresentam variações volumétricas e de resistência. As precipitações de chuvas fazem com que ocorra redução da sucção do solo e conseqüentemente a redução de sua resistência, sendo uma das causas de diversos deslizamentos de taludes. No Brasil tem-se como exemplo os deslizamentos que ocorrem na Serra do Mar - SP em épocas de chuva [e.g. Wolle, (1988), Abramento e Pinto (1993)], bem como em diversas regiões urbanas do país.

Diversas estruturas de engenharia são construídas acima do nível da água, tais como, estradas, muros de contenção, fundações de edifícios, barragens e aterros compactados. Muitos problemas em diversas partes do mundo têm ocorrido em obras assentadas em solos não saturados. Isto faz com que a mecânica dos solos não saturados possa se tornar uma importante ferramenta a ser utilizada em projetos de engenharia geotécnica. A curva de retenção do solo tem sido utilizada para se obter algumas das propriedades de resistência e condutividade hidráulica dos solos utilizados nestas obras. Os modelos de previsão da resistência dos solos não saturados devem permitir que os resultados sejam obtidos de forma rápida e confiável. 
Diversos modelos têm sido propostos nos últimos 10 anos para a obtenção da resistência em função da sucção. A viabilidade dos mesmos necessita de resultados de ensaios em solos de diversas partes do mundo. Esta tese pretende abordar alguns aspectos relacionados à resistência ao cisalhamento de um solo residual compactado e ainda apresentar diversos procedimentos de medição de sucção, que incluem o uso de tensiômetro de alta capacidade em ensaios de cisalhamento.

\section{2 - Organização da tese}

No Capítulo 2 é apresentada uma revisão dos aspectos teóricos necessários para compreensão e análise dos resultados desta pesquisa. Inclui-se nesta revisão as diferentes propostas para se equacionar as tensões efetivas dos solos não saturados. Dentre elas, a equação de Bishop (1959) tem sido a mais estudada por diferentes pesquisadores. Utilizando uma outra linha de pensamento, Fredlund et al (1978) propõe o estudo da resistência dos solos não saturados abordando a contribuição da sucção e da pressão confinante de forma independente. As equações de Bishop (1959) e Fredlund et al (1978) são descritas detalhadamente, incluindo as suas limitações e comparação entre as mesmas.

Esta pesquisa foi realizada em corpos de prova compactados em três pontos da curva de compactação, sendo posteriormente ensaiados com diferentes teores de umidade. Ao se variar o teor de umidade dos corpos de prova, a partir das condições de moldagem, podem ocorrer variações estruturais que alteram os valores de resistência ao cisalhamento. Quanto a este aspecto, é apresentado neste capítulo as diferentes estruturas dos corpos de prova moldados ao longo da curva de compactação e as possíveis alterações estruturais devido às variações do teor de umidade. Em relação à curva de retenção é abordada a influência do tipo do solo, da pressão confinante e da história de tensão. Finalizando o Capítulo 2 é apresentada a relação entre a curva de retenção e a resistência ao cisalhamento dos solos não saturados e os modelos de previsão da resistência, propostos por Vanapalli et al (1996) e Khalili e Khabbaz (1998). 
No Capítulo 3 são apresentados os equipamentos utilizados para a realização dos ensaios com seus respectivos princípios de funcionamento. Algumas evidências experimentais indicaram que a calibração do papel filtro Whatman $\mathrm{n}^{\mathrm{o}} 42$, proposta por Chandler et al (1992), não se aplica satisfatoriamente ao lote de papel filtro utilizado nesta pesquisa. Em virtude da necessidade de se obter estas equações, no final deste capítulo são descritas as diferentes técnicas e cuidados necessários para a calibração do papel filtro.

No Capítulo 4, além dos resultados dos ensaios de caracterização, são definidos na curva de compactação as três condições de moldagem estudadas nesta pesquisa. Para estas condições de moldagem são indicados os tipos de ensaios a serem realizados, com os seus objetivos principais e secundários. Concluindo este capítulo estão os aspectos relacionados aos procedimentos dos ensaios e os dados de moldagem e preparação dos corpos de prova.

Os resultados das curvas de retenção com as respectivas análises são apresentados no Capítulo 5. Inicialmente é citado o critério adotado para a determinação do tempo de equilíbrio da sucção dos corpos de prova ao serem colocados na placa de pressão. Para as curvas de retenção determinadas sem confinamento são feitas algumas análises utilizando-se resultados de microscopia eletrônica de varredura. Ainda dentro da discussão dos resultados estão os aspectos relacionados à histerese em função das diferentes trajetórias de umidade e do tipo de compactação utilizados na preparação dos corpos de prova para o ensaio. Finalizando o Capítulo 5 estão os resultados das variações da sucção de entrada de ar em função da pressão de confinamento, determinados para as condições de moldagem na umidade ótima. Em virtude da grande quantidade de ensaios de resistência ao cisalhamento, realizados nesta pesquisa, optou-se por se apresentar no Capítulo 6 apenas estes resultados. Os mesmos são representados graficamente e apresentados em forma de tabela. Para os ensaios realizados em corpos de prova não saturados, são plotadas as respectivas variações de sucção durante a etapa de cisalhamento. 
As sucções dos corpos de prova no início dos ensaios foram determinadas pela técnica do papel filtro e com a utilização do tensiômetro. No Capítulo 7 são feitas as comparações destes valores, para as três condições de moldagem. Estão incluídos também neste capítulo os estudos sobre a pasta de solo utilizada sobre o tensiômetro. Estes estudos foram realizados com pastas que apresentam diferentes consistências e granulometria.

No Capítulo 8 são apresentadas as análises dos ensaios de resistência. Para os resultados dos ensaios não saturados, apresentados em termos de q versus sucção, estão incluídas as respectivas trajetórias de tensão dos corpos de prova até o momento da ruptura. O principal enfoque deste capítulo está na obtenção dos ajustes dos resultados, representados em termos de q versus sucção, e na determinação das equações representativas das superfícies de ruptura. Para os resultados dos ensaios cujas condições de moldagem e de confinamento obteve-se as respectivas curvas de retenção, foram aplicados os modelos propostos por Vanapalli et al (1996) e Khalili e Khabbaz (1998). No Capítulo 9 são apresentadas as principais conclusões e algumas sugestões para futuras pesquisas. As referências bibliográficas são apresentadas no Capítulo 10. 


\section{2 - REVISÃO BIBLIOGRÁFICA}

Neste capítulo são abordados os principais aspectos teóricos que servirão de base para compreensão dos resultados experimentais. Inicialmente estão as propostas das equações de resistência ao cisalhamento formuladas por Bishop (1959) e Fredlund et al (1978). Em relação à preparação dos corpos de prova para os ensaios, são apresentadas as teorias referentes às diferentes estruturas resultantes das condições de compactação e as variações volumétricas resultantes das diferentes trajetórias de umidade. Em relação às curvas de retenção são descritos alguns fatores que interferem no seu formato, tais como, o tipo de solo, as condições de moldagem e a história de tensão imposta aos corpos de prova. Antes da apresentação dos modelos propostos por Vanapalli et al (1996) e Khalili e Khabbaz (1998) é descrita a relação que existe entre os resultados da curva de retenção e os valores de resistência ao cisalhamento.

\section{1 - Equações para a previsão da resistência ao cisalhamento dos solos não saturados}

Devido ao sucesso da equação das tensões efetivas na previsão do comportamento dos solos saturados, anunciada por Terzaghi (1936), surgiram diversas tentativas de se obter uma equação para as tensões efetivas em solos não saturados. Todas estas equações já estão amplamente divulgadas na literatura técnica especializada [e.g. Fredlund e Rahardjo (1993)]. Em comum as mesmas utilizam uma única variável de estado de tensão para representar a contribuição da tensão total e da sucção para a tensão efetiva.

Os problemas em solos não saturados são mais complexos uma vez que os poros do solo são preenchidos por dois fluidos, ar e água, que devido à tensão superficial entram em equilíbrio a pressões diferentes. Devido a este sistema trifásico (ar, água e partículas do solo) se torna difícil quantificar a parcela de tensão transmitida entre os grãos (tensão efetiva) ao se aplicar um carregamento externo. 
Matyas e Radhakrishina (1968) consideram praticamente impossível encontrar uma equação de tensões efetivas para a previsão do comportamento de um solo não saturado, sendo as mesmas limitadas aos casos onde podem ser verificados experimentalmente.

Em face das dificuldades em se equacionar as tensões efetivas em solos não saturados, utilizando uma única variável de estado de tensões, a contribuição das tensões totais e da sucção para a resistência ao cisalhamento, passou a ser tratada como duas variáveis de estado de tensão independentes. Fredlund et al (1978) propõe uma equação para a resistência ao cisalhamento em solos não saturados onde a sucção e a tensão total são consideradas separadamente. Quando avaliada desta forma, a resistência ao cisalhamento, utilizando o critério de Mohr-Coulomb, é representada por uma superfície em um gráfico tridimensional. Os resultados dos ensaios de resistência não saturado, apresentados no presente trabalho, serão avaliados utilizando-se a expressão de tensões efetivas proposta por Bishop (1959) e a equação proposta por Fredlund et (1978).

\subsection{1 - Equação proposta por Bishop (1959)}

Dentre as diversas equações para as tensões efetivas em solos não saturados a proposta de Bishop (1959) tem sido a mais estudada, sendo a mesma representada pela seguinte expressão:

$\sigma^{\prime}=\left(\sigma-u_{a}\right)+\chi\left(u_{a}-u_{w}\right)$

Onde: $\sigma$ - tensão efetiva, $\mathrm{u}_{\mathrm{a}}$ - poro pressão do ar, $\left(\mathrm{u}_{\mathrm{a}}-\mathrm{u}_{\mathrm{w}}\right)$ - sucção matricial, $\chi$ - parâmetro função do grau de saturação.

O fator $\chi$ é igual a 1 para o solo saturado, e igual a zero para o solo seco. Seu valor depende principalmente do grau de saturação e de forma secundária é função da estrutura do solo e de ciclos de secagem e umedecimento (Bishop et al, 1960). 
Aplicando o critério de Mohr-Coulomb para a proposta de tensões efetivas de Bishop (1959), a resistência ao cisalhamento em solos não saturados é dada por:

$$
\tau=c^{\prime}+\left[\left(\sigma-u_{a}\right)+\chi\left(u_{a}-u_{w}\right)\right] \operatorname{tg} \phi^{\prime}
$$

Esta equação é uma extensão da equação proposta por Terzaghi (1936). Quando o solo está saturado $(\chi=1)$ a equação 2.2 se reduz à equação da resistência ao cisalhamento em solos saturados. A resistência ao cisalhamento, dada pela equação 2.2, é representada em um gráfico bidimensional sendo o estado de tensões de um elemento do solo dado por uma única variável (termo entre colchetes na equação 2.2).

Jennings e Burland (1962) apresentaram a equação 2.2 de forma semelhante à equação das tensões efetivas em solos saturados, proposta por Terzaghi (1936), sendo dada por:

$$
\sigma^{\prime}=\sigma-\left[\chi u_{w}+(1+\chi) u_{a}\right]=\sigma-u^{*}
$$

De forma semelhante ao caso dos solos saturados o princípio das tensões efetivas pode ser anunciado em duas proposições:

- Todos os efeitos medidos devido à variação de tensão, como a compressão, distorção e variação na resistência ao cisalhamento são devidas exclusivamente a variação nas tensões efetivas.

- A tensão efetiva em solos não saturados é definida como um excesso de tensão total sobre a poro pressão equivalente, dada por $u^{*}=\left[\chi u_{w}+(1-\chi) u_{a}\right]$.

Para Bishop e Blight (1963) o valor da sucção representa a maior dificuldade ao se aplicar o princípio das tensões efetivas em solos não saturados, pois a sua variação não representa uma variação equivalente da poro pressão. A variação da sucção atua apenas em uma área da superfície dos grãos do solo. 
O princípio das tensões efetivas em solos não saturados é válido somente quando um incremento de mesmo valor da tensão aplicada ou de sucção corresponde respectivamente a valores equivalentes de variações de volume e resistência (Jennings e Burland, 1962). A verificação da validade da equação 2.2 requer o conhecimento do valor de $\chi$, que só pode ser obtido usando métodos que assumem a validade do princípio das tensões efetivas (Jennings e Burland, 1962). A verificação deste princípio pode ser obtida comparando-se o comportamento de um solo não saturado submetido a um carregamento, com um solo saturado semelhante submetido ao mesmo carregamento (Jennings, 1960). Sob este ponto de vista o $\chi$ pode ser obtido em relação à resistência ao cisalhamento ou em relação à variação volumétrica. A forma de se obter o valor de $\chi$, em termos de resistência e de variação de volume, e como o mesmo varia em função do grau de saturação será apresentada utilizando os trabalhos de Bishop et al (1960), Bishop e Donald (1961) e Jennings e Burland (1962).

\section{a) Obtenção da variação do $\chi$ em termos de ensaios de resistência}

Bishop et al (1960) estudaram solos argilosos compactados com fração menor que 2 $\mu$ de $22 \%$ (Clay Shale) e 4\% (Bolder Clay). A Clay Shale foi utilizada em ensaio triaxial não drenado com as amostras compactadas com teor de umidade de $18.6 \%$. $\mathrm{Na}$ etapa de adensamento e de cisalhamento do corpo de prova são medidas as variações de " $u_{\mathrm{a}}$ " e " $\mathrm{u}_{\mathrm{w}}$ ". Os resultados destes ensaios estão apresentados na Figura 2.1. Os mesmos estão plotados de forma a se evitar a sobreposição de círculos de Mohr e permitir a obtenção de $\chi$ diretamente do gráfico. Os ensaios realizados nos corpos de prova saturados estão representados pela reta inclinada cuja abscissa é dada por $\left(\sigma_{1+} \sigma_{3}\right) / 2-\mathrm{u}_{\mathrm{w}}$ e a ordenada por $\left(\sigma_{1}-\sigma_{3}\right) / 2$. Os ensaios não saturados são representados em termos de $\left(\sigma_{1+} \sigma_{3}\right) / 2$ - $\mathrm{u}_{\mathrm{w}}$ e $\left(\sigma_{1+} \sigma_{3}\right) / 2-\mathrm{u}_{\mathrm{a}}$ na abscissa e $\left(\sigma_{1}-\sigma_{3}\right) / 2 \mathrm{em}$ ordenada. 


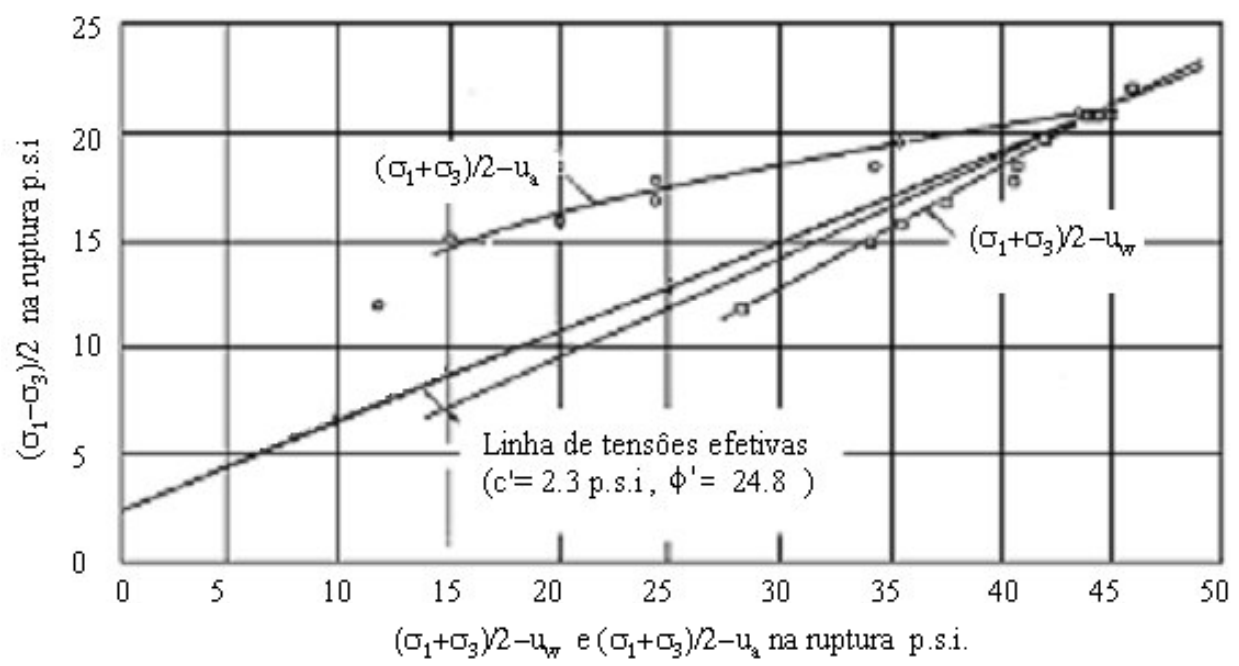

Figura 2.1 - Resultados de ensaios triaxiais não drenados realizados em amostras argilosas (clay shale) compactadas (Bishop et al 1960).

A Figura 2.2 apresenta esquematicamente como se determina o valor de $\chi$ para este tipo de representação dos resultados. Da equação 2.1 tem-se que o valor de $\chi$ é dado por:

$\chi=\frac{\sigma^{\prime}-\left(\sigma-u_{a}\right)}{\left(u_{a}-u_{w}\right)}$

Para um determinado valor de resistência o termo $\sigma$ ' representa a tensão efetiva obtida do ensaio saturado, correspondendo ao valor de b (Figura 2.2). O termo $\left(\sigma-\mathrm{u}_{\mathrm{a}}\right)$ é dado pelo comprimento c e a sucção pela diferença entre os termos $\left(\sigma_{1+} \sigma_{3}\right) / 2-\mathrm{u}_{\mathrm{w}} \mathrm{e}$ $\left(\sigma_{1+} \sigma_{3}\right) / 2-\mathrm{u}_{\mathrm{a}}$, sendo representada por a-c. Desta forma o valor de $\chi$ é obtido da seguinte expressão:

$\chi=\frac{b-c}{a-c}$ 


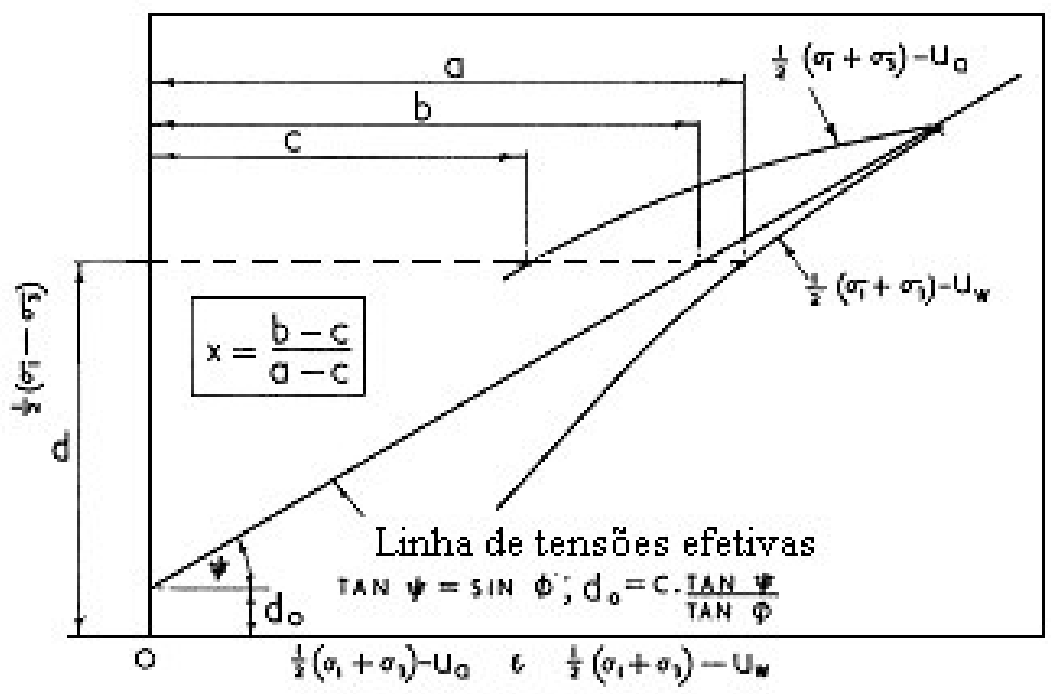

Figura 2.2 - Determinação do valor de $\chi$ para ensaios triaxiais realizados com umidade constante e diferentes pressões confinantes (Bishop et al 1960).

As amostras do solo Bolder Clay foram submetidas a ensaios de resistência a compressão simples. Nestes ensaios os corpos de prova foram colocados na câmara triaxial e submetidos externamente a uma pressão de $\operatorname{ar}\left(\mathrm{u}_{\mathrm{a}}=\sigma_{3}\right)$. Este mesmo valor de pressão é aplicado internamente no corpo de prova. Para se obter corpos de prova com diferentes valores de sucção, os mesmos foram compactados com vários teores de umidade. Cabe salientar que esta forma de se moldar os corpos de prova faz com que apresentem diferentes estruturas de poros. Quando se faz com que $u_{a}=\sigma_{3}$, o termo $\left(\sigma_{1+} \sigma_{3}\right) / 2-\mathrm{u}_{\mathrm{a}}$ se reduz a $\left(\sigma_{1}-\sigma_{3}\right) / 2$, sendo representado sobre a envoltória de tensões efetivas. Os resultados dos ensaios realizados na Bolder clay estão apresentados na Figura 2.3. A forma de se obter o $\chi$ esta representada esquematicamente na Figura 2.4 . 


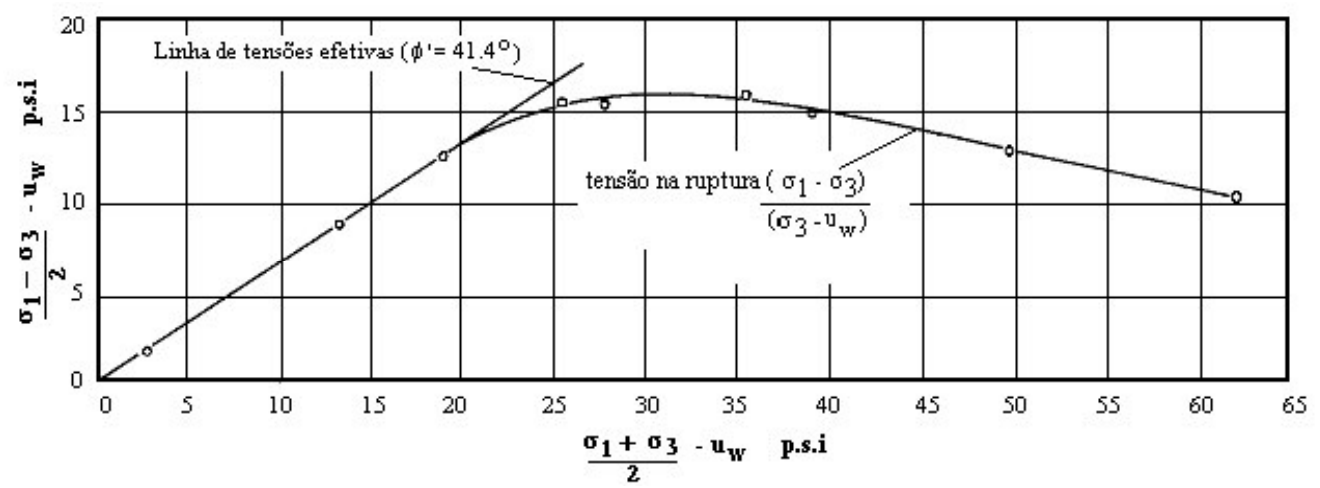

Figura 2.3 - Resultados dos testes triaxiais não confinados realizados em corpos de prova (Bolder clay) compactados com diferentes umidades (Bishop et al 1960).

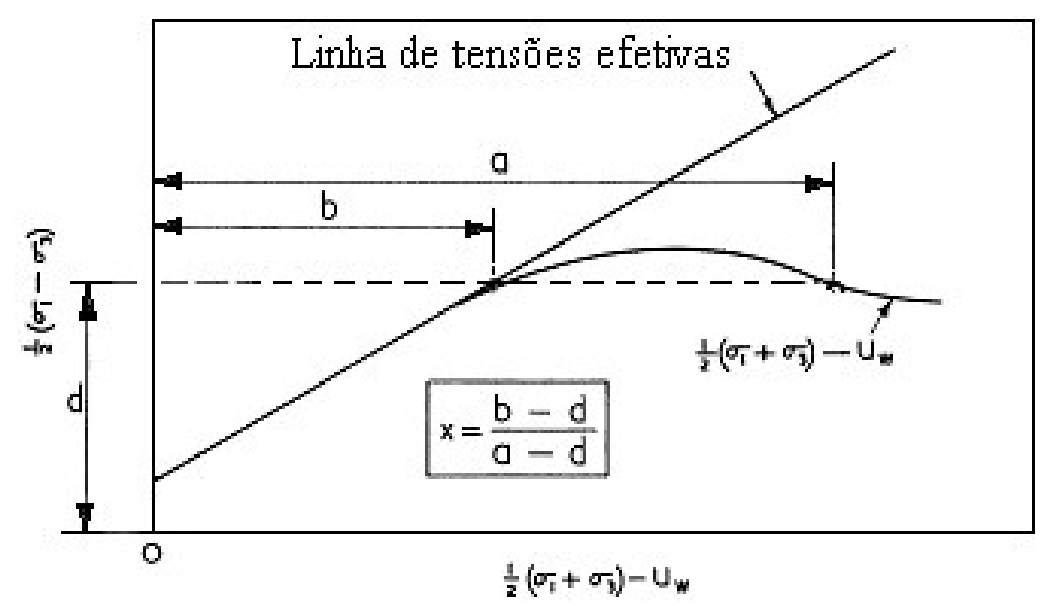

Figura 2.4 - Método para se calcular o valor de $\chi$ em ensaios triaxiais não confinados $\left(\mathrm{u}_{\mathrm{a}}=\sigma_{3}\right)$ (Bishop et al 1960).

Bishop e Donald (1961) realizaram ensaios triaxiais drenados e com umidade constante e ensaios de adensamento sobre um solo siltoso (Breahead Silt). $\mathrm{Na}$ preparação da amostra o silte foi preparado com a consistência de lama e drenado a uma sucção constante $0.2 \mathrm{kPa}(0.9$ p.s.i), sendo posteriormente submetido a uma pressão confinante de $14 \mathrm{kPa}$ (2 p.s.i). Partindo desta condição inicial os corpos de prova foram ensaiados com diferentes valores de sucção. 
Nos ensaios drenados $\sigma_{3}, \mathrm{u}_{\mathrm{a}}$ e $\mathrm{u}_{\mathrm{w}}$ variam durante o cisalhamento e os valores de $\left(\sigma_{3^{-}}\right.$ $\left.\mathrm{u}_{\mathrm{a}}\right)$ e $\left(\mathrm{u}_{\mathrm{a}}-\mathrm{u}_{\mathrm{w}}\right)$ são mantidos constantes. Nos testes com teor de umidade constante o valor de $u_{a}$ permanece inalterado sendo obtidas as variações de $u_{w}$. Na Figura 2.5 estão apresentados os resultados dos ensaios drenados e não drenados realizados no Breahead Silt, indicando também como se obtém o valor de $\chi$.

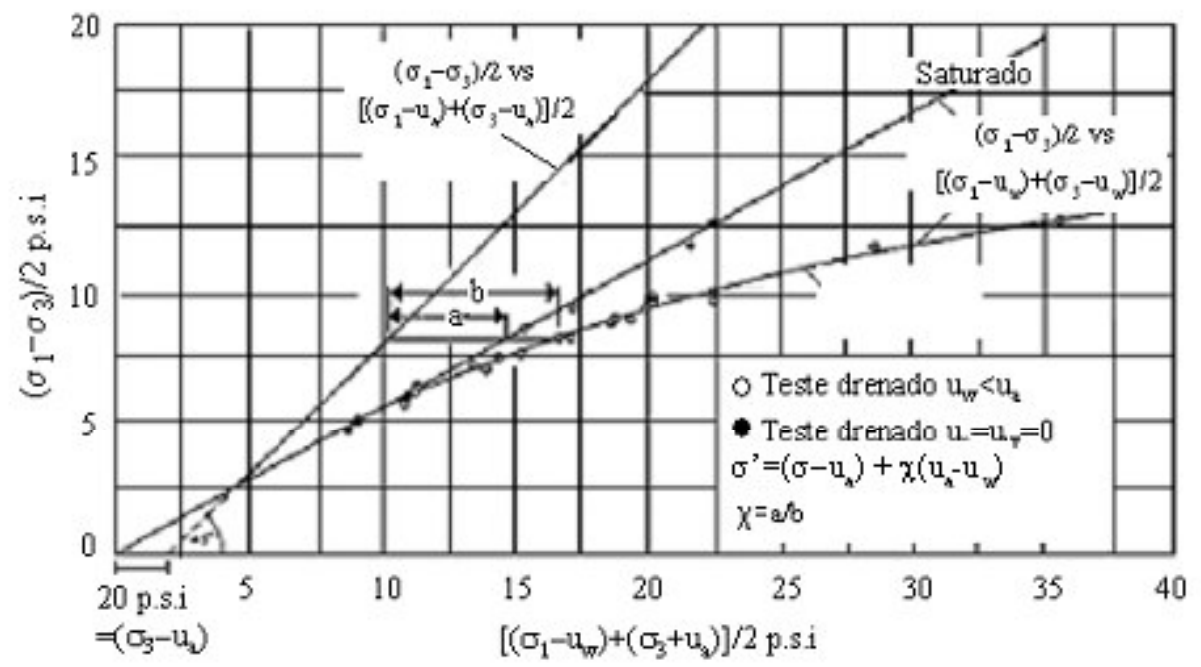

Figura 2.5 - Determinação do valor de $\chi$ para o solo siltoso, obtido de ensaios triaxiais com sucção controlada realizados na condição drenada e a umidade constante (Bishop e Donald, 1961).

\section{b) Obtenção da variação do $\chi$ em termos de variação volumétrica}

Os valores de $\chi$ para o Breahead Silt também foi obtida em termos de variação volumétrica. Foi realizado um ensaio de adensamento em uma célula triaxial com $\left(\sigma_{3}-\mathrm{u}_{\mathrm{a}}\right)=14 \mathrm{kPa}(2$ p.s.i.) mantida constante, variando-se o valor da sucção (translação de eixos). Neste tipo de ensaio o adensamento do corpo de prova é proporcionado apenas pelo aumento da sucção. Os resultados estão apresentados na Figura 2.6, juntamente com os procedimentos para se obter o valor de $\chi$ em termos de variação volumétrica. Verifica-se nesta Figura que para o valor de $\left(\sigma-\mathrm{u}_{\mathrm{w}}\right)=50 \mathrm{kPa}(7$ p.s.i) ao corpo de prova passa ao estado não saturado e a sucção não consegue ser tão efetiva quanto à tensão confinante em produzir variações volumétricas. 
A linha pontilhada representa as tensões efetivas do solo, sendo a mesma um prolongamento da condição saturada. O valor de $\chi$ foi determinado para diferentes índices de vazios. Utilizando a equação 2.4, o valor de $\sigma$ ' e dado pela abscissa corresponde à condição saturada (linha pontilhada). $\mathrm{O}$ valor de $\left(\sigma-\mathrm{u}_{\mathrm{a}}\right)$ é constante e igual a $14 \mathrm{kPa}(2 \mathrm{p} . s . i)$. A sucção é representada pela diferença entre $\left(\sigma-\mathrm{u}_{\mathrm{w}}\right)$, correspondente ao solo não saturado, e $\left(\sigma-\mathrm{u}_{\mathrm{a}}\right)$. As variações do $\chi$ com o grau de saturação, obtidas para todos os ensaios realizados no Breahead silt, estão apresentadas na Figura 2.7. Observa-se nesta Figura que para este solo os valores de $\chi$ independe do tipo de ensaio realizado.

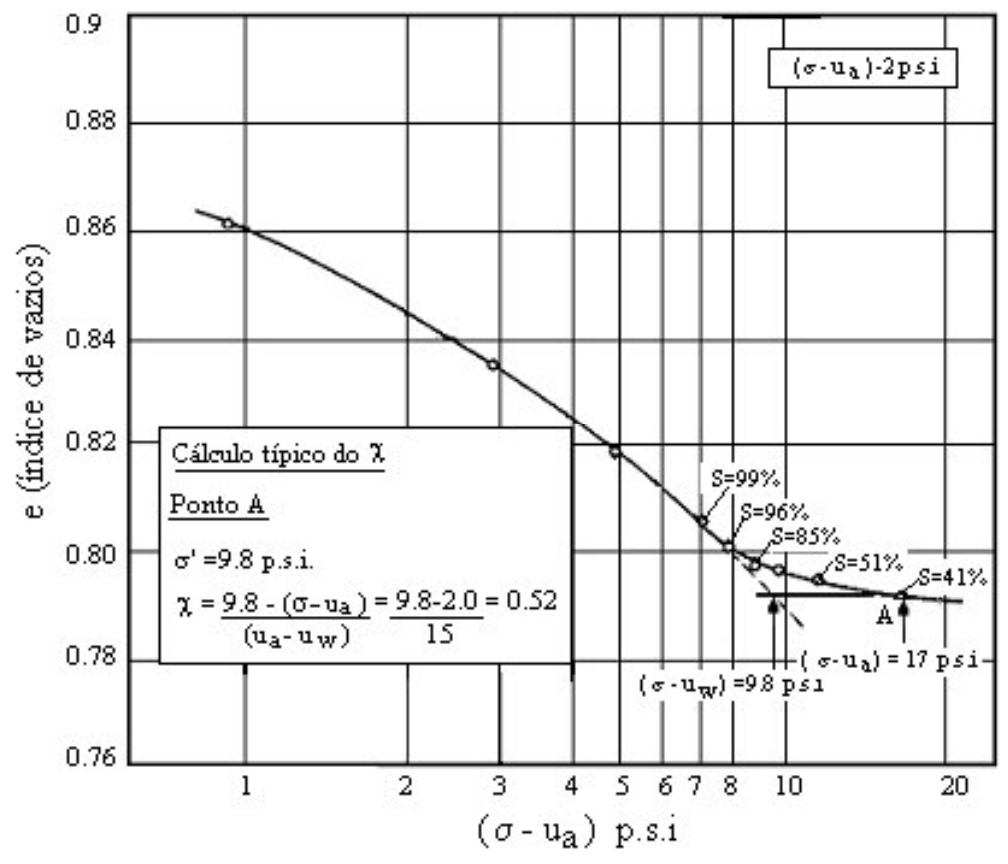

Figura 2.6 - Ensaio de adensamento (Breahead silt) com incremento de sucção (Bishop e Donald, 1961). 


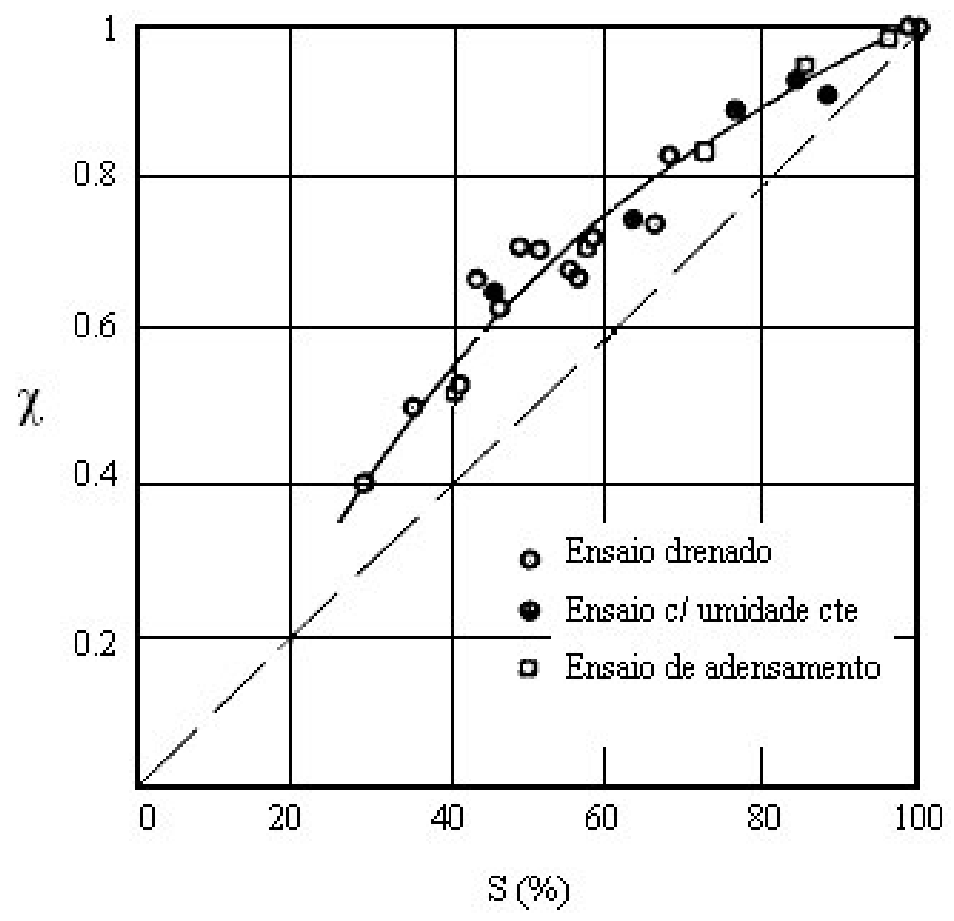

Figura 2.7 - Variação de $\chi$ em função do grau de saturação obtido para um solo siltoso (Breahead silt) (Bishop e Donald, 1961).

Jennings e Burland (1962) estudaram o parâmetro $\chi$ em termos de variação de volume, utilizando um solo siltoso e um solo argilo siltoso. Estes solos foram umedecidos até atingirem a condição de lama, sendo em seguida colocados na placa de pressão no interior de um molde de $8 \mathrm{~cm}$ de diâmetro e com $8 \mathrm{~cm}$ de altura. Para cada sucção aplicada o corpo de prova perde água até atingir o equilíbrio, obtendo-se novamente seu peso e as suas dimensões. Desta forma, para diferentes sucções aplicadas obteve-se o grau de saturação do corpo de prova. Os resultados destes ensaios e a forma de se obter a variação do valor de $\chi$, estão apresentados Figura 2.8. 


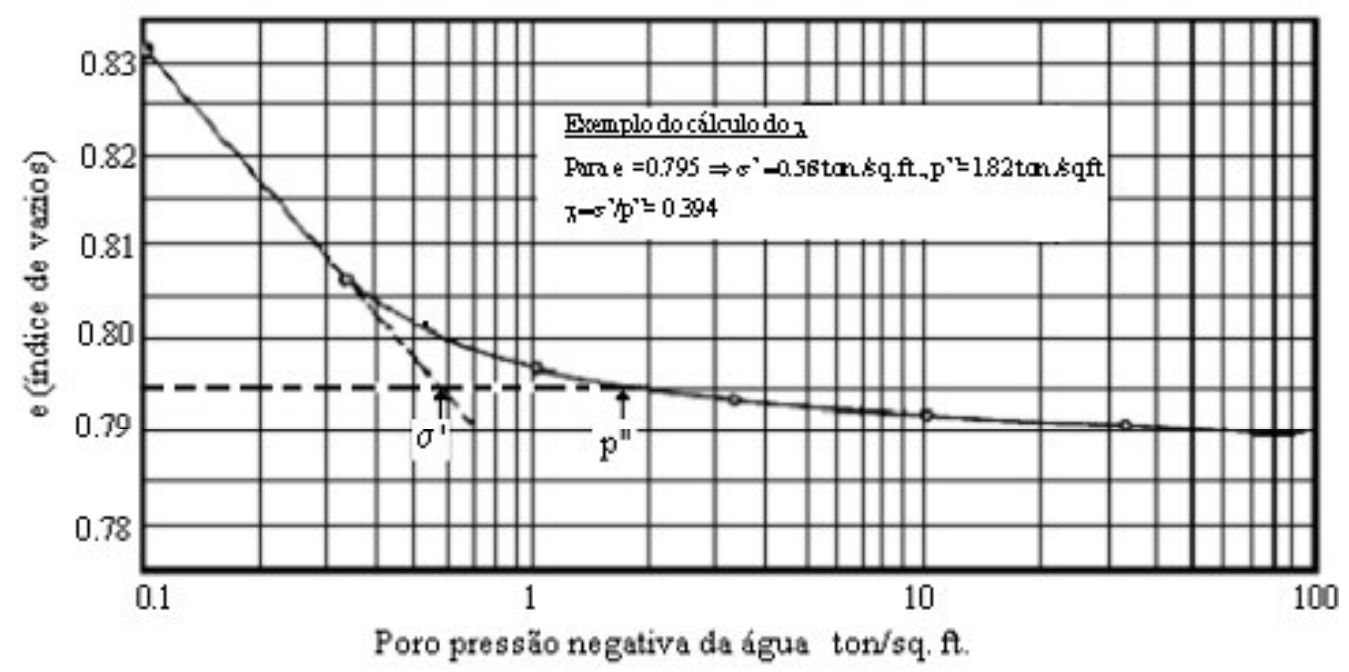

Figura 2.8 - Variação do índice de vazios devido ao acréscimo de sucção (Jennings e Burland, 1962).

Donald (1960) estudou a variação de $\chi$ utilizando os resultados de diversas curvas de retenção que representam diferentes tipos de solo. As curvas foram normalizadas em relação às suas respectivas entradas de ar, estando cada grau de saturação relacionada a um valor de $\chi$. A relação entre cada grau de saturação e $\chi$ foi obtida utilizando-se a equação proposta por Aitchison (1960). Este equação se aplica estritamente a solos idealizados compostos de partículas esféricas uniformes, incompreensíveis e a solos relativamente incompressíveis. Com estes procedimentos Donald (1960) obteve praticamente uma única relação entre $\chi$ e o grau de saturação. Para solos idealizados desta forma, o valor de $\chi$ é único para análise em termos de resistência e variação de volume. Na Figura 2.9 estão plotados os valores de $\chi$ em função do grau de saturação, obtidos dos resultados apresentados anteriormente na parte a e b deste item. Nesta figura as curvas 1 e 2 foram obtidas de ensaios de resistência ao cisalhamento. A curva 3 foi obtida tanta para a variação de volume como em termos de resistência ao cisalhamento e as curvas 4 e 5 foram determinadas para variação de volume. Segundo Coleman (1962) o parâmetro $\chi$ esta fortemente relacionado a estrutura do solo, o que provavelmente explica as variações das relações apresentadas na Figura 2.9, quando se tenta relacioná-lo ao grau de saturação. 


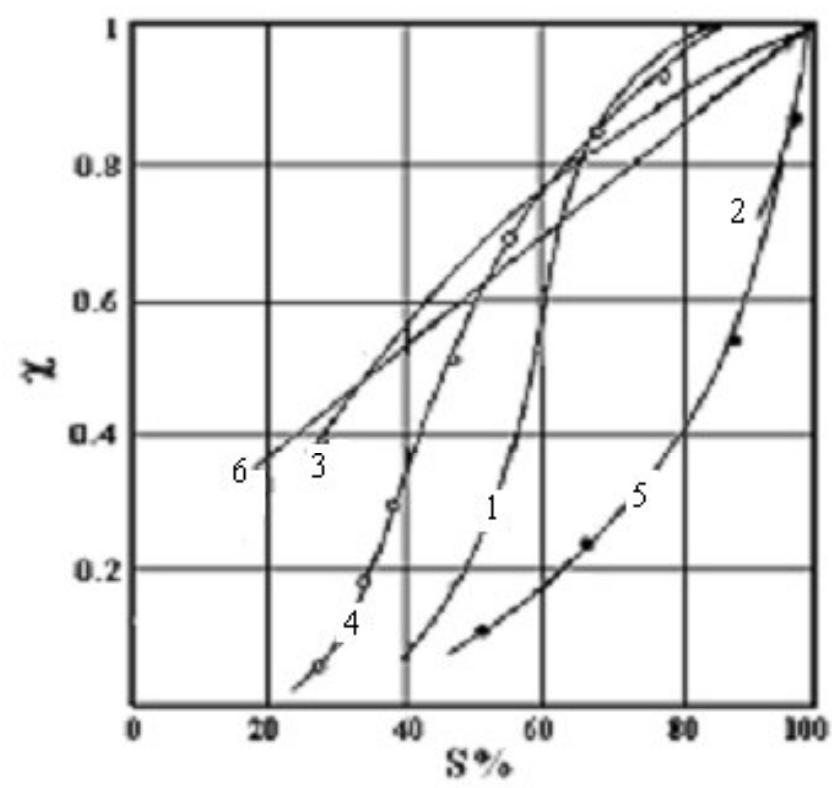

1.Argil a Compactada $(-2 \mu=4 \%)-$ Bishop et al $(1960)$
2.Argila Compactada $(-2 \mu=22 \%)$-Bishop et al $(1960)$
3. Silte - Bishop e Donald (1961)
4. Silte $(-2 \mu=3 \%)$
5.Argila Siltosa $(-2 \mu=23 \%)$
6. Curva teórica de Donald (1960)

Figura 2.9 - Variação dos valores de $\chi$ em função do grau de saturação obtidos para diferentes tipos de solos (Jennings e Burland, 1962).

Analisando estes resultados, Jennings e Burland (1962) sugerem que existe um grau crítico de saturação acima do qual o princípio das tensões efetivas é obedecido. Suas conclusões baseiam-se na comparação com a relação teórica apresentada por Donald (1960), mostrada na Figura 2.9 pela curva número 6. Esta curva teórica obtida por Donald (1960), para solos formados de partículas esféricas, proporcionam solos com estruturas incompreensíveis onde é possível para os mesmos se obter uma equação de tensões efetivas. Para solos siltosos o grau crítico de saturação é da ordem de 40 a $50 \%$ e para solos argilosos fica acima de $85 \%$.

O valor de $\chi$ quando obtido pela comparação entre o comportamento de um solo na condição saturada e não saturada, não tem significância física sendo apenas um parâmetro empírico (Jennings e Burland, 1962). 
Quando calculado para ensaios de resistência ou variação de volume, conforme verificado nos resultados anteriores, os seus valores não são necessariamente idênticos.

Para o trecho onde o $\chi$ obedece à relação teórica, em ensaios de resistência ou variação de volume, a equação 2.3 pode se definida como pressão intergranular. A tensão efetiva é aquela que controla o comportamento do solo o que nem sempre é verdade para a tensão intergranular (Jennings e Burland, 1962). Isto se deve ao fato de que as tensões efetivas são na maioria dos solos não saturados governadas de forma diferente em relação à $\sigma$ e $u^{*}$.

Em termos de variação volumétrica tem-se que, de acordo com a equação 2.1, uma redução na sucção provoca uma redução na tensão efetiva que deve ser acompanhada por um aumento do volume do solo. No entanto, quando um solo não saturado submetido a um valor pequeno de carregamento é umedecido o fenômeno do colapso pode ocorrer, dando-se de acordo com a teoria das tensões efetivas um comportamento inverso (Jennings e Burland, 1962).

A Figura 2.10 mostra a estrutura de um solo saturado que é submetida a um acréscimo igual de carregamento externo e de sucção. Um carregamento externo transmite em condições drenadas, forças normais e cisalhantes entre os grãos tendendo a formar uma estrutura mais densa (Figuras 2.10a e 2.10b) conforme mostrado nas partes (a) e (b). Os meniscos formados pelo aumento de sucção (Figuras 210c e 2.10d) transmitem apenas forças normais entre grãos, aumentando a estabilidade relativa da estrutura. Desta forma, a estrutura do solo não apresenta a mesma variação volumétrica proporcionada pelo carregamento externo. Isto mostra que o princípio das tensões efetivas não se aplica para solos que apresentam o fenômeno de colapso quando umedecidos.

Khalili (2000) afirma que recentemente, em função dos resultados obtidos por diversos pesquisadores, é possível se explicar o fenômeno do colapso dos solos não saturados em termos da equação de tensões efetivas proposta por Bishop (1959), 
necessitando que seja aplicado um apropriado modelo de plasticidade. Neste caso o fenômeno do colapso do solo, ao ser umedecido, é considerado como uma contração volumétrica plástica com tensão efetiva constante.
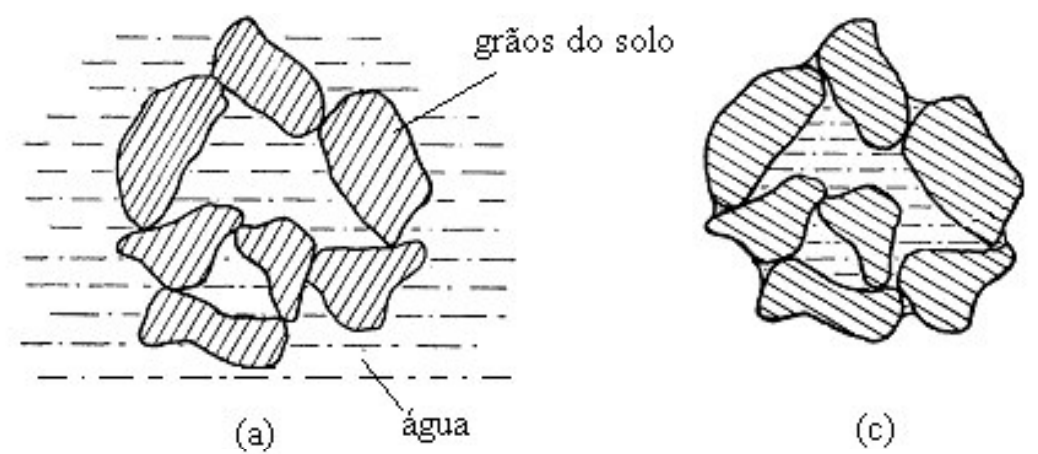

(c)

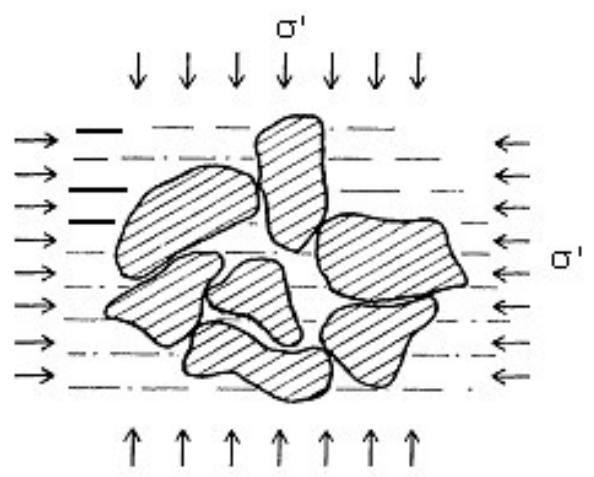

(b)

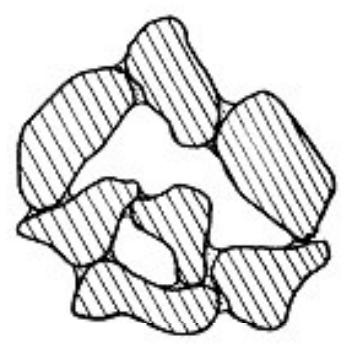

(d)

Figura 2.10 - Variação volumétrica da estrutura do solo em função de um mesmo incremento de carregamento externo (partes (a) e(b)) e de sucção (Partes (c) e (d)). (Jennings e Burland, 1962).

Bishop e Blight (1963) verificaram que a equação de Bishop (1959) pode ser usada com menor dificuldade em termos de resistência ao cisalhamento, controlada por forças intergranular na ruptura, que em termos de variação de volume.

A resistência ao cisalhamento depende principalmente da contribuição das forças normais nos contatos das partículas. Tanto a sucção quanto os carregamentos externos contribuem com as forças de contato, sendo razoável se admitir que uma variação em $\sigma$ seja equivalente a uma variação da sucção (Burland, 1965). 
A diferença fundamental entre as forças externas e a força aplicada internamente pela sucção é a forma como atuam entre as partículas do solo. As forças externas são transmitidas entre os grãos o que não ocorre com a sucção que apenas atrai um grão contra o outro.

\subsection{2 - Equação proposta por Fredlund, Morgenstern e Widger (1978)}

Seguindo uma linha de pensamento diferente, Fredlund et al (1978) não se preocuparam em definir uma equação para as tensões efetivas em solos não saturados, dadas as dificuldades encontradas na aplicação deste conceito. Estes pesquisadores concluíram que duas variáveis de estado de tensão podem ser usadas para descrever o estado de tensão de um solo não saturado. Fredlund et al (1978) definiram a interface ar-água como uma quarta fase independente, denominada membrana contrátil. As variáveis de estado de tensão são examinadas sob o ponto de vista da mecânica do contínuo. As partículas do solo são consideradas incompressíveis e o solo quimicamente inerte. Cada fase é considerada independentemente, estando associada a ela um campo de tensão. A Figura 2.11 mostra um elemento do solo não saturado onde estão indicadas as variáveis de estado de tensão para as partículas do solo $\left(\sigma-\mathrm{u}_{\mathrm{w}}\right)$ e para a membrana contrátil $\left(\mathrm{u}_{\mathrm{a}}-\mathrm{u}_{\mathrm{w}}\right)$.

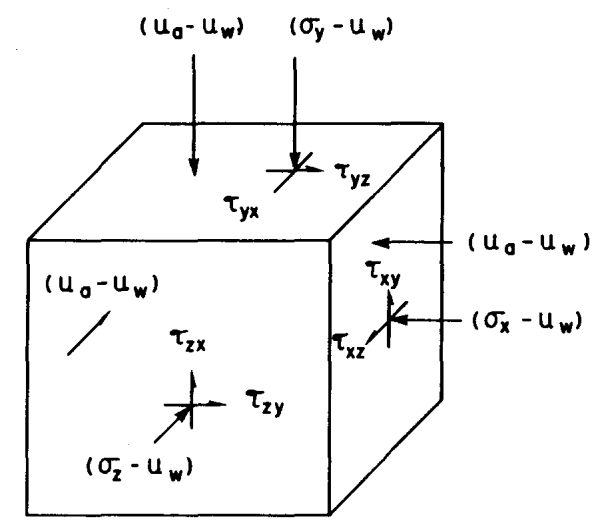

Figura 2.11 - Variáveis de estado de tensão aplicadas a um elemento de solo não saturado. (Fredlund e Morgenstern, 1977). 
Três possíveis combinações de variáveis podem ser usadas para definir o estado de tensão. São elas:

- $\left(\sigma-\mathrm{u}_{\mathrm{w}}\right)$ e $\left(\mathrm{u}_{\mathrm{a}}-\mathrm{u}_{\mathrm{w}}\right)$

- $\left(\sigma-\mathrm{u}_{\mathrm{a}}\right)$ e $\left(\mathrm{u}_{\mathrm{a}}-\mathrm{u}_{\mathrm{w}}\right)$

- $\left(\sigma-\mathrm{u}_{\mathrm{a}}\right)$ e $\left(\sigma-\mathrm{u}_{\mathrm{w}}\right)$

Fredlund e Morgenstern (1977) apresentam a definição de variável de estado de tensão como sendo aquela que não produz distorção ou variação de volume em um elemento do solo quando seus componentes variam, mas o seu valor permanece inalterado. Escolhendo as variáveis $\left(\sigma-\mathrm{u}_{\mathrm{w}}\right)$ e $\left(\mathrm{u}_{\mathrm{a}}-\mathrm{u}_{\mathrm{w}}\right)$, atuando em um elemento do solo não saturado, pode-se alterar os valores de $\sigma, u_{a}$ e $u_{w}$ de forma que $\left(\sigma-u_{a}\right)$ e $\left(u_{a^{-}}\right.$ $\mathrm{u}_{\mathrm{w}}$ ) permaneçam constantes. Se o equilíbrio do elemento é mantido, sem que ocorram variações volumétricas, os valores de $\left(\sigma-\mathrm{u}_{\mathrm{w}}\right)$ e $\left(\mathrm{u}_{\mathrm{a}}-\mathrm{u}_{\mathrm{w}}\right)$ são considerados variáveis de estado de tensão.

A Figura 2.12 apresenta um teste de compressão isotrópica sobre um solo argiloso onde se pode constatar o termo $\left(\sigma_{3}-u_{a}\right)$ como uma variável de estado de tensão. Neste ensaio a tensão confinante e a poro pressão do ar são controladas e a poro pressão da água é medida. Na primeira etapa (até 6000 minutos), $\sigma_{3}$ varia e o termo $\left(\sigma_{3}-u_{a}\right)$ é mantido constante (Figura 2.12a). Para esta situação observa-se nas Figuras 2.12b e 2.12 c que praticamente não ocorrem variações de sucção e variações volumétricas. Estas variações são percebidas quando o termo $\left(\sigma_{3}-u_{a}\right)$ varia e a condição de equilíbrio não mais existe, o que foi constatado para o tempo superior a 6000 minutos. 

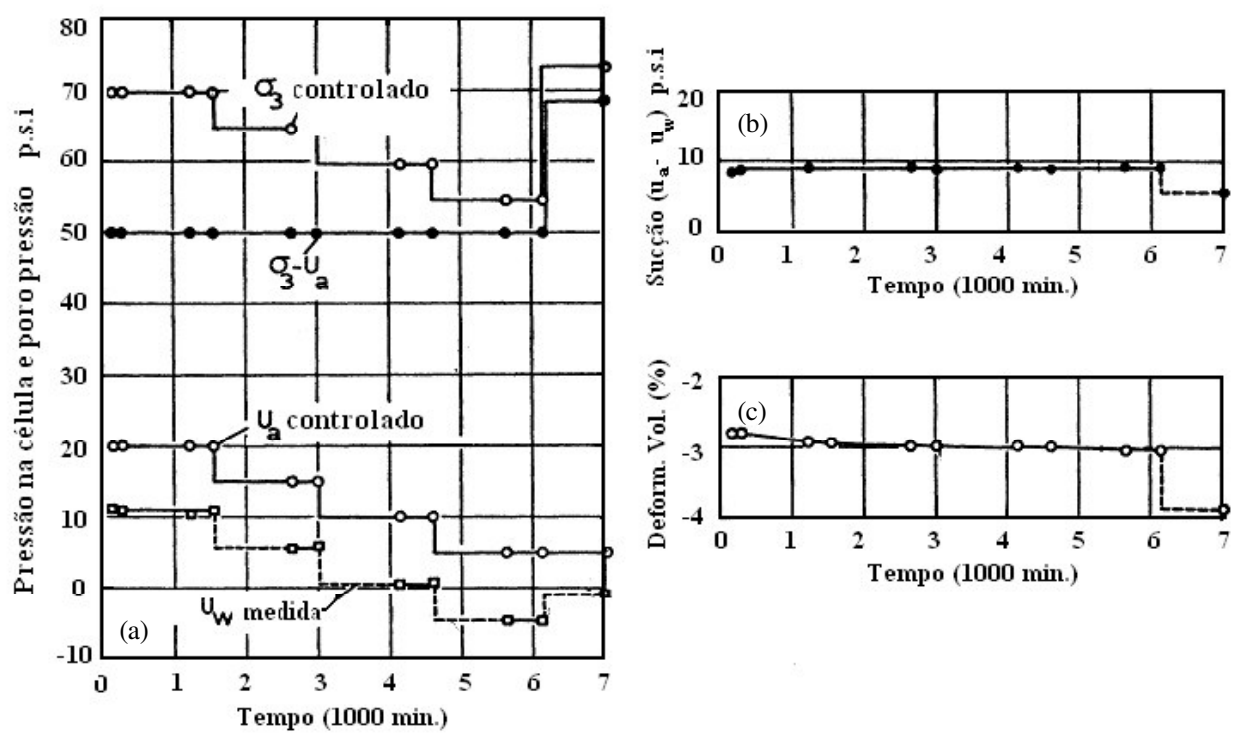

Figura 2.12 - Verificação da sucção e da tensão confinante como variáveis de estado de tensão. (Bishop e Blight, 1963).

As variáveis $\left(\sigma-\mathrm{u}_{\mathrm{a}}\right)$ e $\left(\mathrm{u}_{\mathrm{a}}-\mathrm{u}_{\mathrm{w}}\right)$ mostram-se mais satisfatórias para a prática de engenharia, com a vantagem adicional de que a variação na tensão normal pode ser separada do efeito causado pela variação na poro pressão $\left(\mathrm{u}_{\mathrm{w}}\right)$ (Fredlund; Rahardjo, 1993). Fredlund et al (1978), tomando como base os trabalhos de Bishop et al (1960) e do MIT (1963), formularam uma equação de resistência ao cisalhamento, dada por:

$\tau=c^{\prime}+\left(\sigma-u_{a}\right) \tan \phi^{\prime}+\left(u_{a}-u_{w}\right) \tan \phi^{b}$

Onde: c' - coesão efetiva, $u_{\mathrm{a}}$ - poro pressão do ar, $\mathrm{u}_{\mathrm{w}}$ - poro pressão da água, $\left(\mathrm{u}_{\mathrm{a}}-\mathrm{u}_{\mathrm{w}}\right)$ - sucção matricial, $\phi$ ' - ângulo de atrito efetivo, $\phi^{\mathrm{b}}$ - razão do incremento da resistência com a sucção.

A equação de resistência ao cisalhamento para solos saturados é um caso particular das equações 2.2 e 2.6. De fato, quando $u_{a}=u_{w}$ estas equações se reduzem à equação proposta por Terzaghi (1936). A resistência ao cisalhamento dada pela equação 2.6 é plotada em um gráfico tridimensional onde nos eixos horizontais estão os valores da tensão e da sucção. As variáveis de estado de tensão são empregadas independentemente, podendo-se avaliar a influência de cada uma delas na resistência ao cisalhamento. 
Considerando que os ângulos $\phi^{\prime}$ e $\phi^{\mathrm{b}}$ não variam com o acréscimo de sucção, a superfície tangente aos círculos de Mohr na ruptura define um plano. A Figura 2.13 mostra a superfície de ruptura baseada no critério de Mohr e Coulomb. Evidencias experimental mostram que $\phi^{\mathrm{b}}$ se reduz com o aumento da sucção [e.g. Escário e Sáez, (1986), Abramento e Pinto (1993), Rohm e Vilar (1995)]. Alguns autores observaram que o valor de $\phi$ ' também pode variar em função da sucção [e.g. Escário e Sáez (1986), Escário e Jucá (1989), Rohm e Vilar (1995)]. Alguns parâmetros obtidos para os solos naturais do Brasil são apresentados por De Campos (1997).

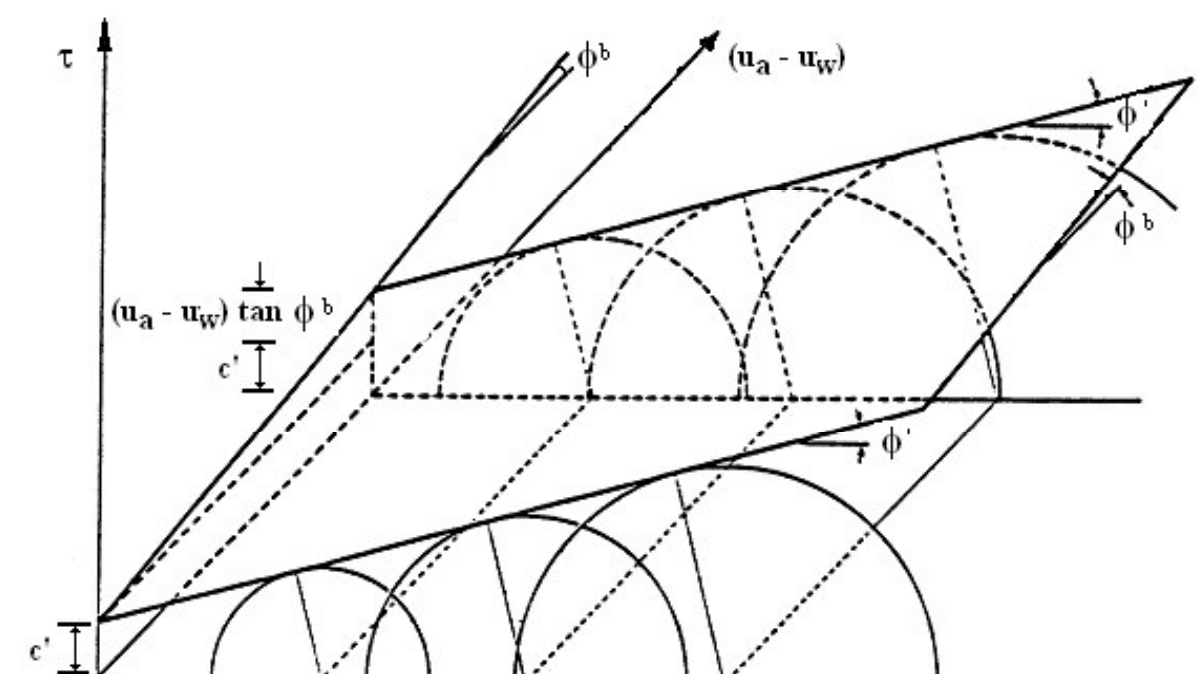

Figura 2.13 - Representação da equação de Fredlund et al (1978) para resistência ao cisalhamento baseada no critério de Mohr e Coulomb.

A representação da superfície de ruptura por um plano, apresentado na Figura 2.13, foi determinada das análises dos resultados de ensaios triaxiais com sucção controlada realizados por Bishop et al (1960), citados no item 2.1, e ensaios triaxiais realizados no MIT (1963), que apresentam esta tendência. No entanto a não linearidade foi verificada para alguns solos em ensaios de cisalhamento direto com sucção controlada (Escário e Sáes, 1986). Fredlund et al (1987) sugerem diversas maneiras de se trabalhar com solos que apresentam variações não lineares de resistência em função da sucção. 
A envoltória pode ser adotada como bilinear ou quando a tendência for altamente não linear a mesma pode ser discretizada em pequenos segmentos lineares.

\subsection{3 - Comparação entre as equações de resistência ao cisalhamento propostas por Bishop (1959) e Fredlund et al (1978)}

Comparando as equações propostas por Bishop (1959) e Fredlund et al (1978) para a resistência ao cisalhamento de solos não saturados temos que o valor de " $\chi$ " é dado por:

$\chi=\frac{\operatorname{tg} \phi^{b}}{\operatorname{tg} \phi^{\prime}}$

Para uma superfície de ruptura plana onde $\phi^{\prime}$ e $\phi^{\mathrm{b}}$ apresentam valores constantes, tem-se um único valor de $\chi$ em termos de resistência ao cisalhamento. A equação proposta por Bishop (1959) utiliza uma única envoltória de resistência que representa os solos na condição saturada e não saturada. Para um ensaio não saturado os incrementos na resistência ao cisalhamento em função do aumento do valor da sucção, têm significados diferentes ao se aplicar às equações 2.2 e 2.6.

Para a proposta de Bishop (1959), que utiliza uma única envoltória de resistência, um incremento na sucção corresponde a um incremento nas tensões dada por $\chi\left(\mathrm{u}_{\mathrm{a}}-\mathrm{u}_{\mathrm{w}}\right)$. Para a proposta de Fredlund et al (1978), que representa a resistência em um gráfico tridimensional, um incremento na sucção corresponde a uma translação da envoltória de ruptura da condição saturada de um valor igual a $\left(\mathrm{u}_{\mathrm{a}}-\mathrm{u}_{\mathrm{w}}\right) \operatorname{tg} \phi^{\mathrm{b}}$. Estas considerações podem ser visualizadas na Figura 2.14.

A representação da resistência ao cisalhamento em um gráfico tridimensional já havia sido proposta anteriormente por Bishop e Blight (1963), utilizando para cada eixo os valores de $\left(\sigma_{1}-\sigma_{3}\right) / 2,\left(\sigma_{1+} \sigma_{3}\right) / 2-\mathrm{u}_{\mathrm{a}} \mathrm{e}\left(\mathrm{u}_{\mathrm{a}}-\mathrm{u}_{\mathrm{w}}\right)$. Para este tipo de representação, apresentada na Figura 2.15, a superfície de ruptura passa pelo ponto de máxima ordenada dos círculos de Mohr. 


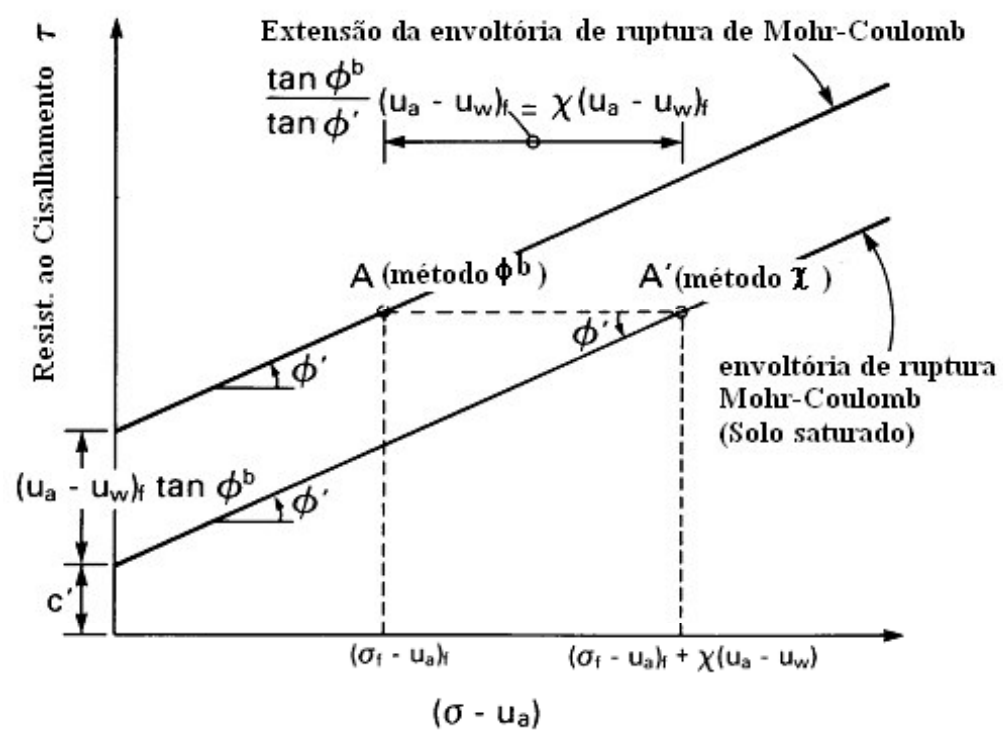

Figura 2.14 - Comparação do efeito da sucção na resistência ao cisalhamento utilizando as equações propostas por Bishop (1959) e Fredlund et al (1978) (Fredlund e Rahardjo, 1993).
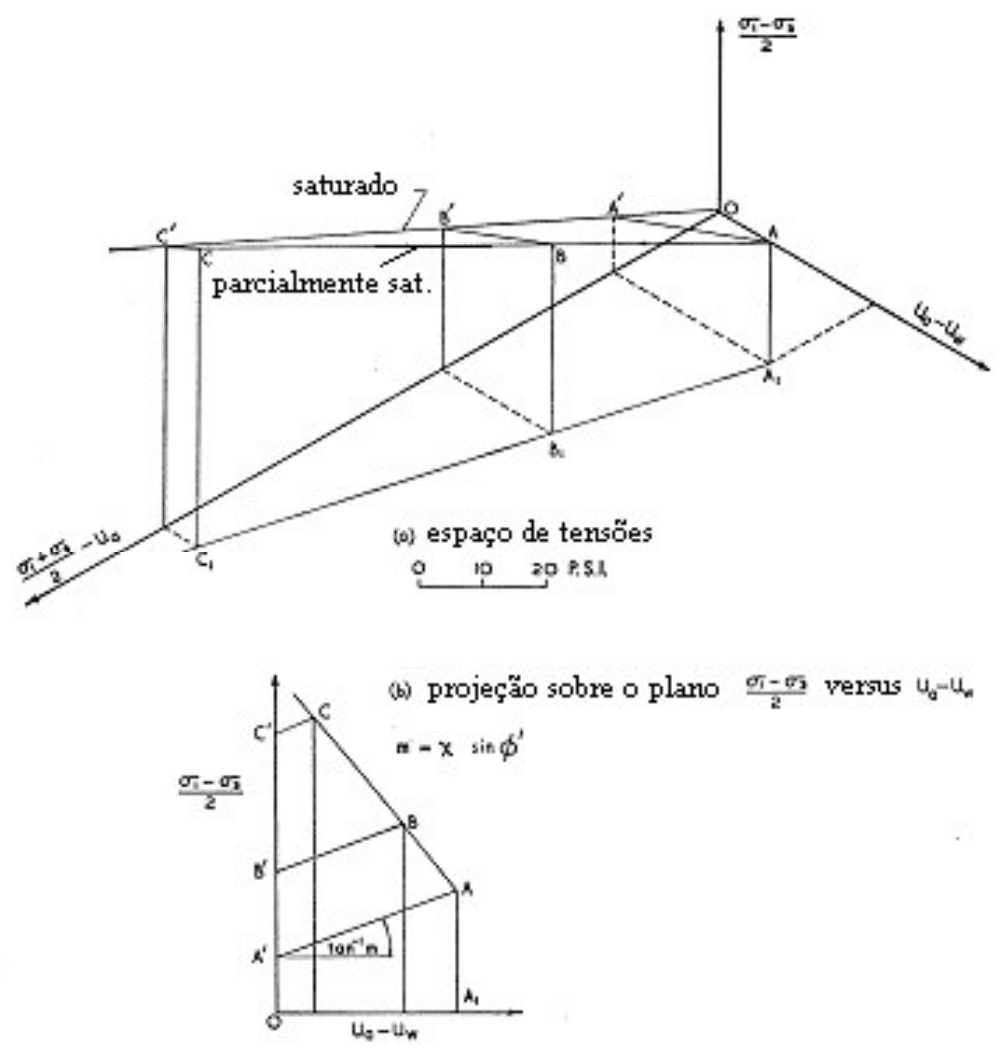

Figura 2.15 - Resultados de ensaios triaxiais realizados em corpos de prova compactados com teor de umidade de $11.6 \%$ (Bishop e Blight, 1963). 
Na Figura 2.15 o ponto A é o resultado de um ensaio não confinado e os pontos B e C são de amostras moldadas com uma mesma umidade e submetidas a diferentes pressões confinantes. Na parte (b) da Figura 2.15, as inclinações das retas AA', BB' e CC' estão relacionadas com o valor de $\chi$ pela seguinte expressão:

$m=\chi \operatorname{sen} \phi^{\prime}$

Em relação à proposta de Fredlund et al (1978), o valor de “m” na equação 2.8, está relacionado ao valor de $\phi^{\mathrm{b}}$. Gulhati e Satija (1981) e Abramento e Pinto (1993) realizaram ensaios triaxiais não saturados, utilizando para análise de seus resultados as equações 2.2 e 2.6 .

Estes autores observaram que a relação entre o valor de $\chi$ e o grau de saturação apresenta considerável dispersão, o mesmo não sendo constatado para a relação entre $\phi^{\mathrm{b}}$ e sucção. No entanto, não se sabe se este tipo de comportamento ocorre para diferentes tipos de solo. Estes autores encontraram valor de $\chi$ maior que 1 . Para que isto ocorra se faz necessário que o incremento na resistência em função da sucção, representada pelo valor de $\phi^{\mathrm{b}}$, seja maior que a parcela de aumento da resistência atribuída a pressão de confinamento, representada por $\phi$ '. Com os conhecimentos disponíveis fica difícil de se compreender estes resultados.

Abramento e Pinto (1993) salientam que existe uma grande influência dos valores de parâmetros efetivos na determinação de $\chi$. Ao utilizarem o ângulo de atrito efetivo de $38^{\circ}$, determinados em ensaios triaxiais $\mathrm{CU}$, encontraram valores de $\chi$ igual a 1.4 . O valor $\chi$ seria menor ou igual a 1 para ângulo de atrito igual a $40^{\circ}$. Variando-se o ângulo de atrito de apenas $2^{\circ}$ os valores de $\chi$ passam a apresentar valores coerentes com a teoria desenvolvida para sua determinação. Reavaliando os resultados destes ensaios triaxiais CU, publicados em Abramento (1988), verifica-se que o melhor ajuste da envoltória de resistência se obtém ao se adotar ângulo de atrito igual a $40^{\circ} \mathrm{e}$ não $38^{\circ}$. 
Apesar dos valores de $\chi$ não poderem ser aplicados na equação 2.2 de forma a representar as tensões efetivas dos solos não saturados, a proposta de Bishop (1959) aplicada em termos de resistência ao cisalhamento, tem sido utilizada por diversos autores, tais como, Khalili e Khabbaz (1998) e Oberg e Sallfors (1995). No entanto, a equação 2.8 formulada por Fredlund et al (1978), tem despertado maior interesse.

\section{2 - Características dos solos compactados}

Os valores de resistência ao cisalhamento estão relacionados às trajetórias de tensões impostas aos corpos de prova durante a sua fase de preparação e cisalhamento. Os corpos de prova, ensaiados nesta pesquisa, foram moldados em três pontos da curva de compactação e preparados para a fase de cisalhamento impondose diferentes trajetórias de umidade. As estruturas iniciais, função das condições de moldagem, se alteram ao se aplicar este procedimento. É importante entender estas modificações estruturais para uma melhor interpretação dos resultados dos ensaios. Os possíveis arranjos das partículas nos solos naturais e compactados são os mais diversos possíveis e função de diferentes fatores. Neste item são apresentados alguns aspectos relacionados às diferentes características dos solos compactados em diferentes condições da curva de compactação.

\subsection{1 - Estrutura dos corpos de prova moldados para a obtenção da curva de compactação}

Lambe (1958), utilizando os conceitos da química dos colóides, propôs o tipo de arranjo estrutural apresentado pelas amostras argilosas moldadas na curva de compactação. As partículas do solo são consideradas como colóide, quando as forças elétricas, que atuam entre as mesmas, superam as forças de massa. Na Figura 2.16 a amostra compactada no ramo seco (Ponto A) não ocorre a formação da dupla camada, devido à deficiência de água. Desta forma se reduz a repulsão entre as partículas tendendo a formar uma estrutura floculada. 
No ponto B ocorre a redução da concentração eletrolítica, diminuindo o grau de floculação, o que permite uma maior orientação das partículas. As partículas estando mais próximas produzem uma estrutura mais densa. A adição de água funciona como um lubrificante fazendo com que as partículas deslizem entre si. Para umidades maiores que a umidade ótima ocorre uma maior expansão da dupla camada e as partículas dos colóides ficam alinhadas formando uma estrutura dispersa. O maior grau de alinhamento e o completo desenvolvimento da dupla camada, faz com que as forças de repulsão superem as força atrativas reduzindo a densidade.

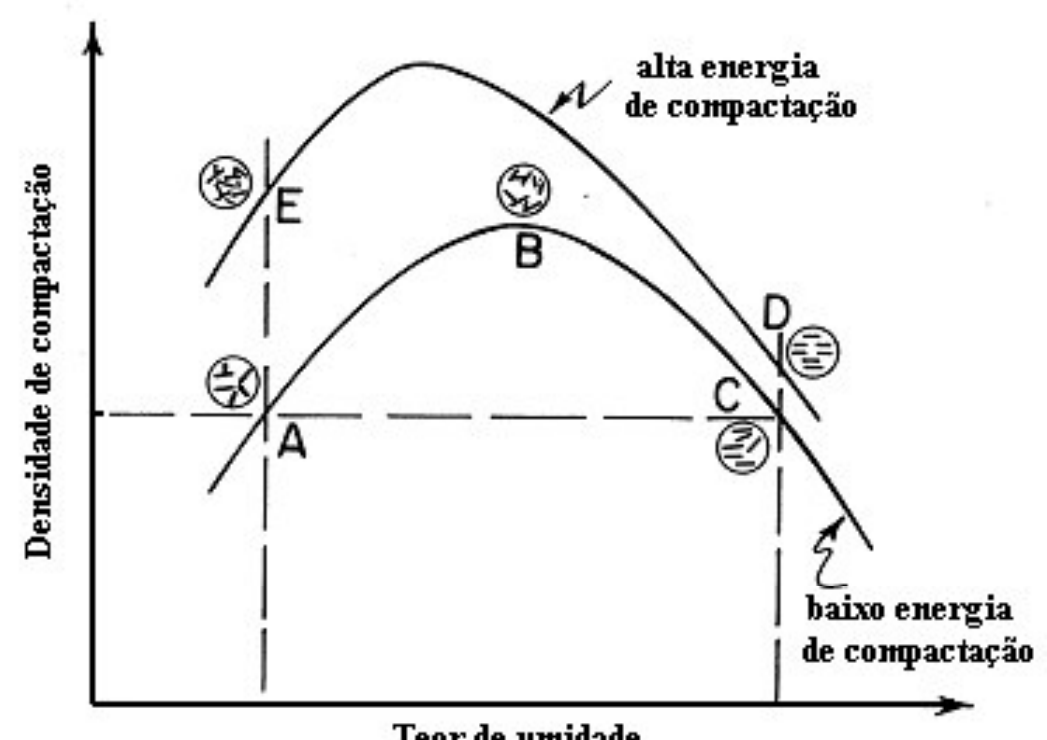

Figura 2.16 - Variação da estrutura do solo na compactação (Lambe; 1958).

Seed e Chan (1959) salientam o fato de que Lambe (1958) propôs estes diferentes tipos de estrutura moldando os corpos de prova por pisoteamento. Neste procedimento foi utilizado o molde Harvad Miniatura, não existindo confirmação de suas hipóteses para outros métodos de compactação (estática e dinâmica). As variações das estruturas com o incremento do teor de umidade dependem do tipo de solo. Seed e Chan (1959) sugerem cinco tipos de classificação para os solos, em função do tipo de estrutura de poros resultante da compactação: 
Classe 1 - Solos que apresentam tendência a dispersar apenas por incremento da umidade.

Classe 2 - Solos que apresentam tendência a flocular, de forma que um aumento na umidade não produz aumento da dispersão. A combinação do aumento de umidade com um método de compactação que produz grandes deformações cisalhantes podem produzir uma estrutura dispersa.

Classe 3 - Solos onde a tendência a flocular é tão grande que só um aumento da umidade e utilização de um método de compactação com grandes deformações cisalhantes produzem uma estrutura dispersa.

Classe 4 - Solos que tendem a dispersar mesmo quando moldados no ramo seco, com o método de compactação induzindo ou não deformações cisalhantes.

Classe 5 - Solos que apresentam pronunciado incremento na dispersão quando compactado no ramo úmido, mas tal fato é mascarado por outros fatores de forma a não se perceber as variações estruturais ocorridas.

As deformações cisalhantes produzidas pelos métodos de compactação interferem na estrutura do solo. Para os solos que se enquadram na classe 2, a deformação cisalhante é de fundamental importância na compactação das amostras no ramo úmido. De acordo com o método empregado a estrutura resultante pode ser floculada ou dispersa.

Os principais tipos de compactação são a estática, dinâmica e por pisoteamento, com as deformações cisalhantes aumentado nesta ordem. Na compactação estática a amostra é submetida a um esforço uniformemente distribuído sobre toda a sua superfície, de forma que não ocorrem deformações cisalhantes. A compactação dinâmica é muito utilizada para obtenção da curva de compactação ao se deixar cair sobre a amostra de solo um peso de uma altura constante. Como a área deste peso é 
menor que a área da amostra, ocorrem deformações cisalhantes quando o mesmo penetra no solo.

A compactação por pisoteamento utiliza uma haste acoplada a uma mola onde se regula o esforço aplicado a amostra. Como a área da haste é menor que a do peso utilizado na compactação dinâmica, ocorre uma maior penetração no solo e consequentemente maiores deformações cisalhantes.

\subsection{2 - Formação de agregações de partículas no processo de compactação}

O aprimoramento das técnicas de observação da microestrutura do solo, utilizando a microscopia eletrônica de varredura e a técnica de intrusão de mercúrio, fez com que as diferentes estruturas proposta por Lambe (1958) fossem revistas. Diversos autores concluíram que em amostras compactadas com baixo grau de saturação as partículas não estão dispostas de forma homogênea em toda o volume do corpo de prova. Croney et al (1958) concluíram que o solo argiloso compactado não se apresenta como uma massa uniforme de partículas, mas com agregações separadas por vazios. Brackley (1973) sugere que as agregações das partículas de argila embora saturada são mantidas unidas por sucção, estando os vazios entre as agregações preenchidas com ar.

Toll (2000) compactou amostras de um solo pedregulhoso laterítico usando três esforços de compactação. Em seus experimentos verificou que a compactação na umidade ótima pode ou não apresentar algum nível de agregação. Para a curva Proctor normal a sucção do corpo de prova moldado nas condições da umidade ótima

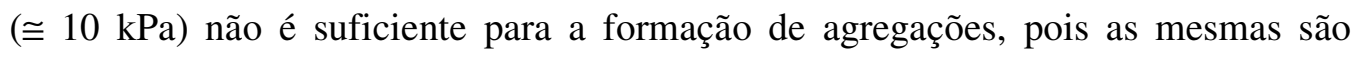
facilmente destruídas pelos esforços de compactação.

No entanto, ao se aplicar uma energia de compactação equivalente a do Proctor Modificado a sucção do corpo de prova moldado na umidade ótima passa a ser maior

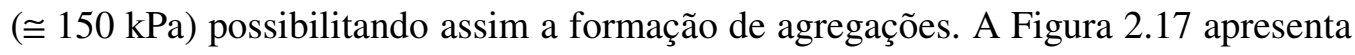
o incremento do grau de agregação das partículas do solo em função do grau de 
saturação. Verifica-se nesta figura que para grau de saturação menor que $90 \%$ o solo começa a apresentar aumento de agregações, tornando-se totalmente agregado para valores inferiores a $50 \%$.

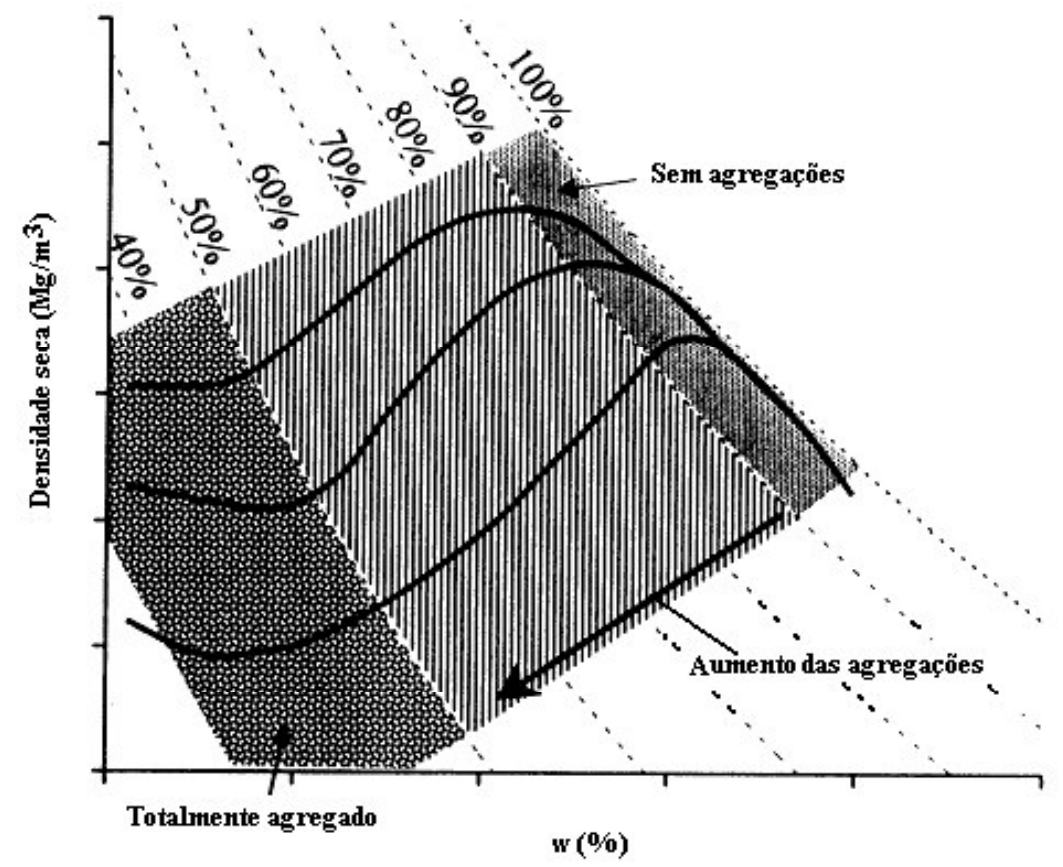

Figura 2.17 - Variação da agregação de partículas em função do grau de saturação na compactação (Toll, 2000).

Delage et al (1996) estudou a estrutura de um solo siltoso $\left(\mathrm{w}_{\mathrm{l}}=37 \%\right.$ e $\left.\mathrm{w}_{\mathrm{p}}=19 \%\right)$ compactado estaticamente. Em seus estudos foram utilizadas a microscopia eletrônica de varredura e a técnica de intrusão de mercúrio. Para a aplicação da intrusão de mercúrio a água deve ser totalmente removida dos poros do solo. No entanto, a remoção da água por secagem faz com que se formem meniscos que podem ocasionar variações nos arranjos das partículas. Para se evitar estas variações, a amostra foi rapidamente congelada em nitrogênio líquido e submetida a vácuo.

Neste procedimento ocorre a sublimação da água presente nos poros do solo. Para a amostra compactada no ramo seco constatou-se uma distribuição bimodal de poros. A Figura 2.18 apresenta as distribuições dos poros dos corpos de prova compactados no ramo seco, umidade ótima e no ramo úmido, obtidas por intrusão de mercúrio. 
Observa-se nesta figura que para diâmetro de poros menores que $0.1 \mu \mathrm{m}$ as curvas são as mesmas para os três corpos de prova. Este fato indica que, para este intervalo de diâmetro de poro, os corpos de prova apresentam estruturas semelhantes.

Para o corpo de prova moldado no ramo seco fica bem caracterizada a distribuição bimodal de poros, apresentando valores médios de $4 \mu \mathrm{m}$ e $0,2 \mu \mathrm{m}$. Na foto apresentada na Figura 2.19 observa-se a formação de agregação de partículas de um solo siltoso compactado no ramo seco.

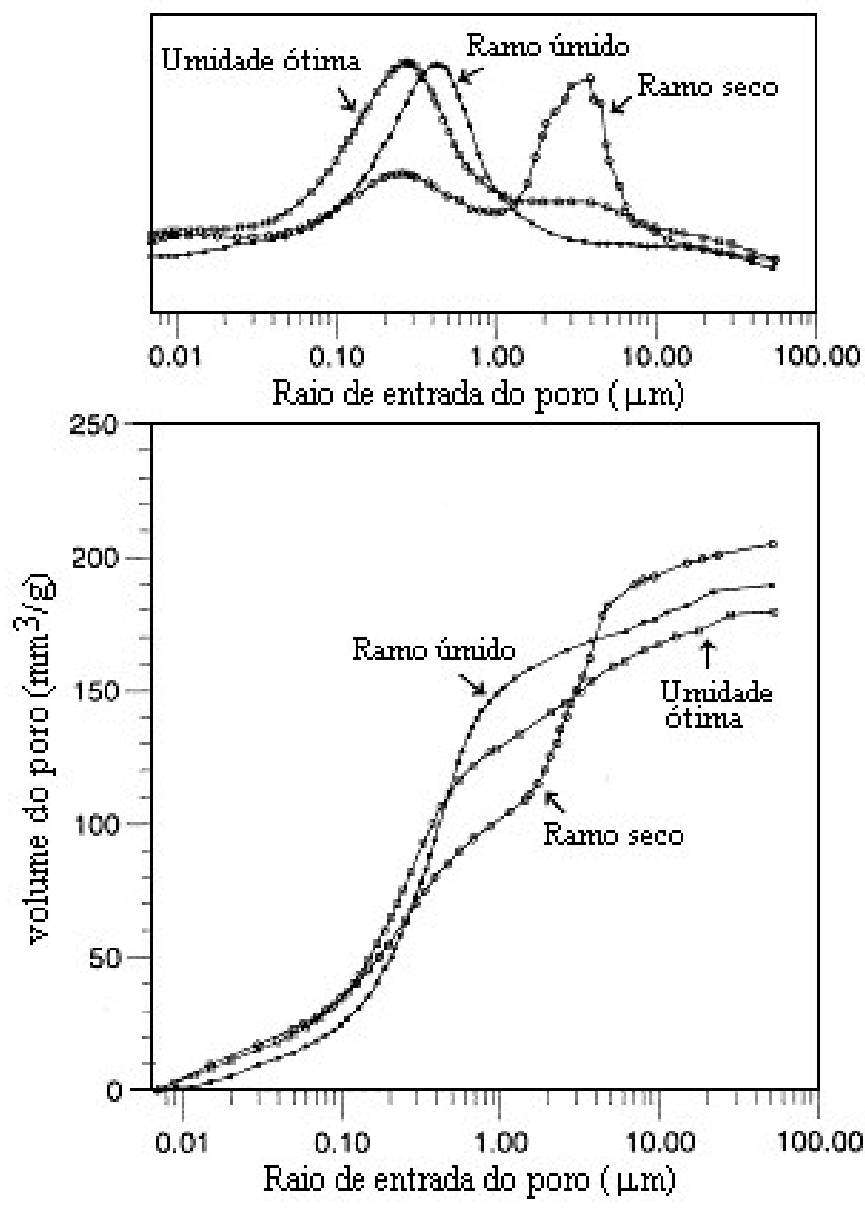

Figura 2.18 - Distribuição de volume de poros em função do diâmetro (Delage et al; 1996). 


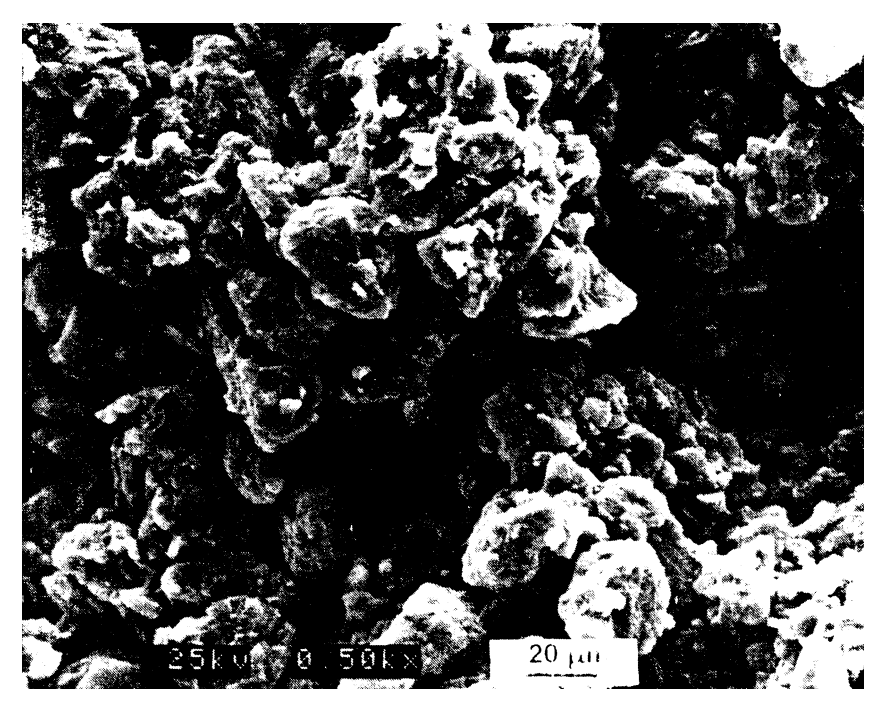

Figura 2.19 - Imagem de microscopia eletrônica de varredura obtida de uma amostra compactada no ramo seco, mostrando a formação de agregações (Delage et al, 1996).

Ahmed et al (1974) propôs alguns intervalos de diâmetros dos poros para facilitar a análise dos resultados. Valores de diâmetro menores que $0,5 \mu \mathrm{m}$ são denominados de poros finos, valores entre $0,5 \mu \mathrm{m}$ e $50 \mu \mathrm{m}$ são denominados de poros médios e acima de $50 \mu \mathrm{m}$ poros grandes. Estes pesquisadores estudaram a influência de diversos esforços, tipos de compactação e umidade de moldagem na distribuição de poros. Foi utilizado um solo argiloso conhecido comercialmente como Grundite, moldados com diferentes teores de umidade na curva de compactação. Estes estudos baseiam-se nos resultados de intrusão de mercúrio. Na Figura 2.20 estão os resultados de amostras compactadas dinamicamente (Proctor Normal) com diferentes teores de umidades iniciais. Ahmed et al (1974) verificaram que o tipo de compactação não interfere muito na distribuição de poros, ao contrário do que foi constatado na Figura 2.20 para as variações no teor de umidade. Este fato pode ser observado pelos resultados apresentados na Figura 2.21 para amostras de solo compactado no ramo seco. 


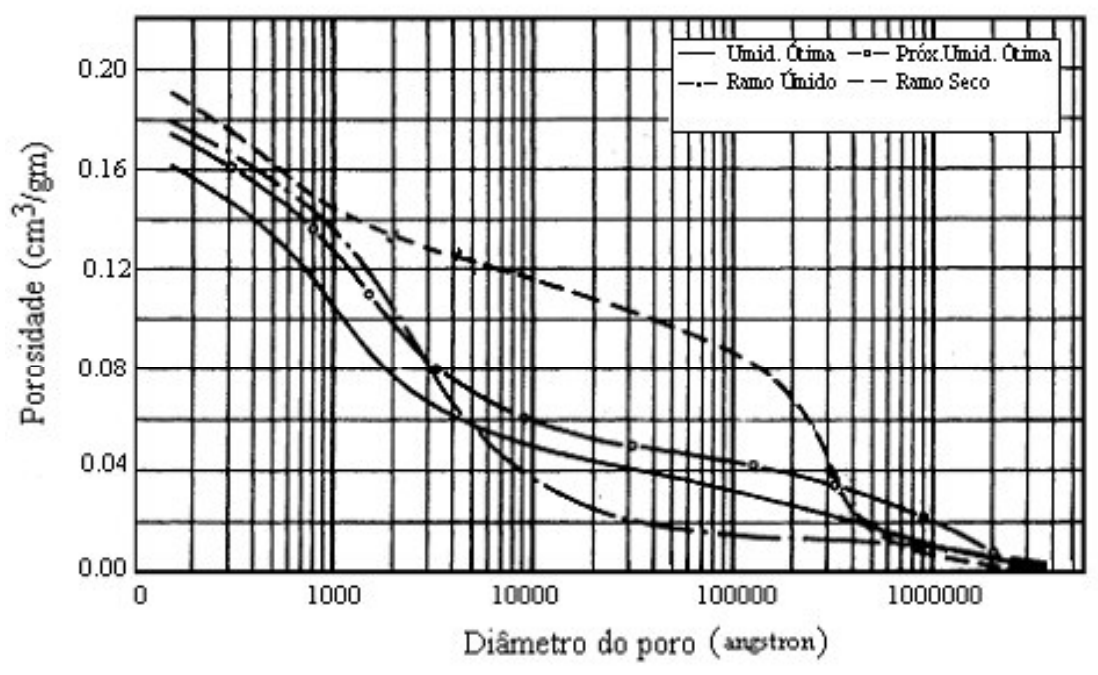

Figura 2.20 - Resultado do ensaio de intrusão de mercúrio realizado em amostras compactadas dinamicamente (Proctor Normal) em diferentes pontos da curva de compactação (Ahmed et al; 1974).

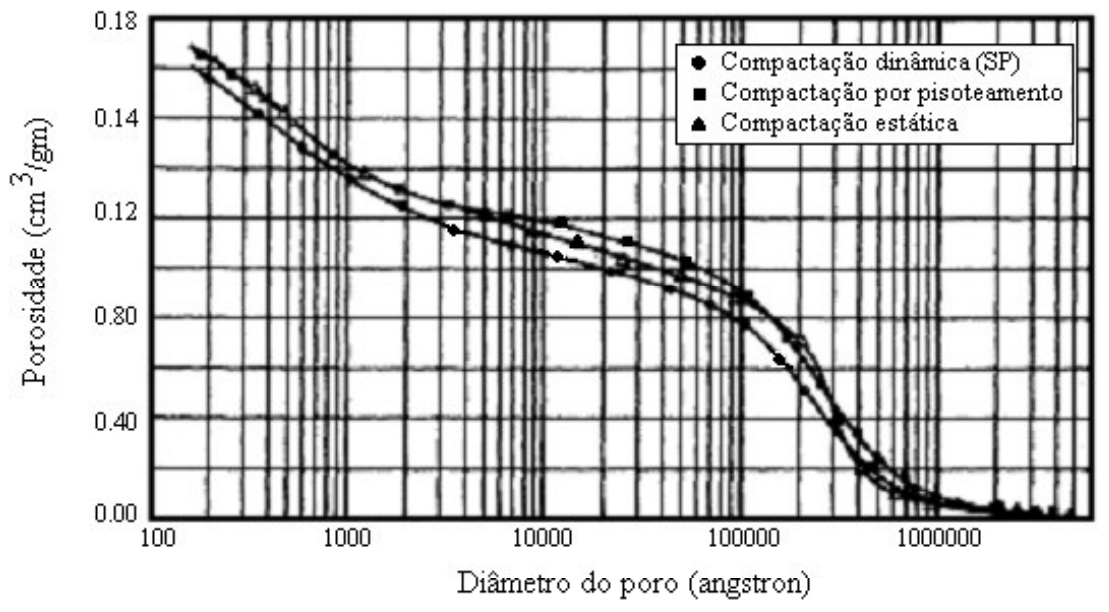

Figura 2.21 - Resultado do ensaio de intrusão de mercúrio realizado em amostras compactadas no ramo seco utilizando diferentes métodos de compactação (Ahmed et al, 1974). 


\subsection{3 - Características de expansão e contração em função da variação do teor de umidade}

Neste item são apresentadas algumas características das variações volumétricas de amostras de solo compactadas nas condições da curva de compactação. A compactação do solo nestas condições confere aos corpos de prova diferentes propriedades de variação volumétrica, em função da secagem ou umedecimento. Os solos compactados no ramo seco, em relação às condições de compactação no ramo úmido, apresentam estruturas mais sensíveis a alterações (Lambe, 1958). O maior entrosamento entre as partículas de solo compactado nesta condição de moldagem esta associado a menores reduções de volume durante a secagem (Lambe, 1958). Para Seed e Chan (1959) esta característica sugere que a contração volumétrica apresentada por um corpo de prova pode servir como um indicativo da orientação das partículas.

A Figura 2.22 apresenta uma comparação entre a contração axial de corpos de prova compactados no ramo seco e no ramo úmido. Para estes testes o solo compactado em três pontos do ramo seco foi umedecido, com o volume permanecendo constante, até atingirem as mesmas condições de moldagem do solo compactado no ramo úmido. Os corpos de prova assim preparados apresentam o mesmo valor de densidade e umidade e diferentes estruturas iniciais. Observa-se na Figura 2.22 que quanto maior a dispersão das partículas do solo após a moldagem, menor é a contração axial do corpo de prova.

A expansão é maior para as estruturas floculadas, diminuindo este valor à medida que as partículas apresentam um arranjo mais disperso. Seed e Chan (1959) também analisaram a influência da estrutura dos corpos de prova nos valores da pressão de expansão. Na Figura 2.23 está a variação deste valor para uma argila siltosa moldada em diferentes pontos da curva de compactação. Estes resultados foram obtidos por inundação dos corpos de prova não sendo permitida a sua variação volumétrica. 
Observa-se que as amostras compactadas no ramo seco apresentam maior pressão de expansão, reduzindo este valor à medida que aumenta a umidade de moldagem.

Tendência semelhante foi constatada por Attom et al (2001) ao moldar três diferentes tipos de solo com a mesma densidade seca e com teores de umidade de 10, 15, 20, 25 e $30 \%$. Conforme citado no item 2.2.2, estes corpos de prova apresentam diferentes estruturas iniciais, aumentando o grau de dispersão das partículas de solo na medida em que aumenta o teor de umidade de moldagem. A pressão de expansão também foi determinada sem permitir a variação volumétrica do corpo de prova.

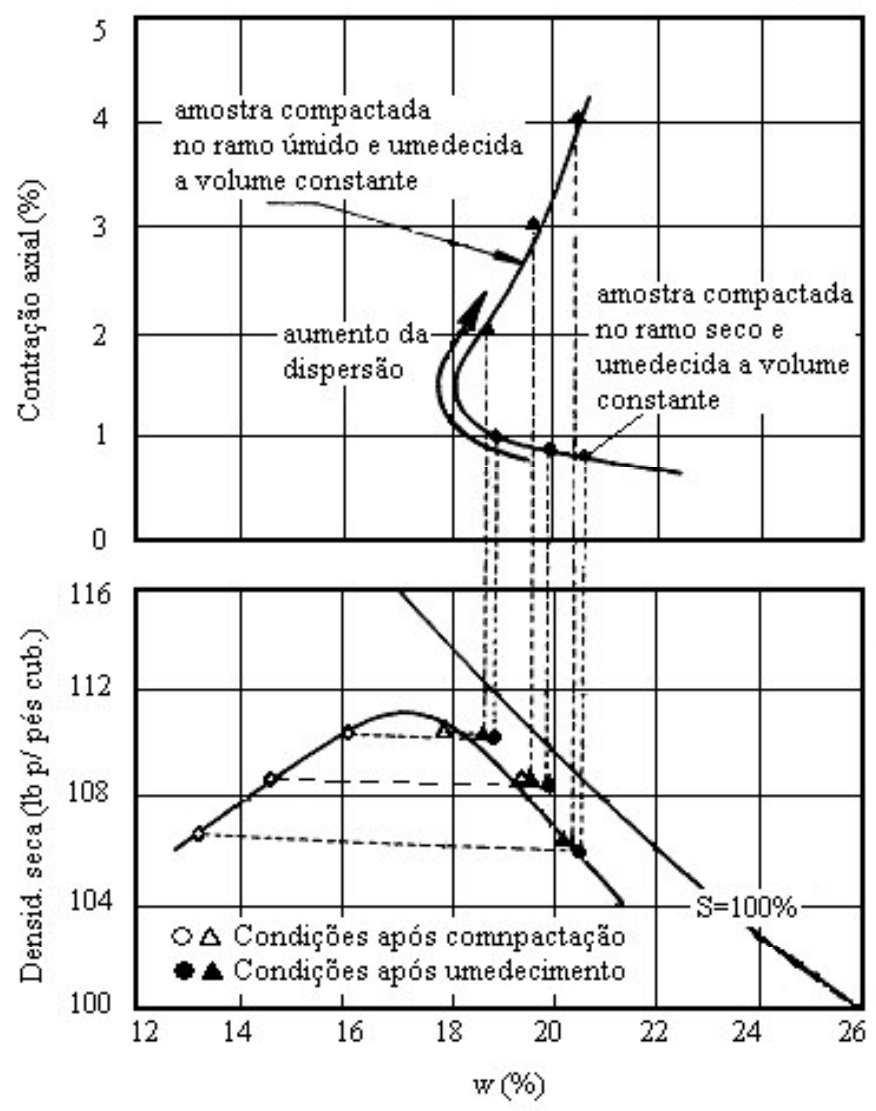

Figura 2.22 - Valores da contração axial apresentada por corpos de prova compactados no ramo seco e no ramo úmido (Seed e Chan, 1959). 

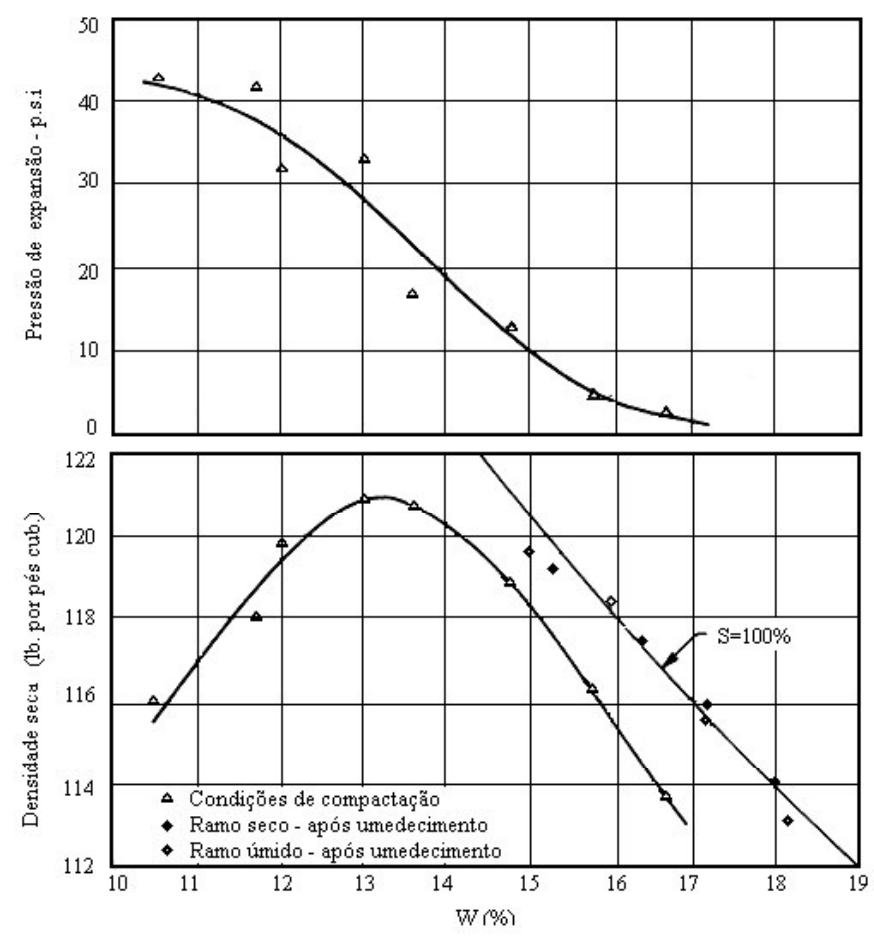

Figura 2.23 - Valores da pressão de expansão correspondentes a corpos de prova moldados ao longo da curva de compactação (Seed e Chan, 1959).

Khattab et al (2002) obtiveram a curva de pressão de expansão em função do teor de umidade para amostras compactadas estaticamente em quatro pontos da curva de compactação. Foi utilizado neste estudo um solo argiloso bentonitico altamente expansivo (FOCA). Na Figura 2.24 está a relação entre a pressão de expansão, determinada a volume constante, e o teor de umidade de moldagem. Para estes resultados não foi observada a mesma tendência dos resultados apresentados na Figura 2.23, devido ao valor da pressão de expansão do corpo de prova compactado com teor de umidade de $29 \%$. Em relação aos resultados obtidos por Seed e Chan (1959) e Attom et al (2000), era de se esperar que um aumento da pressão de expansão com a redução do teor de umidade. 


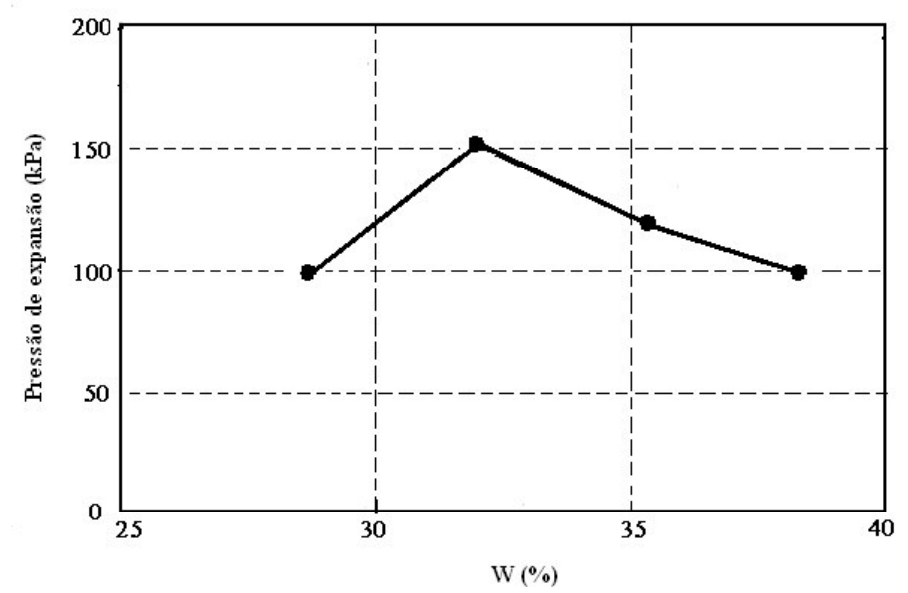

Figura 2.24 - Valores da pressão de expansão obtidos de corpos de prova compactados estaticamente na curva de compactação (Khattab et al, 2002).

\subsection{4 - Variação da estrutura de poros do corpo de prova após o umedecimento ou secagem}

As variações volumétricas apresentadas pelos corpos de prova, citadas no item 2.2.3, podem ser acompanhadas de variações estruturais. Simms e Yanful (2001) compactaram, com teor de umidade acima da ótima, um solo proveniente de um depósito glacial de Ontário (Canadá) utilizando o molde Proctor normal. Foram moldados 4 corpos de prova que após serem saturados por contrapressão foram colocados na placa de pressão. Ao atingirem a sucção de 0, 840, 1400 e $2500 \mathrm{kPa}$ foi retirado um corpo de prova para a obtenção da distribuição de poros por intrusão de mercúrio, estando estes resultados apresentados na Figura 2.25. Observa-se nesta

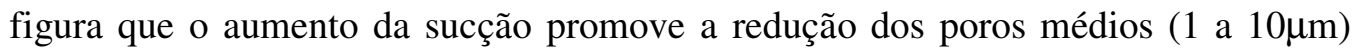
com os poros finos $(<0.1 \mu \mathrm{m})$ permanecendo praticamente inalterados. Os termos poros médios e poros finos foram utilizados de acordo com a proposta de Ahmed et al (1974) apresentada no item 2.2.2. 


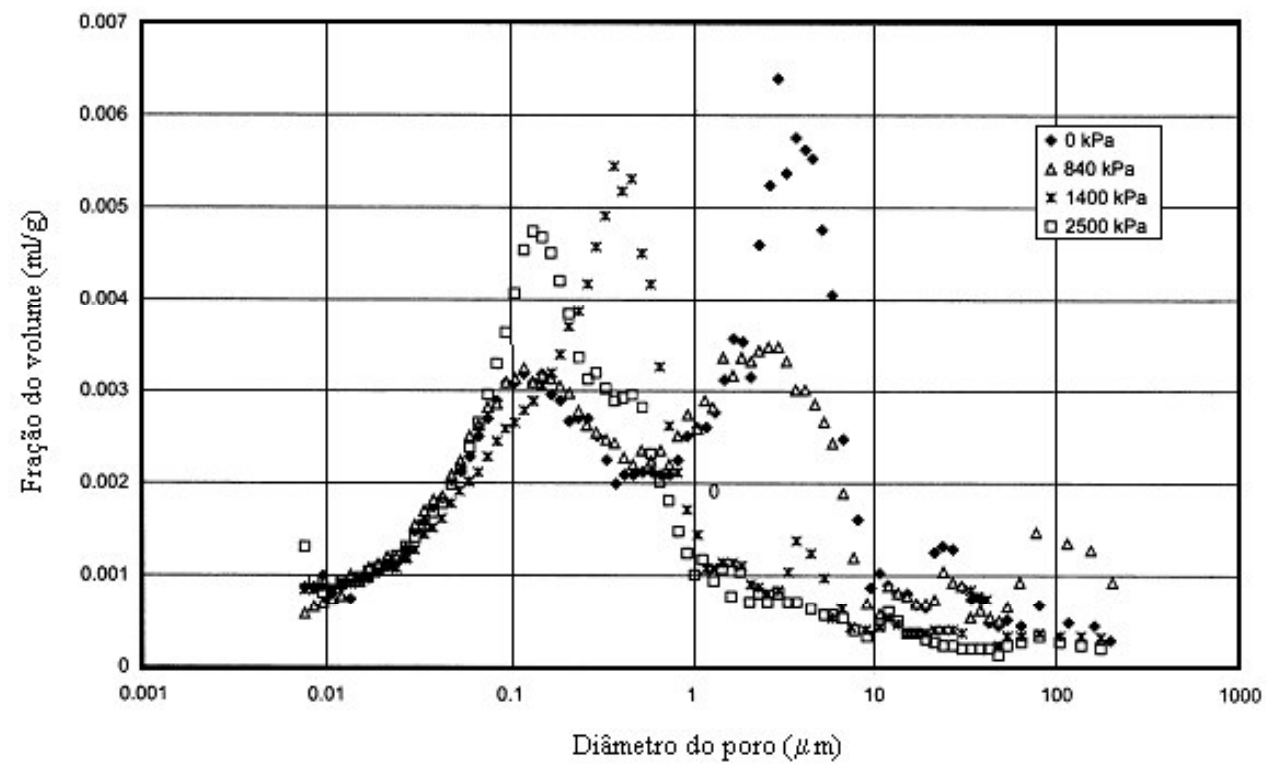

Figura 2.25 - Distribuição de poros de um mesmo solo moldado no ramo úmido após atingir diferentes valores sucções (Simms e Yanful, 2001).

Os esforços a que os corpos de prova foram submetidos, em função da variação de sucção, não foram suficientes para promover a redução dos poros finos. Bengochea et al (1979) chegaram à mesma conclusão estudando solos preparados pela mistura de silte e caulim com diferentes proporções, afirmando que os pequenos poros estão relacionados ao tamanho das partículas de argila, mineralogia, potencial de expansão e plasticidade, sendo independentes da variação de umidade ou sucção. Na Figura 2.22, Seed e Chan (1959) não levam em consideração as prováveis variações da estrutura do corpo de prova moldado no ramo seco ao ser umedecido até as condições do ramo úmido. Suas conclusões baseiam-se na hipótese que a estrutura deste corpo de prova permanece inalterada durante o umedecimento.

\subsection{5 - Sucção dos corpos de prova moldados na curva de compactação}

Olson e Langfelder (1965) determinaram a sucção inicial para solos moldados com diferentes umidades e três níveis de esforços de compactação. As sucções iniciais nas respectivas curvas de compactação foram determinadas pela técnica da translação de eixos. 
Os resultados obtidos por estes autores estão apresentados na Figura 2.26. Foi utilizada a argila Grundite compactada estaticamente. Observa-se nesta figura que a sucção inicial esta mais fortemente relacionada ao teor de umidade sendo em segundo plano função da energia de compactação. Para umidades menores que $19 \%$ o aumento da energia de compactação não influenciam os valores da sucção dos corpos de prova.

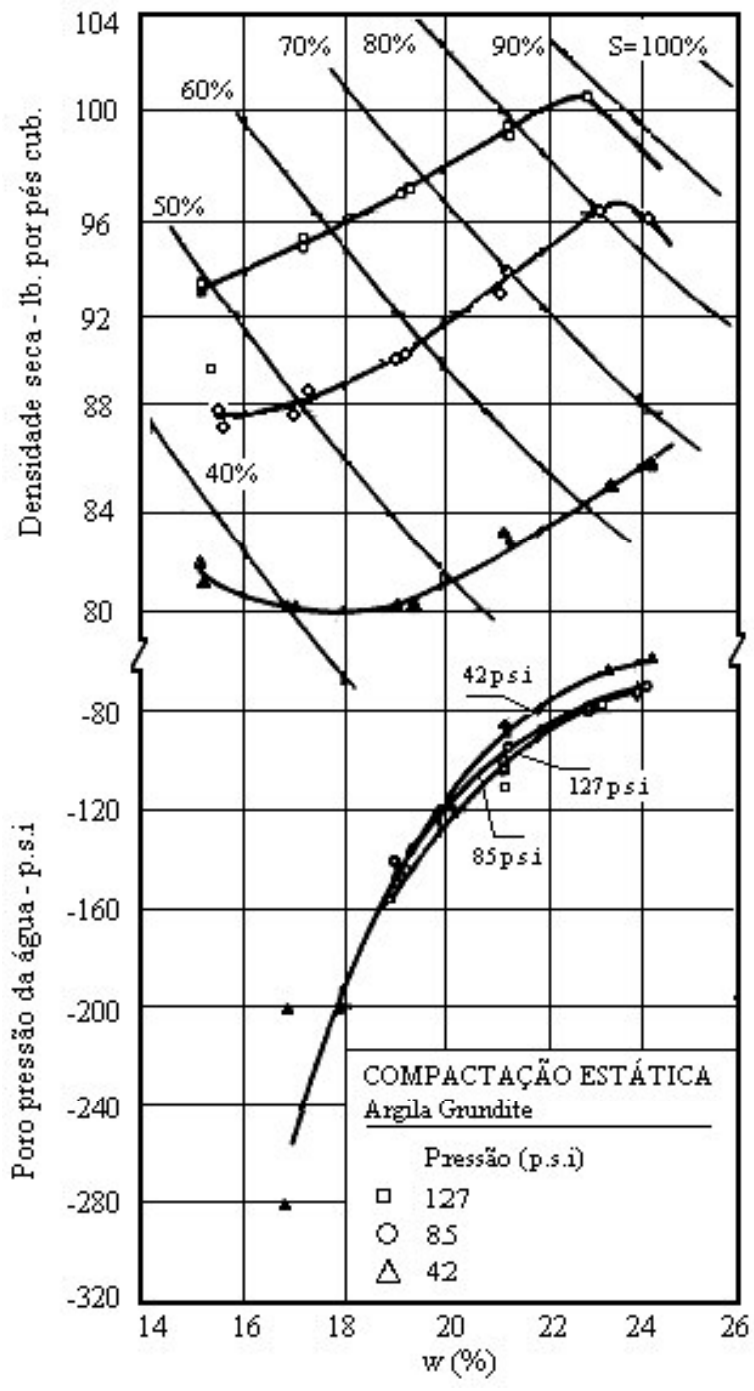

Figura 2.26 - Valores das sucções iniciais dos corpos de prova compactados ao longo da curva de compactação (Olson e Langfelder, 1965). 
Suriol et al (2002) determinaram as curvas de compactação de um silte de baixa plasticidade ( $\mathrm{IP}=11.8 \%$ ) submetido a diferentes energias de compactação. Para estes resultados, apresentados na Figura 2.27, foram definidas as linhas que representam o mesmo valor de sucção dos corpos de prova. Observa-se nesta figura que a energia de compactação não influencia a sucção inicial dos corpos de prova moldados no ramo seco. Para valores maiores de umidade as linhas que representam a sucção passam a ficar cada vez mais inclinadas, aproximando-se do mesmo grau de inclinação da curva de saturação $(S=100 \%)$. O aumento da inclinação destas linhas indica que a energia de compactação começa a influenciar nos valores de sucção inicial dos corpos de prova. Estes resultados são semelhantes aos encontrados por Olson e Langfelder (1965).

Marinho e Stuermer (2000) empregaram três energias de compactação em um solo residual de Gnaisse retirado próximo do local onde foram obtidas as amostras utilizadas nesta pesquisa. Na Figura 2.28 estão apresentadas as três curvas de compactação e as curvas que representam os corpos de prova com a mesma sucção. Na Figura 2.28 observa-se a mesma tendência dos resultados obtidos por Olson e Langfelder (1965) e Suriol et al (2002).

O fato da sucção no ramo seco apresentar valores semelhantes para diferentes esforços de compactação provavelmente deve-se à resistência das agregações. A sucção no interior das agregações é suficiente para que as mesmas resistam aos esforços de compactação sem deformar. Assim sendo não ocorrem variações estruturais dos corpos de prova. 


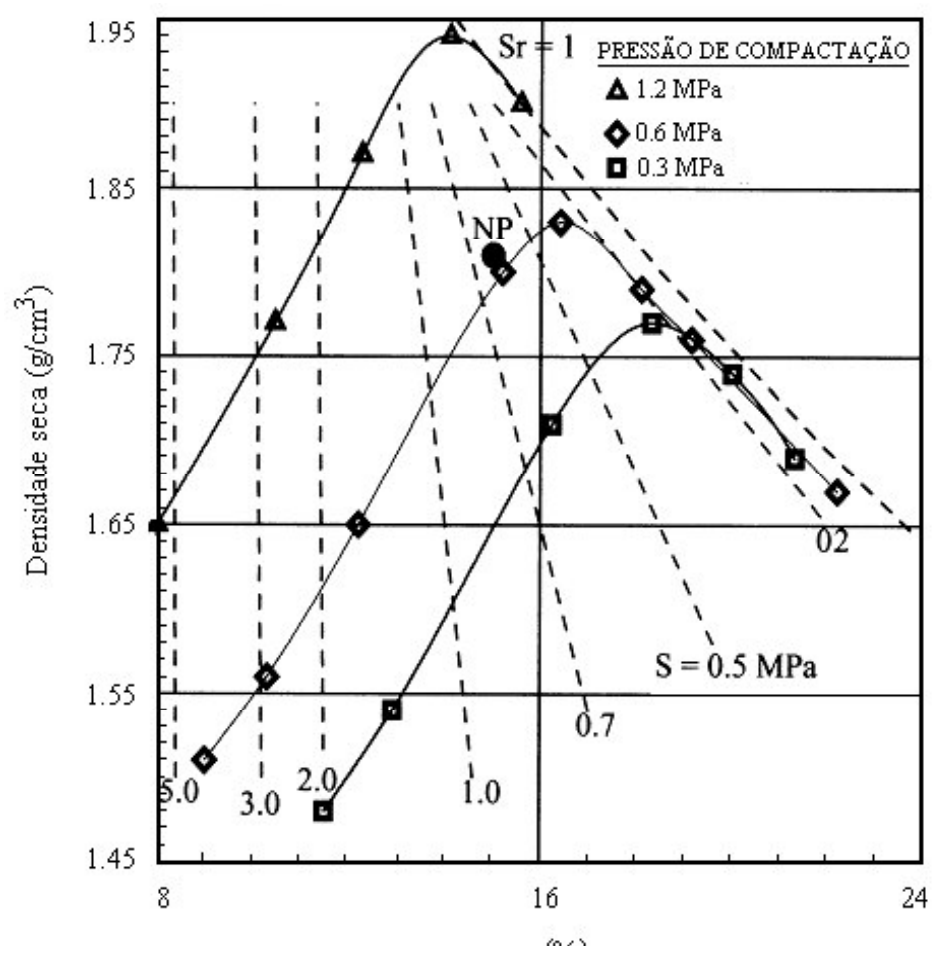

Figura 2.27 - Curvas de mesma sucção obtida de um silte de baixa plasticidade compactado estaticamente com diferentes energias (Suriol et al, 2002).

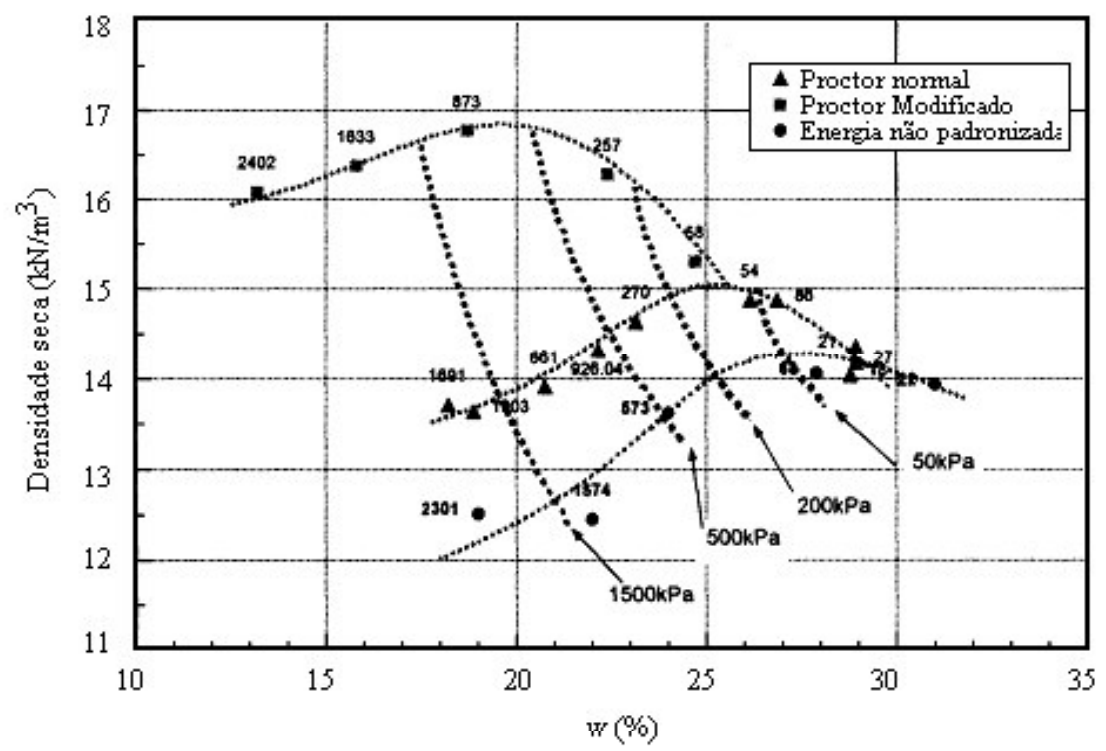

Figura 2.28 - Curvas de compactação e de mesmo valor de sucção de um solo residual de gnaisse (Marinho e Stuermer, 2000). 


\subsection{6 - Influência da compactação nos valores da resistência ao cisalhamento e deformação axial}

Neste item são tratados alguns aspectos referentes ao comportamento dos solos, moldados na curva de compactação, em ensaios de resistência. Seed e Chan (1958) realizaram ensaios não drenados sobre amostras de caolinita preparadas com diferentes teores de umidade e moldadas com a mesma energia de compactação. Estes ensaios estão apresentados na Figura 2.29. Os resultados representados pelas curvas 1 e 2 correspondem a corpos de prova moldados no ramo seco. A curva 3 corresponde a moldagem na umidade ótima e as curvas 4 e 5 e 6 são de corpos de prova compactados no ramo úmido. A numeração das curvas aumenta à medida que aumenta o teor de umidade de moldagem. Observa-se na Figura 2.29 que os corpos de prova compactados no ramo seco apresentam resistência e módulo de deformabilidade maiores, rompendo com valor de deformação axial menor. Com o aumento do teor de umidade de moldagem, o valor da resistência e do módulo de deformabilidade dos corpos de prova passa a diminuir gradativamente, ocorrendo a ruptura para valores maiores de deformação axial.

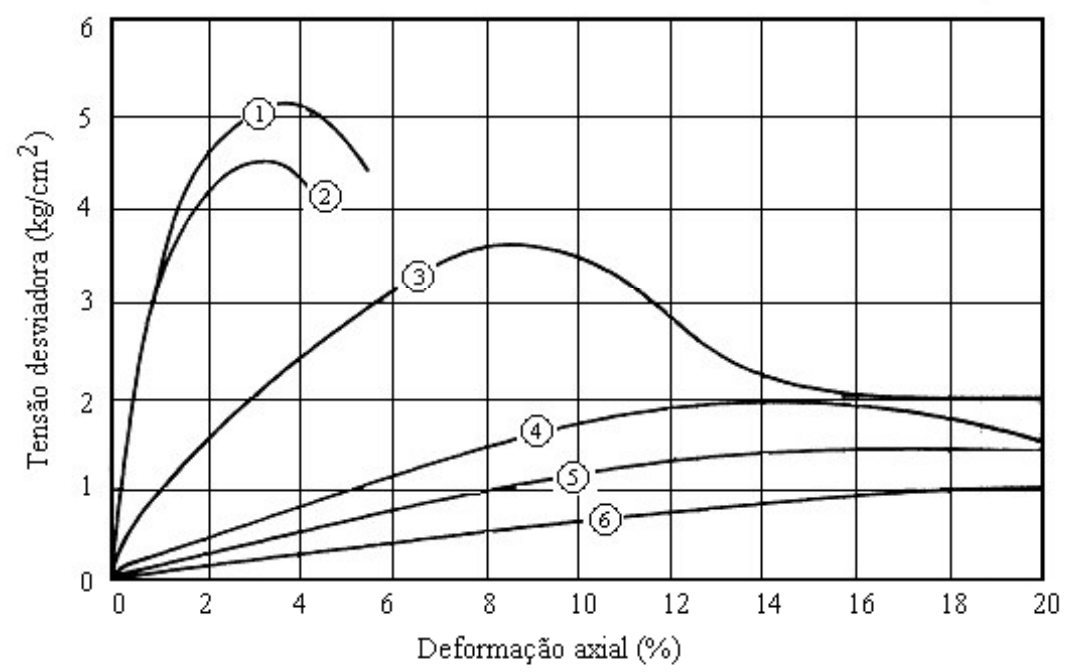

Figura 2.29 - Resultados dos ensaio não drenados realizados em uma caolinita compactada ao longo da curva de compactação (Seed e Chan, 1959). 
Nos ensaios da Figura 2.29 os corpos de prova apresentam estruturas e teores de umidade diferentes. Com o objetivo de se avaliar apenas os efeitos do tipo de estrutura resultante da compactação, Seed e Chan (1959) realizaram ensaios sobre amostras saturadas. Com este objetivo a argila siltosa foi compactada no ramo seco e no ramo úmido da curva de compactação. Os procedimentos de saturação foram realizados de forma que os corpos de prova passem a apresentar o mesmo valor de densidade. Os resultados destes ensaios estão na Figura 2.30. Observa-se nesta Figura que o corpo de prova moldado no ramo seco apresenta maior resistência para valores de deformação axial de até $18 \%$. A partir deste valor de deformação axial, os resultados destes ensaios passam a ser semelhantes.

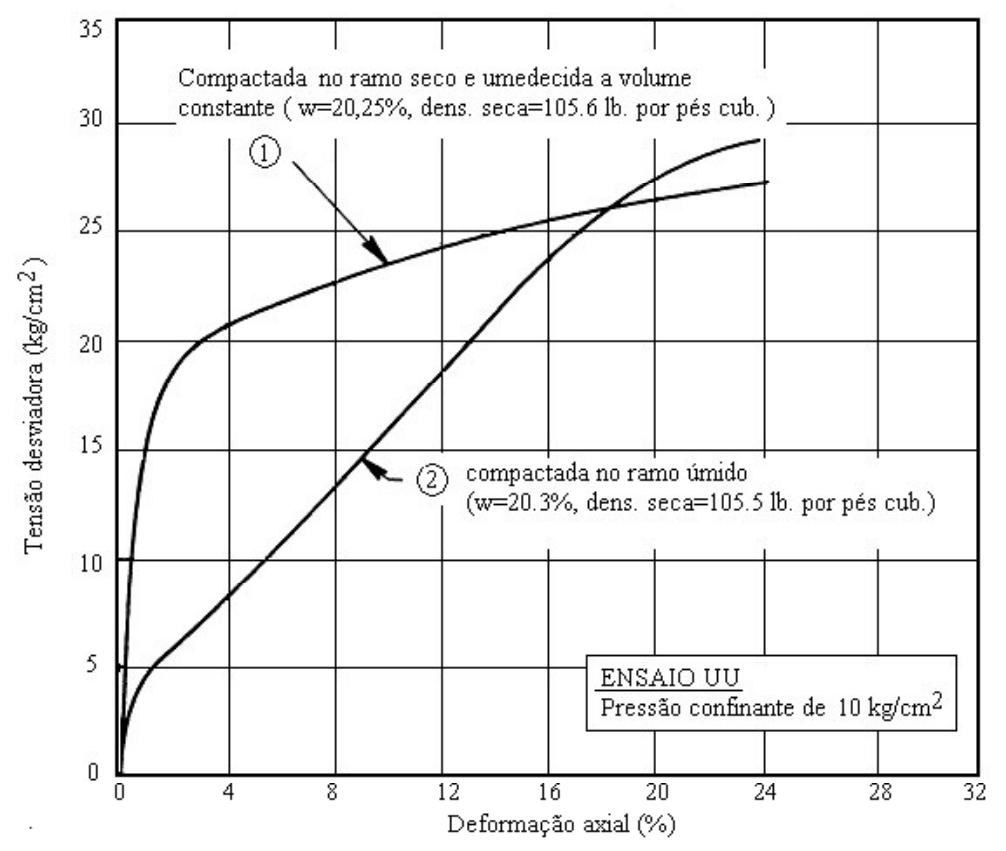

Figura 2.30 - Resultados dos ensaios triaxiais não drenados (UU) realizados em corpos de prova saturados, compactados em pontos distintos da curva de compactação (Seed e Chan, 1959).

Em função do critério de ruptura adotado, estes corpos de prova podem ou não apresentar o mesmo valor de resistência. Se o critério de ruptura do corpo de prova for o resultado do ensaio para grandes valores de deformação axial, constata-se que a estrutura não tem nenhuma influência sobre a resistência em ensaios não drenados. 
Caso seja adotado como critério de ruptura, um valor de deformação axial inferior a $18 \%$, o corpo de prova compactado no ramo seco apresenta maior resistência.

Seed e Chan (1959) afirmam que uma avaliação mais realística somente pode ser feita em termos de tensões efetivas atuando nos corpos de prova na ruptura. Para este estudo realizaram ensaios triaxiais consolidados não drenados (CU) com medição da poro pressão. Utilizaram amostras de argila siltosa compactadas com a mesma energia para as condições de moldagem no ramo seco e no ramo, sendo em seguida submetidas à saturação. Na Figura 2.32 estão apresentados os resultados destes ensaios. A parte (d) desta Figura mostra as condições de moldagem e o caminho seguido pelos corpos de prova durante os procedimentos de saturação. A parte (a) apresenta a tensão desviadora em função da deformação axial.

As tensões efetivas foram obtidas subtraindo-se das tensões aplicadas, o valor da poro pressão representada na parte (b). As análises em termos de tensões efetivas foram feitas pelos valores de $\sigma_{1}{ }_{1}$ dividido $\sigma_{3}$, apresentada na parte (c). Os autores não entram em consideração sobre as variações estruturais dos corpos de prova após a saturação. Na Figura 2.31d observa-se que neste procedimento, ocorreu o aumento da densidade destes corpos de prova. Analisando estes ensaios em termos de tensões efetivas (Figura 2.31c) verifica-se que os resultados são semelhantes. Desta forma pode-se concluir que, ao se analisar estes ensaios em termos de tensões efetivas, a estrutura destes corpos de prova não interferem no valor da resistência ao cisalhamento na condição saturada. 


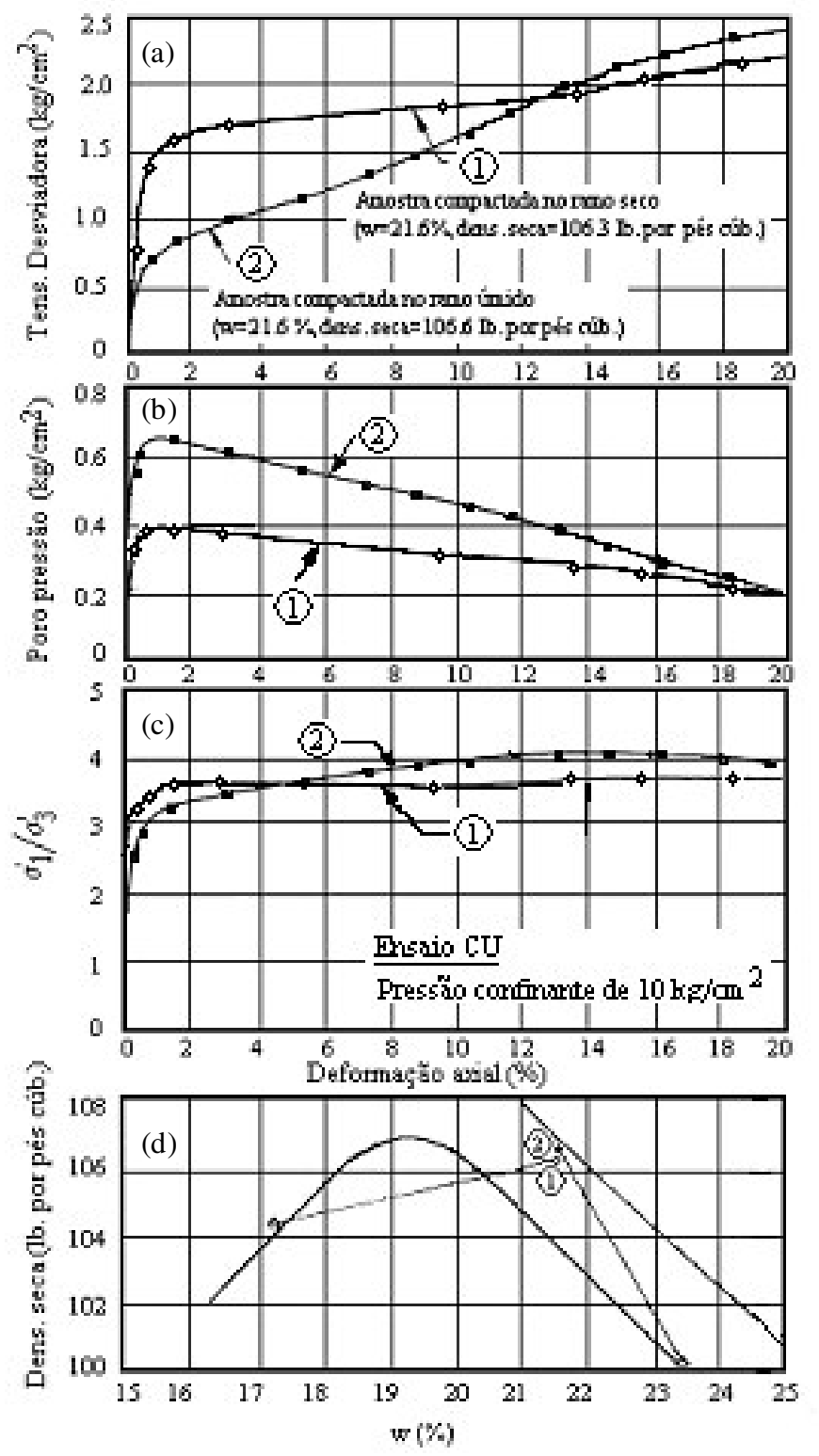

Figura 2.31 - Comparação entre os resultados dos ensaios triaxiais saturados CU realizados em corpos de prova compactados no ramo seco e no ramo úmido (Seed e Chan, 1959). 


\section{3 - Equações da curva de retenção e principais aspectos que interferem em seu formato}

Diversas propriedades dos solos compactados estão correlacionadas com a forma da curva de retenção, tais como, tipo de solo, umidade de moldagem, energia de compactação, história de tensões e ciclos de umedecimento e secagem. Vanapalli (1994) afirma que a curva de retenção representa indiretamente o comportamento mecânico dos solos não saturados. Os ensaios de laboratório em solos não saturados consomem tempo, são caros e demandam técnicos especializados para a execução dos mesmos. Estes fatores não são interessantes para a aplicação prática da engenharia, que necessita de procedimentos mais rápidos para a obtenção das propriedades do solo utilizados em projetos.

A curva de retenção tem sido utilizada como importante ferramenta na mecânica dos solos não saturados. As propriedades de resistência ao cisalhamento e de fluxo têm sido obtidas através da utilização de modelos que utilizam a curva de retenção. Neste item são abordados as principais feições da curva de retenção, a sua representação matemática por meio de equações e alguns aspectos que interferem no seu formato.

\subsection{1 - Definição de alguns aspectos da curva de retenção}

A curva de retenção é a relação entre a quantidade de água e a sucção do solo. A quantidade de água pode ser representada pela umidade gravimétrica (w), umidade volumétrica $(\theta)$ ou pelo grau de saturação $(S)$. O valor de $S, \theta$ e w estão relacionados entre si através das seguintes equações:

$\theta=\frac{S e}{1+e}=S n$

$$
\theta_{w}=\rho_{d} w
$$

Onde: e - índice de vazios, $\rho_{\mathrm{d}}$ - densidade seca, $\mathrm{n}$ - porosidade. 
Para pequenos intervalos de sucção a quantidade de água, presente nos poros do solo, pode ser representada em escala linear. Para a representação de toda a curva de retenção, devido aos elevados valores de sucção, utiliza-se a representação em um gráfico semilog. As curvas de retenção são geralmente plotadas na escala semi log usando na ordenada o valor do grau de saturação. Este tipo de representação é mais facilmente compreendido pelos engenheiros geotécnicos (Vanapalli, 1994). Em algumas situações como em problemas de análise de fluxo utiliza-se a umidade volumétrica.

A sucção do solo pode ser dividida em sucção matricial e sucção osmótica. A sucção matricial esta relacionada ao tipo de partícula e ao arranjo estrutural (matriz do solo), sendo seu valor representado pela diferença entre a poro pressão do ar e da água $\left(\mathrm{u}_{\mathrm{a}}{ }^{-}\right.$ $\mathrm{u}_{\mathrm{w}}$ ). A sucção osmótica é função da quantidade de sais dissolvidos no interior do solo. A sucção total corresponde à soma das duas parcelas anteriores. A sucção matricial faz com que surjam meniscos no interior do solo. Estes meniscos são similares aos meniscos formados pela interface ar-água no interior de um tubo capilar. Utilizando o modelo do tubo capilar, obtém-se uma relação entre a sucção matricial e o raio de curvatura do menisco de água formado entre as partículas do solo, dada por:

$\left(u_{a}-u_{w}\right)=\frac{2 T_{s}}{R}$

Onde $\mathrm{T}_{\mathrm{s}}$ - tensão superficial e $\mathrm{R}$ - raio de curvatura do menisco.

No caso do menisco apresentar dois raios de curvatura a equação 2.11 é representada por:

$\left(u_{a}-u_{w}\right)=T_{s}\left(\frac{1}{R_{1}}+\frac{1}{R_{2}}\right)$ 
A equação 2.12 reduz-se a equação 2.11 quando os raios são iguais. O modelo do tubo capilar explica como a água pode ser mantida com uma pressão negativa nos capilares do solo, no entanto apresenta limitações ao supor que o solo apresenta capilares de diâmetros constantes. Os meniscos atraem uma partícula do solo de encontro à outra, aumentando assim a componente normal das forças que atuam entre elas. Estas componentes de força entre as partículas proporcionam aumento da resistência ao cisalhamento.

Ao longo da curva de retenção, partindo da condição saturada, à medida que a sucção aumenta pode-se identificar a sucção de entrada de ar e a sucção residual. A Figura 2.32 apresenta esquematicamente a entrada do menisco de água no interior do solo para diferentes valores de sucção. Quando o solo esta saturado a interface ar-água é representada pela linha 1 . Com o aumento da sucção se atinge o início da entrada de ar e a interface penetra no solo. A partir deste momento os meniscos formados pela interface ar-água passam a apresentar raios menores com o aumento da sucção, conforme ilustrado na Figura 2.32 pelas linhas 2, 3, 4 e 5.

Fredlund e Xing (1994) sugerem um procedimento gráfico para a determinação da sucção correspondente a entrada de ar e ao valor de umidade volumétrica residual. A entrada de ar é definida como a intercessão entre a reta horizontal, correspondente ao estado saturado, com a reta tangente que passa pelo ponto de inflexão da curva. A intercessão desta última reta com a reta tangente a curva e que passa pelo valor de sucção de $10^{6} \mathrm{kPa}$, define o valor de umidade volumétrica residual. Estes procedimentos estão ilustrados na Figura 2.33, sendo válidos para a curva plotada na escala semilog. Não existe um consenso sobre o valor da sucção residual. Alguns pesquisadores adotam o valor de $1500 \mathrm{kPa}$ que corresponde à sucção do ponto de murcha das plantas. 


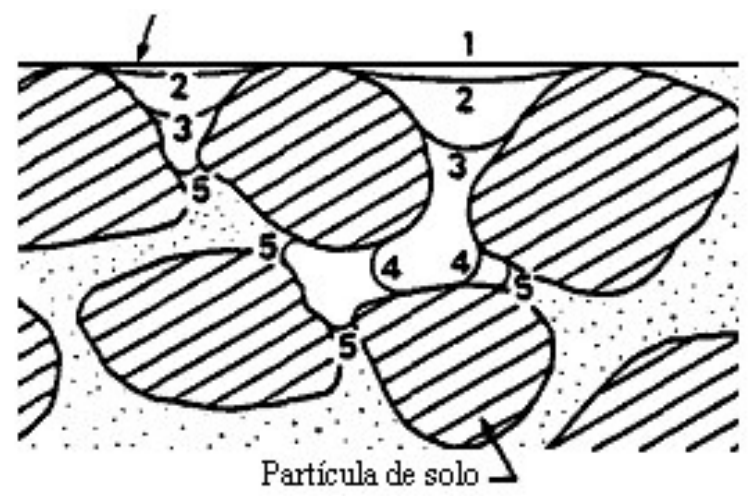

Figura 2.32 - Penetração da interface ar água no interior do solo em função do aumento de sucção (Fredlund e Rahardjo, 1993).

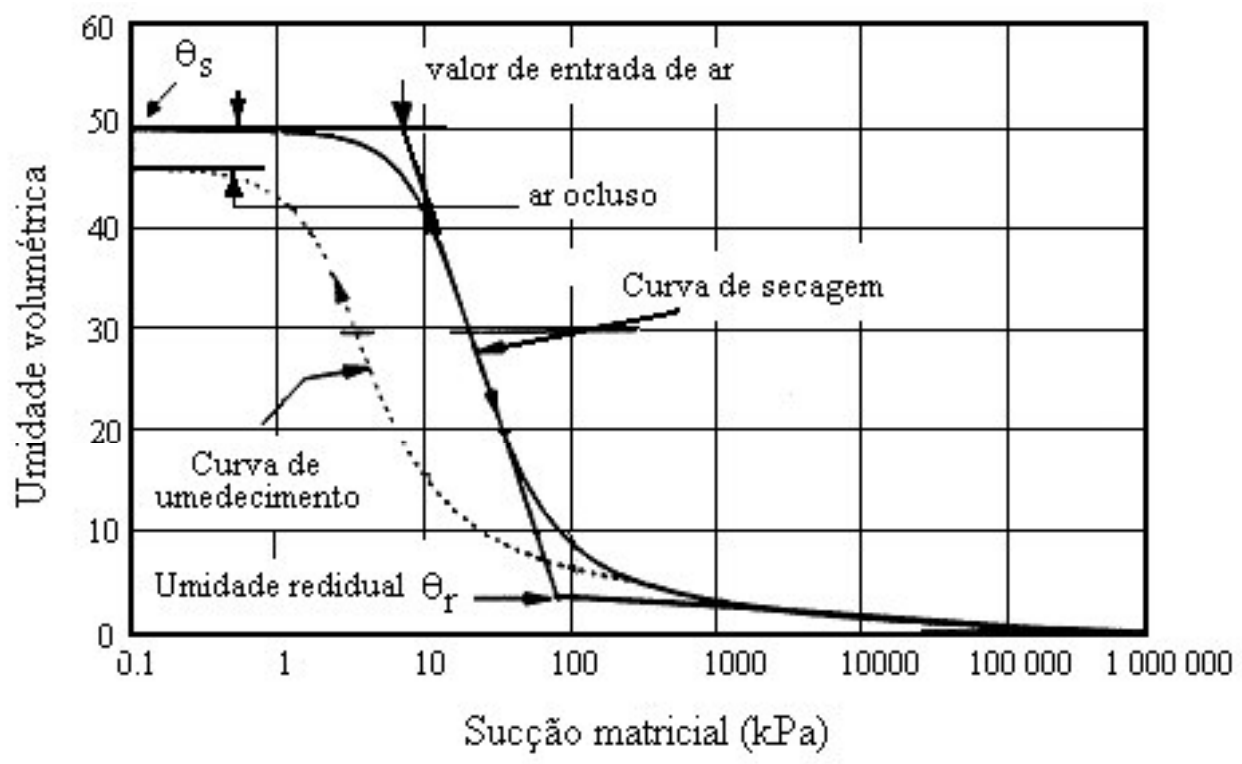

Figura 2.33 - Principais feições da curva de retenção (Fredlund e Xing, 1994). 
Croney e Colleman (1961), ao obterem as curvas de retenção de solos argilosos, constataram que para umidades próximas a zero os valores da sucção são da ordem $10^{6} \mathrm{kPa}$. Sucção desta ordem de grandeza foram obtidas com a utilização de solução de ácido sulfúrico em dessecadores. Nestes ensaios as amostras são colocadas no interior do dessecador ficando expostas à umidade relativa do ar, que é função da solução utilizada. Quanto menor a umidade relativa, maior será o valor da sucção imposta a o corpo de prova. Algumas evidências experimentais, entre elas os resultados obtidos por Croney e Collemam (1961), permitem concluir que o valor de $10^{6} \mathrm{kPa}$ é a máxima ordem de grandeza para a sucção de meios porosos (Fredlund e Xing 1994).

\subsection{2 - Principais equações para representar a curva de retenção}

Os valores experimentais da curva de retenção podem ser representados por equações matemáticas. Na Tabela 2.1 estão apresentadas as equações mais utilizadas. Gerscovich e Sayão (2002) estudaram as curvas de retenção de 11 solos do Brazil, incluindo solo residual, sedimentar e coluvionar, verificando que as equações propostas por van Genuchtem (1990) e Fredlund e Xing (1994) apresentam uma boa estimativa dos valores experimentais.

Tabela 2.1 - Principais equações para representar a curva de retenção.

\begin{tabular}{|l|l|l|l|}
\hline \multicolumn{1}{|c|}{ Autores } & Ano & \multicolumn{1}{|c|}{ Equação } & \multicolumn{1}{c|}{ Parâmetros } \\
\hline Brooks e Corey & 1964 & $\Theta=\left(\frac{\psi_{b}}{\psi}\right)^{\lambda} ; \theta \leq 1$ & $\begin{array}{l}\psi_{\mathrm{b}} \text { - Sucção correspondente à } \\
\text { entrada de ar } \\
\psi \text { - Sucção matricial } \\
\lambda \text { - Parâmetro obtido graficamente }\end{array}$ \\
\hline van Genunchtem & 1980 & $\Theta=\left[\frac{1}{1+\alpha \psi^{n}}\right]^{m}$ & $\begin{array}{l}\psi \text { - Sucção matricial } \\
\alpha, \mathrm{m} \text { e n - Parâmetros de ajuste }\end{array}$ \\
\hline Fredlund e Xing & 1994 & $\theta=C(\psi) \frac{\theta_{s}}{\ln \left[e+\left(\frac{\psi}{a}\right)^{n}\right]^{m}}$ & $\begin{array}{l}\psi \text { - Sucção matricial } \\
\theta_{\mathrm{s}} \text { - Umidade volumétrica na } \\
\text { saturação } \\
\text { a, n e m - Parâmetros de ajuste }\end{array}$ \\
\hline
\end{tabular}


Para os resultados obtidos nesta pesquisa, optou-se por se aplicar a equação proposta por Fredlund e Xing (1994). Esta equação é baseada nas seguintes hipóteses:

- A curva de retenção depende da distribuição de poros.

- Os meniscos formados possuem formato esférico, que se justifica assumindo que os poros apresentam seção circular e os canais que interligam os mesmos são cilíndricos e dispostos de forma aleatória.

Fredlund e Xing (1994) propuseram a seguinte relação entre a umidade volumétrica e a sucção:

$\theta=\theta_{s}\left[\frac{1}{\ln \left(e+(\psi / a)^{n}\right.}\right]^{m}$

Onde: $\psi$ - sucção, $\theta_{\mathrm{s}}$ - umidade volumétrica na saturação; a, m e n são parâmetros que modificam o formato da curva.

O valor da umidade volumétrica normalizada $(\Theta)$, dada pela relação entre a umidade volumétrica e a umidade volumétrica na saturação, é igual ao grau de saturação e a equação 2.13 pode ser representada por:

$S=\left[\frac{1}{\ln \left(e+(\psi / a)^{n}\right.}\right]^{m}$

Onde: S - grau de saturação

Fredlund e Xing (1994) acrescentaram o termo C $(\psi)$ que multiplicado pela equação 2.14 faz com que a curva de retenção apresente, para valores de grau de saturação próximo de zero, sucção de $10^{6} \mathrm{kPa}$. Este termo é dado por:

$C(\psi)=1-\left[\frac{\ln \left(1+\psi / \psi_{r}\right)}{\ln \left[1+\left(1000000 / \psi_{r}\right)\right.}\right]$

Onde: $\psi_{\mathrm{r}}$ - Valor da sucção correspondente a umidade volumétrica residual. 
Os valores de a, m e n podem ser obtidos graficamente. Quando se utiliza para representar a curva de retenção a equação 2.14 multiplicada pela equação.2.15 estes parâmetros podem ser estimados pelas seguintes expressões:

$$
\begin{aligned}
& a=\psi_{i} \\
& m=3,67 \ln \left[\frac{\theta_{s} C\left(\psi_{i}\right)}{\theta_{i}}\right] \\
& n=\frac{1,31^{m+1}}{m C\left(\psi_{i}\right)} 3,72 S^{*} \\
& S^{*}=\frac{S}{\theta_{s}}-\frac{\psi_{i}}{1,31^{m}\left(\psi_{i}+\psi_{r}\right) \ln \left(1+\left(1000000 / \psi_{r}\right)\right.} \\
& S=\frac{\theta_{i}}{\ln \left(\psi p / \psi_{i}\right)}
\end{aligned}
$$

Os valores de $\psi_{\mathrm{i}}, \theta_{\mathrm{i}}, \theta_{\mathrm{s}}, \psi_{\mathrm{r}}$ e $\psi_{\mathrm{p}}$ são obtidos graficamente como indicado na Figura 2.34. O ponto de inflexão da curva de retenção corresponde às coordenadas de $\psi_{\mathrm{i}} \mathrm{e}$ $\theta_{\mathrm{i}}$. Passando-se uma tangente pelo ponto de inflexão a reta intercepta o eixo das abscissas no valor de sucção correspondente a $\psi_{\mathrm{p}}$. As coordenadas de $\left(\psi_{\mathrm{r}}, \theta_{\mathrm{r}}\right)$ representa o ponto onde a curva de retenção passa a decrescer linearmente até $10^{6}$ $\mathrm{kPa}$. O procedimento gráfico para se encontrar os parâmetros a, n e m fornecem apenas valores aproximados. Um melhor ajuste aos pontos experimentais pode ser obtido ao se utilizar programas computacionais, aplicando-se o método dos mínimos quadrados (Fredlund e Xing, 1994). Os parâmetros a, n e m estão relacionados ao formato da curva de retenção. Observa-se na Figura 2.35 que com o aumento do valor do parâmetro a, a curva se desloca para a direita, alterando assim o valor da sucção de entrada de ar. O valor do parâmetro $n$ faz com que a curva de retenção gire em torno do ponto de inflexão, conforme ilustrado na Figura 2.36. À medida que o valor de $\mathrm{n}$ aumenta a curva gira no sentido horário. $\mathrm{O}$ aumento do valor de $\mathrm{m}$ faz com que, para valores elevados de sucção, a curva de retenção se aproxime do eixo das abscissas, conforme apresentado na Figura 2.37. 


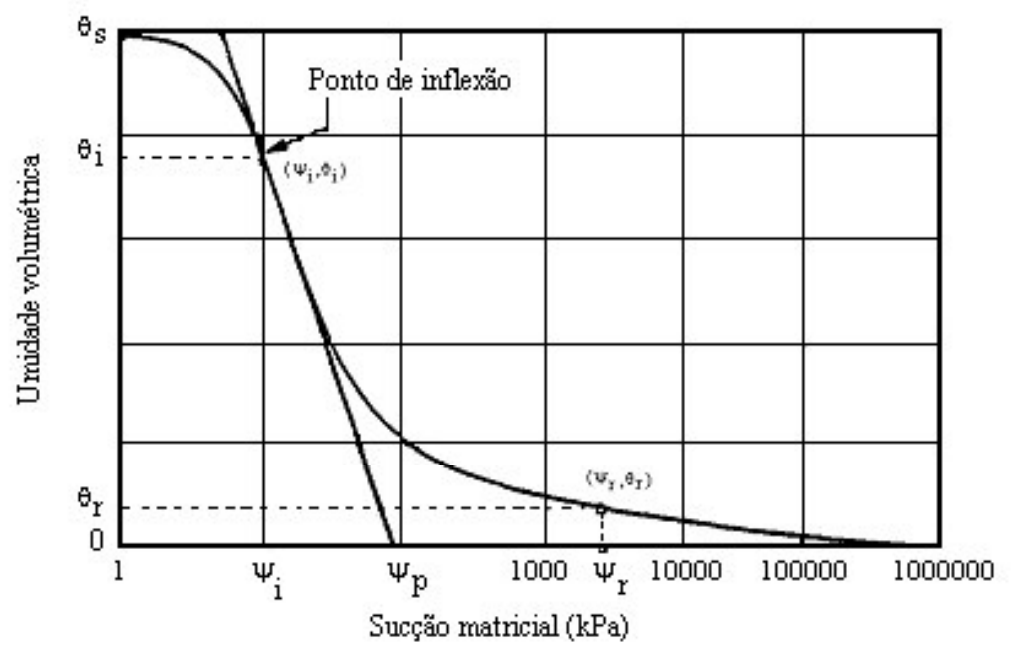

Figura 2.34 - Determinação gráfica dos parâmetros utilizados para calcular os valores de a, n e m (Fredlund e Xing 1994).

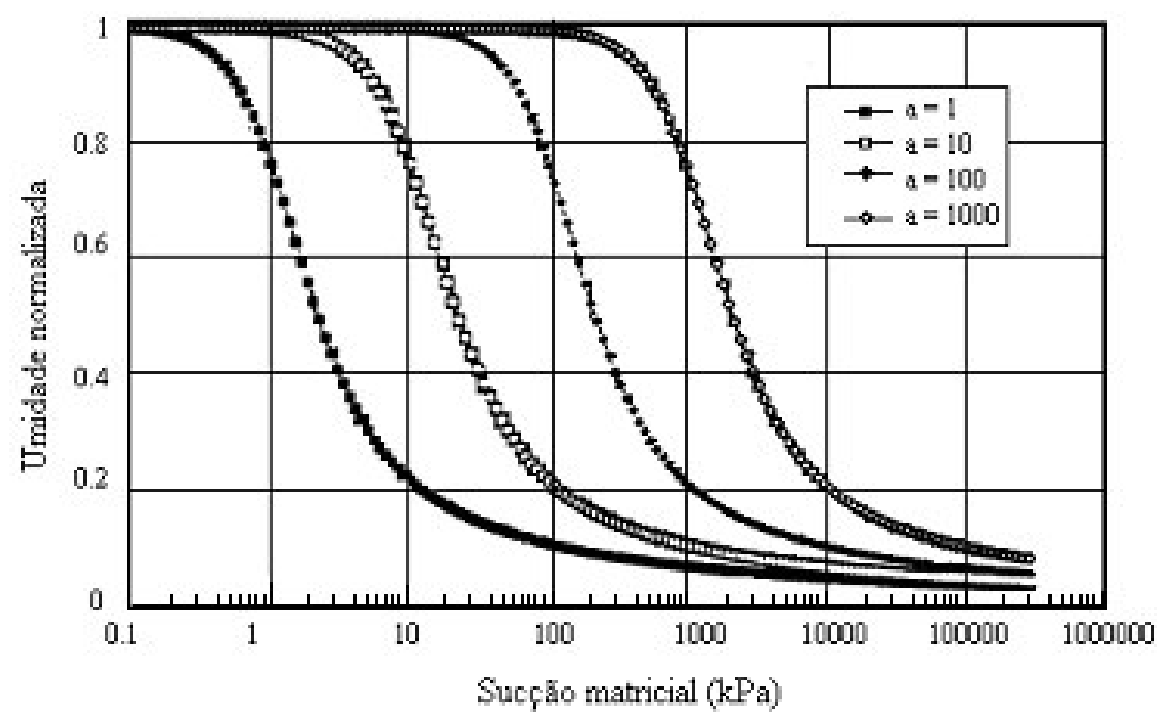

Figura 2.35 - Influência do parâmetro a na curva de retenção (Fredlund e Xing, 1994). 


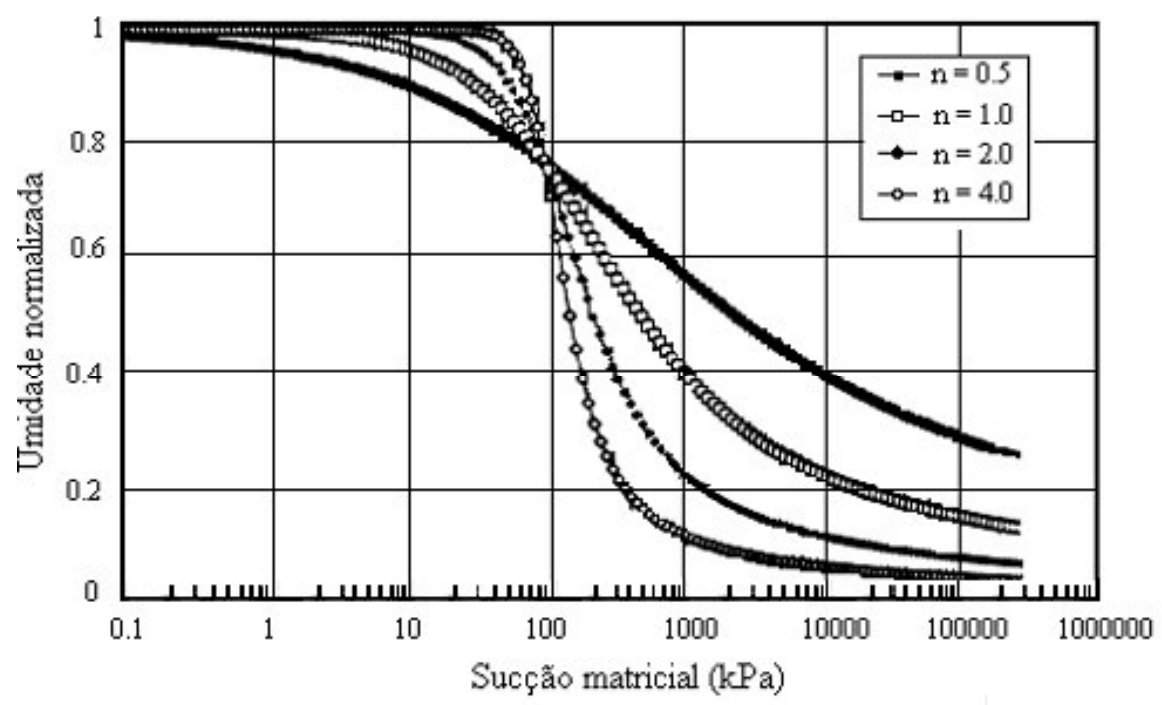

Figura 2.36 - Influência do parâmetro n na curva de retenção (Fredlund e Xing, 1994).

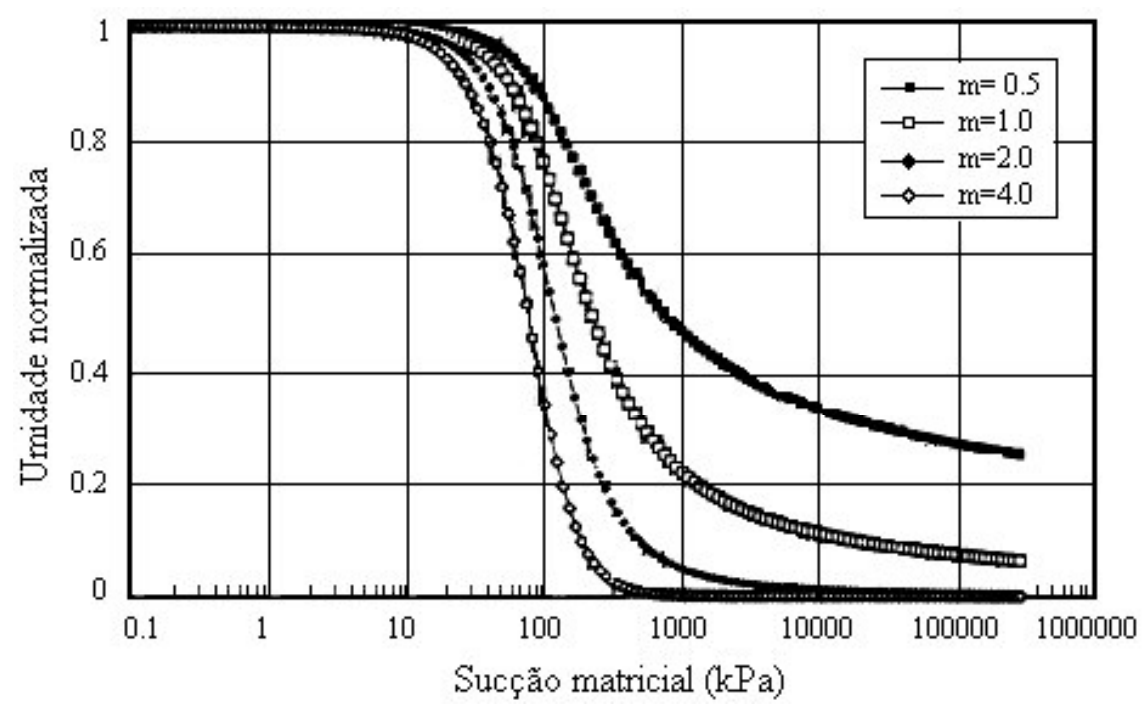

Figura 2.37 - Influência do parâmetro m na curva de retenção (Fredlund e Xing, 1994). 


\subsection{3 - Fatores que afetam a curva de retenção}

Os solos arenosos apresentam valor de sucção de entrada de ar menor que os solos siltosos ou argilosos, devido à formação de poros de maiores dimensões. Ao se aplicar uma determinada pressão de confinamento estes poros de maiores dimensões podem diminuir, fazendo com que a entrada de ar ocorra corresponda a um valor maior de sucção. Diversos fatores interferem no formato da curva de retenção. Dentre estes fatores são investigados neste item a influência do tipo de solo, da umidade de moldagem e da história de tensão.

\section{a) Tipo de solo}

O tipo de solo influencia no valor de entrada de ar e na inclinação da curva de retenção. Esta inclinação refere-se ao trecho entre a sucção de entrada de ar e a sucção residual, definida por Marinho (1994) como capacidade de sucção. As areias apresentam pequena capacidade de retenção de água, devido aos grandes poros interconectados presentes em sua estrutura. Desta forma a entrada ar ocorre para pequenos valores de sucção. Estes solos apresentam em geral pequena variação de diâmetro de poro, dessaturando rapidamente após atingirem a sucção de entrada de ar.

Os solos argilosos apresentam em geral, em relação aos solos arenosos, uma maior capacidade de retenção de água. Quanto maior a plasticidade das argilas maior será o valor de entrada de ar e de sucção residual (Fredlund, 1998). Os solos argilosos dessaturam de foram mais lenta, indicando que apresentam poros com diferentes diâmetros. Os solos siltosos apresentam comportamento intermediário entre os arenosos e os argilosos. As variações da sucção de entrada de ar e a inclinação da curva de retenção para diferentes tipos de solo estão esquematicamente apresentadas na Figura 2.38. 


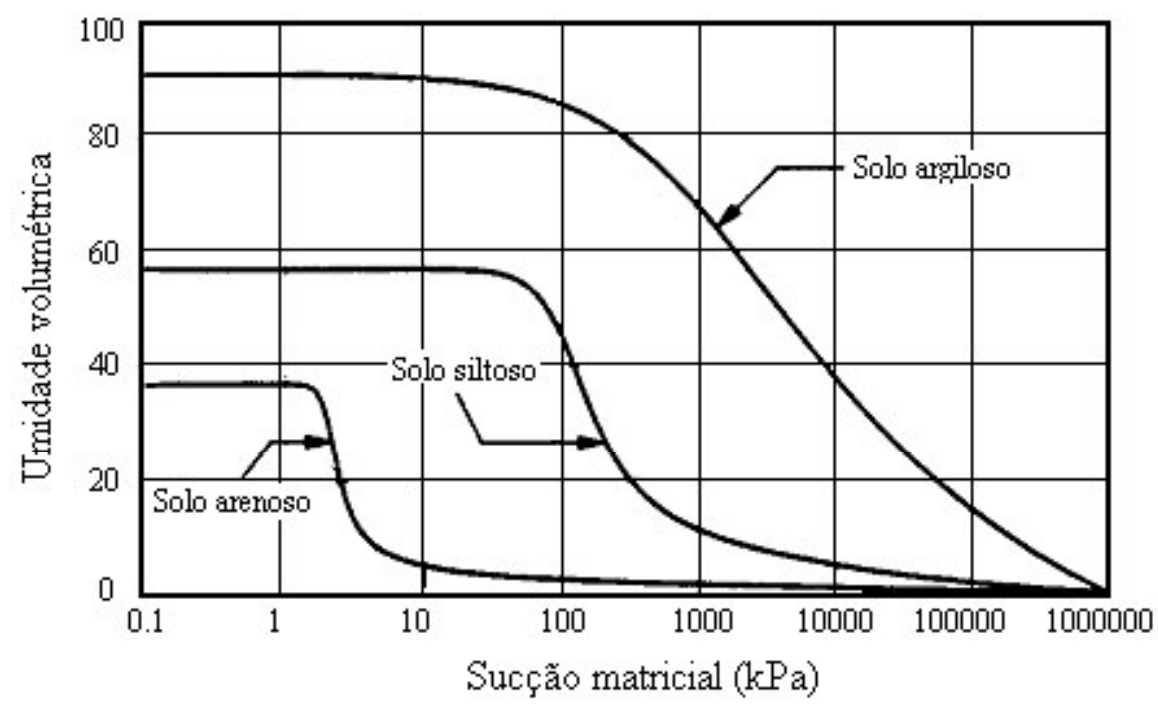

Figura 2.38 - Representação esquemática de curvas de retenção para diferentes tipos de solo (Vanapalli, 1994).

\section{b) Umidade de moldagem}

Nos itens 2.2.1 e 2.2.2 foram descritas as diferentes estruturas dos solos compactados nas condições da curva de compactação. Em função da umidade de moldagem as partículas do solo podem estar presentes na estrutura do corpo de prova na forma de agregações. Portanto, corpos de prova de um mesmo tipo de solo moldado com diferentes teores de umidade apresentam curvas de retenção distintas. Vanapalli et al (1999) realizaram ensaios para obtenção da curva de retenção de um solo argilo arenoso, compactado estaticamente em três condições de moldagem. Estas condições de moldagem representam o ramo seco, umidade ótima e o ramo úmido da curva de compactação. As amostras foram compactadas estaticamente em uma única camada dentro de um molde de $10 \mathrm{~cm}$ de diâmetro e $2 \mathrm{~cm}$ de altura. Em seguida foi cravado neste molde um anel de adensamento. As amostras foram montadas no oedômetro e saturadas ( $\cong 36$ horas) pelo topo e pela base não sendo permitido que ocorressem variações volumétricas. 
Na Figura 2.39 estão apresentadas as curvas de retenção para estas três condições de moldagem. Para a amostra moldada no ramo seco o arranjo das agregações permite que entre as mesmas formem-se grandes poros interconectados (Vanapalli et al, 1996). Desta forma a dessaturação inicial é controlada pela macroestrutura. A compactação no ramo úmido faz com que este solo apresente uma estrutura mais homogênea. Para esta condição de moldagem a capacidade de retenção de água e a resistência a dessaturação são maiores, sendo a mesma controlada pela sua microestrutura. As amostras moldadas na umidade ótima apresenta características intermediarias em relação às duas condições de moldagem analisadas anteriormente. Para valores elevados de sucção $(20000-30000 \mathrm{kPa})$ as curvas de retenção são semelhantes e governadas pela dessaturação dos microporos. Vanapalli et al (1999) afirmam que estas conclusões podem ser válidas para todos os solos finos, mas necessitam de trabalhos adicionais com solos de diferentes origens.

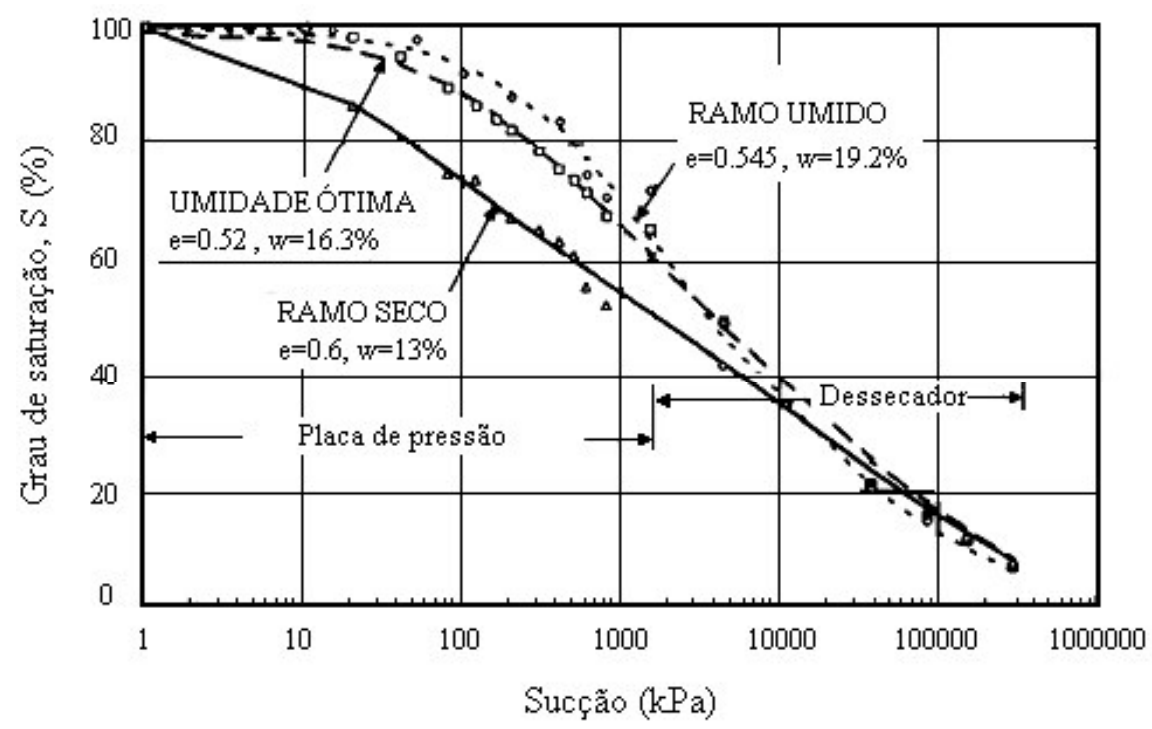

Figura 2.39 - Comparação entre as curvas de retenção obtidas de amostras compactadas com diferentes umidades (Vanapalli et al, 1999). 


\section{c) História de tensões}

As amostras compactadas podem ser submetidas a diferentes histórias de tensões. As variações do carregamento externo e da sucção, podem produzir alterações na estrutura do solo. Existe uma infinidade de combinações possíveis para as trajetórias de tensões. Com amostras moldadas conforme a parte "b" deste item, Vanapalli et al (1999) simularam diferentes pressões de confinamento. Para cada condição de moldagem foram utilizados 3 corpos de prova submetidos às pressões confinantes de $25 \mathrm{kPa}, 100 \mathrm{kPa}$ e $200 \mathrm{kPa}$. A simulação destas pressões confinantes indica que os corpos de prova não estão submetidos a carregamentos externos, mas a uma história de tensão que simula estas condições. Vanapalli (1994) propôs um método indireto para se impor uma condição de carregamento desejada. Neste procedimento o corpo de prova saturado é adensado até atingir um determinado valor de tensão efetiva. Após o alívio desta tensão o valor do índice de vazios deve corresponder, na curva de adensamento, ao ponto submetido à pressão confinante que se deseja simular. A Figura 2.40 apresenta esquematicamente este procedimento quando se deseja simular uma pressão de confinamento de $100 \mathrm{kPa}$.

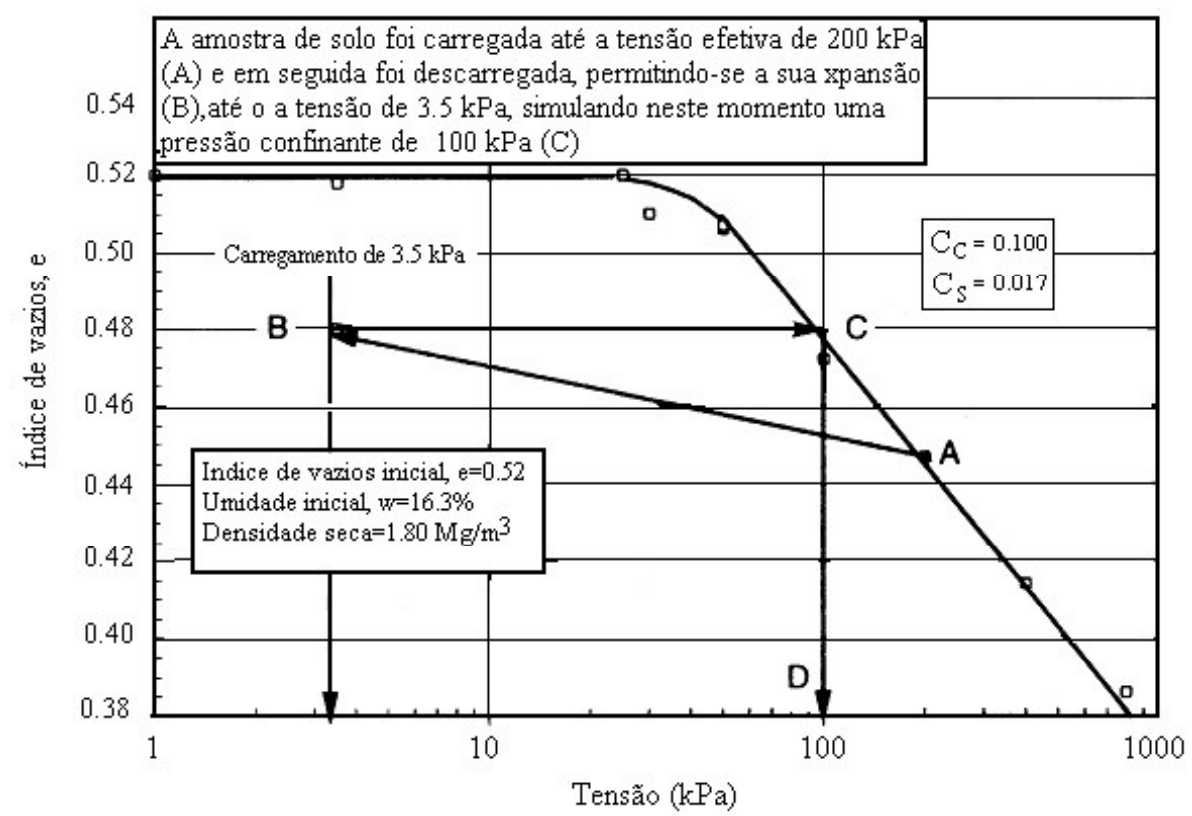

Figura 2.40 - Procedimentos para se simular uma pressão confinante de $100 \mathrm{kPa}$ (Vanapalli, 1994). 
Observa-se na Figura 2.40 que o corpo de prova saturado foi adensado até as condições correspondente ao ponto A. Em seguida a pressão de adensamento foi aliviada, e o mesmo passa a ser representado pelo ponto B. Para estas condições o corpo de prova está com o mesmo índice de vazios do ponto $\mathrm{C}$, simulando assim uma pressão confinante de $100 \mathrm{kPa}$. Na Figura 2.41 estão os resultados das curvas de retenção determinadas por Vanapalli et al (1994) para corpos de prova moldados no ramo seco. Observa-se nesta Figura que ocorre aumento da sucção de entrada de ar com o aumento da pressão de confinamento. Os resultados obtidos para as condições de moldagem no ramo úmido estão apresentados na Figura 2.42. Nesta condição de moldagem os procedimentos para se simular diferentes pressões de confinamento nos corpos de prova não interferem no formato das curvas de retenção. A dessaturação do corpo de prova é governada pelos microporos para todos os níveis de sucções (Vanapalli et al, 1999). As amostras moldadas na umidade ótima apresentaram comportamento intermediário em relação às amostras moldadas no ramo seco e úmido.

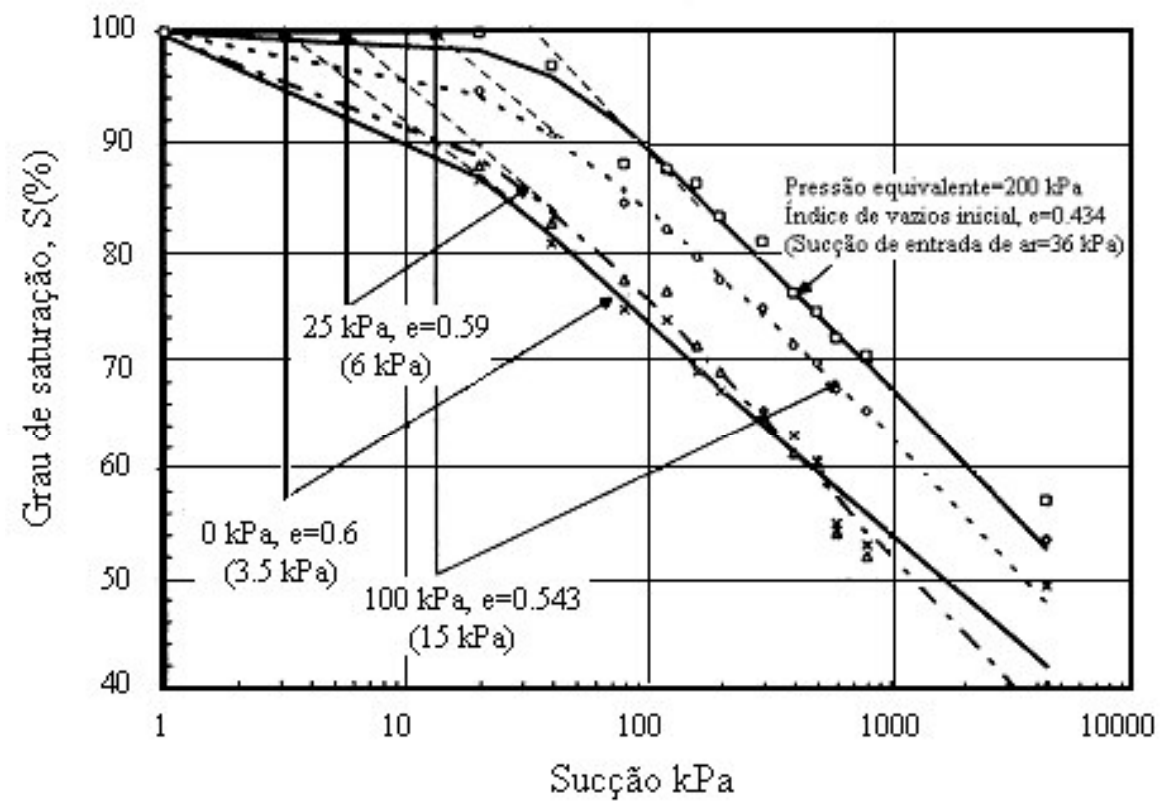

Figura 2.41 - Variação do valor da sucção referente à entrada de ar para um solo argiloso compactado estaticamente no ramo seco e submetido a diferentes pressões de confinamento (Vanapalli et al, 1999). 


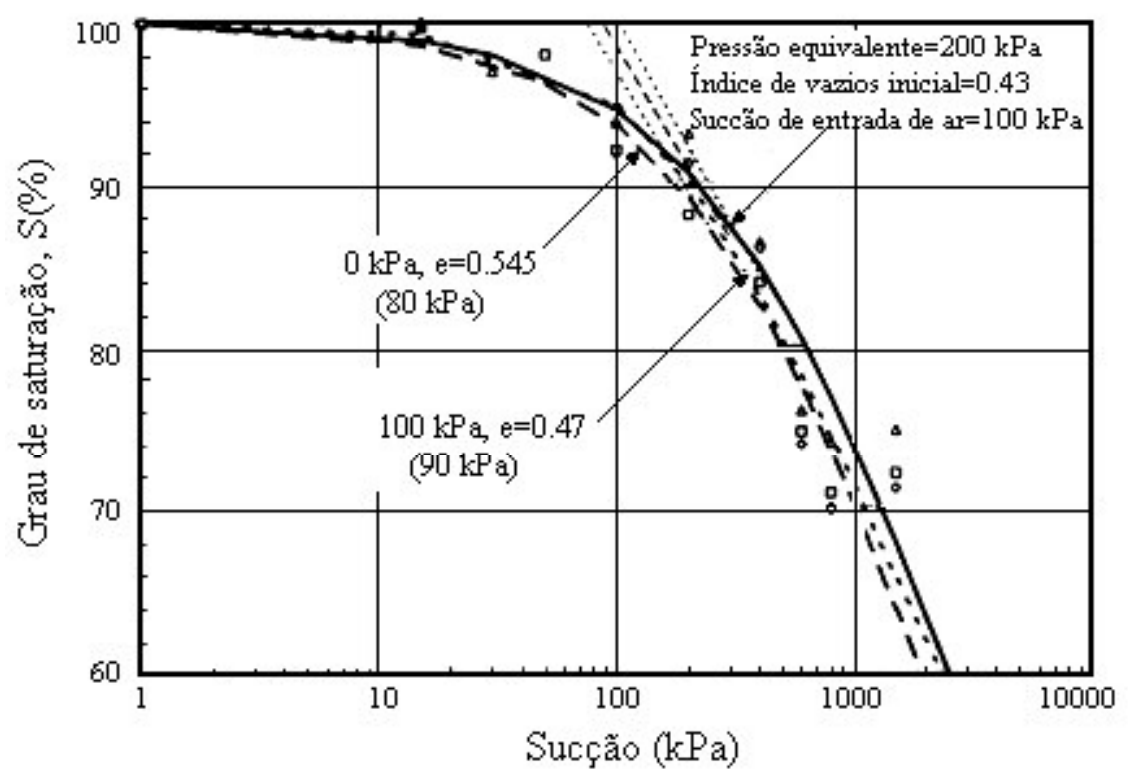

Figura 2.42 - Variação do valor da sucção referente à entrada de ar para um solo argiloso compactado estaticamente no ramo úmido e submetido a diferentes pressões de confinamento (Vanapalli et al, 1999).

\section{d) Ciclos de secagem e umedecimento}

A curva de retenção não é única para um mesmo corpo de prova, podendo ser diferente quando obtida por processo de secagem ou umedecimento. A variação da estrutura do corpo de prova durante a secagem e a formação de ar ocluso durante o umedecimento são os dois principais fatores que interferem neste fenômeno. Como visto no item 2.2.4 a estrutura do corpo de prova pode variar quando umedecido ou secado.

Os solos de estruturas compressíveis, quando submetidos à secagem, apresentam aumento de densidade até que o limite de contração seja alcançado (Croney, 1952 ). Na Figura 2.43 estão apresentadas uma família de curvas de retenção de um solo argiloso indeformado, submetido a ciclos de secagem e umedecimento. O corpo de prova moldado do solo indeformado foi colocado na placa de sucção, onde foi submetido à saturação $(\mathrm{pF} 0.8 \cong 0,6 \mathrm{kPa})$. 
Partindo desta condição inicial, foi submetido à secagem seguindo a curva $\mathrm{A}$, sendo posteriormente umedecido (curva B) e novamente secado (curva C). A diferença entre as curvas A e B não é atribuída unicamente à permanência de ar ocluso, indicando também o rearranjo das partículas induzido pelo processo de secagem (Croney, 1952). As curvas B e C formam um loop de histerese, onde as variações estruturais e volumétricas do primeiro ciclo de secagem não ocorrem mais. Na Figura 2.43 foi feito um pequeno loop no primeiro ciclo de secagem, partindo da sucção de $2.9 \mathrm{PF}(\cong 80 \mathrm{kPa})$. Observa-se que ao ser saturado, partindo deste valor de sucção, o corpo de prova passa a apresentar as mesmas condições do inicio destes ensaios, sugerindo que até este nível de sucção não ocorreram variações volumétricas irrecuperáveis.

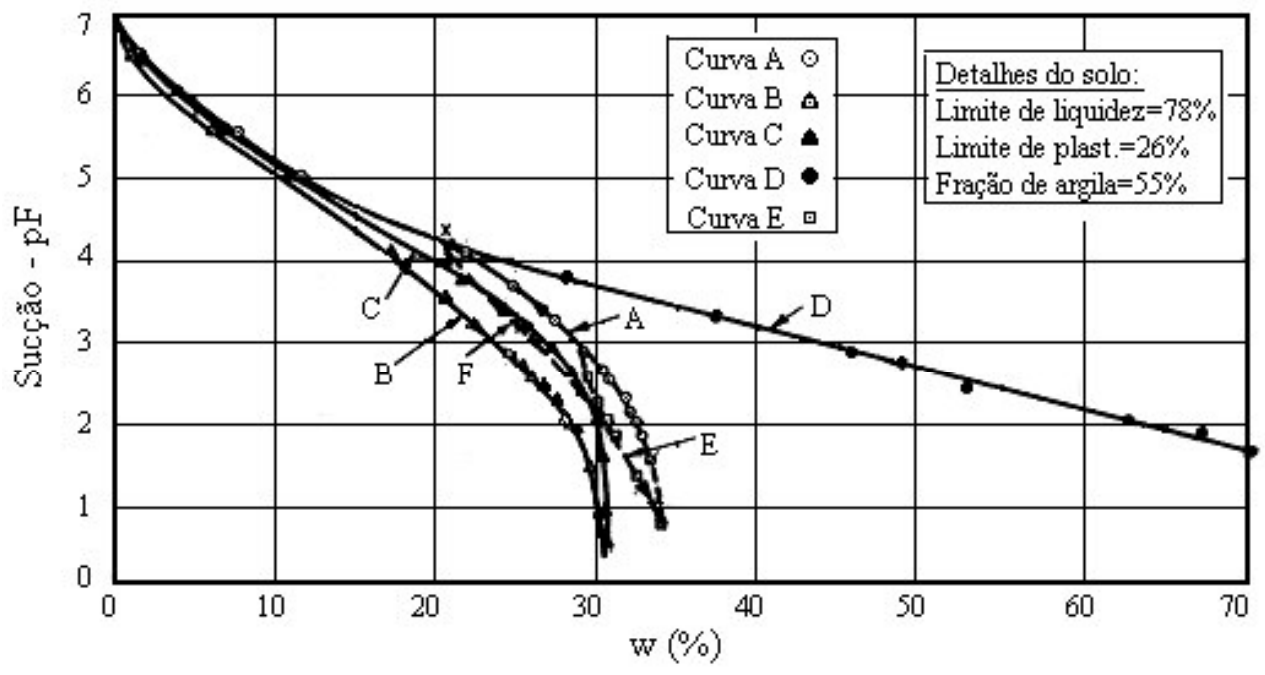

Figura 2.43 - Curvas de retenção obtidas em ciclos de secagem e umedecimento (Croney, 1952).

Croney (1952) afirma que provavelmente nenhuma reorientação das partículas ocorre até que a sucção não exceda o máximo valor a que esteve submetido durante a sua história geológica de formação. A curva D foi obtida da amostra deste solo preparada com a consistência de lama submetida posteriormente a secagem. Segundo Croney (1952), o ponto onde as curvas A e D coincidem, representa a máxima sucção imposta ao solo indeformado durante a sua formação. As variações estruturais no primeiro ciclo de secagem só ocorrem a partir deste valor de sucção. 
Mesmo para solos incompressíveis o ciclo de secagem e umedecimento podem não coincidir para o valor de sucção igual a zero. Este fato deve-se a maneira como a água é retida na estrutura do solo durante a secagem e umedecimento. Na Figura 2.44 observa-se que a mesma sucção mantida durante a secagem e umedecimento corresponde a diferentes teores de umidade. Durante a secagem a sucção é mantida na entrada do poro menor, estando o interior do poro maior preenchido com água. A mesma sucção mantida no processo de umedecimento esta associada ao poro menor ficando o interior preenchido com ar. Portanto a capacidade de retenção de água está associada à entrada do poro e não ao seu interior (Dineen e Ridley, 1999).

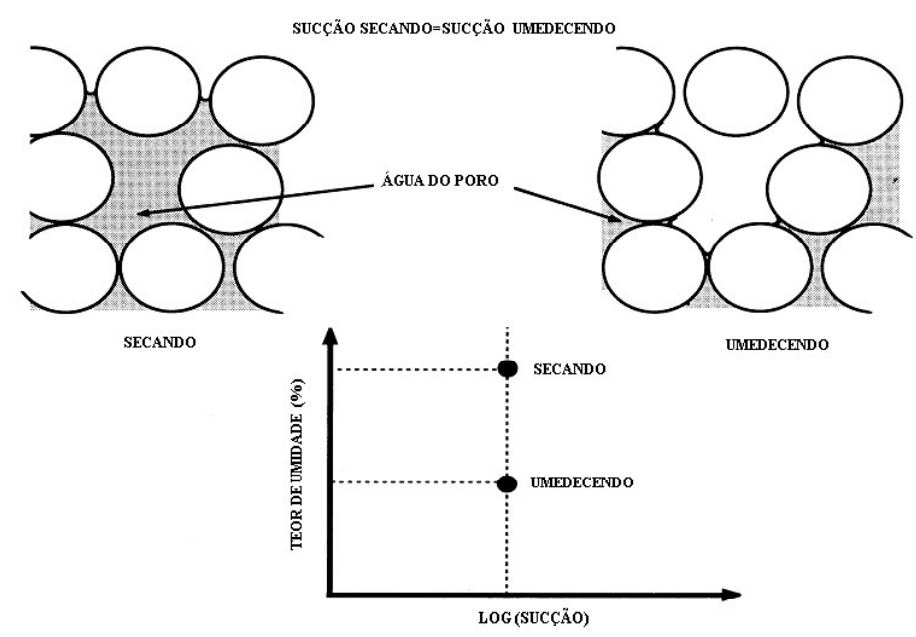

Figura 2.44 - Variação dos teores de umidades para um mesmo valor de sucção em função de ciclos de secagem e umedecimento (Dineen e Ridley, 1999).

Algumas pesquisas têm demonstrado que ciclos de secagem e umedecimento influenciam nos valores de resistência ao cisalhamento. Nishimura e Fredlund (2002) estudaram estes aspectos utilizando um solo siltoso e um caolim compactados estaticamente. Após a moldagem estes corpos de prova foram colocados em uma câmara com umidade relativa controlada. No interior desta câmara de ensaio os mesmos passam a perder água até atingirem o equilíbrio (1 mês) com a umidade relativa ambiente. Cada valor de umidade relativa corresponde a uma determinada sucção total imposta aos corpos de prova. 
Em seguida são retirados da câmara e utilizados em ensaios de compressão simples. Alguns corpos de provas foram secados (umidade relativa de $40 \%$ ) e posteriormente umedecidos na câmara sendo submetidos às umidades relativas de 50\%, 60\%, 70\% e $80 \%$. Após absorverem água e entrar equilíbrio com a sucção imposta, foram também utilizadas em ensaios de compressão simples. Nas Figuras 2.45 e 2.46 estão plotados os resultados da resistência ao cisalhamento destes corpos de prova em função da sucção. Os corpos de prova submetidos à secagem e umedecimento apresentaram, para elevados valores de sucção (além da sucção residual), resistência menor em relação aos que foram submetidos apenas a secagem. Portanto os ciclos de secagem e umedecimento podem provocar uma pequena histerese em relação aos valores de resistência ao cisalhamento.

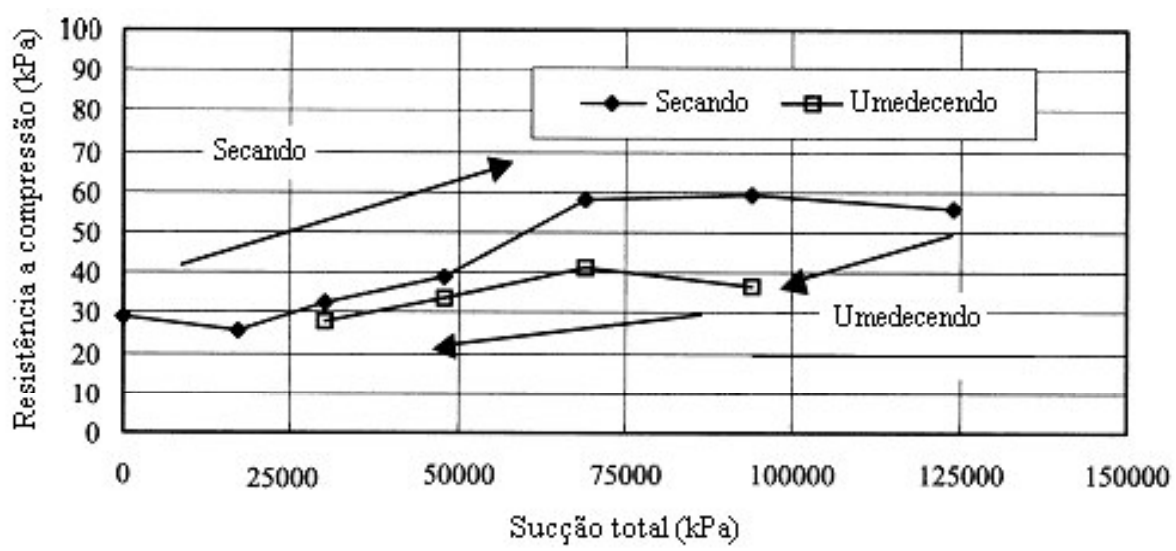

Figura 2.45 - Relação entre a resistência a compressão simples e a sucção total obtida para um solo siltoso (Nishimura e Fredlund, 2002).

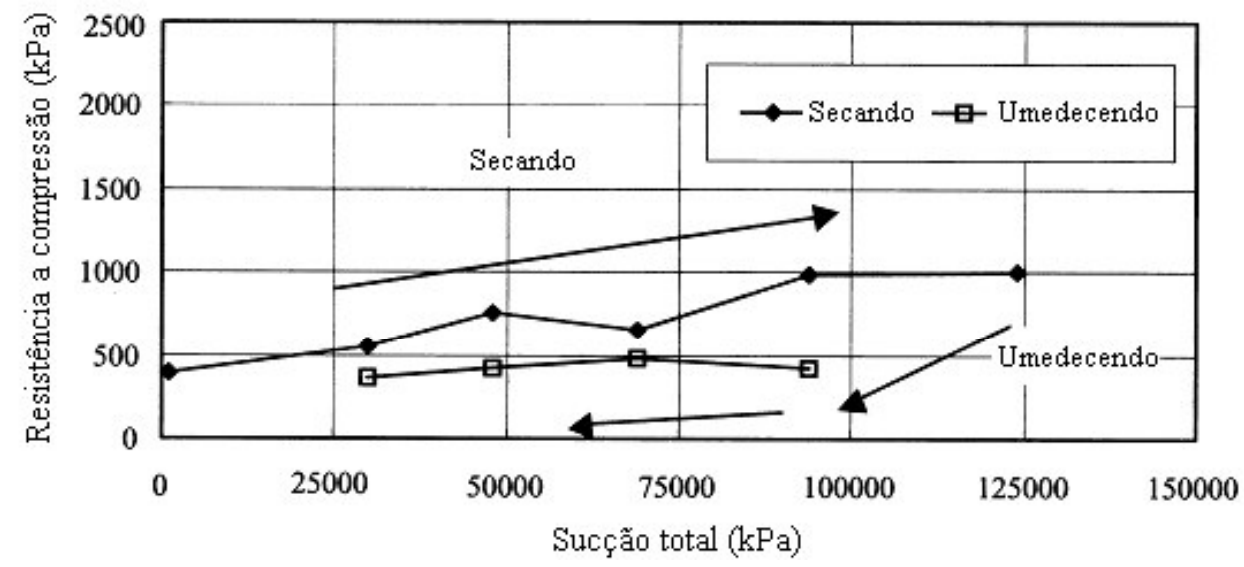

Figura 2.46 - Relação entre a resistência a compressão simples e a sucção total obtida para um caolim (Nishimura e Fredlund 2002). 


\section{4 - Modelos de previsão da resistência em função da curva de retenção}

Os modelos de previsão da resistência ao cisalhamento em função da sucção surgiram nos últimos 8 anos utilizando como principal ferramenta a curva de retenção. Estas propostas semi-empíricas tem como principal objetivo a rápida estimativa da resistência para fins práticos de engenharia. Os ensaios em solos não saturados são mais elaborados e consomem tempo. Portanto a partir da curva de retenção e com os parâmetros de resistência efetiva, obtidos em ensaios saturados, a resistência do solo no estado não saturado pode ser prevista com maior rapidez. No presente trabalho são utilizados dois modelos de previsão da resistência. Seus aspectos teóricos e limitações estão descritos neste item.

\subsection{1 - Relação entre a curva de retenção e a resistência ao cisalhamento}

Fredlund et al (1995) verificaram a relação entre os valores de resistência em função da sucção com a curva de retenção. Suas conclusões estão apresentadas esquematicamente na Figura 2.47, onde se observa que para valores de sucção menores que a entrada de ar a sucção é tão efetiva quanto à tensão confinante na mobilização de resistência, de forma que $\phi$ ' é igual a $\phi_{b}$. Para valores de sucção maiores que a entrada de ar a contribuição da sucção na resistência ao cisalhamento decresce de forma não linear. A perda de resistência após a sucção correspondente à entrada de ar, já havia sido constatada por Bishop et al (1975) ao realizar ensaios triaxiais em solos argilosos. Além da sucção residual, a resistência ao cisalhamento em função da sucção pode aumentar, permanecer constante ou decrescer. 


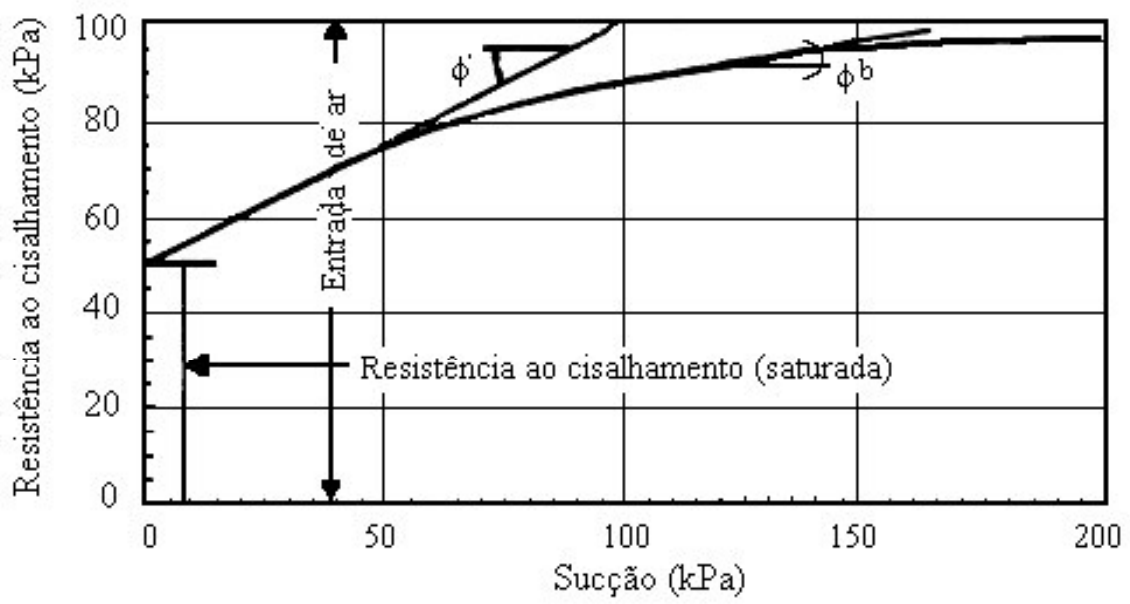

Figura 2.47 - Relação entre a resistência ao cisalhamento e a curva de retenção (Fredlund et al, 1995).

A resistência de solos siltosos e arenosos geralmente diminui para valores de sucções próximas ao valor residual. Não existem muitas evidências experimentais que possam explicar este tipo de comportamento (Vanapalli et al, 1996). A relação entre a resistência ao cisalhamento e a curva de retenção corresponde à forma como a água se encontra no interior do solo. White et al (1970) formularam uma teoria para a dessaturação de meios porosos, cujo mecanismo permite a definição de quatro regiões distintas de saturação. Na Figura 2.48 estão apresentadas as diversas regiões em que se divide a curva de retenção. Estas diferentes condições em que a água se encontra no interior da estrutura do solo estão ilustradas na Figura 2.49.

Na região de efeito de contorno (Figura 2.49a) os poros estão preenchidos com água e o solo está saturado, com o ar podendo estar presente na forma de ar ocluso. $\mathrm{Na}$ zona de transição (Figura 2.50b) ocorre significativa dessaturação, que vai diminuindo de intensidade à medida que se aproxima da zona residual. Nesta zona a água esta presente de forma descontínua. A observação da correlação entre a curva de retenção e a resistência ao cisalhamento do solo não saturado, possibilitou que a mesma fosse usada como uma importante ferramenta de alguns modelos de previsão da resistência. 


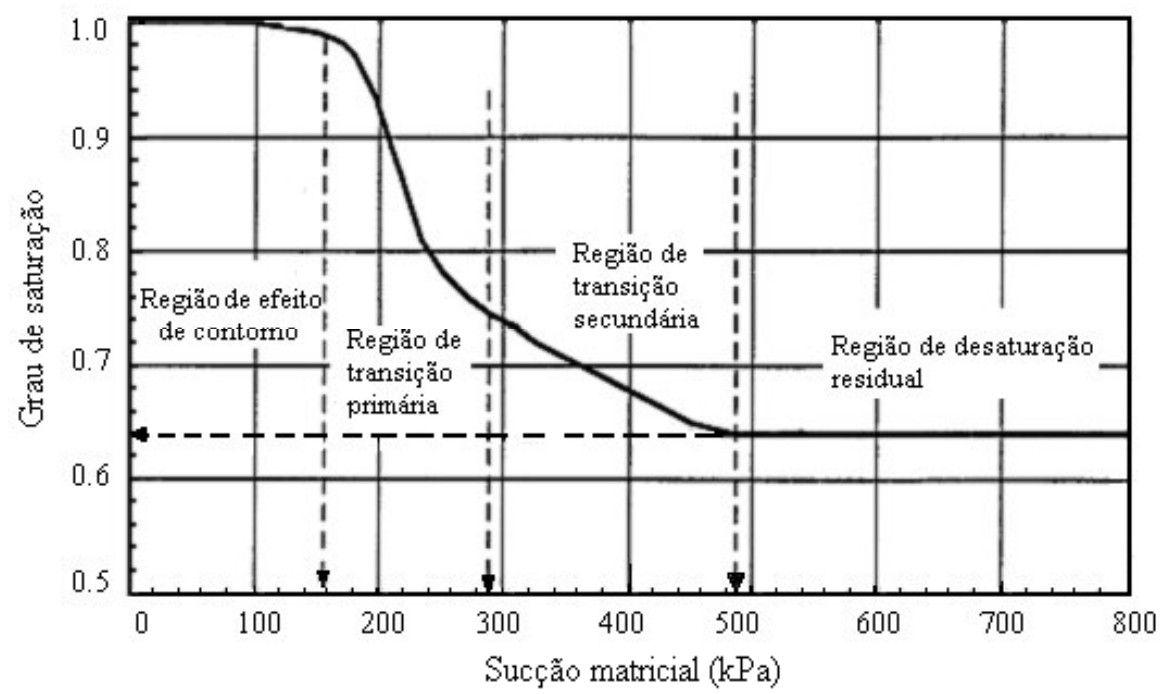

Figura 2.48 - Regiões em que se divide a curva de retenção em função da dessaturação (Vanapalli (1994) modificado de White et al (1970)).

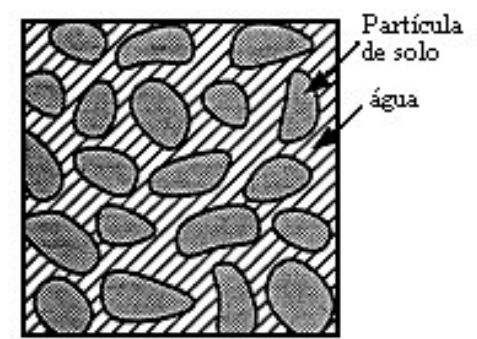

(a) Região de efeito de contomo

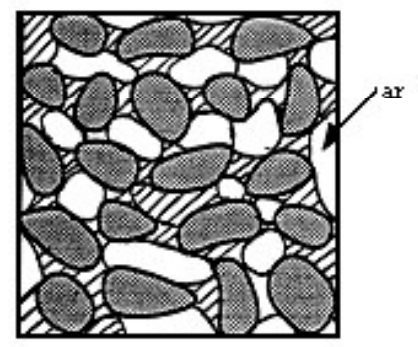

(c) Região de transição secundária

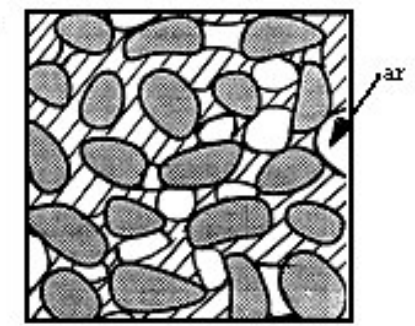

(b) Região de transição primária

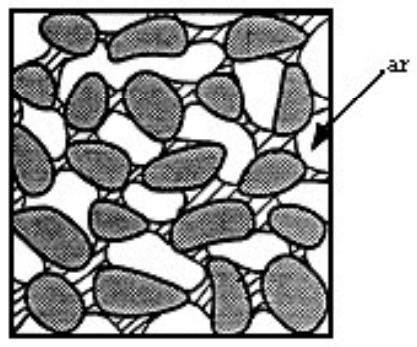

(d) Região de desaturação residual

Figura 2.49 - Redução da área de água em função das diferentes regiões de dessaturação (Vanapalli, 1994). 


\subsection{2 - Modelo de previsão da resistência ao cisalhamento proposto por Vanapalli et al (1996)}

Este modelo está fundamentado na representação da resistência ao cisalhamento dos solos não saturados utilizando duas variáveis independentes de estado de tensão, conforme proposta de Fredlund et al (1978). Seu desenvolvimento teórico está relacionado à forma como a água se encontra no interior do solo. A relação da sucção com a resistência ao cisalhamento é função da área de água normalizada $\left(\mathrm{a}_{\mathrm{w}}\right)$ definida como:

$a_{w}=\frac{A d_{w}}{A t_{w}}$

Onde: $\mathrm{a}_{\mathrm{w}}$ - área de água normalizada; $\mathrm{At}_{\mathrm{w}}$ - área total de água na saturação; $\mathrm{Ad}_{\mathrm{w}}$ - área de água correspondente a algum grau de saturação.

$\mathrm{O}$ valor de $\mathrm{a}_{\mathrm{w}}$ varia de 1 na saturação até zero quando o solo está seco. Raciocínio semelhante foi utilizado por Skempton (1960) para interpretar o valor de $\chi$. Devido à similaridade entre $\mathrm{a}_{\mathrm{w}}$ e a umidade volumétrica normalizada $(\Theta)$ a seguinte relação pode ser escrita:

$a_{w}=(\Theta)^{k}$

Onde: $\kappa$ é um parâmetro de forma, $\Theta$ - relação entre a umidade volumétrica e a umidade volumétrica na saturação $\left(\theta / \theta_{\mathrm{s}}\right)$.

O parâmetro $\kappa$ foi utilizado para se obter uma melhor correlação entre os valores dados pelo modelo e os valores experimentais dos ensaios de resistência. Em termos de área de água normalizada a contribuição da sucção na resistência ao cisalhamento pode ser escrita como:

$$
\tau_{u s}=\left(u_{a}-u_{w}\right)\left[a_{w} \tan \phi^{\prime}\right]
$$


Substituindo a equação 2.22 na equação 2.23 tem-se:

$$
\tau=\left(u_{a}-u_{w}\right)\left[(\Theta)^{\kappa} \tan \phi^{\prime}\right]
$$

Portanto, a resistência ao cisalhamento de um solo não saturado é representada pela seguinte equação:

$$
\tau=c^{\prime}+\left(\sigma-u_{a}\right) \tan \phi^{\prime}+\left(u_{a}-u_{w}\right)\left[(\Theta)^{\kappa} \tan \phi^{\prime}\right]
$$

Os valores de umidade volumétrica e sucção são obtidos da curva de retenção. A relação entre ambos pode ser obtida matematicamente usando a equação proposta por Fredlund e Xing (1994) ou qualquer outra relação que se ajuste aos dados experimentais. Os parâmetros $\phi$ ' e c' são considerados constantes e são obtidos em ensaios triaxiais ou de cisalhamento direto na condição saturada. Para se aplicar equação 2.25 deve-se determinar o valor de $\kappa$ que proporciona o melhor ajuste aos resultados experimentais. Vanapalli e Fredlund (2000) afirmam que o parâmetro $\kappa$ pode ser influenciado pelo índice de plasticidade, estrutura do solo e o tipo de compactação. Apesar da necessidade de mais estudos para estabelecer uma forma de se determinar $\kappa$, estes autores propuseram uma correlação com o índice de plasticidade, apresentada na Figura 2.50. Esta relação foi obtida utilizando os resultados de Escário e Jucá (1996), Vanapalli et al (1996) e Adaams et al (1996).

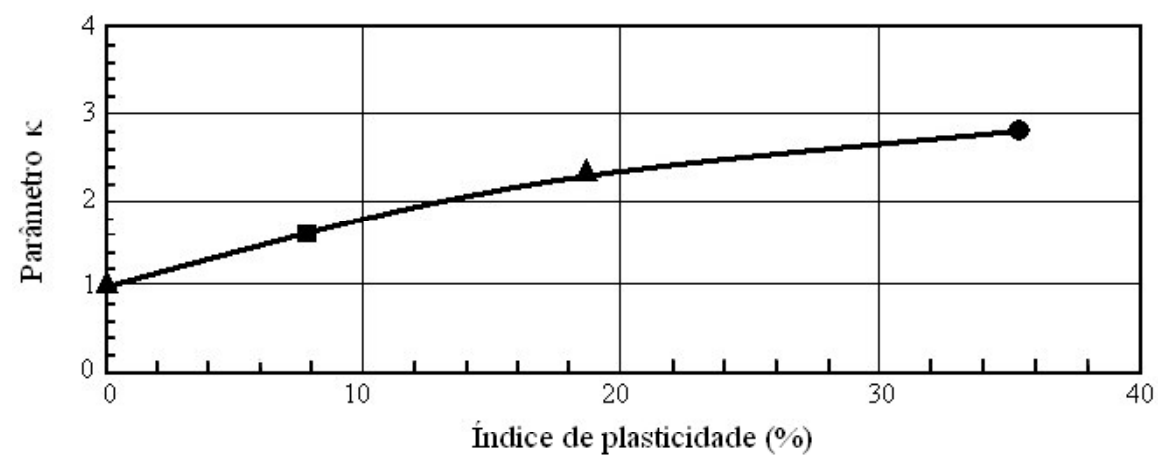

Figura 2.50 - Relação entre o IP e o parâmetro k (Vanapalli e Fredlund, 2000). 
Com a possibilidade de se estimar o valor de $\kappa$, utilizando a relação da Figura 2.50, este modelo deixa de ser uma proposta de ajuste aos valores experimentais para ser um modelo de previsão da resistência ao cisalhamento em função da sucção. Vanapalli et al (1996) afirmam que $\phi$ ' pode ser assumido como um valor constante para variações de sucção de 0 a $500 \mathrm{kPa}$, que é geralmente a variação de interesse na engenharia geotécnica. A curva de retenção, utilizada na aplicação deste modelo, deve ser obtida de forma a simular as mesmas condições do solo que se pretende prever a sua resistência. Se este solo apresenta uma determinada pressão de confinamento, a curva de retenção deve ser determinada utilizando um corpo de prova submetido a este mesmo confinamento.

Vanapalli et al (1996) estudaram a aplicabilidade de seu modelo realizando ensaios em um solo siltoso (Indian Head Till). Este solo apresenta limite de liquidez de $35.5 \%$ e limite de plasticidade de $16.8 \%$. A fração de areia, silte e argila correspondem a $28 \%, 42 \%$ e $30 \%$, respectivamente. As amostras foram compactadas estaticamente em três condições iniciais de moldagem, de forma a representar o ramo seco, umidade ótima e o ramo úmido. Os valores de resistência foram obtidos em ensaios de cisalhamento direto modificado (Gan e Fredlund, 1988) realizados em múltiplos estágios. Na Figura 2.51 estão os valores experimentais, obtidos para os corpos de prova moldados no ramo seco, e o resultado previsto pelo modelo ao se utilizar a equação 2.25. Neste caso o valor de $\kappa$ foi utilizado como um parâmetro de ajuste aos pontos experimentais. $\mathrm{O}$ valor de $\kappa=2.2$ fornece o melhor ajuste. Para todas as condições de moldagem e pressões confinantes o valor de $\kappa$ variou entre 2.2 e 2.8 . 


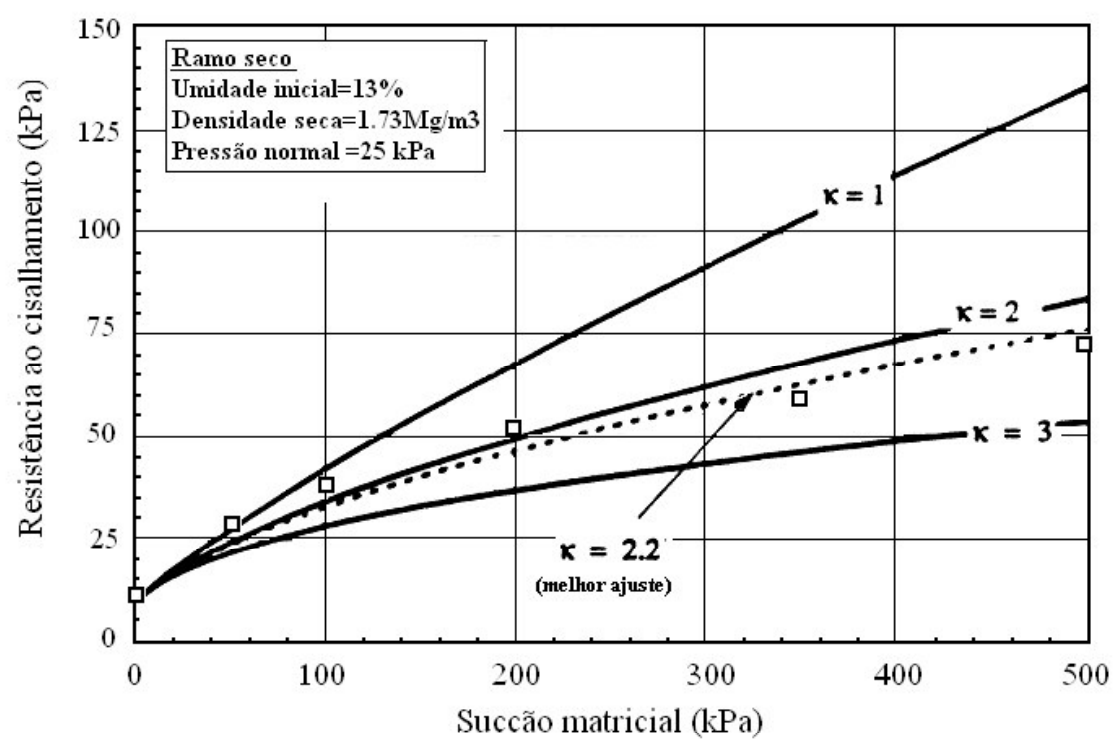

Figura 2.51 - Ajuste de $\kappa$ aos valores experimentais obtidos em ensaios de cisalhamento direto com sucção controlada (Vanapalli et al, 1996).

\subsection{3 - Modelo de previsão da resistência ao cisalhamento proposto por Khalili e Khabbaz (1998)}

Este modelo baseia-se na equação de tensões efetivas em solos não saturados proposta por Bishop (1959). Os autores propõem uma relação única para o valor de $\chi$, dada pela relação entre a sucção e a sucção correspondente à entrada de ar. A equação de resistência ao cisalhamento, utilizando a proposta de Bishop (1959), é igual a:

$\tau=c^{\prime}+\left[\left(\sigma-u_{a}\right)+\chi\left(u_{a}-u_{w}\right)\right] \tan \phi^{\prime}$

Na saturação $u_{a}=u_{w}$ e a equação anterior se reduz a:

$\tau_{0}=c^{\prime}+\left(\sigma-u_{a}\right) \tan \phi^{\prime}$ 
A diferença entre as equações 2.26 e 2.27 representa o acréscimo de resistência atribuída à sucção matricial, representada pela seguinte equação:

$\tau-\tau_{0}=\chi\left(u_{a}-u_{w}\right) \tan \phi^{\prime}$

Portanto o valor de $\chi$ obtido da equação 2.28 é dado por:

$\chi=\frac{\tau-\tau_{0}}{\left(u_{a}-u_{w}\right) \tan \phi^{\prime}}$

Na equação 2.29 supõe-se que $\phi$ ' é constante e independente da matriz de sucção. Na Figura 2.52 esta apresentada esquematicamente como se determina os valores de $\chi$ em função da sucção utilizando a equação 2.28 e os resultados dos ensaios de resistência.

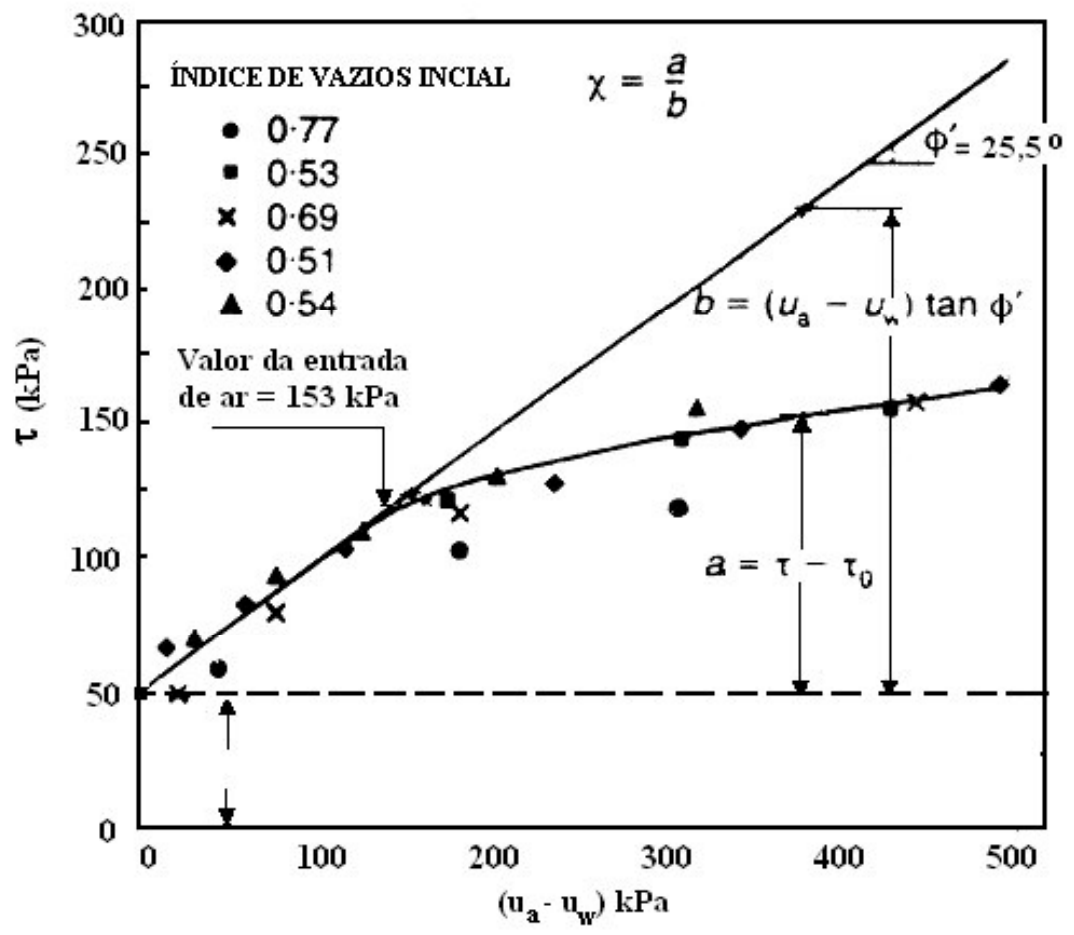

Figura 2.52 - Determinação gráfica do valor de $\chi$ (khalili e khabbaz, 1998). 
Khalili de Khabbaz (1998) analisaram 14 casos publicados na literatura onde foram fornecidos os valores da resistência ao cisalhamento em função da sucção. Os valores de $\chi$ em função da sucção, obtidos destes resultados, estão apresentados na Figura 2.53. Khalili e Khabbaz (1998) afirmam que a intercessão das relações obtidas entre o valor de $\chi$ e a sucção com o valor de $\chi=1$, correspondem às respectivas sucções de entrada de ar de cada solo.

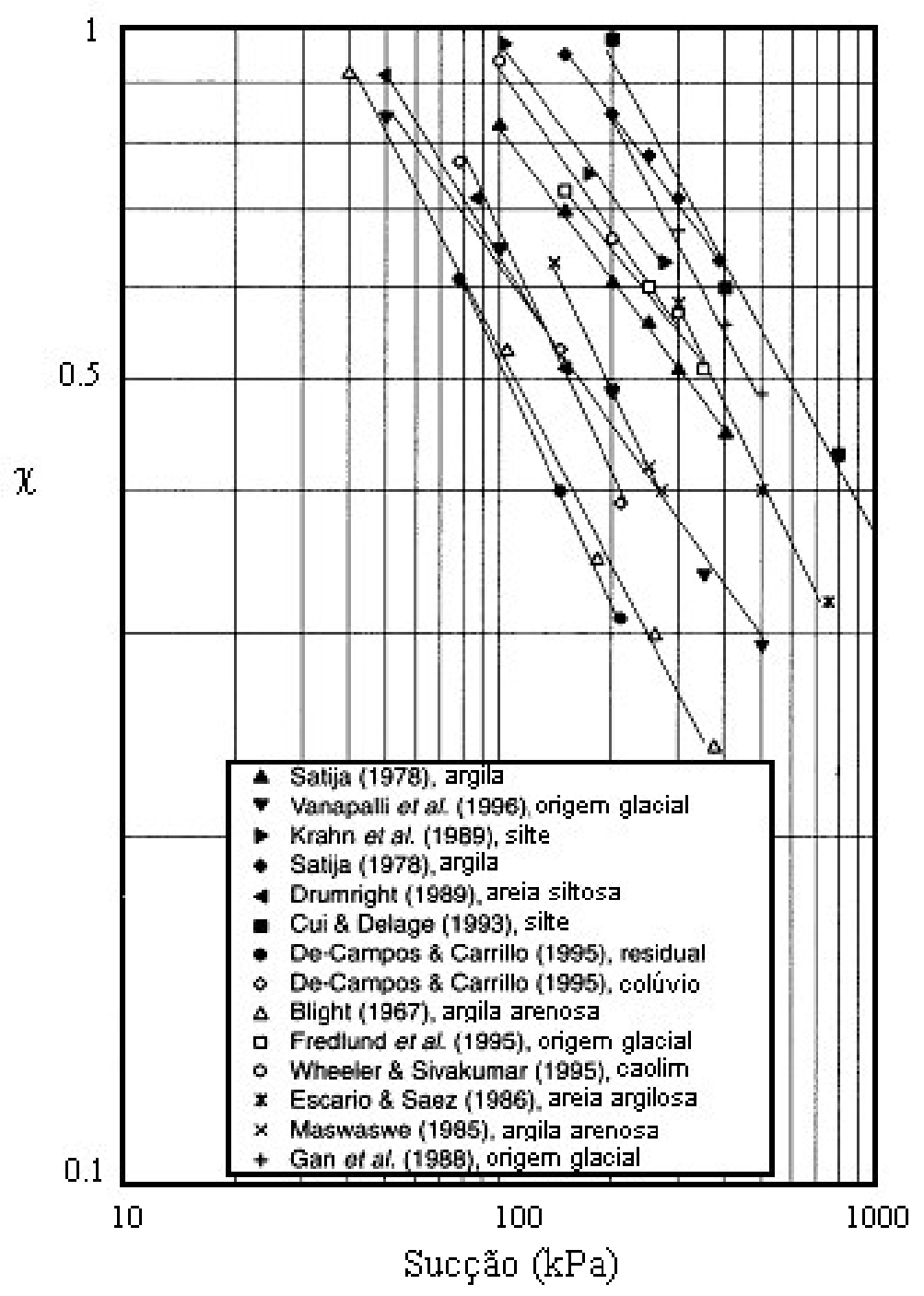

Figura 2.53 - Relação entre $\chi$ e a sucção matricial (khalili e khabbaz 1998). 
Os valores de $\chi$ em função da sucção (Figura 2.53) foram normalizados em relação às respectivas sucções de entrada de ar, estando estes resultados apresentados na Figura 2.54. Observa-se nesta Figura que os valores experimentais apresentam uma pequena dispersão, cujos limites estão representadas pelas linhas pontilhadas. A reta limite inferior corresponde aos solos granulares e a reta limite superior está relacionada aos solos finos. $\mathrm{O}$ valor médio desta faixa de variação é dado pela bissetriz do ângulo formado entre estas duas linhas, cuja equação é dada por:

$\chi=\left[\frac{\left(u_{a}-u_{w}\right)}{\left(u_{a}-u_{w}\right)_{b}}\right]^{-0,55}, C c=0.94$

Onde: $\left(\mathrm{u}_{\mathrm{a}}-\mathrm{u}_{\mathrm{w}}\right)_{\mathrm{b}}$ - valor da sucção correspondente a entrada de ar e Cc - coeficiente de correlação.

Para se aplicar a equação 2.26 deve-se obter os valores dos parâmetros efetivos do solo e a sucção correspondente a entrada de ar. A boa correlação entre o valor de $\chi$ e a sucção, constatada na Figura 2.54, sugere que este parâmetro está fortemente relacionado com a estrutura do corpo de prova, conforme sugerido por Coleman (1962).

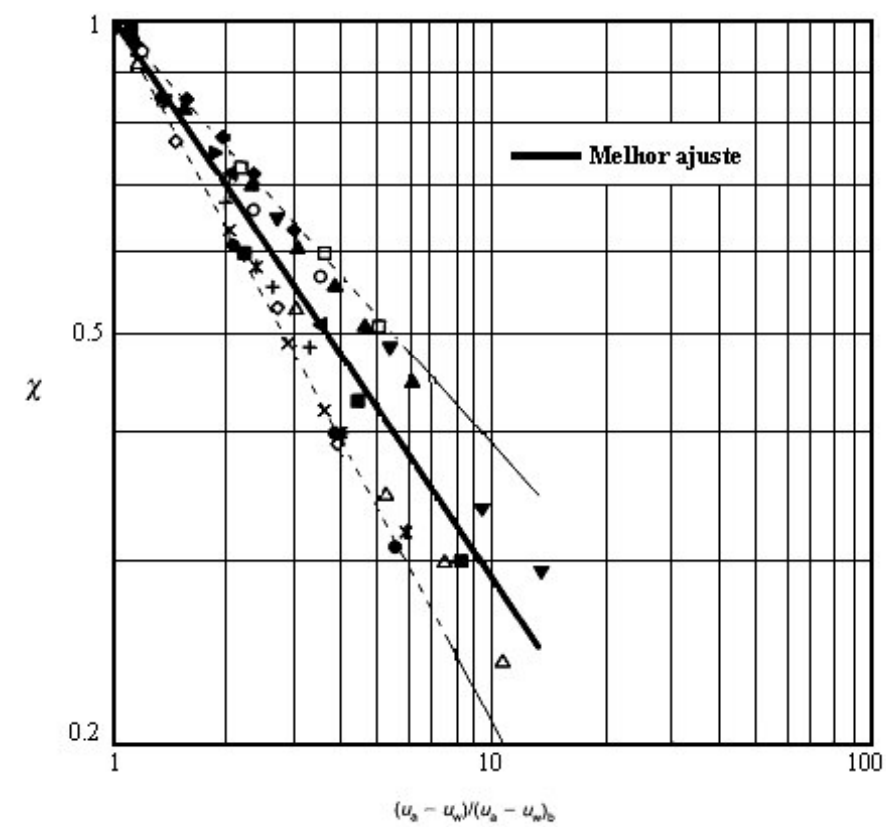

Figura 2.54 - Variação de $\chi$ em função da sucção normalizada em relação à entrada de ar (Khalili e Khabbaz, 1998). 


\section{3 - DESCRIÇÃO DOS EQUIPAMENTOS UTILIZADOS E PROCEDIMENTOS PARA A CALIBRAÇÃO DO PAPEL FITRO}

Na presente pesquisa foram utilizados alguns equipamentos que ainda não são de uso comum nos laboratórios de geotécnica. Entre eles estão a placa de sucção, placa de pressão e o tensiômetro. Neste capítulo estes equipamentos são resumidamente descritos juntamente com o seu princípio de funcionamento. Em função da necessidade de se obter a curva de calibração do lote de papel filtro utilizado nesta pesquisa, são também apresentados os procedimentos e os cuidados que devem ser tomados para se obter estes resultados.

\section{1 - Placa de sucção}

A placa de sucção foi utilizada para se obter os pontos experimentais da curva de retenção para valores de sucção entre 0 e $30 \mathrm{kPa}$. Este equipamento consiste em uma base de latão de formato circular apresentando em seu interior um recipiente onde é colocada a pedra porosa de alta entrada de ar (100 kPa). O esquema da placa de sucção utilizada nesta pesquisa esta apresentada na Figura 3.1. A pedra porosa, fabricada pela Soil Moisture Equipament Corp. possui as seguintes características:

- Diâmetro de $15 \mathrm{~cm}$

- Espessura de 0,7 cm

- Entrada de ar de $100 \mathrm{kPa}$.

- Porosidade de $34 \%$

- Máximo diâmetro do poro de $2.1 \mu \mathrm{m}$

- Permeabilidade saturada de $3.46 \times 10^{-7} \mathrm{~cm} / \mathrm{s}$. 


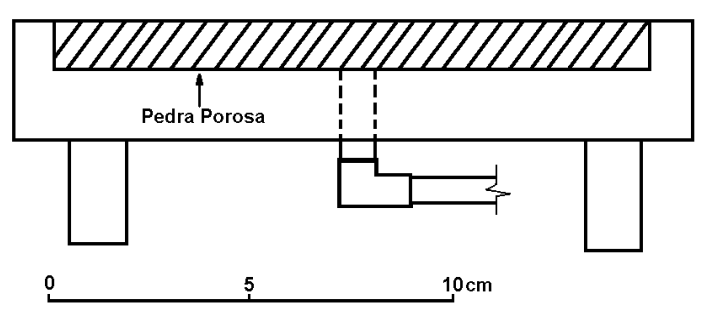

Figura 3.1 - Esquema da placa de sucção.

\subsection{1 - Saturação da pedra porosa}

Para a saturação da pedra porosa, o conjunto apresentado na Figura 3.1 é colocado no interior de um dessecador, contendo água destilada, para a aplicação de vácuo. A placa de sucção fica submetida a vácuo até o momento em que não se percebe mais a saída de ar da pedra porosa. Após esta primeira etapa, a placa de sucção é retirada do dessecador e conectada pela base por um tubo plástico preenchido com água, estando a sua outra extremidade no interior de um reservatório de água. A placa de sucção é mais uma vez imersa em água destilada para os procedimentos de circulação de água pela pedra porosa. Para que isto ocorra o reservatório de água, conectado à outra extremidade do tubo, deve estar com uma altura inferior a da placa de sucção. A passagem contínua de água destilada pela pedra porosa auxilia na remoção do ar presente em seu interior.

\subsection{2 - Princípio de funcionamento}

Na Figura 3.2 esta esquematicamente apresentada a placa de sucção e os acessórios necessários para se impor um determinado valor de sucção aos corpos de prova. A sucção aplicada pela pedra porosa esta relacionada à diferença da sua altura em relação ao recipiente de água colocado na outra extremidade do tubo. A placa de sucção fica apoiada em suporte de metal que pode ser encaixado em pinos espaçados de $0,5 \mathrm{~m}$ até a altura de 3 metros. 
O valor da sucção de entrada de ar da pedra porosa impede que a água presente em seu interior e na tubulação escoe completamente para o reservatório de água. Desta forma, a água da pedra porosa passa a ficar com uma pressão negativa correspondente à sua diferença de altura em relação ao reservatório de água. Um desnível de 1 metro corresponde a uma sucção igual a $10 \mathrm{kPa}$. A altura do reservatório de água pode ser regulada ao longo da haste metálica, possibilitando assim um ajuste fino da sucção imposta pela pedra porosa. A utilização deste equipamento é limitado para sucções de aproximadamente $90 \mathrm{kPa}$, a partir da qual a água presente no interior da tubulação cavita.

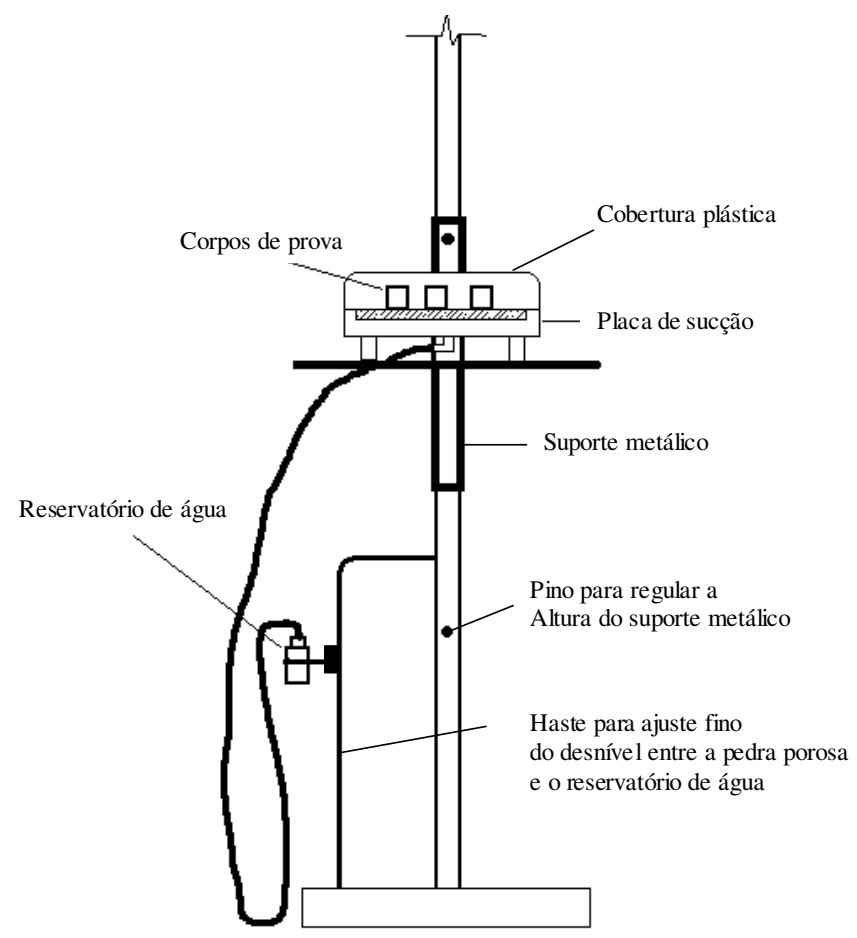

Figura 3.2 - Equipamento utilizado para o ensaio da placa de sucção (sem escala). 


\section{2 - Placa de pressão}

O esquema da placa de pressão está apresentado na Figura 3.3. Este equipamento é composto de uma base de latão, semelhante à placa de sucção, e de mais duas peças que em conjunto formam uma câmara que possibilita a aplicação da técnica da translação de eixos. A vedação entre estas peças é feita com utilização de o-rings. Seis parafusos conectados à base e a tampa unem as três peças, citadas anteriormente, garantindo um ambiente capaz de suportar elevadas pressões de ar.

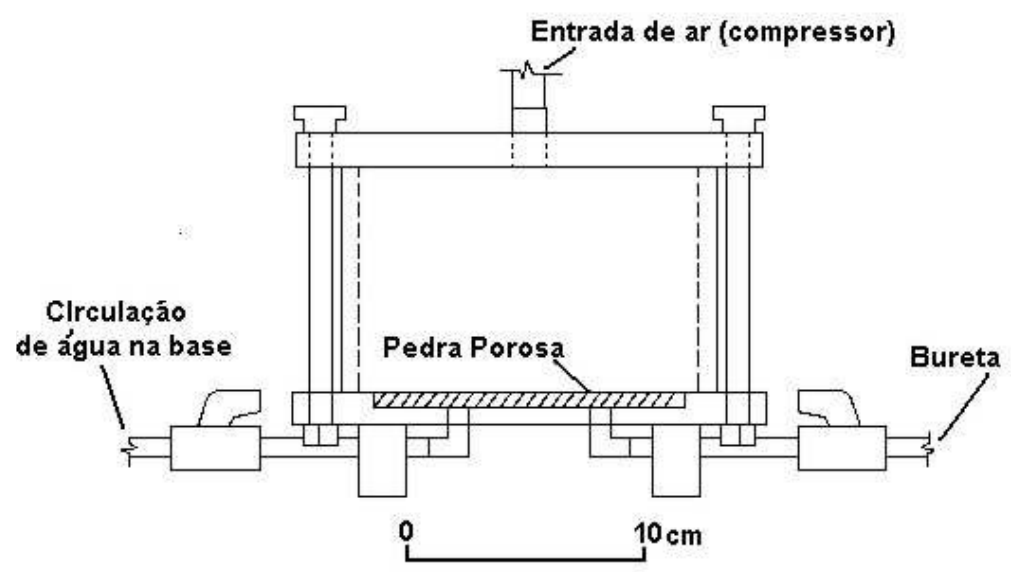

Figura 3.3 - Detalhes da placa de pressão.

\subsection{1 - Saturação da pedra porosa}

A pedra porosa utilizada tem capacidade de medir sucções de até $500 \mathrm{kPa}$, apresentando as seguintes características:

- Diâmetro de $15 \mathrm{~cm}$

- Espessura de 0,7 cm

- Entrada de ar de $500 \mathrm{kPa}$.

- Porosidade de $31 \%$

- Máximo diâmetro do poro de 0,5 $\mu \mathrm{m}$

- Permeabilidade saturada de $1,21 \times 10^{-7} \mathrm{~cm} / \mathrm{s}$. 
A saturação é realizada em três etapas. Primeiramente a base do equipamento é colocada no dessecador, sendo submersa em água e submetida a vácuo. A partir do momento em que cessa a saída de ar da pedra porosa, a base é retirada do dessecador e submetida à circulação de água. Neste procedimento a câmara é preenchida com água até a metade de sua altura, sendo posteriormente fechada e aplicada uma pressão de ar no seu interior. Após a abertura da conexão com a bureta a água passa a fluir continuamente pela pedra porosa. Finalmente é feita a circulação de água pela base da pedra, utilizando para isto as duas conexões da base.

\subsection{2 - Princípio de funcionamento}

Na placa de pressão a sucção máxima permitida é função da entrada de ar da pedra porosa e da capacidade do sistema de aplicação de pressão de ar. Neste equipamento a sucção é imposta utilizando-se a técnica da translação de eixos proposta por Hilf (1956). A água da pedra porosa está conectada ao exterior da câmara por uma tubulação conectada a uma bureta. Como a água da pedra porosa esta com pressão atmosférica (pressão relativa igual a zero), a sucção imposta neste equipamento corresponde ao valor da pressão de ar aplicada. O corpo de prova colocado sobre a pedra porosa tende a ganhar ou perder água, caso a sua sucção seja maior ou menor que a sucção aplicada pela pedra porosa. A estabilização da sucção imposta ao corpo de prova é acompanhada pela variação do nível de água da bureta.

\section{3 - Tensiômetro de alta capacidade}

Ridley e Burland (1993) desenvolveram um equipamento capaz de medir de forma direta a poro pressão da água presente na estrutura do solo, evitando assim o uso da técnica da translação de eixos. Nesta pesquisa foi utilizado o tensiômetro semelhante ao desenvolvido no Imperial College por Ridley e Burland (1993). Este equipamento, apresentado na Figura 3.4, consiste basicamente de um transdutor, uma pedra porosa e água. 
O transdutor é do tipo Entran EPX, acoplado a uma cápsula de aço inox. Esta cápsula é composta de uma câmara, com pequeno volume de água, que está em contato com uma pedra porosa de alta entrada de ar e um diafragma. O acabamento da parede interna desta cápsula de aço inox deve estar isento de imperfeições, para se evitar a formação de potenciais núcleos de cavitação (Marinho,1998). Na montagem deste equipamento deve-se tomar cuidado para que a cápsula ou a pedra porosa não toque na parte sensível do diafragma (Marinho, 1998).

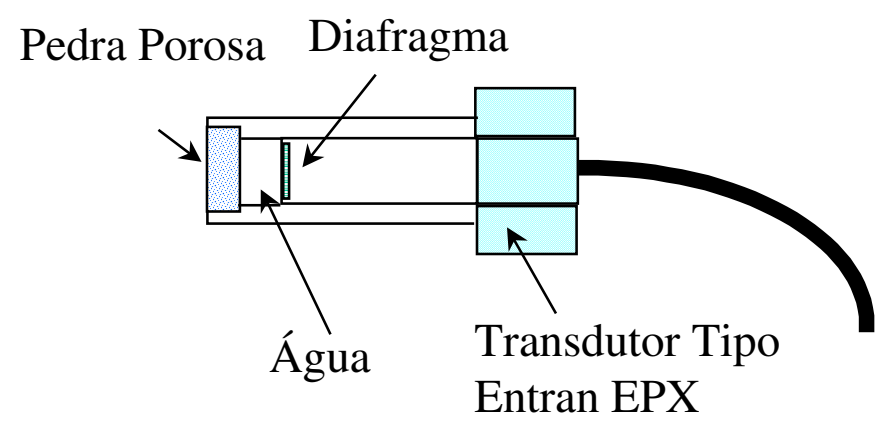

Figura 3.4 - Representação esquemática do tensiômetro.

\subsection{1 - Princípio de funcionamento}

Para se medir o valor da sucção de um corpo de prova com o tensiômetro deve-se garantir que a água presente em sua estrutura apresente uma continuidade hidráulica com a água da pedra porosa deste equipamento. Para que isto ocorra, foi utilizada uma pasta preparada com o mesmo solo e com teor de umidade próxima ao limite de liquidez. A pasta é primeiramente colocada sobre o tensiômetro, sendo em seguida assentado o corpo de prova sobre a mesma. Neste momento a pasta passa a perder água para o corpo de prova até o momento em que ambos estejam com a mesma sucção. Como a pasta esta em contato com a pedra porosa do tensiômetro, a pressão negativa da água presente em sua estrutura é transmitida ao diafragma do transdutor. $\mathrm{O}$ valor da resistência elétrica do diafragma varia com a sua flexão. 
A variação da voltagem é transmitida para o sistema de aquisição de dados onde é convertida, através de sua calibração, em unidades de pressão (kPa). A estabilização da sucção do corpo de prova e sua variação durante o cisalhamento são acompanhadas na tela do computador, utilizando o software TRIAX desenvolvido na Universidade de Durhan.

\subsection{2 - Saturação e calibração}

Para que o tensiômetro possa ser capaz de medir valores elevados de sucção, deve-se garantir que a pedra porosa esteja saturada e a parede interna da câmara, preenchida com água, não apresente bolhas de ar. O volume reduzido de água no interior do tensiômetro e o acabamento interno da cápsula de aço inox reduzem o número de potenciais núcleos de cavitação. A cavitação da água do tensiômetro pode ocorrer na parede interna da câmara (perda de adesão) ou na pedra porosa (Tarantino et al, 2000). Segundo o modelo das cavidades proposto por Harvev et al (1994), a cavitação não ocorre no interior da água (perda de coesão). A possibilidade da cavitação ocorrer no próprio líquido necessita de uma grande concentração de energia que não é possível para medidas de sucção em solos (Marinho, 1998).

Para a saturação o tensiômetro é inicialmente submetido a vácuo sendo em seguida imerso em uma solução contendo lauril sulfato de sódio. Este procedimento é realizado em um cilindro contendo aproximadamente metade do volume com esta solução, conforme apresentado na Figura 3.5. Na posição indicada nesta figura, este vácuo esta sendo aplicado diretamente sobre a pedra porosa. Em seguida o cilindro é colocado na posição vertical fazendo com que o tensiômetro entre em contato com a solução. Este procedimento é repetido diversas vezes.

Segundo Marinho (1998), esta técnica não é suficiente para eliminar totalmente o ar presente no tensiômetro. A complementação da saturação foi obtida por ciclos de pressão positiva de água sobre o tensiômetro (4 MPa) (Marinho e Pinto, 1997). Com pressões elevadas o ar, presente no interior da pedra porosa, se dissolve na água. 
Ao se aliviar a pressão, apesar de ocorrer novamente a expansão do ar, parte dele sai dissolvido na água. São necessários diversos ciclos de pressão e descompressão para a saturação do tensiômetro. Tarantino et al (2000) afirmam que ciclos de cavitação melhoram a performance do tensiômetro, possibilitando a medição da sucção por um tempo maior. No entanto, Guan e Fredlund (1996) constataram que estes ciclos de cavitação podem danificar a pedra porosa, sendo necessário que seja trocada.

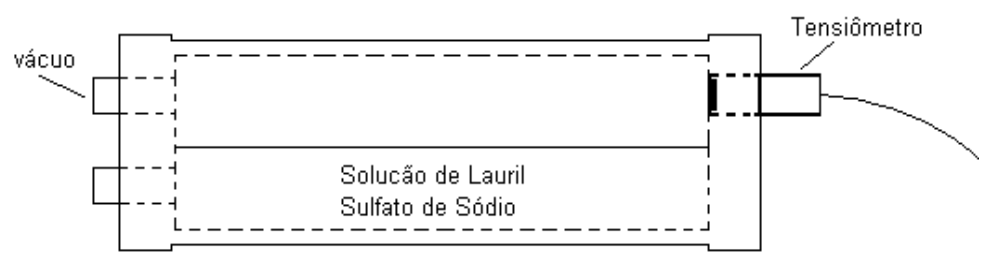

Figura 3.5 - Equipamento utilizado na saturação do tensiômetro.

A confirmação da saturação do tensiômetro é obtida pelo seu tempo de resposta a ciclos de variação de pressão positiva de água. Ao se aplicar uma pressão e em seguida reduzir este valor para zero, o tensiômetro deve acompanhar esta redução instantaneamente. Na Figura 3.6 estão as respostas de dois tensiômetros ao se aplicar ciclos de pressão e descompressão hidráulica. Observa-se nos trechos correspondentes ao alívio de pressão que a resposta do tensiômetro saturado é imediata. Para o tensiômetro não saturado a resposta é mais lenta, reduzindo sua pressão de forma gradativa. A velocidade de resposta do tensiômetro é um excelente indicador da sua saturação (Take e Bolton, 2003). Uma outra forma de se constatar a saturação do tensiômetro, proposta por Meilane et al (2002), é feita pelo acompanhamento das variações de sua leitura em função de pequenas flutuações nos valores da pressão de água aplicada. A calibração do tensiômetro utilizado nesta pesquisa foi determinada para valores de pressão positiva, fazendo-se a extrapolação para valores negativos. Tarantino e Mongiovi (2002) constataram um erro em torno de 1 a $1.5 \%$ no valor da sucção medida, ao se utilizar uma calibração obtida pelo método da extrapolação, justificando assim este procedimento. 


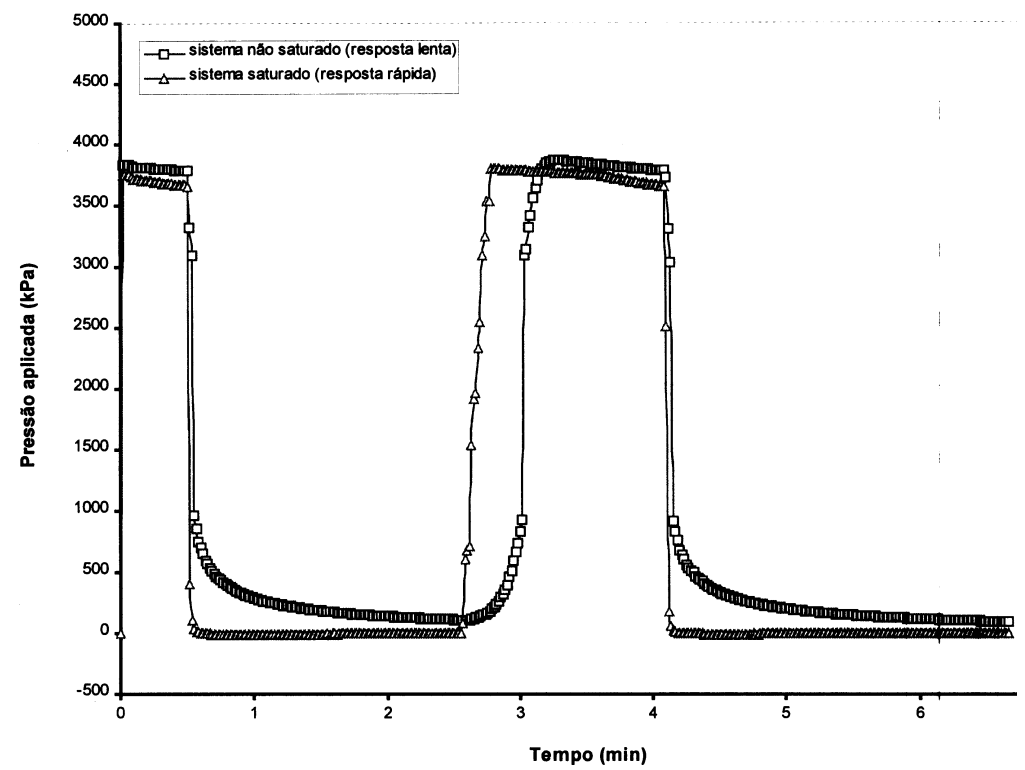

Figura 3.6 - Resposta do tensiômetro a ciclos de pressão hidrostática (Kuwajima, 2000).

\section{4 - Célula de cisalhamento com tensiômetro na base}

O esquema da célula equipada com o tensiômetro está apresentado na Figura 3.7. Nesta célula foram realizados ensaios triaxiais $\mathrm{CD}$ saturado e $\mathrm{CW}$ não saturado. A fase de cisalhamento do corpo de prova, foi realizada com deformação controlada e carregamento controlado. Os ensaios com deformação controlada foram realizados em uma prensa fabricada pela Wykham Ferrance. Nestes ensaios a célula de cisalhamento é colocada no prato da prensa que se eleva com uma velocidade prédeterminada. Os esforços são transmitidos ao corpo de prova por meio de um pistão incorporado a um anel dinamométrico. 


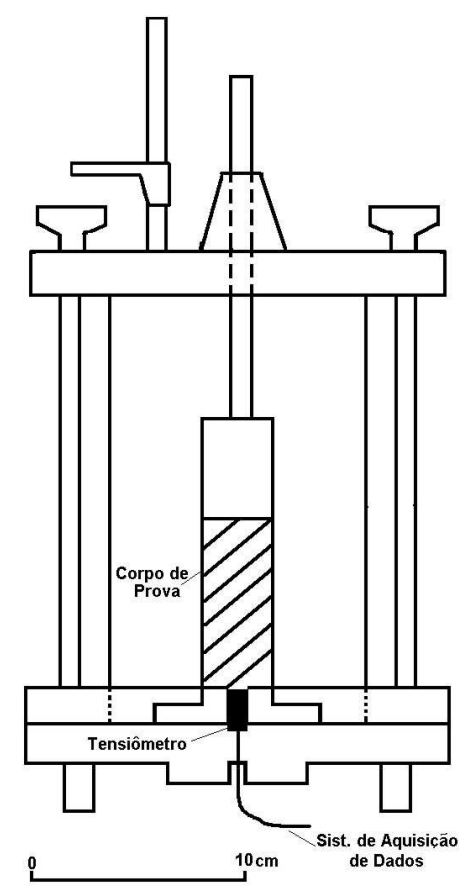

Figura 3.7. - Esquema da célula de cisalhamento utilizada nos ensaios triaxiais CD saturado e CW não saturado.

Na Figura 3.8 está uma representação esquemática dos acessórios utilizados para a realização dos ensaios triaxais com carregamento controlado. O sistema de aplicação de carregamento utiliza um pequeno pórtico metálico que fica apoiado diretamente sobre o pistão colocado no topo do corpo de prova. Um sistema de roldanas e um contrapeso possibilitam que o peso deste pórtico não seja transmitido diretamente para o corpo de prova, durante os procedimentos de montagem do ensaio. A pressão confinante é aplicada pelo compressor utilizando para isto uma interface ar-água. O tensiômetro e um transdutor de pressão, utilizado para a medição da pressão de confinamento, estão conectados a um conversor que por sua vez transmitem a leitura destes canais para o computador. Após a fase de adensamento do corpo de prova, são colocados os incrementos de peso na parte inferior do pórtico metálico, iniciando assim a fase de cisalhamento. Em seguida espera-se a estabilização da variação de sucção do corpo de prova medida pelo tensiômetro e da deformação axial obtida pelo extensômetro colocado no topo da célula. Após a estabilização destes valores acrescenta-se um novo carregamento até que a ruptura do corpo de prova seja atingida. 


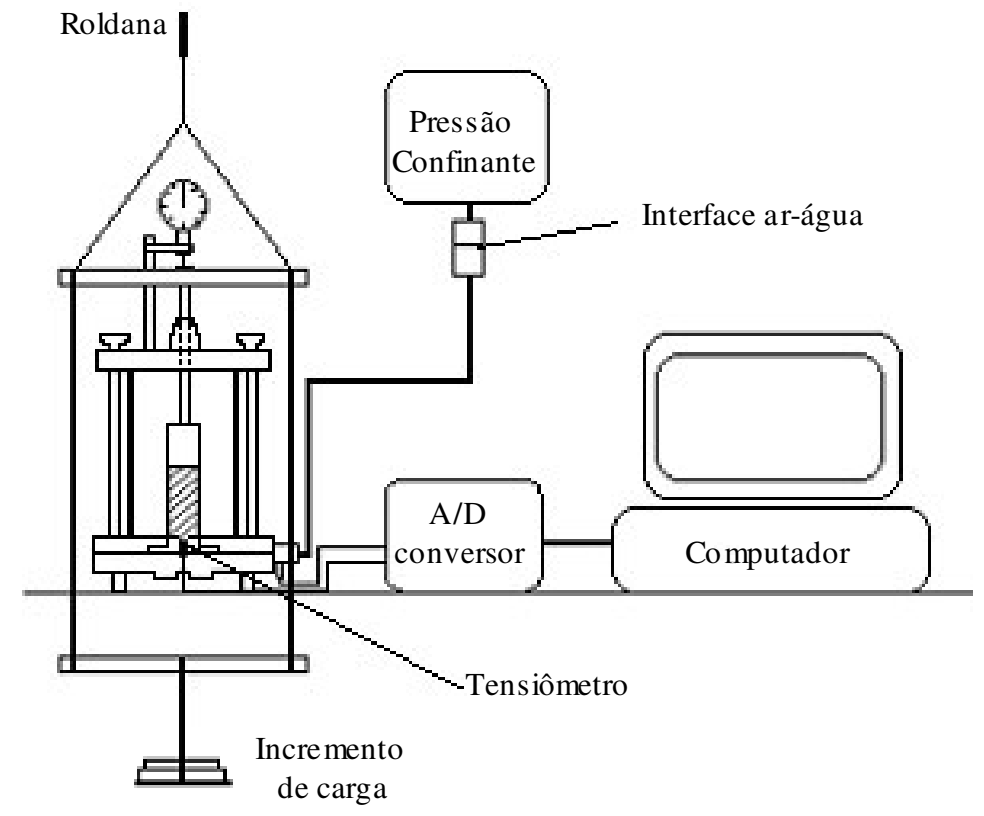

Figura 3.8 - Representação esquemática do ensaio triaxial realizado com carregamento controlado.

\section{5 - Molde tripartido utilizado para moldagem dos corpos de prova}

Com o objetivo de minimizar os efeitos da extrusão dos corpos de prova do molde de compactação, utilizou-se um molde tripartido. O molde tripartido é composto de uma base, cilindro e colarinho. O cilindro é composto de três peças que devem ser montadas com a mesma orientação da peça original. Durante a compactação as peças do cilindro são mantidas unidas com a utilização de uma braçadeira. O cilindro apresenta diâmetro interno de $3,8 \mathrm{~cm}$ e altura de $8,02 \mathrm{~cm}$. O pistão apresenta uma graduação que deve ser utilizada para o controle da espessura de cada camada de solo compactada. 


\section{6 - Prensa do tipo Bishop Wesley utilizada nos ensaios triaxais saturados}

Além dos ensaios realizados com a célula apresentada na Figura 3.7, foram realizados alguns ensaios triaxiais saturados utilizando uma prensa do tipo Bishop Wesley. A pressão confinante, a contra pressão e a tensão desviadora são transmitidas ao corpo de prova por reguladores de pressão com interface ar/água. Ao regulador de contra pressão está conectado o medidor de variação de volume do corpo de prova. A tensão desviadora é aplicada através da elevação da base da prensa e a força transmitida ao topo do corpo de prova é obtida através de uma célula de carga com capacidade de $5 \mathrm{kN}$.

Todos os dados do ensaio são monitorados através da célula de carga e de transdutores de pressão e de deslocamento conectados a um sistema de aquisição de dados. O sistema de aquisição de dados contém 16 canais e capacidade de medir até 100 mv com resolução de 0,6 $\mu \mathrm{v}$. A calibração da célula de carga e dos transdutores de pressão converte os valores de voltagem de cada canal em unidades de engenharia. Os valores de cada canal são transmitidos do sistema de aquisição de dados para um computador, sendo todo o ensaio gerenciado pelo software TRIAX desenvolvido na Universidade de Durhan. Para o ensaio são utilizados 7 canais que fornecem os seguintes resultados:

- Força vertical aplicada ao corpo de prova (célula de carga)

- Deslocamento axial (medido externamente)

- Pressão confinante

- Poro pressão no topo do corpo de prova

- Poro pressão na base do corpo de prova

- Pressão aplicada na câmara inferior (controle da tensão desviadora)

- Variação volumétrica

Todo o conjunto de equipamentos citado acima permite a realização de ensaio saturados com diversas trajetórias de tensões. A Figura 3.9 apresenta o esquema do ensaio. 


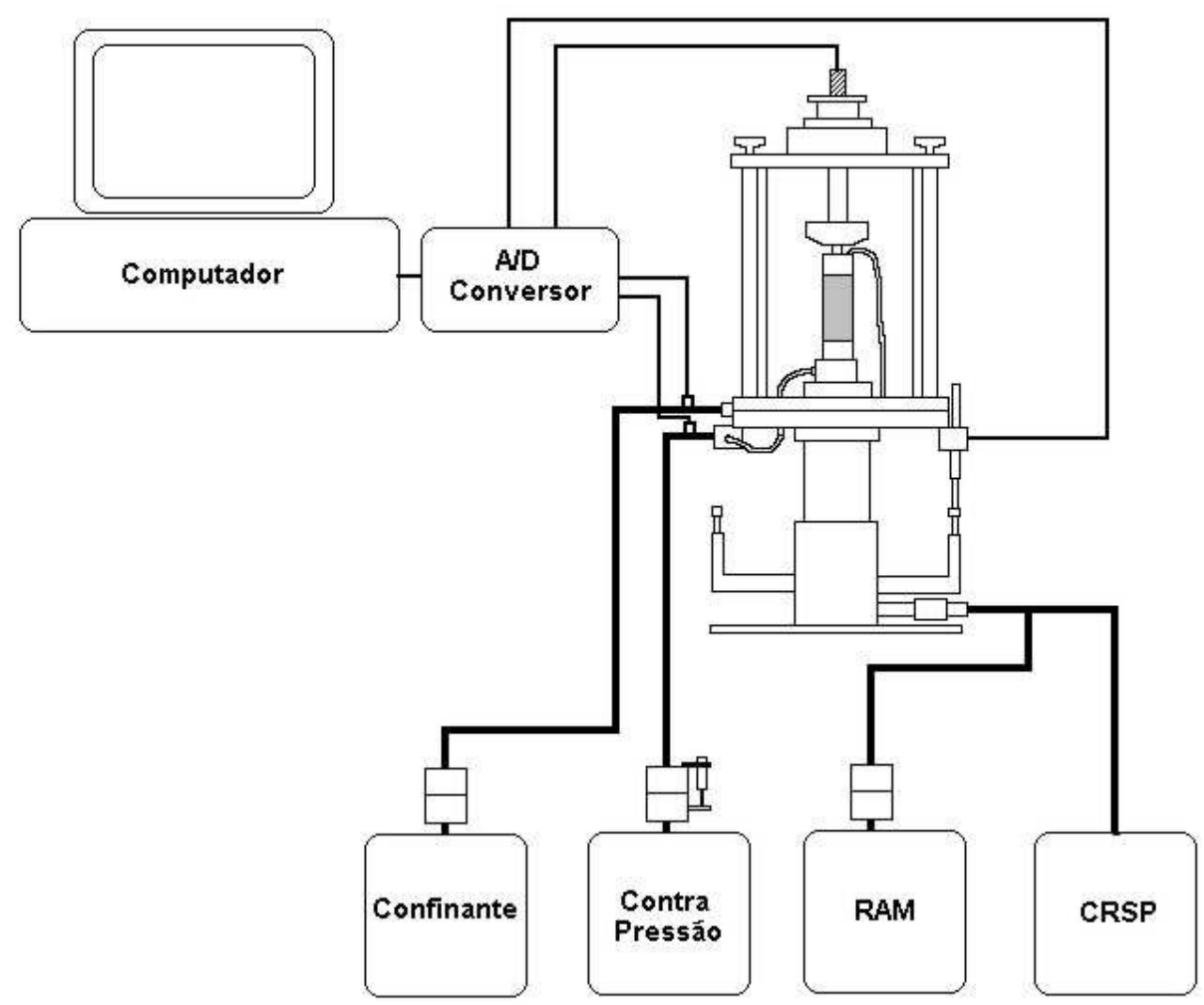

Figura 3.9 - Esquema do ensaio triaxial realizado na prensa Bishop Wesley.

\section{7 - Procedimentos utilizados para a calibração do papel filtro}

Para o lote de papel filtro Whatman $\mathrm{n}^{\mathrm{o}} 42$ utilizado nesta pesquisa, algumas evidências obtidas experimentalmente indicaram que a utilização da calibração proposta por Chandler et al (1992) não forneciam valores corretos de sucção. Portanto foi feita a calibração deste lote, estando a mesma incluída nos resultados experimentais do item 7.3. Os cuidados e os procedimentos para a calibração do papel filtro são apresentados neste item. 


\subsection{1 - Equipamentos e métodos para se gerar sucção}

Para se obter a calibração do papel filtro pode-se utilizar diferentes equipamentos e procedimentos para se impor uma sucção conhecida. O papel filtro ao ser submetido a estes valores de sucção passa a absorver água até que o equilíbrio seja atingido. O valor da sucção imposta e o teor de umidade do papel filtro correspondem a um ponto da curva de calibração. A Tabela 3.1 apresenta algumas técnicas que podem ser empregadas para se gerar um determinado valor de sucção.

Tabela 3.1 - Procedimentos que podem ser utilizados para a calibração do papel filtro (Marinho, 1994).

\begin{tabular}{|l|c|l|}
\hline \multicolumn{1}{|c|}{ Técnica } & $\begin{array}{c}\text { Faixa de Sucção para } \\
\text { Calibração }\end{array}$ & \multicolumn{1}{|c|}{ Comentários } \\
\hline Placa de sucção & 0 a $100 \mathrm{kPa}$ & Sucção gerada diretamente \\
\hline Amostras de campo & 0 a $2 \mathrm{MPa}$ & $\begin{array}{l}\text { Utiliza a habilidade dos solos } \\
\text { plásticos de sustentar a média da } \\
\text { tensão efetiva quando retirado do } \\
\text { campo }\end{array}$ \\
\hline Amostras oedométricas & $0.1 \mathrm{a} 2 \mathrm{MPa}$ & $\begin{array}{l}\text { A amostra de solo apresenta uma } \\
\text { sucção igual ao valor do } \\
\text { descarregamento uni-dimensional } \\
\text { e não drenado. }\end{array}$ \\
\hline Placa de pressão & 0 a $1.5 \mathrm{MPa}$ & $\begin{array}{l}\text { Usa a técnica da translação de } \\
\text { eixos. }\end{array}$ \\
\hline Dessecador & 0.5 a $30 \mathrm{MPa}$ & $\begin{array}{l}\text { O valor da sucção está } \\
\text { relacionado à umidade relativa } \\
\text { que é função da molaridade de } \\
\text { soluções salinas. }\end{array}$ \\
\hline
\end{tabular}

A forma com que o papel filtro entra em equilíbrio com a sucção imposta faz com que o mesmo esteja medindo a sucção matricial ou total. Quando o papel filtro está em contato direto com a fonte geradora de sucção, a troca de água se dá por forças capilares, medindo-se assim a sucção matricial. Quando não ocorre contato direto entre esta fonte e o papel filtro, a transferência de água se dá pela fase de vapor. Para escapar da fonte de sucção a água deve vencer as forças capilares e de adesão, correspondentes a sucção matricial, e as forças osmóticas (correspondente à sucção osmótica). Submetido a estas condições o papel filtro passa a medir a sucção total. 
Analisando os resultados de algumas calibrações do papel filtro, obtidas por diferentes pesquisadores, Leong et al (2002) verificaram que para valores de sucção superiores a $1000 \mathrm{kPa}$ o papel filtro mede apenas a sucção total, independentemente de estar ou não em contato com a fonte geradora de sucção. Este fato ocorre devido à predominância da transferência de água para o papel filtro pela fase de vapor.

\subsection{2 - Fatores importantes da calibração}

Diversos fatores devem ser levados em consideração para que a utilização de papel seja feita de forma adequada. Para se obter a calibração do papel filtro utilizando os diferentes equipamentos e técnicas apresentadas na Tabela 3.1, alguns cuidados devem ser tomados. Entre eles se destacam os seguintes:

a) Manuseio do papel filtro antes de sua utilização - É importante a utilização de pinça para se evitar o contato direto das mãos com o papel filtro. A caixa de sua embalagem deve ser mantida fechada, evitando-se assim que os mesmos absorvam umidade do ambiente, o que pode ocasionar alterações em sua calibração. Alguns pesquisadores têm recorrido ao tratamento do papel para evitar a proliferação de fungos [e.g. Fawcett e Collins (1967), Hamblim (1981)].

b) Tempo de equilíbrio - O tempo de equilíbrio é função da fonte geradora de sucção, das condições de contato e do valor da sucção que está sendo aplicada ao papel filtro (Leong et al, 2002). Na calibração obtida nesta pesquisa utilizou-se a placa de pressão para valores de sucção menores que $500 \mathrm{kPa}$. Para valores maiores de sucção, foram utilizadas soluções de $\mathrm{NaCl}$ colocadas em dessecadores. A umidade relativa do ambiente interno do dessecador é função da molaridade da solução utilizada. O valor desta umidade está relacionado com a sucção pela seguinte equação, apresentada por Marinho (1994):

$\operatorname{Sucção~}(k P a)=-135055 \ln (R H)$

Onde: $\mathrm{RH}$ - umidade relativa. 
O tempo para que o papel filtro entre em equilíbrio com a umidade relativa do interior do dessecador, entre outros fatores, é função da sua distância em relação à solução utilizada. Houston et al (1994) utilizaram soluções de nitrato de magnésio $\left(\mathrm{MgNO}_{3}\right)$, cloreto de amônia $\left(\mathrm{NH}_{4} \mathrm{Cl}\right)$, sulfato de cálcio e água destilada. O papel filtro, colocado de 1 a $3 \mathrm{~cm}$ acima da superfície da solução, foi mantido por um período de 7 dias. Marinho (1994), utilizando soluções de $\mathrm{NaCl}$ com diferentes concentrações, sugeriu diferentes tempos de equilíbrio em função do valor da sucção total aplicada. Os resultados do tempo de equilíbrio obtidos por Marinho (1994) estão apresentados na Tabela 3.2. Nestes experimentos o papel filtro foi mantido a uma distância de $8 \mathrm{~mm}$ da solução.

Tabela 3.2 - Tempo de equilíbrio sugerido para medição da sucção utilizando soluções de $\mathrm{NaCl}$ (Marinho, 1994).

\begin{tabular}{|c|c|}
\hline Nível de Sucção Total $(\mathrm{kPa})$ & Tempo de Equilíbrio Sugerido \\
\hline $0-100$ & Maior que 30 dias \\
\hline $100-250$ & 30 dias \\
\hline $250-1000$ & 15 dias \\
\hline $1000-30000$ & 7 dias \\
\hline
\end{tabular}

Utilizando a equação 3.1 e os resultados de Robinsom (1945), que estabelece a relação entre a molaridade do $\mathrm{NaCl}$ e a umidade relativa, Marinho (1994) obteve uma equação que relaciona a sucção com a concentração molar da solução, dada por:

$\operatorname{Sucção~}(k P a)=459895 m^{1,00122}$

Os valores do tempo de equilíbrio citados anteriormente por Houston et al (1994) e Marinho (1994) foram obtidos para testes sobre condições específicas. A menos que estas condições sejam satisfeitas, deve-se proceder a estudos preliminares na determinação deste tempo. Nas calibrações dos papéis filtro, realizadas nesta pesquisa com a utilização de soluções salinas em dessecadores, foram empregados os mesmos procedimentos adotados por Marinho (1994). Desta forma foram adotados os tempos de equilíbrio sugeridos na Tabela 3.2. Na placa de pressão o papel filtro foi mantido por um período mínimo de 7 dias. 
C) Variação da temperatura - Al-khafaf e Hanks (1974) estudaram a influência da temperatura na calibração do papel filtro. O solo foi colocado no interior de um recipiente com o papel filtro apoiado em sua superfície. O recipiente foi colocado em um ambiente com variação de temperatura de $\pm 2^{\circ} \mathrm{C}$ e $\pm 1^{\circ} \mathrm{C}$. Os papeis submetidos ao ambiente cuja variação de temperatura foi de $\pm 2^{\circ} \mathrm{C}$, apresentaram maior dispersão nos valores de umidade. Os autores concluíram que a temperatura absoluta não é tão importante e sim a sua variação. Portanto o ideal é minimizar as variações de temperatura ao se realizar a calibração do papel filtro.

\subsection{3 - Algumas calibrações propostas}

Os papéis utilizados para se medir a sucção são quantitativos do tipo II, tais como o Whatman $\mathrm{n}^{\mathrm{o}}$ 42, Fisherbrand 9-790A e Scheicher \& Shuel $\mathrm{n}^{\mathrm{o}}$ 586. Na literatura são apresentadas diversas calibrações. Fawcett e Collins (1967) trataram o papel filtro Whatman $\mathrm{n}^{\mathrm{o}} 42$ com cloreto de mercúrio $\left(\mathrm{HgCl}_{2}\right)$ utilizando para a calibração a membrana de pressão, placa de pressão e dessecador. Investigando diferentes lotes deste tipo de papel, verificaram que existe uma boa concordância nos valores de sucção para papeis de um mesmo lote e de lotes diferentes. Hamblim (1981) também tratou o papel filtro Whatman $\mathrm{n}^{\mathrm{o}} 42$ com solução de $0.005 \%$ de $\mathrm{HgCl}_{2}$, utilizando a mesma técnica de Fawcett e Collins (1967) para a sua calibração. Estes autores obtiveram a curva de calibração para o papel submetido a tratamento contra fungos e papel sem tratamento, não observando nenhuma diferença entre estas calibrações. Chandler e Gutierrez (1986) utilizaram a argila de Londres (wl=70\% e wp $=26 \%$ ) consolidada em oedômetro por um período de 3 dias até se alcançar o equilíbrio de umidade. Após este período o corpo de prova foi descarregado, removido do oedômetro e colocado o papel filtro em contato direto com o mesmo. $\mathrm{O}$ corpo de prova e o papel filtro foram envoltos em filme plásticos, parafinados e mantidos a uma temperatura de $21^{\circ} \mathrm{C}\left( \pm 2^{\circ} \mathrm{C}\right)$ por 5 dias. Neste procedimento se supõe que o descarregamento ocorra sem drenagem e que a tensão aplicada, que variou até $2000 \mathrm{kPa}$, seja igual à sucção de amostra após descarregamento. 
Utilizando os seus resultados, os de Fawcett e collins (1967) e os de Hamblim (1981), Chandler et al (1992) obtiveram uma boa correlação $\left(r^{2}=0.96\right)$ para valores de sucção variando de 60 a $6000 \mathrm{kPa}$. Para sucções inferiores a $80 \mathrm{kPa}$, estes pesquisadores utilizaram a placa de pressão, amostras de ensaios triaxiais, amostras de oedômetro e papel filtro submerso em água destilada. As calibrações do papel filtro Whatman $\mathrm{n}^{\mathrm{o}} 42$, obtidas pelos pesquisadores citados neste item, estão apresentadas na Figura 3.10. A equação obtida por Chandler et al (1992) é uma das mais utilizadas sendo dada pelas seguintes expressões:

Para $\mathrm{w} \leq 47 \%$ :

$\operatorname{Sucção}(k P a)=10^{(4,84-0,062 W)}$

para $\mathrm{w}>47 \%$ :

$\operatorname{Sucção~}(k P a)=10^{(6,05-2,48 \log w)}$

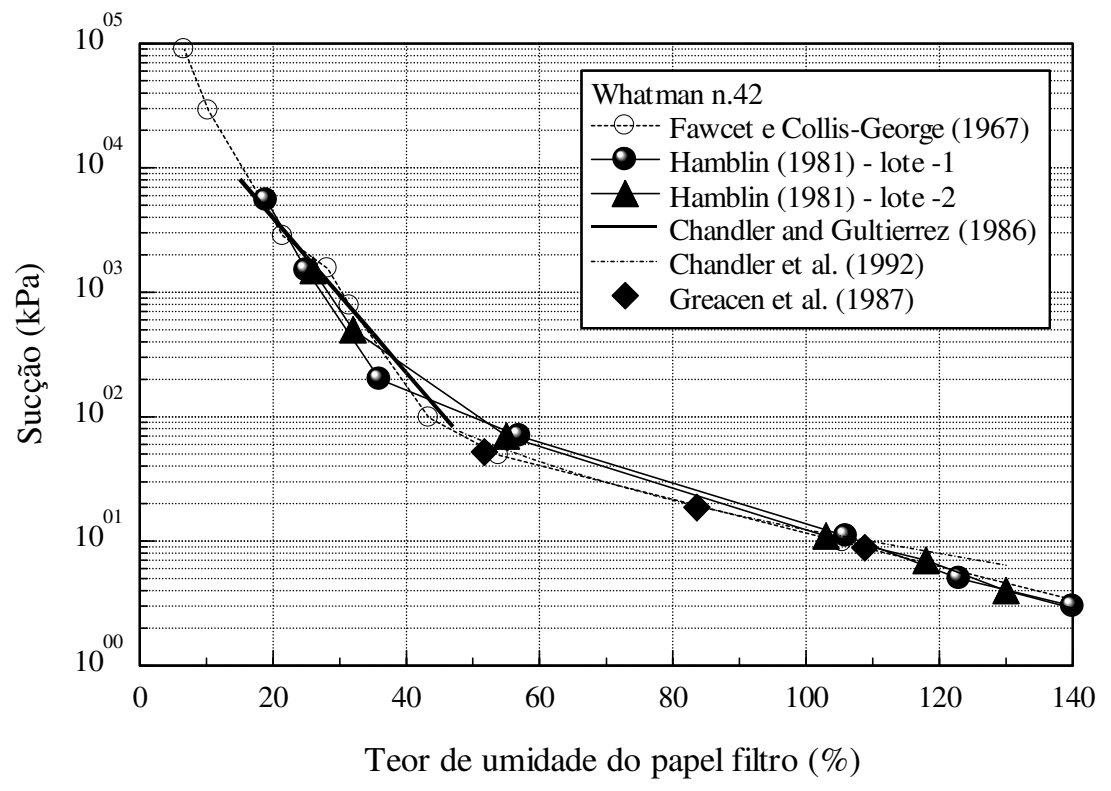

Figura 3.10 - Algumas calibrações propostas para o papel filtro Whatman $n^{0} 42$ (Marinho, 1994). 


\section{4 - CARACTERIZAÇÃO do SOLO E PROGRAMAÇÃo DOS ENSAIOS DE LABORATÓRIO}

Este capítulo apresenta inicialmente alguns aspectos geológicos da região de onde foram coletadas as amostras. Em seguida são apresentadas as etapas de preparação para seu armazenamento e os resultados dos ensaios de caracterização. Em função destes resultados, foram determinadas as condições de moldagem dos corpos de prova e definida a programação dos ensaios. Para cada tipo de ensaio são descritos os cuidados na preparação dos corpos de prova e os procedimentos para a sua realização.

\section{1 - Aspectos geológicos regionais}

A cidade de São Paulo situa-se no platô paulistano, o qual apresenta altitudes que variam entre 715 e 900 metros, compreendendo uma área de $500 \mathrm{~km}^{2}$. A topografia do embasamento cristalino é irregular, formando grandes depressões e elevações, compondo uma bacia sedimentar preenchida com sedimentos terciários e quaternários. Os solos que preenchem esta bacia são bastante heterogêneos, devido a processos de intemperismo e laterização. Estes processos originaram solos sobreadensados por ressecamento e ricos em óxido de ferro na parte mais alta da cidade. A rede de drenagem é formada pelos rios Tiête, Pinheiros, Tamanduatei e tributários. Os depósitos quaternários se caracterizam por aluviões depositados nas várzeas dos rios, compostos de argila orgânica mole e areias finas argilosas. $\mathrm{O}$ fundo desta bacia sedimentar é formado por rochas metamórficas e gnaisses resultantes do retrabalhamento das rochas de ciclos mais antigos. 


\section{2 - Local de amostragem}

O solo estudado nesta pesquisa foi retirado do campo experimental da USP, situado na borda oeste da bacia sedimentar do platô paulistano. Nesta região afloram a rocha sã do embasamento cristalino e solos residuais de gnaisse formados pelo intemperismo deste mesmo embasamento, que podem apresentar espessuras de até $20 \mathrm{~m}$ (ABEF, 1989). O local escolhido para a retirada das amostras consiste em um talude de solo residual de gnaisse, composto basicamente de areia siltosa micácea com núcleos de caulim derivados de feldspato e por pequenos veios de quartzo.

\section{3 - Retirada da amostra e armazenamento}

Este solo já foi utilizado em outras pesquisas, entre elas estão as dissertações de mestrado Stuermer (1998), Vieira (1999) e Kuwagima (2000). Antes da retirada da amostra foi feita a remoção da vegetação existente na base do talude, sendo posteriormente feita a cobertura com uma lona. $\mathrm{O}$ procedimento utilizado foi o de se raspar o talude em uma área de 3 metros de largura por 2,5 metros de altura, com utilização de pá e picareta. O solo que se acumulou sobre a lona foi colocado em sacos plásticos e levados para o laboratório onde foi destorroado e passado na peneira de malha número 10 (\# 2mm). Neste procedimento, realizado com a umidade de campo, obteve-se em torno de $300 \mathrm{~kg}$ de material passando, ficando retido $15 \mathrm{~kg}$. Optou-se por trabalhar com esta fração do solo (<\#10) com o intuito de se obter, no procedimento de compactação, corpos de prova mais homogêneos. A umidade da amostra no momento da coleta no campo foi de $19 \%$. Após completa homogeneização por quarteamento, este solo foi armazenado em 4 depósitos e protegidos para se evitar perda de umidade. Na Figura 4.1 está apresentada uma visão geral do talude de onde foram coletadas as amostras utilizadas nesta pesquisa. 


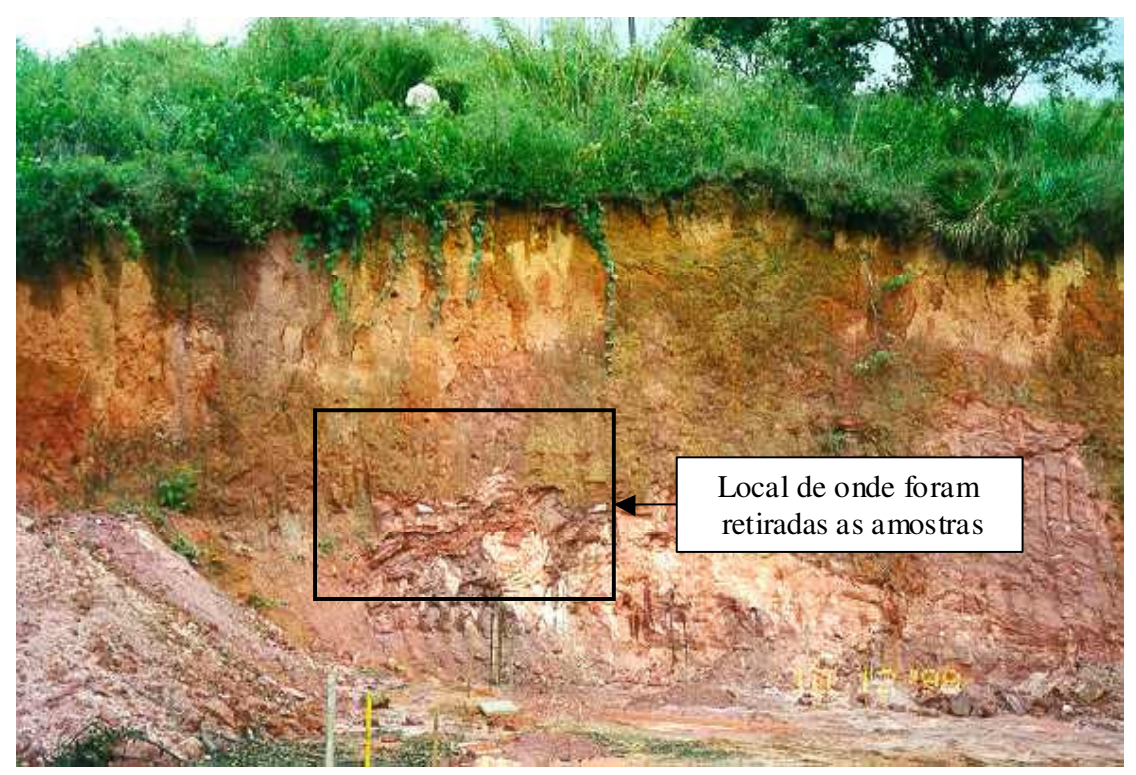

Figura 4.1 - Visão geral do talude de onde foram retiradas as amostras de solo utilizada nesta pesquisa.

\section{4 - Ensaios de caracterização}

Após os procedimentos citados no item anterior, as amostras foram preparadas para os ensaios de caracterização seguindo as recomendações da NBR 6457. Por apresentar porcentagem retida na peneira $n^{\circ} 40$ menor quer que $10 \%$, a realização dos ensaios de limite de liquidez, limite de plasticidade e massa específica dos grãos, foram realizadas sem a secagem prévia do solo. A realização dos ensaios seguiu as recomendações das seguintes normas técnicas:

- Limite de liquidez - NBR 6459

- $\quad$ Limite de plasticidade - NBR 7180

- Massa específica dos grãos - NBR 6508

- Análise granulométrica - NBR 7181

A Figura 4.2 apresenta a curva granulométrica obtida para este solo. Observa-se nesta figura a predominância de silte (46\%) seguida de areia (34\%) e argila (20\%). Pelo formato da curva, trata-se de um solo bem graduado apresentando grãos em uma ampla faixa de diâmetro. No entanto, o termo bem graduado é comumente 
empregado para solos granulares. O solo residual de gnaisse utilizado nesta pesquisa é um solo fino, apresentado em torno de $70 \%$ de material passando na peneira de $0.0075 \mathrm{~mm}$ (\# 200).

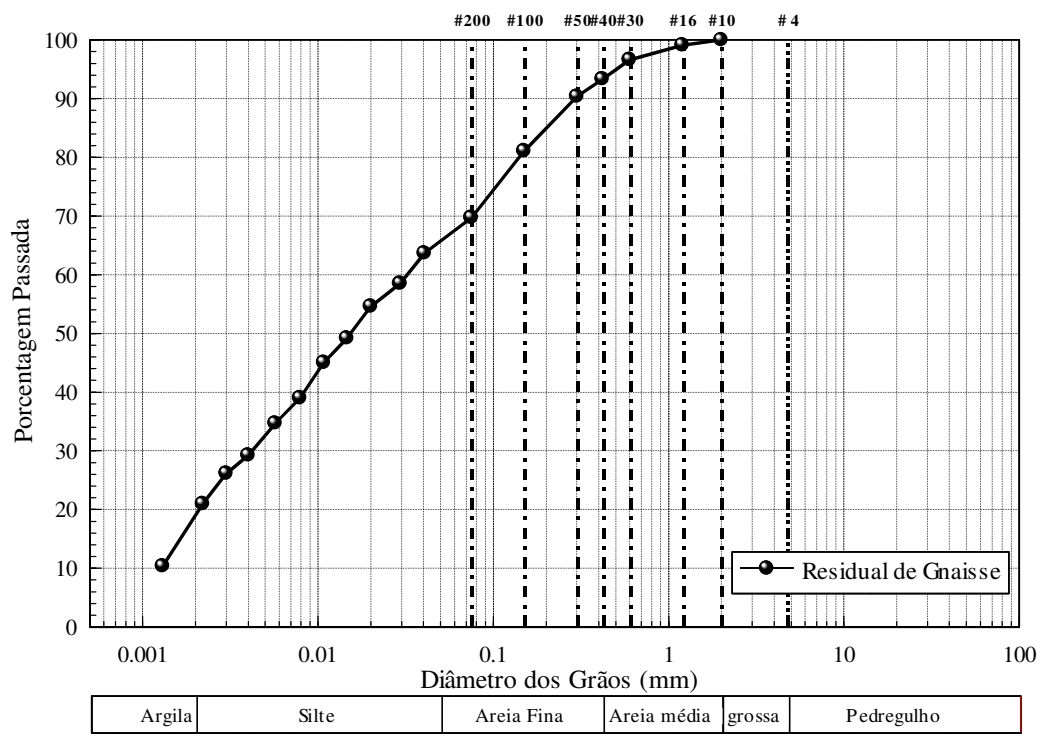

Figura 4.2 - Curva Granulométrica do solo residual de gnaisse.

De acordo com os resultados dos ensaios de caracterização, este solo apresenta limite de liquidez $\left(\mathrm{w}_{\mathrm{l}}\right)$ de $47 \%$, limite de plasticidade $\left(\mathrm{w}_{\mathrm{p}}\right)$ de $34 \%$ e densidade dos grãos de $2.71 \mathrm{~g} / \mathrm{cm}^{3}$. Utilizando os valores do índice de plasticidade e do limite de liquidez, tem-se na carta de plasticidade de Casagrande que este solo é classificado como um silte de baixa compressibilidade (ML). Na Tabela 4.1 estão apresentados os resultados dos ensaios de caracterização. A localização da classificação deste solo na carta de plasticidade está indicada Figura 4.3.

Tabela 4.1 - Resultados dos ensaios de caracterização.

\begin{tabular}{|l|l|}
\hline Densidade dos grãos $\left(\mathrm{g} / \mathrm{cm}^{3}\right)$ & 2.71 \\
\hline Limite de liquidez $(\%)$ & 47 \\
\hline Limite de Plasticidade (\%) & 34 \\
\hline Índice de Plasticidade (\%) & 13 \\
\hline Areia média (\%) & 6 \\
\hline Areia Fina (\%) & 28 \\
\hline Silte (\%) & 46 \\
\hline Argila (\%) & 20 \\
\hline Classificação unificada & ML \\
\hline
\end{tabular}




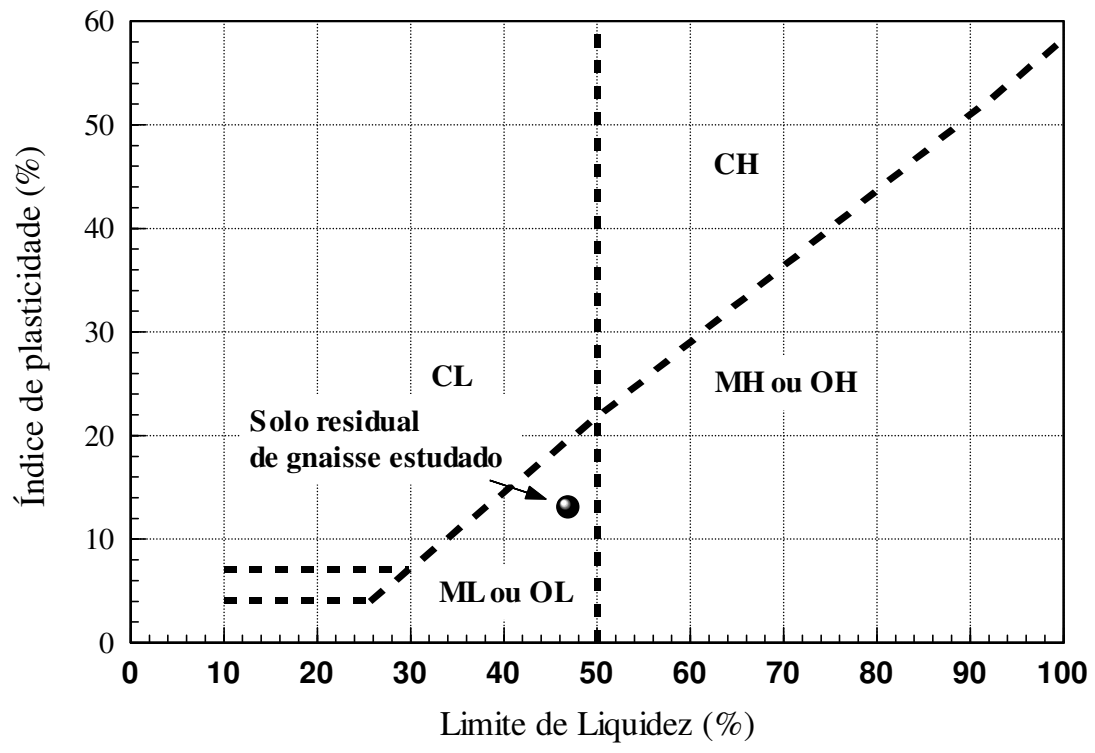

Figura 4.3 - Classificação do solo residual de gnaisse na carta de plasticidade.

\section{5 - Determinação da curva de compactação}

Seguindo as recomendações da NBR 7182 e utilizando o solo preparado conforme descrito no item 4.3, foi determinada a curva de compactação. Através da inspeção táctil-visual admitiu-se que a umidade do solo (w=19\%) estivesse em torno de 5\% abaixo da umidade ótima. Desta forma não foi feita sua secagem prévia, iniciando o ensaio com a umidade de campo. As amostras foram compactadas no cilindro Proctor (volume de $1000 \mathrm{~cm}^{3}$ ) em três camadas, não se fazendo o reuso do material. Foi aplicada a energia de compactação normal, que corresponde à utilização do soquete pequeno com aplicação de 26 golpes por camada. Na Figura 4.4 estão apresentados os resultados experimentais e a curva de compactação obtida. Neste ensaio as coordenadas do ponto correspondente à umidade ótima é dada pela densidade seca máxima de $1.53 \mathrm{~g} / \mathrm{cm}^{3}$ e teor de umidade gravimétrica de $25.3 \%$. A curva de compactação deste solo é bastante abatida, ou seja, para o intervalo de umidade de 17 a $28 \%$ a densidade seca variou apenas de $0.05 \mathrm{~g} / \mathrm{cm}^{3}$. Este formato da curva de compactação é típico dos solos siltosos. 


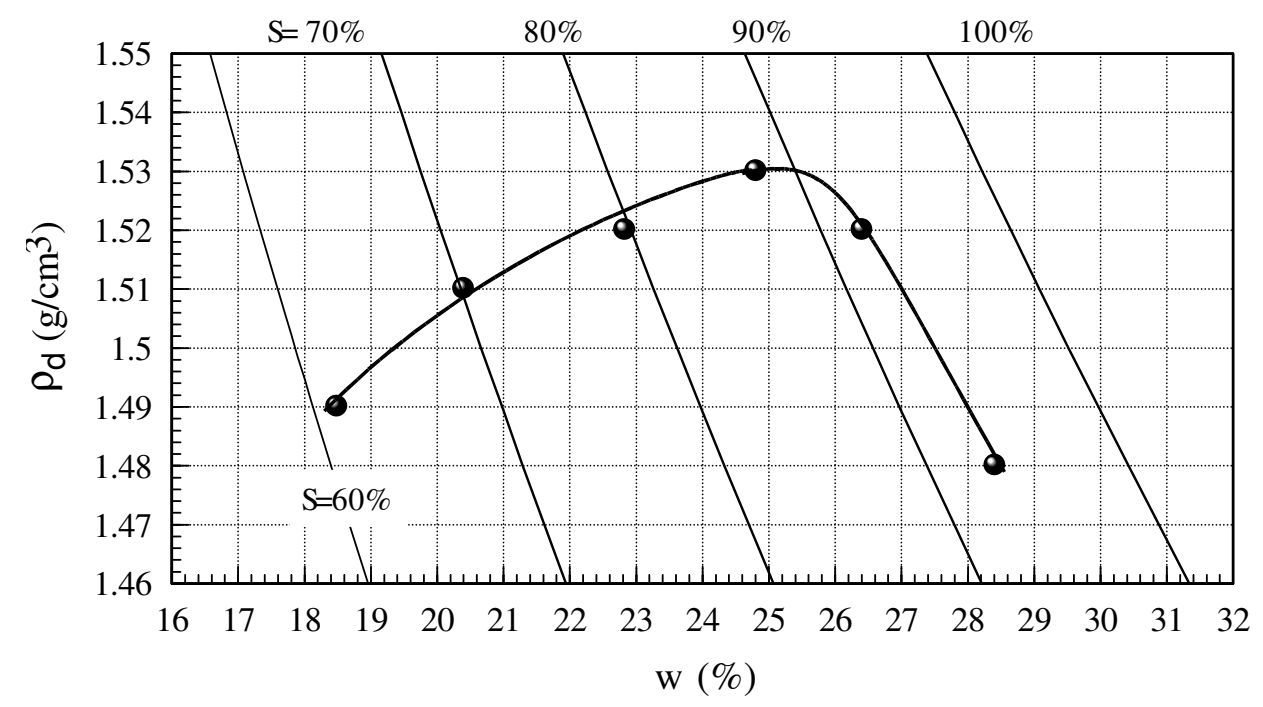

Figura 4.4 - Curva de compactação do solo residual de gnaisse.

\section{6 - Definição dos pontos de estudo e programação dos ensaios}

Conforme citado no item 2.2.2, os corpos de prova moldados para a determinação da curva de compactação apresentam diferentes estruturas em função da porcentagem de partículas presentes como agregações. Com o intuito de se verificar a influencia das condições de moldagem na curva de retenção e na resistência deste solo, foram escolhidos três pontos da curva de compactação. No gráfico da Figura 4.5 estão indicados os pontos de estudo. Nesta pesquisa as letras $\mathrm{O}$, $\mathrm{S}$ e $\mathrm{U}$ indicam respectivamente a moldagem dos corpos de prova na umidade ótima, no ramo seco e no ramo úmido. Os pontos de estudo, assim definidos, abrangem umidades que variam de $17 \%$ a $28 \%$ e densidade seca de $1.48 \mathrm{~g} / \mathrm{cm}^{3}$ a $1.53 \mathrm{~g} / \mathrm{cm}^{3}$. Na Tabela 4.2 estão indicados os dados de moldagem referentes a estes pontos. 


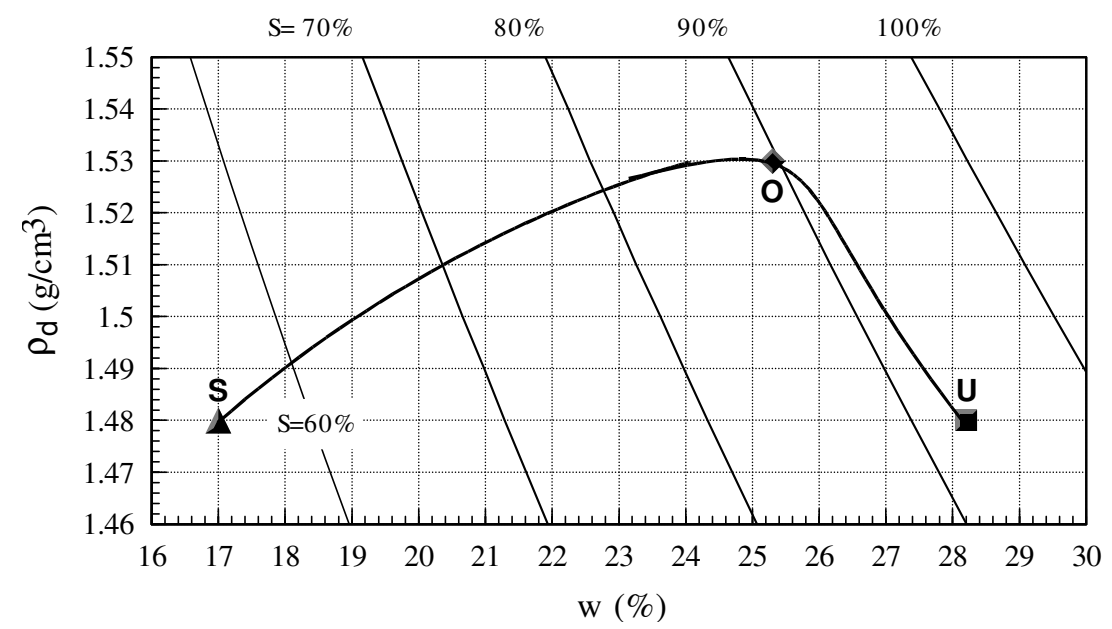

Figura 4.5 - Localização dos pontos de estudo na curva de compactação.

Tabela 4.2 - Pontos de estudo com as respectivas condições de moldagem.

\begin{tabular}{|c|c|c|c|c|c|}
\hline Moldagem & $\mathrm{w}(\%)$ & $\rho_{\mathrm{d}}\left(\mathrm{g} / \mathrm{cm}^{3}\right)$ & $\mathrm{e}$ & $\mathrm{S}(\%)$ & $\theta_{\mathrm{w}}(\%)$ \\
\hline $\mathrm{O}$ & 25.3 & 1.53 & 0.77 & 88.9 & 38.7 \\
\hline $\mathrm{S}$ & 17 & 1.48 & 0.83 & 55.4 & 25.2 \\
\hline $\mathrm{U}$ & 28.2 & 1.48 & 0.83 & 91.9 & 41.7 \\
\hline
\end{tabular}

$\rho_{\mathrm{d}}$ - densidade seca

Nesta pesquisa serão abordados dois importantes aspectos da mecânica dos solos não saturados. Para os pontos de moldagem dados na Tabela 4.2, serão estudados alguns aspectos da curva de retenção e, como enfoque principal, serão realizados ensaios de resistência com o solo preparado conforme citado no item 4.3. Da curva de retenção pode-se obter algumas das propriedades hidráulicas e mecânicas do solo não saturado. Nesta pesquisa, as curvas de retenção foram determinadas com o objetivo de complementar as análises dos resultados dos ensaios de resistência. O reconhecimento da relação entre a curva de retenção e os valores da resistência dos solos não saturados, foi utilizado por Vanapalli et al (1996) e Khalili e Khabazz (1998) na elaboração de seus modelos. Para os três pontos de estudo serão determinadas as relações entre q e a sucção para diferentes valores de pressão de confinamento. Estas relações são definidas dos resultados de ensaios triaxiais não saturados realizados com medição da variação da sucção com o tensiômetro. Com a utilização do tensiômetro, ao contrário da técnica de translação de eixos, não se controla a sucção do corpo de prova, mas se acompanha a sua variação durante o 
ensaio. Quando se utiliza o tensiômetro, dependendo do tipo de solo, podem ser realizados até dois ensaios por dia. Quando o ensaio é realizado com a técnica da translação de eixos, deve-se impor ao corpo de prova uma sucção inicial que deve ser mantida Constant durante a fase de cisalhamento. Sendo assim, a realização destes ensaios pode durar mais de 15 dias.

Além dos objetivos principais dos ensaios da curva de retenção e de resistência, citados anteriormente, alguns outros aspectos secundários serão analisados. $\mathrm{Na}$ Tabela 4.3 estão definidos os objetivos principais e os aspectos secundários desta pesquisa. A Figura 4.6 apresenta esquematicamente os ensaios que serão realizados com o intuito de cumprir os objetivos descritos na Tabela 4.3.

Tabela 4.3 - Resumo dos aspectos que serão abordados nesta pesquisa.

\begin{tabular}{|c|c|c|}
\hline Tipo de Ensaio & Objetivo Principal & Objetivos Secundários \\
\hline $\begin{array}{l}\text { CURVAS DE } \\
\text { RETENÇÃO }\end{array}$ & $\begin{array}{l}\text { Aplicação dos modelos } \\
\text { de previsão da resistência }\end{array}$ & $\begin{array}{l}\text {-Analisar a influência das diferentes } \\
\text { estruturas de moldagem. } \\
\text {-Analisar a histerese da curva obtida } \\
\text { por secagem e umedecimento. } \\
\text {-Analisar a influência do tipo de } \\
\text { compactação. } \\
\text { - Analisar a variação da entrada de ar } \\
\text { em função do confinamento. }\end{array}$ \\
\hline $\begin{array}{l}\text { ENSAIOS DE } \\
\text { RESISTÊNCIA }\end{array}$ & $\begin{array}{l}\text { Determinação das } \\
\text { superfícies de ruptura }\end{array}$ & $\begin{array}{l}\text {-Analisar a histerese no valor da } \\
\text { resistência. } \\
\text {-Analisar a influência do tipo de } \\
\text { carregamento utilizado na etapa de } \\
\text { cisalhamento. } \\
\text {-analisar a variação da sucção do } \\
\text { corpo de prova durante o ensaio. }\end{array}$ \\
\hline
\end{tabular}




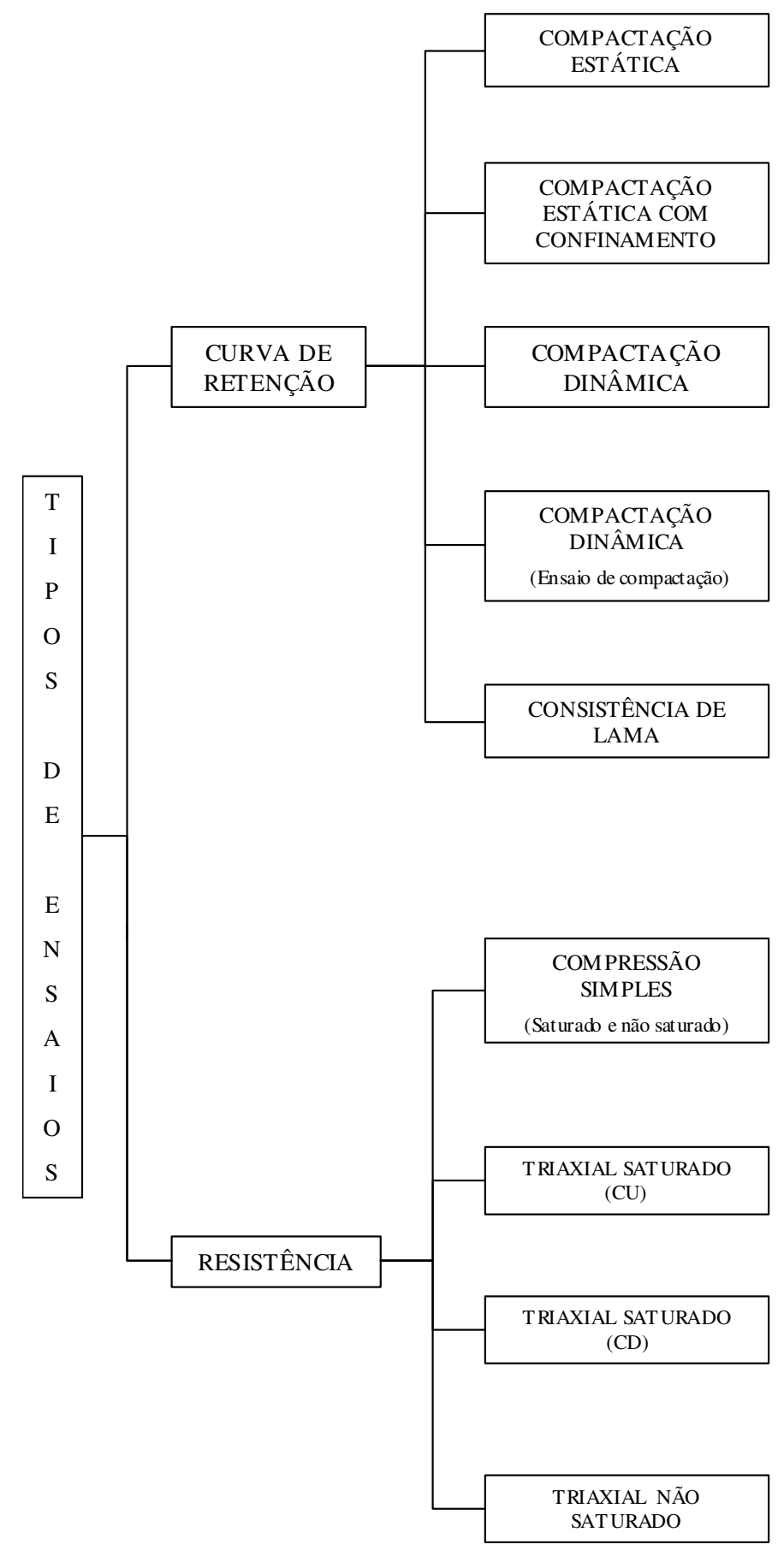

Obtida para os três pontos de estudo (saturados e secados)

Obtida para o ponto "O" com confinamentos de 100 , 200 e $300 \mathrm{kPa}$ (saturados e secados)

Obtida para os três pontos de estudo (saturados e secados)

Obtida para os corpos de prova utilizados na curva de compactação (secagem a partir da umidade de moldagem)

Obtida para o solo que passa na \# 10 e \#40.

Ensaios realizados nos três pontos de estudo com carregamento e deformação controlada

Realizados nos três pontos de estudo com deformação controlada

\begin{tabular}{|c|c|}
\hline $\begin{array}{l}\text { Utilizando } \\
\text { controlado } \\
\text { apenas para c }\end{array}$ & $\begin{array}{l}\text { carregamento } \\
\text { e realizados } \\
\text { o ponto } \mathrm{O}\end{array}$ \\
\hline $\begin{array}{l}\text { Realizados } \mathrm{n} \\
\text { estudo con } \\
\text { controlado } \\
\text { sucção } \\
\text { tensiômetro }\end{array}$ & $\begin{array}{l}\text { nos três pontos de } \\
\mathrm{m} \text { carregamento } \\
\text { e medida da } \\
\text { utilizando }\end{array}$ \\
\hline
\end{tabular}

Figura 4.6 - Ensaios a serem realizados em cada condição de moldagem. 


\section{7 - Curva de retenção e principais objetivos de sua determinação}

As curvas de retenção foram determinadas como uma ferramenta de auxílio na interpretação dos ensaios de resistência. As programações dos ensaios foram praticamente iguais para os três pontos de moldagem apresentados na Figura 4.5. Foram investigados alguns fatores que interferem no formato das curvas de retenção. Entre eles esta o efeito do tipo de estrutura dos corpos de prova resultante das condições de moldagem, o tipo de compactação utilizada, a histerese da curva de retenção determinada por secagem e umedecimento e os efeitos da aplicação de confinamento nos valores da sucção de entrada de ar. Neste item são descritos, para cada curva de retenção, as etapas de moldagem e preparação dos corpos de prova, os equipamentos utilizados e os procedimentos para a sua realização. Na Tabela 4.4 estão apresentados os tipos de moldagem dos corpos de prova, utilizados para a determinação das curvas de retenção de cada ponto de estudo, com os seus respectivos objetivos.

Tabela 4.4 - Tipos de curva de retenção determinadas nos pontos de estudo.

\begin{tabular}{|c|c|c|}
\hline \multicolumn{3}{|c|}{ CURVA DE RETENÇÃO } \\
\hline Moldagem & Objetivo & Observações \\
\hline $\begin{array}{l}\text { Compactação } \\
\text { estática }\end{array}$ & $\begin{array}{l}\text { - Serão utilizadas na aplicação dos } \\
\text { modelos de Vanapalli et al (1996) e } \\
\text { Khalili de Khabbaz (1998) } \\
\text { - Analisar a influência da estrutura de } \\
\text { moldagem no formato da curva de } \\
\text { retenção. } \\
\text { - Verificar a histerese das curvas de } \\
\text { retenção obtidas por secagem em } \\
\text { umedecimento. } \\
\text { •Estimar os valores do teor de umidade } \\
\text { que os corpos de prova devem ter após a } \\
\text { etapa de preparação. } \\
\text {-Verificar a variação nos valores da } \\
\text { sucção de entrada de ar em função do } \\
\text { confinamento. }\end{array}$ & $\begin{array}{l}\text {-Determinadas sem } \\
\text { confinamento para os pontos de } \\
\text { estudo da Figura } 4.4 \text {. } \\
\text { • Obtidas simulando um } \\
\text { confinamento de } 100,200 \text { e } 300 \\
\text { kPa para a moldagem da } \\
\text { umidade ótima. }\end{array}$ \\
\hline $\begin{array}{l}\text { Compactação } \\
\text { dinâmica }\end{array}$ & $\begin{array}{l}\text { - Analisar o efeito do tipo de } \\
\text { compactação. } \\
\text { •Estudar o formato das curvas obtidas } \\
\text { para diferentes pontos da curva de } \\
\text { compactação. }\end{array}$ & $\begin{array}{l}\text { - Determinadas para os três } \\
\text { pontos de estudo e para os } \\
\text { corpos de prova da curva de } \\
\text { compactação. }\end{array}$ \\
\hline Lama & $\begin{array}{l}\text {-Auxiliar nas análises das curvas } \\
\text { anteriores. } \\
\text {-Analisar as variações volumétricas } \\
\text { durante a secagem. }\end{array}$ & $\begin{array}{l}\text { - Obtida com o solo que passa na } \\
\text { peneira } \mathrm{n}^{\mathrm{o}} 10 \text { e } 40 .\end{array}$ \\
\hline
\end{tabular}




\section{8 - Procedimentos utilizados para a determinação das curvas de retenção dos corpos de prova compactados estaticamente}

Inicialmente as curvas de retenção foram obtidas sem confinamento utilizando corpos de prova compactados estaticamente nas três condições definidas na Tabela 4.2. Posteriormente, para as condições de moldagem na umidade ótima, as mesmas foram definidas em corpos de prova submetidos às pressões confinantes de 100, 200 e $300 \mathrm{kPa}$. Neste item são descritos os procedimentos de moldagem dos corpos de prova, e os procedimentos de utilização da placa de sucção, placa de pressão e do papel filtro.

\subsection{1 - Moldagem dos corpos de prova e preparação para o ensaio}

Para as curvas determinadas sem confinamento foram moldados 3 corpos de prova com densidade seca e teor de umidade correspondente aos pontos $\mathrm{O}, \mathrm{S}$ e $\mathrm{U}$, definidos na Figura 4.5 e na Tabela 4.2. Para se analisar o efeito da pressão confinante no valor de entrada de ar, foram moldados mais 3 corpos de prova na umidade ótima (ponto O). Na Figura 4.7 esta a representação esquemática dos tipos de curva de retenção que serão determinadas em cada ponto de estudo.

Considerando o tempo de estabilização e o diâmetro da pedra porosa da placa de sucção e de pressão, os corpos de prova foram moldados com altura e diâmetro de $3.8 \mathrm{~cm}$. Com isto podem ser colocados simultaneamente até três corpos de prova em cada ensaio realizado nestes equipamentos.

Para a moldagem dos corpos de prova foi utilizado o molde tripartido, sendo a compactação realizada em uma única camada. Os dados de moldagem estão apresentados na Tabela 4.5. As letras CR indicam que os corpos de prova foram utilizados para os ensaios da curva de retenção e as letras $\mathrm{O}, \mathrm{S}$ ou $\mathrm{U}$ se referem às condições de moldagem dadas na Tabela 4.2. 


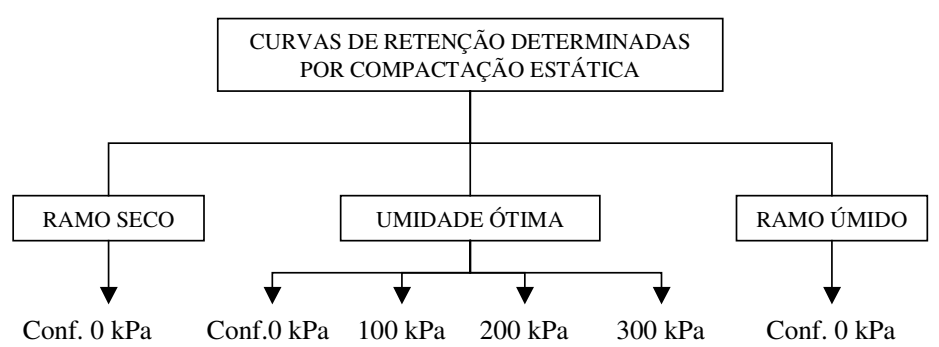

Figura 4.7 - Curvas de retenção obtidas por compactação estática.

Tabela 4.5 - Condições iniciais de moldagem dos corpos de prova utilizados para a determinação das curvas de retenção determinadas por compactação estática.

\begin{tabular}{|c|c|c|c|c|c|c|}
\hline C.P. & $\mathrm{w}(\%)$ & $\rho\left(\mathrm{g} / \mathrm{cm}^{3}\right)$ & $\rho_{\mathrm{d}}\left(\mathrm{g} / \mathrm{cm}^{3}\right)$ & $\mathrm{e}$ & $\mathrm{S}(\%)$ & $\theta_{\mathrm{w}}$ \\
\hline CRO1 & 25.2 & 1.89 & 1.51 & 0.79 & 86.2 & 38.1 \\
\hline CRO2 & 25.4 & 1.89 & 1.50 & 0.80 & 86.0 & 38.2 \\
\hline CRO3 & 25.4 & 1.89 & 1.51 & 0.80 & 86.2 & 38.3 \\
\hline CRO4 & 25.4 & 1.88 & 1.50 & 0.81 & 84.8 & 38.0 \\
\hline CRS1 & 17.5 & 1.71 & 1.45 & 0.86 & 54.8 & 25.4 \\
\hline CRU1 & 27.3 & 1.88 & 1.48 & 0.83 & 88.8 & 40.3 \\
\hline
\end{tabular}

CR - Curva de retenção, $\mathrm{O}, \mathrm{S}$ e U - Condições de moldagem, $\rho$ - Densidade úmida

Após a moldagem dos corpos de prova vem a etapa de preparação para o ensaio. Nesta etapa os mesmos foram inicialmente saturados por aspersão de água destilada. Neste processo passam a apresentar aumento de volume e perda de consistência, dificultando assim o seu manuseio. Desta forma, interrompeu-se o procedimento de saturação no momento em que começam a ficar menos consistentes. Na Tabela 4.6 estão apresentados os dados dos corpos de prova após a etapa de saturação. O grau de saturação final variou entre 92 e 96\%. Os corpos de prova CRO2, CRO3 e CRO4 foram utilizados para a determinação da curva de retenção com confinamento.

Tabela 4.6 - Dados dos corpos de prova utilizados para a determinação das curvas de retenção obtidas por compactação estática, após os procedimentos de saturação.

\begin{tabular}{|l|l|l|l|l|l|l|}
\hline C.P. & $\mathrm{w}(\%)$ & $\rho\left(\mathrm{g} / \mathrm{cm}^{3}\right)$ & $\rho_{\mathrm{d}}\left(\mathrm{g} / \mathrm{cm}^{3}\right)$ & $\mathrm{e}$ & $\mathrm{S}(\%)$ & $\theta_{\mathrm{w}}(\%)$ \\
\hline CRO1 & 32.9 & 1.87 & 1.41 & 0.93 & 96.2 & 46.3 \\
\hline CRO2 & 34.8 & 1.82 & 1.35 & 1.01 & 93.2 & 46.9 \\
\hline CRO3 & 35.2 & 1.82 & 1.35 & 1.01 & 94.2 & 47.4 \\
\hline CRO4 & 34.4 & 1.85 & 1.38 & 0.96 & 96.7 & 47.4 \\
\hline CRS1 & 36.1 & 1.79 & 1.32 & 1.06 & 92.2 & 47.4 \\
\hline CRU1 & 34.4 & 1.84 & 1.37 & 0.97 & 95.7 & 47.2 \\
\hline
\end{tabular}


Para simular uma pressão de confinamento foi empregado o método proposto por Vanapalli (1994), apresentado no item 2.3.3. Após a saturação, os corpos de prova foram adensados isotropicamente até uma determinada tensão efetiva previamente arbitrada e em seguida o confinamento é retirado. O índice de vazios após descarregamento deve ser semelhante ao índice de vazios da curva de adensamento correspondente a tensão que se deseja simular. As tensões confinantes induzidas foram de $100 \mathrm{kPa}(\mathrm{CRO} 2), 200 \mathrm{kPa}(\mathrm{CRO} 3)$ e $300 \mathrm{kPa}$ (CRO4). Para isto os corpos de prova tiveram que ser adensados a pressões hidrostáticas de $600 \mathrm{kPa}, 1000 \mathrm{kPa}$ e $2000 \mathrm{kPa}$, respectivamente. Os resultados destes ensaios estão apresentados na Figura 4.8. Para ilustrar este procedimento, será tomado como exemplo o corpo de prova CRO2. Na Figura 4.8, o ponto A representa a condição deste corpo de prova após saturação (ver Tabela 4.6). O ensaio é iniciado e no final do adensamento o mesmo passa a ser representado pelo ponto B. Em seguida a pressão isotrópica é aliviada e após o descarregamento do ensaio as condições do corpo de prova corresponde ao ponto $\mathrm{C}$. $\mathrm{O}$ índice de vazios do ponto $\mathrm{C}$ é igual ao do ponto $\mathrm{D}$, localizado sobre a curva de adensamento. No eixo das abscissas o ponto D esta submetido a um confinamento de $100 \mathrm{kPa}$. Desta forma as condições do corpo de prova no ponto $\mathrm{C}$, que são semelhantes à do ponto $\mathrm{D}$ na curva de adensamento, simula uma pressão de confinamento de $100 \mathrm{kPa}$.

Na Tabela 4.7 estão os dados dos corpos de prova após a realização das etapas de adensamento isotrópico e descarregamento. Estas condições correspondem às letras C, F e G indicadas na Figura 4.8. Ao se utilizar deste artifício, Vanapalli (1994) se refere a uma pseudotensão de confinamento. O confinamento não esta sendo aplicado diretamente no corpo de prova, mas o seu índice de vazios corresponde, na curva de adensamento, à pressão confinante que se deseja simular.

Durante a saturação por aspersão de água é permitido que os corpos de prova apresentem variações volumétricas, ou seja, expandam livremente. Estas variações volumétricas atingem valores de até $12 \%$. Na Tabela 4.8 estão os valores iniciais e finais do índice de vazios, grau de saturação e as variações volumétricas observadas após os procedimentos de saturação. 


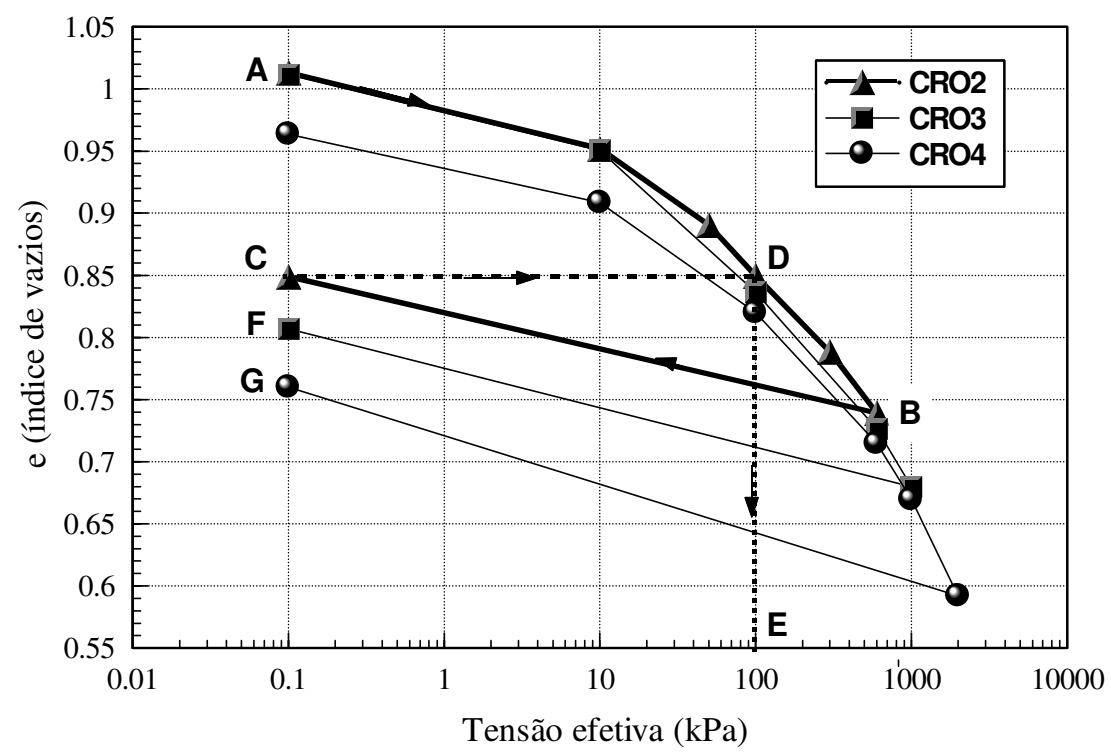

Figura 4.8 - Resultados dos ensaios de adensamento dos corpos de prova utilizados para a determinação das curvas de retenção submetidas a diferentes pressões confinantes.

Tabela 4.7 - Dados finais da preparação dos corpos de prova utilizados na determinação das curvas de retenção submetidas a diferentes pressões confinantes.

\begin{tabular}{|c|c|c|c|c|c|c|}
\hline C.P. & $\begin{array}{c}\text { Tens. Conf. } \\
(\mathrm{kPa})\end{array}$ & $\begin{array}{c}\mathrm{w} \\
(\%)\end{array}$ & $\begin{array}{c}\rho_{\mathrm{d}} \\
\left(\mathrm{g} / \mathrm{cm}^{3}\right)\end{array}$ & $\mathrm{e}$ & $\begin{array}{c}\mathrm{S} \\
(\%)\end{array}$ & $\begin{array}{c}\theta_{\mathrm{w}} \\
(\%)\end{array}$ \\
\hline CRO2 & 100 & 29.2 & 1.45 & 0.87 & 91.4 & 42.4 \\
\hline CRO3 & 200 & 27.7 & 1.49 & 0.82 & 91.3 & 41.2 \\
\hline CRO4 & 300 & 28.6 & 1.50 & 0.76 & 98.1 & 43.3 \\
\hline
\end{tabular}

CR - Curva de retenção, O, S e U - Condições de moldagem

Tabela 4.8 - Dados das variações volumétricas dos corpos de prova ao serem saturados por aspersão de água destilada.

\begin{tabular}{|c|c|c|c|c|c|c|c|}
\hline C.P. & e (inicial) & $\begin{array}{c}\mathrm{e} \\
\text { (após sat.) }\end{array}$ & $\begin{array}{c}\mathrm{S}(\%) \\
\text { Inic. }\end{array}$ & $\begin{array}{c}\mathrm{S}(\%) \\
\text { sat. }\end{array}$ & $\begin{array}{c}\text { Vol. Inic. } \\
\left(\mathrm{cm}^{3}\right)\end{array}$ & $\begin{array}{c}\text { Vol. Sat. } \\
\left(\mathrm{cm}^{3}\right)\end{array}$ & $\begin{array}{c}\Delta \mathrm{v} \\
(\%)\end{array}$ \\
\hline CRO1 & 0.79 & 0.93 & 86.2 & 96.2 & 43.5 & 46.8 & 7.6 \\
\hline CRO2 & 0.80 & 1.01 & 86.0 & 93.2 & 44.0 & 49.2 & 11.8 \\
\hline CRO3 & 0.80 & 1.01 & 86.2 & 94.2 & 44.2 & 49.4 & 11.8 \\
\hline CRO4 & 0.81 & 0.96 & 84.8 & 96.7 & 44.4 & 48.1 & 8.3 \\
\hline CRS1 & 0.86 & 1.06 & 54.8 & 92.2 & 43.9 & 48.5 & 10.5 \\
\hline CRU1 & 0.83 & 0.97 & 88.8 & 95.7 & 43.4 & 46.8 & 7.8 \\
\hline
\end{tabular}




\subsection{2 - Utilização da placa de sucção}

Após os procedimentos de preparação descritos no item anterior, os corpos de prova (CRO1, CRS1 e CRU1) foram colocados na placa de sucção (item 3.1) para obtenção do inicio da curva de retenção. Neste equipamento foram aplicadas as sucções de 1, 4, 6, 8, 10, 12, 14, 16, 20, 25 e $30 \mathrm{kPa}$. Como inicialmente os corpos de prova estão com umidade muito elevada, parte do solo fica aderido à pedra porosa durante sua retirada para pesagem e obtenção de suas dimensões. Para se evitar esta perda de material foi colocado papel filtro comum entre o corpo de prova e a fonte de sucção. Sobre os corpos de prova foi colocado um recipiente contendo algodão embebido em água. Isto melhora o contato dos corpos de prova com a pedra porosa e faz com que o ambiente interno da câmara deste equipamento apresente umidade relativa elevada.

Após estes cuidados iniciais, o conjunto contendo a placa de sucção e os corpos de prova é isolado do meio ambiente, colocando-se um recipiente plástico sobre os mesmos (ver Fig. 3.2). Após a montagem se aplica a sucção desejada, conforme indicado no item 3.1.2. No início do ensaio os corpos de prova passam a perder água para a pedra porosa, aumentando assim os seus valores de sucção. Esta água passa pela pedra porosa e acaba saindo no reservatório de água, ilustrado na Figura 3.2.

A partir do momento em que cessa a saída de água neste reservatório, os corpos de prova apresentam a mesma sucção que está sendo imposta pela pedra porosa da placa de sucção. Atingido o equilíbrio o ensaio é desmontado e os corpos de prova são pesados e medidos com a utilização de paquímetro. Para que não ocorram variações de sucção durante este procedimento, a placa de sucção deve ser mantida no mesmo local e à mesma distância do reservatório de água. 


\subsection{3 - Utilização da placa de pressão}

Ao serem retirados da placa de sucção, os corpos de prova CRO1, CRS1 e CRU1, foram colocados na placa de pressão. Neste equipamento foram submetidos às sucções de 50, 70, 150, 200, 250, 300, 350 e $400 \mathrm{kPa}$. Os corpos de prova submetidos a um pseudo confinamento (CRO2, CRO3 e CRO4) foram ensaiados com as sucções de $30 \mathrm{kPa}, 100 \mathrm{kPa}, 200 \mathrm{kPa}$ e $400 \mathrm{kPa}$. Na montagem destes ensaios deve-se assegurar que a pedra porosa esteja saturada e as conexões com o meio externo estejam fechadas. Antes da colocação dos corpos de prova deve-se retirar o excesso de água da superfície da pedra porosa, com o auxílio de um pano úmido. $\mathrm{Na}$ colocação dos corpos de prova sobre a pedra porosa foram utilizados os mesmos procedimentos da placa de sucção. Após o fechamento deste equipamento, aplica-se uma pressão de ar no interior da câmara, equivalente à sucção que se deseja impor aos corpos de prova (ver Figura 3.3). De forma a se permitir a saída de água dos corpos de prova, abre-se a conexão da pedra porosa com a bureta.

O tempo necessário para que os corpos de prova atinjam a sucção imposta na placa de pressão foi determinado pelo monitoramento da variação de seus teores de umidade. Em determinados intervalos de tempo o equipamento é aberto para a obtenção do peso dos corpos de prova, repetindo-se este procedimento até apresentarem valores praticamente constante. Inicialmente foi feita uma tentativa de se obter o tempo de equilíbrio pela variação do nível de água na bureta (Figura 3.3). A saída de água na bureta se dá com maior intensidade no início e depois passa a apresentar uma variação menor e constante, ficando difícil de se determinar o momento em que os corpos de prova apresentam a mesma sucção da pedra porosa.

No item 5.1 é apresentado como foi definido o tempo de equilíbrio nos ensaios da placa de pressão. No final do ensaio a conexão da pedra porosa com a bureta é fechada, sendo em seguida retirada a pressão de ar. A câmara é aberta e os corpos de prova são pesados e medidos. 


\subsection{4 - Utilização do papel filtro}

A placa de pressão pode ser utilizada até valores de sucções de $500 \mathrm{kPa}$, correspondendo este limite ao valor de entrada de ar da pedra porosa deste equipamento. Portanto, para sucções maiores que $500 \mathrm{kPa}$, a curva de retenção de cada corpo de prova foi determinada com a utilização da técnica do papel filtro. Nesta pesquisa foi utilizado o papel filtro Whatman $\mathrm{n}^{\mathrm{o}}$ 42. Ao se utilizar esta técnica o ideal é que cada valor de sucção seja determinado pela média de pelo menos dois resultados. Como os corpos de prova têm diâmetro de $3.8 \mathrm{~cm}$ e o papel filtro tem diâmetro de $7 \mathrm{~cm}$, houve a necessidade de serem cortados. Foram colocados dois papeis na superfície lateral dos corpos de prova. Em seguida o corpo de prova com os papeis são envoltos em filme plástico, papel alumínio e deixados em repouso em uma caixa de isopor por um período de 7 dias. Após este período se determina a umidade do papel filtro.

Ao se retirar o filme plástico que envolve o corpo de prova, o papel filtro é retirado com o auxílio de uma pinça, não devendo ficar exposto ao ar por mais que 5 segundos, e colocado em sacos auto selante. Após a pesagem do saco com o papel filtro úmido, o papel é retirado e colocado na estufa, por um período mínimo de 2 horas, a uma temperatura de $105^{\circ} \mathrm{C}$. Depois de decorrido este tempo, cada papel filtro é retirado da estufa e colocado no mesmo saco auto selante para obtenção do peso do papel seco. Todo o manuseio do papel filtro se dá com a utilização da pinça e as pesagens em balanças de alta precisão. Com a obtenção da umidade do papel filtro utiliza-se a sua curva de calibração para determinação do valor da sucção do corpo de prova. Para a determinação dos próximos pontos do ensaio, os corpos de prova são expostos ao ar, controlando-se nesta etapa a variação do teor de umidade. Ao atingirem a umidade desejada, a sucção é determinada seguindo os procedimentos descritos anteriormente. Nesta pesquisa foi investigada a histerese das curvas de retenção determinadas sem confinamento utilizando os corpos de prova moldados na umidade ótima no ramo seco e no ramo úmido. Desta forma, após a obtenção destas curvas seguindo a trajetória de secagem os corpos de prova foram novamente umedecidos. 
Após a aspersão de água destilada os mesmos foram envoltos em filme plástico e deixados em repouso para a homogeneização da umidade. Em seguida foram colocados dois papéis filtro na sua superfície lateral, seguindo-se os cuidados citados anteriormente neste item. Para a obtenção dos próximos pontos os corpos de prova são novamente umedecidos repetindo-se todos os procedimentos anteriores. As curvas de retenção, seguindo o caminho do umedecimento dos corpos de prova, foram todas determinadas apenas com a utilização do papel filtro.

\section{9 - Procedimentos utilizados na obtenção da curva de retenção dos corpos de prova compactados dinamicamente}

Estas curvas foram determinadas com os corpos de prova moldados no ensaio de compactação e para mais três corpos de prova moldados nos pontos de estudo, definidos na Figura 4.5. A estrutura dos solos moldados por compactação dinâmica é mais heterogenea, em relação à obtida por compactação estática. Com o objetivo de se obter corpos de prova mais representativos desta condição de moldagem, os mesmos foram moldados com dimensões maiores que os moldados por compactação estática. Em função destas dimensões, tornou-se inviável a utilização das placas de sucção e de pressão. Sendo assim estas curvas foram obtidas apenas com a utilização da técnica do papel filtro. Este item descreve os procedimentos de moldagem e preparação dos corpos de prova compactados dinamicamente e os procedimentos para obtenção destas curvas de retenção.

\subsection{1 - Moldagem dos corpos de prova e preparação para o ensaio}

Para a compactação dos corpos de prova nas condições de moldagem dadas na Tabela 4.2, foram separados em torno de 500g para cada ponto. Após a adição de água destilada ou exposição ao ar para atingirem as umidades desejadas, o solo foi novamente passado na peneira de malha de $2 \mathrm{~mm}$ (\#10) para se destorroar as pequenas agregações de partículas. Em seguida foram armazenados em sacos plásticos por 24 horas, para homogeneização da umidade.

Estes corpos de prova foram compactados no molde Proctor, seguindo os mesmos procedimentos dos que foram moldados para a definição da curva de compactação. 
No entanto para se evitar descontinuidades entre camadas, as amostras foram compactadas em uma única camada. Utilizando um torno manual foi feita a regularização do topo e a redução do volume destes corpos de prova, apresentando após esta etapa diâmetro e altura respectivamente iguais a $7 \mathrm{~cm}$ e altura de $4 \mathrm{~cm}$. Antes do inicio dos ensaios da curva de retenção, os mesmos foram saturados por aspersão de água destilada. Os dados de moldagem e de saturação dos corpos de prova compactados nos pontos de estudo estão respectivamente nas Tabela 4.9 e 4.10 .

Os seis corpos de prova moldados no ensaio da curva de compactação foram utilizados para se obter suas respectivas curvas de retenção a partir do teor de umidade de moldagem. Para a obtenção da curva de retenção, os mesmos foram utilizados com as dimensões do cilindro Proctor (Vol. $\left.\cong 1000 \mathrm{~cm}^{3}\right)$. Nas Tabelas 4.11 estão os dados dos corpos de prova moldados para a determinação da curva de compactação. Nesta tabela a letra $\mathrm{P}$ indica que foram compactados no cilindro Proctor.

As variações volumétricas apresentadas pelos corpos de prova após a etapa de saturação estão indicadas na Tabela 4.12. Comparando os resultados das Tabelas 4.8 e 4.12, observa-se que os corpos de prova compactados estaticamente apresentaram variações volumétricas maiores que a apresentada pelos corpos de prova compactados dinamicamente. Este fato foi constatado para as três condições de moldagem.

Tabela 4.9 - Dados iniciais de moldagem dos corpos de prova compactados dinamicamente nas condições dos pontos de estudo (O, S e U).

\begin{tabular}{|c|c|c|c|c|c|c|}
\hline C.P. & $\mathrm{w}(\%)$ & $\rho\left(\mathrm{g} / \mathrm{cm}^{3}\right)$ & $\rho_{\mathrm{d}}\left(\mathrm{g} / \mathrm{cm}^{3}\right)$ & $\mathrm{e}$ & $\mathrm{S}(\%)$ & $\theta_{\mathrm{w}}(\%)$ \\
\hline CRO5 & 25.5 & 1.88 & 1.50 & 0.81 & 85.7 & 38.3 \\
\hline CRS2 & 18.0 & 1.72 & 1.46 & 0.86 & 57.0 & 26.3 \\
\hline CRU2 & 28.8 & 1.91 & 1.48 & 0.83 & 93.9 & 42.6 \\
\hline
\end{tabular}


Tabela 4.10 - Dados dos corpos de prova compactados dinamicamente nas condições dos pontos de estudo após a etapa de saturação (O, S e U).

\begin{tabular}{|c|c|c|c|c|c|c|}
\hline C.P. & $\mathrm{w}(\%)$ & $\rho\left(\mathrm{g} / \mathrm{cm}^{3}\right)$ & $\rho_{\mathrm{d}}\left(\mathrm{g} / \mathrm{cm}^{3}\right)$ & $\mathrm{e}$ & $\mathrm{S}(\%)$ & $\theta_{\mathrm{w}}(\%)$ \\
\hline CRO5 & 29.37 & 1.90 & 1.47 & 0.85 & 93.7 & 43.0 \\
\hline CRS2 & 31.28 & 1.79 & 1.37 & 0.98 & 86.1 & 42.7 \\
\hline CRU2 & 30.62 & 1.89 & 1.45 & 0.87 & 95.3 & 44.4 \\
\hline
\end{tabular}

Tabela 4.11 - Dados iniciais de moldagem dos corpos de prova obtidos na determinação da curva de compactação.

\begin{tabular}{|c|c|c|c|c|c|c|}
\hline C.P. & $\mathrm{w}(\%)$ & $\rho\left(\mathrm{g} / \mathrm{cm}^{3}\right)$ & $\rho_{\mathrm{d}}\left(\mathrm{g} / \mathrm{cm}^{3}\right)$ & $\mathrm{e}_{\mathrm{f}}$ & $\mathrm{S}(\%)$ & $\theta_{\mathrm{w}}(\%)$ \\
\hline CRP1 & 18.5 & 1.77 & 1.49 & 0.81 & 61.6 & 27.6 \\
\hline CRP2 & 20.4 & 1.82 & 1.51 & 0.79 & 69.7 & 30.8 \\
\hline CRP3 & 22.8 & 1.87 & 1.52 & 0.78 & 79.5 & 34.8 \\
\hline CRP4 & 24.8 & 1.91 & 1.53 & 0.77 & 87.2 & 38.0 \\
\hline CRP5 & 26.6 & 1.93 & 1.52 & 0.78 & 91.9 & 40.2 \\
\hline CRP6 & 28.4 & 1.90 & 1.48 & 0.84 & 92.2 & 42.0 \\
\hline
\end{tabular}

CRP - Curva de Retenção do ensaio Compactação (Proctor)

Tabela 4.12 - Dados referentes à variação volumétrica dos corpos de prova, compactados dinamicamente, após saturação.

\begin{tabular}{|c|c|c|c|c|c|c|c|}
\hline C.P. & $\begin{array}{c}\mathrm{e} \\
\text { (inicial) }\end{array}$ & $\begin{array}{c}\mathrm{e} \\
\text { (após sat.) }\end{array}$ & $\begin{array}{c}\mathrm{S}(\%) \\
\text { Inic. }\end{array}$ & $\begin{array}{c}\mathrm{S}(\%) \\
\text { sat. }\end{array}$ & $\begin{array}{c}\text { Vol. Inic. } \\
\left(\mathrm{cm}^{3}\right)\end{array}$ & $\begin{array}{c}\text { Vol. Sat. } \\
\left(\mathrm{cm}^{3}\right)\end{array}$ & $\Delta \mathrm{v}(\%)$ \\
\hline CRO5 & 0.77 & 0.85 & 86.8 & 95.0 & 172.9 & 178.2 & 3.1 \\
\hline CRS2 & 0.81 & 0.98 & 54.8 & 87.8 & 161.5 & 172.6 & 6.9 \\
\hline CRU2 & 0.81 & 0.87 & 91.6 & 96.5 & 181.7 & 185.6 & 2.2 \\
\hline
\end{tabular}

\subsection{2 - Utilização do papel filtro na determinação da curva de retenção dos corpos de prova compactados dinamicamente}

Estas curvas foram definidas para dois grupos de corpos de prova. O primeiro deles é composto pelos corpos de prova moldados nos pontos de estudo (Tabela 4.9) e o segundo grupo é formado pelos corpos de prova moldados no ensaio de compactação (Tabela 4.11). Estas curvas foram definidas seguindo apenas o caminho de secagem. Os corpos de prova moldados nos pontos de estudo, foram inicialmente saturados por aspersão de água destilada. Após saturação foram armazenados para homogeneização da umidade. Em função do formato destes corpos de prova foi colocado um papel filtro no topo e outro na base. 
Nos corpos de prova do ensaio de compactação, os papeis filtro foram colocados logo após a moldagem. Em função de suas dimensões foram utilizados 3 papeis filtro inteiros, colocados em sua superfície lateral. Os procedimentos para a determinação da curva de retenção com a utilização do papel filtro estão apresentados no item 4.8.4.

\subsection{0 - Procedimentos utilizados na determinação da curva de retenção da lama}

Conforme descrito no item 3.3.1, a medição da sucção com o tensiômetro é realizada com a utilização de uma pasta de solo colocado sobre o mesmo. Colocada sobre tensiômetro com a consistência de lama, a mesma passa a perder água para o corpo de prova aumentando assim o seu valor de sucção. Esta transferência de água ocorre até o momento em que a pasta apresenta o mesmo valor de sucção do corpo de prova. Um dos aspectos que serão verificados é se existe alguma interferência no valor de sucção medida pelo tensiômetro, quando a sucção da pasta passa a ser maior que a sua sucção de entrada de ar.

Com este intuito foram determinadas as curvas de retenção da lama do solo que passa na peneira $n^{0} 10$ e $n^{0} 40$. Além dos aspectos anteriores, a curva de retenção da lama será utilizada na interpretação dos resultados das curvas de retenção obtidas nas outras condições de moldagem. Neste item são descritos os procedimentos de preparação da lama e da utilização da placa de sucção e de pressão.

\subsection{1 - Preparação das amostras e moldagem dos corpos de prova}

Os corpos de prova foram moldados com o solo que passa nas peneiras $\mathrm{n}^{\mathrm{o}} 10$ e $\mathrm{n}^{\mathrm{o}}$ 40. O solo foi colocado em um recipiente de porcelana, sendo em seguida adicionada pequenas quantidades de água destilada, fazendo-se a homogeneização com auxílio de uma espátula até que apresente a consistência de lama. A quantidade de solo e de água adicionada é calculada de forma a produzir uma lama com teor de umidade superior ao limite de liquidez. Após esta etapa inicial de preparação, os corpo de prova foram moldados no interior de uma anel de PVC. 
Este anel apresenta diâmetro de $3.7 \mathrm{~cm}$ e altura de $1.5 \mathrm{~cm}$. A curva de retenção foi inicialmente determinada com a utilização da placa de sucção. Sobre a pedra porosa deste equipamento foram colocados papeis filtro de uso comum em laboratório, cortados com o mesmo diâmetro dos moldes de PVC. Estes moldes foram colocados sobre os papeis e com o auxílio de uma espátula foram preenchidos com a lama. Durante o ensaio na placa de sucção os corpos de prova passam a perder água e a apresentar redução de volume. Para evitar que fiquem aderidos aos moldes de PVC, passou-se uma pequena quantidade de vaselina no interior dos mesmos.

Na placa de sucção foram aplicadas as sucções de 5, 10 e $30 \mathrm{kPa}$. A partir destes valores foi utilizada a placa de pressão com sucções de 50, 100, 150, 250, 350 e 450 $\mathrm{kPa}$. Devido a algumas dificuldades experimentais, tais como a pequena espessura dos corpos de prova e à sua maior fragilidade para sucções superiores a $450 \mathrm{kPa}$, optou-se por não se utilizar o papel filtro na determinação da curva de retenção para valores maiores de sucção.

\subsection{2 - Procedimentos da utilização da placa de sucção e de pressão}

Na placa de sucção foram moldados 6 corpos de prova, sendo três do solo que passa na peneira $n^{0} 10$ e três do solo que passa na peneira $n^{-} 40$. Para os níveis de sucção empregado neste equipamento, o corpo de prova continua aderido ao molde apresentando apenas redução de altura. Após a obtenção destas reduções de altura com o paquímetro, os corpos de prova foram retirados juntamente com o molde de PVC, para se executar os procedimentos de pesagem. Devido à baixa consistência dos mesmos, fica inviável recolocá-los na placa de sucção. Para cada sucção $(5,10$ e $30 \mathrm{kPa}$ ) aplicada foi retirado apenas 1 corpo de prova de cada tipo de lama. Os outros permanecem no equipamento e são submetidos às sucções posteriores. Desta forma, cada ponto da curva de retenção determinado na placa de sucção, corresponde a diferentes corpos de prova.

Para a placa de pressão foram moldados mais 4 corpos de prova, sendo dois do solo que passa na peneira $\mathrm{n}^{\mathrm{o}} 10$ e 2 na peneira $\mathrm{n}^{\mathrm{o}} 40$. A partir da sucção de $50 \mathrm{kPa}$, 
imposta neste equipamento, os corpos de prova apresentam uma consistência que permite a sua reutilização para as sucções posteriores. Para este valor de sucção o corpo de prova descola do molde de PVC, não sendo mais necessário a sua utilização. Ao serem retirados da placa de pressão para a obtenção do peso úmido, as sucções dos corpos de prova foram determinadas com o tensiômetro. Desta forma serão comparados os valores da sucção imposta aos corpos de prova na placa de pressão, com os valores das sucções medidas com o tensiômetro. Estes resultados fazem parte das análises realizadas no Capítulo 7.

\subsection{1 - Ensaios de resistência ao cisalhamento}

Os tipos de ensaio de resistência ao cisalhamento e os seus principais objetivos foram apresentados na Figura 4.6 e na Tabela 4.3. Foram todos realizados em corpos de prova compactados estaticamente nos três pontos de estudo definidos na Figura 4.5. Neste item são descritos os principais objetivos da realização destes ensaios e os procedimentos de moldagem e preparação dos corpos de prova. Na etapa de preparação são definidas, em função dos aspectos de resistência a serem investigados, as diferentes trajetórias de umidade impostas aos corpos de prova. Finalizando este item são apresentados os procedimentos empregados na montagem e realização destes ensaios.

\subsection{1 - Moldagem dos corpos de prova e trajetórias de umidade utilizadas em sua preparação para realização dos ensaios}

Devido à perda de água por evaporação durante os procedimentos de moldagem, as amostras de solo foram preparadas para a compactação com teores de umidade $1 \%$ acima dos valores da Tabela 4.2. Em função da formação de pequenas agregações de partículas de solo, estas amostras foram novamente passadas na peneira de malha de $2 \mathrm{~mm}$ (\#10). Após estes procedimentos iniciais as mesmas foram armazenadas em sacos plásticos para homogeneização da umidade.

Os corpos de prova foram compactados em cinco camadas no interior do molde tripartido, descrito no item 3.5. A quantidade de amostra colocada em cada camada é uma função da densidade seca e da umidade de moldagem. Antes da compactação da 
camada subseqüente é importante escarificar a camada anterior de forma a permitir uma melhor aderência entre as mesmas. $\mathrm{O}$ valor do volume do corpo de prova, utilizado para o cálculo da quantidade de amostra de solo a ser compactada em cada camada, não é o mesmo do molde tripartido. Verificou-se em alguns testes que após a retirada do corpo de prova do molde, ocorre uma pequena variação volumétrica devido ao alívio de tensões. O aumento médio de volume é de $1.5 \%$ em relação ao volume do molde tripartido. Essas considerações levam a uma maior precisão nas características desejadas para cada corpo de prova. Após a compactação da última camada, o corpo de prova fica fortemente aderido à parede interna do molde tripartido. Para se evitar que venham a ser danificados durante a retirada das partes que o compõem, deve-se dar inicialmente um pequeno deslocamento no corpo de prova. Este procedimento é feito na prensa de moldagem, utilizando o pistão sobre o mesmo. Com a moldagem no molde tripartido os corpos de prova apresentam diâmetro de aproximadamente $3.8 \mathrm{~cm}$ e altura de $8 \mathrm{~cm}$. Todos os ensaios de resistência desta pesquisa foram realizados em corpos de prova moldados com os mesmos procedimentos citados acima. No entanto, para apresentarem antes do início do ensaio diferentes valores de sucção, os mesmos foram preparados seguindo 5 trajetórias de umidade. Na Figura 4.9 estão apresentadas esquematicamente as trajetórias de umidade utilizadas na etapa de preparação dos corpos de prova para o ensaio. Estas trajetórias correspondem aos seguintes procedimentos:

1) Trajetória 1 (Saturação sem expansão) - Os corpos de prova são saturados por contra-pressão, evitando assim que apresentem variações volumétricas significativas.

2) Trajetória 2 (Saturação com expansão livre) - O procedimento de saturação é feito por aspersão de água destilada e os corpos de prova expandem livremente.

3) Trajetória 3 (Umedecimento) - A partir das condições iniciais de moldagem os corpos de prova são umedecidos por aspersão de água destilada até atingirem o teor de umidade desejada, permitindo-se a sua variação volumétrica. 
4) Trajetória 4 (Secagem) - A partir do teor de umidade de moldagem os corpos de prova são deixados secar ao ar até atingirem a sucção desejada.

5) Trajetória 5 (Saturação e secagem) - Os corpos de prova são saturados por aspersão de água, permitindo-se que expandam livremente. A partir da saturação são secados ao ar até atingirem o teor de umidade desejado.

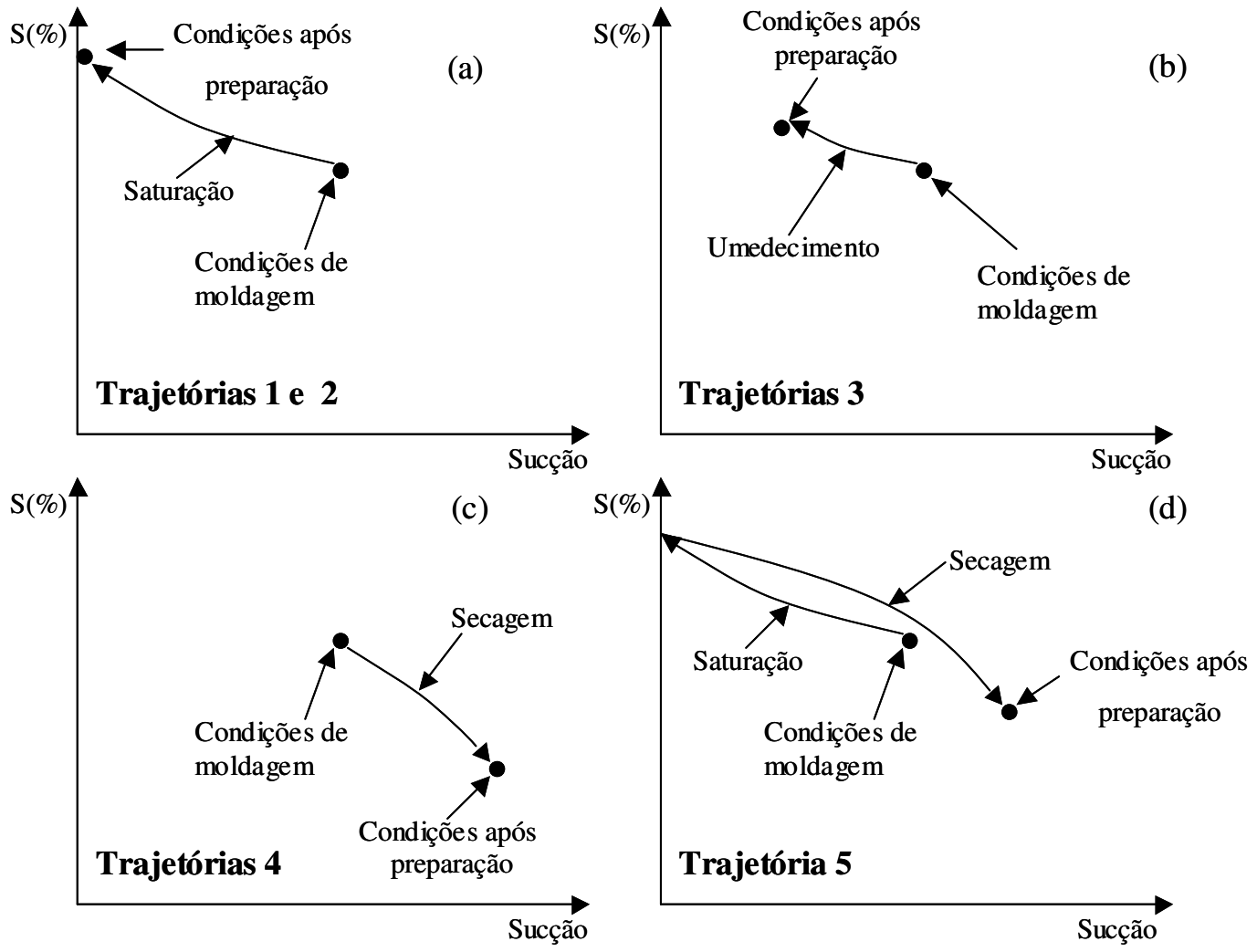

Figura 4.9 - Representação esquemática das diferentes trajetórias de umidade impostas aos corpos de prova na etapa de preparação para os ensaios de resistência ao cisalhamento. 


\subsection{2 - Preparação dos corpos de prova e procedimentos utilizados nos ensaios de resistência ao cisalhamento}

Cada tipo de ensaio foi realizado com um objetivo que para serem alcançados requerem cuidados diferenciados para a sua execução. Este item descreve como os corpos de prova foram preparados, juntamente com os objetivos e os procedimentos de cada ensaio. Foram realizados os seguintes ensaios de resistência:

1) Ensaio de compressão simples - Conforme citado no item 4.10.1, a partir das condições iniciais de moldagem, os corpos de prova foram preparados seguindo 5 diferentes tipos de trajetória de umidade. Para os ensaios de compressão simples realizados nesta pesquisa foram empregadas as trajetórias 3, 4 e 5 .

Após esta etapa de preparação, os mesmos foram envoltos em filme plástico e deixados em repouso por 48 hs no interior de uma caixa de isopor para permitir a homogeneização da umidade. O procedimento de aspersão de água no corpo de prova faz com que apresente inicialmente um teor de umidade maior em sua superfície. Na etapa de homogeneização da umidade ocorre a redistribuição deste excesso de água em todo o volume do corpo de prova. Após moldagem, preparação e homogeneização da umidade, todos os corpos de prova tiveram os seus valores de sucção determinados com o papel filtro. Os procedimentos para a determinação desta sucção foram apresentados no item 4.8.4.

Após a obtenção da sucção com o papel filtro, os corpos de prova foram ensaiados na célula de cisalhamento apresentada na Figura 3.7. Para os corpos de prova que apresentaram sucções menores que a capacidade de medição do tensiômetro, foram obtidas as respectivas variações da sua sucção durante a fase de cisalhamento. Sobre o tensiômetro foi colocada uma pasta preparada com o solo que passa na peneira de malha $0.42 \mathrm{~mm}$ (\#40). A quantidade de pasta utilizada deve ser suficiente para preencher a pequena reentrância localizada acima da pedra porosa $(\cong 0,4 \mathrm{~mm})$. 
O corpo de prova é posicionado sobre a pasta e em seu topo é colocada uma pedra porosa e um top cap, sendo posteriormente envolto em filme plástico para se evitar a perda de água por evaporação, durante a execução do ensaio. A sua ligação com o ambiente externo é mantida aberta durante todo o ensaio. Nos ensaios de compressão simples realizados nesta pesquisa não foram observadas variações no teor de umidade. Portanto os mesmos são drenados ao ar e realizados com umidade constante $(\mathrm{CW})$. Ao se supor que o ar se apresenta de forma contínua no interior do corpo de prova, tem-se que a sua pressão relativa é nula e o valor medido pelo tensiômetro refere-se à sucção matricial. Após a estabilização da medição da sucção inicial do corpo de prova inicia-se a etapa de cisalhamento, realizada com carregamento controlado e deformação controlada. Para estes dois tipos de ensaios os procedimentos de preparação e montagem são os mesmos até o momento do início do cisalhamento.

Após cada incremento de peso, durante a realização dos ensaios realizados com carregamento controlado, deve-se esperar a estabilização do valor da sucção, medida no tensiômetro, e da variação de altura do corpo de prova, acompanhada no extensômetro colocado no topo da célula. Estes valores são anotados na planilha do ensaio e em seguida coloca-se o próximo carregamento. Após a ruptura o ensaio é desmontado e se obtém a umidade final do corpo de prova.

Os corpos de prova preparados para os ensaios com deformação controlada apresentaram, em sua grande maioria, valores de sucção maiores que a capacidade do tensiômetro. Nestes ensaios foi colocada uma chapa metálica sobre o tensiômetro, evitando assim que o mesmo fique em contato direto com o corpo de prova. $\mathrm{O}$ cisalhamento foi realizado com velocidade constante e igual a $0.3 \mathrm{~mm} / \mathrm{min}$. Para os ensaios onde foi possível se fazer o acompanhamento da variação da sucção, foram anotadas para diferentes valores de leituras do extensômetro, as forças axiais aplicadas ao corpo de prova, pela leitura do anel dinamométrico, e os valores das sucções medidas pelo tensiômetro. No final do ensaio determinou-se a umidade do corpo de prova. 
Devido à grande quantidade de ensaios de compressão simples, os dados iniciais de moldagem e de preparação dos corpos de prova são apresentados no Capítulo 6, juntamente com os resultados dos ensaios.

Para os ensaios realizados com deformação controlada foi investigada a influência da velocidade aplicada na etapa de cisalhamento. Estes ensaios foram realizados em corpos de prova moldados na umidade ótima (Ponto $\mathrm{O}$ ) e ensaiados nas condições de moldagem, ou seja, não sendo submetidos a nenhuma das trajetórias definidas na Figura 4.9. Foram aplicadas as velocidades $0.03,0.06,0.1,0.225,0.3$ e $0.5 \mathrm{~mm} / \mathrm{min}$.

Na Tabela 4.13 está apresentada a quantidade de corpos de prova ensaiados em cada ponto de estudo, o tipo de carregamento utilizado e as trajetórias de umidade impostas na etapa de preparação. Os tipos de envoltórias de ruptura obtidas dos resultados destes ensaios e os seus principais objetivos estão apresentados na Tabela 4.14.

Tabela 4.13 - Quantidade de corpos de prova ensaiados em compressão simples com as trajetórias de umidade impostas em sua preparação.

\begin{tabular}{|l|l|c|c|c|}
\hline \multicolumn{2}{|c|}{ Umidade Ótima } & Traj. 3 & Traj.4 & Traj. 5 \\
\hline \multirow{2}{*}{ Compressão simples } & Carreg. Controlado & 4 & 4 & 0 \\
\cline { 2 - 5 } & Deform. Controlada & 5 & 17 & 5 \\
\hline \multicolumn{2}{|c|}{ Ramo Seco } & Traj. 3 & Traj.4 & Traj. 5 \\
\hline \multirow{2}{*}{ Compressão simples } & Carreg. Controlado & 5 & 1 & 0 \\
\cline { 2 - 5 } & Deform. Controlada & 9 & 6 & 5 \\
\hline \multicolumn{2}{|r|}{ Ramo Úmido } & Traj. 3 & Traj.4 & Traj. 5 \\
\hline \multirow{2}{*}{ Compressão simples } & Carreg. Controlado & 1 & 5 & 0 \\
\cline { 2 - 5 } & Deform. Controlada & 3 & 14 & 5 \\
\hline
\end{tabular}


Tabela 4.14 - Envoltórias de ruptura obtidas nos ensaios de compressão simples e objetivos de sua obtenção.

\begin{tabular}{|c|c|c|}
\hline \multicolumn{3}{|c|}{ ENSAIOS DE COMPRESSÃO SIMPLES } \\
\hline Tipo & \begin{tabular}{|c|} 
Objetivo \\
\end{tabular} & \begin{tabular}{|l|} 
Observações \\
\end{tabular} \\
\hline $\begin{array}{l}\text { Envoltórias de ruptura } \\
\text { obtidas de corpos de prova } \\
\text { que foram umedecidos ou } \\
\text { secados. }\end{array}$ & $\begin{array}{l}\text { • Comparação dos resultados em } \\
\text { função das diferentes condições de } \\
\text { moldagem (pontos O, S e U). } \\
\text { •Para uma mesma condição de } \\
\text { moldagem, verificar as diferenças } \\
\text { nas envoltórias em função do tipo } \\
\text { de carregamento na fase de } \\
\text { cisalhamento. } \\
\text {-As envoltórias obtidas utilizando } \\
\text { o carregamento controlado serão } \\
\text { utilizadas na determinação das } \\
\text { superfícies de ruptura. }\end{array}$ & $\begin{array}{l}\text { - Obtidas para os três pontos } \\
\text { de estudo. } \\
\text { •Ensaios realizados com } \\
\text { deformação controlada e } \\
\text { carregamento controlado. }\end{array}$ \\
\hline $\begin{array}{l}\text { Envoltórias de ruptura } \\
\text { obtidas de corpos de prova } \\
\text { que foram saturados e } \\
\text { secados. }\end{array}$ & $\begin{array}{l}\text { - Comparar estas envoltórias com } \\
\text { as obtidas em corpos de prova que } \\
\text { foram umedecidos ou secados e } \\
\text { cisalhados com deformação } \\
\text { controlada. } \\
\text { •Será verificada, para cada } \\
\text { condição de moldagem, a histerese } \\
\text { nos valores de resistência devido às } \\
\text { diferentes trajetórias de umidade } \\
\text { seguidas na preparação dos corpos } \\
\text { de prova. }\end{array}$ & $\begin{array}{l}\text {-Determinadas para os três } \\
\text { pontos de estudo, utilizando a } \\
\text { deformação controlada na } \\
\text { fase de cisalhamento. }\end{array}$ \\
\hline
\end{tabular}

2) Ensaios triaxiais saturados - Foram realizados em cada ponto de estudo, três ensaios do tipo CAU (consolidado anisotropicamente e cisalhado sem drenagem). Após a montagem do ensaio, utilizando o equipamento da Figura 3.9, os corpos de prova foram saturados por contra pressão (trajetória 1). O procedimento de saturação foi acompanhado pela medição do parâmetro $\bar{B}$. Os corpos de prova foram considerados saturados quando os valores deste parâmetro foram superiores a 0.85. Após saturação foram adensados anisotropicamente, com relação entre a tensão confinante e a tensão axial igual a 0.7. Para cada condição de moldagem os corpos de prova foram adensados até atingirem tensões confinantes efetivas $\left(\sigma_{3}^{\prime}\right)$ iguais a 30 $\mathrm{kPa}, 80 \mathrm{kPa}$ e $150 \mathrm{kPa}$. Terminadas as etapas iniciais de saturação e adensamento, os corpos de prova foram cisalhados com o acompanhamento da variação da poro pressão. A etapa de cisalhamento foi realizada com tensão controlada, com incrementos de $80 \mathrm{kPa}$ por hora. Os dados iniciais de moldagem destes corpos de prova estão apresentados na Tabela 4.15. 
Tabela 4.15 - Dados iniciais dos corpos de prova utilizados nos ensaios triaxiais CAU realizados com medição da poro pressão.

\begin{tabular}{|c|c|c|c|c|c|}
\hline \multicolumn{7}{|c|}{ UMIDADE ÓTIMA } \\
\hline C.P. & $\mathrm{w}(\%)$ & $\rho_{\mathrm{d}}\left(\mathrm{g} / \mathrm{cm}^{3}\right)$ & $\mathrm{e}_{\mathrm{f}}$ & $\mathrm{S}(\%)$ & $\theta_{\mathrm{w}}(\%)$ \\
\hline CUO1 & 25.03 & 1.51 & 0.79 & 85.4 & 37.8 \\
\hline CUO2 & 25.18 & 1.50 & 0.80 & 84.9 & 37.8 \\
\hline CUO3 & 25.18 & 1.50 & 0.81 & 84.6 & 37.8 \\
\hline \multicolumn{7}{|c|}{ RAMO SECO } \\
\hline C.P. & $\mathrm{w}(\%)$ & $\rho_{\mathrm{d}}\left(\mathrm{g} / \mathrm{cm}^{3}\right)$ & $\mathrm{e}_{\mathrm{f}}$ & $\mathrm{S}(\%)$ & $\theta_{\mathrm{w}}(\%)$ \\
\hline CUS1 & 16.90 & 1.47 & 0.84 & 54.6 & 24.9 \\
\hline CUS2 & 16.90 & 1.48 & 0.83 & 55.4 & 25.0 \\
\hline CUS3 & 16.90 & 1.49 & 0.82 & 55.8 & 25.1 \\
\hline \multicolumn{7}{|c|}{ RAMO ÚMIDO } \\
\hline C.P. & $\mathrm{w}(\%)$ & $\rho_{\mathrm{d}}\left(\mathrm{g} / \mathrm{cm}^{3}\right)$ & $\mathrm{e}_{\mathrm{f}}$ & $\mathrm{S}(\%)$ & $\theta_{\mathrm{w}}(\%)$ \\
\hline CUU1 & 28.17 & 1.46 & 0.86 & 89.2 & 41.2 \\
\hline CUU2 & 27.9 & 1.47 & 0.84 & 90.2 & 41.1 \\
\hline CUU3 & 27.9 & 1.47 & 0.85 & 89.0 & 40.9 \\
\hline
\end{tabular}

Alem dos ensaios CAU foram realizados, na célula apresentada na Figura 3.7, mais três ensaios CD com carregamento controlado para as condições de moldagem na umidade ótima. Antes da montagem destes ensaios os corpos de prova foram saturados por aspersão de água destilada, permitindo-se que expandam livremente (trajetória 2- Figura 4.8a). Os dados iniciais de moldagem e os dados após saturação estão apresentados nas Tabela 4.16 e 4.17. Na última coluna da Tabela 4.17, tem-se que as variações volumétricas, apresentadas pelos corpos de prova após saturação, variaram entre 8.4 a $10.6 \%$.

Antes da montagem destes ensaios, coloca-se sobre o tensiômetro a pasta de solo. A seguir o corpo de prova é colocado sobre a pasta, sendo posteriormente envolto por uma membrana de borracha. No topo do corpo de prova é colocada uma pedra porosa saturada e um top cap conectado a uma bureta no exterior da célula. Deve-se assegurar que a tubulação que liga o corpo de prova com a bureta esteja saturada. Em seguida a célula é preenchida com água para a aplicação da pressão de confinamento. A conexão com a bureta é mantida fechada durante toda a montagem e preenchimento da célula, sendo aberta apenas na etapa de adensamento. A variação volumétrica do corpo de prova durante a fase de adensamento e de cisalhamento é acompanhada pelo nível de água na bureta. 
Tabela 4.16 - Dados de moldagem dos corpos de prova utilizados nos ensaios triaxias CD.

\begin{tabular}{|c|c|c|c|c|c|c|c|}
\hline C.P. & vol. $\left(\mathrm{cm}^{3}\right)$ & $\mathrm{w}(\%)$ & $\rho\left(\mathrm{g} / \mathrm{cm}^{3}\right)$ & $\rho_{\mathrm{d}}\left(\mathrm{g} / \mathrm{cm}^{3}\right)$ & $\mathrm{e}_{\mathrm{f}}$ & $\mathrm{S}(\%)$ & $\theta_{\mathrm{w}}$ \\
\hline CDO1 & 93.4 & 25.8 & 1.89 & 1.50 & 0.81 & 86.6 & 38.7 \\
\hline CDO2 & 93.0 & 25.8 & 1.90 & 1.51 & 0.80 & 87.7 & 38.9 \\
\hline CDO3 & 92.6 & 25.8 & 1.90 & 1.51 & 0.79 & 88.3 & 39.0 \\
\hline
\end{tabular}

$\mathrm{CDO}$ - ensaio triaxial CD realizado em corpos de prova moldados no ponto $\mathrm{O}$.

Tabela 4.17 - Dados dos corpos de prova utilizados no ensaio triaxiais CD após saturação.

\begin{tabular}{|c|c|c|c|c|c|c|c|c|}
\hline C.P. & vol. $\left(\mathrm{cm}^{3}\right)$ & $\mathrm{w}(\%)$ & $\rho\left(\mathrm{g} / \mathrm{cm}^{3}\right)$ & $\rho_{\mathrm{d}}\left(\mathrm{g} / \mathrm{cm}^{3}\right)$ & $\mathrm{e}_{\mathrm{f}}$ & $\mathrm{S}(\%)$ & $\theta_{\mathrm{w}}$ & $\Delta \mathrm{v}(\%)$ \\
\hline CDO1 & 101.3 & 33.6 & 1.85 & 1.38 & 0.96 & 94.9 & 46.5 & 8.4 \\
\hline CDO2 & 101.7 & 34.1 & 1.85 & 1.38 & 0.97 & 95.7 & 47.0 & 9.3 \\
\hline CDO3 & 102.4 & 34.4 & 1.84 & 1.37 & 0.98 & 94.8 & 47.0 & 10.6 \\
\hline
\end{tabular}

$\mathrm{CDO}$ - ensaio triaxial CD realizado em corpos de prova moldados no ponto $\mathrm{O}$.

Ao se aplicar a pressão de confinamento pode-se verificar, pela leitura de sucção do tensiômetro, se os corpos de prova estão saturados. No momento da aplicação desta pressão a leitura do tensiômetro varia de zero a um valor de pressão positiva que é função do grau de saturação do corpo de prova. Caso esteja saturado a leitura do tensiômetro é igual à da pressão confinante aplicada.

Após a aplicação da pressão confinante deve-se esperar a completa dissipação da pressão positiva lida no tensiômetro. Após este momento se procede a leitura do nível de água na bureta, de forma a se obter a variação volumétrica do corpo de prova. Após a etapa de adensamento, ajusta-se o pistão no topo do corpo de prova e inicia-se a fase de cisalhamento. Após cada incremento de carregamento, acompanha-se o nível de água da bureta e a variação de altura do corpo de prova. O próximo carregamento só é aplicado após completa dissipação da poro pressão e estabilização da leitura do extensômetro. A estabilização destes valores ocorre praticamente no mesmo instante. Na Tabela 4.18 estão os tipos de ensaios triaxiais saturados realizados nesta pesquisa e os objetivos de sua realização. 
Tabela 4.18 - Tipos de ensaios triaxiais CAU e CD saturados e objetivos de sua realização.

\begin{tabular}{|c|c|c|}
\hline \multicolumn{3}{|c|}{ ENSAIOS TRIAXIAIS SATURADOS } \\
\hline Tipo & Objetivo & \begin{tabular}{|l|} 
Observações \\
\end{tabular} \\
\hline $\begin{array}{l}\text { CAU (consolidado } \\
\text { anisotropicamente e } \\
\text { não drenado) }\end{array}$ & $\begin{array}{l}\text { - Determinação dos parâmetros } \\
\text { efetivos do solo. } \\
\text { - Utilização nas análises para a } \\
\text { determinação das superfícies } \\
\text { de ruptura. }\end{array}$ & $\begin{array}{l}\text { - Determinados em corpos de } \\
\text { prova moldados nos três pontos } \\
\text { de estudo (Figura 4.4). } \\
\text { - Utilização da tensão controlada } \\
\text { durante o cisalhamento. } \\
\text { • Corpos de prova saturados por } \\
\text { contra pressão (trajetória 1) }\end{array}$ \\
\hline $\begin{array}{l}\text { CD (utilizando um } \\
\text { tensiômetro na base } \\
\text { do corpo de prova) }\end{array}$ & $\begin{array}{l}\text { - Determinação dos parâmetros } \\
\text { efetivos do solo. } \\
\text { - Utilização na determinação da } \\
\text { superfície de ruptura. } \\
\text { - Comparação dos parâmetros } \\
\text { efetivos com os obtidos no } \\
\text { ensaio CAU. } \\
\text {-Serão utilizadas na aplicação } \\
\text { dos modelos de Vanapalli et al } \\
\text { (1996) e Khalili de Khabbaz } \\
\text { (1998) }\end{array}$ & 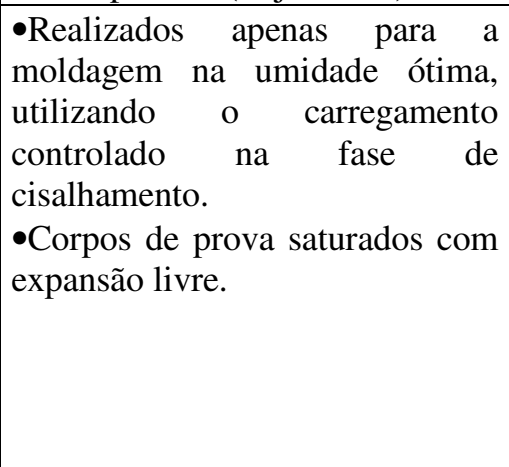 \\
\hline
\end{tabular}

3) Ensaios triaxiais CW não saturados - Estes ensaios foram realizados em corpos de prova moldados nos três pontos de estudo, definidos na Tabela 4.2. Para que os mesmos apresentem sucções iniciais diferentes, após a moldagem os corpos de prova foram preparados por umedecimento (trajetória 3) ou secagem (trajetória 4), até atingirem um valor de teor de umidade predeterminado. A relação entre o teor de umidade e a sucção, é obtida dos resultados das curvas de retenção. Neste procedimento de preparação, os corpos de prova não ficam exatamente com a sucção desejada. Para se corrigir as pequenas diferenças nestes valores, os mesmos foram colocados na placa de pressão com a mesma sucção que se pretendia atingir durante a secagem ou umedecimento. Após um período de 4 dias os corpos de prova foram retirados deste equipamento e as respectivas sucções foram determinadas com a técnica do papel filtro. Os dados de moldagem e de preparação destes corpos de prova são apresentados no Capítulo 6.

Nestes ensaios foram determinados os tempos em que a sucção medida no tensiômetro se iguala à sucção dos corpos de prova. Para se obter o valor deste tempo de equilíbrio, o corpo de prova foi colocado sobre o tensiômetro sendo 
posteriormente envolto apenas em filme plástico. Após a estabilização da leitura do tensiômetro o filme plástico é retirado para a colocação da membrana de borracha, da pedra porosa e do top cap. Os valores das sucções impostas na placa de pressão, medidos com o papel filtro e pelo tensiômetro no início dos ensaios serão analisados no Capítulo 7.

Em todos os ensaios foram utilizados os mesmos procedimentos de montagem dos ensaios de compressão simples descrito na parte 1 deste item. Esta semelhança ocorre até o momento da determinação da sucção inicial dos corpos de prova. A partir deste ponto a célula do ensaio é preenchida com água sendo em seguida aplicada a pressão de confinamento. Como os corpos de prova não estão saturados, os mesmos permanecem durante todo o ensaio conectados pelo topo com o meio externo, ou seja drenado ao ar. Para isto a pedra porosa deve estar seca e a tubulação conectada a bureta não deve conter água. A pressão de confinamento faz com que a sucção do corpo de prova diminua, sendo considerado o fim da fase de adensamento o momento em que a mesma se estabiliza neste novo valor. A etapa de cisalhamento, realizada com carregamento controlado, foi apresentada na parte 1 deste item. De forma semelhante aos ensaios de compressão simples, não foram observadas variações dos teores de umidade dos corpos de prova durante o ensaio. Portanto trata-se de um ensaio triaxial $\mathrm{CW}$ não saturado, drenado ao ar e com umidade constante. A Tabela 4.19 apresenta, para cada ponto de estudo, a quantidade de corpos de prova ensaiados e as respectivas pressões de confinamento. Na Tabela 4.20 estão indicados os objetivos da realização destes ensaios.

Tabela 4.19 - Quantidade de corpos de prova utilizados nos ensaios triaxiais CW não saturados

\begin{tabular}{|l|c|c|c|c|}
\hline$\sigma_{3}(\mathrm{kPa})$ & 50 & 100 & 200 & 300 \\
\hline Ponto O & 6 & 7 & 1 & 6 \\
\hline Ponto S & 5 & 4 & 5 & 5 \\
\hline Ponto U & 4 & 5 & 5 & 4 \\
\hline
\end{tabular}


Tabela 4.20 - Objetivos da realização dos ensaios triaxiais não saturados.

\begin{tabular}{|c|c|c|}
\hline \multicolumn{3}{|c|}{ ENSAIOS TRIAXIAIS NÃO SATURADOS } \\
\hline Tipo & Objetivo & Observações \\
\hline $\begin{array}{l}\text { Ensaio triaxial não } \\
\text { saturado drenado ao ar e } \\
\text { realizado com umidade } \\
\text { Constante }(\mathrm{CW}) .\end{array}$ & $\begin{array}{l}\text { •Obtenção das envoltórias de } \\
\text { ruptura para diferentes } \\
\text { pressões de confinamento. } \\
\text { - Utilização na determinação } \\
\text { das superfícies de ruptura. }\end{array}$ & $\begin{array}{l}\text { - Realizado em corpos de prova } \\
\text { moldados nos três pontos de } \\
\text { estudo (Figura } 4.5 \text { ) e } \\
\text { submetidos às pressões } \\
\text { confinantes de } 50,100,200 \mathrm{e} \\
300 \mathrm{kPa} \text {. } \\
\text { - Corpos de prova preparados } \\
\text { por umedecimento ou secagem. } \\
\text { - Cisalhados com carregamento } \\
\text { controlado. }\end{array}$ \\
\hline
\end{tabular}




\section{5 - APRESENTAÇÃO E DISCUSSÃO DOS RESULTADOS DA CURVA DE RETENÇÃO}

Neste capítulo são apresentados todos os resultados das curvas de retenção obtidas nesta pesquisa. Inicialmente é abordado o critério utilizado para a determinação do tempo de equilíbrio da sucção, ao se utilizar a placa de pressão. Posteriormente são apresentados, em diferentes itens, os resultados das curvas de retenção citadas na Tabela 4.4. Para estes resultados experimentais foi ajustada a equação proposta por Fredlund e Xing (1994). Na parte final são discutidos os aspectos relacionados à histerese, tipo de compactação e valores da sucção de entrada de ar.

\section{1 - Critério adotado para a estabilização da sucção na placa de sucção e de pressão}

Algumas dificuldades experimentais impossibilitaram a determinação do tempo necessário para que a sucção do corpo de prova se torne igual à sucção imposta pela pedra porosa da placa de pressão. Normalmente a determinação deste tempo de equilíbrio e feita pelo acompanhamento da variação do nível de água na bureta conectada à pedra porosa deste equipamento. No entanto, na placa de pressão ocorre um suprimento constante de ar vindo do compressor. Este ar chega a câmara do ensaio com uma determinada quantidade de vapor de água. Com pequenas variações de temperatura ocorre a condensação do vapor de água na parede interna da câmara. Esta água escorre para a pedra porosa e passa para a bureta, ficando assim inviável a determinação do tempo de equilíbrio pela variação do seu nível de água. Desta forma, optou-se por se obter o tempo de equilíbrio pelo acompanhamento da variação dos teores de umidade dos corpos de prova em função do tempo. 
Para isto, em determinados intervalos de tempo o ensaio é desmontado para se realizar a pesagem dos corpos de prova. Na Figura 5.1 estão apresentadas as variações de umidade dos corpos de prova CRO1, CRO2 e CRO3 (ver Tabela 4.5) em função do tempo ao serem submetidos à sucção de $200 \mathrm{kPa}$ na placa de pressão.

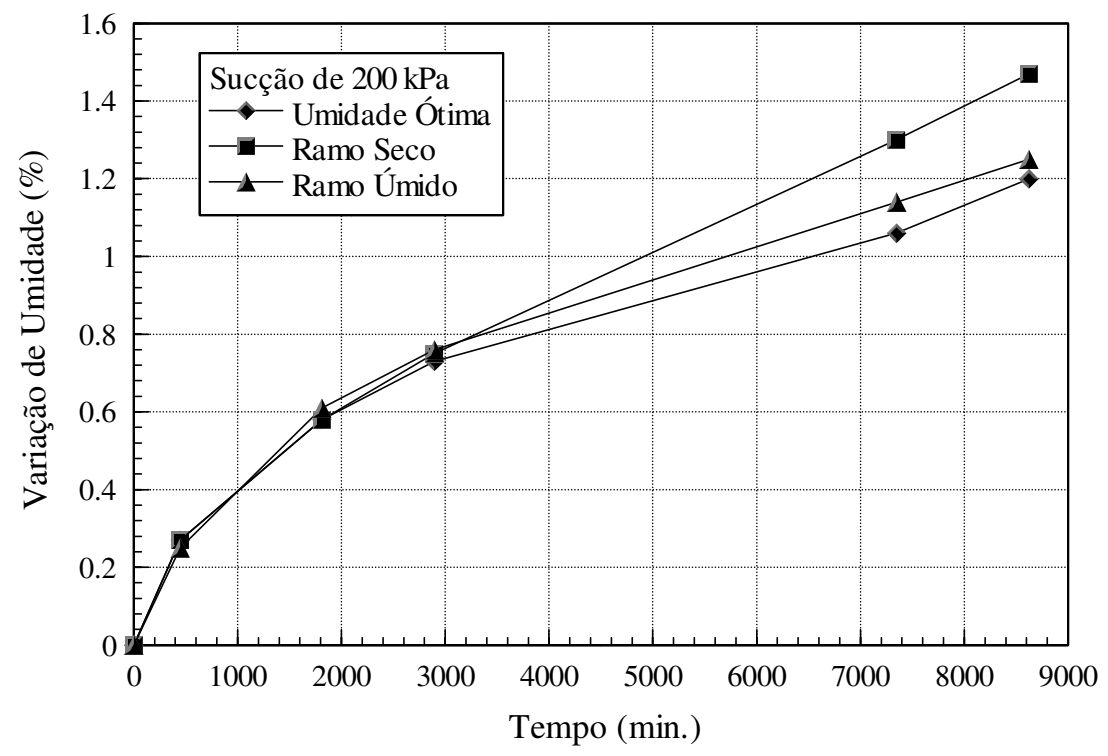

Figura 5.1 - Variação da umidade dos corpos de prova CRO1, CRO2 e CRO3 ao serem submetidos na placa de pressão a uma sucção de $200 \mathrm{kPa}$.

Na Figura 5.1 observa-se que a variação do teor de umidade gravimétrica é maior no início do ensaio, reduzindo gradativamente de valor até o tempo de 3000 minutos (2 dias). A partir deste tempo as variações de umidade permanecem praticamente constantes para as três condições de moldagem. Para todos os outros valores de sucções aplicados na placa de pressão, os corpos de prova apresentaram a mesma tendência, ou seja, não ocorre a estabilização do teor de umidade gravimétrico com o tempo. Ao se utilizar a placa de sucção e a placa de pressão os corpos de prova ficam submetidos a dois diferentes valores de sucção. A pedra porosa impõe uma sucção matricial e a umidade relativa, do ambiente interno deste equipamento, aplica uma sucção total. A relação entre a umidade relativa e a sucção total é dada pela equação 3.1, estando representada graficamente na Figura 5.2. Desta Figura constata-se que a sucção de $400 \mathrm{kPa}$, valor máximo aplicado na placa de pressão, corresponde a uma umidade relativa de $99.7 \%$. 
Valores desta ordem de grandeza são improváveis de serem mantidos no interior da placa de pressão. Desta forma, a sucção total imposta pela umidade relativa é superior à sucção dos corpos de prova e à sucção matricial aplicada pela pedra porosa.

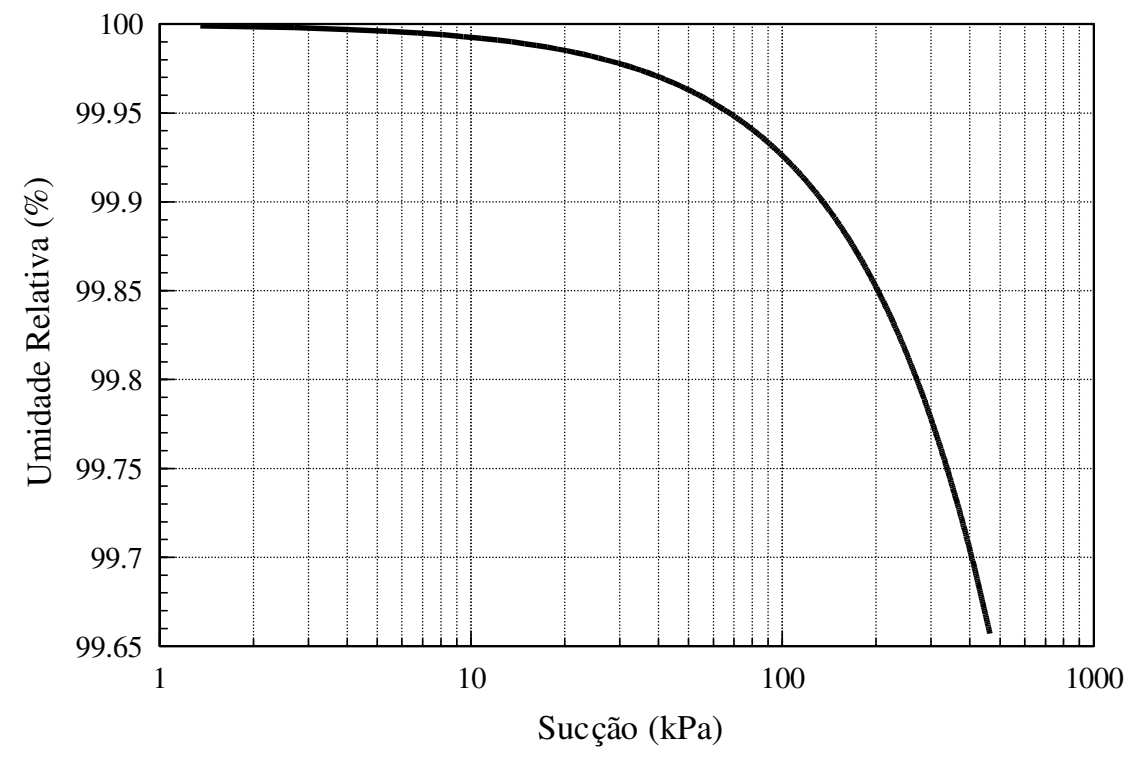

Figura 5.2 - Variação da umidade relativa em função da sucção.

A Figura 5.3 apresenta esquematicamente a placa de pressão e as prováveis transferências de água que ocorre entre o corpo de prova, a pedra porosa e o ambiente interno da câmara de ensaio. A Figura 5.3a representa o momento em que o corpo de prova é colocado sobre a pedra porosa. Neste instante os mesmos passam a perder água para a pedra porosa e para o ambiente interno da câmara deste equipamento, aumentando assim o seu valor de sucção. No momento em que seu valor de sucção se iguala à sucção imposta pela pedra porosa, cessa a perda de água para a mesma, conforme ilustrado na Figura 5.3b. O corpo de prova continua a perder água para o ambiente interno da câmara, ficando com sucção maior que a sucção imposta pela pedra porosa. Como a sucção da pedra porosa não varia, ela passa a fornecer água para o corpo de prova de forma a reduzir a sua sucção, conforme ilustrado na Figura 5.3c. 
Devido à baixa permeabilidade da pedra e à maior área do corpo de prova em contato com o ambiente interno da placa de pressão, a perda de água é maior que o acréscimo de água vindo da pedra porosa. Desta forma passam a perder água a uma taxa aproximadamente constante, para os tempos de ensaio utilizados (6 dias).

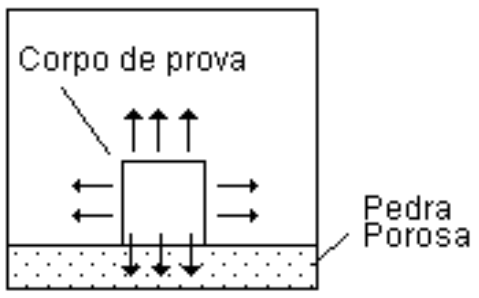

a) Ao se aplicar a succáo

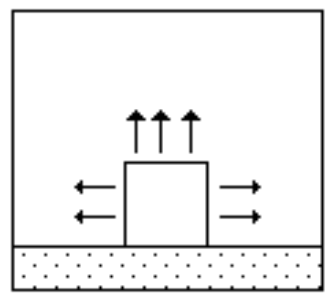

b) Ao atingir a sucóáda dedra porosa

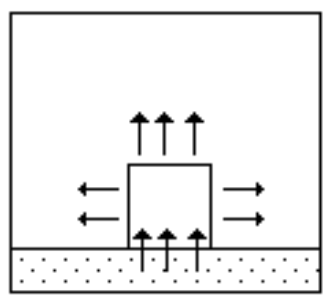

C) Após atingir a succáda pedra porosa

Figura 5.3 - Variação da umidade do corpo de prova quando submetido a um determinado valor de sucção na placa de pressão.

Portanto, o tempo de equilíbrio utilizado para a placa de pressão é o tempo a partir do qual os corpos de prova passam a perder água a uma taxa constante. Na Figura 5.1 este tempo corresponde a 3000 minutos, ou seja, aproximadamente dois dias. Para todos os valores de sucção imposta na placa de pressão os tempos de equilíbrio variaram entre 2 a 3 dias. O ideal é que na placa de pressão possa se controlar a umidade relativa no interior da câmara do ensaio. 
Desta forma, o corpo de prova ficará submetido a um único valor de sucção, imposta pela pedra porosa e pela umidade relativa. Para a placa de sucção (Figura 3.2) o ambiente em torno do corpo de prova não está conectado ao compressor, sendo razoável se admitir que a água que sai no reservatório de água deste equipamento seja proveniente apenas dos corpos de prova. Na placa de sucção a estabilização da sucção do corpo de prova foi constatada pela saída de água no reservatório inferior. O tempo de equilíbrio, de forma semelhante à placa de pressão, também variou entre 2 a 3 dias.

\section{2 - Resultados dos ensaios da curva de retenção}

Na Tabela 4.4 estão apresentadas as características e objetivos das curvas de retenção determinadas nesta pesquisa. O enfoque principal foi dado para as condições de moldagem escolhidas na curva de compactação, definidas na Figura 4.5. As análises destas curvas foram realizadas utilizando-se os valores do grau de saturação e do teor de umidade em função da sucção e pelo acompanhamento da variação do índice de vazios. Para as curvas de retenção determinadas sem confinamento as análises foram complementadas com os resultados de microscopia eletrônica de varredura.

\subsection{1 - Curvas de retenção determinadas sem confinamento utilizando corpos de prova compactados estaticamente}

Estas curvas foram definidas para 3 corpos de prova compactados estaticamente nas condições de moldagem definidas na Tabela 4.2. Os dados de moldagem destes corpos de prova (CRO1, CRS1 e CRU1) estão apresentados na Tabela 4.5. As variações do grau de saturação em função da sucção, obtidas para estes corpos de prova durante a secagem, estão apresentadas na Figura 5.4. Observase nesta figura uma grande semelhança entre as curvas obtidas para as condições de moldagem na umidade ótima e no ramo úmido. A curva obtida para a moldagem no ramo seco se diferencia das demais a partir da sucção em torno de $10 \mathrm{kPa}$. Para este valor de sucção ocorre o início da entrada de ar do corpo de prova e o grau de saturação se reduz para $80 \%$, mantendo-se constante até o valor de $40 \mathrm{kPa}$. A partir 
deste valor passa a ocorrer novamente a dessaturação do corpo de prova. De fato esta curva apresenta dois pontos de inflexão, caracterizando-se por apresentar uma distribuição bimodal de poros. A compactação no ramo seco resulta na formação de agregações de partículas [e.g. Croney et al (1958), Brackley (1973), Toll (2000)]. Em função da sucção no interior destas agregações, as mesmas se comportam como um único grão do solo. O esforço da compactação não é suficiente para desagregar este aglomerado de partículas. A estrutura resultante se caracteriza pelos macroporos, formados pelos vazios entre as agregações, e os microporos formado no interior das agregações. Provavelmente a semelhança das curvas obtidas para as condições de moldagem na umidade ótima e no ramo úmido, apresentadas na Figura 5.4, esteja relacionada à ausência de agregações após a compactação, resultando na formação estruturas semelhantes. Na Figura 5.4 estão indicados os intervalos de sucção correspondentes aos resultados obtidos com a placa de sucção, placa de pressão e o papel filtro. Observa-se que na transição entre a placa de pressão e o papel filtro ocorre uma pequena descontinuidade na definição da curva de retenção. O papel filtro provavelmente esta medindo um valor entre a sucção matricial e total. Os valores medidos com o papel filtro são analisados no Capítulo 7.

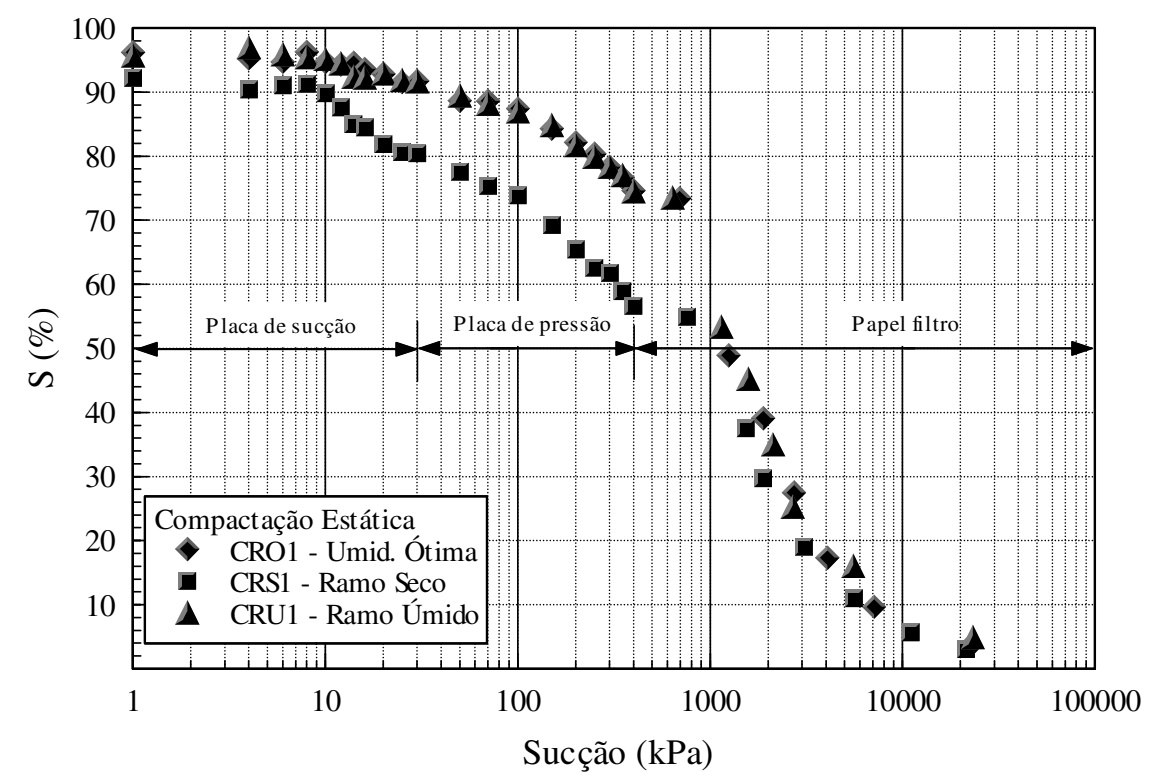

Figura 5.4 - Curvas de retenção determinadas sem confinamento utilizando corpos de prova compactados estaticamente nos pontos de estudo (O, S e U). 
Na Figura 5.5 estão apresentadas, para as curvas obtidas sem confinamento, as variações dos índices de vazios em função dos teores de umidade gravimétrica e do grau de saturação. Os símbolos vazados apresentados nesta figura correspondem às condições iniciais de moldagem. No início dos procedimentos de secagem os corpos de prova apresentam maiores reduções de volume e à medida que o grau de saturação diminui estas variações volumétricas passam a serem menores, tornando-se praticamente nulas para valores de grau de saturação inferiores a 50\%. O grau de saturação de 50\% corresponde, nas curvas de retenção apresentadas na Figura 5.4, a valores de sucções em torno de $1000 \mathrm{kPa}$. Este fato indica que a efetividade da sucção em relação à contração volumétrica dos corpos de prova se dá até este valor de sucção. Na Figura 5.5 constata-se que, para as condições de moldagem no ramo seco, as variações volumétricas dos corpos de prova durante a secagem são inferiores ao aumento de volume apresentado durante a saturação inicial. Desta forma, ao contrário do que ocorre para os corpos de prova moldados na umidade ótima e no ramo úmido, o índice de vazios no final do ensaio é superior ao índice de vazios de moldagem. Provavelmente este fato esteja relacionado à entrada de ar para baixos valores de sucção. Ao se atingir o valor da entrada de ar durante a secagem, a sucção perde em parte a sua eficácia em proporcionar variações volumétricas no corpo de prova.

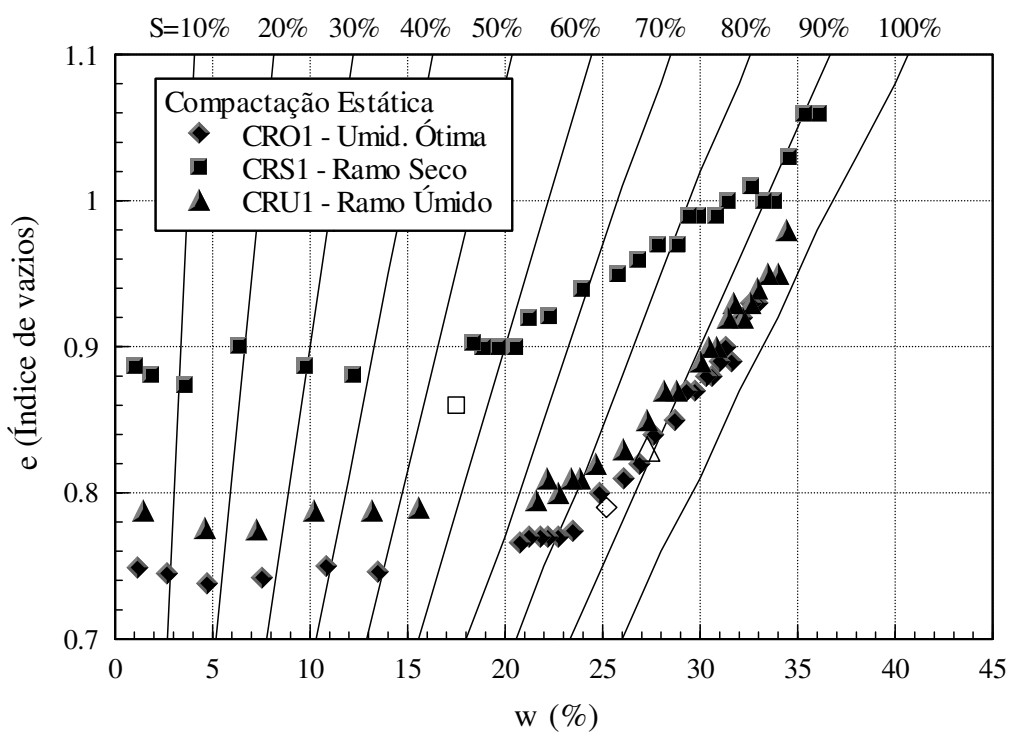

Figura 5.5 - Variação do índice de vazios em função da umidade gravimétrica e do grau de saturação. 
Nem sempre fica tão evidenciado na curva de retenção, a distribuição bimodal de poros. Com o objetivo de se verificar a estrutura dos corpos de prova para as condições de moldagem apresentadas na Tabela 4.2, foram realizados ensaios de microscopia eletrônica de varredura. Para a obtenção destas imagens os corpos de prova foram secados em estufa. As variações volumétricas, após este procedimento, foram da ordem de $2 \%$ para a moldagem na umidade ótima e $4 \%$ para a moldagem no ramo úmido. Para as condições de moldagem no ramo seco estas variações praticamente não ocorrem. Estes valores de contrações volumétricas são pequenos de forma que os resultados destes ensaios podem ser considerados como representativos das respectivas condições de moldagem.

As imagens obtidas para as condições de moldagem na umidade ótima, no ramo seco e no ramo úmido estão apresentadas na Figura 5.6 com uma ampliação de 4000 vezes. Observa-se nas Figuras 5.6a e 5.6c que a estrutura correspondente à umidade ótima é semelhante à imagem do ramo úmido, apresentando um aspecto homogêneo. Para o ramo seco (Figura 5.6b), já se observam aglomerações de partículas, com alguns vazios maiores entre as mesmas. Na imagem da Figura 5.7, correspondente ao ramo seco com uma aplicação de 2000 vezes, pode-se visualizar melhor as agregações de partículas. A imagem da Figura 5.6c, correspondente ao ramo úmido, está apresentada na Figura 5.8 com uma ampliação de 8000 vezes. Nesta figura constata-se a dispersão das partículas do solo. No centro da imagem (Figura 5.8) observa-se claramente o alinhamento de partículas de argila.

Os valores do teor de umidade (gravimétrico e volumétrico), grau de saturação e índice de vazios em função da sucção, obtidas para os corpos de prova compactados estaticamente nos pontos de estudo, estão apresentadas na Figura 5.9. Observa-se nesta figura que para as curvas de retenção plotadas em termos de teor de umidade gravimétrica não se percebe diferenças tão significativas quanto às observadas em termos de grau de saturação. Na Tabela 5.1 estão apresentados os resultados experimentais obtidos para as três condições de moldagem durante o ciclo de secagem e umedecimento. 


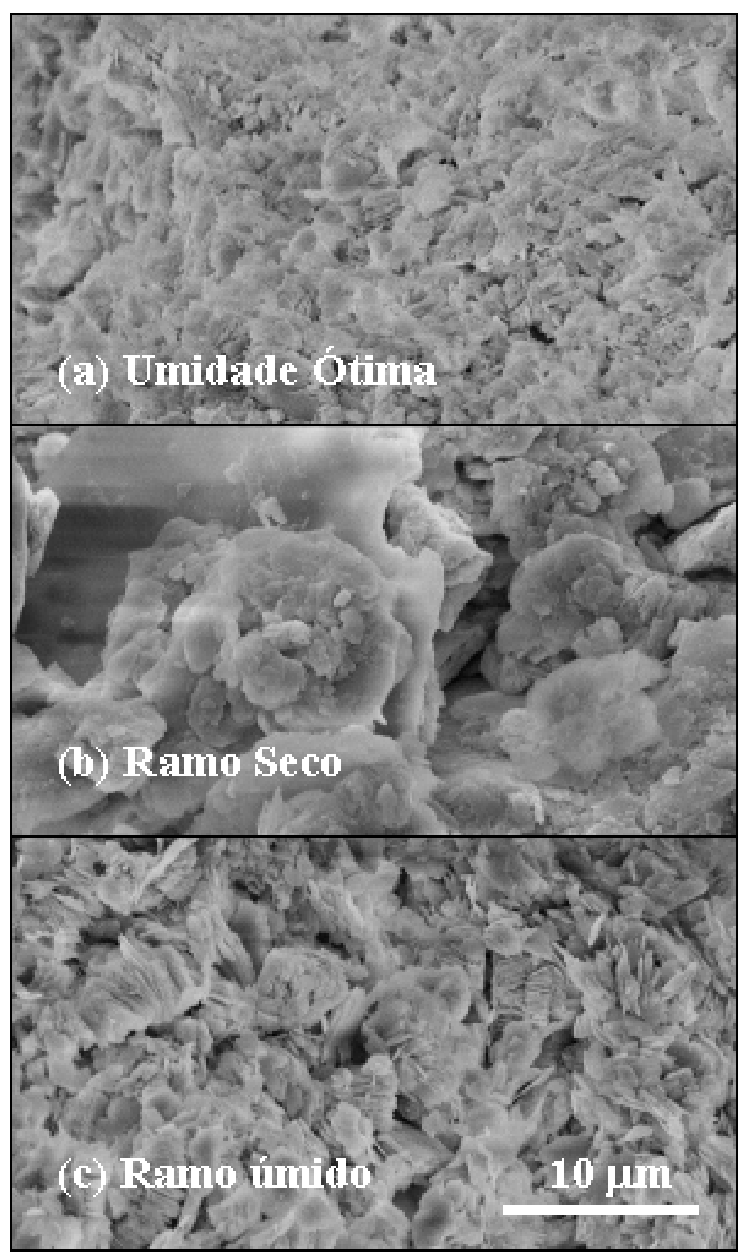

Figura 5.6 - Imagens de microscopia eletrônica de varredura obtidas de corpos de prova moldados na curva de compactação (x4000). 


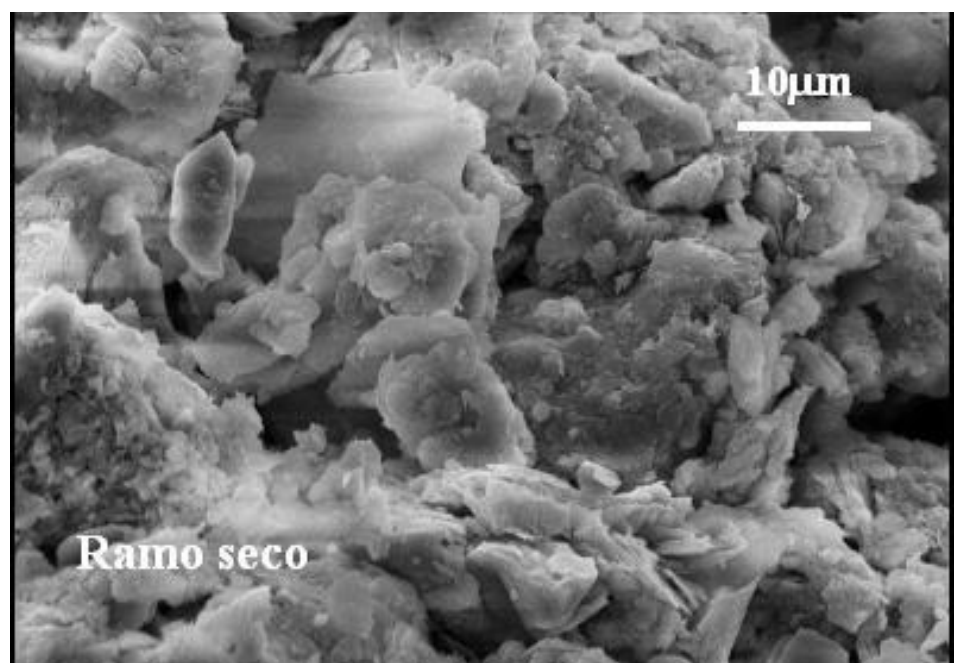

Figura 5.7 - Imagem de microscopia eletrônica de varredura obtida do corpo de prova moldado no ramo seco (x2000).

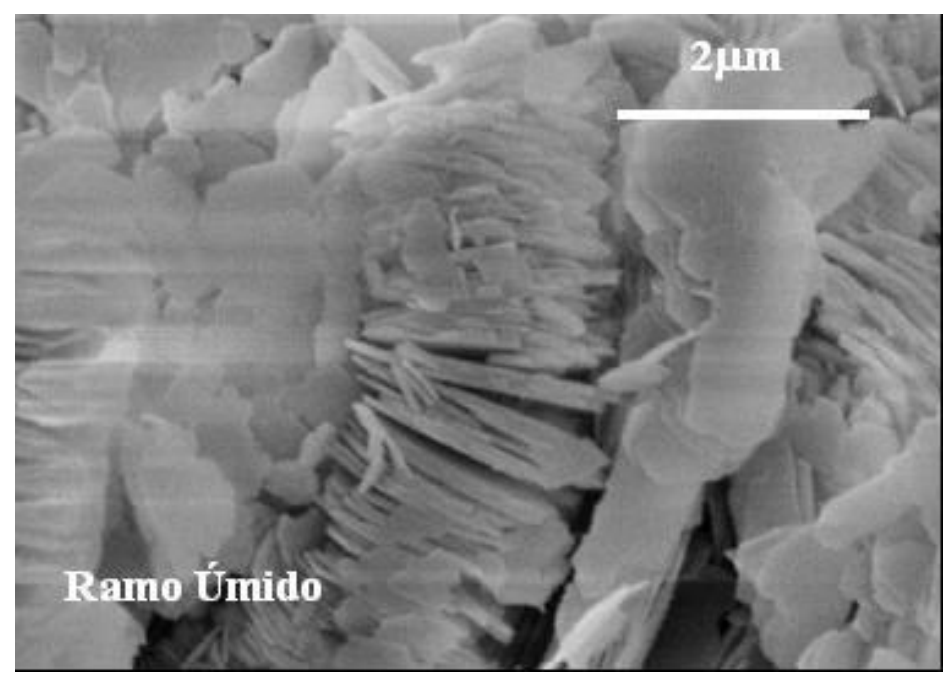

Figura 5.8 - Imagem de microscopia eletrônica de varredura obtida do corpo de prova moldado no ramo úmido (x8000). 

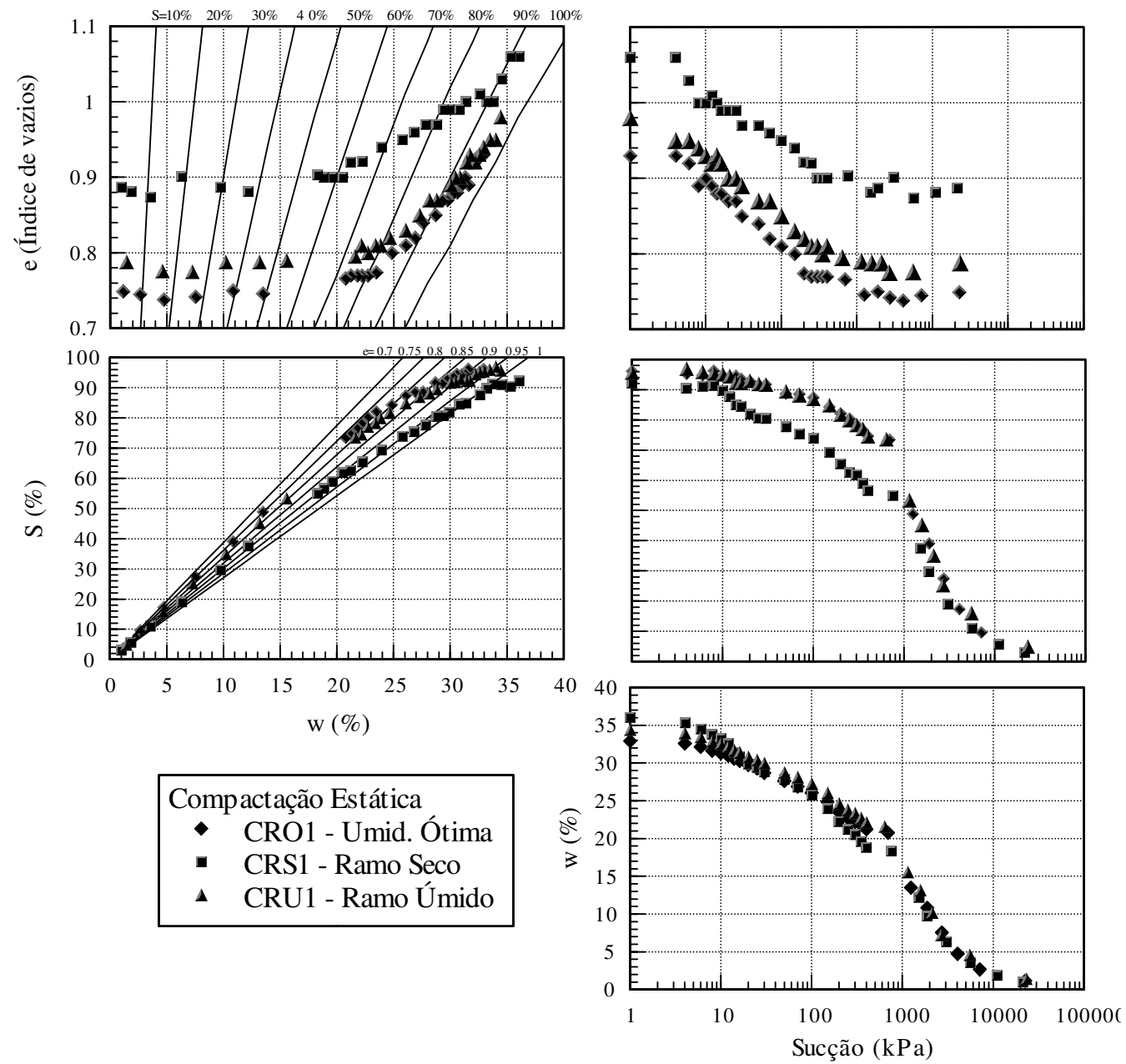

Figura 5.9 - Relação entre os teores de umidade (gravimétrico e volumétrico), grau de saturação, índice de vazios e a sucção dos corpos de prova compactados estaticamente nos pontos de estudo $(\mathrm{O}, \mathrm{S}$ e $\mathrm{U})$. 
Tabela 5.1 - Resultados experimentais das curvas de retenção determinadas sem confinamento, obtidas dos corpos de prova compactados estaticamente nos pontos de estudo.

\begin{tabular}{|c|c|c|c|c|c|c|c|c|c|c|c|c|c|c|}
\hline \multicolumn{5}{|c|}{ CRO1 - Umidade Ótima (secando) } & \multicolumn{5}{|c|}{ CRS1 - Ramo Seco (secando) } & \multicolumn{5}{|c|}{ CRU1 - Ramo úmido (secando) } \\
\hline $\begin{array}{c}\text { Sucção } \\
(\mathrm{kPa})\end{array}$ & $\mathrm{e}$ & $\begin{array}{l}\theta \mathrm{w} \\
(\%)\end{array}$ & \begin{tabular}{|c|}
$\mathrm{W}$ \\
$(\%)$
\end{tabular} & $\mathrm{S}(\%)$ & $\begin{array}{c}\text { Sucção } \\
(\mathrm{kPa})\end{array}$ & $\mathrm{e}$ & $\begin{array}{l}\theta \mathrm{w} \\
(\%)\end{array}$ & \begin{tabular}{|c|}
$\mathrm{W}$ \\
$(\%)$ \\
\end{tabular} & \begin{tabular}{|c|}
$\mathrm{S}$ \\
$(\%)$
\end{tabular} & $\begin{array}{c}\text { Sucção } \\
(\mathrm{kPa})\end{array}$ & e & $\begin{array}{c}\theta \mathrm{w} \\
(\%)\end{array}$ & $\mathrm{w}(\%)$ & $\mathrm{S}(\%)$ \\
\hline 1 & 0.93 & 46.3 & 32.9 & 96.2 & 1 & 1.06 & 47.4 & 36.1 & 92.2 & 1 & 0.98 & 47.2 & 34.4 & 95.7 \\
\hline 4 & 0.93 & 45.8 & 32.6 & 95.3 & 4 & 1.06 & 46.5 & 35.3 & 90.4 & 4 & 0.95 & 47.3 & 34.0 & 97.0 \\
\hline 6 & 0.92 & 45.4 & 32.1 & 94.7 & 6 & 1.03 & 46.1 & 34.5 & 91.1 & 6 & 0.95 & 46.6 & 33.5 & 95.9 \\
\hline 8 & 0.89 & 45.3 & 31.6 & 96.3 & 8 & 1.00 & 45.7 & 33.8 & 91.3 & 8 & 0.94 & 46.1 & 32.9 & 95.5 \\
\hline 10 & 0.90 & 44.8 & 31.3 & 94.7 & 10 & 1.00 & 45.0 & 33.2 & 89.8 & 10 & 0.93 & 45.8 & 32.6 & 95.2 \\
\hline 12 & 0.89 & 44.4 & 31.0 & 94.3 & 12 & 1.01 & 44.0 & 32.6 & 87.6 & 12 & 0.92 & 45.4 & 32.2 & 94.5 \\
\hline 14 & 0.88 & 44.2 & 30.6 & 94.6 & 14 & 1.00 & 42.5 & 31.4 & 85.0 & 14 & 0.93 & 44.5 & 31.7 & 92.4 \\
\hline 16 & 0.88 & 43.7 & 30.3 & 93.6 & 16 & 0.99 & 42.0 & 30.8 & 84.5 & 16 & 0.92 & 44.3 & 31.4 & 92.3 \\
\hline 20 & 0.87 & 43.1 & 29.7 & 92.9 & 20 & 0.99 & 40.7 & 29.9 & 81.9 & 20 & 0.90 & 44.0 & 30.8 & 92.9 \\
\hline 25 & 0.87 & 42.5 & 29.3 & 91.5 & 25 & 0.99 & 40.1 & 29.4 & 80.6 & 25 & 0.90 & 43.5 & 30.4 & 91.9 \\
\hline 30 & 0.85 & 42.1 & 28.7 & 91.8 & 30 & 0.97 & 39.6 & 28.8 & 80.4 & 30 & 0.89 & 43.1 & 30.0 & 91.7 \\
\hline 50 & 0.84 & 40.6 & 27.6 & 88.7 & 50 & 0.97 & 38.2 & 27.8 & 77.6 & 50 & 0.87 & 41.7 & .8 & 89.5 \\
\hline 70 & 0.82 & 40.0 & 26.9 & 88.6 & 70 & 0.96 & 37.0 & 26.8 & 75.4 & 70 & 0.87 & 40.9 & 28.1 & 88.2 \\
\hline 100 & 0.81 & 39.1 & 26.1 & 87.5 & 100 & 0.95 & 35.9 & 25.8 & 73.9 & 100 & 0.85 & 40.0 & 27.3 & 87.0 \\
\hline 150 & 0.80 & 37.4 & 24.8 & 84.3 & 150 & 0.94 & 33.5 & 23.9 & 69.3 & 150 & 0.83 & 38.6 & 26.1 & 84.9 \\
\hline 200 & 0.77 & 35.9 & 23.5 & \begin{tabular}{|l}
82.2 \\
\end{tabular} & 200 & 0.92 & 31.4 & 22.2 & 65.4 & 200 & 0.82 & 36.8 & 24.6 & 81.8 \\
\hline 250 & 0.77 & 34.9 & 22.7 & 80.4 & 250 & 0.92 & 30.0 & 21.2 & 62.6 & 250 & 0.81 & 35.7 & 23.8 & 79.9 \\
\hline 300 & 0.77 & 34.0 & 22.2 & 78.3 & 300 & 0.90 & 29.3 & 20.5 & 61.8 & 300 & 0.81 & 35.0 & 23.4 & 78.3 \\
\hline 350 & 0.77 & 33.4 & 21.8 & 76.7 & 350 & 0.90 & 27.9 & \begin{tabular}{|l|}
19.6 \\
\end{tabular} & 58.9 & 350 & 0.80 & 34.2 & 22.7 & 77.1 \\
\hline 400 & 0.77 & 32.5 & 21.2 & 74.7 & 400 & 0.90 & 26.9 & 18.8 & 56.6 & 400 & 0.81 & 33.2 & 22.1 & 74.5 \\
\hline 693 & 0.77 & 31.9 & 20.8 & 73.4 & 757 & 0.90 & 26.1 & 18.3 & 55.0 & 637 & 0.80 & 32.6 & 21.6 & 73.6 \\
\hline 1245 & 0.75 & 20.9 & 13.5 & 48.9 & 1529 & \begin{tabular}{|l|}
0.88 \\
\end{tabular} & 17.6 & 12.2 & 37.5 & 1144 & 0.79 & 23.6 & 15.6 & 53.4 \\
\hline 1885 & 0.75 & 16.8 & 10.8 & 39.1 & 1888 & 0.89 & 14.0 & 9.7 & 29.7 & 1574 & 0.79 & 20.0 & 13.2 & 45.3 \\
\hline 2727 & 0.74 & 11.7 & 7.5 & 27.5 & 3070 & 0.90 & 9.0 & 6.3 & 19.0 & 2123 & 0.79 & 15.4 & 10.2 & 35.1 \\
\hline 4064 & 0.74 & 7.4 & 4.7 & 17.3 & 5589 & 0.87 & 5.1 & 3.6 & 11.0 & 2685 & 0.78 & 11.1 & 7.2 & 25.3 \\
\hline 7119 & 0.75 & 4.1 & 2.7 & 9.7 & 11011 & 0.88 & 2.7 & 1.8 & 5.7 & 5545 & 0.78 & 7.0 & 4.6 & 16.1 \\
\hline 22628 & 0.85 & 1.7 & 1.2 & 3.7 & 21367 & 0.89 & 1.4 & 1.0 & 3.0 & 23211 & 0.79 & 2.2 & 1.4 & 5.0 \\
\hline \multicolumn{5}{|c|}{$\begin{array}{l}\text { CRO1 - Umidade Ótima } \\
\text { (Umedecendo) }\end{array}$} & \multicolumn{5}{|c|}{$\begin{array}{l}\text { CRS1 - Ramo Seco } \\
\text { (Umedecendo) }\end{array}$} & \multicolumn{5}{|c|}{$\begin{array}{l}\text { CRU1 - Ramo úmido } \\
\text { (umedecendo) }\end{array}$} \\
\hline 3677 & 0.75 & 7.6 & \begin{tabular}{|l|}
4.9 \\
\end{tabular} & 17.7 & 3977 & 0.89 & 6.6 & 4.6 & 14.1 & 4012 & 0.79 & 7.6 & 4.8 & 16.5 \\
\hline 1901 & 0.75 & 15.1 & 9.8 & 35.1 & 1828 & 0.89 & 14.2 & 9.9 & 30.2 & 2082 & 0.80 & 15.9 & 10.6 & 35.7 \\
\hline 1525 & 0.76 & 9.7 & 14.6 & 52.3 & 1660 & 0.89 & 21.3 & 14.9 & 45.2 & 1370 & 0.79 & 22.7 & 15.0 & 51.3 \\
\hline 777 & 0.77 & 30.3 & 19.7 & 69.9 & 234 & 0.91 & 29.2 & 20.6 & 61.2 & 712 & 0.81 & 29.6 & 19.8 & 65.9 \\
\hline 6 & 0.88 & 42.5 & 29.5 & 90.6 & 3 & 1.02 & 43.7 & 32.6 & 86.6 & 7 & 0.90 & 42.7 & 30.0 & 90.0 \\
\hline
\end{tabular}




\subsection{2 - Curvas de retenção determinadas com confinamento utilizando corpos de prova compactados estaticamente na umidade ótima}

Neste item estão os resultados e as análises das curvas de retenção obtidas para os corpos de prova moldados na umidade ótima e submetidos a diferentes pressões de confinamento. Os dados de moldagem e preparação destes corpos de prova (CRO2, CRO3 e CRO4) e os procedimentos para se simular as pressões confinantes foram apresentados no item 4.8.1. Os resultados destas curvas de retenção, dados pelo grau de saturação em função da sucção, estão apresentados na Figura 5.10. Para se comparar todas as curvas obtidas para esta condição de moldagem foi incluída nesta figura, a curva de retenção obtida sem confinamento. Não se consegue perceber que os valores das pressões de confinamento tenham proporcionado diferenças significativas entre estas curvas de retenção. No entanto, as mesmas não iniciam com o mesmo valor de grau de saturação, dificultando assim a análise destes resultados.

Utilizando a relação entre o teor de umidade gravimétrico e a sucção, apresentada na Figura 5.11, estas diferenças são mais facilmente percebidas. Como era de se esperar, quanto maior o valor do confinamento aplicado, menor o valor do teor de umidade inicial do corpo de prova. As diferenças entre estas curvas ocorrem para sucções próximas de $1000 \mathrm{kPa}$. Sendo assim, os esforços transmitidos aos corpos de prova durante a preparação para o inicio dos ensaios, provavelmente reduzem apenas os poros de maiores dimensões, relacionados às sucções de até $1000 \mathrm{kPa}$.

As variações do índice de vazios em função do teor de umidade e do grau de saturação estão apresentadas na Figura 5.12. Observa-se nesta figura que os valores dos índices de vazios iniciais e finais de cada curva de retenção são menores à medida que aumenta o valor da pressão de confinamento dos corpos de prova. De forma semelhante ao encontrado para as curvas de retenção apresentadas no item anterior, tem-se na Figura 5.11 que as variações volumétricas destes corpos de prova se tornam nulas para valores de grau de saturação inferiores a $50 \%$. 
Nas curvas de retenção apresentadas na Figura 5.10, este valor corresponde à sucção em torno de $1000 \mathrm{kPa}$ e aos seus respectivos ponto de inflexão. Os valores do teor de umidade (gravimétrico e volumétrico), grau de saturação e do índice de vazios em função da sucção, obtidas para os corpos de prova moldados na umidade ótima e submetidos a diferentes pressões de confinamento, estão apresentadas na Figura 5.13. $\mathrm{Na}$ tabela 5.2 estão os resultados experimentais.

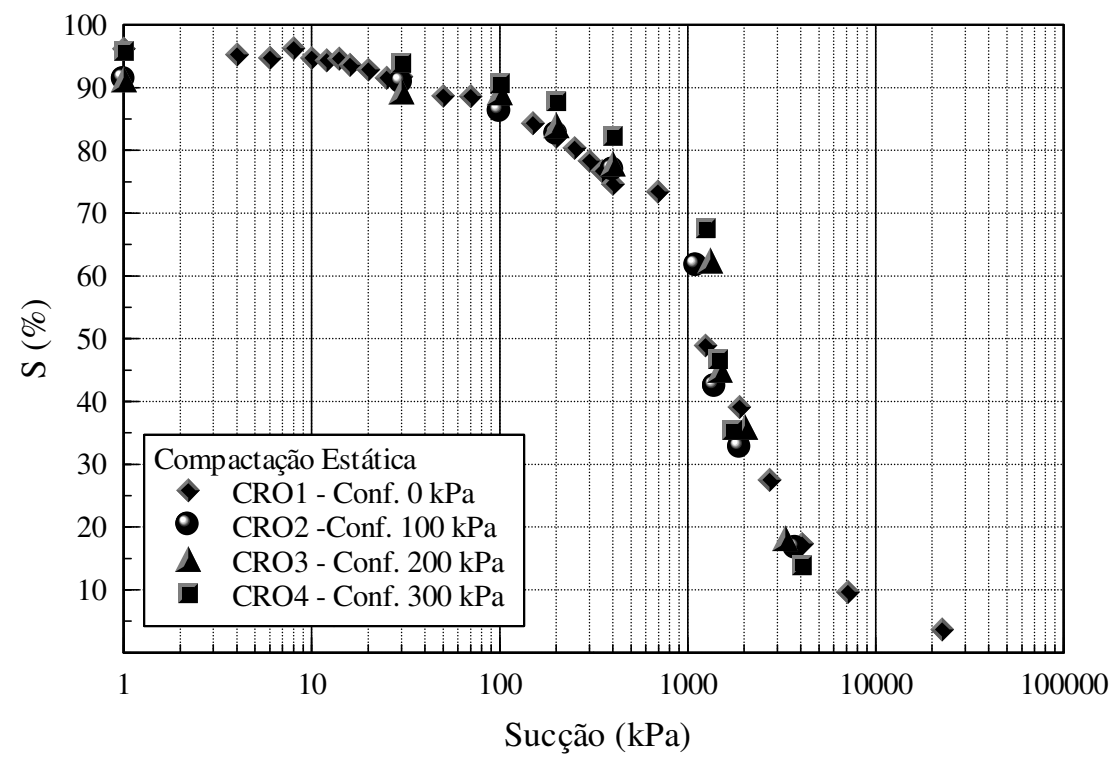

Figura 5.10 - Curvas de retenção dos corpos de prova compactados na umidade ótima e submetidos a diferentes pressões de confinamento. 


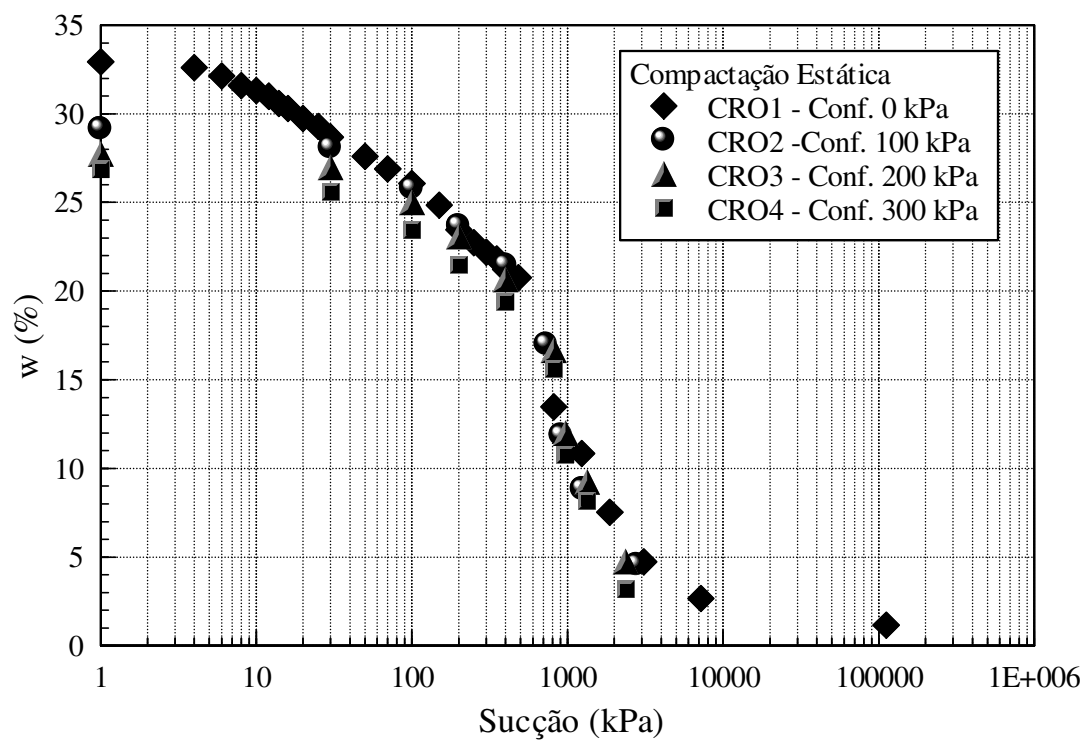

Figura 5.11 - Curva de retenção em função da umidade gravimétrica obtidas em corpos de prova compactados na umidade ótima e submetidos a diferentes pressões de confinamento.

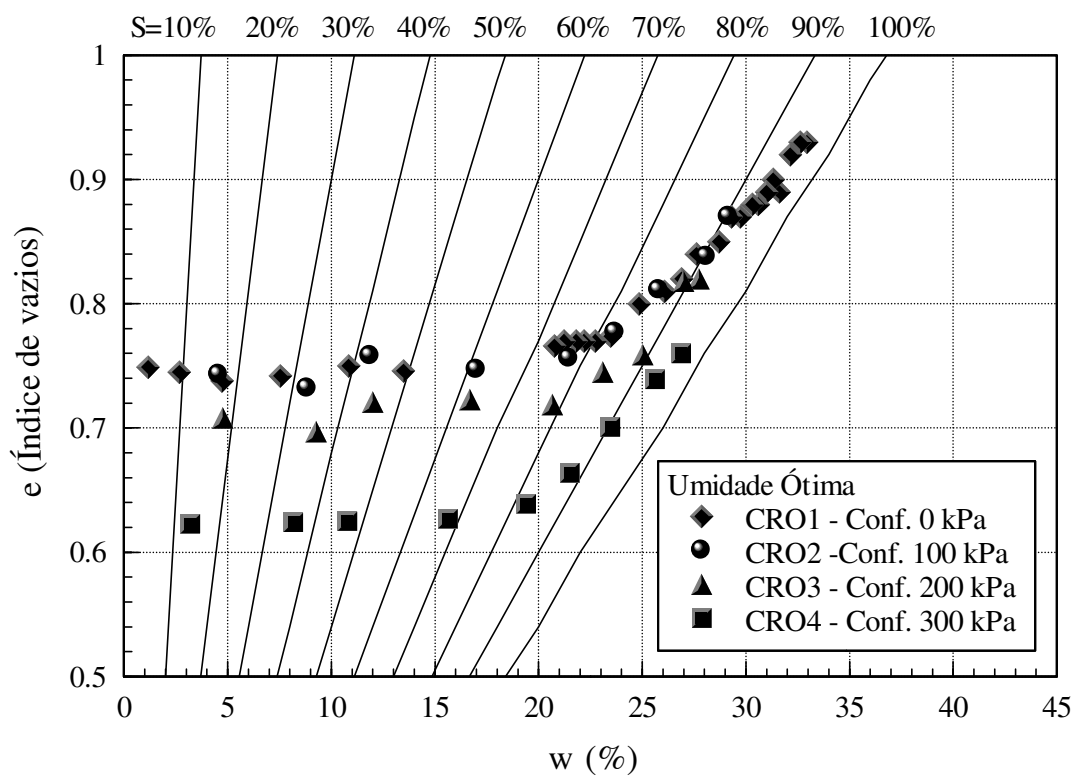

Figura 5.12 - Variação do índice de vazios em função do teor de umidade e do grau de saturação dos corpos de prova compactados na umidade ótima. 

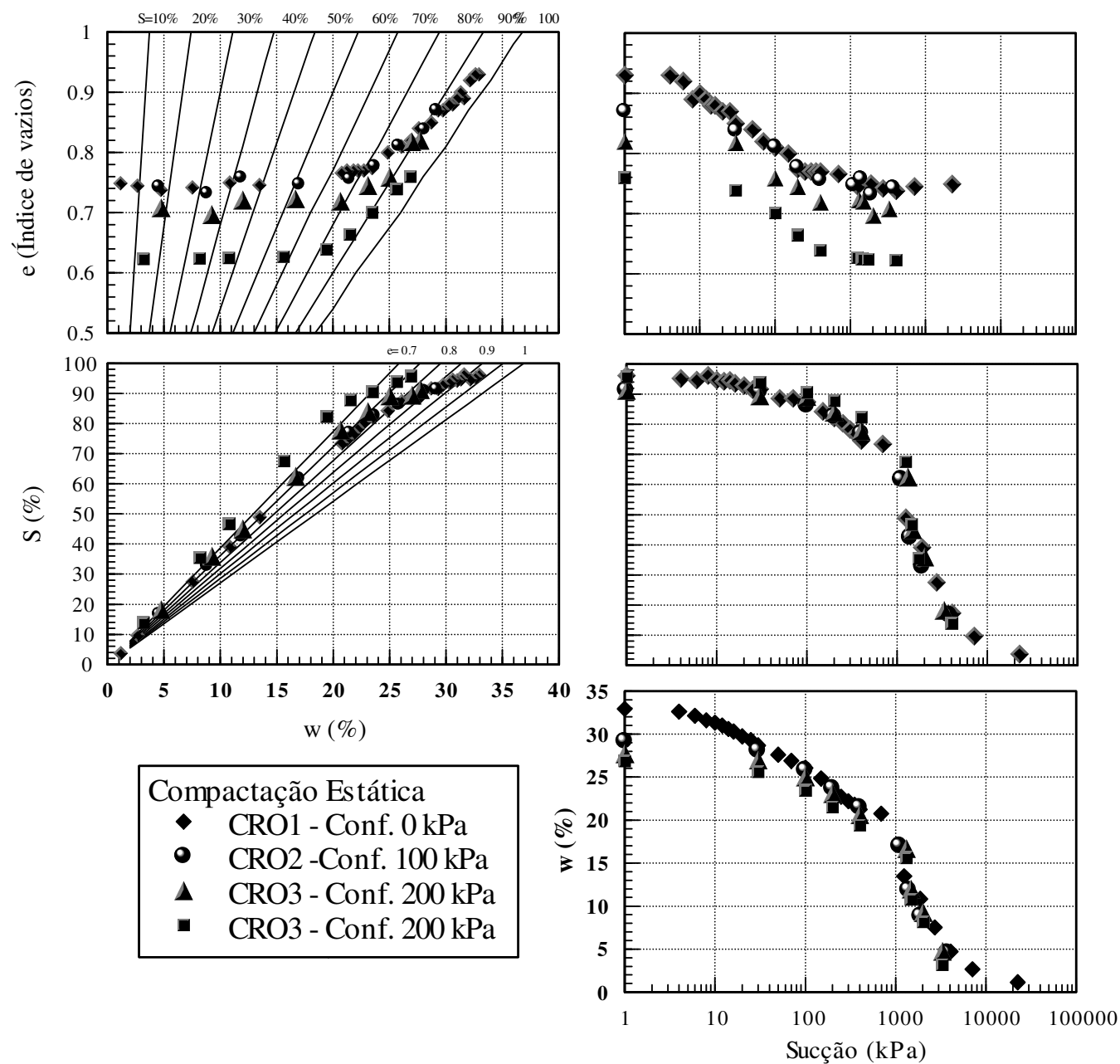

Figura 5.13 - Relação entre os teores de umidade (gravimétrico e volumétrico), grau de saturação, índice de vazios e a sucção dos corpos de prova moldados estaticamente na umidade ótima e submetidos a diferentes pressões confinantes. 
Tabela 5.2 - Resultados experimentais das curvas de retenção dos corpos de prova compactados estaticamente na umidade ótima e submetidos a diferentes pressões de confinamento.

\begin{tabular}{|c|c|c|c|c|}
\hline \multicolumn{5}{|c|}{ CRO2 - Umidade Ótima (Conf. 100 kPa) } \\
\hline Sucção & $\mathrm{e}$ & $\theta \mathrm{w}(\%)$ & $\mathrm{w}(\%)$ & $\mathrm{S}(\%)$ \\
\hline 1 & 0.87 & 42.4 & 29.2 & 91.4 \\
\hline 30 & 0.84 & 41.4 & 28.1 & 90.8 \\
\hline 100 & 0.81 & 38.6 & 25.8 & 86.2 \\
\hline 200 & 0.78 & 36.1 & 23.7 & 82.6 \\
\hline 400 & 0.76 & 33.1 & 21.5 & 76.9 \\
\hline 1110 & 0.75 & 26.4 & 17.0 & 61.7 \\
\hline 1397 & 0.76 & 18.3 & 11.9 & 42.4 \\
\hline 1901 & 0.73 & 13.8 & 8.8 & 32.7 \\
\hline 3757 & 0.74 & 7.1 & 4.6 & 16.7 \\
\hline \multicolumn{5}{|c|}{ CRO3 - Umidade Ótima (conf. $200 \mathrm{kPa}$ ) } \\
\hline 1 & 0.82 & 41.2 & 27.7 & 91.3 \\
\hline 30 & 0.82 & 40.2 & 27.0 & 89.4 \\
\hline 100 & 0.76 & 38.5 & 25.0 & 89.3 \\
\hline 200 & 0.74 & 35.9 & 23.1 & 84.0 \\
\hline 400 & 0.72 & 32.6 & 20.7 & 77.9 \\
\hline 1318 & 0.72 & 26.2 & 16.7 & 62.5 \\
\hline 1487 & 0.72 & 18.9 & 12.0 & 45.0 \\
\hline 2022 & 0.70 & 14.8 & 9.3 & 36.0 \\
\hline 3303 & 0.71 & 7.5 & 4.8 & 18.2 \\
\hline \multicolumn{5}{|c|}{ CRO4 - Umidade Ótima (Conf. 300 kPa) } \\
\hline 1 & 0.76 & 41.4 & 26.9 & 95.8 \\
\hline 30 & 0.74 & 39.9 & 25.6 & 93.9 \\
\hline 100 & 0.70 & 37.4 & 23.5 & 90.7 \\
\hline 200 & 0.66 & 35.0 & 21.5 & 87.8 \\
\hline 400 & 0.64 & 32.1 & 19.4 & 82.3 \\
\hline 1244 & 0.63 & 26.0 & 15.6 & 67.6 \\
\hline 1450 & 0.62 & 18.0 & 10.8 & 46.8 \\
\hline 1723 & 0.62 & 13.6 & 8.2 & 35.5 \\
\hline 4050 & 0.62 & 5.3 & 3.2 & 13.9 \\
\hline
\end{tabular}




\subsection{3 - Curvas de retenção determinadas sem confinamento utilizando corpos de prova compactados dinamicamente nos pontos de estudo}

As curvas de retenção dos corpos de prova compactados dinamicamente nos três pontos de estudo foram determinadas apenas com a utilização da técnica do papel filtro, seguindo o caminho de secagem dos corpos de prova após os procedimentos de saturação descritos no item 4.8.1. Os pontos experimentais do grau de saturação dos corpos de prova em função da sucção estão apresentados na Figura 5.14. De forma semelhante às curvas obtidas por compactação estática, observa-se nesta figura a semelhança das curvas de retenção dos corpos de prova moldados na umidade ótima e no ramo úmido. Para a curva de retenção correspondente ao ramo seco não ficou caracterizada a distribuição bimodal de poros, provavelmente devido à destruição das agregações das partículas do solo ocasionada pelas deformações cisalhantes deste método de compactação. Ao contrário do que foi observado para as curvas de retenção descritas nos itens 5.5.1 e 5.5.2, não se constata na Figura 5.14 a mesma convergência para sucções superiores a $1000 \mathrm{kPa}$. Este fato indica que as estruturas dos poros relacionados às sucções superiores a $1000 \mathrm{kPa}$ são diferentes quando se molda os corpos de prova por compactação dinâmica.

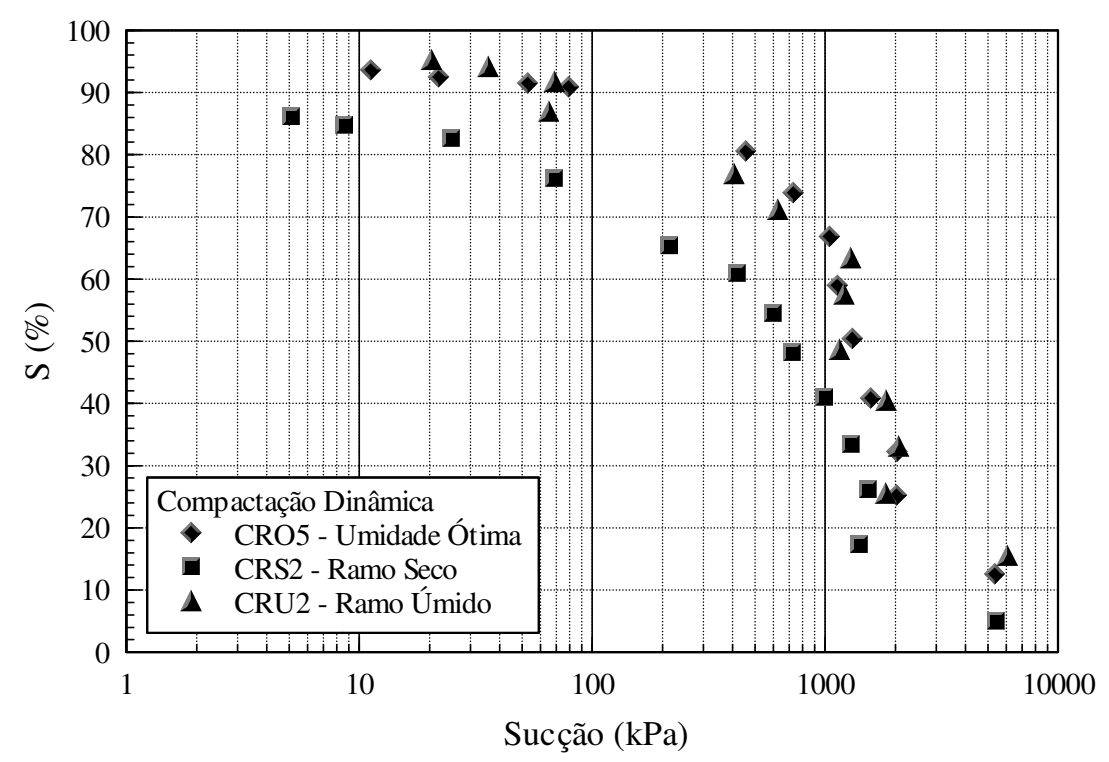

Figura 5.14 - Curvas de retenção dos corpos de prova compactados dinamicamente nos pontos de estudo (O, S e U). 
As variações dos índices de vazios durante a secagem e as condições iniciais de moldagem dos corpos de prova, indicadas pelos símbolos vazados, estão apresentadas na Figura 5.15. Nesta figura tem-se que as variações volumétricas praticamente não mais ocorrem para graus de saturação menores que $50 \%$. Em relação ao volume dos corpos de prova após os procedimentos inicias de saturação, a maior contração volumétrica foi observada para o corpo de prova compactado na umidade ótima (Ponto O). Os valores das contrações volumétricas obtidas no final do ensaio para as condições de moldagem na umidade ótima, ramo seco e ramo úmido, foram respectivamente iguais a 7\%,6\% e 5.6\%. De forma semelhante ao resultado da curva de retenção obtida por compactação estática, o índice de vazios final do corpo de prova moldado no ramo seco é maior que o índice de vazios de moldagem. $\mathrm{Na}$ Figura 5.16 estão apresentadas as relações entre os teores de umidade (gravimétrico e volumétrico), grau de saturação, índice de vazios e a sucção para os corpos de prova compactados dinamicamente nos três pontos de estudo. Os resultados experimentais estão apresentados na Tabela 5.3.

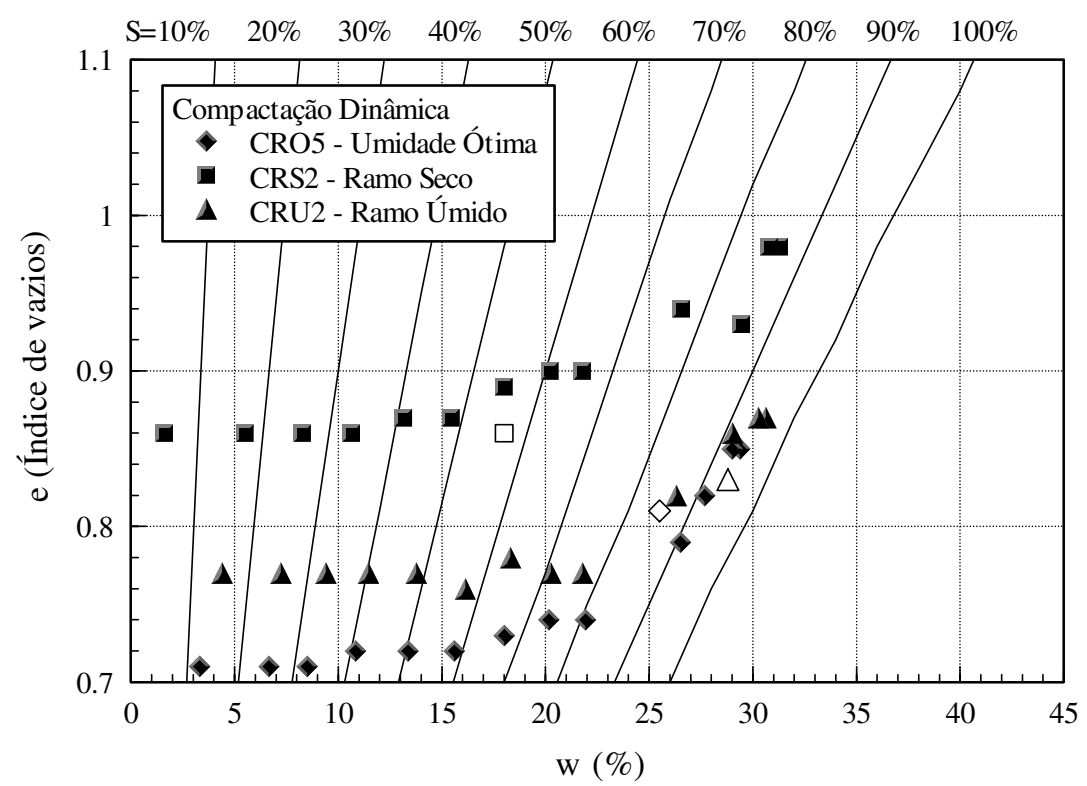

Figura 5.15 - Variação do índice de vazios em função da umidade gravimétrica e do grau de saturação das curvas de retenção obtidas por compactação dinâmica. 

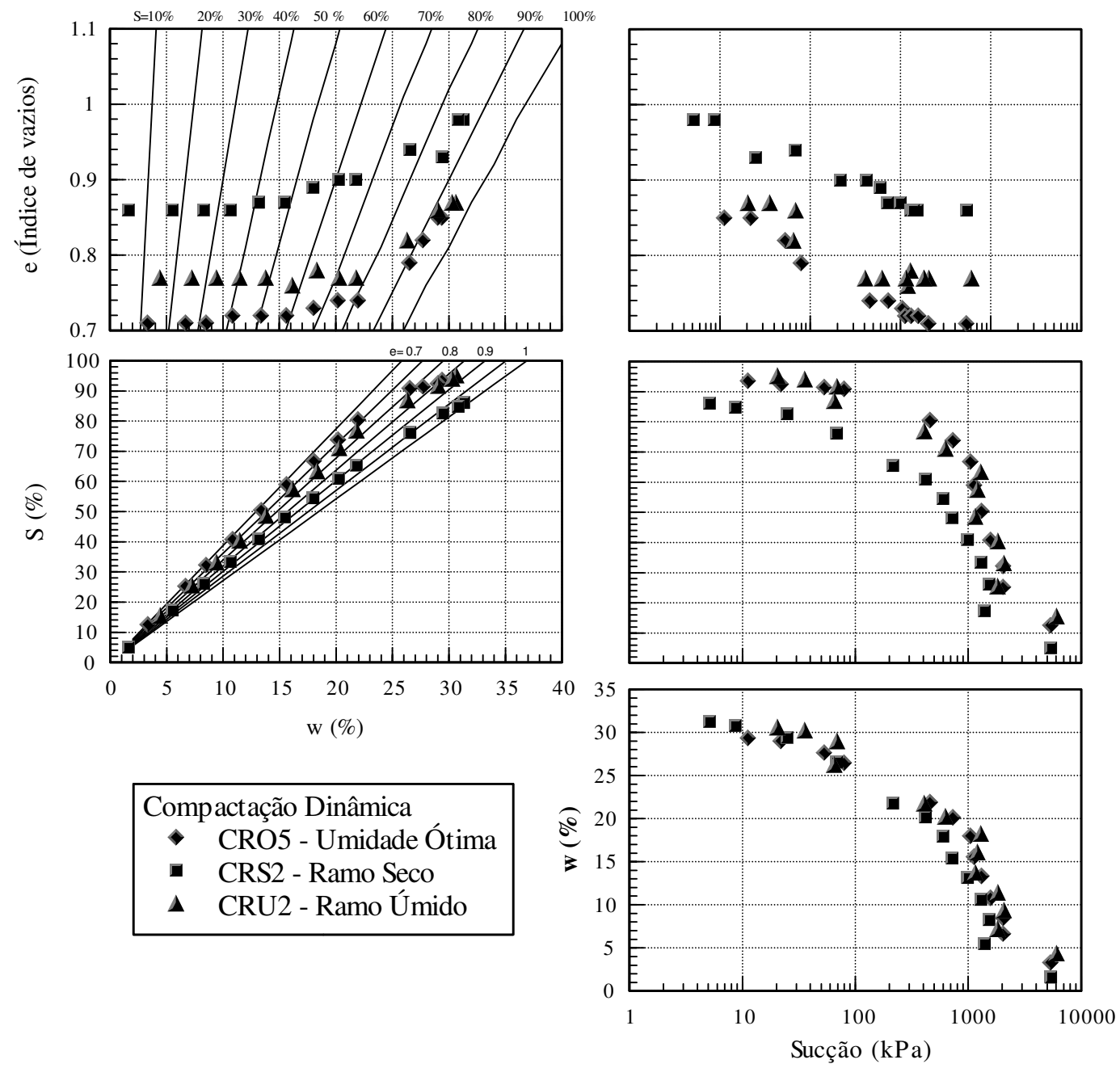

Figura 5.16 - Relações entre os teores de umidade (gravimétrico e volumétrico), grau de saturação, índice de vazios e a sucção dos corpos de prova compactados estaticamente nos três pontos de estudo $(\mathrm{O}, \mathrm{S}$ e $\mathrm{U})$. 
Tabela 5.3 - Resultados experimentais das curvas de retenção dos corpos de prova compactados dinamicamente nos pontos de estudo (O, S e U).

\begin{tabular}{|c|c|c|c|c|}
\hline \multicolumn{5}{|c|}{ CRO5 - Umidade Ótima } \\
\hline Sucção & $\mathrm{e}$ & $\theta_{\mathrm{w}}(\%)$ & $\mathrm{w}(\%)$ & $\mathrm{S}(\%)$ \\
\hline 11 & 0.85 & 43.0 & 29.4 & 93.7 \\
\hline 22 & 0.85 & 42.5 & 29.0 & 92.5 \\
\hline 53 & 0.82 & 41.2 & 27.7 & 91.5 \\
\hline 79 & 0.79 & 40.1 & 26.5 & 91.0 \\
\hline 455 & 0.74 & 34.2 & 21.9 & 80.6 \\
\hline 729 & 0.74 & 31.4 & 20.2 & 73.9 \\
\hline 1041 & 0.73 & 28.2 & 18.0 & 66.9 \\
\hline 1123 & 0.72 & 24.6 & 15.6 & 59.0 \\
\hline 1304 & 0.72 & 21.1 & 13.4 & 50.5 \\
\hline 1566 & 0.72 & 17.1 & 10.8 & 40.9 \\
\hline 2031 & 0.71 & 13.4 & 8.5 & 32.3 \\
\hline 2021 & 0.71 & 10.5 & 6.7 & 25.3 \\
\hline 5329 & 0.71 & 5.2 & 3.3 & 12.6 \\
\hline \multicolumn{5}{|c|}{ CRS2 - Ramo Seco } \\
\hline 5 & 0.98 & 42.7 & 31.3 & 86.2 \\
\hline 9 & 0.98 & 42.1 & 30.8 & 84.8 \\
\hline 25 & 0.97 & 40.6 & 29.4 & 82.64 \\
\hline 68 & 0.94 & 37.0 & 26.6 & 76.2 \\
\hline 214 & 0.90 & 31.0 & 21.8 & 65.4 \\
\hline 595 & 0.90 & 28.9 & 20.2 & 61.0 \\
\hline 714 & 0.89 & 25.7 & 18.0 & 54.6 \\
\hline 720 & 0.87 & 22.4 & 15.4 & 48.2 \\
\hline 990 & 0.87 & 19.1 & 13.1 & 41.1 \\
\hline 1288 & 0.86 & 15.5 & 10.6 & 33.5 \\
\hline 1525 & 0.86 & 12.1 & 8.3 & 26.2 \\
\hline 1394 & 0.86 & 8.0 & 5.5 & 17.4 \\
\hline 4714 & 0.86 & 2.4 & 1.6 & 5.1 \\
\hline \multicolumn{5}{|c|}{ CRU2 - Ramo Úmido } \\
\hline 20 & 0.87 & 44.4 & 30.6 & 95.3 \\
\hline 36 & 0.87 & 43.9 & 30.3 & 94.2 \\
\hline 65 & 0.86 & 42.4 & 29.0 & 91.8 \\
\hline 405 & 0.82 & 39.2 & 26.3 & 87.0 \\
\hline 625 & 0.77 & 33.4 & 21.8 & 77.0 \\
\hline 732 & 0.77 & 31.0 & 20.3 & 71.2 \\
\hline 1284 & 0.78 & 27.8 & 18.3 & 63.4 \\
\hline 1200 & 0.76 & 24.9 & 16.1 & 57.6 \\
\hline 1150 & 0.77 & 21.1 & 13.8 & 48.7 \\
\hline 1823 & 0.77 & 17.6 & 11.5 & 40.5 \\
\hline 2060 & 0.77 & 14.4 & 9.4 & 33.2 \\
\hline 1813 & 0.77 & 11.1 & 7.2 & 25.6 \\
\hline 6046 & 0.77 & 6.8 & 4.4 & 15.6 \\
\hline
\end{tabular}




\subsection{4 - Curva de retenção dos corpos de prova moldados para a obtenção da curva de compactação}

Estas curvas de retenção foram determinadas com os corpos de prova moldados para a determinação da curva de compactação (CRP1 a CRP6). Os dados de moldagem estão apresentados na Tabela 4.11. Na determinação destas curvas de retenção os corpos de prova foram submetidos apenas a secagem a partir do teor de umidade de moldagem. Os valores de sucção foram determinados utilizando-se apenas a técnica do papel filtro. Na Figura 5.17 estão os valores experimentais do grau de saturação em função da sucção. A convergência observada entre estas curvas de retenção para os valores de sucção superiores $1000 \mathrm{kPa}$, provavelmente esteja relacionada à semelhança da distribuição de poros correspondentes a esta faixa de sucção.

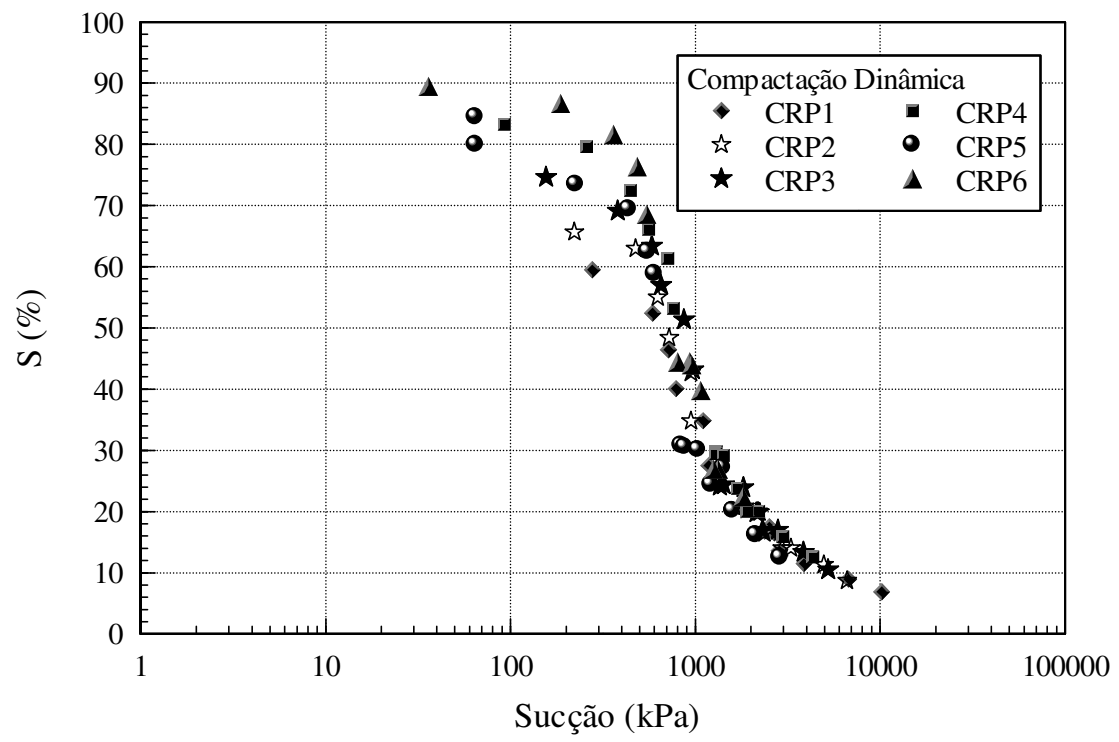

Figura 5.17 - Curvas de retenção obtidas dos corpos de prova moldados para a obtenção da curva de compactação.

$\mathrm{Na}$ Figura 5.18a estão representados os pontos experimentais da curva de compactação correspondentes aos corpos de prova CRP1 a CRP6. Os valores das sucções iniciais de moldagem destes corpos de prova em relação ao teor de umidade estão apresentados na Figura 5.18b. 
O eixo que representa o valor da sucção dos corpos de prova na Figura 5.18b, está invertido para se poder comparar estes resultados com os obtidos por Olson e Langfelder (1965) que plotaram os seus resultados em termos de poro pressão da água (ver Figura 2.26). O formato da relação entre a sucção dos corpos de prova e o teor de umidade de moldagem, obtido por estes pesquisadores, é semelhante ao resultado apresentado na Figura 5.18b.

Não foi obtida nesta pesquisa a curva de compactação para energias maiores que a Proctor Normal. No entanto, de acordo com os resultados encontrados por Olson e Langfelder (1965), Marinho e Stuermer (2000) e Suriol et al (2002) (item 2.2.5), provavelmente a sucção inicial dos corpos dos prova representados na Figura 5.18, seja mais fortemente afetada pelo teor de umidade de moldagem e não pela energia de compactação utilizada.

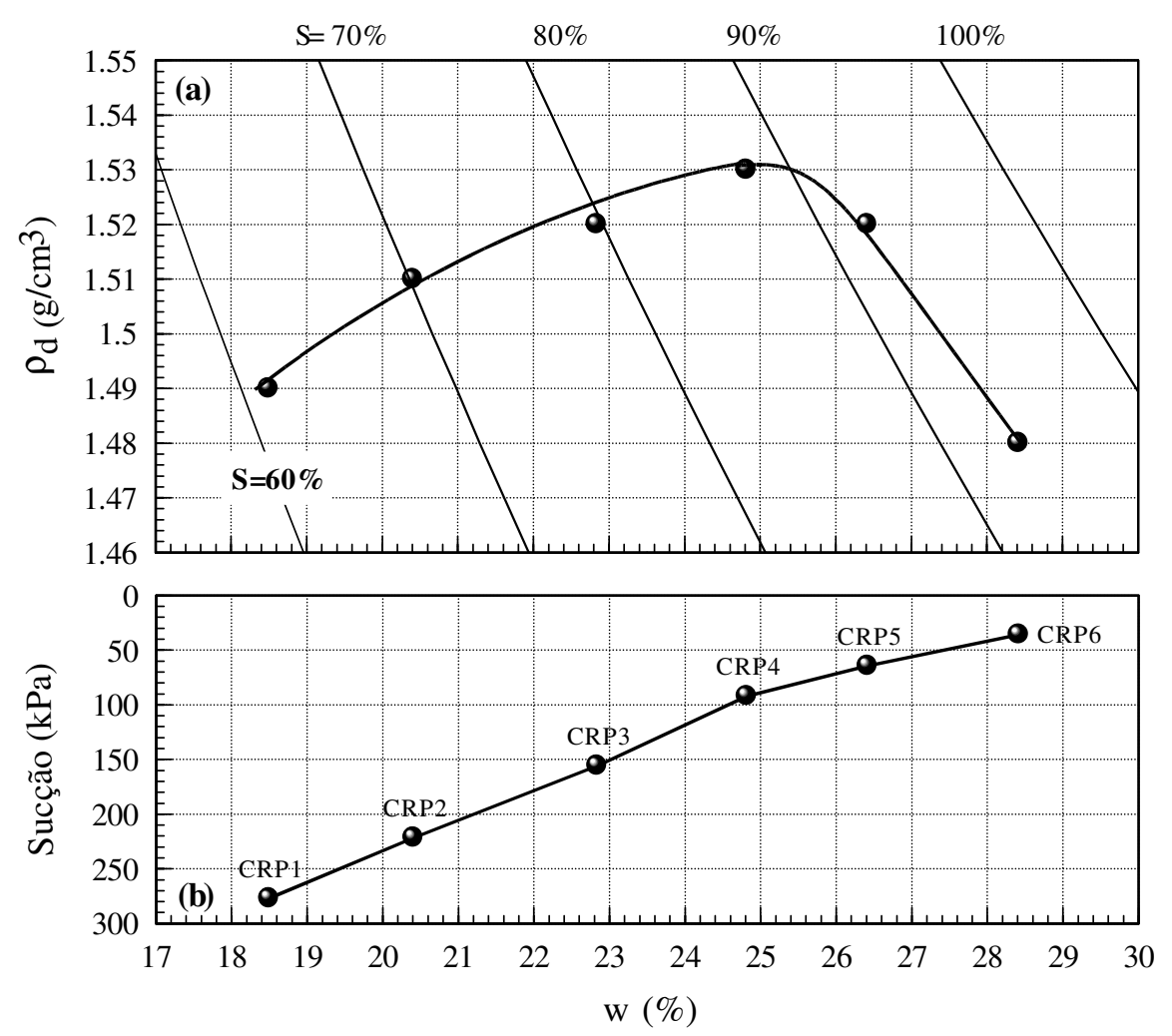

Figura 5.18 - Sucções iniciais dos corpos de prova compactados para a obtenção da curva de compactação. 


\subsection{5 - Curva de retenção da lama}

As curvas de retenção da lama foram obtidas para amostras distintas, uma formada com o solo que e passa na peneira de malha $n^{\circ} 10$ e outra com o solo que passa na peneira $n^{\circ} 40$. Para a sua determinação foram moldados 5 corpos de prova para cada tipo de solo. Na placa de sucção os pontos experimentais foram definidos para 3 diferentes corpos de prova, um para cada sucção aplicada $(5,10$ e $30 \mathrm{kPa}) . \mathrm{Na}$ placa de pressão foram utilizados dois corpos de prova para cada tipo de solo, sendo os pontos experimentais representados pela média destes valores. Ao serem retirados da placa de pressão, para obtenção do peso úmido e de suas dimensões, a sucção dos corpos de prova foi determinada com o tensiômetro. Os procedimentos utilizados nas placas de sucção e de pressão foram descritos no item 4.10.2. Na Figura 5.19 estão os valores do grau de saturação em função da sucção, obtidos para os dois tipos de lama. Apesar do solo que passa na peneira $n^{\circ} 40$ ter uma maior quantidade de finos, observa-se nesta figura que as diferenças entre estas curvas de retenção são imperceptíveis.

As variações dos índices de vazios destes corpos de prova em função do grau de saturação e da umidade gravimétrica estão apresentadas na Figura 5.20. Observa-se nesta Figura que as contrações volumétricas são semelhantes durante o procedimento de secagem destes corpos de prova. Os índices de vazios finais dos mesmos, após secagem em estufa, foram iguais a 1.02 (\#10) e 1.05 (\#40). Estes valores finais de índice de vazios são maiores que os obtidos para as curvas de retenção apresentadas nos itens anteriores. Este fato deve estar relacionado à estrutura que vai se formando durante a secagem destes corpos de prova. Os corpos de prova moldados com a

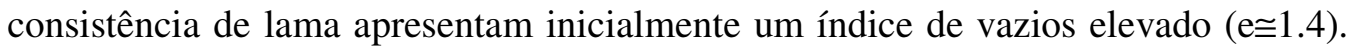
Provavelmente, durante a secagem as partículas do solo passam a formar uma estrutura com poros de dimensões maiores que os apresentados pelos corpos de prova moldados por compactação estática e dinâmica. Na Figura 5.21 estão apresentadas os valores do teor de umidade (gravimétrico e volumétrico), grau de saturação e índice de vazios em função da sucção obtidos dos corpos de prova moldados com a consistência de lama. 
Os resultados experimentais estão apresentados na Tabela 5.4. Nesta tabela estão incluídos os valores das sucções dos corpos de prova determinadas com o tensiômetro.

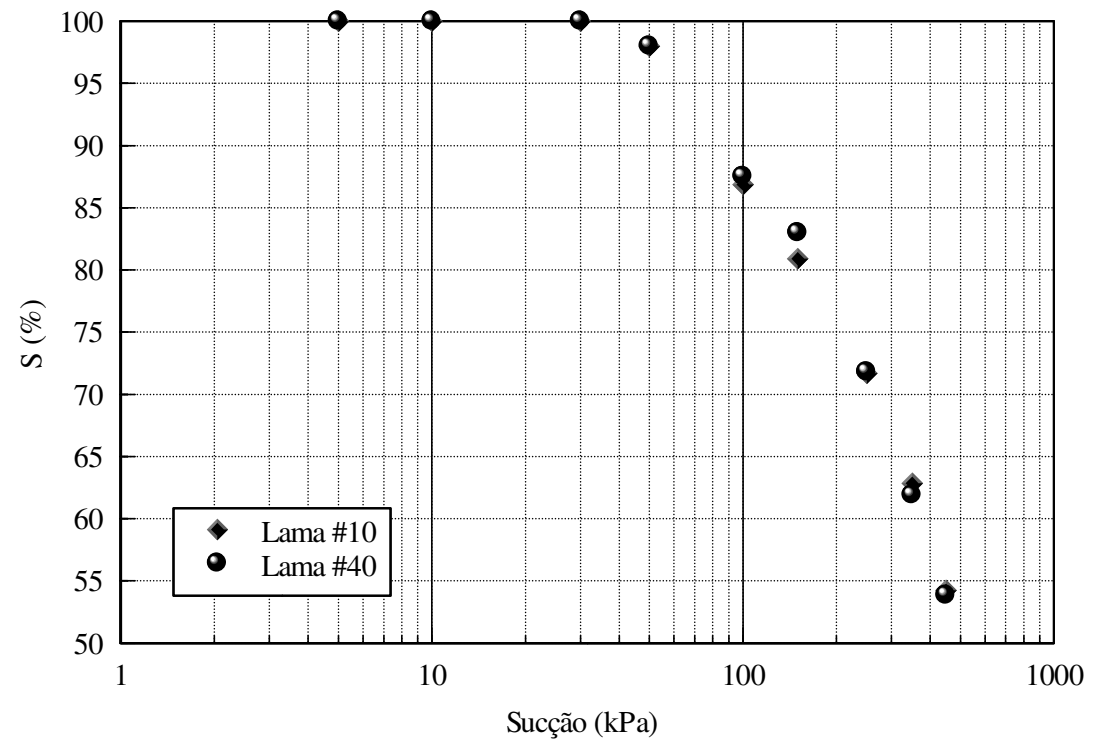

Figura 5.19 - Curvas de retenção dos corpos de prova moldados com a consistência de lama.

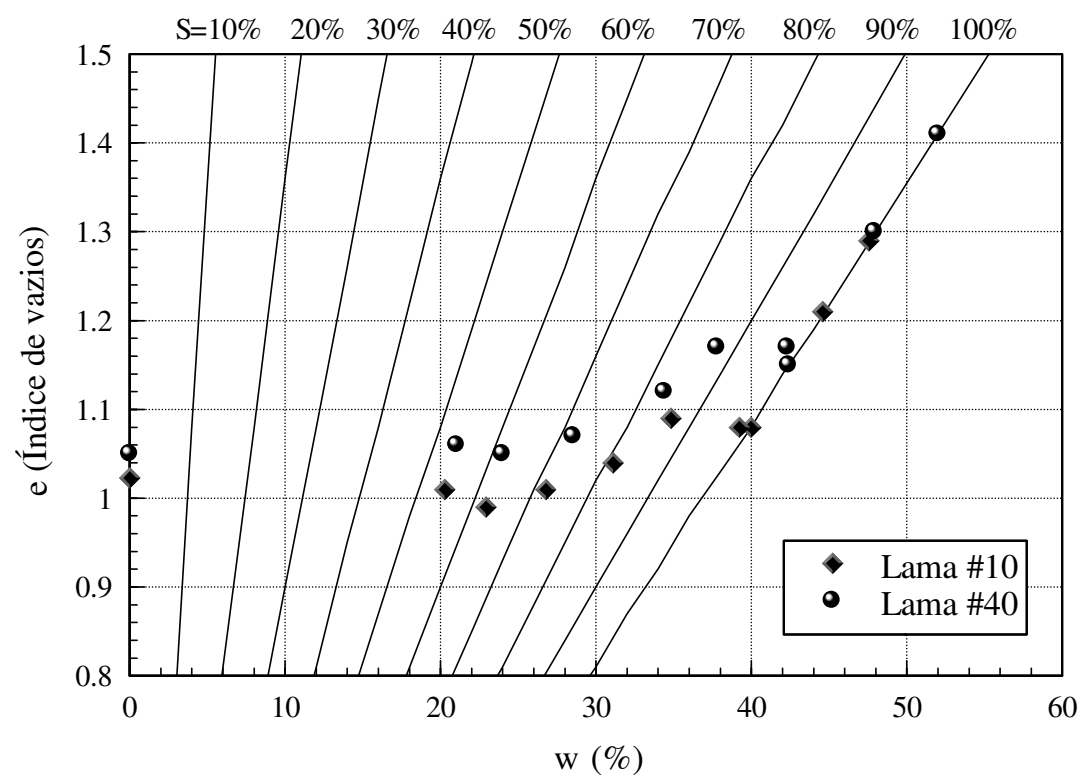

Figura 5.20 - Variação do índice de vazios da lama em função do teor de umidade e do grau de saturação. 

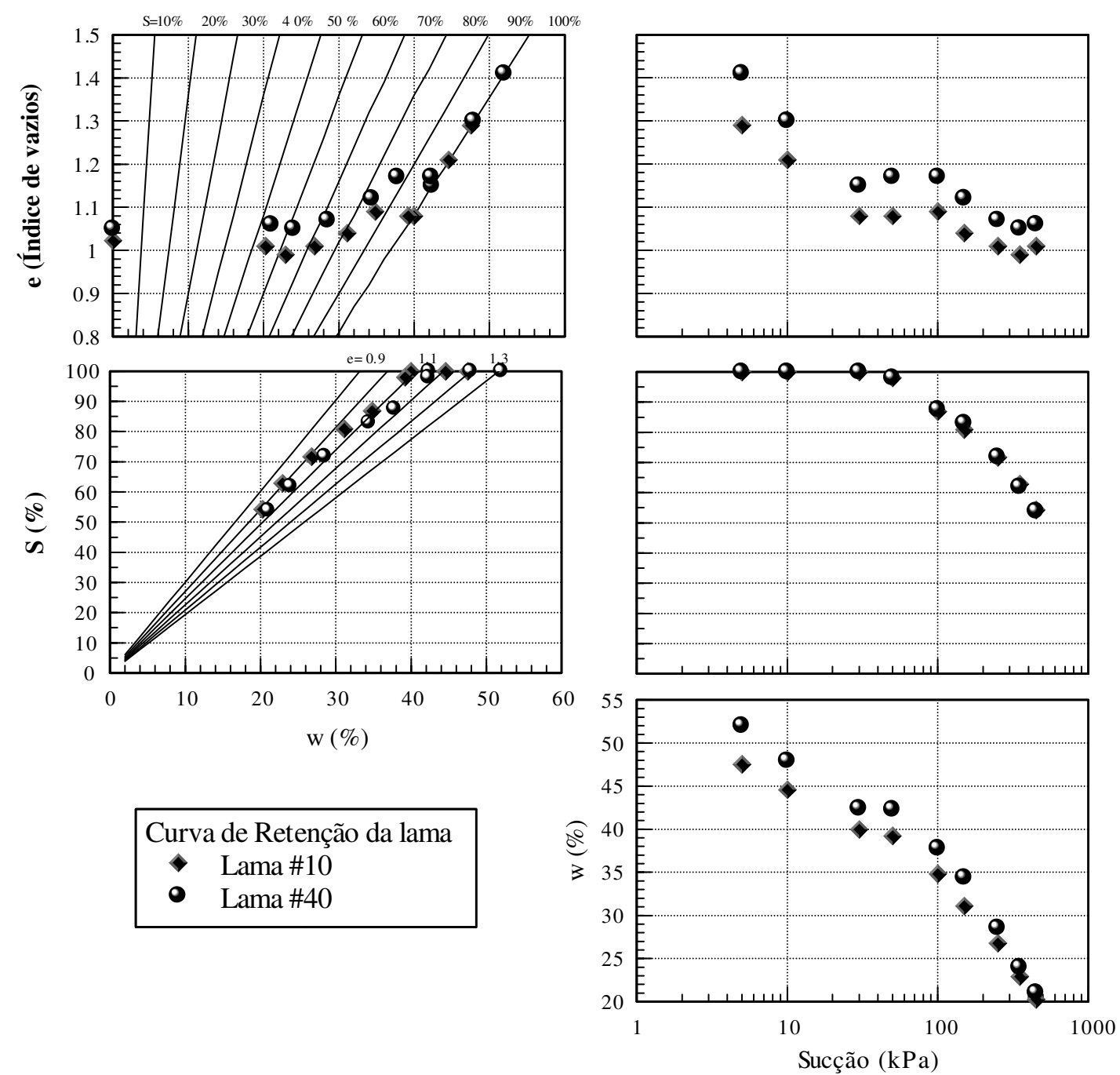

Figura 5.21 - Relações entre os teores de umidade (gravimétrico e volumétrico), grau de saturação, índice de vazios e a sucção dos corpos de prova moldados com a consistência de lama. 
Tabela 5.4 - Resultados experimentas das curvas de retenção dos corpos de prova moldados com a consistência de lama.

\begin{tabular}{|c|c|c|c|c|c|}
\hline \multicolumn{5}{|c|}{ Lama \#10 } \\
\hline Sucção $(\mathrm{kPa}) *$ & $\mathrm{e}$ & $\theta \mathrm{w}(\%)$ & $\mathrm{w}(\%)$ & $\mathrm{S}(\%)$ & $\begin{array}{c}\text { Sucção } \\
\text { Tens. (kPa) }\end{array}$ \\
\hline 5 & 1.29 & 56.3 & 47.5 & 100.0 & --- \\
\hline 10 & 1.21 & 54.7 & 44.6 & 100.0 & --- \\
\hline 30 & 1.08 & 52.0 & 40.0 & 100.0 & --- \\
\hline 50 & 1.08 & 51.0 & 39.2 & 98.0 & --- \\
\hline 100 & 1.09 & 45.2 & 34.8 & 86.9 & 45.4 \\
\hline 150 & 1.04 & 41.3 & 31.1 & 80.9 & 113.3 \\
\hline 250 & 1.01 & 36.1 & 26.8 & 71.7 & 183.4 \\
\hline 350 & 0.99 & 31.2 & 22.9 & 62.9 & 285.0 \\
\hline 450 & 1.01 & 27.3 & 20.3 & 54.3 & 361.5 \\
\hline & & Lama \#40 & & \\
\hline Sucção (kPa)* & $\mathrm{e}$ & $\theta \mathrm{w}(\%)$ & $\mathrm{w}(\%)$ & $\mathrm{S}(\%)$ & $\begin{array}{c}\text { Sucção } \\
\text { Tens. (kPa) }\end{array}$ \\
\hline 5 & 1.41 & 58.5 & 52.0 & 100.0 & --- \\
\hline 10 & 1.30 & 56.5 & 47.9 & 100.0 & --- \\
\hline 30 & 1.15 & 53.5 & 42.4 & 100.0 & --- \\
\hline 50 & 1.17 & 52.8 & 42.3 & 98.0 & --- \\
\hline 100 & 1.17 & 47.2 & 37.8 & 87.5 & 51.4 \\
\hline 150 & 1.12 & 43.9 & 34.4 & 83.0 & 87.9 \\
\hline 250 & 1.07 & 37.2 & 28.5 & 71.8 & 188.4 \\
\hline 350 & 1.05 & 31.7 & 24.0 & 61.9 & 294.5 \\
\hline 450 & 1.06 & 27.7 & 21.0 & 53.9 & 374.2 \\
\hline
\end{tabular}

* - Valor da sucção imposta nas placas de sucção e de pressão. 


\section{3 - Aspectos relacionados à histerese}

Após o ciclo de secagem, para a obtenção das curvas de retenção descritas no item 5.2.1, as mesmas foram determinadas seguindo o caminho do umedecimento. Neste item é verificada a histerese destas curvas de retenção em função dos ciclos de umidade. O umedecimento foi feito por aspersão de água em diversas etapas e as correspondentes sucções obtidas com utilização de papel filtro. Nas Figuras 5.22, 5.23 e 5.24 estão apresentadas, respectivamente para os pontos $\mathrm{O}$, S e U, os valores experimentais da sucção em função do grau de saturação para o ciclo de secagem e de umedecimento. Observa-se nestas figuras que ocorre uma pequena histerese para graus de saturação correspondentes a sucções menores que $100 \mathrm{kPa}$.

Na Figura 5.25 são apresentadas as relações entre os índices de vazios, teor de umidade gravimétrica e o grau de saturação. Constata-se que no ciclo de umedecimento, a relação definida entre o índice de vazios e o teor de umidade é igual aos resultados do ciclo de secagem. Desta forma, as contrações volumétricas apresentadas durante o ciclo de secagem foram recuperadas durante o ciclo de umedecimento. Fleureau et al (2001) também constataram a reversibilidade da variação do índice de vazios em função do teor de umidade durante o ciclo de secagem e umedecimento. Seus resultados foram obtidos para um solo $\left(\mathrm{w}_{1}=35 \%\right.$, $\mathrm{IP}=17 \%$ ) compactado na umidade ótima e em mais dois pontos do ramo úmido.

A histerese observada nas curvas de retenção apresentadas nas Figuras 5.22, 5.23 e 5.24 deve-se provavelmente apenas à presença de ar ocluso no interior dos corpos de prova. De acordo com a Figura 2.44 tem-se que durante a saturação dos corpos de prova a água encontra dificuldades para penetrar nos macroporos, fazendo com que no interior de sua matriz o ar permaneça ocluso. A porcentagem de ar ocluso foi obtida, nas Figuras 5.22, 5.23 e 5.24, pela diferença entre o grau de saturação das curvas de umedecimento e secagem, correspondente a valores de sucção de $1 \mathrm{kPa}$. Estes valores correspondem aproximadamente a $4 \%$ para as condições de moldagem na umidade ótima, no ramo seco e no ramo úmido. 


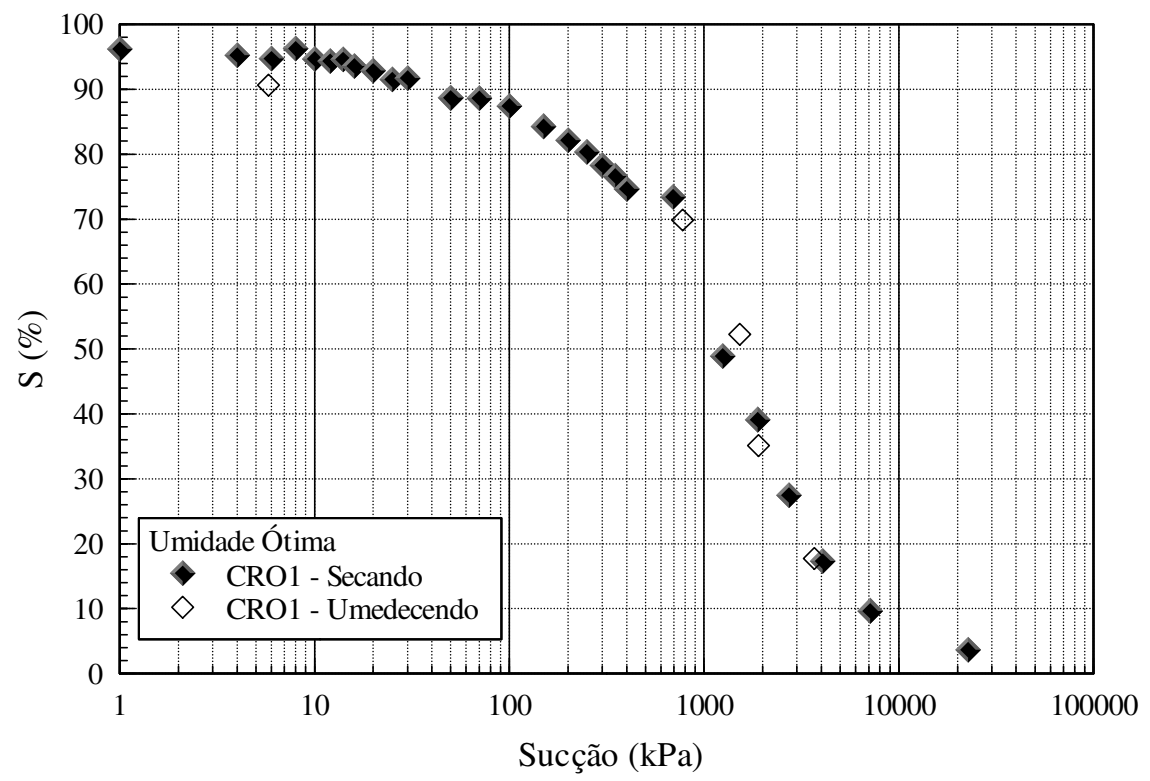

Figura 5.22 - Curvas de retenção do corpo de prova compactado estaticamente na umidade ótima, obtidas por secagem e umedecimento (Ponto $\mathrm{O}$ ).

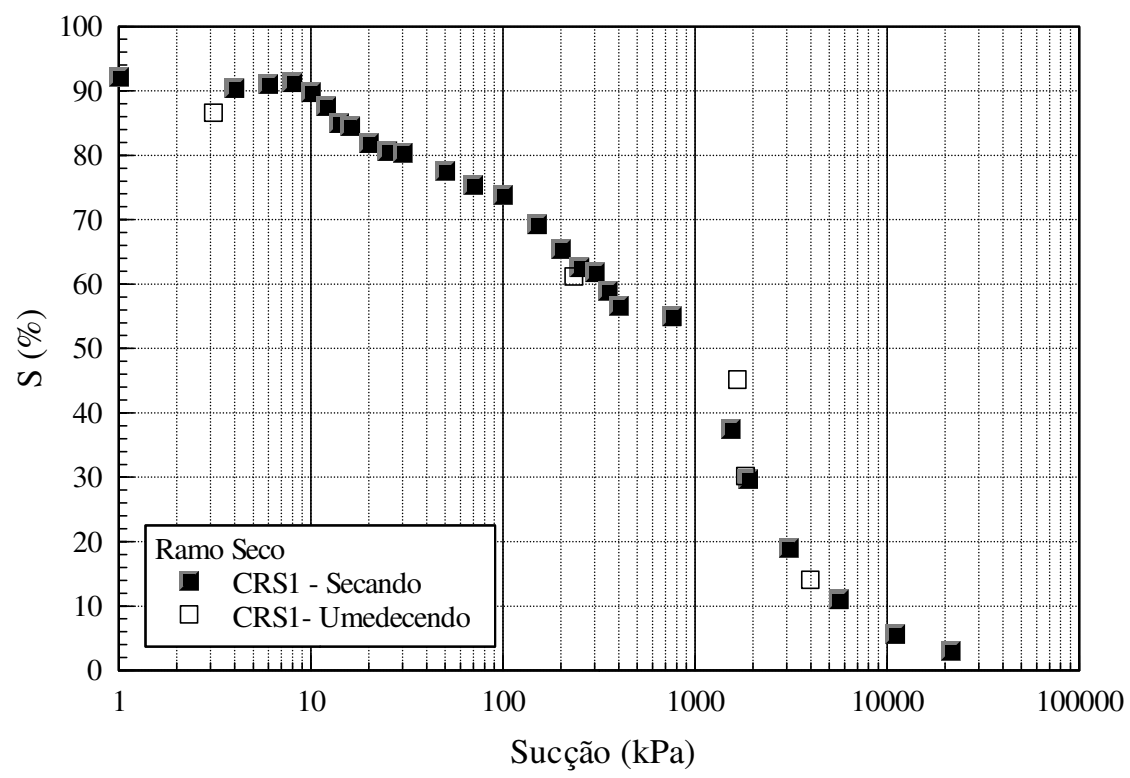

Figura 5.23 - Curvas de retenção do corpo de prova compactado estaticamente no ramo seco, obtidas por secagem e umedecimento (Ponto $\mathrm{S}$ ). 


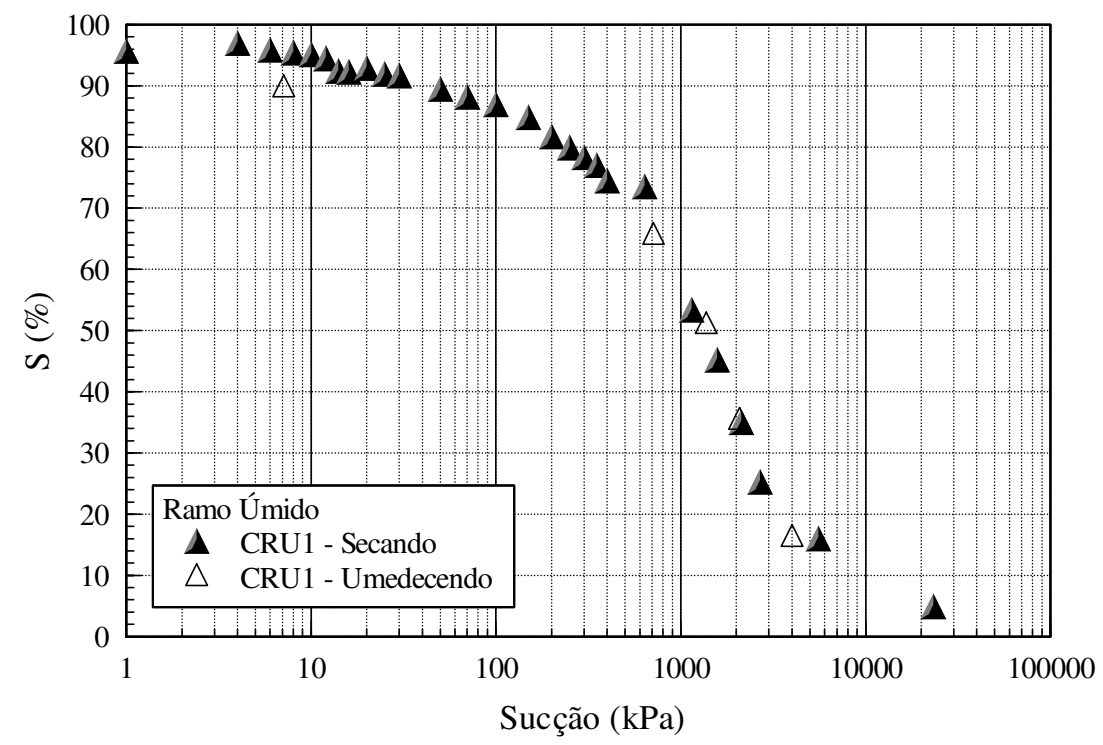

Figura 5.24 - Curvas de retenção do corpo de prova compactada estaticamente no ramo úmido, obtidas por secagem e umedecimento (Ponto U).

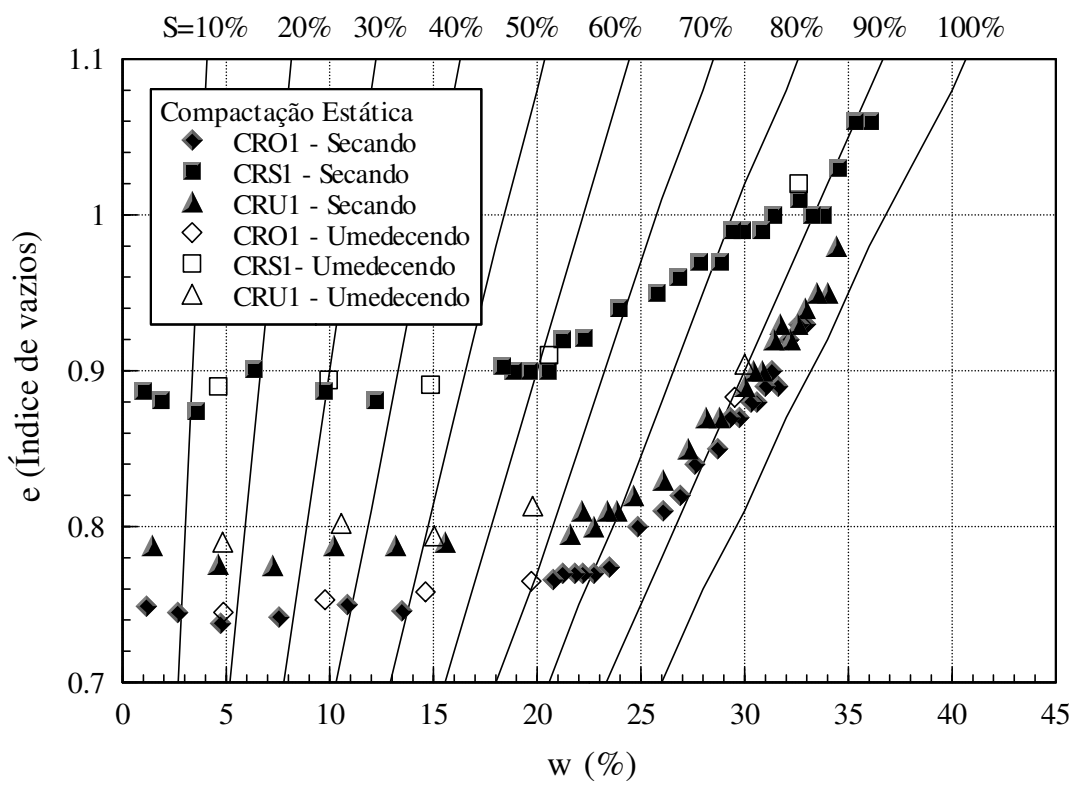

Figura 5.25 - Variação do índice de vazios, em função do teor de umidade e do grau de saturação, obtida durante a secagem e o umedecimento dos corpos de prova compactados estaticamente nos três pontos de estudo (O, S e U). 


\section{4 - Efeito do tipo de compactação na curva de retenção}

O tipo de compactação pode produzir para uma mesma condição de moldagem, corpos de prova com diferentes estruturas. A compactação dinâmica, quando comparada com a compactação estática, produz maiores deformações cisalhantes no solo. Com o intuito de se verificar como a curva de retenção é afetada pelo tipo de compactação, são comparados neste item os resultados apresentados nos itens 5.2.1 e 5.2.3. As Figuras 5.26, 5.27 e 5.28 apresentam as relações entre o grau de saturação e a sucção, para os corpos de prova moldados por compactação estática e dinâmica. Apesar do fato da compactação dinâmica produzir maiores deformações cisalhantes, observa-se nestas figuras que as curvas de retenção são praticamente iguais. Desta forma constata-se que, em relação à compactação estática, a energia normal aplicada na compactação dinâmica não foi suficiente para produzir corpos de prova com estruturas diferentes.

Na Figura 5.29 estão apresentadas as variações dos índices de vazios em função da umidade gravimétrica e do grau de saturação para os dois tipos de compactação. Observa-se nesta figura que para cada condição inicial de moldagem, independentemente do tipo de compactação empregado, as variações dos índices de vazios dos corpos de prova também são semelhantes para as condições de moldagem no ramo seco e ramo úmido. Para a condição de moldagem na umidade ótima foi constatada uma pequena diferença, com o corpo de prova compactado dinamicamente apresentando maiores variações do índice de vazios. As diferenças dos índices de vazios no final do ensaio, entre estes dois tipos de compactação, são da ordem de 0.04. Valores desta ordem de grandeza podem ser considerados desprezíveis de forma que as estruturas destes corpos de prova, moldados por compactação estática e dinâmica ao longo da curva de compactação, podem ser consideradas semelhantes. 


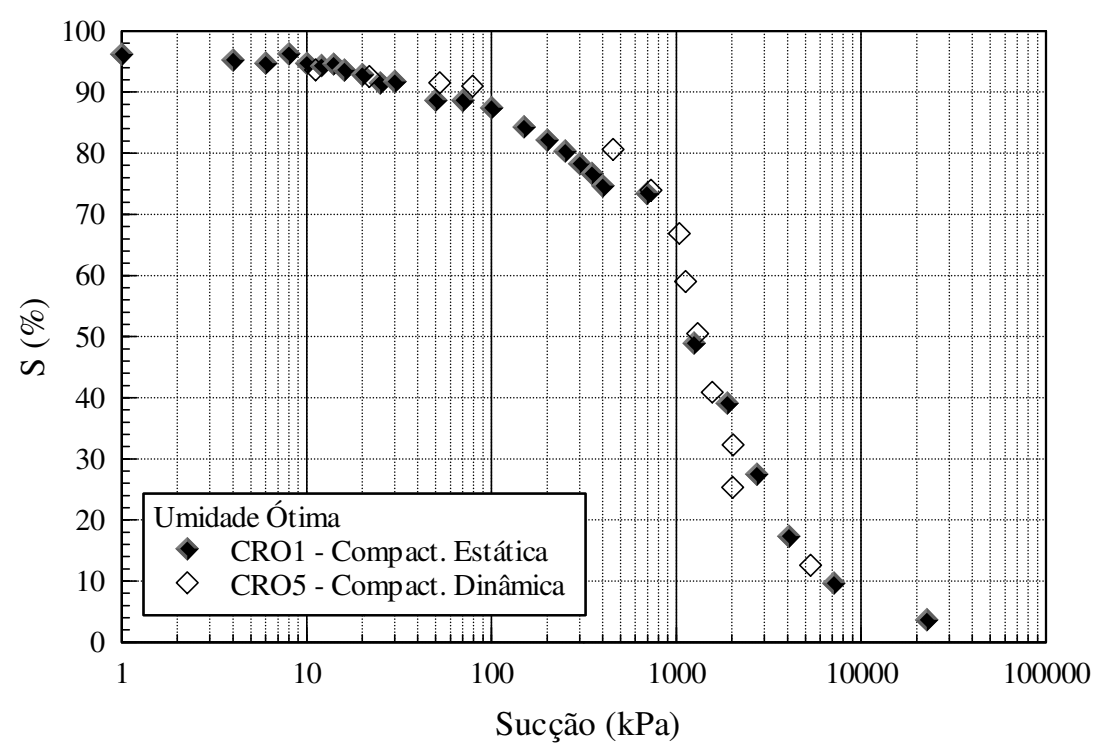

Figura 5.26 - Comparação entre as curvas de retenção obtidas em corpos de prova moldados na umidade ótima por compactação estática e dinâmica (Ponto O).

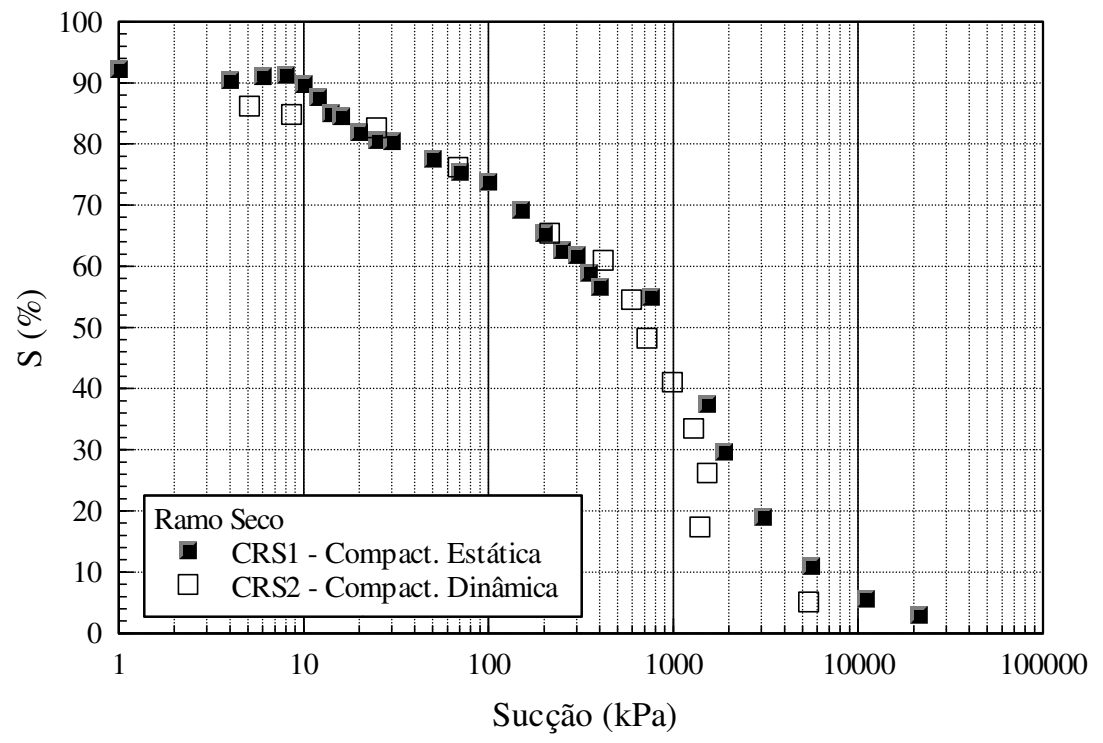

Figura 5.27 - Comparação entre as curvas de retenção obtidas em corpos de prova moldados no ramo seco por compactação estática e dinâmica (Ponto S). 


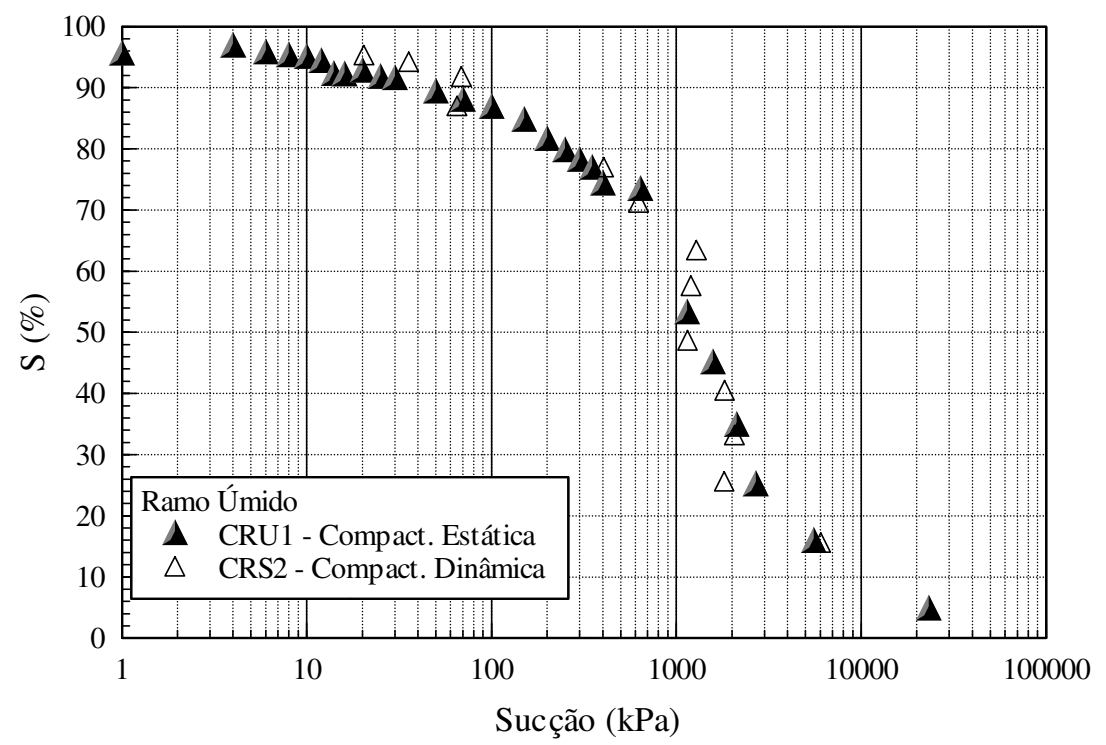

Figura 5.28 - Comparação entre as curvas de retenção obtidas em corpos de prova moldados no ramo úmido por compactação estática e dinâmica (Ponto U).

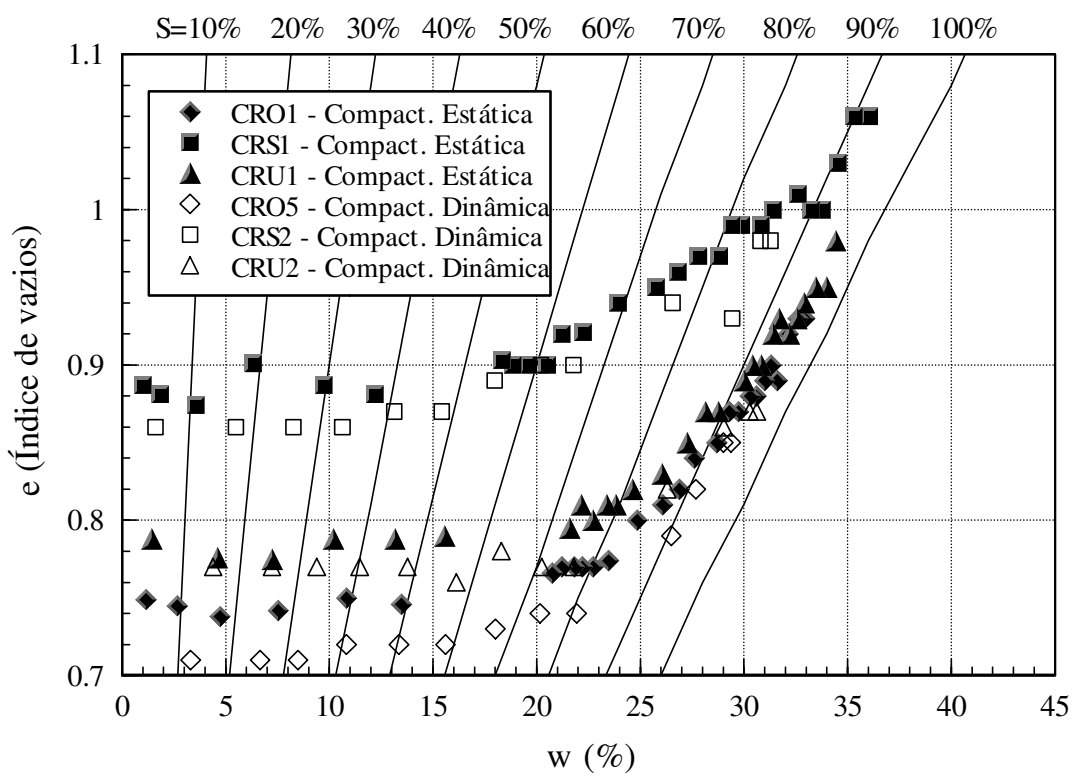

Figura 5.29 - Variação do índice de vazios, em função do teor de umidade e do grau de saturação, dos corpos de prova moldados por compactação estática e dinâmica nos pontos de estudo (O, S e U). 


\section{5 - Aplicação da equação de ajuste proposta por Fredlund e Xing (1994) aos valores experimentais da curva de retenção}

A aplicação dos modelos de previsão da resistência requer a obtenção de uma equação matemática que represente os pontos experimentais da curva de retenção. Para os ajustes das curvas obtidas nesta pesquisa foi utilizada a equação proposta por Fredlund e Xing (1994), descrita no item 2.3.2. Os ajustes foram feitos para as curvas de retenção obtidas dos corpos de prova compactados estaticamente nos pontos de estudo, apresentadas nos itens 5.2.1 a 5.2.3, e dos corpos de prova moldados com consistência de lama, apresentada no item 5.2.5. A equação proposta por Fredlund e Xing (1994) não possibilitou um ajuste adequado para os resultados experimentais do corpo de prova moldado no ramo seco. De acordo com as análises do item 5.2.1 esta curva apresenta dois pontos de inflexão, indicando assim uma distribuição bimodal de poros. Para contornar este problema foram utilizadas duas equações de ajuste. $\mathrm{O}$ primeiro ajuste foi feito para sucções de até $50 \mathrm{kPa}$ e o segundo para o restante da curva. Com exceção dos resultados para sucções de até $50 \mathrm{kPa}$, do corpo de prova moldado no ramo seco, todas as curvas de retenção foram ajustadas utilizando-se a equação 2.14 multiplicada pelo termo $\mathrm{C}(\psi)$, dado pela equação 2.15. Para o primeiro trecho da curva de retenção do ramo seco ( 0 a $50 \mathrm{kPa})$, foi aplicada apenas a equação 2.14 .

Ao se utilizar a equação 2.14 multiplicada por $\mathrm{C}(\psi)$, os valores de a, n e m são determinados pelas equações 2.16 a 2.20. Os parâmetros utilizados nestas equações foram estimados de forma semelhante aos procedimentos da Figuras 2.34, no entanto foram utilizados os resultados experimentais dados pelos valores do grau de saturação em função da sucção. Os parâmetros estimados para o cálculo de a, n e m estão apresentados na Tabela 5.5. Nesta Tabela os corpos de prova CRO1, CRS1 e CRU1 representam as curvas de retenção determinadas sem confinamento em corpos de prova moldados respectivamente na umidade ótima, ramo seco e ramo úmido. As curvas de retenção determinadas com pressão de confinamento de 100, 200 e 300 $\mathrm{kPa}$ correspondem respectivamente aos corpos de prova CRO2, CRO3 e CRO4. 
$\mathrm{Na}$ Tabela 5.5 o valor de $\mathrm{S}_{\mathrm{i}}$ corresponde ao grau de saturação do ponto de inflexão da curva de retenção e $S_{\text {sat. }}$ corresponde ao maior valor do grau de saturação atingido durante a preparação do corpo de prova. $\mathrm{O}$ significado dos outros valores pode ser visto no item 2.3.2. Substituindo-se os valores da Tabela 5.5 nas equações 2.16 a 2.20 obteve-se uma primeira aproximação para os parâmetros a, n e m dados na Tabela 5.6.

Tabela 5.5 - Valores obtidos da curva de retenção em função do grau de saturação, utilizados para aplicação da equação proposta por Fredlund e Xing (1994).

\begin{tabular}{|c|c|c|c|c|c|c|c|c|c|}
\hline Parâmetro & CRO1 & CRO2 & CRO3 & CRO4 & $\begin{array}{c}\text { CRS1 } \\
(0 \text { a 50 kPa })\end{array}$ & $\begin{array}{c}\text { CRS1 } \\
(>50 \mathrm{kPa})\end{array}$ & CRU1 & Lama\#10 & Lama\#40 \\
\hline$\psi_{\mathrm{i}}$ & 1000 & 900 & 1000 & 1000 & 15 & 1000 & 1000 & 500 & 500 \\
\hline$\psi_{\mathrm{r}}$ & 3000 & 3000 & 3000 & 3000 & --- & 3000 & 3000 & 3000 & 3000 \\
\hline$\psi_{\mathrm{p}}$ & 6000 & 3000 & 3000 & 2500 & 7000 & 7000 & 5000 & 3000 & 3000 \\
\hline $\mathrm{S}_{\mathrm{i}}$ & 0.50 & 0.50 & 0.50 & 0.50 & 0.85 & 0.40 & 0.45 & 0.50 & 0.50 \\
\hline $\mathrm{S}_{\mathrm{sat}} \cdot$ & 0.96 & 0.91 & 0.91 & 0.96 & 0.92 & 0.80 & 0.95 & 1.00 & 1.00 \\
\hline
\end{tabular}

Tabela 5.6 - Valores iniciais dos parâmetros da equação proposta por Fredlund e Xing (1994), utilizados no ajuste das curvas de retenção.

\begin{tabular}{|c|c|c|c|c|c|c|c|c|c|}
\hline Parâmetro & CRO1 & CRO2 & CRO3 & CRO4 & $\begin{array}{c}\text { CRS1 }(0 \text { a 50 } \\
\mathrm{kPa})\end{array}$ & $\begin{array}{c}\text { CRS1 }(>50 \\
\mathrm{kPa})\end{array}$ & CRU1 & Lama\#10 & Lama\#40 \\
\hline $\mathrm{C}(\psi)$ & 0.95 & 0.95 & 0.95 & 0.95 & --- & 0.95 & 0.95 & 0.97 & 0.97 \\
\hline$S$ & 0.28 & 0.42 & 0.46 & 0.55 & 0.00 & 0.21 & 0.28 & 0.28 & 0.28 \\
\hline$S^{*}$ & 0.27 & 0.43 & 0.48 & 0.54 & --- & 0.23 & 0.27 & 0.27 & 0.27 \\
\hline $\mathrm{a}$ & 1000 & 900 & 1000 & 1000 & 15 & 1000 & 1000 & 500 & 500 \\
\hline $\mathrm{n}$ & 1.017 & 1.719 & 1.884 & 2.074 & 0.036 & 0.870 & 0.986 & 1.000 & 1.000 \\
\hline $\mathrm{m}$ & 2.208 & 2.028 & 2.011 & 2.208 & 0.290 & 2.358 & 2.556 & 2.445 & 2.445 \\
\hline
\end{tabular}

As curvas de retenção em termos de grau de saturação, representadas pela equação de Fredlund e Xing (1994), iniciam para grau de saturação igual a 100\%. No entanto, as curvas de retenção obtidas nesta pesquisa iniciam com grau de saturação em torno de $95 \%$. Desta forma a equação proposta por estes autores foi multiplicada por um fator que faz com que o início dos ajustes coincida com os valores experimentais. Utilizando uma planilha eletrônica, os valores iniciais dos parâmetros a, n e m (Tabela 5.6) e o fator de correção do início da curva, observa-se que as equações de ajuste obtidas já estão bem próximas dos pontos experimentais. A partir das estimativas iniciais da Tabela 5.6, os valores de a, $\mathrm{n}$ e $\mathrm{m}$ foram alterados para possibilitar o melhor ajuste possível. Para se verificar a qualidade do ajuste final, foi determinado o valor do coeficiente de correlação ao quadrado representado por $\mathrm{r}^{2}$. $\mathrm{O}$ 
ajuste realizado com planilha eletrônica permite que se utilize o bom senso ao se desconsiderar resultados que estão incoerentes ou ajustar melhor um determinado trecho da curva que seja de maior interesse. Os valores finais dos parâmetros a, n e m, o fator de correção do início da curva e o quadrado dos coeficientes de correlação estão apresentados na Tabela 5.7. De forma a se evitar uma grande quantidade de ajustes e pontos experimentais, dificultando a visualização dos mesmos, a aplicação do modelo de Fredlund e Xing (1994) esta representada individualmente para cada curva de retenção nas Figuras 5.30 a 5.37.

Tabela 5.7 - Parâmetros de ajuste da curva de retenção ao se utilizar a equação de Fredlund e Xing (1994).

\begin{tabular}{|c|c|c|c|c|c|c|c|c|c|}
\hline Parâmetro & CRO1 & CRO2 & CRO3 & CRO4 & $\begin{array}{c}\text { CRS1 } \\
(0 \mathrm{a} 50 \mathrm{kPa})\end{array}$ & $\begin{array}{c}\text { CRS1 } \\
(>50 \mathrm{kPa})\end{array}$ & CRU1 & $\begin{array}{c}\text { Lama } \\
\# 10\end{array}$ & $\begin{array}{c}\text { Lama } \\
\# 40\end{array}$ \\
\hline $\mathrm{a}$ & 1000 & 1100 & 1350 & 1000 & 10 & 1000 & 950 & 370 & 430 \\
\hline $\mathrm{n}$ & 1.3 & 1.4 & 1.75 & 1.9 & 4 & 1 & 1.1 & 1.44 & 1.4 \\
\hline $\mathrm{m}$ & 2 & 2.1 & 2 & 1.5 & 0.1 & 2.35 & 2 & 1.8 & 2.2 \\
\hline Fator & 0.97 & 0.96 & 0.95 & 0.965 & 0.45 & 0.91 & 0.978 & 1 & 1 \\
\hline $\mathrm{r}^{2}$ & 0.99 & 0.97 & 0.99 & 0.95 & 0.98 & 0.99 & 0.99 & 0.99 & 0.99 \\
\hline
\end{tabular}

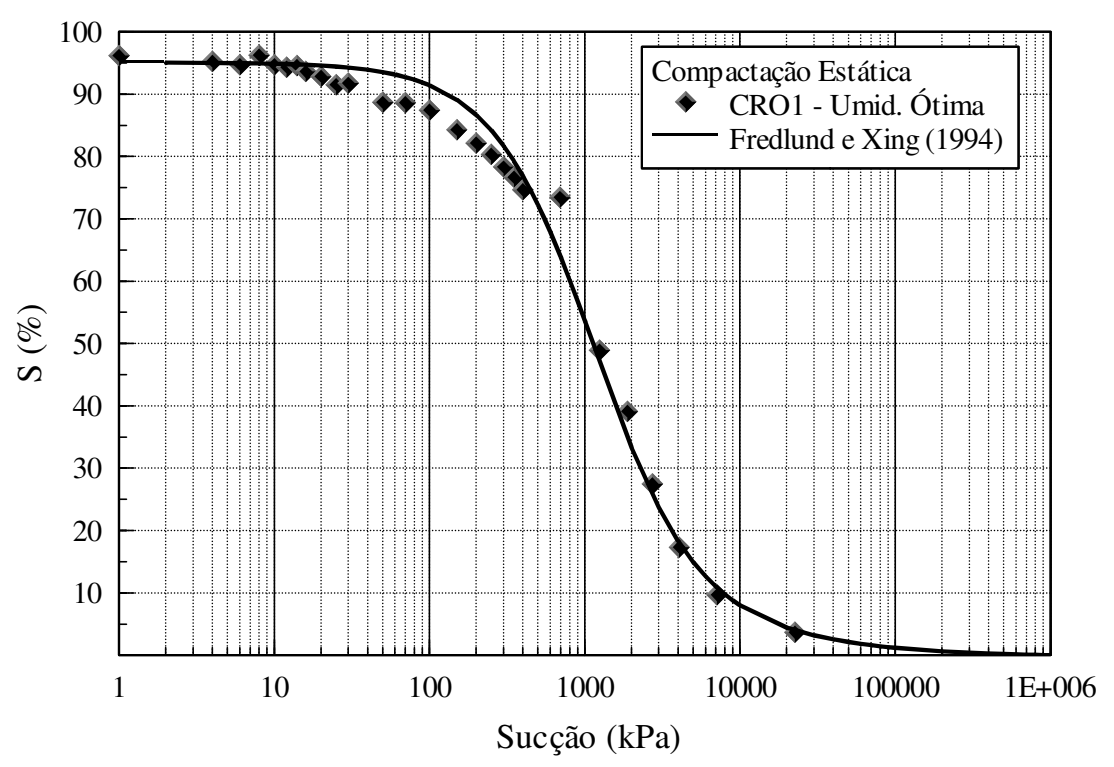

Figura 5.30 - Ajuste aos pontos experimentais da curva de retenção definida sem confinamento utilizando o corpo de prova compactado estaticamente na umidade ótima (CRO1). 


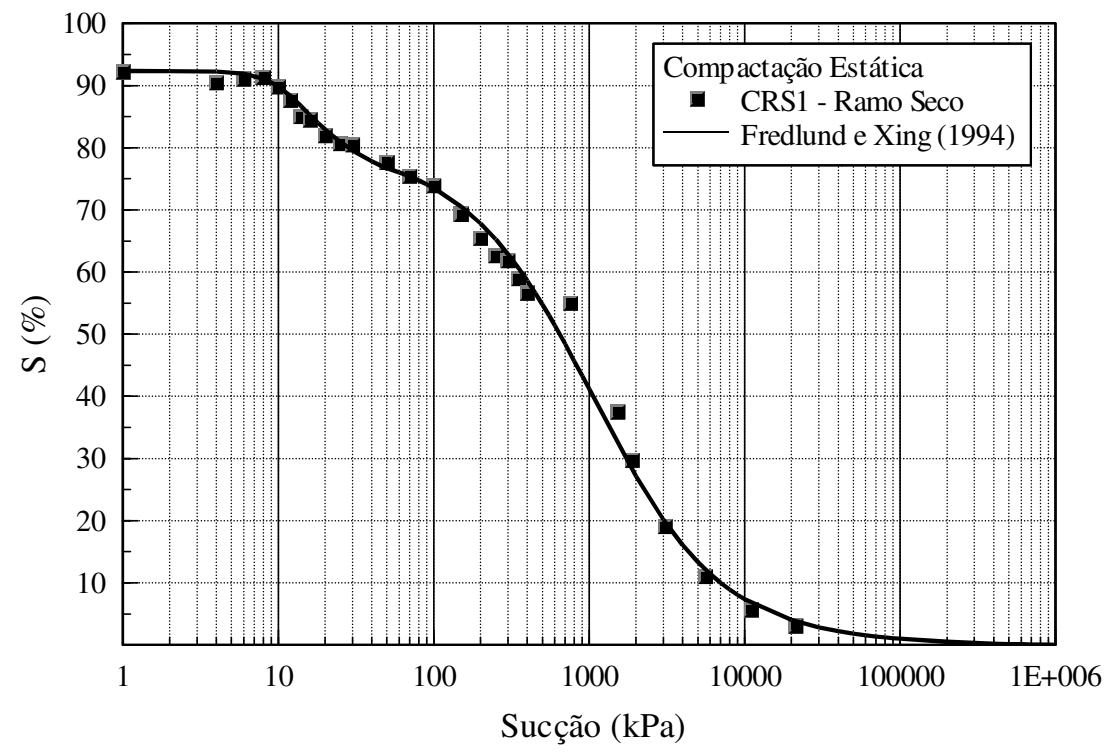

Figura 5.31 - Ajuste aos pontos experimentais da curva de retenção definida sem confinamento utilizando o corpo de prova compactado estaticamente no ramo seco (CRS1).

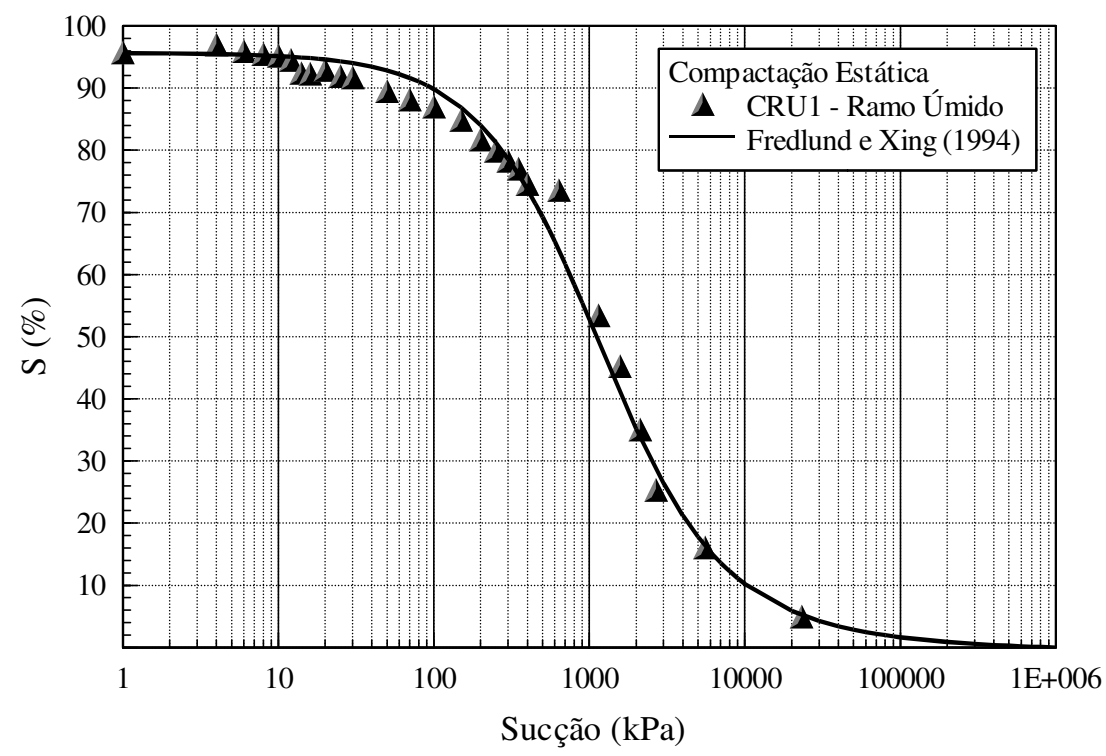

Figura 5.32 - Ajuste aos pontos experimentais da curva de retenção definida sem confinamento utilizando o corpo de prova compactado estaticamente no ramo úmido (CRU1). 


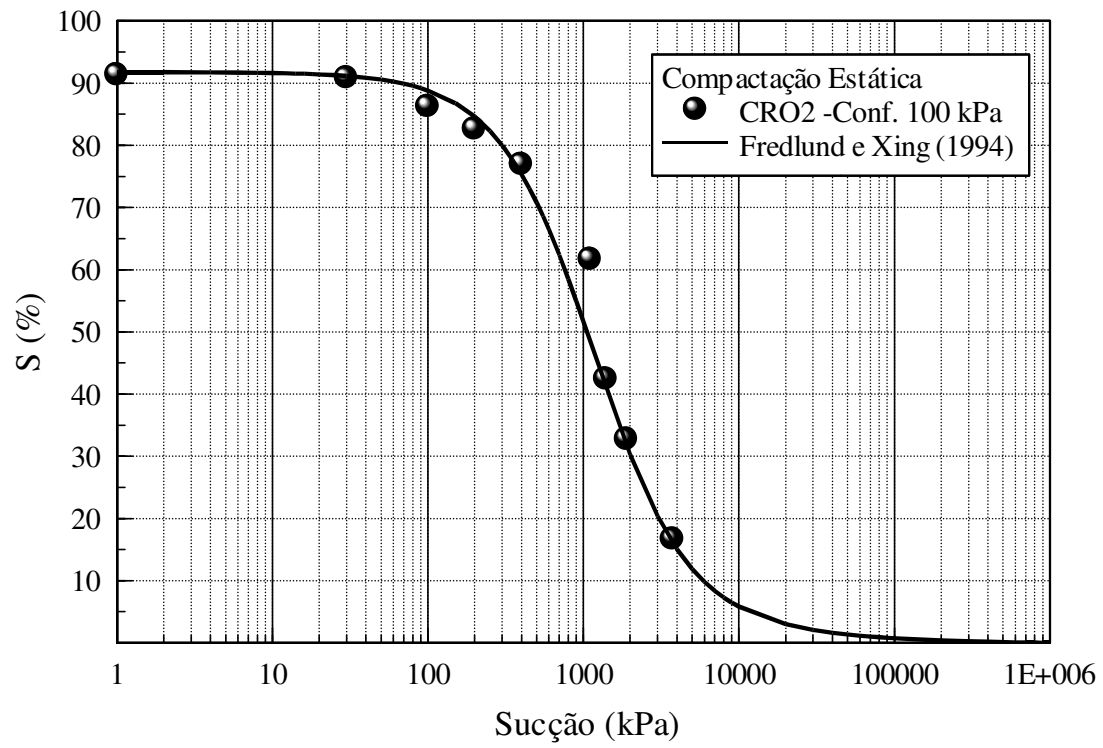

Figura 5.33 - Ajuste aos pontos experimentais da curva de retenção definida com confinamento de $100 \mathrm{kPa}$ utilizando o corpo de prova compactado estaticamente na umidade ótima (CRO2).

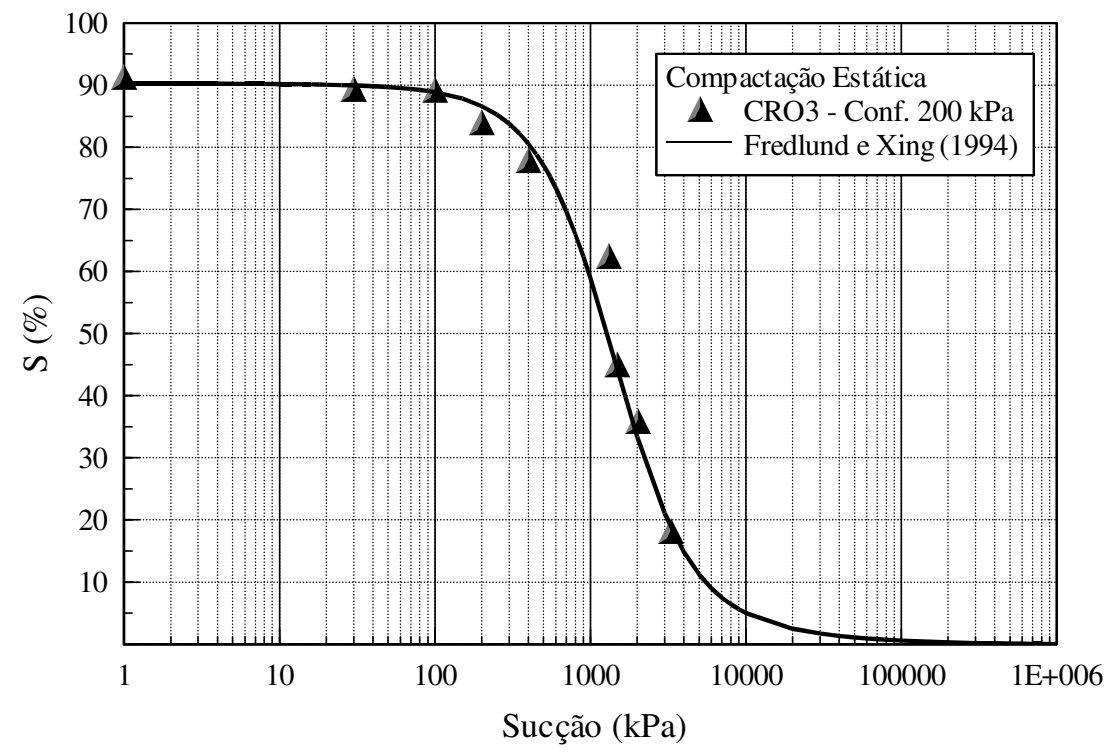

Figura 5.34 - Ajuste aos pontos experimentais da curva de retenção definida com confinamento de $200 \mathrm{kPa}$ utilizando d corpo de prova compactado estaticamente na umidade ótima (CRO3). 


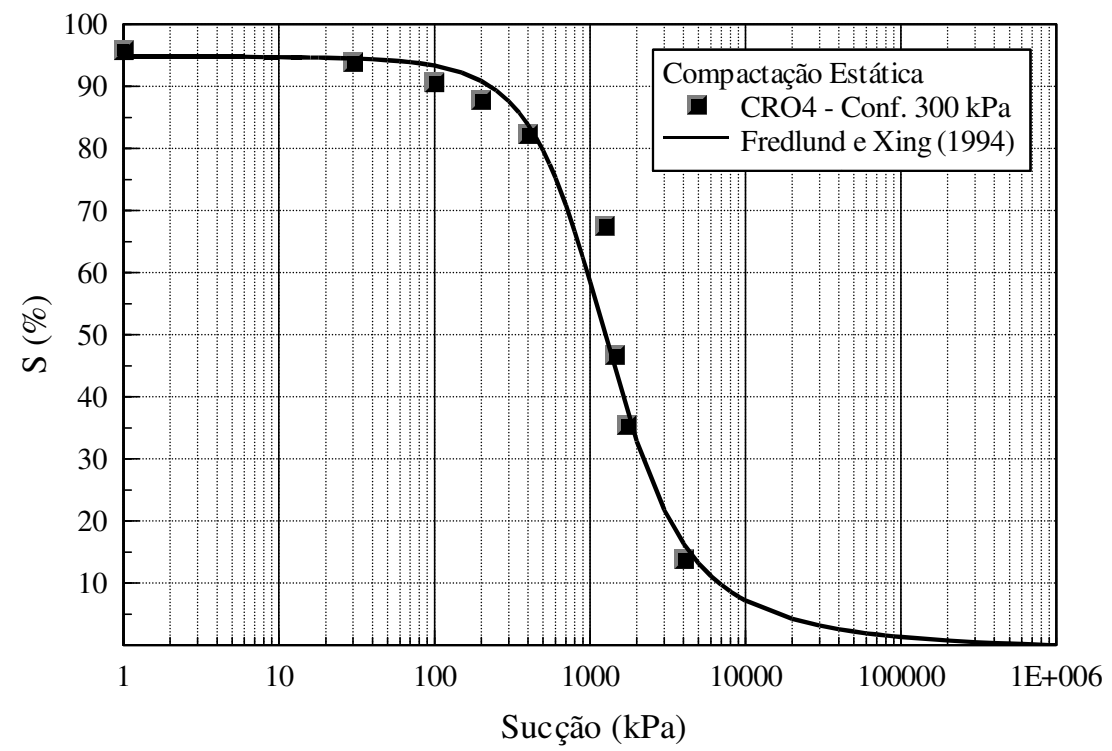

Figura 5.35 - Ajuste aos pontos experimentais da curva de retenção definida com confinamento de $300 \mathrm{kPa}$ utilizando o corpo de prova compactado estaticamente na umidade ótima (CRO4).

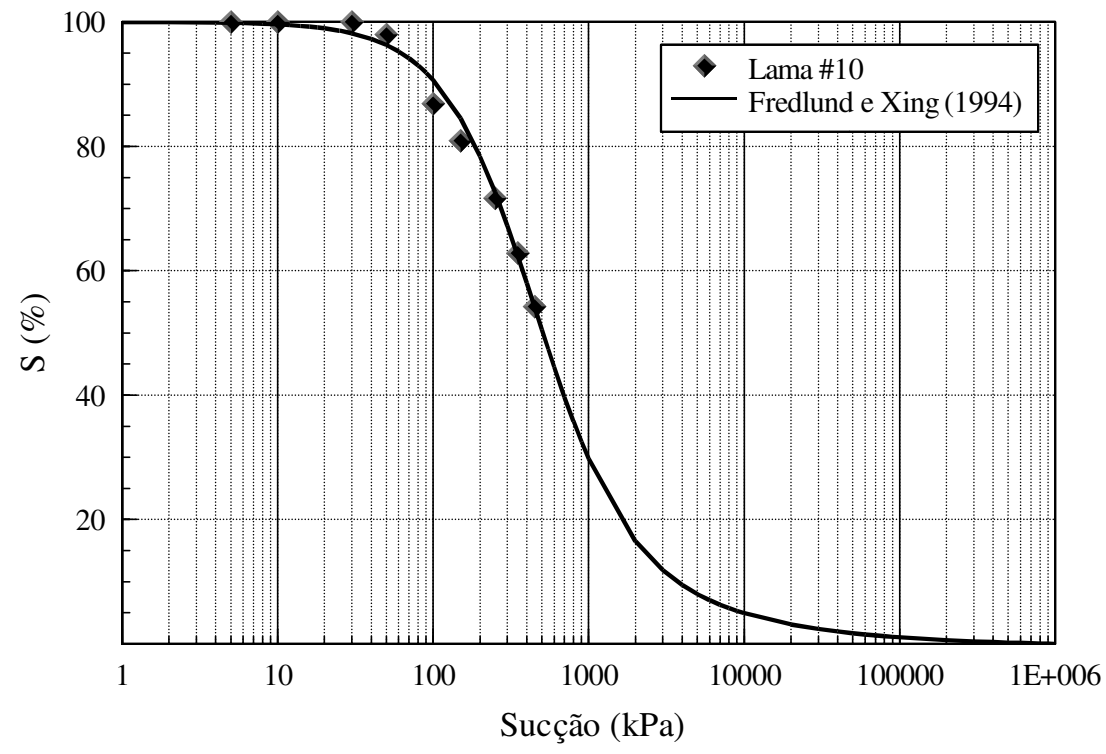

Figura 5.36 - Ajuste aos pontos experimentais da curva de retenção da lama formada como o solo que passa na peneira $\mathrm{n}^{\mathrm{o}} 10$. 


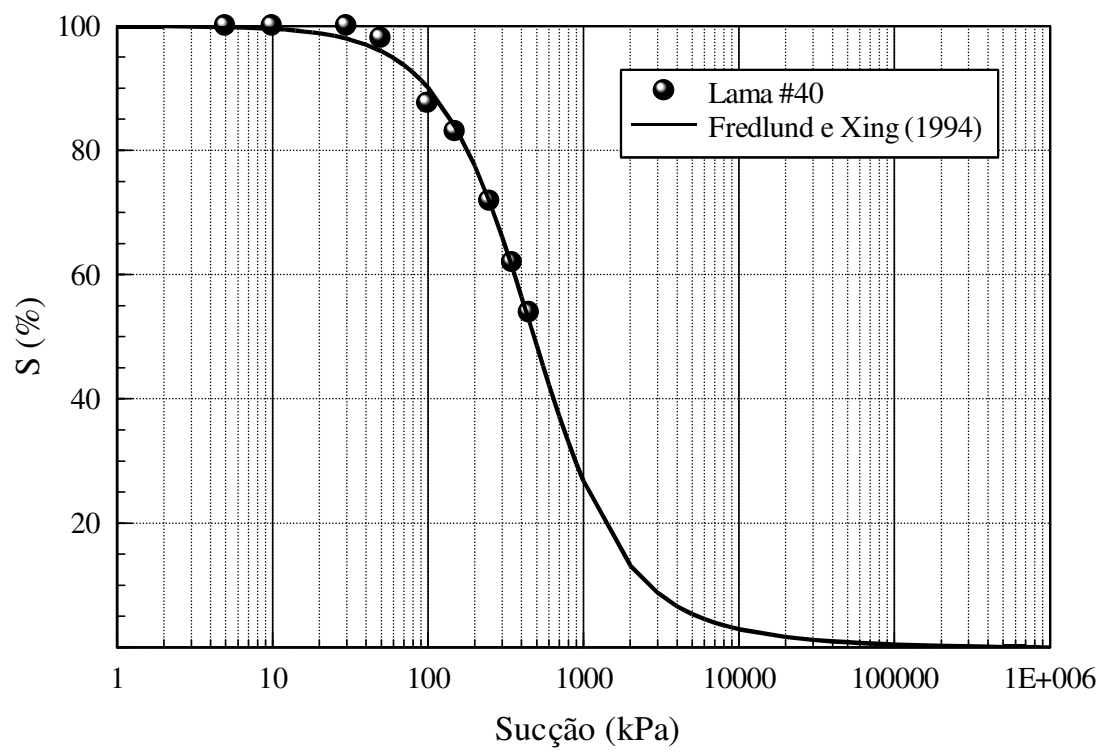

Figura 5.37 - Ajuste aos pontos experimentais da curva de retenção da lama formada com o solo que passa na peneira $\mathrm{n}^{\circ} 40$.

\section{6 - Variação da sucção de entrada de ar}

Neste item são analisadas as variações da sucção de entrada de ar em função das diferentes estruturas resultantes das condições de moldagem e das diferentes pressões de confinamento aplicadas. Estes valores foram determinados para os resultados das curvas de retenção obtidas em corpos de prova compactados estaticamente nos pontos de estudo (itens 5.2.1 a 5.2.3) e moldados com consistência de lama (item 5.2.5). Estas curvas de retenção serão representadas pelas suas respectivas equações de ajuste definidas no item 5.5. Utilizando estes resultados, a entrada de ar corresponde à sucção definida pela intersecção da linha horizontal, traçada pela parte inicial da curva, e a linha tangente que passa pelo seu ponto de inflexão. As sucções assim determinadas correspondem à entrada de ar generalizada estando o início da dessaturação do corpo de prova relacionado a valores menores de sucção.

Na Figura 5.38 estão definidas as sucções de entrada de ar dos corpos de prova compactados estaticamente nas condições da umidade ótima (CRO1, CRO2, CRO3 e 
CRO4). Os resultados para os corpos de prova moldados no ramo seco (CRS1), ramo úmido (CRS1) e com a consistência de lama estão apresentados na Figura 5.39.

As sucções correspondentes a entrada de ar generalizada, determinadas nas Figuras 5.38 e 5.39, estão apresentadas na Tabela 5.8. Para as curvas obtidas sem confinamento e determinadas para o ramo seco (CRS1), umidade ótima (CRO1) e o ramo úmido (CRU1) estes valores são respectivamente iguais a 8, 250 e $250 \mathrm{kPa}$. Com estes resultados constata-se que a sucção de entrada de ar generalizada, correspondentes aos corpos de prova compactados estaticamente ao longo da curva de compactação, aumenta do ramo seco até a umidade ótima. A partir da umidade ótima as estruturas dos corpos de prova, conforme as análises do item 2.5.1, são semelhantes e os valores da sucção de entrada de ar permanecem constantes.

Para as curvas de retenção determinadas com confinamento de 0, 100, 200 e 300 kPa, obtidas em corpos de prova moldados na umidade ótima (CRO1 a CRO4), as sucções correspondentes à entrada de ar generalizada variaram de 250 a $400 \mathrm{kPa}$.

Na Figura 5.40 estão os resultados obtidos para esta condição de moldagem, plotados em função da pressão de confinamento. Nesta figura estão também os resultados obtidos por Vanapalli (1994), Rassan e Willians (1999) e Charles e Pang (2000). Os valores obtidos por Vanapalli (1994) e Charles e Pang (2000) referem-se à sucção de entrada de ar generalizada. Os resultados de Rassam de Willians (1999) foram obtidos de ensaios de resistência, onde a sucção de entrada de ar corresponde ao valor em que a resistência ao cisalhamento em função da sucção passa a apresentar uma relação não linear. Os valores de sucção assim obtidos correspondem ao início da dessaturação dos corpos de prova. Rassam de Willians (1999) e Charles e Pang (2000) utilizaram amostras indeformadas cuja porosidade de sua estrutura justificam os baixos valores da sucção de entrada de ar observadas na Figura 5.40. Para os solos pesquisados por estes autores também foi constatado o aumento da sucção de entrada de ar em função da pressão confinante. 

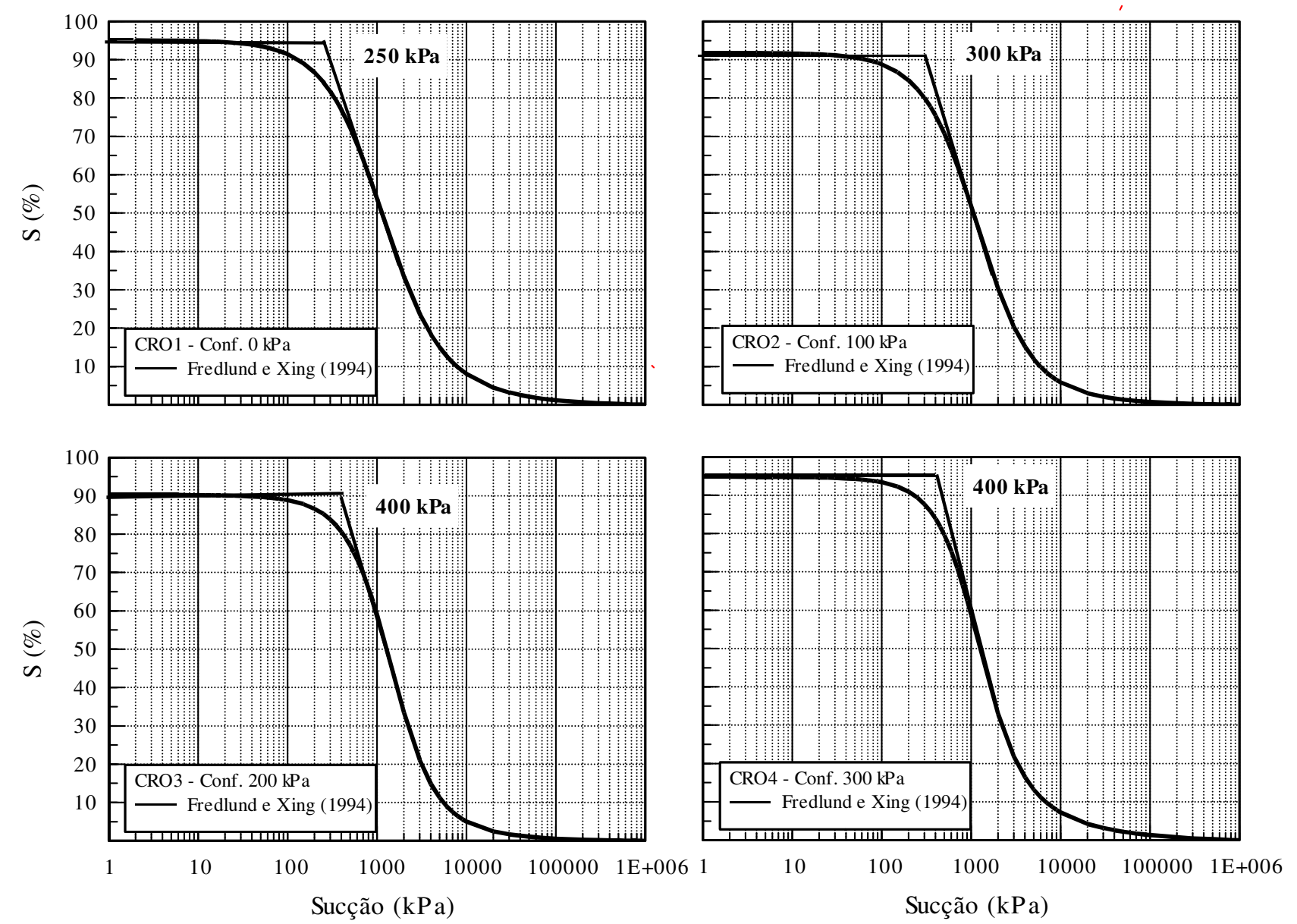

Figura 5.38 - Determinação da entrada de ar das curvas de retenção dos corpos de prova moldados na umidade ótima. 

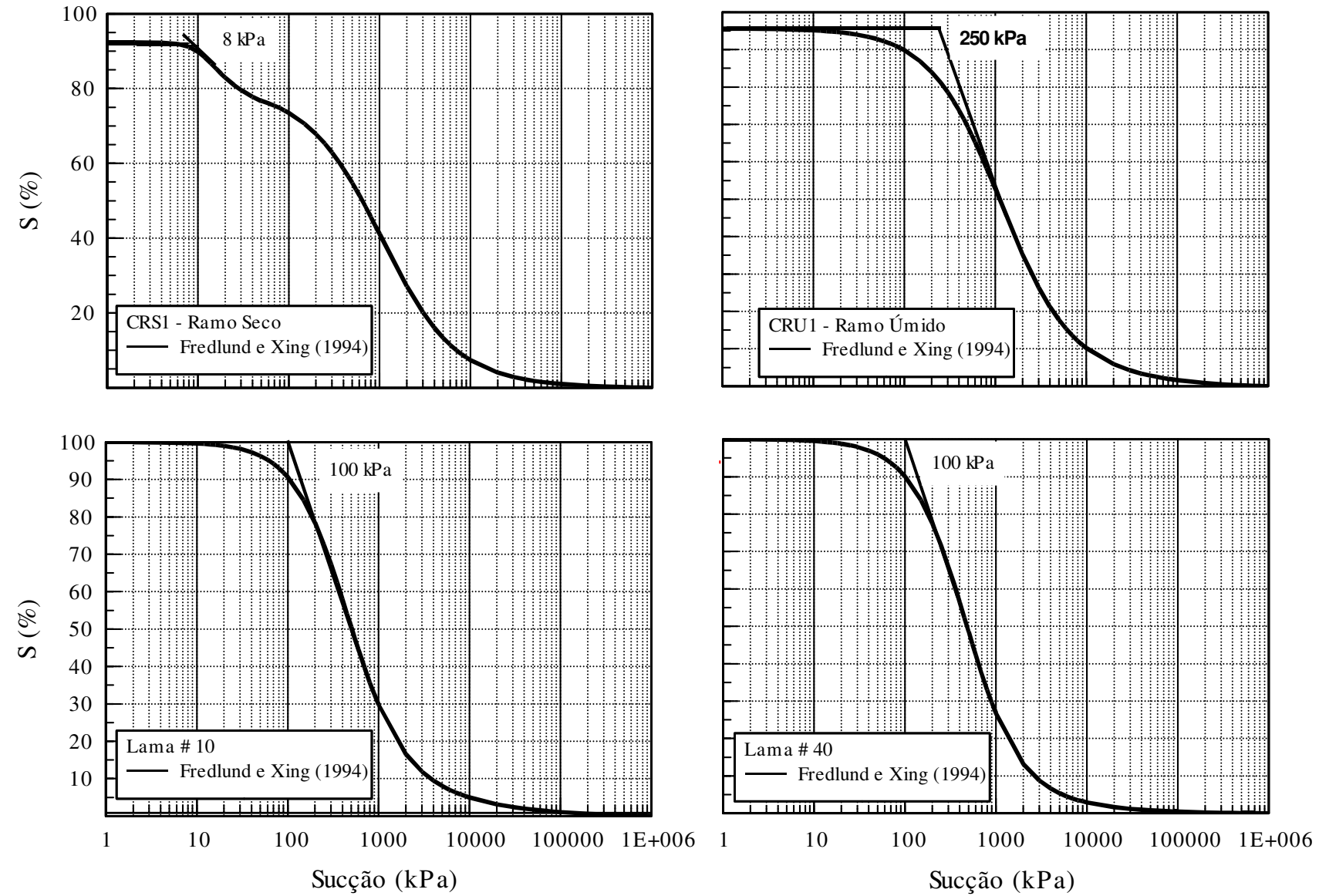

Figura 5.39 - Determinação da entrada de ar das curvas de retenção dos corpos de prova moldados no ramo seco, ramo úmido e com a consistência de lama. 
Tabela 5.8 - Valores da sucção de entrada de ar em função das condições de moldagem e da pressão de confinamento aplicada aos corpos de prova.

\begin{tabular}{|c|c|c|}
\hline C.P. & $\begin{array}{c}\text { Tens. Conf. } \\
(\mathrm{kPa})\end{array}$ & $\begin{array}{c}\text { Entrada de ar } \\
(\mathrm{kPa})\end{array}$ \\
\hline CRO1 & 0 & 250 \\
\hline CRO2 & 100 & 300 \\
\hline CRO3 & 200 & 370 \\
\hline CRO4 & 300 & 400 \\
\hline CRS1 & 0 & 8 \\
\hline CRU1 & 0 & 250 \\
\hline Lama \#10 & 0 & 100 \\
\hline Lama \#40 & 0 & 100 \\
\hline
\end{tabular}

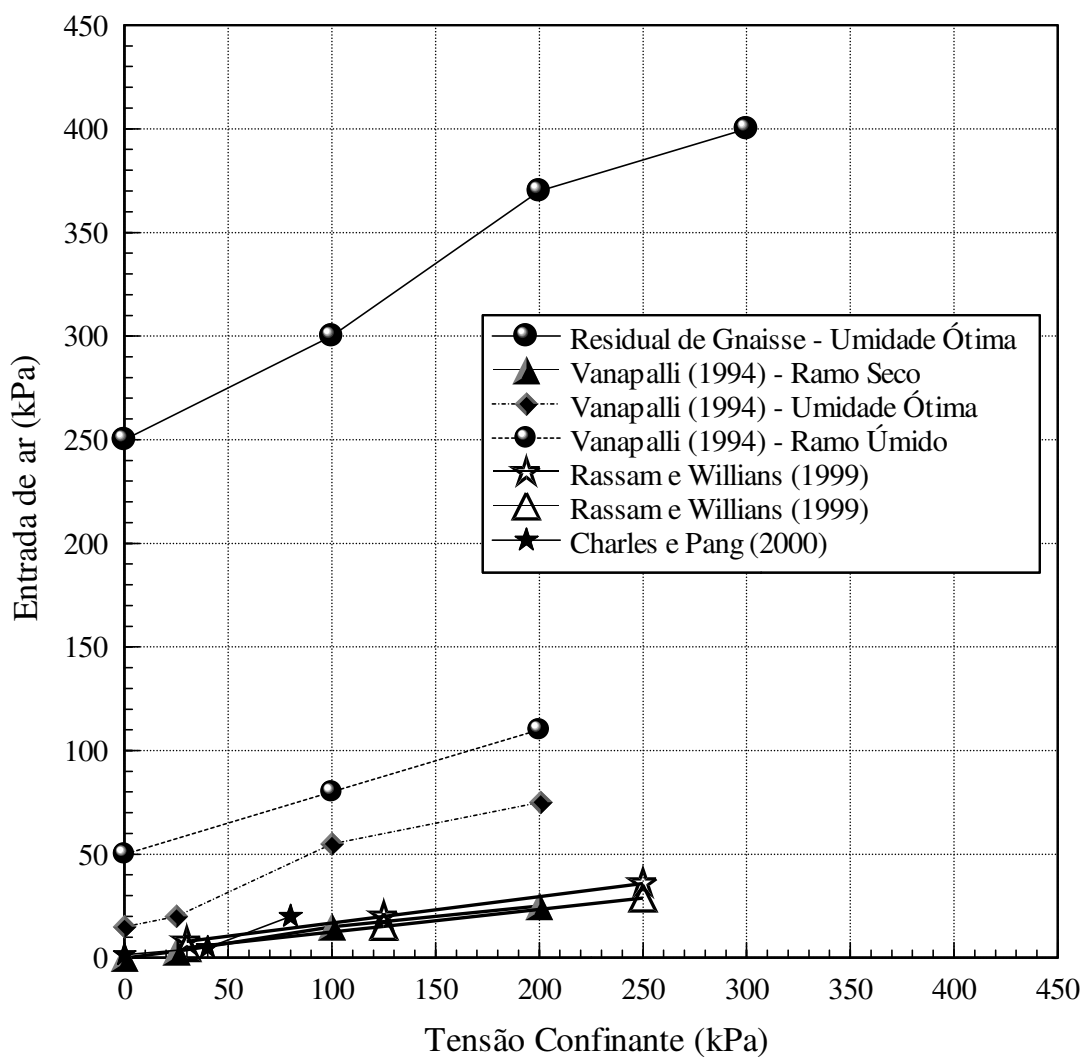

Figura 5.40 - Relações entre a entrada de ar e a tensão confinante obtidas para os ensaios desta pesquisa e encontrados na literatura. 


\section{6 - RESUltados DOS ENSAIOS DE RESISTENCIA AO CISALHAMENTO}

Neste capítulo são apresentados os resultados dos ensaios de resistência ao cisalhamento descritos no item 4.11. Com o objetivo de se ter uma melhor visualização de todas as etapas seguidas para a realização de cada tipo de ensaio, optou-se por se apresentar neste capítulo os dados de moldagem e preparação dos corpos de prova juntamente com os seus respectivos resultados de resistência. Inicialmente são apresentados os resultados dos ensaios de compressão simples, realizados para a investigação de diferentes procedimentos de preparação dos corpos de prova e de execução dos ensaios. Nos itens subseqüentes são apresentados os resultados dos ensaios triaxiais saturados e não saturados.

\section{1 - Resultados dos ensaios de compressão simples}

Estes ensaios foram realizados para as três condições de moldagem dadas na Tabela 4.2. Devido à maior facilidade de execução, os mesmos foram planejados para se investigar diferentes aspectos da resistência do solo, relacionados ao tipo de carregamento aplicado na fase de cisalhamento e à trajetória de umidade seguida na preparação do corpo de prova.

Conforme a descrição dos procedimentos de ensaio apresentados no item 4.11.2, entre o tensiômetro e o corpo de prova deve ser colocada uma pasta de solo para proporcionar uma continuidade hidráulica entre ambos. Com o objetivo de se verificar o efeito da compressibilidade da pasta durante a fase de cisalhamento, foram realizados ensaios com deformação controlada e com carregamento controlado. 
Para as condições de moldagem na umidade ótima foram realizados ensaios com deformação controlada aplicando-se diferentes velocidades na fase de cisalhamento. Nestes ensaios foi analisada a influência da velocidade nas variações da sucção do corpo de prova.

Nas Tabela 6.1 a 6.3 estão apresentados, para os ensaios de compressão simples realizados nesta pesquisa, o tipo de carregamento utilizado na etapa de cisalhamento e o número de corpos de prova ensaiados, com as respectivas trajetórias de umidade impostas na etapa de preparação. Na última coluna destas tabelas é apresentado um resumo dos tipos de resultados obtidos. Os objetivos destes ensaios foram apresentados na Tabela 4.14.

Tabela 6.1 - Tipos de ensaios de compressão simples e resultados obtidos para a condição de moldagem na umidade ótima.

\begin{tabular}{|c|c|c|c|c|}
\hline \multicolumn{5}{|c|}{ UMIDADE ÓTIMA } \\
\hline $\begin{array}{c}\text { Tipo de } \\
\text { carregamento }\end{array}$ & Item & $\begin{array}{l}\mathrm{N}^{\mathrm{o}} \mathrm{de} \\
\text { C.P. }\end{array}$ & $\begin{array}{l}\text { Trajetória } \\
\text { de umidade }\end{array}$ & Resultados obtidos \\
\hline $\begin{array}{l}\text { Deformação } \\
\text { Controlada }\end{array}$ & 6.1 .1 & 22 & $\begin{array}{l}5 \text { C.P. - Traj. } 3 \\
17 \text { C.P - Traj. } 4\end{array}$ & $\begin{array}{l}\text { - Sucção inicial determinada com o P.F.para } \\
\text { todos os C.P. } \\
\text { - Suçãão inicial e na ruptura determinada } \\
\text { com o tensiômetro (medição da variação da } \\
\text { sucção durante o ensaio) para } 6 \text { C.P. } \\
\text { - Gráficos de tensão versus deformação. } \\
\end{array}$ \\
\hline $\begin{array}{l}\text { Deformação } \\
\text { Controlada }\end{array}$ & 6.1 .2 & 5 & 5 & $\begin{array}{l}\text {-Sucção inicial determinada com o P.F. para } \\
\text { todos os C.P. } \\
\text { •Suçãa inicial e na ruptura determinada } \\
\text { com o tensiômetro (medida da variação da } \\
\text { sucção durante o ensaio) para todos os C.P. } \\
\text { - Gráficos de tensão. versus deformação } \\
\end{array}$ \\
\hline $\begin{array}{l}\text { Deformação } \\
\text { Controlada }\end{array}$ & 6.1 .4 & 6 & $\begin{array}{l}\text { Umidade de } \\
\text { moldagem }\end{array}$ & $\begin{array}{l}\text {-Sucção inicial determinada com o P.F. para } \\
\text { todos os C.P. } \\
\text {-Suç̧ão inicial e na ruptura determinada } \\
\text { com o tensiômetro (medida da variação da } \\
\text { sucção durante o ensaio) para todos os C.P. } \\
\text { - Gráfico de tensão. versus deformação para } \\
\text { diferentes velocidades de cisalhamento. }\end{array}$ \\
\hline $\begin{array}{c}\text { Carregamento } \\
\text { Controlado }\end{array}$ & 6.1 .3 & 8 & $\begin{array}{l}4 \text { C.P. - Traj. } 3 \\
4 \text { C.P. - Traj. } 4\end{array}$ & $\begin{array}{l}\text {-Sucção inicial determinada com o P.F. para } \\
\text { todos os C.P. } \\
\text { •Suçãa inicial e na ruptura determinada } \\
\text { com o tensiômetro (medida da variação da } \\
\text { sucção durante o ensaio) para todos os C.P. } \\
\text { • gráficos de tensão. versus deformação } \\
\end{array}$ \\
\hline
\end{tabular}


Tabela 6.2 - Tipos de ensaios de compressão simples e resultados obtidos para a condição de moldagem no ramo seco.

\begin{tabular}{|c|c|c|c|c|}
\hline \multicolumn{5}{|c|}{ RAMO SECO } \\
\hline $\begin{array}{c}\text { Tipo de } \\
\text { carregamento }\end{array}$ & Item & $\begin{array}{l}\mathrm{N}^{\mathrm{o}} \mathrm{de} \\
\text { C.P. }\end{array}$ & $\begin{array}{c}\text { Trajetória } \\
\text { de umidade }\end{array}$ & Resultados obtidos \\
\hline $\begin{array}{l}\text { Deformação } \\
\text { Controlada }\end{array}$ & 6.1 .1 & 15 & $\begin{array}{l}9 \text { C.P. - Traj. } 3 \\
6 \text { C.P. - Traj. } 4\end{array}$ & $\begin{array}{l}\text { - Sucção inicial determinada com o P.F. para } \\
\text { todos os C.P. } \\
\text {-Sucção inicial e na ruptura determinada } \\
\text { com o tensiômetro (medida da variação da } \\
\text { sucção durante o ensaio) para } 8 \text { C.P. } \\
\text { - Gráficos de tensão. versus deformação. }\end{array}$ \\
\hline $\begin{array}{l}\text { Deformação } \\
\text { Controlada }\end{array}$ & 6.1 .2 & 5 & 5 & $\begin{array}{l}\text { - Sucção inicial determinada com o P.F. para } \\
\text { todos os C.P. } \\
\text {-Sucção inicial e na ruptura determinada } \\
\text { com o tensiômetro (medida da variação da } \\
\text { sucção durante o ensaio) para todos os C.P. } \\
\text { - Gráficos de tensão. versus deformação }\end{array}$ \\
\hline $\begin{array}{l}\text { Carregamento } \\
\text { Controlado }\end{array}$ & 6.1 .3 & 6 & 6 C.P. - Traj. 3 & $\begin{array}{l}\text { - Sucção inicial determinada com o P.F. para } \\
\text { todos os C.P. } \\
\text {-Sucção inicial e na ruptura determinada } \\
\text { com o tensiômetro (medida da variação da } \\
\text { sucção durante o ensaio) para todos os C.P. } \\
\text { - Gráficos de tensão. versus deformação }\end{array}$ \\
\hline
\end{tabular}

Tabela 6.3 - Tipos de ensaios de compressão simples e de resultados obtidos para a condição de moldagem no ramo úmido.

\begin{tabular}{|c|c|c|c|c|}
\hline \multicolumn{5}{|c|}{ RAMO ÚMIDO } \\
\hline $\begin{array}{c}\text { Tipo de } \\
\text { carregamento }\end{array}$ & Item & $\begin{array}{l}\mathrm{N}^{\mathrm{o}} \mathrm{de} \\
\text { C.P. }\end{array}$ & $\begin{array}{c}\text { Trajetória } \\
\text { de umidade }\end{array}$ & Resultados obtidos \\
\hline $\begin{array}{c}\text { Deformação } \\
\text { Controlada }\end{array}$ & 6.1 .1 & 17 & $\begin{array}{c}3 \text { C.P. - Traj. } 3 \\
14 \text { C.P. - Traj. } 4\end{array}$ & $\begin{array}{l}\text { - Sucção inicial determinada com o P.F. para } \\
\text { todos os C.P. } \\
\text { - Sucção inicial e na ruptura determinada } \\
\text { com o tensiômetro (medida da variação da } \\
\text { sucção durante o ensaio) para } 8 \text { C.P. } \\
\text { - Gráficos de tensão versus deformação. }\end{array}$ \\
\hline $\begin{array}{l}\text { Deformação } \\
\text { Controlada }\end{array}$ & 6.1 .2 & 5 & 5 & $\begin{array}{l}\text { - Sucção inicial determinada com o P.F. para } \\
\text { todos os C.P. } \\
\text {-Sucção inicial e na ruptura determinada } \\
\text { com o tensiômetro (medida da variação da } \\
\text { sucção durante o ensaio) para todos os C.P. } \\
\text { - Gráficos de tensão. versus deformação }\end{array}$ \\
\hline & & & & $\begin{array}{l}\text { - Sucção inicial determinada com o P.F. para } \\
\text { todos os C.P. }\end{array}$ \\
\hline $\begin{array}{l}\text { Carregamento } \\
\text { Controlado }\end{array}$ & 6.1 .3 & 6 & $\begin{array}{l}1 \text { C.P. - Traj. } 3 \\
5 \text { C.P. - Traj. } 4\end{array}$ & $\begin{array}{l}\text { - Sucção inicial e na ruptura determinada } \\
\text { com o tensiômetro (medida da variação da } \\
\text { sucção durante o ensaio) para todos os C.P. } \\
\text { - Envoltória de ruptura - q versus sucção }\end{array}$ \\
\hline
\end{tabular}


Os diferentes tipos de ensaio serão apresentados separadamente nos itens seguintes, em função das trajetórias de umidade seguida na preparação dos corpos de prova e do tipo de carregamento empregado na fase de cisalhamento.

\subsection{1 - Ensaios com deformação controlada realizados em corpos de prova que foram umedecidos ou secados (trajetórias 3 e 4).}

As trajetórias de umidade 3 e 4, impostas a estes corpos de prova na fase de preparação para o ensaio, podem ser visualizadas na Figura 4.9. Nas Tabelas 6.4, 6.5 e 6.6 estão apresentados os dados iniciais de moldagem, os dados após umedecimento ou secagem e os resultados dos ensaios realizados nas condições de moldagem definidas na Tabela 4.2. Fazem parte dos resultados dos ensaios o valor da sucção inicial determinada com o papel filtro, a sucção inicial e na ruptura medida com o tensiômetro. Além destes valores de sucção, os resultados apresentam o valor de q, p e os valores do módulo de deformabilidade tangente e das deformações axiais na ruptura. Os valores de q e p correspondem ao ponto de máxima ordenada do círculo de Mohr na ruptura, representado pelas seguintes equações:

$$
\begin{aligned}
& q=\frac{\left(\sigma_{1}-\sigma_{3}\right)}{2} \\
& p=\frac{\left(\sigma_{1}+\sigma_{3}\right)}{2}
\end{aligned}
$$

Das Tabelas 6.4. 6.5 e 6.6 observa-se que os valores iniciais de sucção obtidos com o papel filtro, independentemente do ponto de estudo ( $\mathrm{O}, \mathrm{S}$ ou $\mathrm{U})$, são sempre superiores aos valores obtidos com o tensiômetro. No capítulo 7 são analisados os valores das sucções obtidas ao se utilizar diferentes técnicas e equipamentos. 
Tabela 6.4 - Condições iniciais de moldagem, preparação dos corpos de prova e resultados dos ensaios de compressão simples realizados com deformação controlada (Ponto O).

\begin{tabular}{|c|c|c|c|c|c|c|c|c|c|c|c|c|c|c|c|c|c|}
\hline \multicolumn{6}{|c|}{ MOLDAGEM } & \multicolumn{6}{|c|}{ PREPARAÇÃO } & \multicolumn{6}{|c|}{ RESULTADOS } \\
\hline C.P. & $\begin{array}{l}\mathrm{W} \\
(\%)\end{array}$ & $\mathrm{e}$ & $\begin{array}{c}S \\
(\%)\end{array}$ & $\begin{array}{c}\theta_{\mathrm{w}} \\
(\%)\end{array}$ & $\begin{array}{c}\rho_{\mathrm{d}} \\
\left(\mathrm{g} / \mathrm{cm}^{3}\right)\end{array}$ & Traj. & $\begin{array}{l}\mathrm{W} \\
(\%)\end{array}$ & $\mathrm{e}$ & $\begin{array}{c}\mathrm{S} \\
(\%)\end{array}$ & $\begin{array}{c}\theta_{\mathrm{w}} \\
(\%)\end{array}$ & $\begin{array}{c}\rho_{\mathrm{d}} \\
\left(\mathrm{g} / \mathrm{cm}^{3}\right)\end{array}$ & $\begin{array}{c}\mathrm{q} \\
(\mathrm{kPa})\end{array}$ & $\begin{array}{c}\varepsilon_{\mathrm{f}} \\
(\%)\end{array}$ & $\begin{array}{c}\mathrm{E}_{\mathrm{tg}} \\
(\mathrm{MPa})\end{array}$ & $\begin{array}{l}\text { P.F. } \\
(\mathrm{kPa})\end{array}$ & $\begin{array}{l}\text { Suc. Inic. } \\
\text { Tens.(kPa) }\end{array}$ & $\begin{array}{l}\text { Suc. Rupt. } \\
\text { Tens.(kPa) }\end{array}$ \\
\hline CSO1 & 25.2 & 0.79 & 86.2 & 38.1 & 1.51 & 4 & 24.5 & 0.80 & 82.5 & 36.8 & 1.50 & 113.9 & 3.3 & 8.3 & 157 & --- & --- \\
\hline $\mathrm{CSO} 2$ & 25.2 & 0.80 & 85.0 & 37.9 & 1.50 & 4 & 22.5 & 0.80 & 76.7 & 34.0 & 1.51 & 134.2 & 2.7 & 14.1 & 427 & --- & $\begin{array}{ll}-- \\
--\end{array}$ \\
\hline $\mathrm{CSO} 3$ & 25.2 & 0.80 & 85.0 & 37.9 & 1.50 & 4 & 20.3 & 0.78 & 70.6 & 30.9 & 1.52 & 191.5 & 2.5 & 19.9 & 600 & $-{ }_{---}$ & --- \\
\hline $\mathrm{CSO} 4$ & 25.2 & 0.80 & 85.2 & 37.9 & 1.50 & 4 & 17.2 & 0.76 & 61.2 & 26.5 & 1.54 & 239.1 & 2.4 & 26.0 & 743 & --- & --- \\
\hline CSO5 & 25.2 & 0.81 & 84.0 & 37.7 & 1.49 & 4 & 16.3 & 0.77 & 57.2 & 24.9 & 1.53 & 244.8 & 2.0 & 26.9 & 761 & --- & --- \\
\hline CSO6 & 25.2 & 0.81 & 84.7 & 37.8 & 1.50 & 4 & 14.4 & 0.76 & 51.4 & 22.2 & 1.54 & 280.1 & 2.5 & 29.1 & 963 & --- & --- \\
\hline CSO7 & 25.2 & 0.79 & 86.3 & 38.1 & 1.51 & 4 & 11.4 & 0.76 & 40.5 & 17.5 & 1.54 & 286.7 & 2.2 & 31.0 & 1583 & --- & --- \\
\hline CSO8 & 25.2 & 0.79 & 86.2 & 38.1 & 1.51 & 4 & 8.4 & 0.77 & 29.6 & 12.8 & 1.53 & 271.2 & 1.9 & 33.8 & 1855 & --- & --- \\
\hline CSO9 & 25.2 & 0.80 & 85.0 & 37.9 & 1.50 & 4 & 5.9 & 0.77 & 21.0 & 9.1 & 1.53 & 262.3 & 1.9 & 36.1 & 3312 & --- & --- \\
\hline CSO10 & 25.2 & 0.80 & 85.4 & 38.0 & 1.51 & 4 & 24.5 & 0.80 & 83.2 & 37.0 & 1.51 & 103.5 & 3.5 & 8.0 & 125 & --- & --- \\
\hline CSO11 & 25.2 & 0.78 & 88.1 & 38.5 & 1.53 & 4 & 24.5 & 0.77 & 86.5 & 37.6 & 1.53 & 120.4 & 3.3 & 8.8 & 117 & --- & --- \\
\hline CSO12 & 25.2 & 0.77 & 88.2 & 38.5 & 1.53 & 3 & 27.7 & 0.81 & 93.3 & 41.6 & 1.50 & 58.0 & 5.5 & 1.8 & 23 & --- & --- \\
\hline $\mathrm{CSO} 13$ & 25.3 & 0.79 & 86.8 & 38.3 & 1.51 & 3 & 28.6 & 0.86 & 89.9 & 41.6 & 1.45 & 41.6 & 5.3 & 1.8 & 22 & 12.5 & 28.1 \\
\hline CSO14 & 25.3 & 0.77 & 88.6 & 38.7 & 1.53 & 3 & 27.4 & 0.83 & 89.7 & 40.6 & 1.48 & 55.6 & 6.0 & 2.5 & 39 & 21.4 & 41.1 \\
\hline CSO15 & 25.3 & 0.78 & 87.9 & 38.5 & 1.52 & 3 & 26.4 & 0.81 & 88.4 & 39.6 & 1.50 & 67.6 & 5.1 & 3.5 & 55 & 29.4 & 47.8 \\
\hline CSO16 & 25.3 & 0.77 & 88.9 & 38.7 & 1.53 & 3 & 25.5 & 0.79 & 87.7 & 38.6 & 1.52 & 83.7 & 4.8 & 4.9 & 126 & 37.8 & 67.5 \\
\hline CSO17 & 25.3 & 0.79 & 87.0 & 38.4 & 1.52 & 4 & 24.4 & 0.78 & 85.3 & 37.3 & 1.53 & 104.1 & 4.3 & 7.4 & 300 & 81.1 & 87.8 \\
\hline CSO18 & 25.3 & 0.78 & 87.7 & 38.5 & 1.52 & 4 & 23.6 & 0.76 & 83.5 & 36.2 & 1.54 & 121.1 & 4.1 & 8.9 & 400 & 132.2 & 109.5 \\
\hline CSO19 & 25.3 & 0.77 & 89.2 & 38.8 & 1.53 & 4 & 4.3 & 0.74 & 15.9 & 6.7 & 1.56 & 284.9 & 2.2 & 38.4 & 6267 & --- & --- \\
\hline $\mathrm{CSO} 20$ & 25.3 & 0.78 & 87.8 & 38.5 & 1.52 & 4 & 2.9 & 0.75 & 10.4 & 4.4 & 1.55 & 259.0 & 1.9 & 38.4 & 8775 & --- & --- \\
\hline $\mathrm{CSO} 21$ & 25.3 & 0.76 & 90.4 & 39.0 & 1.54 & 4 & 2.3 & 0.74 & 8.3 & 3.5 & 1.56 & 272.3 & 2.0 & 40.1 & 10643 & --- & --- \\
\hline $\mathrm{CSO} 22$ & 25.3 & 0.78 & 88.0 & 38.6 & 1.52 & 4 & 2.0 & 0.74 & 7.4 & 3.2 & 1.56 & 262.9 & 1.9 & 37.2 & 12021 & --- & --- \\
\hline
\end{tabular}

trajetótia 3 - umedecimento, trajetória 4 - secagem, q - tensão desviadora dividida por dois, $\varepsilon_{\mathrm{f}}$ - deformação na ruptura, P.F. - Sucção obtida com o papel filtro 
Tabela 6.5 - Condições iniciais de moldagem, preparação dos corpos de prova e resultados dos ensaios de compressão simples realizados com deformação controlada (Ponto S).

\begin{tabular}{|c|c|c|c|c|c|c|c|c|c|c|c|c|c|c|c|c|c|}
\hline \multicolumn{6}{|c|}{ MOLDAGEM } & \multicolumn{6}{|c|}{ PREPARAÇÃO } & \multicolumn{6}{|c|}{ RESULTADOS } \\
\hline C.P. & $\begin{array}{l}\mathrm{W} \\
(\%)\end{array}$ & $\mathrm{e}$ & $\begin{array}{c}\mathrm{S} \\
(\%)\end{array}$ & $\begin{array}{c}\theta_{\mathrm{w}} \\
(\%)\end{array}$ & $\begin{array}{c}\rho_{\mathrm{d}} \\
\left(\mathrm{g} / \mathrm{cm}^{3}\right)\end{array}$ & Traj. & $\begin{array}{c}\mathrm{W} \\
(\%) \\
\end{array}$ & $\mathrm{e}$ & $\begin{array}{c}\mathrm{S} \\
(\%)\end{array}$ & $\begin{array}{c}\theta_{\mathrm{w}} \\
(\%)\end{array}$ & $\begin{array}{c}\rho_{\mathrm{d}} \\
\left(\mathrm{g} / \mathrm{cm}^{3}\right)\end{array}$ & $\begin{array}{c}\mathrm{q} \\
(\mathrm{kPa})\end{array}$ & $\begin{array}{c}\varepsilon_{\mathrm{f}} \\
(\%)\end{array}$ & $\begin{array}{c}\mathrm{E}_{\mathrm{tg}} \\
(\mathrm{MPa})\end{array}$ & $\begin{array}{l}\text { P.F. } \\
(\mathrm{kPa})\end{array}$ & $\begin{array}{l}\text { Suc. Inic. } \\
\text { Tens.(kPa) }\end{array}$ & $\begin{array}{l}\text { Suc. Rupt. } \\
\text { Tens.(kPa) }\end{array}$ \\
\hline CSS1 & 17.5 & 0.85 & 56.1 & 25.7 & 1.47 & 3 & 30.7 & 0.97 & 85.5 & 42.1 & 1.37 & 21.8 & 5.6 & 0.8 & 15 & 9.4 & 15.8 \\
\hline $\mathrm{CSS} 2$ & 17.5 & 0.85 & 55.8 & 25.6 & 1.46 & 3 & 28.8 & 0.96 & 80.9 & 39.7 & 1.38 & 25.2 & 4.2 & 1.6 & 22 & 14.2 & 17.7 \\
\hline CSS3 & 17.5 & 0.85 & 55.8 & 25.6 & 1.47 & 3 & 28.3 & 0.95 & 80.9 & 39.4 & 1.39 & 25.3 & 4.7 & 1.4 & 22 & 16.7 & 20.0 \\
\hline CSS4 & 17.5 & 0.85 & 55.6 & 25.6 & 1.46 & 3 & 26.4 & 0.94 & 76.0 & 36.9 & 1.39 & 29.8 & 3.9 & 1.9 & 34 & 24.5 & 25.3 \\
\hline CSS5 & 17.5 & 0.84 & 56.2 & 25.7 & 1.47 & 3 & 25.4 & 0.93 & 74.2 & 35.7 & 1.41 & 34.9 & 3.2 & 2.2 & 46 & 30.6 & 31.3 \\
\hline CSS6 & 17.5 & 0.85 & 55.8 & 25.6 & 1.47 & 3 & 23.6 & 0.91 & 70.1 & 33.5 & 1.42 & 44.6 & 3.4 & 3.0 & 79 & 46.7 & 46.3 \\
\hline CSS7 & 17.5 & 0.84 & 56.3 & 25.7 & 1.47 & 3 & 22.3 & 0.90 & 67.5 & 31.9 & 1.43 & 51.0 & 3.0 & 3.7 & 116 & 63.3 & 59.3 \\
\hline CSS8 & 17.5 & 0.86 & 54.9 & 25.4 & 1.45 & 3 & 19.7 & 0.89 & 60.0 & 28.2 & 1.44 & 79.5 & 2.9 & 6.1 & 198 & 123.9 & 119.1 \\
\hline CSS9 & 17.5 & 0.86 & 55.1 & 25.5 & 1.46 & 3 & 18.1 & 0.88 & 56.0 & 26.2 & 1.44 & 91.1 & 1.8 & 10.3 & 306 & --- & --- \\
\hline $\mathrm{CSS} 10$ & 17.5 & 0.84 & 56.4 & 25.8 & 1.47 & 4 & 12.5 & 0.84 & 40.4 & 18.4 & 1.48 & 188.5 & 1.8 & 26.1 & 878 & --- & --- \\
\hline CSS11 & 17.5 & 0.84 & 56.6 & 25.8 & 1.47 & 4 & 9.2 & 0.83 & 30.1 & 13.7 & 1.48 & 173.7 & 1.7 & 25.6 & 1179 & --- & --- \\
\hline $\mathrm{CSS} 12$ & 17.5 & 0.85 & 56.0 & 25.7 & 1.47 & 4 & 7.3 & 0.85 & 23.4 & 10.7 & 1.47 & 162.5 & 1.5 & 23.7 & 1682 & --- & --- \\
\hline CSS13 & 17.5 & 0.84 & 56.2 & 25.7 & 1.47 & 4 & 6.1 & 0.84 & 19.7 & 9.0 & 1.48 & 163.3 & 1.5 & 22.4 & 2046 & --- & --- \\
\hline CSS14 & 17.5 & 0.83 & 56.9 & 25.9 & 1.48 & 4 & 4.8 & 0.83 & 15.8 & 7.2 & 1.48 & 157.3 & 1.6 & 23.5 & 2540 & --- & --- \\
\hline CSS15 & 17.5 & 0.85 & 56.0 & 25.7 & 1.47 & 4 & 3.6 & 0.85 & 11.5 & 5.3 & 1.47 & 153.7 & 1.5 & 23.7 & 3975 & --- & --- \\
\hline
\end{tabular}

trajetótia 3 - umedecimento, trajetória 4 - secagem, q - tensão desviadora dividida por dois, $\varepsilon_{\mathrm{f}}$ - deformação na ruptura, P.F. - Sucção obtida com o papel filtro 
Tabela 6.6 - Condições iniciais de moldagem, preparação dos corpos de prova e resultados dos ensaios de compressão simples realizados com deformação controlada (Ponto U).

\begin{tabular}{|c|c|c|c|c|c|c|c|c|c|c|c|c|c|c|c|c|c|}
\hline \multicolumn{6}{|c|}{ MOLDAGEM } & \multicolumn{6}{|c|}{ PREPARAÇÃO } & \multicolumn{6}{|c|}{ RESULTADOS } \\
\hline C.P. & $\begin{array}{c}\mathrm{W} \\
(\%) \\
\end{array}$ & e & $\begin{array}{c}\mathrm{S} \\
(\%) \\
\end{array}$ & $\begin{array}{c}\theta_{\mathrm{w}} \\
(\%)\end{array}$ & $\begin{array}{c}\rho_{\mathrm{d}} \\
\left(\mathrm{g} / \mathrm{cm}^{3}\right)\end{array}$ & Traj. & $\begin{array}{c}\mathrm{W} \\
(\%) \\
\end{array}$ & e & $\begin{array}{c}\mathrm{S} \\
(\%) \\
\end{array}$ & $\begin{array}{c}\theta_{\mathrm{w}} \\
(\%)\end{array}$ & $\begin{array}{c}\rho_{\mathrm{d}} \\
\left(\mathrm{g} / \mathrm{cm}^{3}\right)\end{array}$ & $\begin{array}{c}\mathrm{q} \\
(\mathrm{kPa})\end{array}$ & $\begin{array}{c}\varepsilon_{\mathrm{f}} \\
(\%)\end{array}$ & $\begin{array}{c}\mathrm{E}_{\mathrm{tg}} \\
(\mathrm{MPa})\end{array}$ & $\begin{array}{l}\text { P.F. } \\
(\mathrm{kPa})\end{array}$ & $\begin{array}{l}\text { Suc. Inic. } \\
\text { Tens.(kPa) }\end{array}$ & $\begin{array}{l}\text { Suc. Rupt. } \\
\text { Tens.(kPa) }\end{array}$ \\
\hline CSU1 & 28.0 & 0.85 & 89.6 & 41.1 & 1.47 & 3 & 29.9 & 0.89 & 90.9 & 42.8 & 1.43 & 35.8 & 7.4 & 0.8 & 13 & 9.2 & 26.2 \\
\hline CSU2 & 28.0 & 0.84 & 90.6 & 41.3 & 1.48 & 3 & 29.0 & 0.86 & 91.1 & 42.2 & 1.46 & 47.0 & 6.6 & 1.6 & 21 & 14.7 & 35.0 \\
\hline CSU3 & 28.0 & 0.84 & 89.7 & 41.1 & 1.47 & 3 & 28.1 & 0.86 & 89.0 & 41.1 & 1.46 & 59.0 & 6.7 & 1.4 & 35 & 24.5 & 44.7 \\
\hline CSU4 & 28.0 & 0.84 & 90.5 & 41.2 & 1.48 & 4 & 27.1 & 0.82 & 89.1 & 40.2 & 1.49 & 77.1 & 5.6 & 1.9 & 91 & 54.5 & 64.5 \\
\hline CSU5 & 28.0 & 0.84 & 90.5 & 41.2 & 1.48 & 4 & 26.6 & 0.83 & 86.8 & 39.4 & 1.48 & 76.1 & 5.2 & 2.2 & 71 & 46.4 & 60.0 \\
\hline CSU6 & 28.0 & 0.84 & 90.0 & 41.1 & 1.47 & 4 & 25.2 & 0.81 & 83.9 & 37.6 & 1.49 & 107.9 & 4.9 & 3.0 & 244 & 138.1 & 100.8 \\
\hline CSU7 & 28.0 & 0.84 & 90.1 & 41.2 & 1.47 & 4 & 23.2 & 0.80 & 78.4 & 34.9 & 1.51 & 136.5 & 3.5 & 3.7 & 367 & --- & --- \\
\hline CSU8 & 28.0 & 0.85 & 89.2 & 41.0 & 1.47 & 4 & 21.2 & 0.79 & 72.7 & 32.1 & 1.51 & 179.9 & 4.0 & 6.1 & 517 & --- & --- \\
\hline CSU9 & 28.0 & 0.84 & 89.8 & 41.1 & 1.47 & 4 & 17.4 & 0.78 & 60.7 & 26.5 & 1.53 & 236.2 & 3.5 & 10.3 & 613 & --- & --- \\
\hline CSU10 & 28.0 & 0.84 & 90.0 & 41.1 & 1.47 & 4 & 15.7 & 0.77 & 54.8 & 23.9 & 1.53 & 255.6 & 3.2 & 26.1 & 695 & --- & --- \\
\hline CSU11 & 28.0 & 0.85 & 89.4 & 41.0 & 1.47 & 4 & 13.2 & 0.77 & 46.5 & 20.2 & 1.53 & 243.8 & 3.1 & 25.6 & 821 & --- & --- \\
\hline CSU12 & 28.0 & 0.84 & 90.0 & 41.1 & 1.47 & 4 & 9.5 & 0.77 & 33.2 & 14.5 & 1.53 & 251.5 & 2.7 & 23.7 & 1192 & --- & --- \\
\hline CSU13 & 28.0 & 0.85 & 89.5 & 41.0 & 1.47 & 4 & 8.2 & 0.78 & 28.5 & 12.4 & 1.53 & 215.0 & 2.4 & 22.4 & 1256 & --- & --- \\
\hline CSU14 & 28.0 & 0.84 & 90.3 & 41.2 & 1.47 & 4 & 6.2 & 0.77 & 21.7 & 9.5 & 1.53 & 247.2 & 2.4 & 23.5 & 1897 & --- & --- \\
\hline CSU15 & 28.0 & 0.84 & 89.8 & 41.1 & 1.47 & 4 & 4.7 & 0.78 & 16.1 & 7.1 & 1.52 & 213.5 & 2.1 & 23.7 & 2637 & --- & --- \\
\hline CSU16 & 28.0 & 0.86 & 88.7 & 40.9 & 1.46 & 4 & 25.9 & 0.84 & 83.4 & 38.1 & 1.47 & 92.6 & 4.6 & 64.7 & 325 & 107.0 & 90.0 \\
\hline CSU17 & 28.0 & 0.85 & 88.9 & \begin{tabular}{|l|}
40.9 \\
\end{tabular} & 1.46 & 4 & 26.7 & 0.84 & 86.0 & 39.3 & 1.47 & 86.7 & 4.4 & 55.5 & 174 & 78.0 & 77.0 \\
\hline
\end{tabular}

trajetótia 3 - umedecimento, trajetória 4 - secagem, q - tensão desviadora dividida por dois, $\varepsilon_{\mathrm{f}}$ - deformação na ruptura, P.F. - Sucção obtida com o papel filtro 
Os resultados da variação da tensão desviadora em função da deformação axial, obtidos de corpos de prova moldados na umidade ótima, no ramo seco e no ramo úmido, estão apresentados respectivamente nas Figuras 6.1, 6.2 e 6.3. Para alguns resultados estão indicados os respectivos valores das sucções iniciais determinadas com o papel filtro. Observa-se nestas figuras que quanto maior o valor da sucção inicial, maior será o valor do módulo de deformabilidade tangente e da resistência e menores os valores das deformações axiais na ruptura. Sendo assim, como era de se esperar, o aumento da sucção torna o corpo de prova mais resistente, independentemente de sua condição inicial de moldagem. Para todos os ensaios apresentados nas Figuras 6.1, 6.2 e 6.3 os corpos de prova definem um plano de ruptura, tornando-se mais friáveis com o aumento do valor da sucção inicial.

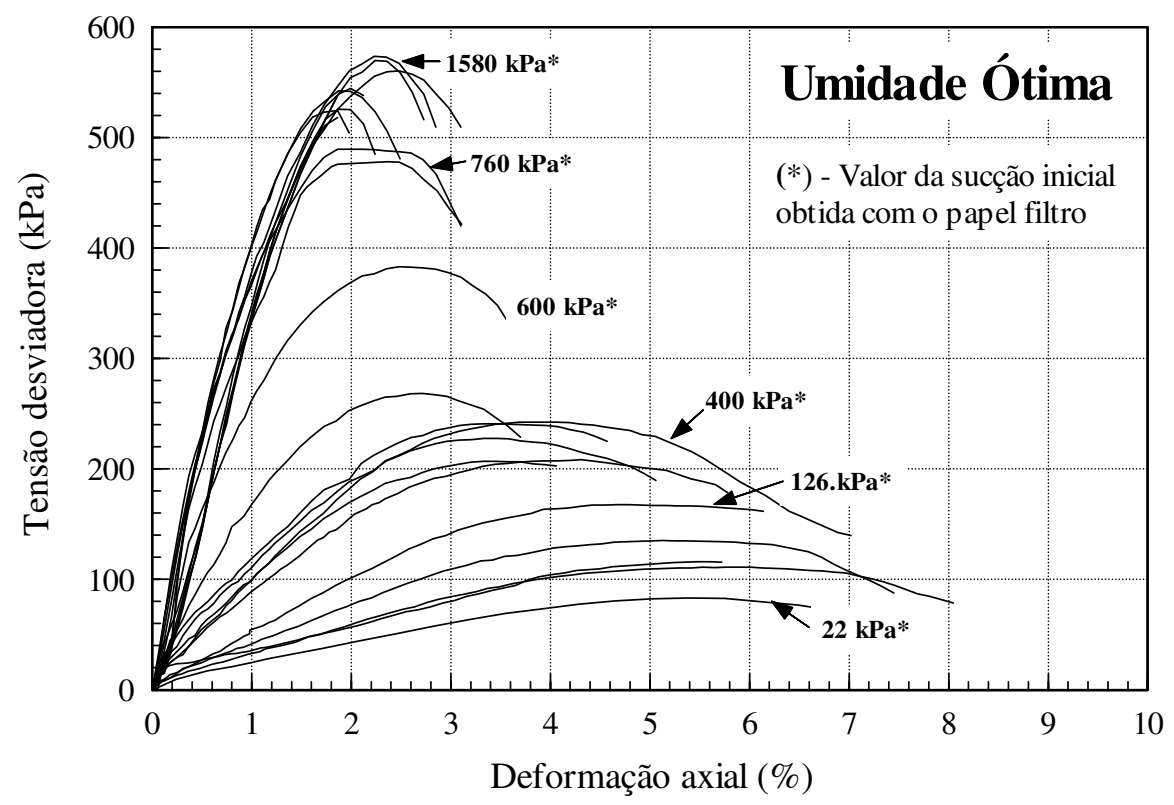

Figura 6.1 - Resultados dos ensaios de compressão simples realizados com deformação controlada em corpos de prova compactados na umidade ótima (Ponto O). 


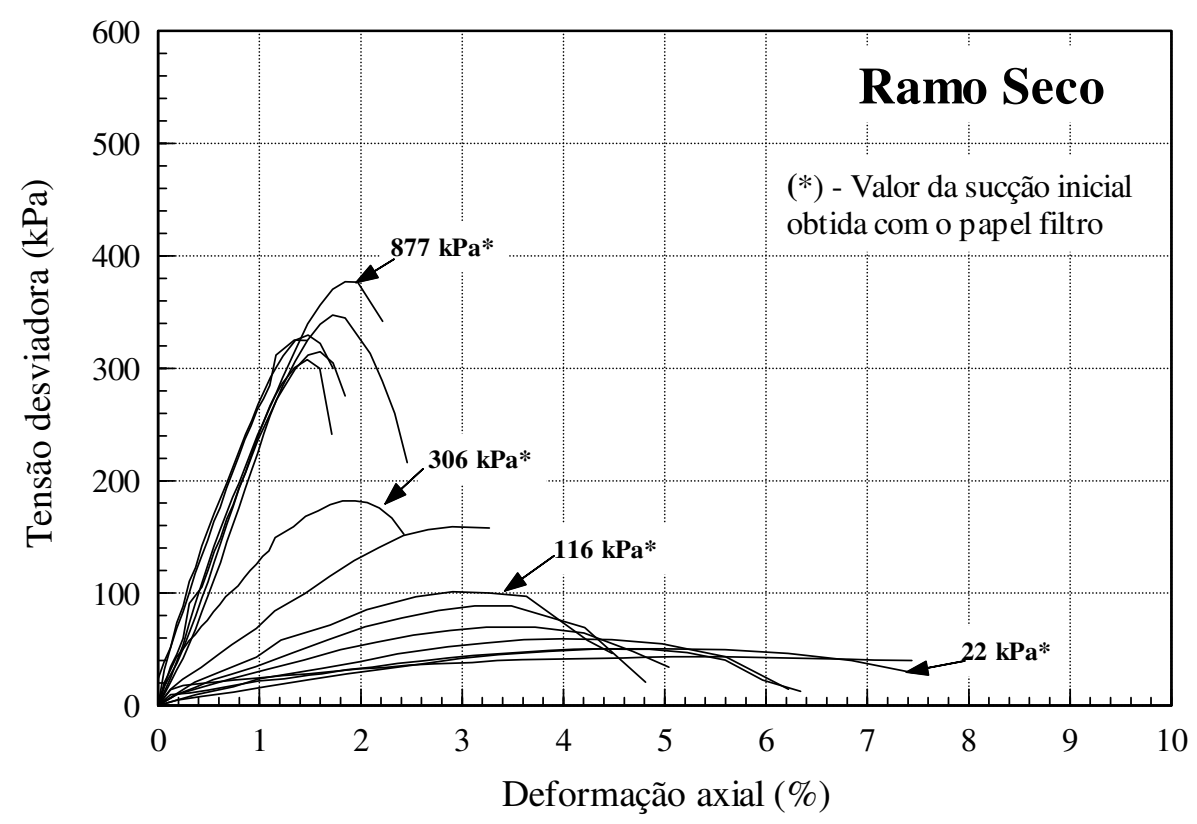

Figura 6.2 - Resultados dos ensaios de compressão simples realizados com deformação controlada em corpos de prova compactados no ramo seco (Ponto S).

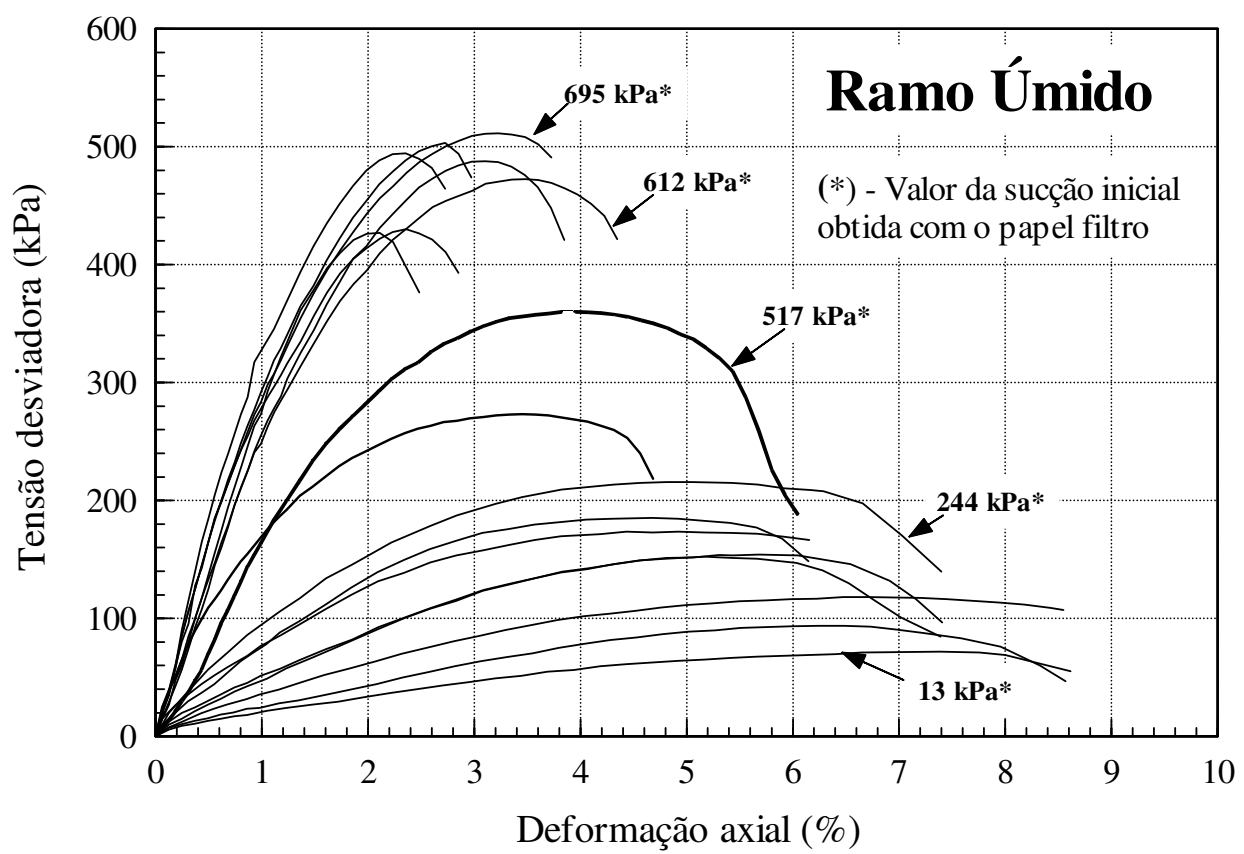

Figura 6.3 - Resultados dos ensaios de compressão simples realizados com deformação controlada em corpos de prova compactados no ramo úmido (Ponto U). 
De acordo com os dados das Tabelas 6.4 a 6.6, tem-se que alguns corpos de prova foram ensaiados com o acompanhamento da variação da sucção medida com o tensiômetro. Os resultados destes ensaios, para as condições de moldagem na umidade ótima, ramo seco e ramo úmido estão apresentados respectivamente nas Figuras 6.4, 6.5 e 6.6. Para cada ensaio de compressão simples, representados pelos símbolos dados nas legendas destas figuras, tem-se na parte (a) os valores da variação da tensão desviadora em função da deformação axial e na parte (b) os valores da variação da sucção em função da deformação axial. Os pontos dos gráficos situados sobre o eixo das ordenadas, correspondente à parte (b) destas figuras, representam os valores da sucção inicial dos corpos de prova, determinados antes do início da etapa de cisalhamento.

Com os resultados dos ensaios realizados em corpos de prova com sucções iniciais semelhantes pode-se comparar as variações da tensão desviadora e da sucção em função da deformação axial, para as três condições de moldagem. Com exemplo temse os resultados dos corpos de prova CSO16 (Figura 6.4), CSS6 (Figura 6.5) e CSU4 (Figura 6.6) que apresentam sucção inicial em torno de $50 \mathrm{kPa}$. Observa-se que entre os corpos de prova moldados na umidade ótima (CSO16) e no ramo úmido (CSU4), as variações das tensões desviadoras e da sucção em função da deformação axial, são semelhantes. No entanto, o corpo de prova moldado no ramo seco (CSS6) apresenta em relação aos demais, uma tensão de ruptura menor. De forma geral observa-se na parte (a) das Figuras 6.4, 6.5 e 6.6 que quanto maior o valor da sucção inicial do corpo de prova, menor é a sua deformação axial na ruptura. Apesar das semelhanças dos resultados observadas entre as Figuras 6.4 e 6.6, constata-se que para a moldagem no ramo úmido as deformações axiais na ruptura (5\% a 7.5\%) são maiores que a apresentada pelos corpos de prova moldados na umidade ótima (4\% a 5\%).

Nas Figuras 6.4b e 6.6b, constata-se que no início dos ensaios ocorre uma pequena redução nos valores de sucção. Após esta redução inicial a sucção passa a aumentar, para deformações axiais inferiores a $2 \%$, tendendo a se estabilizar para valores correspondentes à ruptura do corpo de prova. 
Quanto maior o valor da sucção inicial, maior é a redução da sucção dos corpos de prova no início do ensaio. No entanto, o pequeno aumento da sucção que ocorre em seguida, nem sempre é suficiente para que os corpos de prova rompam com sucção maior que a inicial.

Os corpos de prova moldados no ramo seco apresentam, em relação à moldagem na umidade ótima e no ramo úmido, um comportamento diferente. Para os valares de sucção inicial destes ensaios, as tensões e as deformações axiais na ruptura são menores ( 3 a $5.5 \%$ ), e as variações de sucção durante o ensaio são pequenas. $\mathrm{Na}$ Figura 6.5, observa-se que os corpos de prova com sucção inicial inferiores a $50 \mathrm{kPa}$, rompem praticamente sem variação da sucção. As reduções dos valores da sucção no inicio do cisalhamento, observadas nesta Figura, só ocorrem para os corpos de prova com sucções inciais superiores a $50 \mathrm{kPa}$.
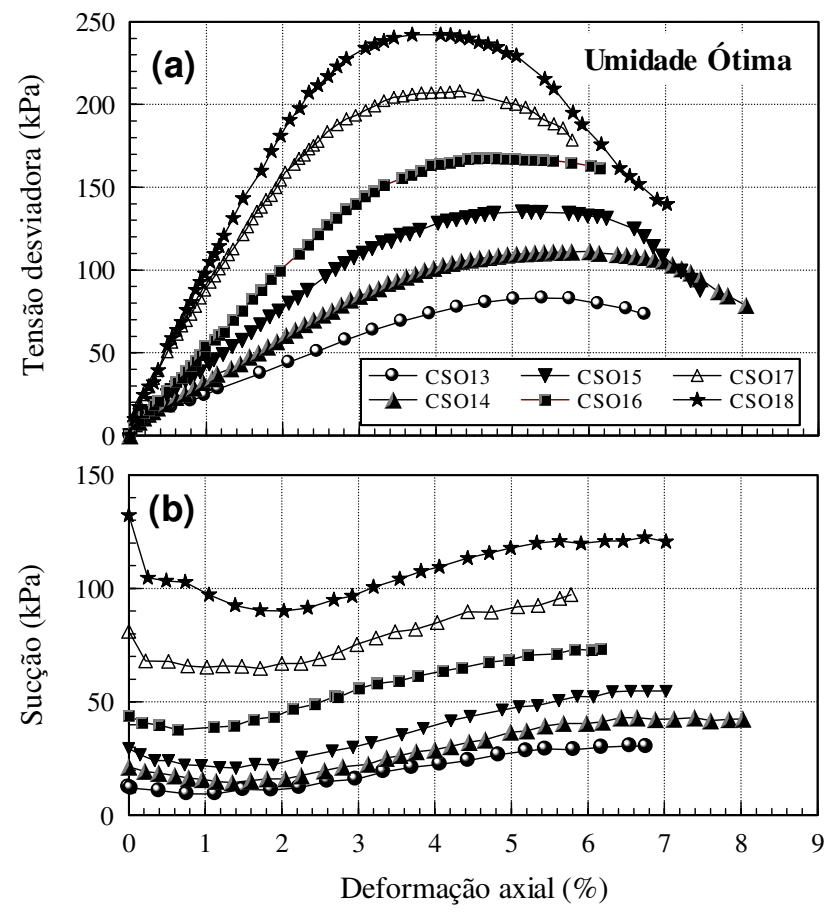

Figura 6.4 - Resultados dos ensaios de compressão simples realizados com deformação controlada utilizando corpos de prova compactados na umidade ótima e preparados por secagem ou umedecimento (ponto $\mathrm{O}$ ). 

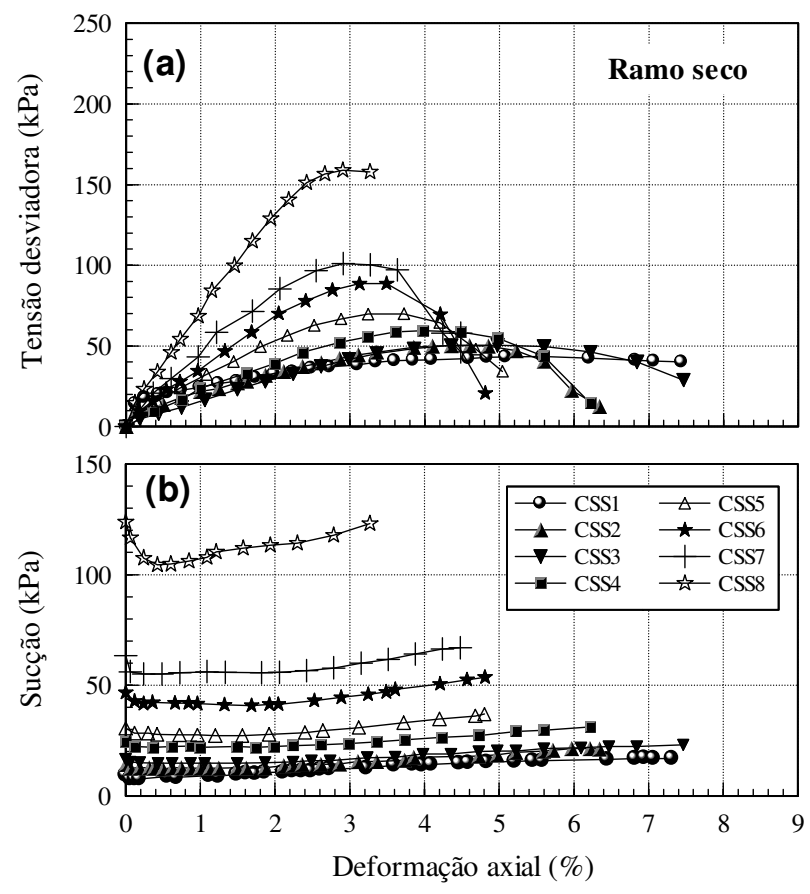

Figura 6.5 - Resultados dos ensaios de compressão simples realizados com deformação controlada utilizando corpos de prova compactados no ramo seco e preparados por secagem ou umedecimento (ponto $S$ ).

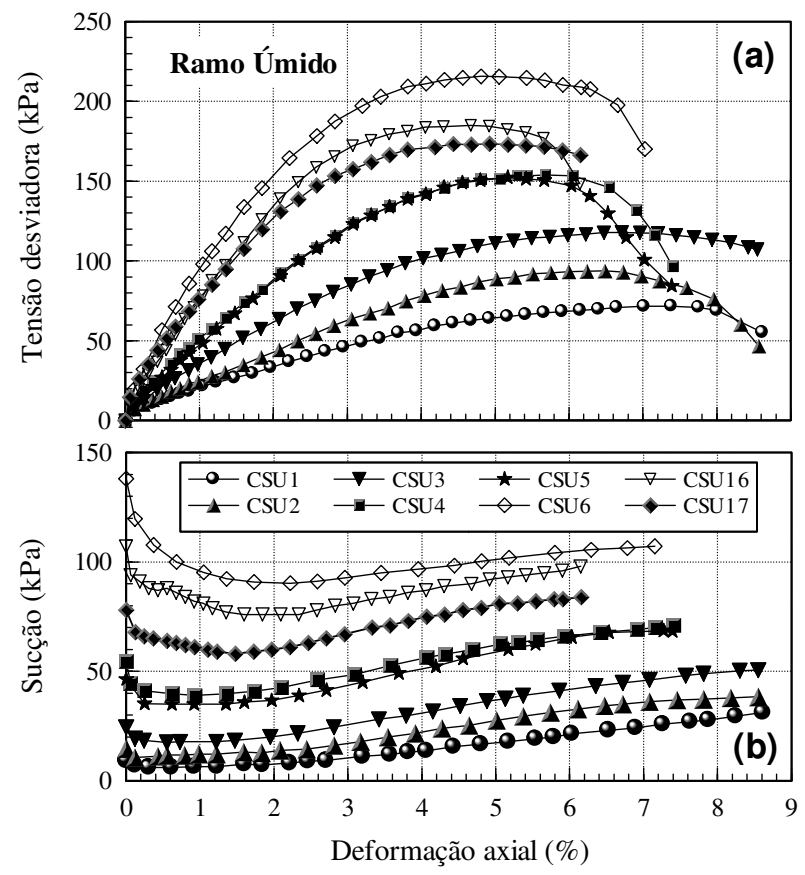

Figura 6.6 - Resultados dos ensaios de compressão simples realizados com deformação controlada utilizando corpos de prova compactados no ramo úmido e preparados por secagem ou umedecimento (ponto U). 


\subsection{2 - Ensaios com deformação controlada realizados em corpos de prova que foram saturados e secados (trajetória 5)}

Estes corpos de prova, a partir das condições iniciais de moldagem, foram saturados e depois secados até atingirem o teor de umidade correspondente à sucção desejada. Estes valores de teor de umidade foram arbitrados pelos resultados das curvas de retenção definidas sem confinamento para cada condição de moldagem. $\mathrm{Na}$ Tabela 6.7 estão os dados de moldagem e preparação dos corpos de prova juntamente com os respectivos resultados dos ensaios de resistência ao cisalhamento. Para todos estes ensaios foram determinadas as sucções iniciais com o papel filtro. Com o tensiômetro obteve-se a variação da sucção durante a fase de cisalhamento. Os resultados da variação da tensão desviadora e da sucção em função da deformação axial, obtidos para as três condições de moldagem, estão apresentados nas Figuras $6.7,6.8$ e 6.9 .

De forma análoga aos resultados do item anterior observa-se à semelhança dos resultados dos ensaios realizados em corpos de prova moldados na umidade ótima (Figura 6.7) e no ramo úmido (Figura 6.9). Este fato pode ser verificado ao se comparar os resultados dos ensaios realizados com os corpos de prova CSO25 (Figura 6.7) e CSU20 (Figura 6.9). Ambos apresentam inicialmente sucção em torno de $200 \mathrm{kPa}$ e rompem com tensão próximas de $250 \mathrm{kPa}$.

O corpo de prova CSS19 moldado no ramo seco, também apresenta sucção inicial em torno de $200 \mathrm{kPa}$. No entanto, em ralação aos ensaios CSO25 e CSU20, apresenta resistência menor, rompendo com tensão desviadora de $200 \mathrm{kPa}$. Estas mesmas observações são obtidas ao se comparar nas Figuras 6.7, 6.8 e 6.9, os resultados de outros corpos de prova com sucções iniciais semelhantes.

Quanto maior a sucção inicial dos corpos de prova (Figuras 6.7b, 6.8b e 6.9b) maior a redução da sucção no inicio do ensaio. Esta redução da sucção ocorre de forma gradativa até o valor da deformação axial correspondente à ruptura do corpo de prova, permanecendo praticamente constante a partir deste momento. 
Tabela 6.7 - Condições iniciais de moldagem, preparação por saturação e secagem e resultados dos ensaios de compressão simples realizados com deformação controlada nos três pontos de estudo $(\mathrm{O}, \mathrm{S}$ e $\mathrm{U})$.

\begin{tabular}{|c|c|c|c|c|c|c|c|c|c|c|c|c|c|c|c|c|c|c|c|c|c|c|}
\hline \multirow{7}{*}{ 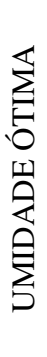 } & \multicolumn{6}{|c|}{ MOLDAGEM } & \multicolumn{5}{|c|}{ SATURAÇÃO } & \multicolumn{5}{|c|}{ SECAGEM } & \multicolumn{6}{|c|}{ RESULTADOS } \\
\hline & C.P. & $\begin{array}{l}\mathrm{W} \\
(\%)\end{array}$ & $\mathrm{e}$ & $\begin{array}{c}\mathrm{S} \\
(\%)\end{array}$ & $\begin{array}{l}\theta_{\mathrm{w}} \\
(\%)\end{array}$ & $\begin{array}{c}\rho_{\mathrm{d}} \\
\left(\mathrm{g} / \mathrm{cm}^{3}\right)\end{array}$ & $\begin{array}{l}\mathrm{W} \\
(\%)\end{array}$ & $\mathrm{e}$ & $\begin{array}{c}S \\
(\%)\end{array}$ & $\begin{array}{l}\theta_{\mathrm{w}} \\
(\%)\end{array}$ & $\begin{array}{c}\rho_{\mathrm{d}} \\
\left(\mathrm{g} / \mathrm{cm}^{3}\right)\end{array}$ & $\begin{array}{l}\mathrm{W} \\
(\%)\end{array}$ & $\mathrm{e}$ & $\begin{array}{c}\mathrm{S} \\
(\%)\end{array}$ & $\begin{array}{l}\theta_{\mathrm{w}} \\
(\%)\end{array}$ & $\begin{array}{c}\rho_{\mathrm{d}} \\
\left(\mathrm{g} / \mathrm{cm}^{3}\right)\end{array}$ & $\begin{array}{c}\mathrm{q} \\
(\mathrm{kPa})\end{array}$ & $\begin{array}{c}\varepsilon_{\mathrm{f}} \\
(\%)\end{array}$ & $\begin{array}{c}\mathrm{E}_{\mathrm{tg}} \\
(\mathrm{MPa})\end{array}$ & $\begin{array}{l}\text { P.F. } \\
(\mathrm{kPa})\end{array}$ & $\begin{array}{l}\text { Suc. Inic. } \\
\text { Tens.(kPa) }\end{array}$ & $\begin{array}{l}\text { Suc. Rupt. } \\
\text { Tens.(kPa) }\end{array}$ \\
\hline & $\mathrm{CSO} 23$ & 25.0 & 0.78 & 87.2 & 38.2 & 1.52 & 31.3 & 0.90 & 94.2 & 44.6 & 1.43 & 28.6 & 0.85 & 91.1 & 41.7 & 1.47 & 48.9 & 6.3 & 1.7 & 42 & 19.7 & 31.8 \\
\hline & $\mathrm{CSO} 24$ & 25.0 & 0.78 & 87.6 & 38.2 & 1.53 & 31.8 & 0.90 & 95.4 & 45.3 & 1.42 & 25.7 & 0.81 & 84.5 & 37.9 & 1.49 & 79.9 & 4.5 & 3.4 & 202 & 85.0 & 58.7 \\
\hline & $\mathrm{CSO} 25$ & 25.0 & 0.79 & 86.1 & 38 & 1.52 & 31.9 & 0.92 & 94.4 & 45.2 & 1.41 & 23.4 & 0.80 & 78.0 & 34.8 & 1.50 & 120.7 & 3.9 & 5.7 & 481 & 186.0 & 116.0 \\
\hline & $\mathrm{CSO} 26$ & 25.0 & 0.78 & 87.1 & 38.2 & 1.52 & 31.2 & 0.90 & 93.7 & 44.4 & 1.42 & 21.4 & 0.77 & 74.3 & 32.4 & 1.53 & 179.3 & 4.1 & 10.4 & 619 & 315.0 & 204.0 \\
\hline & $\mathrm{CSO} 27$ & 25.0 & 0.78 & 86.7 & 38.0 & 1.52 & 30.8 & 0.89 & 93.4 & 44.1 & 1.43 & 19.8 & 0.77 & 69.5 & 30.2 & 1.53 & 211.6 & 3.6 & 12.5 & 898 & 425.0 & 285.0 \\
\hline \multirow{7}{*}{ 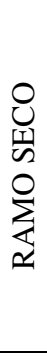 } & \multicolumn{6}{|c|}{ MOLDAGEM } & \multicolumn{5}{|c|}{ SATURAÇÃO } & \multicolumn{5}{|c|}{ SECAGEM } & \multicolumn{6}{|c|}{ RESULTADOS } \\
\hline & C.P. & $\begin{array}{l}\mathrm{W} \\
(\%)\end{array}$ & e & $\begin{array}{c}\mathrm{S} \\
(\%)\end{array}$ & $\begin{array}{l}\theta_{\mathrm{w}} \\
(\%)\end{array}$ & $\begin{array}{c}\rho_{\mathrm{d}} \\
\left(\mathrm{g} / \mathrm{cm}^{3}\right)\end{array}$ & $\begin{array}{l}\mathrm{W} \\
(\%)\end{array}$ & $\mathrm{e}$ & $\begin{array}{c}\mathrm{S} \\
(\%)\end{array}$ & $\begin{array}{c}\theta_{\mathrm{w}} \\
(\%)\end{array}$ & $\begin{array}{c}\rho_{\mathrm{d}} \\
\left(\mathrm{g} / \mathrm{cm}^{3}\right)\end{array}$ & $\begin{array}{l}\mathrm{w} \\
(\%)\end{array}$ & $\mathrm{e}$ & $\begin{array}{l}\text { S } \\
(\%)\end{array}$ & $\begin{array}{r}\theta_{\mathrm{w}} \\
(\%)\end{array}$ & $\begin{array}{c}\rho_{\mathrm{d}} \\
\left(\mathrm{g} / \mathrm{cm}^{3}\right)\end{array}$ & $\begin{array}{c}\mathrm{q} \\
(\mathrm{kPa})\end{array}$ & $\begin{array}{c}\varepsilon_{\mathrm{f}} \\
(\%)\end{array}$ & $\begin{array}{c}\mathrm{E}_{\mathrm{tg}} \\
(\mathrm{MPa})\end{array}$ & $\begin{array}{l}\text { P.F. } \\
(\mathrm{kPa})\end{array}$ & $\begin{array}{l}\text { Suc. Inic. } \\
\text { Tens.(kPa) }\end{array}$ & $\begin{array}{l}\text { Suc. Rupt. } \\
\text { Tens.(kPa) }\end{array}$ \\
\hline & CSS16 & 17.0 & 0.82 & 56.2 & 25.4 & 1.49 & 34.9 & 1.00 & 94.9 & 47.4 & 1.36 & 28.7 & 0.91 & 85.9 & 41.0 & 1.42 & 35.0 & 6.4 & 1.1 & 54 & 18.0 & 21.4 \\
\hline & CSS17 & 17.0 & 0.83 & 55.6 & 25.3 & 1.48 & 35.9 & 1.07 & 91 & 47.0 & 1.31 & 25.0 & 0.90 & 76.8 & 36.3 & 1.43 & 55.5 & 4.0 & 2.0 & 190 & 71.0 & 48.4 \\
\hline & CSS18 & 17.0 & 0.82 & 56.4 & 25.4 & 1.49 & 36.0 & 1.06 & 92.2 & 47.4 & 1.32 & 21.9 & 0.88 & 67.9 & 31.8 & 1.44 & 84.4 & 4.0 & 3.7 & 589 & 157.0 & 103.0 \\
\hline & CSS19 & 17.0 & 0.82 & 56.3 & 25.4 & 1.49 & 35.0 & 1.04 & 91.0 & 46.7 & 1.33 & 20.4 & 0.89 & 62.7 & 29.5 & 1.44 & 96.6 & 3.7 & 5.0 & 564 & 200.0 & 141.0 \\
\hline & CSS20 & 17.0 & 0.83 & 55.5 & 25.2 & 1.48 & 34.9 & 1.02 & 92.2 & 46.7 & 1.34 & 17.9 & 0.88 & 55.9 & 26.1 & 1.44 & 139.4 & 3.1 & 7.5 & 621 & 373.0 & 289.0 \\
\hline \multirow{7}{*}{ 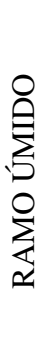 } & \multicolumn{6}{|c|}{ MOLDAGEM } & \multicolumn{5}{|c|}{ SATURAÇÃO } & \multicolumn{5}{|c|}{ SECAGEM } & \multicolumn{6}{|c|}{ RESULTADOS } \\
\hline & C.P. & $\begin{array}{l}\mathrm{W} \\
(\%) \\
\end{array}$ & e & $\begin{array}{c}\mathrm{S} \\
(\%) \\
\end{array}$ & $\begin{array}{c}\theta_{\mathrm{w}} \\
(\%)\end{array}$ & $\begin{array}{c}\rho_{\mathrm{d}} \\
\left(\mathrm{g} / \mathrm{cm}^{3}\right)\end{array}$ & $\begin{array}{l}\mathrm{W} \\
(\%) \\
\end{array}$ & $\mathrm{e}$ & $\begin{array}{c}\mathrm{S} \\
(\%) \\
\end{array}$ & $\begin{array}{c}\theta_{\mathrm{w}} \\
(\%)\end{array}$ & $\begin{array}{c}\rho_{\mathrm{d}} \\
\left(\mathrm{g} / \mathrm{cm}^{3}\right)\end{array}$ & $\begin{array}{l}\mathrm{w} \\
(\%) \\
\end{array}$ & $\mathrm{e}$ & $\begin{array}{c}\mathrm{S} \\
(\%) \\
\end{array}$ & $\begin{array}{c}\theta_{\mathrm{w}} \\
(\%) \\
\end{array}$ & $\begin{array}{c}\rho_{\mathrm{d}} \\
\left(\mathrm{g} / \mathrm{cm}^{3}\right)\end{array}$ & $\begin{array}{c}\mathrm{q} \\
(\mathrm{kPa})\end{array}$ & $\begin{array}{c}\varepsilon_{\mathrm{f}} \\
(\%) \\
\end{array}$ & $\begin{array}{c}\mathrm{E}_{\mathrm{tg}} \\
(\mathrm{MPa})\end{array}$ & $\begin{array}{l}\text { P.F. } \\
(\mathrm{kPa})\end{array}$ & $\begin{array}{l}\text { Suc. Inic. } \\
\text { Tens.(kPa) }\end{array}$ & $\begin{array}{l}\text { Suc. Rupt. } \\
\text { Tens.(kPa) }\end{array}$ \\
\hline & CSU18 & 27.7 & 0.83 & 90.2 & 40.9 & 1.48 & 33 & 0.92 & 96.8 & 46.4 & 1.41 & 28.6 & 0.86 & 90.0 & 41.6 & 1.46 & 50.6 & 5.6 & 1.7 & 76 & 33.0 & 34.0 \\
\hline & CSU19 & 27.7 & 0.83 & 90.9 & 41.0 & 1.48 & 33.5 & 0.94 & 96.4 & 46.8 & 1.40 & 27.0 & 0.83 & 87.9 & 39.9 & 1.48 & 75.8 & 6.0 & 2.6 & 212 & 81.0 & 60.0 \\
\hline & CSU20 & 27.7 & 0.83 & 90.2 & 40.9 & 1.48 & 33.6 & 0.95 & 96.2 & 46.8 & 1.39 & 24.4 & 0.82 & 80.9 & 36.3 & 1.49 & 117.9 & 4.6 & 4.3 & 467 & 201.0 & 117.0 \\
\hline & CSU21 & 27.7 & 0.83 & 90.6 & 41.0 & 1.48 & 33.5 & 0.92 & 98.6 & 47.3 & 1.41 & 23.0 & 0.81 & 76.5 & 34.2 & 1.50 & 147.2 & 4.6 & 7.7 & 521 & 282.0 & 169.0 \\
\hline & CSU22 & 27.7 & 0.84 & 89.4 & 40.8 & 1.47 & 33.3 & 0.95 & 94.7 & 46.2 & 1.39 & 20.8 & 0.80 & 66.9 & 29.7 & 1.51 & 172.7 & 3.9 & 11.8 & 784 & 431.0 & 269.0 \\
\hline
\end{tabular}




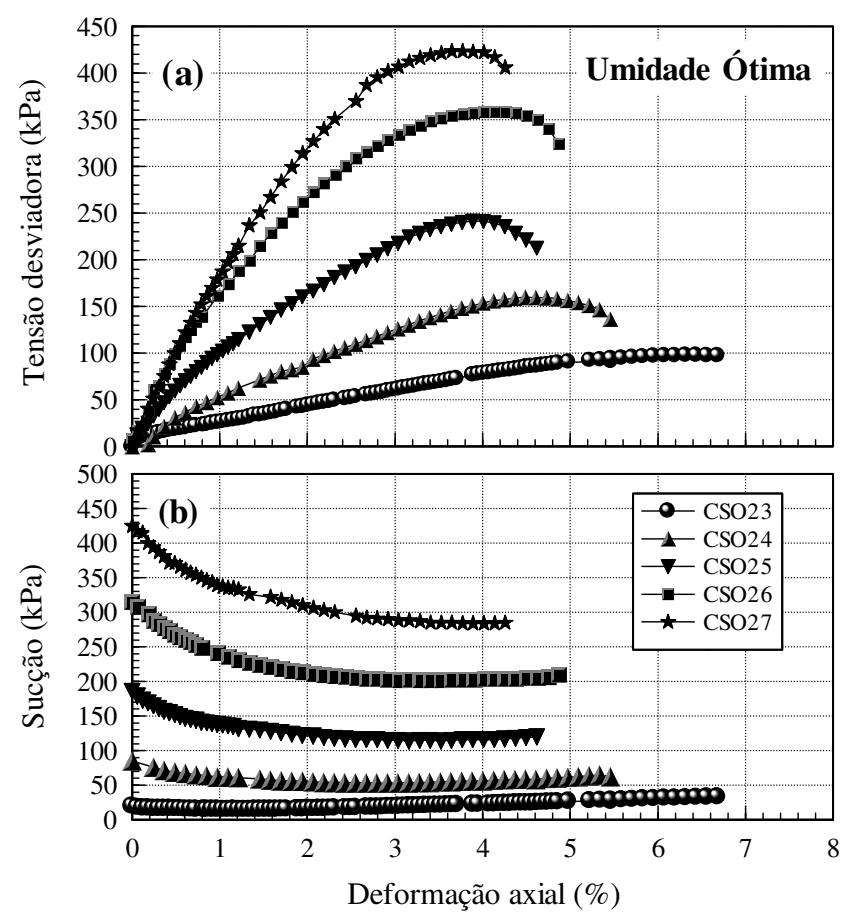

Figura 6.7 - Resultados dos ensaios de compressão simples realizados com deformação controlada utilizando corpos de prova compactados na umidade ótima e preparados por saturação e secagem (ponto O).

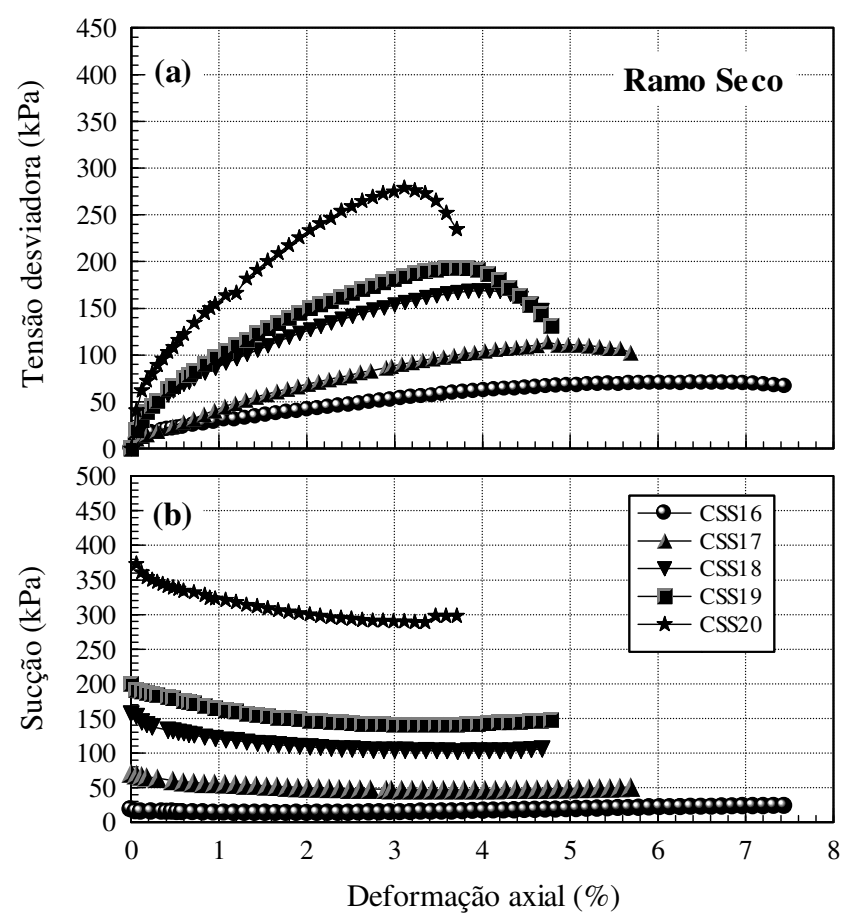

Figura 6.8 - Resultados dos ensaios de compressão simples realizados com deformação controlada utilizando corpos de prova compactados no ramo seco e preparados por saturação e secagem (ponto $S$ ). 

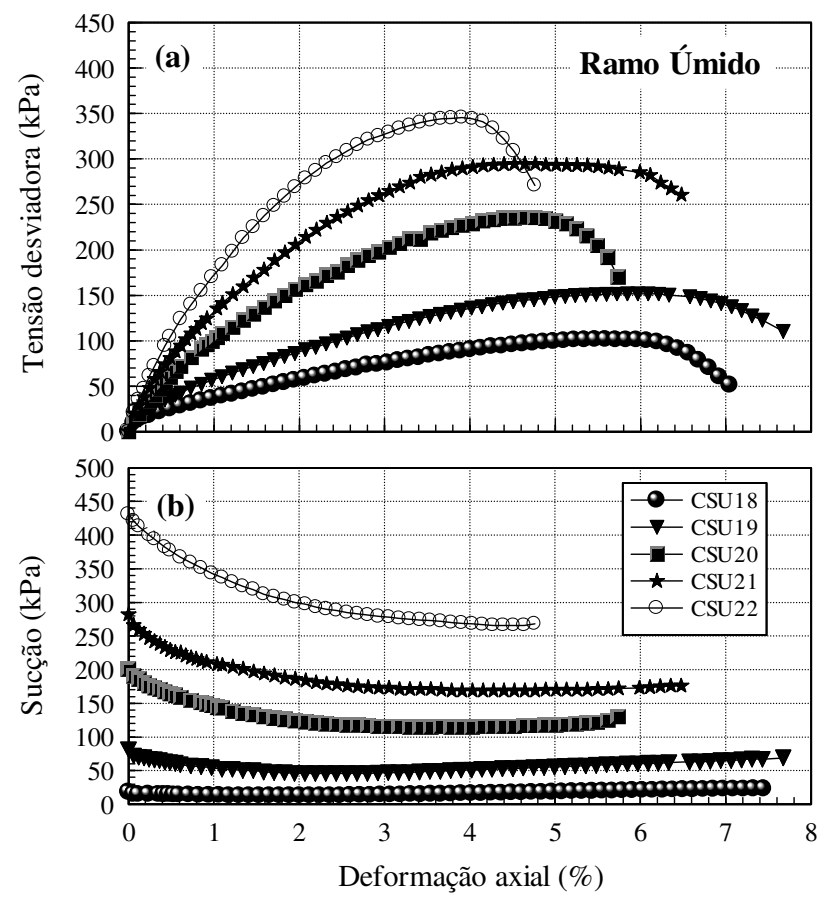

Figura 6.9 - Resultados dos ensaios de compressão simples realizados com deformação controlada utilizando corpos de prova compactados no ramo úmido e preparados por saturação e secagem 2(ponto U).

\subsection{3 - Ensaios com carregamento controlado realizados em corpos de prova que foram umedecidos ou secados (trajetória 3 e 4)}

Neste item são apresentados os resultados dos ensaios de compressão simples realizados com carregamento controlado, utilizando corpos de prova moldados na umidade ótima, ramo seco e ramo úmido (Tabela 4.2). Os procedimentos de realização destes ensaios foram descritos no item 4.11.2. Além dos objetivos indicados na Tabela 4.14, os mesmos foram realizados para se verificar a influência da compressão da pasta no valor da leitura da sucção no tensiômetro. Na Tabela 6.8 estão os dados de moldagem e preparação dos corpos de prova com os respectivos resultados dos ensaios. As variações da tensão desviadora e da sucção, em função das deformações axiais, estão apresentadas nas Figuras 6.10 a 6.12. 
Os ensaios de resistência com carregamento controlado e com medida da variação da sucção com o tensiômetro, cujo esquema esta representado da Figura 3.8, não são comumente realizados nos laboratórios de mecânica dos solos. Para se compreender como foram obtidos os resultados das Figuras 6.10 a 6.12, será utilizado como exemplo o ensaio realizado com o corpo de prova CSO33. Na Figura 6.13 estão as leituras da sucção deste corpo de prova a partir do momento em que é colocado sobre o tensiômetro. A fase de cisalhamento só deve ser iniciada após estabilização da medição da sucção inicial do corpo de prova. Na Figura 6.13 este valor corresponde à sucção de $180 \mathrm{kPa}$ obtida para o tempo de equilíbrio de 22 minutos.

Após o equilíbrio inicia-se a fase de cisalhamento colocando-se o primeiro incremento de carregamento axial, correspondendo neste exemplo ao peso de $2 \mathrm{~kg}$. Na Figura 6.13 se constata que após este acréscimo de carregamento ocorre a diminuição da sucção seguida de um aumento e estabilização para um valor inferior ao inicial. A redução da sucção observada após o acréscimo de carregamento está relacionada à compressão da pasta de solo colocada sobre o tensiômetro.

No entanto, a pasta entra novamente em equilíbrio com a sucção do corpo de prova e a leitura do tensiômetro passa a aumentar e se estabiliza para este novo valor. Neste instante deve ser feita a leitura do valor da sucção e do extensômetro que mede o deslocamento axial do corpo de prova, sendo posteriormente colocado o novo incremento de carregamento axial. Observa-se na Figura 6.13 que para os incrementos colocados a partir do tempo de 80 minutos, passa a ocorrer o aumento do valor da sucção do corpo de prova. A estabilização da sucção ocorre para um valor maior que o correspondente ao carregamento anterior. A ruptura do corpo de prova ocorre com o incremento de $1 \mathrm{~kg}$, colocado depois de decorrido 122 minutos do início do ensaio. Logo após este carregamento o corpo de prova rompeu perdendo assim a continuidade hidráulica com a pasta. Após a retirada do corpo de prova foi colocada água no tensiômetro para se evitar que as leituras de sucção aumentem e o mesmo venha a cavitar. Neste momento o valor da sucção cai instantaneamente para zero. 
Cada ponto dos ensaios apresentado nas Figuras 6.10 a 6.12 corresponde aos resultados obtidos para um determinado incremento de carregamento. Os resultados da variação da sucção do tensiômetro em função do tempo obtidos para outros ensaios de compressão simples estão apresentados no anexo A.

Nas Figuras 6.10 e 6.12 constate-se que existe semelhança nos resultados dos ensaios realizados em corpos de prova moldados na umidade ótima e no ramo úmido. Como exemplo tem-se os corpos de prova CSO35 (Figura 6.10) e CSU27 (Figura 6.12), moldados nestas duas condições de moldagem e com sucção inicial em torno de 300 $\mathrm{kPa}$. Nestas figuras observa-se que a tensão desviadora e a sucção de ruptura destes corpos de prova apresentaram valores similares e respectivamente iguais a 300 e 200 $\mathrm{kPa}$. Esta semelhança pode ser constatada para estas duas condições de moldagem, ao se comparar os resultados de outros corpos de prova que apresentem o mesmo valor de sucção inicial.

O corpo de prova CSS26, moldado no ramo seco (Figura 6.11), apresenta sucção inicial um pouco superior a $300 \mathrm{kPa}$, no entanto a tensão de ruptura é inferior a 250 $\mathrm{kPa}$. Portanto com os ensaios de compressão simples realizados nos corpos de prova CSO35, CSS26 e CSU27, moldados nos três pontos de estudo e com sucções iniciais próximas de $300 \mathrm{kPa}$, fica caracterizada a semelhança dos resultados para a moldagem na umidade ótima e no ramo úmido. O corpo de prova moldado no ramo (CSS26) seco apresentou tensão desviadora de ruptura menor. Nas Figuras 6.10b, 6.11 e 6.12 b verifica-se que quanto maior o valor da sucção inicial do corpo de prova, maior é a redução da sucção no início do ensaio. A redução da sucção ocorre de forma gradativa até se atingir a ruptura do corpo de prova, mantendo-se praticamente constante a partir deste momento. 
Tabela 6.8 - Condições iniciais de moldagem, preparação por umedecimento ou secagem e resultados dos ensaios de compressão simples realizados com carregamento controlado nos três pontos de estudo.

\begin{tabular}{|c|c|c|c|c|c|c|c|c|c|c|c|c|c|c|c|c|c|c|}
\hline \multirow{10}{*}{ 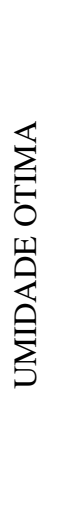 } & \multicolumn{6}{|c|}{ MOLDAGEM } & \multicolumn{6}{|c|}{ PREPARAÇÃO } & \multicolumn{6}{|c|}{ RESULTADOS } \\
\hline & C.P. & $\begin{array}{c}\mathrm{w} \\
(\%)\end{array}$ & $\mathrm{e}$ & $\begin{array}{c}\mathrm{S} \\
(\%)\end{array}$ & $\begin{array}{c}\theta_{\mathrm{w}} \\
(\%)\end{array}$ & $\begin{array}{c}\rho_{d} \\
\left(\mathrm{~g} / \mathrm{cm}^{3}\right)\end{array}$ & Traj. & $\begin{array}{c}\mathrm{w} \\
(\%)\end{array}$ & $\mathrm{e}$ & $\begin{array}{c}\mathrm{S} \\
(\%)\end{array}$ & $\begin{array}{c}\theta_{\mathrm{w}} \\
(\%)\end{array}$ & $\begin{array}{c}\rho_{d} \\
\left(\mathrm{~g} / \mathrm{cm}^{3}\right)\end{array}$ & $\begin{array}{c}\mathrm{q} \\
(\mathrm{kPa})\end{array}$ & $\begin{array}{c}\varepsilon_{\mathrm{f}} \\
(\%)\end{array}$ & $\begin{array}{c}\mathrm{E}_{\mathrm{tg}} \\
(\mathrm{MPa})\end{array}$ & $\begin{array}{l}\text { P.F. } \\
(\mathrm{kPa})\end{array}$ & $\begin{array}{l}\text { Suc. Inic. } \\
\text { Tens.(kPa) }\end{array}$ & $\begin{array}{l}\text { Suc. Rupt. } \\
\text { Tens.(kPa) }\end{array}$ \\
\hline & $\mathrm{CSO} 28$ & 24.8 & 0.80 & 84.2 & 37.4 & 1.51 & 3 & 27.9 & 0.86 & 87.5 & 40.5 & 1.45 & 44.5 & 5.1 & 19.8 & 24 & 19.8 & 26.4 \\
\hline & CSO29 & 24.8 & 0.80 & 84.7 & 37.5 & 1.51 & 3 & 26.9 & 0.84 & 86.9 & 39.7 & 1.47 & 62.0 & 4.6 & 27.4 & 36 & 34.8 & 39.5 \\
\hline & CSO30 & 24.8 & 0.79 & 85.8 & 37.7 & 1.52 & 3 & 26.0 & 0.81 & 87.0 & 38.9 & 1.50 & 78.3 & 5.4 & 46.7 & 55 & 51.5 & 54.8 \\
\hline & CSO31 & 24.8 & 0.80 & 84.4 & 37.5 & 1.51 & 3 & 24.9 & 0.81 & 83.9 & 37.5 & 1.50 & 91.4 & 4.8 & 63.4 & 77 & 76.5 & 71.8 \\
\hline & CSO32 & 24.8 & 0.81 & 82.7 & 37.1 & 1.49 & 4 & 23.8 & 0.81 & 80.2 & 35.8 & 1.50 & 93.9 & 2.7 & 79.5 & 160 & 131.3 & 98.0 \\
\hline & $\mathrm{CSO} 33$ & 24.8 & 0.80 & 83.0 & 37.4 & 1.50 & 4 & 23.2 & 0.80 & 78.9 & 35.0 & 1.51 & 126.1 & 4.1 & 98.9 & 236 & 179.2 & 129.5 \\
\hline & $\mathrm{CSO} 34$ & 24.8 & 0.80 & 83.8 & 37.3 & 1.50 & 4 & 20.2 & 0.78 & 70.1 & 30.7 & 1.52 & 201.9 & 3.7 & 199.3 & --- & 427.8 & 285.0 \\
\hline & CSO35 & 24.8 & 0.80 & 84.1 & 37.4 & 1.51 & 4 & 21.7 & 0.78 & 75.0 & 32.9 & 1.52 & 146.6 & 4.0 & 209.4 & --- & 293.3 & 193.0 \\
\hline & CSS21 & 17.0 & 0.85 & 54.1 & 24.9 & 1.46 & 3 & 29.3 & 0.97 & 82.1 & 40.4 & 1.38 & 20.3 & 5.4 & 10.5 & 14 & 13.2 & 16.4 \\
\hline ○ & CSS22 & 17.0 & 0.89 & 51.7 & 24.4 & 1.43 & 3 & 27.5 & 0.95 & 78.8 & 38.3 & 1.39 & 26.8 & 4.2 & 14.9 & 23 & 21.5 & 23.1 \\
\hline$\sqrt{2}$ & CSS23 & 17.0 & 0.85 & 54.2 & 24.9 & 1.46 & 3 & 25.3 & 0.93 & 73.6 & 35.5 & 1.40 & 38.8 & 5.3 & 22.9 & 39 & 34.5 & 34.8 \\
\hline$\stackrel{0}{\Sigma}$ & CSS24 & 17.0 & 0.88 & 52.2 & 24.5 & 1.44 & 3 & 23.2 & 0.94 & 66.5 & 32.3 & 1.39 & 42.0 & 4.2 & 37.7 & 64 & 60.0 & 57.9 \\
\hline 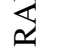 & CSS25 & 17.0 & 0.85 & 54.3 & 24.9 & 1.47 & 3 & 19.1 & 0.88 & 58.6 & 27.5 & 1.44 & 75.7 & 2.9 & 71.2 & 184 & 146.2 & 140.5 \\
\hline & CSS26 & 17.5 & 0.86 & 55.1 & 25.5 & 1.45 & 4 & 17.3 & 0.88 & 53.3 & 25.0 & 1.44 & 117.8 & 3.0 & 119.3 & --- & 327.5 & 275.0 \\
\hline & CSU23 & 28 & 0.9 & 88.3 & 40.8 & 1.458 & 3 & 28.6 & 0.87 & 89.0 & 41.4 & 1.45 & 49.4 & 5.7 & 27.1 & 36 & 35.3 & 37.7 \\
\hline 自 & CSU24 & 28.0 & 0.85 & 89.4 & 41.0 & 1.47 & 4 & 27.5 & 0.85 & 87.7 & 40.3 & 1.47 & 74.3 & 5.6 & 57.7 & 80 & 66.6 & 57.5 \\
\hline$\sum$ & CSU25 & 28.0 & 0.87 & 87.5 & 40.6 & 1.45 & 4 & 25.7 & 0.84 & 82.8 & 37.8 & 1.47 & 100.8 & 4.6 & 111.1 & 242 & 147.0 & 95.7 \\
\hline$\stackrel{\circ}{\circ}$ & CSU26 & 28.0 & 0.85 & 88.9 & 40.9 & 1.46 & 4 & 23.5 & 0.82 & 77.9 & 35.0 & 1.49 & 131.7 & 4.3 & 136.4 & 454 & 274.0 & 159.2 \\
\hline$\sum_{2}$ & CSU27 & 28.0 & 0.85 & 88.8 & 40.9 & 1.46 & 4 & 22.7 & 0.82 & 74.7 & 33.7 & 1.49 & 146.7 & 4.0 & 176.2 & 504 & 306.6 & 179.0 \\
\hline & CSU28 & 28.2 & 0.85 & 90.4 & 41.4 & 1.47 & 4 & 22.3 & 0.81 & 75.0 & 33.5 & 1.50 & 176.7 & 4.9 & 166.8 & --- & 384.0 & 244.0 \\
\hline
\end{tabular}




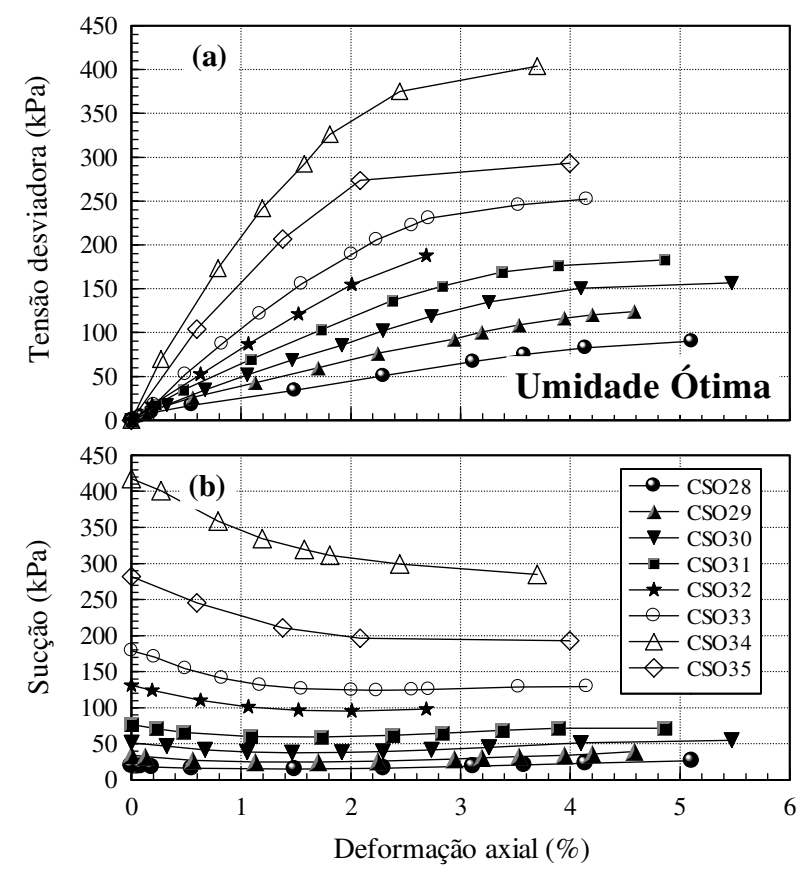

Figura 6.10 - Resultados dos ensaios de compressão simples realizados com carregamento controlado utilizando corpos de prova compactados na umidade ótima e preparados por umedecimento ou secagem (ponto $\mathrm{O}$ ).
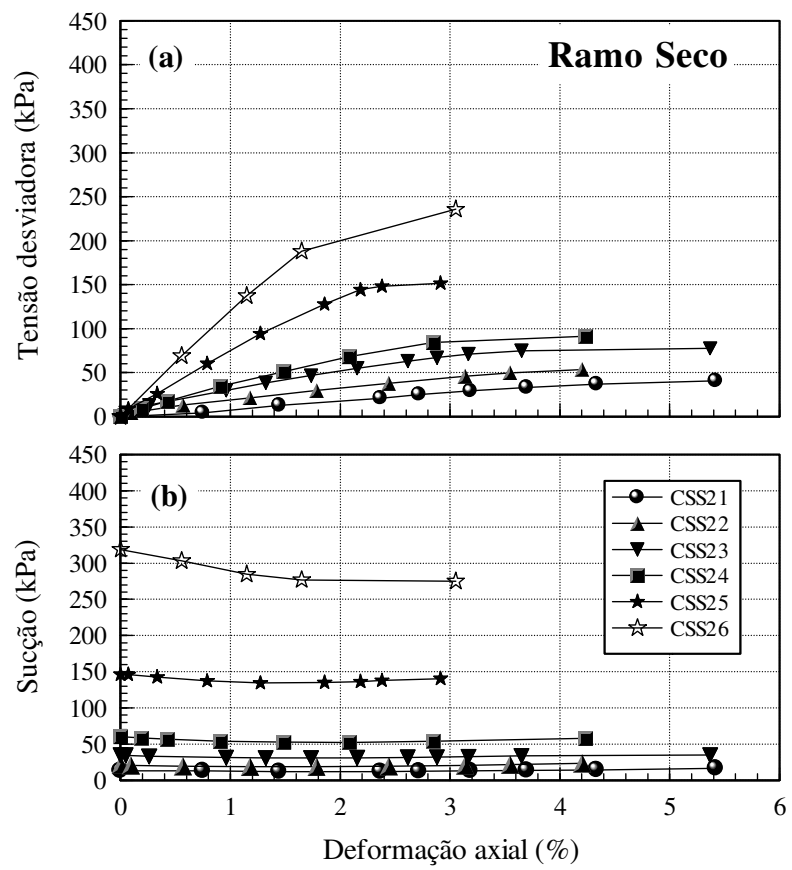

Figura 6.11 - Resultados dos ensaios de compressão simples realizados com carregamento controlado utilizando corpos de prova compactados no ramo seco e preparados por umedecimento ou secagem (ponto $\mathrm{S}$ ). 

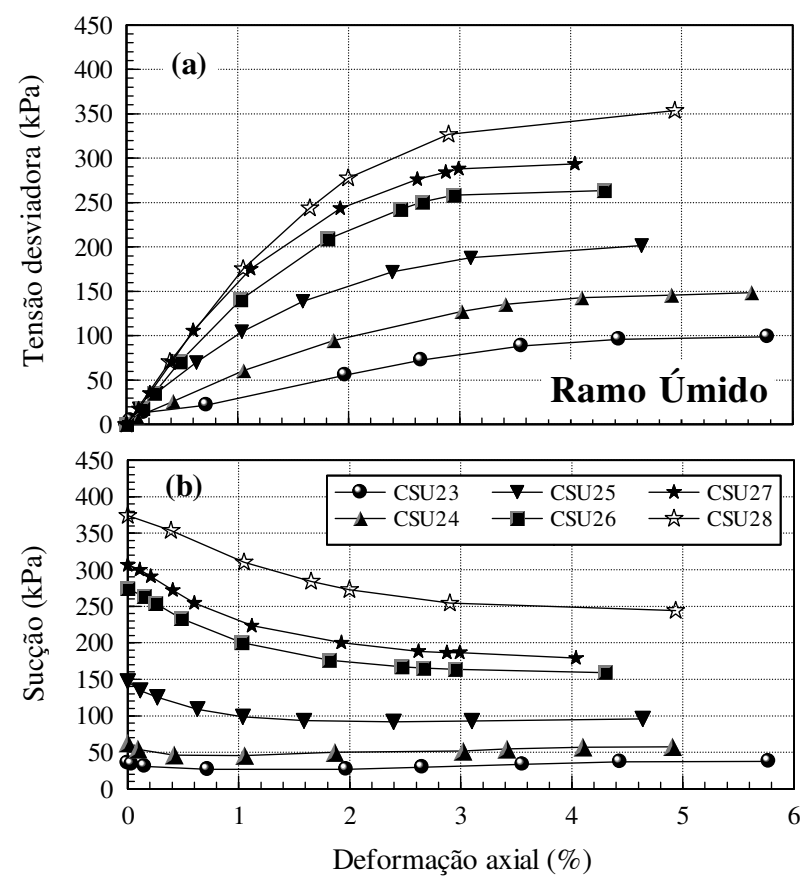

Figura 6.12 - Resultados dos ensaios de compressão simples realizados com carregamento controlado utilizando corpos de prova compactados no ramo úmido e preparados por umedecimento ou secagem (ponto U).

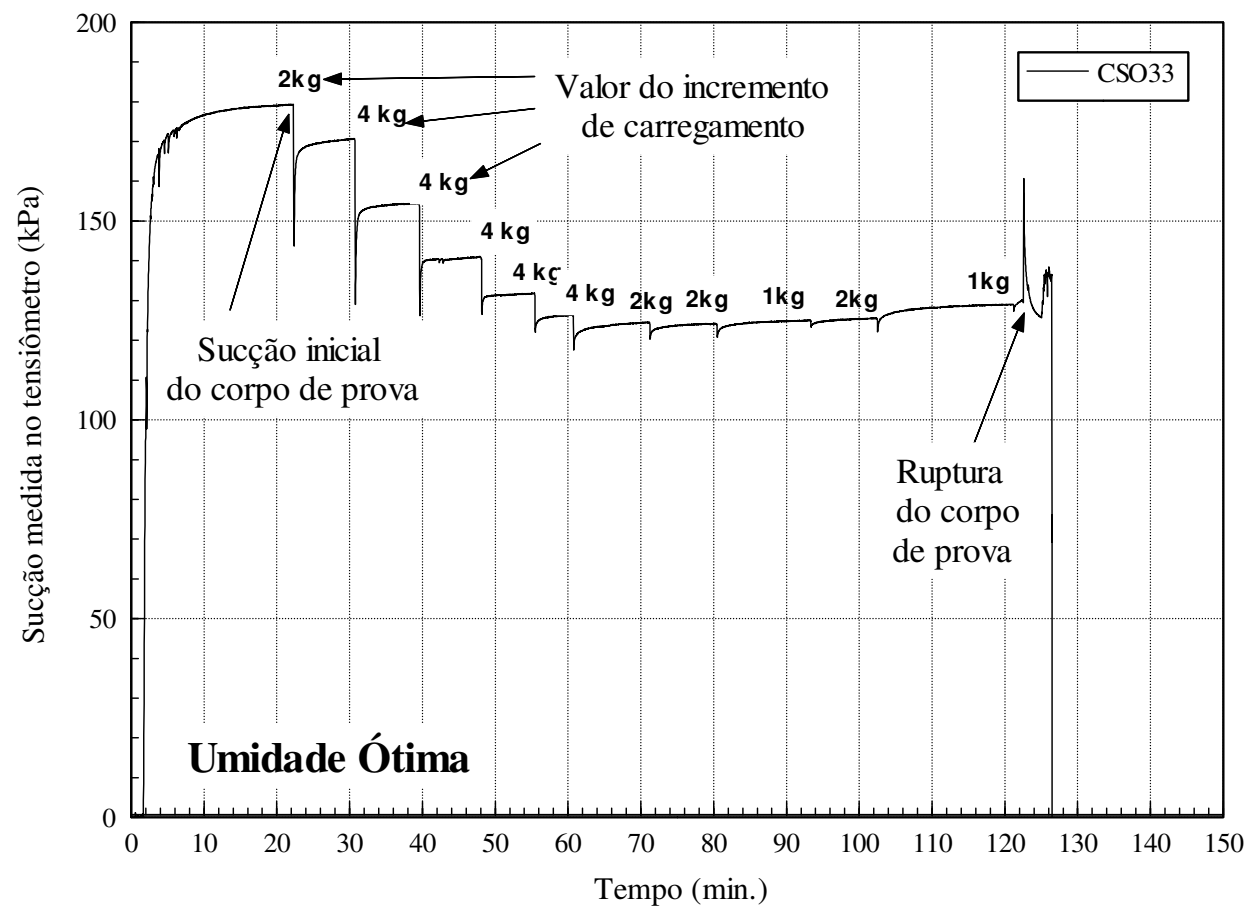

Figura 6.13 - Variação da leitura do tensiômetro em função do tempo para um ensaio de compressão simples realizado com carregamento controlado (ponto O). 


\subsection{4 - Efeito da velocidade de cisalhamento dos corpos de prova nos ensaios realizados com deformação controlada}

Neste item são apresentados os resultados dos ensaios com deformação controlada realizados com diferentes velocidades de cisalhamento utilizando corpos de prova moldados na umidade ótima. Com estes resultados é analisada a influência da velocidade de cisalhamento no valor da tensão axial de ruptura e na variação da sucção dos corpos de prova durante o ensaio. Para os ensaios de compressão simples apresentados nos itens 6.1.1 e 6.1.2, os corpos de prova foram cisalhados com velocidade de $0.3 \mathrm{~mm} / \mathrm{min}$.. Este valor foi definido através de alguns testes, adotando-se como critério que o tempo de ruptura fique em torno de 15 minutos.

Nishimura e Fredlund (2002) realizaram ensaios de compressão simples em amostras compactadas estaticamente, empregando velocidade de $0,5 \mathrm{~mm} /$ minuto. Colmenares

e Ridley (2002), também em ensaio de compressão simples com medição da sucção do corpo de prova com o tensiômetro, adotaram a velocidade de $0,05 \mathrm{~mm} /$ minuto, admitindo que seja suficiente para que as variações de sucções sejam as mesmas em todo o corpo de prova.

Os ensaios apresentados neste item foram realizados em 6 corpos de prova moldados nas condições da umidade ótima, definida na Tabela 4.2. Em função dos valores de velocidade adotados pelos autores citados anteriormente, os mesmos foram ensaiados com velocidades de cisalhamento variando de 0.1 a $0.5 \mathrm{~mm} /$ minuto. Na Tabela 6.9 estão os dados de moldagem dos corpos de prova, as velocidades empregadas no cisalhamento e os resultados dos ensaios. Entre os resultados estão as sucções iniciais dos corpos de prova determinadas com a utilização do papel filtro.

Na Figura 6.14 estão apresentados os resultados da variação de tensão desviadora e da sucção em função da deformação axial. Na parte (a) desta figura observa-se que as velocidades de cisalhamento destes ensaios praticamente não influenciam os módulos de deformabilidade tangente, as deformações axiais de ruptura e os valores das máximas tensões desviadoras suportadas pelos corpos de prova. 
Tabela 6.9 - Dados de moldagem e resultados dos ensaios de compressão simples dos corpos de prova moldados na umidade ótima e ensaiados com diferentes teores de umidade e velocidades de cisalhamento.

\begin{tabular}{|c|c|c|c|c|c|c|c|c|c|c|c|c|}
\hline \multicolumn{9}{|c|}{ MOLDAGEM } & \multicolumn{1}{c|}{ RESULTADOS } \\
\hline C.P. & $\begin{array}{c}\mathrm{w} \\
(\%)\end{array}$ & $\mathrm{e}$ & $\begin{array}{c}\mathrm{S} \\
(\%)\end{array}$ & $\begin{array}{c}\theta_{\mathrm{w}} \\
(\%)\end{array}$ & $\begin{array}{c}\rho_{\mathrm{d}} \\
\left(\mathrm{g} / \mathrm{cm}^{3}\right)\end{array}$ & $\begin{array}{c}\text { Veloc. } \\
(\mathrm{mm} / \mathrm{min} .)\end{array}$ & $\begin{array}{c}\mathrm{q} \\
(\mathrm{kPa})\end{array}$ & $\begin{array}{c}\varepsilon_{\mathrm{f}} \\
-\end{array}$ & $\begin{array}{c}\mathrm{E}_{\mathrm{tg}} \\
(\mathrm{MPa})\end{array}$ & $\begin{array}{c}\text { P.F. } \\
(\mathrm{kPa})\end{array}$ & $\begin{array}{c}\text { Suc. Inic. } \\
\text { Tens.(kPa) }\end{array}$ & $\begin{array}{c}\text { Suc. Rupt. } \\
\text { Tens.(kPa) }\end{array}$ \\
\hline CSO36 & 24.2 & 0.80 & 81.9 & 36.5 & 1.50 & 0.5 & 104.7 & 3.9 & 6.5 & 207 & 78.5 & 79.1 \\
\hline CSO37 & 24.9 & 0.77 & 87.7 & 38.1 & 1.53 & 0.03 & 89.3 & 3.3 & 6.8 & 229 & 86.6 & 89.4 \\
\hline CSO38 & 24.2 & 0.77 & 85.9 & 37.2 & 1.54 & 0.06 & 109.4 & 4.0 & 6.7 & 273 & 87.4 & 90.6 \\
\hline CSO39 & 24.2 & 0.77 & 85.8 & 37.2 & 1.53 & 0.3 & 103.7 & 4.2 & 5.9 & 298 & 96.0 & 89.7 \\
\hline CSO40 & 24.2 & 0.77 & 85.7 & 37.2 & 1.53 & 0.1 & 111.6 & 4.0 & 6.3 & 237 & 81.6 & 86.6 \\
\hline CSO41 & 24.2 & 0.76 & 86.1 & 37.3 & 1.54 & 0.225 & 109.0 & 3.9 & 7.3 & 343 & 82.8 & 86.3 \\
\hline
\end{tabular}


Apenas o ensaio realizado no corpo de prova CSO36 apresentou tensão de ruptura um pouco menor que os demais. Provavelmente este fato deve estar relacionado à sua menor densidade de moldagem, de acordo com os dados apresentados Tabela 6.9. A semelhança dos resultados também é observada na parte (b) da Figura 6.14. Portanto, tem-se que, para esta condição específica de moldagem, a velocidade de cisalhamento dos corpos de prova não interfere nos resultados dos ensaios.

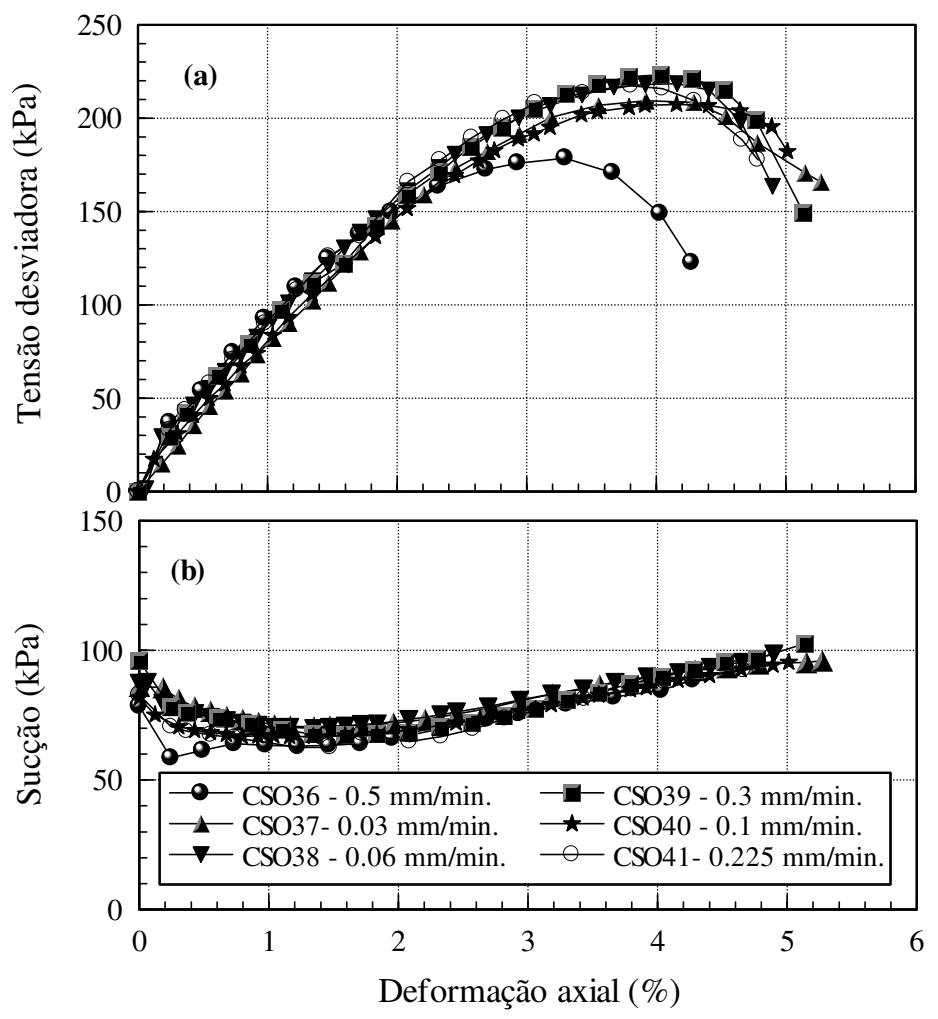

Figura 6.14 - Ensaios de compressão simples realizados com diferentes velocidades de cisalhamento e com medição da variação da sucção.

\section{2 - Resultados dos ensaios triaxiais saturados}

Conforme citado na Tabela 4.18, estes ensaios foram realizados para a determinação das superfícies de ruptura correspondentes às três condições de moldagem descritas na Tabela 4.2. Os parâmetros efetivos do solo, obtidos destes ensaios, também foram utilizados na aplicação dos modelos propostos por Vanapalli et al (1996) e Khalili e Khabbaz (1998). 
Neste item são apresentados os resultados dos ensaios triaxiais CAU realizados com tensão controlada, utilizando corpos de prova compactados nas três condições de moldagem, e os resultados dos ensaios triaxias CD realizados com carregamento controlado para as condições de moldagem na umidade ótima.

\subsection{1 - Ensaios triaxiais CAU realizados com tensão controlada}

Para cada condição de moldagem foram ensaiados três corpos de prova submetidos às pressões de confinamento de 30, 80 e $150 \mathrm{kPa}$. Utilizou-se para a realização destes ensaios a prensa ilustrada na Figura 3.9. Após a montagem dos ensaios os corpos de prova foram saturados por contrapressão. Este tipo de saturação, onde praticamente não ocorrem variações volumétricas do corpo de prova, corresponde à trajetória 1 da Figura 4.9. Após a saturação foram adensados anisotropicamente com uma relação entre as tensões principais igual a 0.7. Os dados de moldagem dos corpos de prova e os procedimentos dos ensaios foram descritos no item 4.11.2.

Nas Figuras 6.15, 6.16 e 6.17 estão apresentados os resultados destes ensaios. $\mathrm{Na}$ parte (a) destas figuras estão as tensões desviadoras em função da deformação axial e na parte (b) estão as variações da poro pressão durante a fase de cisalhamento. Dos resultados destas Figuras tem-se que as deformações axiais na ruptura são superiores a $10 \%$. Como era de se esperar, quanto maior a pressão de confinamento maior é o valor da tensão desviadora na ruptura. Comparando os resultados dos corpos de prova submetidos à mesma pressão confinante, constata-se que as maiores tensões desviadoras correspondem aos corpos de prova moldados na umidade ótima.

Nas Figuras 6.15b, 6.16b e 6.17b, observa-se que a poro pressão aumenta até valores de deformações axiais inferiores a $2 \%$. Quanto maior o valor da pressão confinante aplicada aos corpos de prova, maiores serão os valores positivos da poro pressão no início do ensaio. Após atingirem o valor máximo, as poro pressões passam a diminuir chegando em alguns casos a apresentarem valores negativos (CUO1, CUO2 e CUU1). 
A partir do máximo valor da poro pressão, as respectivas tensões desviadoras passam a aumentar com uma taxa menor, tendendo a se estabilizar com o aumento da deformação axial. Para os corpos de prova CUS3 (Figura 6.16), CUU1 e CUU2 (Figura 6.27) as tensões desviadoras não chegam a definir um valor máximo, aumentando gradativamente com o aumento da deformação axial. Este fato está relacionado às reduções das respectivas poro pressões durante o ensaio. Esta redução implica em aumento das tensões efetivas e conseqüentemente no aumento da resistência dos corpos de prova. O aumento da poro pressão inicial seguida da sua redução, podendo chegar a apresentar valores negativos, pode levar a erros na interpretação dos resultados (Bishop e Henkel, 1962). A ruptura do corpo de prova pode ter ocorrido para tensões desviadoras inferiores ao máximo valor encontrado no ensaio.

O momento da ruptura do corpo de prova pode ser definido normalizando-se as tensões desviadoras em relação à tensão confinante efetiva. Os resultados das tensões desviadoras correspondentes as Figuras 6.15a, 6.16a e 6.17a foram assim normalizados e estão apresentados nas Figuras 6.18, 6.19 e 6.20. Observa-se nestas Figuras que, para a pressão confinante de $30 \mathrm{kPa}$, ocorre a definição de um valor máximo de $\left(\sigma_{1}-\sigma_{3}\right) / \sigma_{3}{ }_{3}$, correspondente a deformações axiais em torno de 2 a $3 \%$, passando em seguida a diminuir como o aumento da deformação axial. Para valores de pressão confinante de 80 e $150 \mathrm{kPa}$, este pico não fica tão bem definido para alguns ensaios, no entanto, a partir de um determinado valor de deformação axial permanecem praticamente constantes.

Para os ensaios triaxiais saturados apresentados neste item, foi adotado como critério de ruptura a máxima relação entre a tensão desviadora e a tensão confinante efetiva, determinadas nas Figuras 6.18a, 6.19a e 6.20a. Os resultados destes ensaios estão apresentados na Tabela 6.10. Nesta tabela estão os valores das pressões de confinamento aplicadas aos corpos de prova, o máximo valor de $\left(\sigma_{1}-\sigma_{3}\right) / \sigma_{3}$ e o valor da deformação axial e da poro pressão na ruptura. 


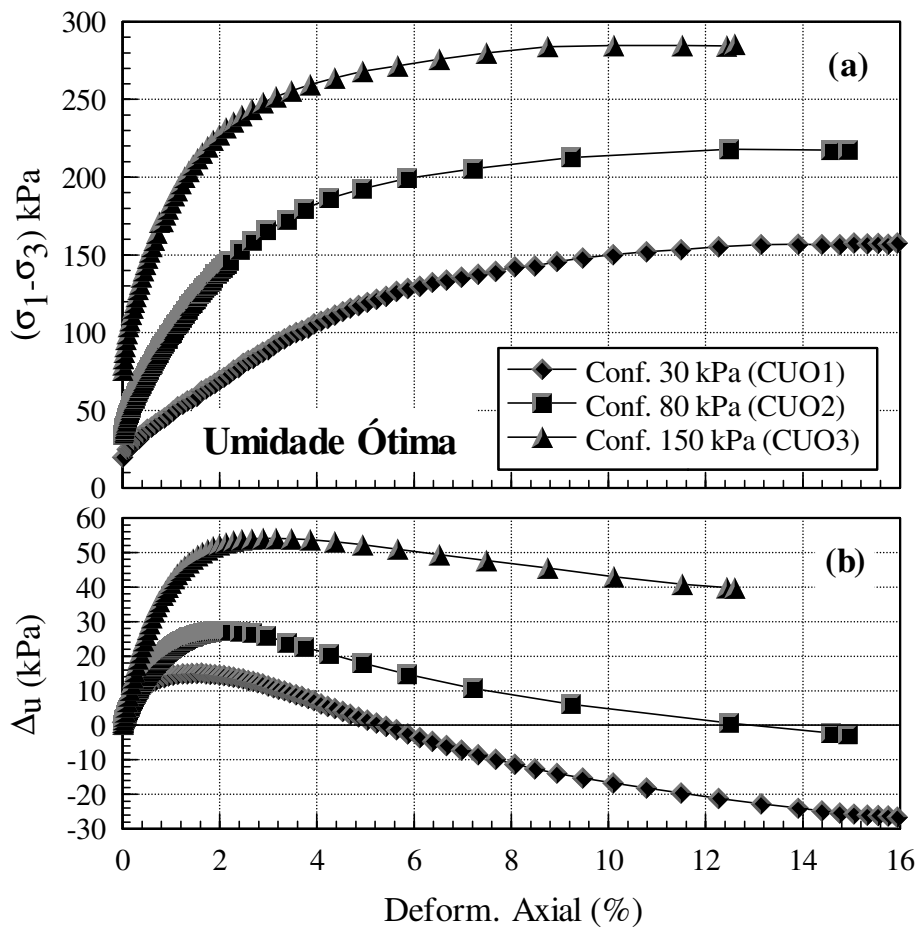

Figura 6.15 - Resultados da tensão desviadora e da poro pressão em função da deformação axial, obtidos dos ensaios triaxiais CAU (ponto O).
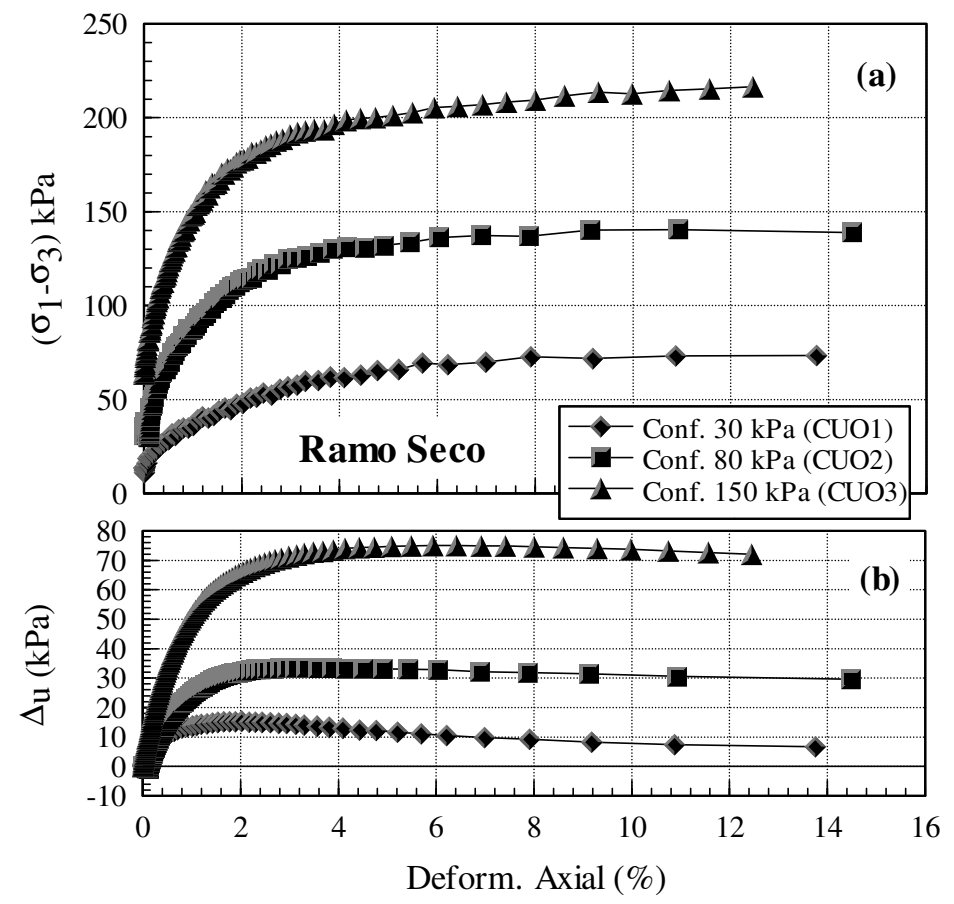

Figura 6.16 - Resultados da tensão desviadora e da poro pressão em função da deformação axial, obtidos dos ensaios triaxiais CAU (ponto $S$ ). 

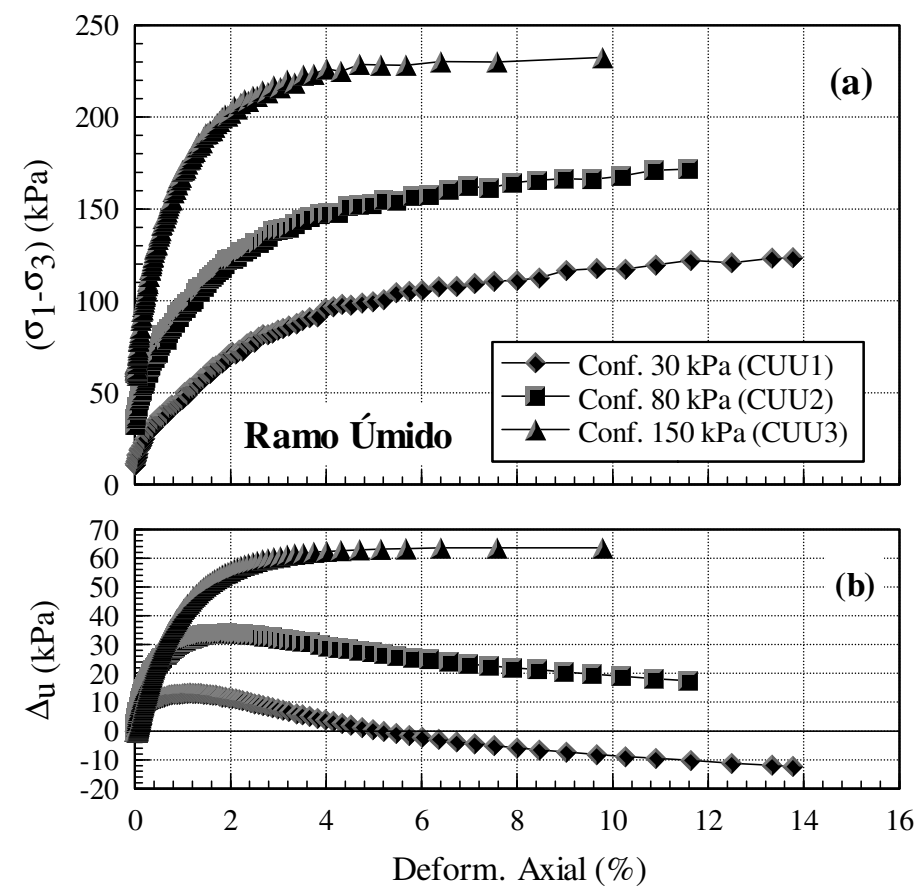

Figura 6.17 - Resultados da tensão desviadora e da poro pressão em função da deformação axial, obtidos dos ensaios triaxiais CAU (ponto U).
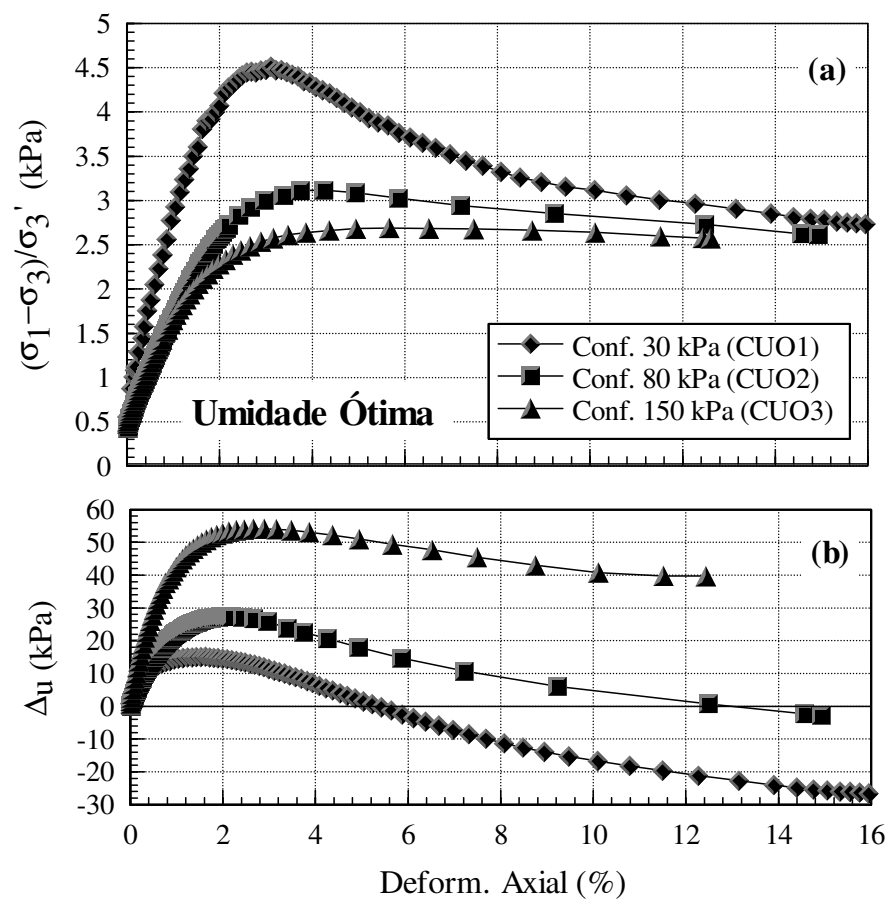

Figura 6.18 - Resultados da tensão desviadora normalizada e da poro pressão em função da deformação axial, obtidos dos ensaios triaxiais CAU (ponto O). 

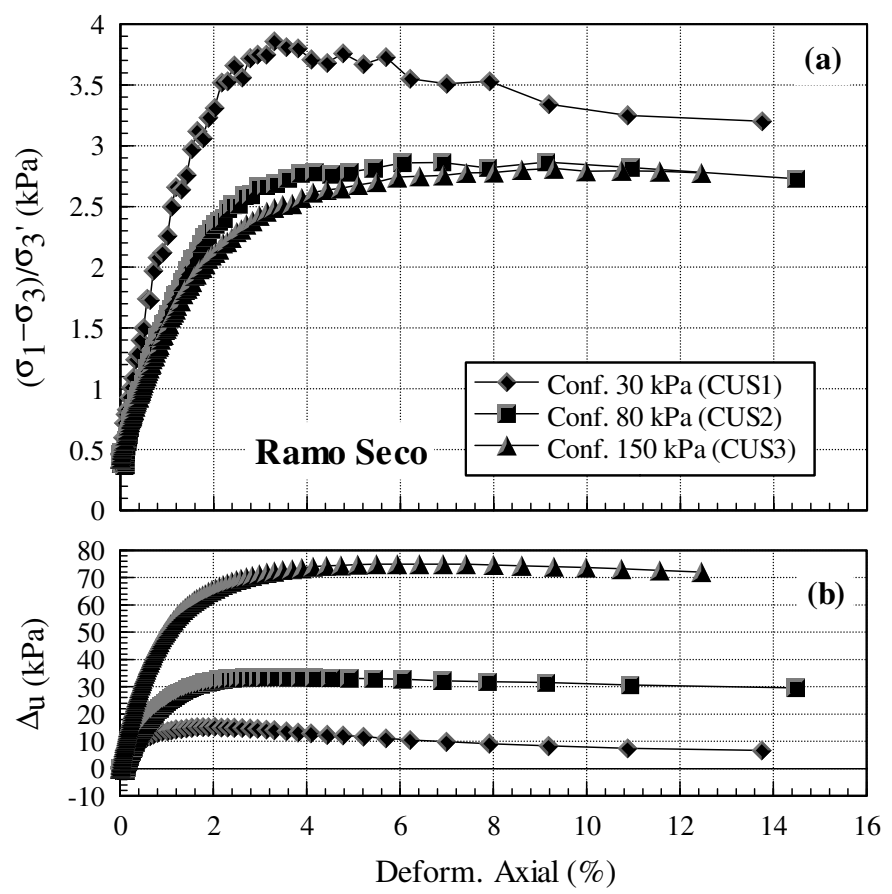

Figura 6.19 - Resultados da tensão desviadora normalizada e da poro pressão em função da deformação axial, obtidos dos ensaios triaxiais CAU (ponto $S$ ).
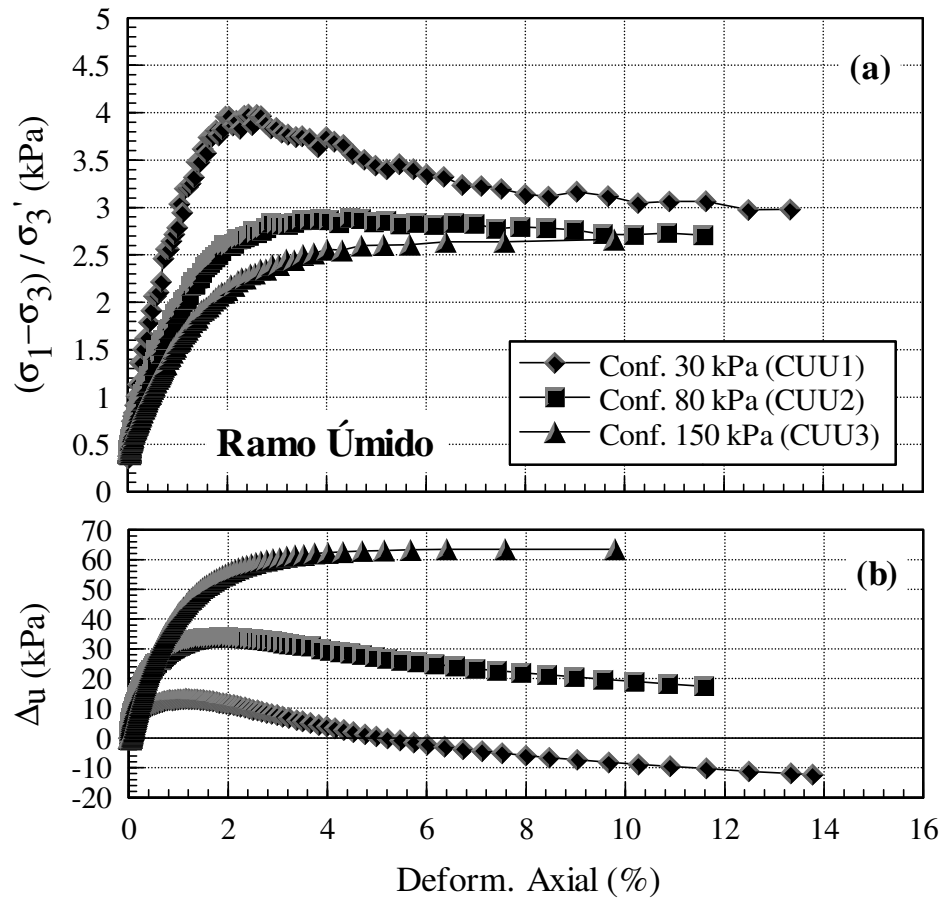

Figura 6.20 - Resultados da tensão desviadora normalizada e da poro pressão em função da deformação axial, obtidos dos ensaios triaxiais CAU (ponto U). 
Tabela 6.10 - Resultados dos ensaios triaxias CAU realizados com tensão controlada nos três pontos de estudo.

\begin{tabular}{|c|c|c|c|c|}
\hline \multicolumn{5}{|c|}{ UMIDADE ÓTIMA } \\
\hline C.P. & $\sigma_{3}(\mathrm{kPa})$ & $\left(\mathrm{q} / \sigma_{3}{ }^{\prime}\right)$ max. & $\varepsilon_{\mathrm{f}}(\%)$ & $\mathrm{u}_{\mathrm{f}}(\mathrm{kPa})$ \\
\hline CUO1 & 30 & 4.49 & 2.9 & 12.1 \\
\hline CUO2 & 80 & 3.12 & 4.2 & 20.6 \\
\hline CUO3 & 150 & 2.69 & 5.7 & 51 \\
\hline \multicolumn{5}{|c|}{ RAMO SECO } \\
\hline C.P. & $\sigma_{3}(\mathrm{kPa})$ & $\left(\mathrm{q} / \sigma_{3}{ }^{\prime}\right)$ max. & $\varepsilon_{\mathrm{f}}(\%)$ & $\Delta \mathrm{u}_{\mathrm{f}}(\mathrm{kPa})$ \\
\hline CUS1 & 30 & 3.86 & 3.3 & 14.1 \\
\hline CUS2 & 80 & 2.86 & 6 & 32.8 \\
\hline CUS3 & 150 & 2.81 & 9.3 & 74 \\
\hline \multicolumn{5}{|c|}{ RAMO ÚMIDO } \\
\hline C.P. & $\sigma_{3}(\mathrm{kPa})$ & $\left(\mathrm{q} / \sigma_{3}{ }^{\prime}\right)$ max. & $\varepsilon_{\mathrm{f}}(\%)$ & $\Delta \mathrm{u}_{\mathrm{f}}(\mathrm{kPa})$ \\
\hline CUU1 & 30 & 3.96 & 2.3 & 10.3 \\
\hline CUU2 & 80 & 2.89 & 4.5 & 28.4 \\
\hline CUU3 & 150 & 2.66 & 9.8 & 63.5 \\
\hline
\end{tabular}

\subsection{2 - Ensaios triaxias CD realizados com carregamento controlado}

Estes ensaios foram realizados apenas para corpos de prova moldados na umidade ótima, preparados seguindo a trajetória 2 (Figura 4.9), ou seja, foram saturados por aspersão de água permitindo-se que expandam livremente. Estes ensaios foram realizados na célula de cisalhamento apresentada na Figura 3.7, com pressões de confinamento de 50, 100 e $200 \mathrm{kPa}$. Todos os procedimentos deste tipo de ensaio estão descritos no item 4.11.2. Os dados dos corpos de prova após os procedimentos de moldagem, saturação e adensamento estão apresentados Tabela 6.11. Na Figura 6.21 estão os valores da tensão desviadora e da variação volumétrica dos corpos de prova em função da deformação axial. Como era de se esperar, observa-se na parte (a) desta figura, que quanto maior o valor da pressão confinante aplicada aos corpos de prova, maiores foram os valores da tensão desviadora na ruptura. De forma semelhante aos ensaios CAU, apresentados no item anterior, as deformações axiais na ruptura foram superiores a $10 \%$. 
Tabela 6.11 - Dados dos corpos de prova utilizados nos ensaios triaxias CD, após moldagem, após saturação e aplicação da tensão confinante (Ponto $\mathrm{O}$ ).

\begin{tabular}{|c|c|c|c|c|c|}
\hline \multicolumn{6}{|c|}{ MOLDAGEM } \\
\hline C.P. & $\mathrm{w}(\%)$ & $\mathrm{e}_{\mathrm{f}}$ & $\mathrm{S}(\%)$ & $\theta_{\mathrm{w}}(\%)$ & $\rho_{\mathrm{d}}\left(\mathrm{g} / \mathrm{cm}^{3}\right)$ \\
\hline CDO1 & 25.8 & 0.79 & 88.3 & 39.0 & 1.51 \\
\hline CDO2 & 25.8 & 0.81 & 86.6 & 38.7 & 1.50 \\
\hline CDO3 & 25.8 & 0.80 & 87.7 & 38.9 & 1.51 \\
\hline \multicolumn{6}{|c|}{ SATURAÇÃO } \\
\hline C.P. & $\mathrm{w}(\%)$ & $\mathrm{e}_{\mathrm{f}}$ & $\mathrm{S}(\%)$ & $\theta_{\mathrm{w}}(\%)$ & $\rho_{\mathrm{d}}\left(\mathrm{g} / \mathrm{cm}^{3}\right)$ \\
\hline CDO1 & 34.4 & 0.98 & 94.8 & 47.0 & 1.37 \\
\hline CDO2 & 33.6 & 0.96 & 94.9 & 46.5 & 1.38 \\
\hline CDO3 & 34.1 & 0.97 & 95.7 & 47.0 & 1.38 \\
\hline APÓS APLICAÇÃO DO CONFINAMENTO \\
\hline C.P. & $\mathrm{w}(\%)$ & $\mathrm{e}_{\mathrm{f}}$ & $\mathrm{S}(\%)$ & $\theta_{\mathrm{w}}(\%)$ & $\rho_{\mathrm{d}}\left(\mathrm{g} / \mathrm{cm}^{3}\right)$ \\
\hline CDO1 - Conf. $50 \mathrm{kPa}$ & 33.2 & 0.95 & 94.6 & 46.1 & 1.39 \\
\hline CDO2- Conf. 100 kPa & 29.0 & 0.84 & 94.2 & 42.9 & 1.48 \\
\hline CDO3 - Conf. 200 kPa & 27.6 & 0.79 & 94.7 & 41.8 & 1.52 \\
\hline
\end{tabular}

Observa-se na Figura $6.21 \mathrm{~b}$ que o volume dos corpos de prova submetidos às pressões confinantes de 50 e $100 \mathrm{kPa}$ diminuem no início do ensaio e, para deformações axiais respectivamente iguais a 6 e $8 \%$, estes valores passam a aumentar até o momento da ruptura. O ensaio realizado com pressão confinante de $200 \mathrm{kPa}$ apresentou apenas a tendência da redução de volume durante o cisalhamento do corpo de prova.

Na Figura 6.21b tem-se que os valores das contrações volumétricas na ruptura são maiores na medida em que aumenta o valor da pressão confinante. Nestes ensaios a máxima contração volumétrica foi de $2.5 \%$, correspondente ao corpo de prova submetido ao confinamento de $200 \mathrm{kPa}$. Na Tabela 6.12 estão apresentados os valores das pressões confinantes aplicadas, os valores das tensões desviadoras e das deformações axiais na ruptura. 


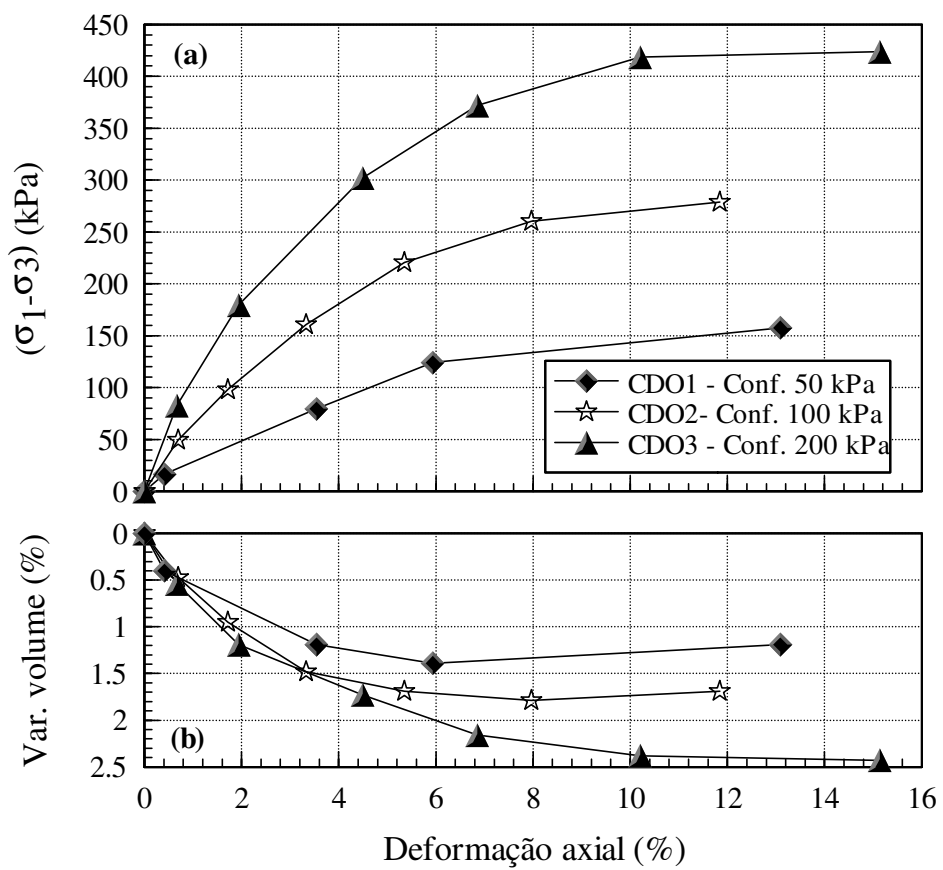

Figura 6.21 - Resultados dos ensaios triaxiais CD realizados com carregamento controlado, utilizando corpos de prova compactados na umidade ótima (Ponto O).

Tabela 6.12 - Resultados dos ensaios triaixias CD realizados com carregamento controlado, utilizando corpos de prova compactados na umidade ótima (ponto O).

\begin{tabular}{|c|c|c|c|}
\hline C.P. & $\begin{array}{c}\text { Tens. Conf. } \\
(\mathrm{kPa})\end{array}$ & $\begin{array}{c}\left(\sigma_{1}-\sigma_{3}\right)_{\mathrm{f}} \\
(\mathrm{kPa})\end{array}$ & $\varepsilon_{\mathrm{f}}(\%)$ \\
\hline $\mathrm{CDO} 1$ & 100 & 278.7 & 11.84 \\
\hline $\mathrm{CDO} 2$ & 200 & 423.6 & 15.14 \\
\hline $\mathrm{CDO} 3$ & 50 & 157.6 & 13.08 \\
\hline
\end{tabular}

Nas Figuras 6.22, 6.23 e 6.24 estão apresentadas, em função do tempo, as variações da poro pressão dos corpos de prova durante o ensaio. Os ensaios triaxiais CD saturados, realizados com medição da variação da poro pressão com o tensiômetro, não são comumente realizados nos laboratórios de mecânica dos solos. Para ilustrar os procedimentos da etapa de cisalhamento será tomado como exemplo o ensaio realizado no corpo de prova $\mathrm{CDO} 3$, apresentado na Figura 6.24. Nesta figura tem-se que até o tempo de 25 minutos foi feita a montagem do ensaio. Esta etapa vai desde a colocação da pasta de solo sobre o tensiômetro até o momento do preenchimento da célula de ensaio com água. 
A partir deste instante inicia-se a fase de adensamento aplicando-se a pressão confinante de $200 \mathrm{kPa}$. Observa-se na Figura 6.24 que logo após a aplicação da pressão de confinamento o tensiômetro lê instantaneamente o valor da poro pressão do corpo de prova. O parâmetro $\bar{B}$ pode ser obtido neste momento, sendo dado pela relação entre o valor da pressão medida pelo tensiômetro e a pressão confinante aplicada. Para este exemplo constata-se que o corpo de prova está saturado, pois os valores destas leituras são iguais.

Para iniciar a fase de cisalhamento deve-se esperar que ocorra a dissipação da pressão positiva medida no tensiômetro. Durante esta fase acompanha-se na bureta a variação volumétrica do corpo de prova. Para o tempo de 140 minutos verifica-se que a pressão positiva já está totalmente dissipada, terminando assim a fase de adensamento.

Em função das variações volumétricas do corpo de prova durante a fase de cisalhamento, o pistão foi novamente ajustado no seu topo. Neste procedimento, realizado no tempo de 120 minutos (Figura 6.24), observa-se que a sensibilidade do tensiômetro é capaz de detectar qualquer esforço de compressão sobre o corpo de prova. $\mathrm{Na}$ fase de cisalhamento foi colocado inicialmente o peso de $10 \mathrm{~kg}$. A dissipação da pressão positiva gerada pelo carregamento, ocorre em aproximadamente 50 minutos, correspondendo na Figura 6.24 ao tempo de 175 minutos. Neste momento mede-se a variação volumétrica do corpo de prova pela leitura do nível da água na bureta, e a sua deformação axial pela leitura do deflectômetro colocado no topo da célula.

Observa-se na Figura 6.24 que a pressão de confinamento, representada pela linha horizontal, se mantem constante durante todo o ensaio. Após o carregamento inicial de $10 \mathrm{~kg}$, foram colocados os incrementos de 12, 16, 10, 8 e $4 \mathrm{~kg}$. Assim que se dissipou a pressão referente ao carregamento de $4 \mathrm{~kg}$ (tempo de 160 minutos), ocorreu a ruptura do corpo de prova. O alívio da pressão sobre o tensiômetro, no momento da ruptura, faz com que o mesmo passe a ler instantaneamente valores de pressão negativa. 
Finalizando este ensaio é feito o alívio da pressão confinante, determinando-se em seguida a umidade do corpo de prova. Para os resultados das Figuras 6.22 e 6.23 tem-se que no momento da aplicação da pressão confinante os valores do parâmetro $\bar{B}$ foram respectivamente iguais a 0.9 e 0.94 .

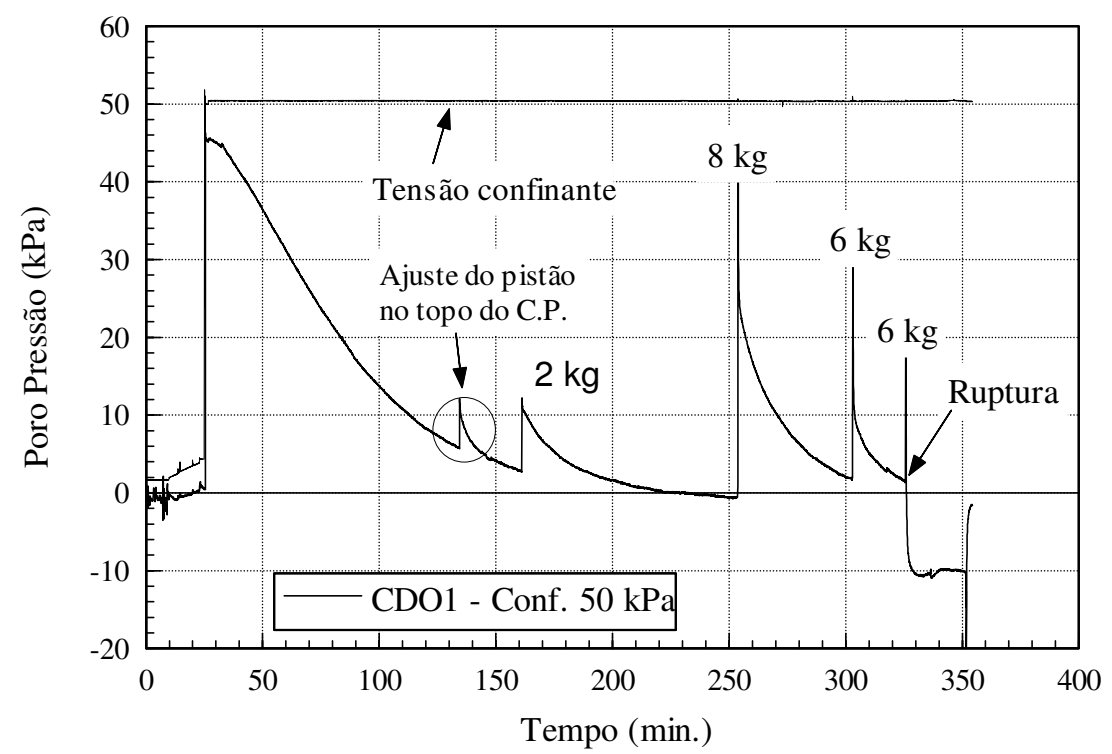

Figura 6.22 - Variação da poro pressão em função do tempo, medida com o tensiômetro no ensaio triaxial $\mathrm{CD}$, realizado com carregamento controlado e pressão confinante de $50 \mathrm{kPa}$ (Ponto O).

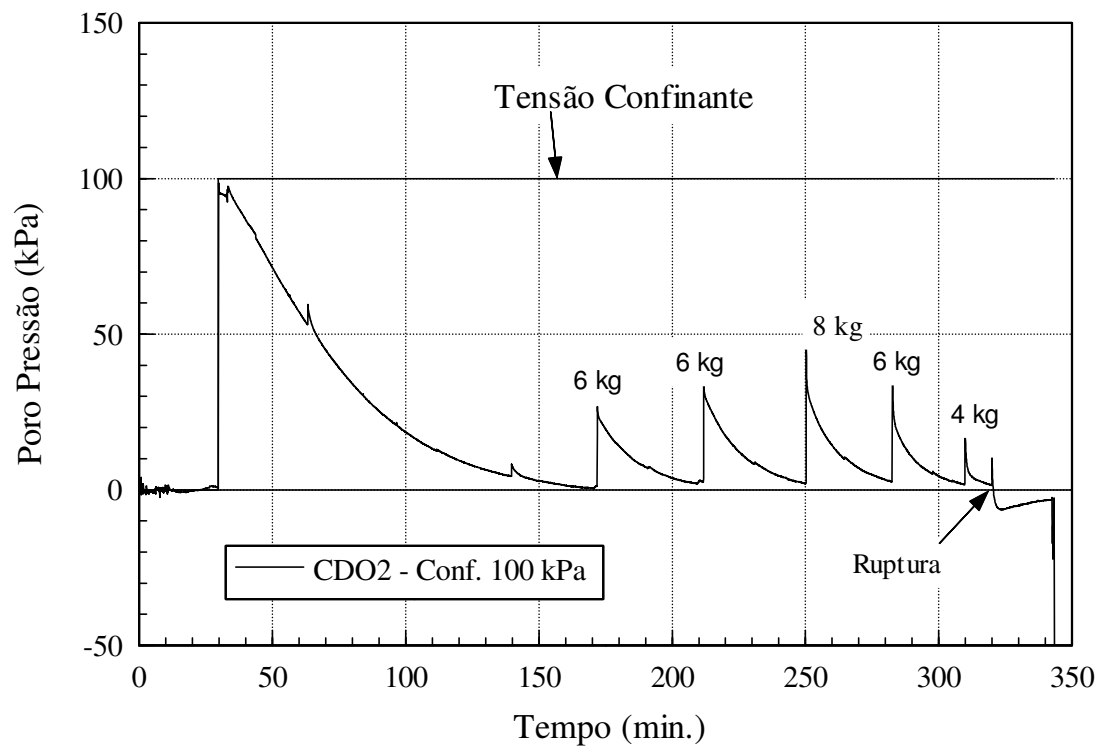

Figura 6.23 - Variação da poro pressão em função do tempo medida, com o tensiômetro no ensaio triaxial $\mathrm{CD}$, realizado com carregamento controlado e pressão confinante de $100 \mathrm{kPa}$ (Ponto O). 


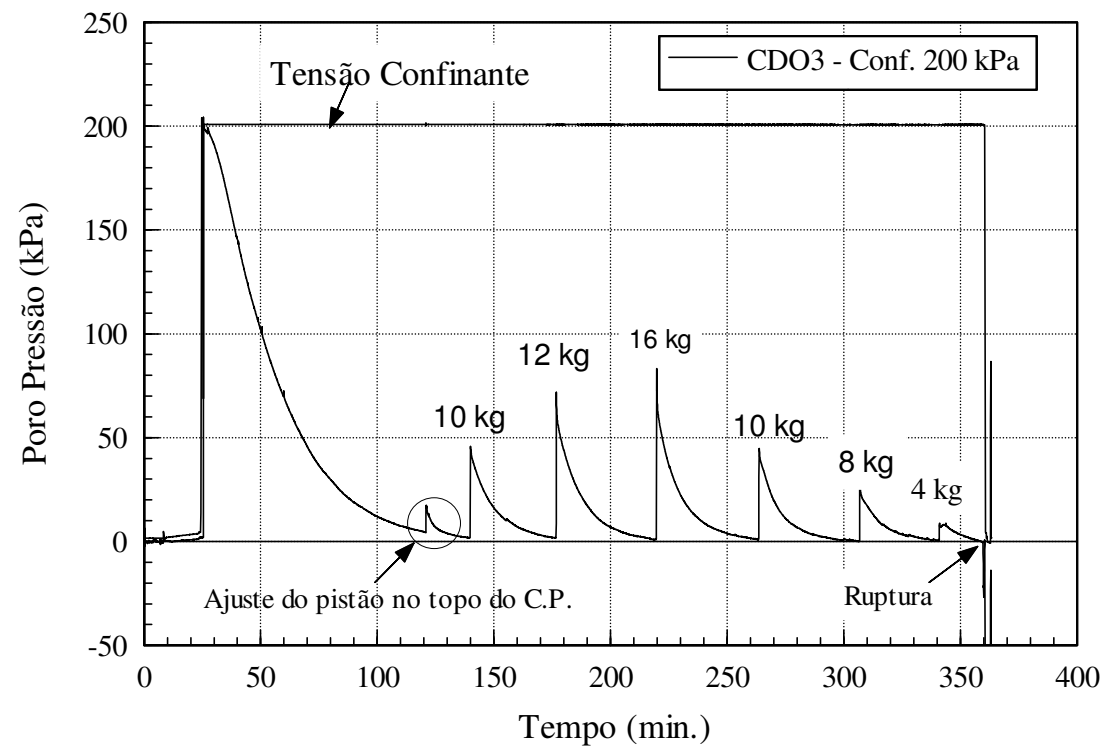

Figura 6.24 - Variação da poro pressão em função do tempo medida, com o tensiômetro no ensaio triaxial $\mathrm{CD}$, realizado com carregamento controlado e pressão confinante de $200 \mathrm{kPa}$ (Ponto O).

\section{3 - Resultados dos ensaios triaxiais CW não saturados}

Estes ensaios foram realizados na célula apresentada na Figura 3.7, utilizando corpos de prova moldados nos três pontos de estudo, definidos na Tabela 4.2. Após moldagem estes corpos de prova foram submetidos a umedecimento (trajetória 3) ou secagem (trajetória 4). No item 4.11.2 estão descritos os procedimentos que foram adotados para a realização destes ensaios.

Nas Tabelas 6.13 a 6.15 estão apresentados os dados de moldagem, os dados de preparação dos corpos de prova e os resultados dos ensaios. Na etapa de preparação estão indicadas as sucções aplicadas nos corpos de prova na placa de pressão, após serem umedecidos ou secados. Na parte referente aos resultados estão incluídos os valores das sucções iniciais, determinadas com o papel filtro e o tensiômetro, os valores das sucções após a aplicação da pressão confinante e no momento da ruptura do corpo de prova, obtidos com o tensiômetro e os valores de q e p na ruptura. 
Para ilustrar as variações da sucção em função do tempo, correspondentes aos ensaios triaxiais CW não saturados, na Figura 6.25 estão os resultados obtidos para o corpo de prova CDU8. Inicialmente o mesmo é colocado sobre o tensiômetro, localizado na célula de ensaio, e em seguida é envolvido em filme plástico para a determinação da sucção inicial. Para este exemplo (CDU8) o valor da sucção foi igual a $197 \mathrm{kPa}$, medido pelo tensiômetro no tempo de 20 minutos. Após a obtenção deste valor, o filme plástico é retirado sendo colocado no corpo de prova a membrana de borracha, o top cap, feito o enchimento da célula com água e o ajuste do pistão no topo do mesmo. Todos estes procedimentos, realizados entre os tempos de 20 a 35 minutos, representam a fase de montagem do ensaio (Figura 6.25). Os procedimentos utilizados durante a montagem podem, em função da consistência do corpo de prova, provocar pequenas alterações no valor da sucção determinada inicialmente no tempo de 20 minutos.

Após o término da montagem, a estabilização da sucção foi constatada para o tempo de 50 minutos. A partir deste instante foi aplicada a pressão confinante de $100 \mathrm{kPa}$, representada pela linha pontilhada. A aplicação desta pressão faz com que o corpo de prova apresente uma redução no seu valor de sucção, que passa a ser igual a $140 \mathrm{kPa}$. A partir deste momento inicia-se a etapa de cisalhamento com a aplicação do carregamento de $8 \mathrm{~kg}$. Após cada incremento de carregamento deve-se esperar a estabilização dos valores da sucção medida com o tensiômetro. Os próximos incrementos de carga foram iguais a 10,10, 10, 8, 6 e $4 \mathrm{~kg}$. Observa-se que ocorre o aumento da sucção do corpo de prova para os dois últimos incrementos de carga, colocados respectivamente nos tempos de 134 e 152 minutos. Após a ruptura o ensaio é desmontado para a determinação do seu teor de umidade. Os resultados de outros ensaios estão apresentados no anexo B. 
Tabela 6.13 - Condições iniciais de moldagem, preparação por umedecimento ou secagem e resultados dos ensaios triaxias CW não saturados realizados com carregamento controlado, utilzando corpos de prova compactados na umidade ótima (Ponto O).

\begin{tabular}{|c|c|c|c|c|c|c|c|c|c|c|c|c|c|c|c|c|c|c|c|c|}
\hline \multicolumn{6}{|c|}{ MOLDAGEM } & \multicolumn{7}{|c|}{ PREPARAÇÃO } & \multicolumn{8}{|c|}{ RESULTADOS } \\
\hline C.P. & $\begin{array}{c}\mathrm{W} \\
(\%)\end{array}$ & $\mathrm{e}$ & $\begin{array}{c}\mathrm{S} \\
(\%)\end{array}$ & $\begin{array}{c}\theta_{\mathrm{w}} \\
(\%)\end{array}$ & $\begin{array}{c}\rho_{\mathrm{d}} \\
\left(\mathrm{g} / \mathrm{cm}^{3}\right)\end{array}$ & Traj. & T.E. & $\begin{array}{c}\mathrm{w} \\
(\%)\end{array}$ & $\mathrm{e}$ & $\begin{array}{c}\mathrm{S} \\
(\%)\end{array}$ & $\begin{array}{c}\theta_{\mathrm{w}} \\
(\%)\end{array}$ & $\begin{array}{c}\rho_{\mathrm{d}} \\
\left(\mathrm{g} / \mathrm{cm}^{3}\right)\end{array}$ & $\begin{array}{l}\text { Suc. Inic. } \\
\text { Tens.(kPa) }\end{array}$ & $\begin{array}{l}\text { Suc.Inic. } \\
\text { P.F. }(\mathrm{kPa})\end{array}$ & $\begin{array}{c}\sigma_{3} \\
(\mathrm{kPa})\end{array}$ & $\begin{array}{c}\text { Suc.tens. } \\
\text { após } \sigma_{3}(\mathrm{kPa})\end{array}$ & $\begin{array}{c}\mathrm{q} \\
(\mathrm{kPa})\end{array}$ & $\begin{array}{c}\mathrm{p} \\
(\mathrm{kPa})\end{array}$ & $\begin{array}{c}\varepsilon_{\mathrm{f}} \\
(\%)\end{array}$ & $\begin{array}{l}\text { Suc.Rupt. } \\
\text { tens. }(\mathrm{kPa})\end{array}$ \\
\hline CDO4 & 25.3 & 0.81 & 84.8 & 37.9 & \begin{tabular}{|l|}
1.50 \\
\end{tabular} & 4 & 100 & 24.5 & 0.84 & 79.0 & 36.1 & 1.47 & 98.5 & 230 & 50 & 69.4 & 162.1 & 212.1 & 7.6 & 75.0 \\
\hline CDO5 & 25.3 & 0.79 & 86.4 & 38.2 & 1.51 & 4 & 100 & 24.7 & 0.81 & 82.3 & 36.9 & 1.49 & 96.8 & 249 & 100 & 48.0 & 189.5 & 289.5 & 7.8 & 57.0 \\
\hline CDO6 & 25.3 & 0.80 & 85.7 & 38.1 & 1.51 & 4 & 100 & 24.7 & 0.81 & 82.3 & 36.9 & 1.50 & 93.5 & 214 & 300 & 16.0 & 310.0 & 610.0 & 12.0 & 0.0 \\
\hline $\mathrm{CDO} 7$ & 25.3 & 0.81 & 85.1 & 37.9 & 1.50 & 4 & 200 & 22.9 & 0.78 & 79.0 & 34.7 & 1.52 & 192.0 & 488 & 50 & 154.0 & 185.5 & 235.5 & 4.6 & 114.2 \\
\hline $\mathrm{CDO} 8$ & 25.3 & 0.80 & 85.2 & 38.0 & 1.50 & 4 & 200 & 22.9 & 0.79 & 78.6 & 34.7 & 1.51 & 176.0 & 446 & 100 & 102.0 & 204.9 & 304.9 & 6.8 & 85.0 \\
\hline CDO9 & 25.0 & 0.80 & 84.4 & 37.6 & 1.50 & 4 & 200 & 22.8 & 0.79 & 78.2 & 34.5 & 1.51 & 182.0 & 427 & 300 & 72.2 & 294.9 & 594.9 & 6.9 & 47.2 \\
\hline $\mathrm{CDO} 10$ & 25.0 & 0.80 & 84.9 & 37.7 & 1.51 & 4 & 300 & 21.6 & 0.79 & 74.4 & 32.7 & 1.52 & 275.0 & 597 & 50 & 200.0 & 200.4 & 250.4 & 4.9 & 144.0 \\
\hline CDO11 & 25.0 & 0.80 & 85.1 & 37.7 & 1.51 & 4 & 300 & 21.7 & 0.78 & 75.2 & 33.0 & 1.52 & 270.7 & 553 & 100 & 200.0 & 269.6 & 369.6 & 4.1 & 134.0 \\
\hline $\mathrm{CDO} 12$ & 25.0 & 0.81 & 84.2 & 37.6 & 1.50 & 4 & 300 & 21.7 & 0.79 & 74.4 & 32.8 & 1.51 & 265.0 & 525 & 300 & 120.0 & 281.9 & 581.9 & 5.6 & 72.4 \\
\hline CDO13 & 25.0 & 0.79 & 85.3 & 37.8 & 1.51 & 4 & 400 & 20.1 & 0.77 & 70.4 & 30.7 & 1.53 & 400.0 & 554 & 100 & 305.0 & 269.2 & 369.2 & 7.4 & 193.0 \\
\hline CDO14 & 25.0 & 0.80 & 84.7 & 37.7 & 1.51 & 4 & 400 & 20.2 & 0.78 & 70.6 & 30.8 & 1.53 & 383.0 & 634 & 50 & 184.0 & 201.0 & 251.0 & 4.8 & 163.0 \\
\hline CDO15 & 24.8 & 0.78 & 86.2 & 37.8 & 1.52 & 4 & 450 & 19.8 & 0.75 & 71.3 & 30.7 & 1.55 & 415.5 & -- & 300 & 249.0 & 427.7 & 727.7 & 10.2 & 153.6 \\
\hline CDO16 & 24.8 & 0.79 & 84.8 & 37.5 & 1.51 & 4 & 450 & 19.9 & 0.76 & 70.8 & 30.6 & 1.54 & 395.0 & -- & 100 & 342.0 & 287.1 & \begin{tabular}{|l|}
387.1 \\
\end{tabular} & 7.0 & 225.7 \\
\hline CDO17 & 24.8 & 0.78 & 85.6 & 37.7 & 1.52 & 4 & 450 & 19.8 & 0.76 & 70.6 & 30.4 & 1.54 & 425.7 & -- & 50 & 396.0 & 262.4 & 312.4 & 3.9 & 267.0 \\
\hline CDO18 & 24.8 & 0.79 & 85.1 & 37.6 & 1.51 & 3 & 50 & 25.9 & 0.82 & 85.3 & 38.5 & 1.49 & 42.0 & -- & 100 & 7.4 & 157.6 & 257.6 & 12.9 & 25.0 \\
\hline CDO19 & 24.8 & 0.79 & 85.3 & 37.6 & 1.52 & 3 & 50 & 25.8 & 0.83 & 84.6 & 38.2 & 1.48 & 40.2 & -- & 50 & 13.2 & 129.9 & 179.9 & 16.4 & 50.6 \\
\hline $\mathrm{CDO} 20$ & 24.8 & 0.80 & 83.5 & 37.2 & 1.50 & 4 & 150 & 23.2 & 0.79 & 79.6 & 35.1 & 1.51 & 136.0 & -- & 300 & 44.5 & 330.2 & 630.2 & 12.2 & 28.4 \\
\hline $\mathrm{CDO} 21$ & 24.8 & 0.79 & 85.3 & 37.6 & 1.52 & 4 & 350 & 20.5 & 0.76 & 73.7 & 31.7 & 1.54 & 337.0 & -- & 300 & 179.0 & 390.2 & 690.2 & 14.8 & 113.0 \\
\hline $\mathrm{CDO} 22$ & 24.8 & 0.79 & 85.4 & 37.6 & 1.52 & 4 & 350 & 20.7 & 0.77 & 73.1 & 31.7 & 1.53 & 330.0 & -- & 100 & 278.2 & 277.2 & \begin{tabular}{|l|}
377.2 \\
\end{tabular} & 6.8 & 189.7 \\
\hline $\mathrm{CDO} 23$ & 25.0 & 0.85 & 84.7 & 37.7 & 1.51 & 4 & 400 & 20.0 & 0.85 & 63.5 & 160.2 & 1.46 & 369.0 & 569 & 200 & 229.0 & 304.2 & 504.2 & 9.8 & 160.2 \\
\hline
\end{tabular}

T.E.- Translação de eixos aplicada na placa de pressão 
Tabela 6.14 - Condições iniciais de moldagem, preparação por umedecimento ou secagem e resultados dos ensaios triaxias CW não saturados realizados com carregamento controlado, utilizando corpos de prova compactados no ramo seco (Ponto S).

\begin{tabular}{|c|c|c|c|c|c|c|c|c|c|c|c|c|c|c|c|c|c|c|c|c|}
\hline \multicolumn{6}{|c|}{ MOLDAGEM } & \multicolumn{7}{|c|}{ PREPARAÇÃO } & \multicolumn{8}{|c|}{ RESULTADOS } \\
\hline C.P. & $\begin{array}{l}\mathrm{w} \\
(\%) \\
\end{array}$ & $\mathrm{e}$ & $\begin{array}{c}\mathrm{S} \\
(\%) \\
\end{array}$ & $\begin{array}{c}\theta_{\mathrm{w}} \\
(\%) \\
\end{array}$ & $\begin{array}{c}\rho_{\mathrm{d}} \\
\left(\mathrm{g} / \mathrm{cm}^{3}\right) \\
\end{array}$ & Traj. & T.E. & $\begin{array}{c}\mathrm{w} \\
(\%) \\
\end{array}$ & $\mathrm{e}$ & $\begin{array}{c}\mathrm{S} \\
(\%) \\
\end{array}$ & $\begin{array}{c}\theta_{\mathrm{w}} \\
(\%) \\
\end{array}$ & $\begin{array}{c}\rho_{\mathrm{d}} \\
\left(\mathrm{g} / \mathrm{cm}^{3}\right)\end{array}$ & $\begin{array}{l}\text { Suc. Inic. } \\
\text { Tens.(kPa) }\end{array}$ & $\begin{array}{l}\text { Suc.Inic. } \\
\text { P.F. (kPa) }\end{array}$ & $\begin{array}{c}\sigma_{3} \\
(\mathrm{kPa}) \\
\end{array}$ & $\begin{array}{c}\text { Suc.tens. } \\
\text { após } \sigma_{3}(\mathrm{kPa})\end{array}$ & $\begin{array}{c}\mathrm{q} \\
(\mathrm{kPa}) \\
\end{array}$ & $\begin{array}{c}\mathrm{p} \\
(\mathrm{kPa}) \\
\end{array}$ & $\begin{array}{c}\varepsilon_{\mathrm{f}} \\
(\%) \\
\end{array}$ & $\begin{array}{l}\text { Suc. Rupt. } \\
\text { tens. (kPa) }\end{array}$ \\
\hline CDS1 & 17.1 & 0.84 & 55.0 & 25.2 & 1.47 & 3 & 100 & 21.9 & 0.93 & 64.0 & 30.8 & 1.41 & 104.0 & 313 & 300 & 52.0 & 262.9 & 562.9 & 10.3 & 60.0 \\
\hline $\mathrm{CDS} 2$ & 17.1 & 0.85 & 54.6 & 25.1 & 1.47 & 3 & 100 & 22.5 & 0.94 & 64.9 & 31.4 & 1.40 & 99.2 & 182 & 200 & 48.0 & 227.5 & 427.5 & 12.0 & 54.1 \\
\hline $\mathrm{CDS} 3$ & 17.1 & 0.85 & 54.6 & 25.1 & 1.47 & 3 & 100 & 22.0 & 0.93 & 64.2 & 30.9 & 1.41 & 99.0 & 262 & 50 & 74.4 & 130.0 & 180.0 & 11.5 & 88.5 \\
\hline CDS4 & 17.1 & 0.85 & 54.5 & 25.1 & 1.47 & 3 & 200 & 18.6 & 0.91 & 55.3 & 26.4 & 1.42 & 235.0 & 424 & 300 & 133.0 & 365.0 & 665.0 & 15.0 & 153.0 \\
\hline CDS5 & 17.1 & 0.85 & 54.5 & 25.0 & 1.46 & 3 & 200 & 18.5 & 0.89 & 56.4 & 26.6 & 1.43 & 227.0 & 433 & 200 & 102.0 & 265.0 & 465.0 & 9.0 & 93.0 \\
\hline CDS6 & 17.1 & 0.85 & 54.6 & 25.1 & 1.47 & 3 & 200 & 18.6 & 0.90 & 56.0 & 26.5 & 1.43 & 227.0 & 436 & 50 & 174.0 & 130.9 & 190.0 & 8.0 & 143.7 \\
\hline CDS7 & 17.1 & 0.85 & 54.7 & 25.1 & 1.47 & 4 & 300 & 16.8 & 0.88 & 51.7 & 24.2 & 1.44 & 350.0 & 583 & 300 & 234.0 & 365.0 & 665.0 & 14.0 & 209.0 \\
\hline CDS8 & 17.1 & 0.85 & 54.6 & 25.1 & 1.47 & 4 & 300 & 17.0 & 0.88 & 52.4 & 24.5 & 1.44 & 350.0 & 622 & 200 & 234.0 & 278.0 & 478.0 & 9.0 & 228.0 \\
\hline CDS9 & 17.1 & 0.85 & 54.7 & 25.1 & 1.47 & 4 & 300 & 16.9 & 0.88 & 52.0 & 24.4 & 1.44 & 396.0 & 619 & 50 & 251.5 & 160.0 & 210.0 & --- & 267.0 \\
\hline CDS10 & 17.1 & 0.85 & 54.6 & 25.1 & 1.47 & 4 & 400 & 16.2 & 0.88 & 50.0 & 23.4 & 1.44 & 453.0 & 659 & 300 & 330.0 & 382.7 & 682.7 & 14.0 & 303.0 \\
\hline CDS11 & 17.1 & 0.85 & 54.7 & 25.1 & 1.47 & 4 & 400 & 16.2 & 0.87 & 50.4 & 23.5 & 1.45 & 472.0 & 642 & 200 & 379.0 & 311.0 & 511.0 & 13.0 & 335.0 \\
\hline CDS12 & 17.1 & 0.85 & 54.4 & 25.0 & 1.46 & 4 & 400 & 16.0 & 0.88 & 49.2 & 23.0 & 1.44 & 511.0 & 598 & 50 & 490.0 & 206.0 & 256.0 & 12.0 & 443.0 \\
\hline CDS13 & 17.6 & 0.87 & 54.8 & 25.5 & 1.45 & 3 & 50 & 25.0 & 0.92 & 73.6 & 35.3 & 1.41 & 46.3 & --- & 300 & 9.6 & 260.5 & 560.5 & 14.3 & 0.0 \\
\hline CDS14 & 17.6 & 0.88 & 54.3 & 25.4 & 1.44 & 3 & 50 & 25.0 & 0.94 & 72.1 & 34.9 & 1.40 & 41.1 & --- & 200 & 19.6 & 225.0 & 425.0 & 14.2 & 18.0 \\
\hline CDS15 & 17.6 & 0.86 & 55.2 & 25.6 & 1.46 & 3 & 0 & 25.4 & 0.94 & 73.5 & 35.5 & 1.40 & 36.0 & --- & 50 & 22.3 & 105.9 & 155.9 & 11.6 & 37 \\
\hline CDS16 & 17.1 & 0.85 & 54.7 & 25.1 & 1.467 & 3 & 200 & 18.5 & 0.8965 & 56.0 & 26.5 & 1.43 & 226.0 & 419 & 100 & 153.0 & 210.0 & 310.0 & 10.0 & 144.0 \\
\hline CDS17 & 17.1 & 0.85 & 54.5 & 25.0 & 1.465 & 4 & 300 & 17.1 & 0.8911 & 51.9 & 24.5 & 1.43 & 377.0 & 596 & 100 & 321.0 & 250.0 & 350.0 & 11.0 & 286.0 \\
\hline CDS18 & 17.1 & 0.86 & 54.5 & 25.0 & 1.465 & 4 & 400 & 16.2 & 0.8794 & 49.8 & 23.3 & 1.44 & 475.0 & 638 & 100 & 433.0 & 237.0 & 337.0 & 12.0 & 374.0 \\
\hline CDS19 & 17.6 & 0.86 & 55.3 & 25.6 & 1.456 & 3 & 50 & 25.6 & 0.9282 & 74.6 & 35.9 & 1.41 & 36.0 & --- & 100 & 19.8 & 132.5 & 282.3 & 14.1 & 32.4 \\
\hline
\end{tabular}

T.E.- Translação de eixos aplicada na placa de pressão 
Tabela 6.15 - Condições iniciais de moldagem, preparação por umedecimento ou secagem e resultados dos ensaios triaxias CW não saturados realizados com carregamento controlado, utilizando corpos de prova compactados no ramo úmido (Ponto U).

\begin{tabular}{|c|c|c|c|c|c|c|c|c|c|c|c|c|c|c|c|c|c|c|c|c|}
\hline \multicolumn{6}{|c|}{ MOLDAGEM } & \multicolumn{7}{|c|}{ PREPARAÇÃO } & \multicolumn{8}{|c|}{ RESULTADOS } \\
\hline C.P. & $\begin{array}{c}\mathrm{w} \\
(\%) \\
\end{array}$ & $\mathrm{e}$ & $\begin{array}{c}\mathrm{S} \\
(\%)\end{array}$ & $\begin{array}{c}\theta_{\mathrm{w}} \\
(\%) \\
\end{array}$ & $\begin{array}{c}\rho_{\mathrm{d}} \\
\left(\mathrm{g} / \mathrm{cm}^{3}\right)\end{array}$ & Traj. & T.E. & $\begin{array}{c}\mathrm{w} \\
(\%)\end{array}$ & $\mathrm{e}$ & $\begin{array}{c}\mathrm{S} \\
(\%)\end{array}$ & $\begin{array}{c}\theta_{\mathrm{w}} \\
(\%)\end{array}$ & $\begin{array}{c}\rho_{\mathrm{d}} \\
\left(\mathrm{g} / \mathrm{cm}^{3}\right) \\
\end{array}$ & $\begin{array}{l}\text { Suc. Inic. } \\
\text { Tens.(kPa) }\end{array}$ & $\begin{array}{l}\text { Suc.Inic. } \\
\text { P.F. (kPa) }\end{array}$ & $\begin{array}{c}\sigma_{3} \\
(\mathrm{kPa})\end{array}$ & $\begin{array}{c}\text { Suc.tens. } \\
\text { após } \sigma_{3}(\mathrm{kPa})\end{array}$ & $\begin{array}{c}\mathrm{q} \\
(\mathrm{kPa}) \\
\end{array}$ & $\begin{array}{c}\mathrm{p} \\
(\mathrm{kPa})\end{array}$ & $\begin{array}{c}\varepsilon_{\mathrm{f}} \\
(\%)\end{array}$ & $\begin{array}{c}\text { Suc.Rupt. } \\
\text { Tens. (kPa) }\end{array}$ \\
\hline CDU1 & 28.2 & 0.86 & 89.0 & 41.1 & 1.46 & 4 & 300 & 24.1 & 0.82 & 79.4 & 35.8 & 1.49 & 258.0 & --- & 200 & 123.0 & 281.0 & 481.0 & 14.0 & 70.0 \\
\hline CDU2 & 28.2 & 0.86 & 89.3 & 41.1 & 1.46 & 4 & 300 & 24.1 & 0.83 & 79.0 & 35.7 & 1.48 & 261.0 & --- & 100 & 181.1 & 218.7 & 325.0 & 11.0 & 108.8 \\
\hline CDU3 & 28.2 & 0.86 & 88.9 & 41.1 & 1.46 & 4 & 300 & 24.1 & 0.82 & 79.3 & 35.8 & 1.49 & 263.0 & --- & 50 & 214.0 & 192.5 & 242.5 & 9.0 & 130.0 \\
\hline CDU4 & 28.2 & 0.86 & 88.4 & 41.0 & 1.45 & 4 & 350 & 22.3 & 0.82 & 73.9 & 33.3 & 1.49 & 370.0 & --- & 200 & 239.0 & 304.1 & 511.5 & 11.0 & 133.3 \\
\hline CDU5 & 28.2 & 0.85 & 89.9 & 41.3 & 1.47 & 4 & 350 & 22.1 & 0.80 & 74.4 & 33.2 & 1.50 & 377.0 & --- & 100 & 317.0 & 255.5 & 355.5 & 10.0 & 185.5 \\
\hline CDU6 & 28.2 & 0.85 & 89.5 & 41.2 & 1.46 & 4 & 350 & 21.8 & 0.81 & 72.8 & 32.6 & 1.50 & 398.0 & --- & 50 & 371.0 & 227.0 & 277.0 & 8.0 & 220.0 \\
\hline CDU7 & 28.2 & 0.84 & 90.9 & 41.5 & 1.47 & 4 & 200 & 24.7 & 0.82 & 81.6 & 36.8 & 1.49 & 201.0 & --- & 50 & 172.0 & 175.0 & 225.0 & 12.0 & 121.0 \\
\hline CDU8 & 28.2 & 0.84 & 91.1 & 41.5 & 1.47 & 4 & 200 & 24.9 & 0.82 & 82.1 & 37.0 & 1.49 & 197.0 & --- & 100 & 138.0 & 210.2 & 310.2 & 15.0 & 102.7 \\
\hline CDU9 & 28.2 & 0.83 & 91.6 & 41.6 & 1.48 & 4 & 200 & 25.1 & 0.82 & 83.5 & 37.5 & 1.49 & 185.0 & --- & 200 & 83.0 & 262.5 & 462.5 & 13.0 & 50.6 \\
\hline CDU10 & 28.2 & 0.84 & 91.0 & 41.5 & 1.47 & 4 & 450 & 21.6 & 0.80 & 73.5 & 32.6 & 1.51 & 427.0 & --- & 50 & 395.0 & 229.0 & 279.0 & 11.0 & 234.0 \\
\hline CDU11 & 28.2 & 0.84 & 90.9 & 41.5 & 1.47 & 4 & 450 & 21.5 & 0.80 & 72.6 & 32.3 & 1.50 & 418.0 & --- & 100 & 354.0 & 259.9 & 375.0 & 10.0 & 213.5 \\
\hline CDU12 & 28.2 & 0.84 & 90.8 & 41.5 & 1.47 & 4 & 450 & 21.4 & 0.80 & 72.2 & 32.1 & 1.50 & 430.0 & --- & 200 & 285.0 & 330.0 & 530.0 & 12.0 & 155.0 \\
\hline CDU13 & 28.2 & 0.85 & 90.0 & 41.3 & 1.47 & 4 & 120 & 26.1 & 0.82 & 86.4 & 38.9 & 1.49 & 90.0 & --- & 50 & 59.5 & 150.0 & 200.0 & 14.6 & 65.8 \\
\hline CDU14 & 28.2 & 0.85 & 90.1 & 41.4 & 1.47 & 4 & 120 & 25.2 & 0.83 & 82.8 & 37.4 & 1.48 & 138.6 & --- & 100 & 77.9 & 188.5 & 288.5 & 10.5 & 62.8 \\
\hline CDU15 & 29.2 & 0.84 & 91.2 & 41.6 & 1.47 & 4 & --- & 25.2 & --- & --- & --- & --- & 136.0 & --- & 200 & 43.4 & 251.0 & 451.0 & 14.1 & 7.5 \\
\hline CDU16 & 28.2 & 0.86 & 88.7 & 41.0 & 1.457 & 4 & 300 & 24.0 & 0.83 & 78.5 & 35.6 & 1.48 & 252.0 & --- & 300 & 84.3 & 310.4 & 620.0 & 12.0 & 18.0 \\
\hline CDU17 & 28.2 & 0.86 & 89.2 & 41.1 & 1.461 & 4 & 350 & 22.6 & 0.83 & 74.0 & 33.5 & 1.48 & 347.0 & --- & 300 & 171.6 & 341.5 & 641.5 & 13.0 & 85.0 \\
\hline CDU18 & 28.2 & 0.84 & 91.0 & 41.5 & 1.474 & 4 & 450 & 21.5 & 0.80 & 72.8 & 32.4 & 1.50 & 440.0 & --- & 300 & 257.0 & 382.8 & 682.8 & 13.7 & 140.0 \\
\hline CDU19 & 28.2 & 0.89 & 86.2 & 40.5 & 1.436 & 4 & 300 & 22.3 & 0.81 & 75.1 & 33.5 & 1.50 & 300.0 & --- & 300 & 136.6 & 331.6 & 631.6 & 14.9 & 63.4 \\
\hline
\end{tabular}

T.E.- Translação de eixos aplicada na placa de pressão 


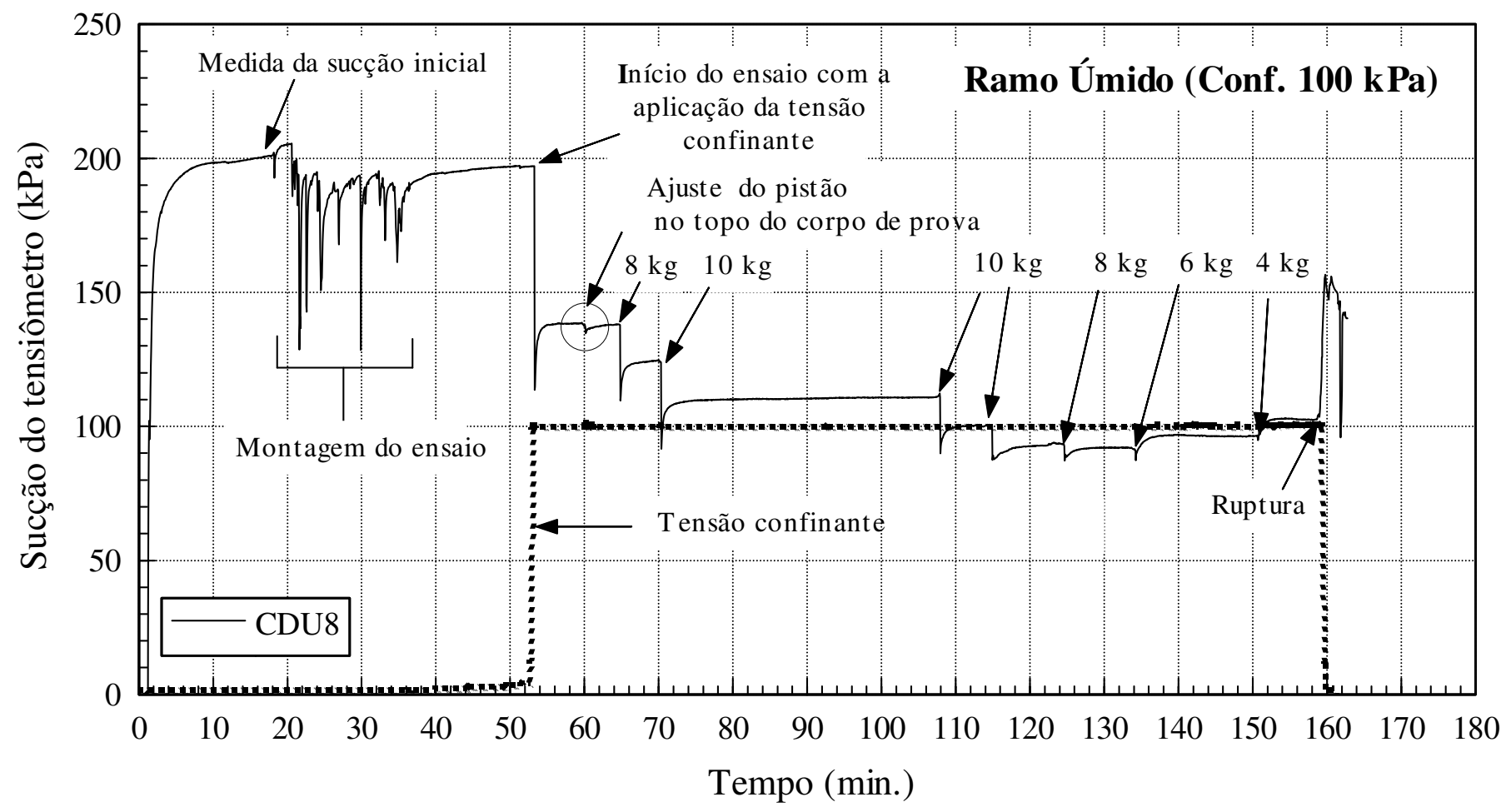

Figura 6.25 - Variação da sucção determinada com o tensiômetro durante a realização de um ensaio triaxial CW não saturado. 
Nas Figuras 6.26 a 6.36 estão apresentados os resultados dos ensaios para as três condições de moldagem. Na parte (a) destas figuras estão os valores das tensões desviadoras em função da deformação axial, e na (b) estão as variações dos valores das sucções durante a etapa de cisalhamento. Os pontos experimentais dos resultados situados sobre o eixo das ordenadas, na parte (b) destas figuras, correspondem às sucções dos corpos de prova após a etapa de confinamento.

Nas Figuras 6.26, 6.27 e 6.28 estão os resultados dos ensaios realizados em corpos de prova moldados na umidade ótima e submetidos respectivamente às pressões confinantes de 50, 100 e $300 \mathrm{kPa}$. Na parte (a) destas figuras observa-se que quanto maior a sucção inicial do corpo de prova, maior é a sua resistência e o módulo de deformabilidade tangente e menor a deformação axial na ruptura.

Nas Figuras 6.26b, 6.27b e 6.28b constata-se que no início da fase de cisalhamento ocorre uma redução nos valores da sucção. Esta redução se dá de forma gradativa, tendendo a se estabilizar ao se aproximar da ruptura do corpo de prova. Quanto maior a sucção inicial dos corpos de prova, maiores as reduções iniciais da sucção. Para os corpos de prova com sucções iniciais (após confinamento) inferiores a 100 $\mathrm{kPa}$, tem-se que após a redução inicial, a sucção se estabiliza e passa a apresentar um pequeno aumento.

As observações feitas para os resultados dos corpos de prova moldados na umidade ótima são válidas para os corpos de prova moldados no ramo úmido, cujos resultados estão apresentados nas Figuras 6.33 a 6.36. A semelhança da estrutura de poros resultante destas duas condições de moldagem já foi observada nos resultados das curvas de retenção e nas observações das imagens de microscopia eletrônica de varredura, apresentadas no item 5.2.1. 
As variações das sucções para as condições de moldagem no ramo seco, apresentadas nas Figuras $6.29 \mathrm{~b}$ a $6.32 \mathrm{~b}$, são menores que as observadas para a moldagem na umidade ótima e no ramo úmido. Este fato pode ser percebido ao se comparar os resultados dos corpos de prova CDO17, CDS12 e CDU10, todos realizados com pressão confinante de $50 \mathrm{kPa}$. Os corpos de prova CDO17 e CDU10 apresentam sucções iniciais iguais a $395 \mathrm{kPa}$ e na ruptura estes valores são respectivamente iguais a $267 \mathrm{kPa}$ e $234 \mathrm{kPa}$, ou seja, apresentaram variação de sucção de 161 e 128 $\mathrm{kPa}$. No entanto, o corpo de prova CDS12 moldado no ramo seco, com sucção inicial igual a $490 \mathrm{kPa}$, apresentou na ruptura variação de sucção de apenas $47 \mathrm{kPa}$.

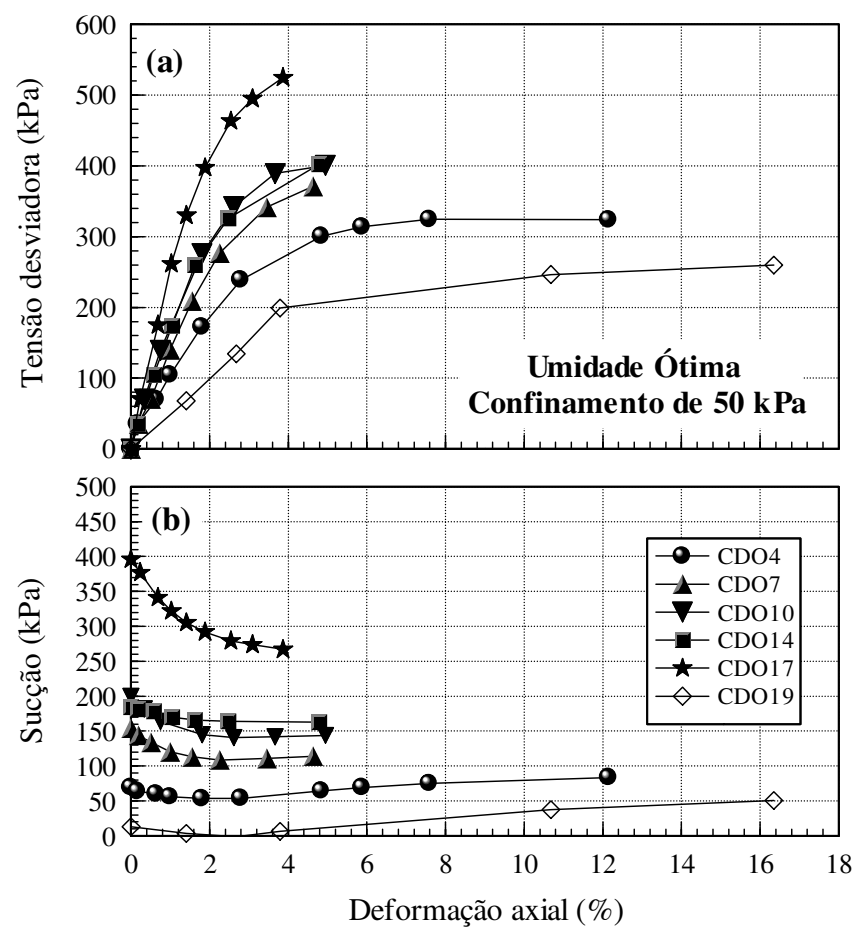

Figura 6.26 - Resultados dos ensaios triaxiais CW não saturados obtidos dos corpos de prova compactados na umidade ótima e ensaiados com confinamento de $50 \mathrm{kPa}$. 

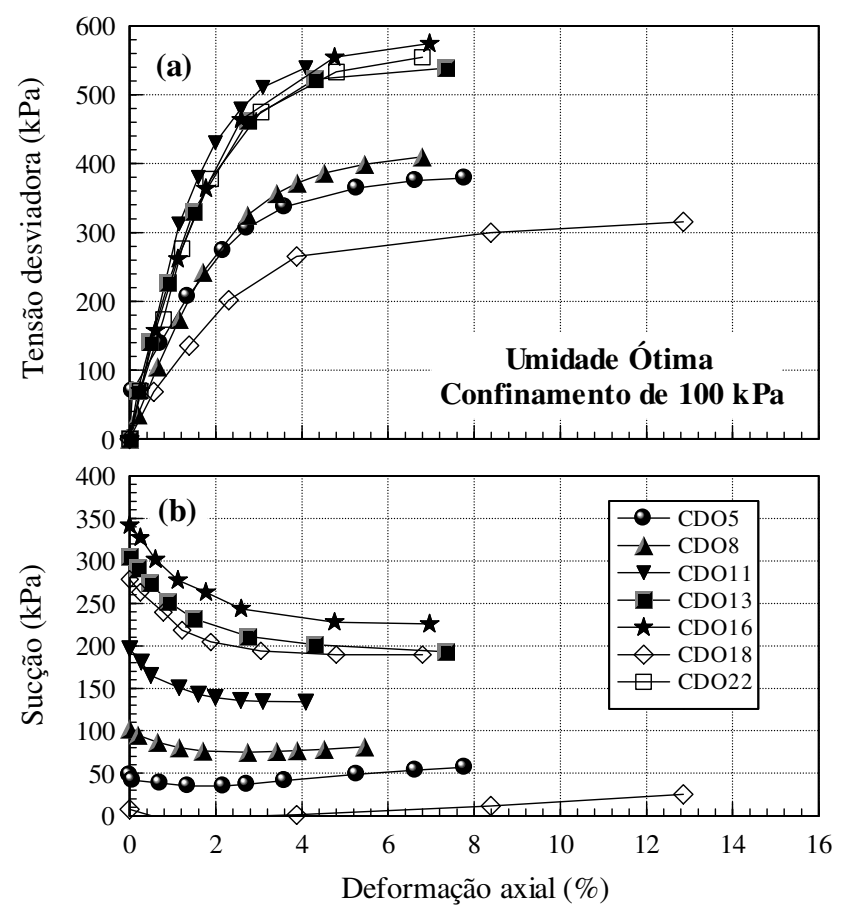

Figura 6.27 - Resultados dos ensaios triaxiais CW não saturados obtidos dos corpos de prova compactados na umidade ótima e ensaiados com confinamento de $100 \mathrm{kPa}$.
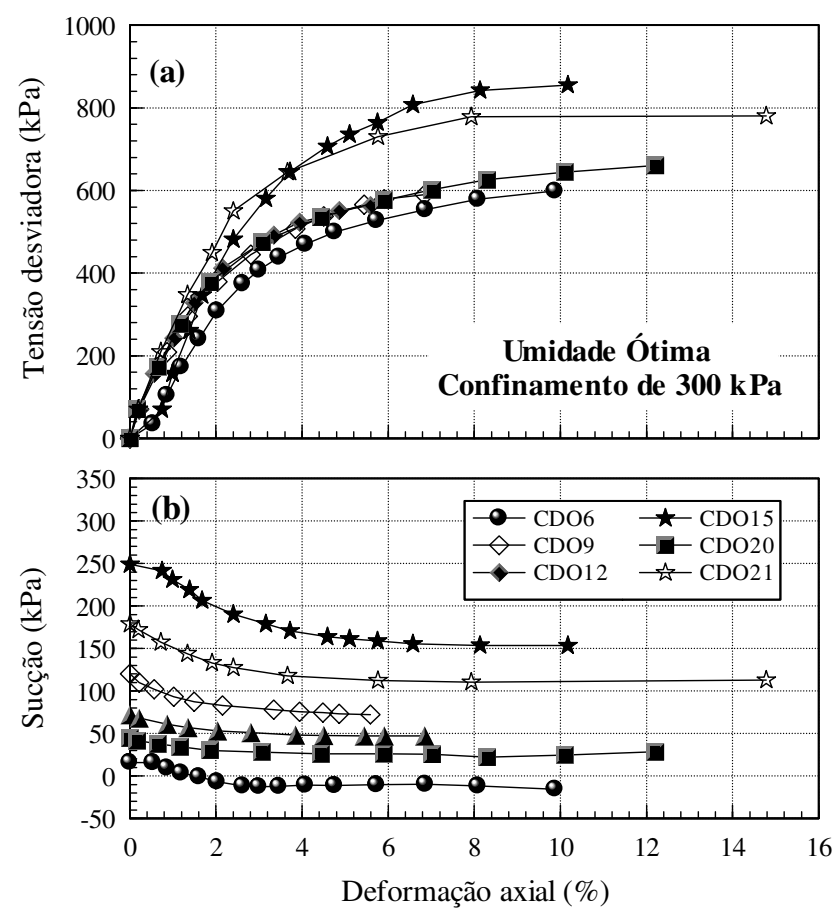

Figura 6.28 - Resultados dos ensaios triaxiais CW não saturados obtidos dos corpos de prova compactados na umidade ótima e ensaiados com confinamento de $300 \mathrm{kPa}$. 


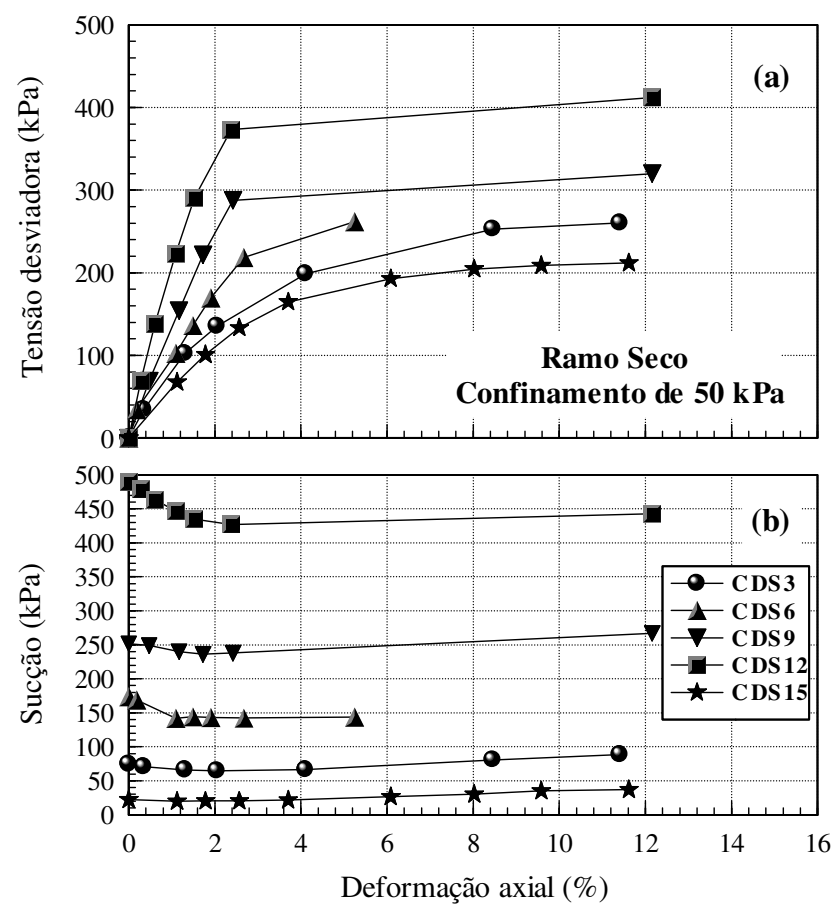

Figura 6.29 - Resultados dos ensaios triaxiais CW não saturados obtidos dos corpos de prova compactados no ramo seco e ensaiados com confinamento de $50 \mathrm{kPa}$.

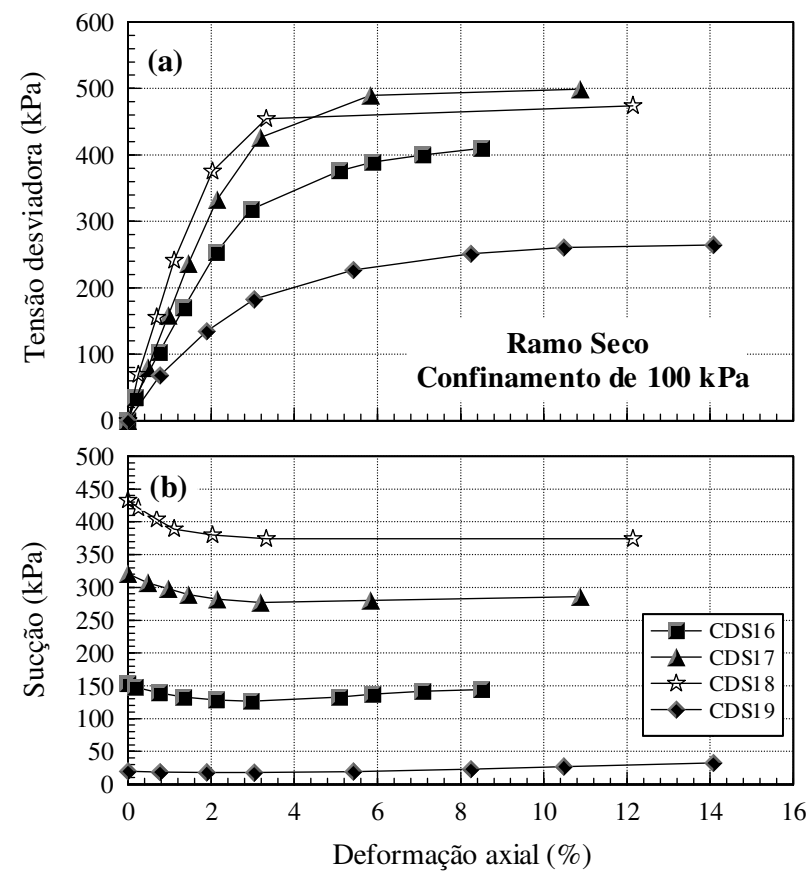

Figura 6.30 - Resultados dos ensaios triaxiais CW não saturados obtidos dos corpos de prova compactados no ramo seco e ensaiados com confinamento de $100 \mathrm{kPa}$. 

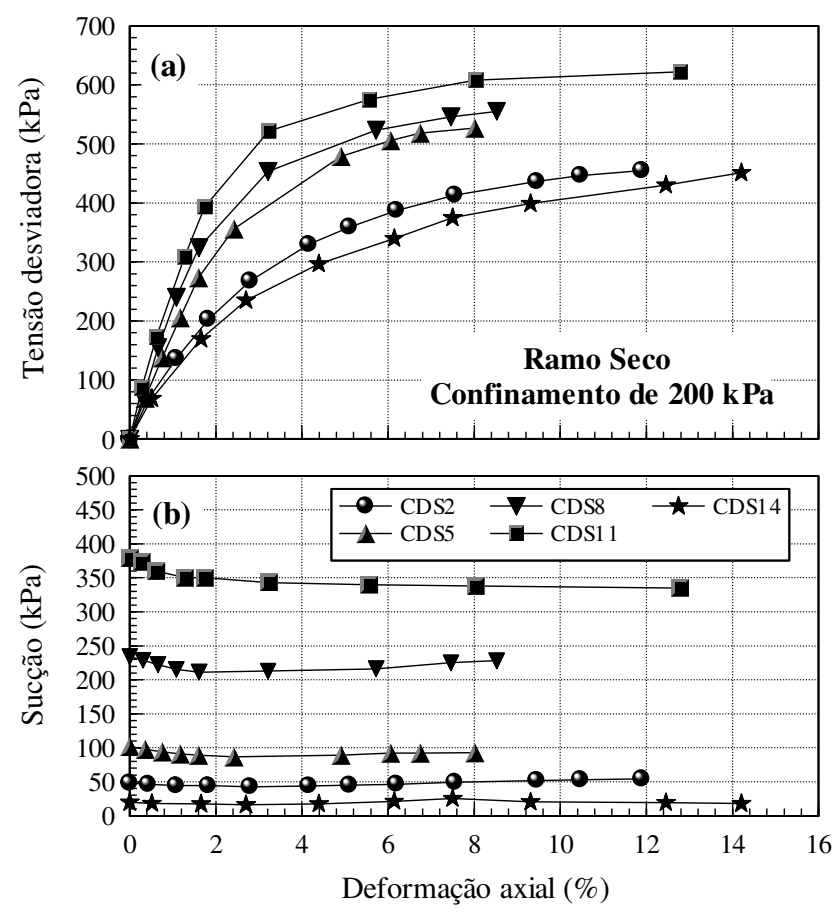

Figura 6.31 - Resultados dos ensaios triaxiais CW não saturados obtidos dos corpos de prova compactados no ramo seco e ensaiados com confinamento de $200 \mathrm{kPa}$.
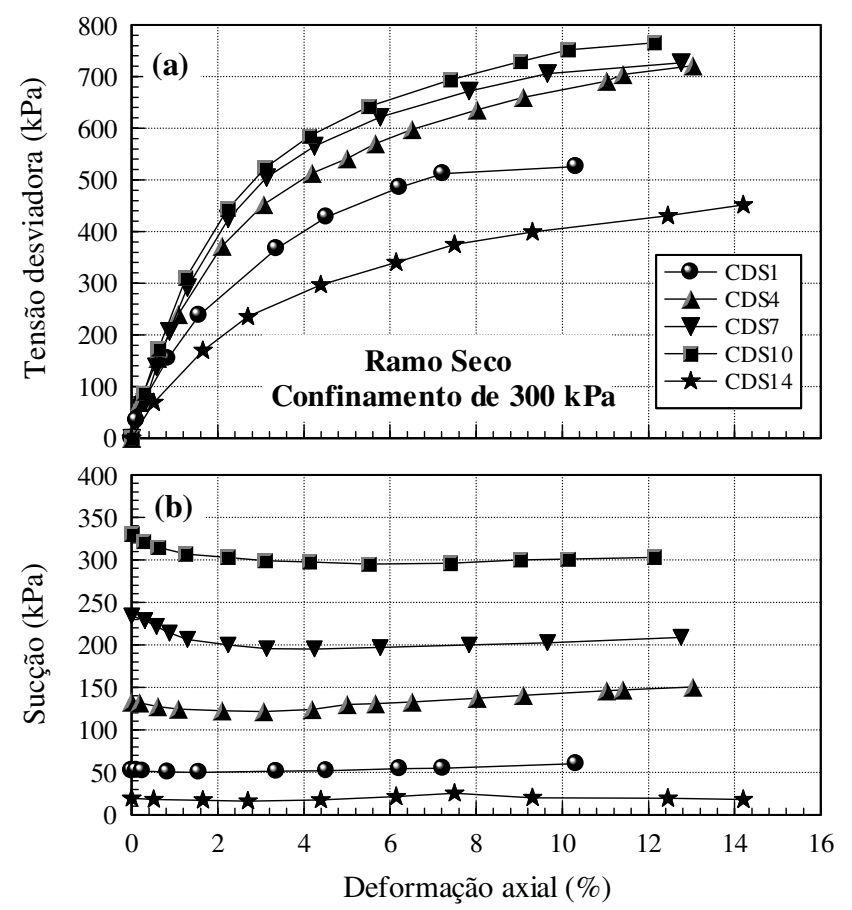

Figura 6.32 - Resultados dos ensaios triaxiais CW não saturados obtidos dos corpos de prova compactados no ramo seco e ensaiados com confinamento de $300 \mathrm{kPa}$. 


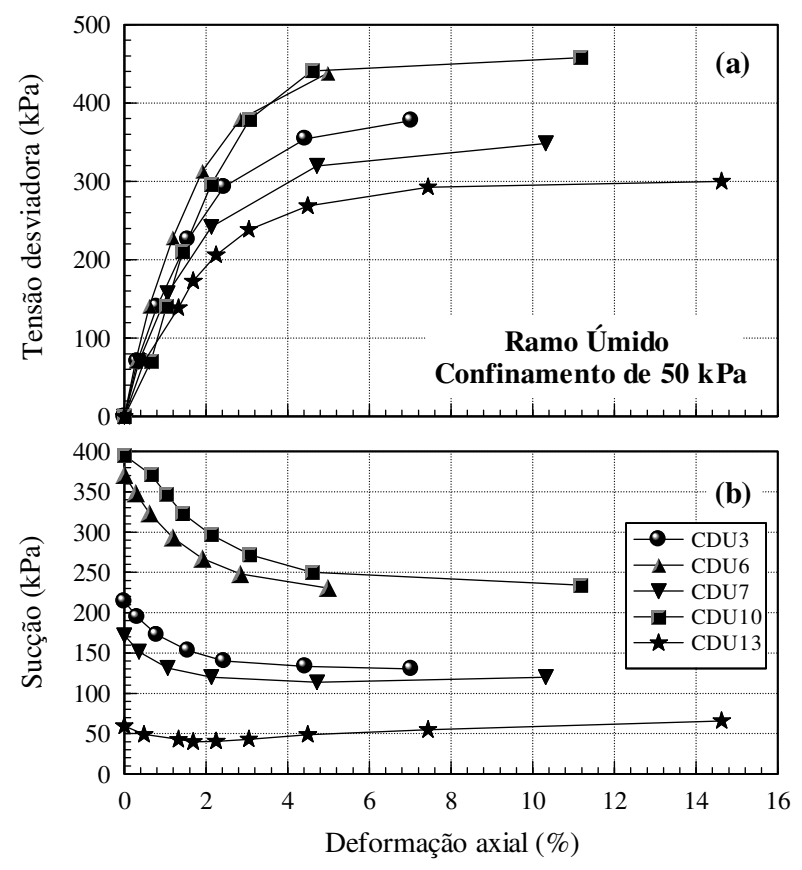

Figura 6.33 - Resultados dos ensaios triaxiais CW não saturados obtidos dos corpos de prova compactados no ramo úmido e ensaiados com confinamento de $50 \mathrm{kPa}$.
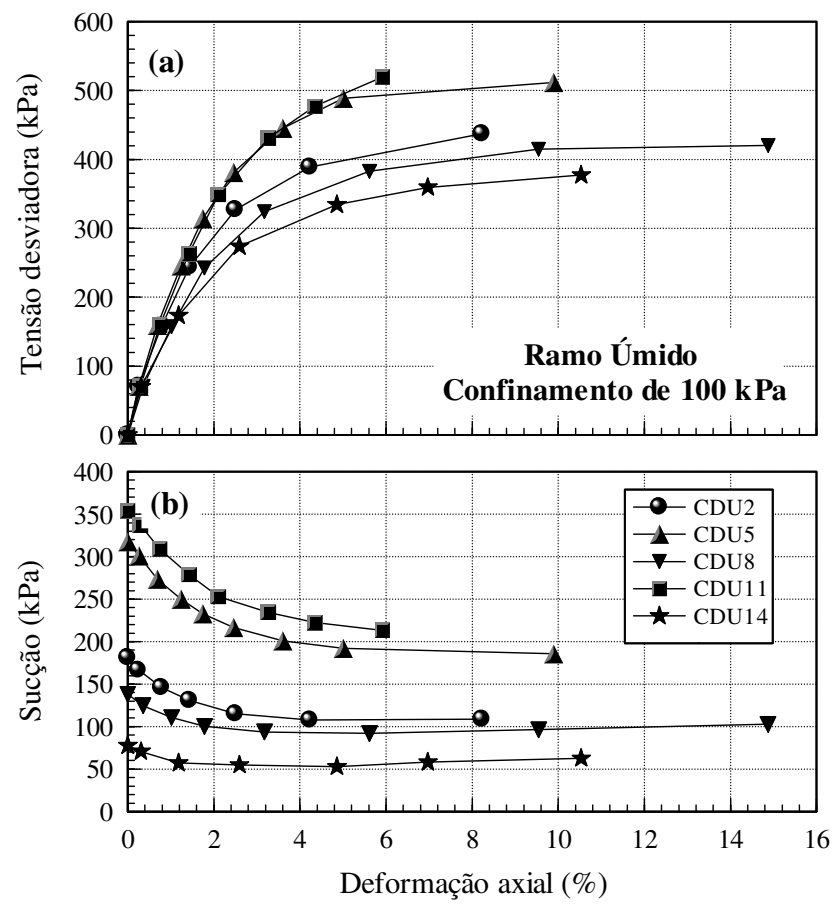

Figura 6.34 - Resultados dos ensaios triaxiais CW não saturados obtidos dos corpos de prova compactados no ramo úmido e ensaiados com confinamento de $100 \mathrm{kPa}$. 

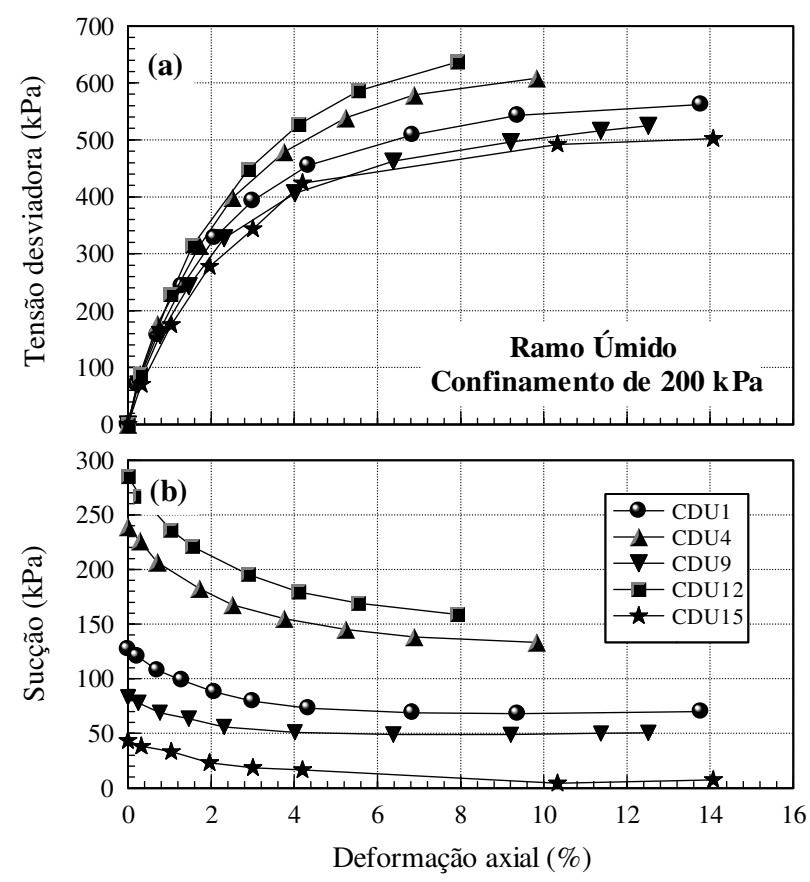

Figura 6.35 - Resultados dos ensaios triaxiais CW não saturados obtidos dos corpos de prova compactados no ramo úmido e ensaiados com confinamento de $200 \mathrm{kPa}$.
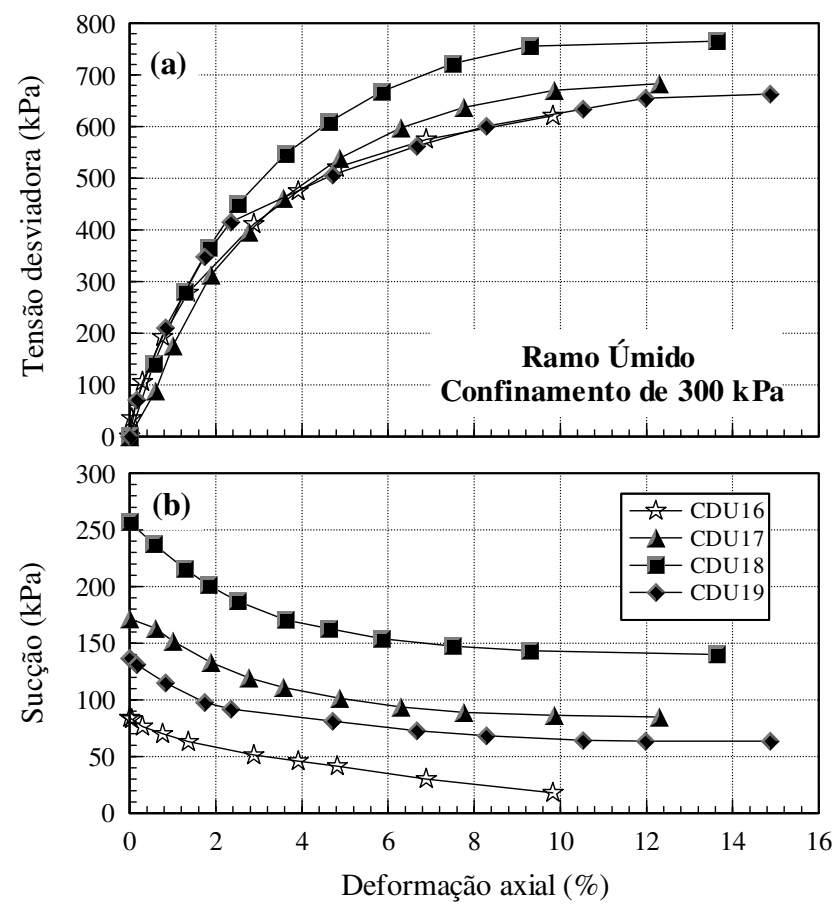

Figura 6.36 - Resultados dos ensaios triaxiais CW não saturados obtidos dos corpos de prova compactados no ramo úmido e ensaiados com confinamento de $300 \mathrm{kPa}$. 


\section{7 - ASPECTOS RELACIONADOS ÀS MEDIÇÕES DAS SUCÇÕES OBTIDAS COM O TENSIÔMETRO, O PAPEL FILTRO E A PLACA DE PRESSÃO}

Nos ensaios das curvas de retenção e de resistência ao cisalhamento foram empregadas diferentes técnicas para se impor ou medir a sucção dos corpos de prova. Para se aplicar um determinado valor de sucção foram utilizadas a placa de sucção e de pressão e para a medição foram utilizados o tensiômetro e a técnica do papel filtro. Neste capítulo são investigados inicialmente alguns aspectos relacionados ao tempo de equilíbrio das medições dos valores de sucção com o tensiômetro. Com este objetivo é verificada a influência da utilização de pastas com várias consistências, corpos de prova com diferentes estruturas e valores de sucção.

Além dos estudos realizados com os valores de sucção medidos com tensiômetro, houve a necessidade de se investigar os valores obtidos com o papel filtro. $\mathrm{Na}$ determinação das curvas de retenção foi observado que o trecho obtido com a utilização do papel filtro (sucção $>400 \mathrm{kPa}$ ) não dava continuidade ao trecho inicial ( sucção $400 \mathrm{kPa}$ ) determinado com a placa de sucção e de pressão. Em função deste fato foi feita a calibração do lote de papel filtro utilizado nesta pesquisa. Os resultados desta calibração são apresentados neste capítulo. Finalmente foram comparados os valores das sucções dos corpos de prova determinados com o papel filtro e o tensiômetro. Para os corpos de prova que foram colocados na placa de pressão, durante a etapa de preparação para o ensaio, os valores citados anteriormente são comparados com o valor da sucção imposta neste equipamento.

\section{1 - Influência da pasta na medição da sucção utilizando o tensiômetro}

Conforme descrito no item 4.11.2 tem-se que ao se utilizar o tensiômetro para medição da sucção do corpo de prova deve-se utilizar uma pasta de solo para proporcionar uma continuidade hidráulica entre ambos. Neste item são apresentados alguns testes realizados antes do início dos ensaios de resistência, com o objetivo de 
se verificar a resposta do tensiômetro ao se utilizar pastas com diferentes consistências. Foram realizados 3 testes em um corpo de prova moldado na umidade ótima. Este corpo de prova foi moldado estaticamente no molde tripartido apresentando diâmetro e altura iguais a $3.8 \mathrm{~cm}$. O corpo de prova foi preparado para apresentar diferentes valores de sucção. Desta forma, foi utilizado nas condições de moldagem, após umedecimento e após secagem. Os dados do corpo de prova para estes 3 testes estão indicados na Tabela 7.1.

Tabela 7.1 - Dados iniciais do corpo de prova compactado na umidade ótima e utilizado para a realização dos testes da medição da sucção com tensiômetro.

\begin{tabular}{|c|c|c|c|c|c|c|}
\hline Teste & $\begin{array}{c}\mathrm{W} \\
(\%)\end{array}$ & $\mathrm{e}$ & $\begin{array}{c}\mathrm{S} \\
(\%)\end{array}$ & $\begin{array}{c}\theta_{\mathrm{w}} \\
(\%)\end{array}$ & $\begin{array}{c}\rho_{\mathrm{d}} \\
\left(\mathrm{g} / \mathrm{cm}^{3}\right)\end{array}$ & Obs. \\
\hline 1 & 24.5 & 0.78 & 85.4 & 37.4 & 1.52 & Dados de moldagem \\
\hline 2 & 27.2 & 0.82 & 89.7 & 40.5 & 1.49 & Após umedecimento \\
\hline 3 & 23.8 & 0.77 & 83.7 & 36.4 & 1.53 & Após secagem \\
\hline
\end{tabular}

O primeiro teste, apresentado na Figura 7.1, foi realizado com a pasta obtida com o solo que passa na peneira $n^{\circ}$ 40. Foram preparadas três pastas cujas diferentes consistências são facilmente percebíveis por análise táctil e visual. Foi preparada uma pasta mais seca $(\mathrm{w}=45 \%)$, uma de consistência intermediária $(\mathrm{w}=50 \%)$ e outra mais fluida $(\mathrm{w}=57 \%)$. Primeiramente foi observada na preparação da pasta a sua consistência, sendo posteriormente determinado o seu teor de umidade. O solo que passa na peneira $n^{-} 40$ apresenta limite de liquidez igual a $47 \%$ e limite de plasticidade de $24 \%$ ( $\mathrm{IP}=23 \%)$. Em relação ao solo que passa na peneira $\mathrm{n}^{\mathrm{o}} 10$ ( $\mathrm{IP}=13 \%)$, o índice de plasticidade é bem maior, sendo esta diferença da ordem de 10 $\%$.

Os resultados do teste $\mathrm{n}^{\mathrm{o}} 1$ estão apresentados na Figura 7.1. Neste teste o corpo de prova foi utilizado nas condições de moldagem (Tabela 7.1). Inicialmente foi determinada a sua sucção utilizando a pasta com umidade de 50\%. O tempo de equilíbrio é atingido depois de decorridos 8 minutos do início do ensaio, correspondendo à sucção de $79 \mathrm{kPa}$. A seguir o ensaio foi desmontado sendo colocado sobre o tensiômetro a pasta com umidade de $45 \%$. 
Após se medir novamente a sucção do corpo de prova, foram colocados e retirados alguns incrementos de carregamento para se verificar a resposta dos valores de sucção medidos pelo tensiômetro. Finalizando este teste, o corpo de prova foi mais uma vez retirado e a sua sucção foi obtida colocando-se sobre toda a área da base a pasta com umidade de 57\%. A espessura da pasta, colocada nesta última etapa do teste, foi aproximadamente igual a $5 \mathrm{~mm}$. Observa-se que após a adição dos incrementos de carga a leitura da sucção diminui, passando a aumentar e se estabilizar em um novo valor. Ao se retirar o incremento de carga ocorre o contrário, a sucção aumenta e diminui de valor até entrar em equilíbrio com o a sucção do corpo de prova. Provavelmente este comportamento deve estar relacionado à compressibilidade da pasta. Assim que se coloca o carregamento, ocorre a redução da sucção da pasta e do corpo de prova. No entanto, devido à sua compressibilidade, a maior redução ocorre na pasta. Como a quantidade de água da pasta é muito pequena em relação ao volume do corpo de prova, tem-se que o valor da sucção de equilíbrio corresponde à nova sucção apresentada pelo corpo de prova. Desta forma, após a redução inicial, a sucção da pasta passa a aumentar até se igualar à sucção de equilíbrio.

No caso do alívio de tensão, após a retirada do carregamento, a pasta apresenta neste momento um aumento de sucção maior que a do corpo de prova, de forma que este valor diminui até que o equilíbrio seja novamente atingido. Para os incrementos de carregamento utilizados neste teste $(1,2$ e $3 \mathrm{~kg}$ ), o tempo para a pasta atingir novamente a sucção do corpo de prova variou de 1 a 3 minutos. O último trecho da Figura 7.1 mostra que para a pasta colocada em toda a base do corpo de prova, o tempo de equilíbrio da medição da sucção aumenta. Neste caso, a quantidade de água da pasta é suficiente para que a sucção do corpo de prova diminua ao se atingir o valor de equilíbrio. As medições da sucção do corpo de prova, apresentadas na Figura 7.1, foram plotadas com a mesma origem na Figura 7.2. Não se observa nesta figura, diferenças no tempo de equilíbrio e nos valores das sucções medidas pelo tensiômetro ao serem utilizadas as pastas com teores de umidade de $50 \%$ e $45 \%$. O tempo de equilíbrio é aproximadamente igual a 8 minutos, correspondendo ao valor de sucção de $79 \mathrm{kPa}$. 


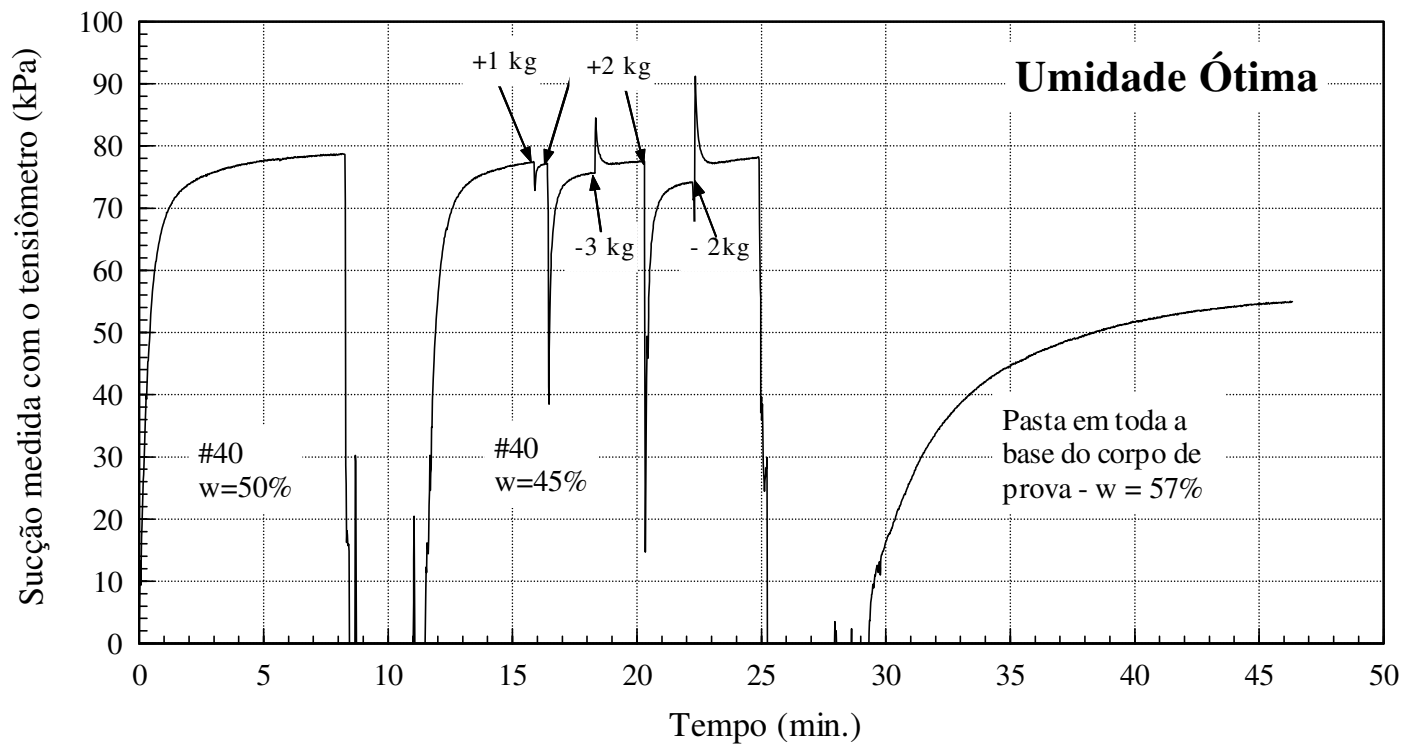

Figura 7.1 - Medição da variação do valor da sucção em função do teor de umidade da pasta e do incremento de carregamento, obtida de um corpo de prova compactado na umidade ótima (teste $\mathrm{n}^{\mathrm{o}} 1$ ).

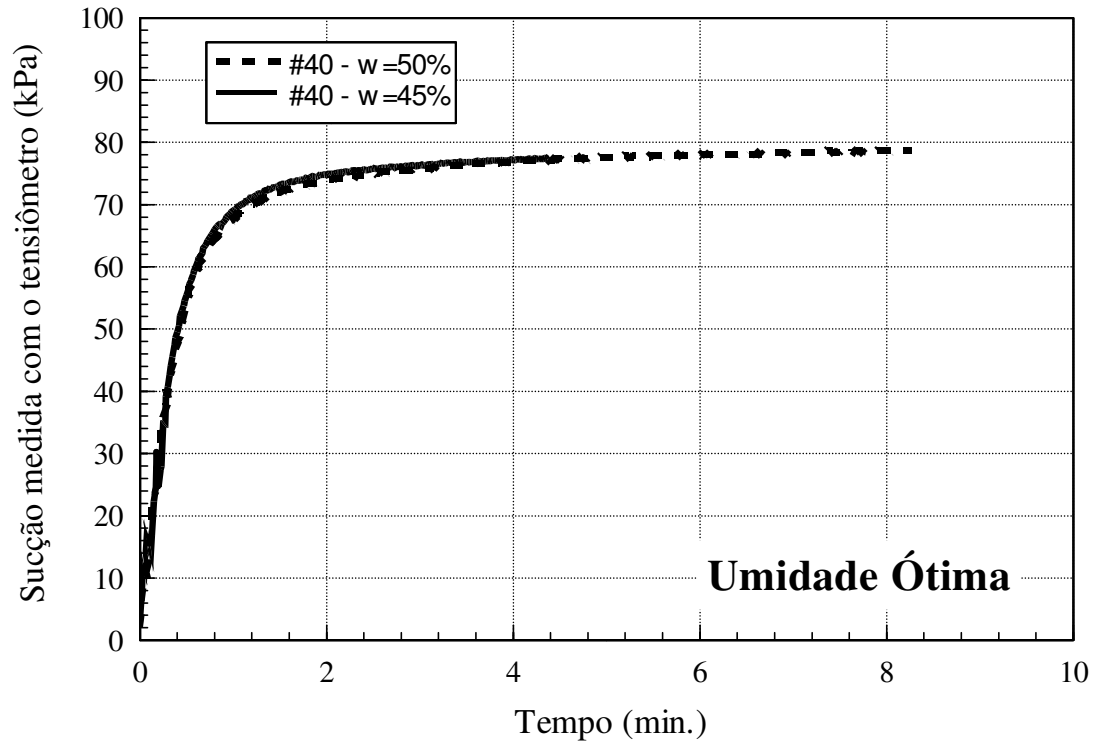

Figura 7.2 - Medição da sucção do corpo de prova do teste $\mathrm{n}^{\mathrm{o}} 1$ utilizando pastas com diferentes teores de umidade. 
Em um segundo teste os mesmos aspectos foram investigados para este corpo de prova, no entanto a sua sucção foi reduzida por aspersão de água destilada. Após o umedecimento o corpo de prova foi envolto em filme plástico e deixado em repouso por 48 horas para a estabilização do teor de umidade em todo o seu volume.

Para este teste foram utilizadas as mesmas pastas do teste $\mathrm{n}^{\mathrm{0}}$ 1. Observa-se na Figura 7.3 que após a obtenção da sucção do corpo de prova foram colocados e retirados vários incrementos de carregamento, objetivando a verificação da compressibilidade da pasta para este novo valor de sucção inicial. As variações das sucções medidas no tensiômetro, devidas aos testes com estes incrementos de carga, foram semelhantes às respostas obtidas no teste $\mathrm{n}^{\mathrm{o}} 1$.

No teste $\mathrm{n}^{\mathrm{o}} 2$ a sucção do corpo de prova foi inicialmente medida com a pasta que apresenta teor de umidade de $50 \%$. Após a estabilização da sucção ( $\cong 15$ minutos) foram colocados os incrementos de $100 \mathrm{~g}, 500 \mathrm{~g}$ e $1 \mathrm{~kg}$. Observa-se na Figura 7.3 que o tempo para que a pasta atinja a sucção do corpo de prova, após os testes com estes carregamentos, é maior à medida que aumenta o valor do incremento de carga, variando neste caso de 3 a 5 minutos.

A redução instantânea da sucção para valor igual a zero, observada nos tempos de 68 e 108 minutos, corresponde à utilização de água para a retirada da pasta colocada sobre o tensiômetro. Para se comparar as medições da sucção do corpo de prova com a utilização das pastas com teores de umidade iguais a $50 \%, 45 \%$ e $57 \%$, os resultados da Figura 7.3 foram plotados com a mesma origem na Figura 7.4. Os dados apresentados na Figura 7.4 correspondem, na Figura 7.3, aos resultados obtidos para o intervalo de tempo de 0 a 14 minutos, 73 a 88 minutos e 113 a 127 minutos. Constata-se que a utilização de pastas com diferentes consistências, não apresenta nenhuma interferência visível nos valores do tempo de equilíbrio e nos valores das sucções medidas com o tensiômetro. Na Figura 7.3 estes valores correspondem respectivamente a 5 minutos e à sucção em torno de $23 \mathrm{kPa}$. 


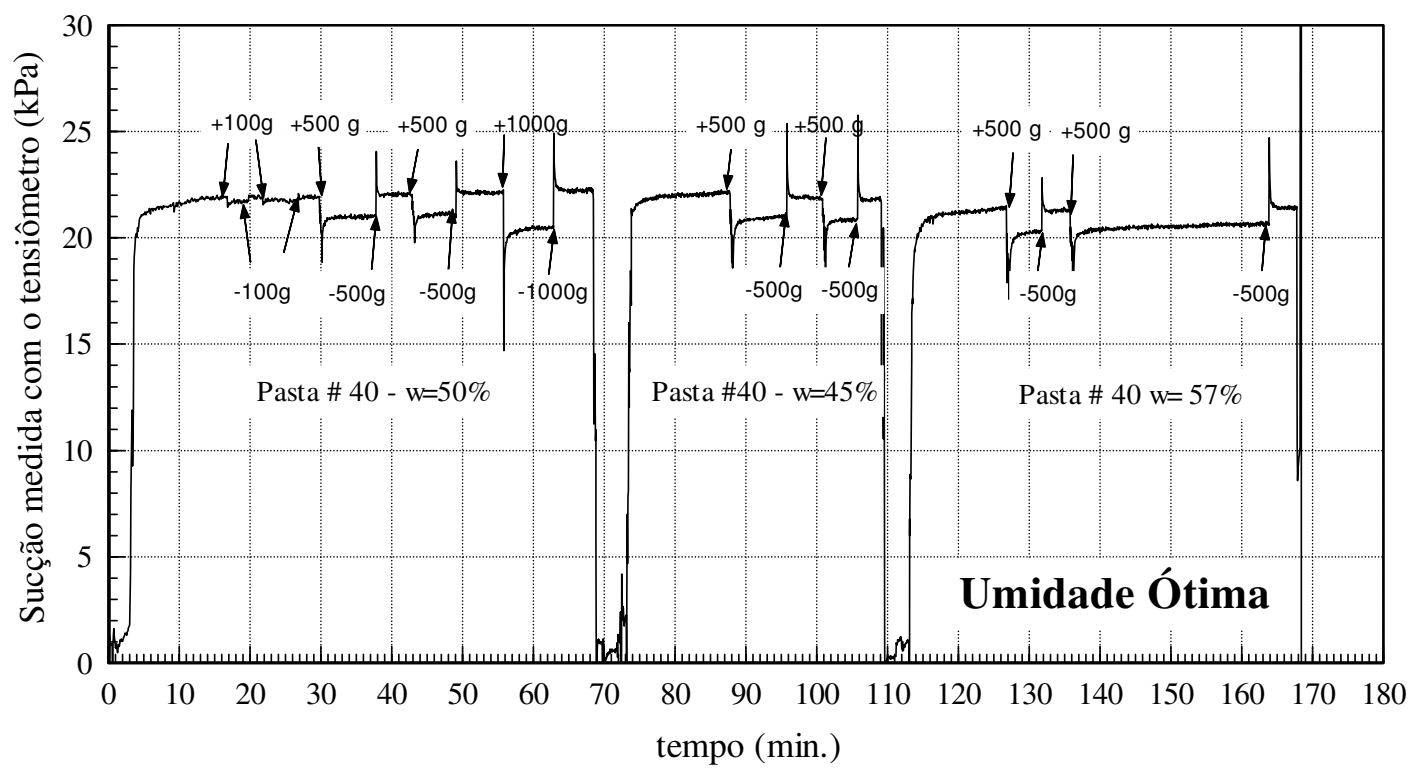

Figura 7.3 - Medição da variação do valor da sucção em função do teor de umidade da pasta e do incremento de carregamento, obtida de um corpo de prova compactado na umidade ótima e posteriormente umedecido (teste $\mathrm{n}^{\mathrm{o}} 2$ ).

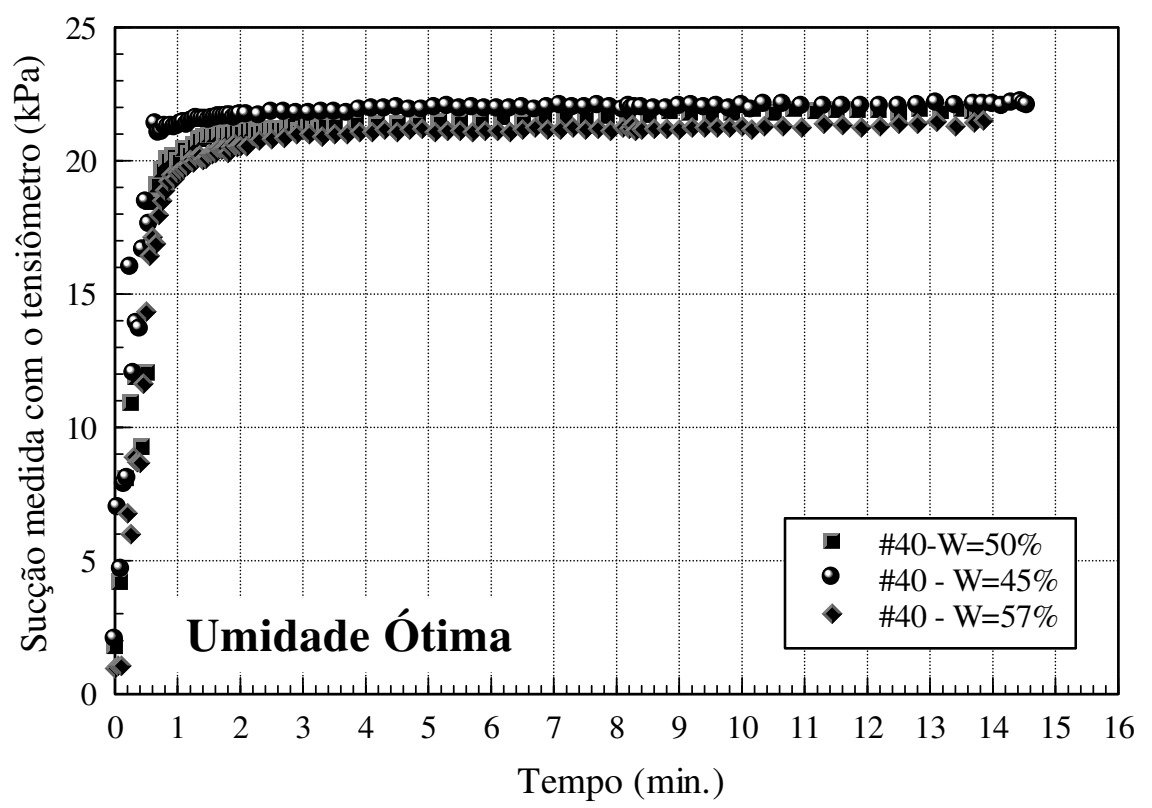

Figura 7.4 - Medição da sucção do corpo de prova do teste $\mathrm{n}^{\mathrm{o}} 2$ utilizando pastas com diferentes teores de umidade. 
Em um terceiro teste o mesmo corpo de prova foi secado ao ar de forma a apresentar sucção maior que as dos testes anteriores. No entanto foi utilizada, além da pasta feita com o solo que passa na peneira $\mathrm{n}^{\mathrm{o}} 40$, uma segunda pasta formada com o solo que passa que peneira $\mathrm{n}^{\mathrm{o}} 10$. Na Figura 7.5 estão apresentados os resultados do teste $\mathrm{n}^{\mathrm{o}}$ 3. Inicialmente a sucção foi determinada utilizando-se a pasta formada com o solo que passa na peneira $n^{0} 10$. Após a medição da sucção do corpo de prova, foram feitos alguns testes com incrementos de carga. Conforme os resultados dos testes anteriores, verifica-se também que para um nível maior de sucção, fica evidente o efeito da compressão e descompressão da pasta, em função do acréscimo ou retirada do carregamento. A estabilização da sucção, medida pelo tensiômetro após estes procedimentos, variou de 2 a 3 minutos. Na Figura 7.6 estão os valores da determinação da sucção do corpo de prova em função do tempo, obtidos dos resultados da Figura 7.5. Observa-se na Figura 7.6 que as pastas preparadas com diferentes consistências e granulometrias não interferem nos valores dos tempos de equilibro e nas medições da sucção do corpo de prova como o tensiômetro. Estes valores correspondem respectivamente a 8 minutos e a $120 \mathbf{k P a}$.

Para os três testes apresentados neste item, procurou-se avaliar a medição da sucção de um corpo de prova moldado na umidade ótima e preparado por umedecimento e secagem, correspondendo a sucções iniciais respectivamente iguais a 78, 23 e 120 $\mathrm{kPa}$. Para a medição destes valores de sucções foram utilizadas pastas com diferentes granulometrias e consistências. Foram realizados também alguns testes com incrementos de carregamento sobre o corpo de prova.

Como conclusão geral tem-se que as medições das sucções do corpo de prova em cada teste foram independentes da consistência da pasta e da sua granulometria (\#10 e \#40). O aspecto da compressão da pasta foi constatado para todos os três testes ao se aplicar diferentes incrementos de carregamento. A estabilização da leitura do tensiômetro esta diretamente relacionada ao valor do incremento de carga aplicado sobre o corpo de prova. Para o nível dos carregamentos aplicados nestes testes ( $100 \mathrm{~g}$ a $2 \mathrm{~kg}$ ) os valores destes tempos de equilíbrio variaram de 1 a 5 minutos. 


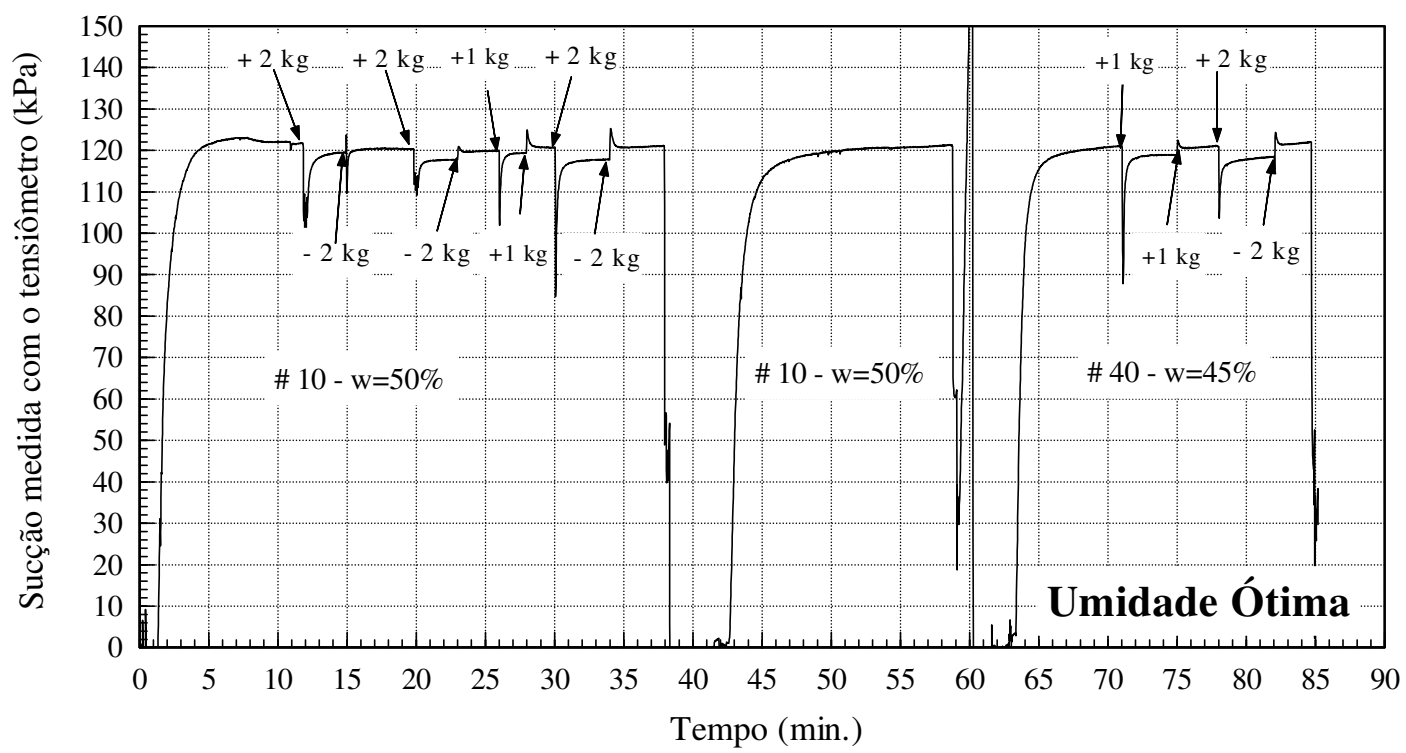

Figura 7.5 - Medição da variação do valor da sucção em função do teor de umidade da pasta e do incremento de carregamento, obtida de um corpo de prova compactado na umidade ótima e posteriormente submetido à secagem (teste $\mathrm{n}^{\mathrm{o}} 3$ ).

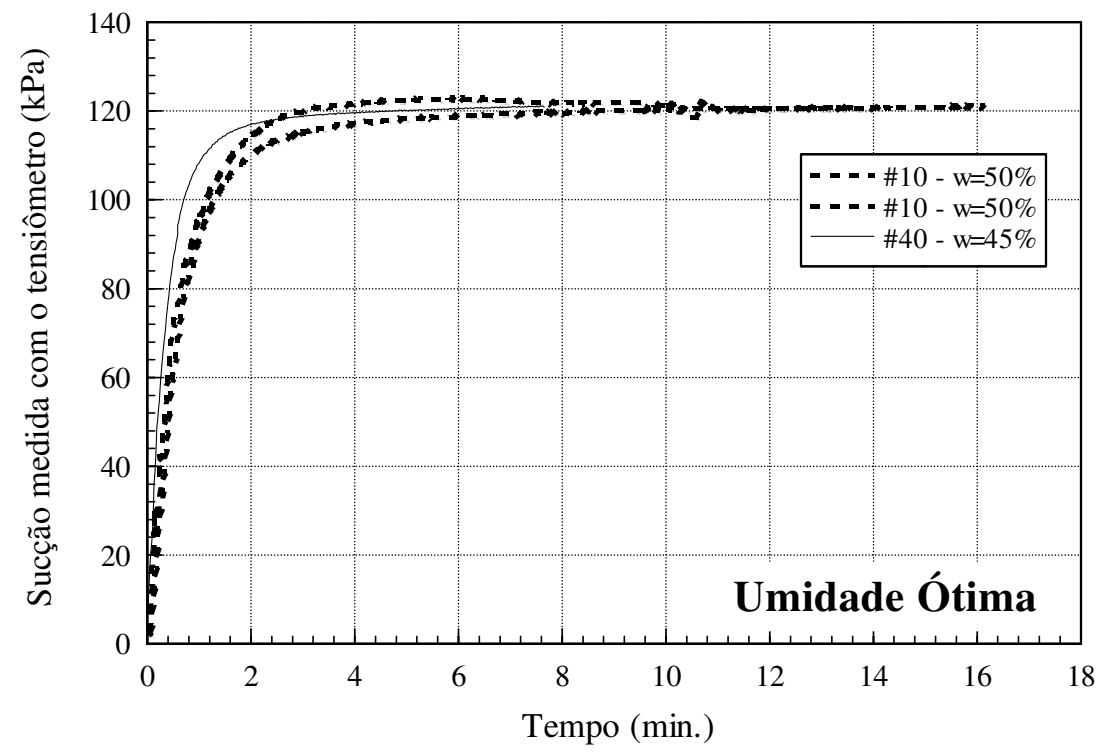

Figura 7.6 - Medição da sucção do corpo de prova do teste $\mathrm{n}^{\mathrm{o}} 3$ utilizando pastas com diferentes teores de umidade. 


\section{2 - Estudo do tempo de equilíbrio das sucções determinadas com o tensiômetro}

Neste item é investigado o tempo em que o tensiômetro atinge a sucção do corpo de prova, definido como tempo de equilíbrio. Com os resultados dos ensaios desta pesquisa são verificadas as influências da estrutura, conferidas pelas diferentes condições de moldagem, e do nível de sucção dos corpos de prova após serem submetidos à secagem ou umedecimento. Foram utilizadas as medições das sucções dos corpos de prova obtidas no início dos ensaios triaxiais CW não saturados, cujos resultados estão apresentados nas Tabelas 6.13, 6.14 e 6.15, e dos corpos de prova moldados com a consistência de lama, utilizados para a determinação de suas respectivas curvas de retenção (item 5.2.5). Na Figura 7.7 estão apresentados os resultados dos corpos de prova moldados na umidade ótima, utilizados nos ensaios triaxiais CW não saturados. Para esta condição de moldagem, a sucção dos corpos de prova variou de $40 \mathrm{kPa}$ a $425 \mathrm{kPa}$. Observa-se nesta Figura que, apesar de apresentar uma certa dispersão, existe uma tendência, representada pela linha pontilhada, de aumento do tempo de equilíbrio em função do valor da sucção do corpo de prova. Para o intervalo de sucção de 40 a $425 \mathrm{kPa}$ o tempo de equilíbrio varia em torno de 10 a 40 minutos.

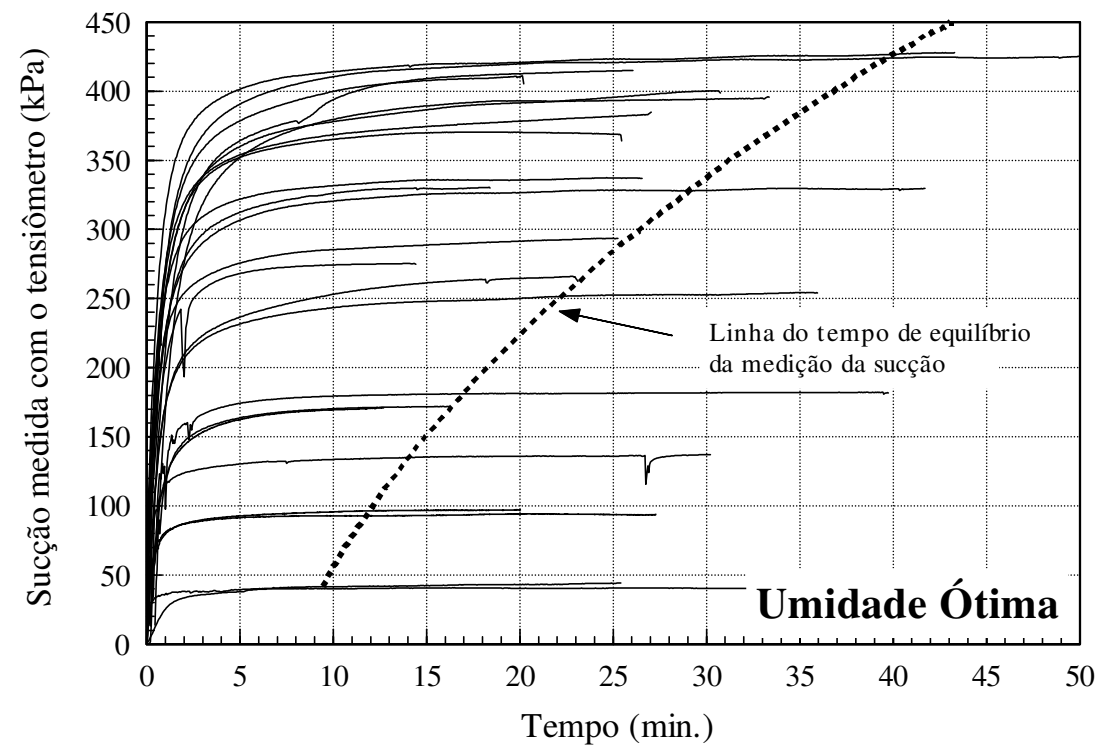

Figura 7.7 - Resultados das medições das sucções iniciais dos corpos de prova compactados na umidade ótima e utilizados nos ensaios triaxiais CW não saturados. 
Na Figura 7.8 estão os resultados das medições realizadas nos corpos de prova moldados no ramo seco no início dos ensaios triaxiais $\mathrm{CW}$ não saturados. De forma semelhante aos resultados da umidade ótima, quanto maior o valor da sucção inicial do corpo de prova, maior é o tempo de equilíbrio. Para esta condição de moldagem os corpos de prova apresentaram sucções variando entre $35 \mathrm{kPa}$ e $510 \mathrm{kPa}$. A linha pontilhada da Figura 7.8, representa a tendência da variação do tempo de equilíbrio em função da sucção. Desta linha de tendência tem-se que, para a faixa de valores da sucção inicial de 35 a $510 \mathrm{kPa}$, o tempo de equilíbrio varia de 8 a $50 \mathrm{kPa}$.

Os resultados dos corpos de prova moldados no ramo úmido, utilizados nos ensaios triaxiais CW não saturados, estão apresentados na Figura 7.9. As sucções iniciais destes corpos de prova variaram de 90 a $450 \mathrm{kPa}$. De forma semelhante aos resultados das Figuras 7.7 e 7.8, a linha pontilhada representa a tendência da variação do tempo de equilíbrio em função da sucção. Para o intervalo dos valores de sucção destes corpos de prova tem-se que para esta condição de moldagem o tempo de equilíbrio variou de 10 a 25 minutos.

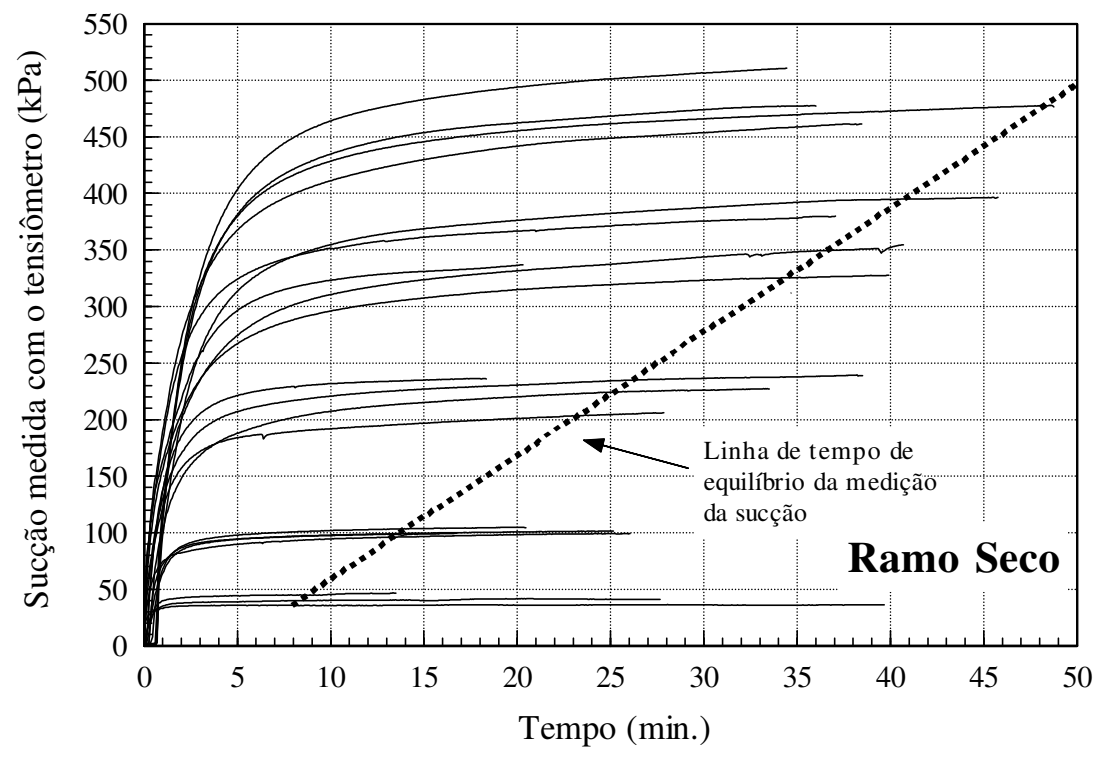

Figura 7.8 - Resultados das medições das sucções iniciais dos corpos de prova compactados no ramo seco e utilizados nos ensaios triaxiais CW não saturados. 


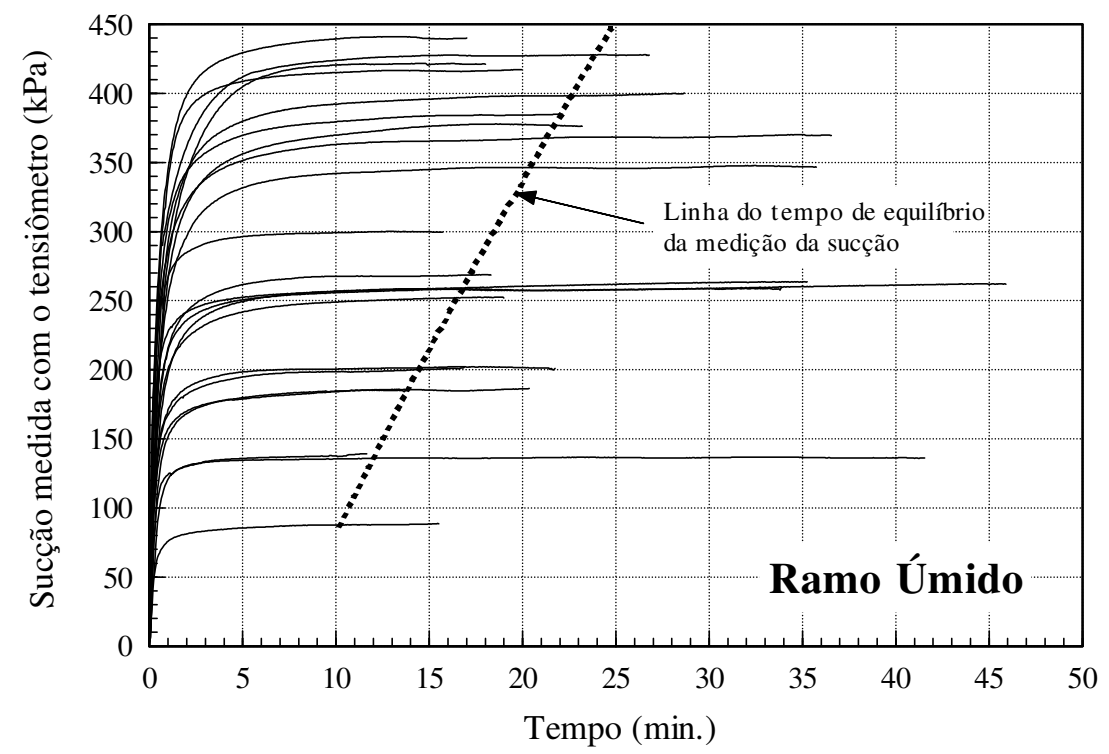

Figura 7.9 - Resultados das medições das sucções iniciais dos corpos de prova compactados no ramo úmido e utilizados nos ensaios triaxiais CW não saturados.

$\mathrm{Na}$ determinação da curva de retenção do solo preparado com a consistência de lama (item 5.2.5), as sucções dos corpos de prova, ao serem retirados da placa de pressão, foram determinadas com o tensiômetro. Para as sucções de 100, 150, 250, 350 e 450 $\mathrm{KPa}$, aplicadas na placa de pressão, foram colocados 2 corpos de prova moldados com a lama preparada com o solo que passa na peneira $\mathrm{n}^{\mathrm{o}} 10$ e dois com a lama preparada com o solo que passa na peneira $\mathrm{n}^{-0} 40$. Os valores das medições da sucção destes corpos de prova com o tensiômetro estão apresentados nas Figuras 7.10 e 7.11. A linha pontilhada indica a variação do tempo de equilíbrio em função da sucção. Para o intervalo de sucção destes corpos de prova, variando de 50 a $350 \mathrm{kPa}$, o tempo de equilíbrio variou de 5 a 15 minutos. 


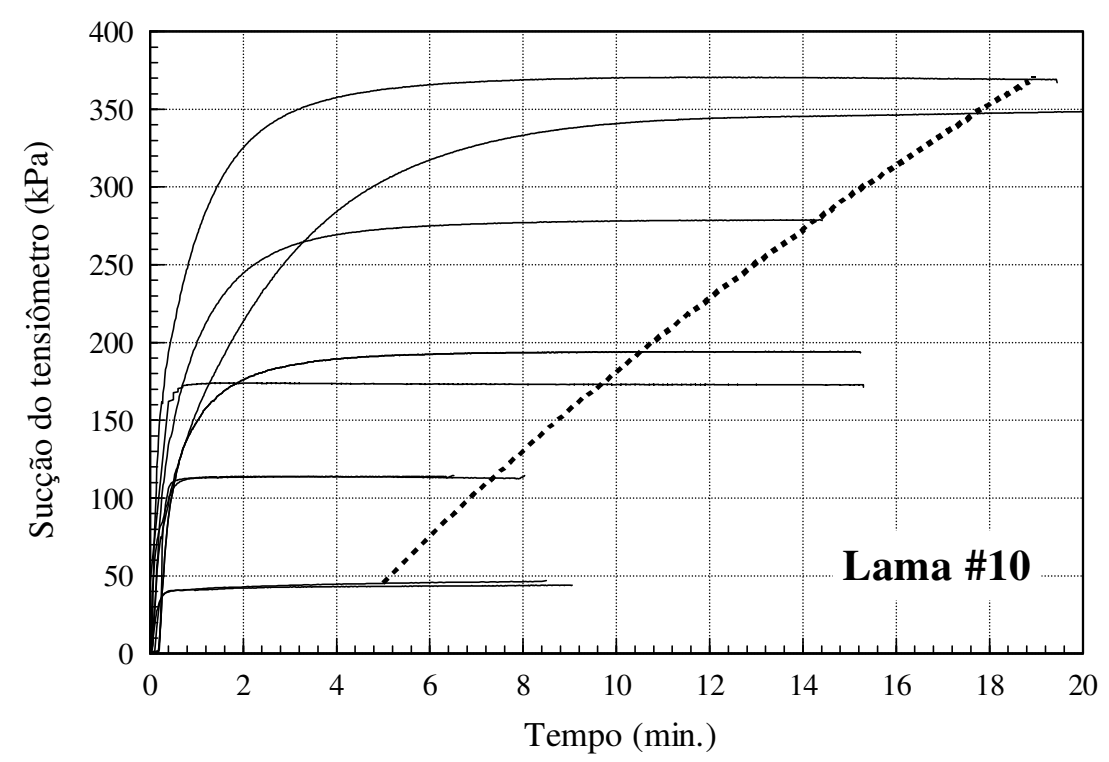

Figura 7.10 - Resultados das medições das sucções dos corpos de prova utilizados na determinação da curva de retenção da lama preparada com o solo que passa na peneira $\mathrm{n}^{\mathrm{o}} 10$.

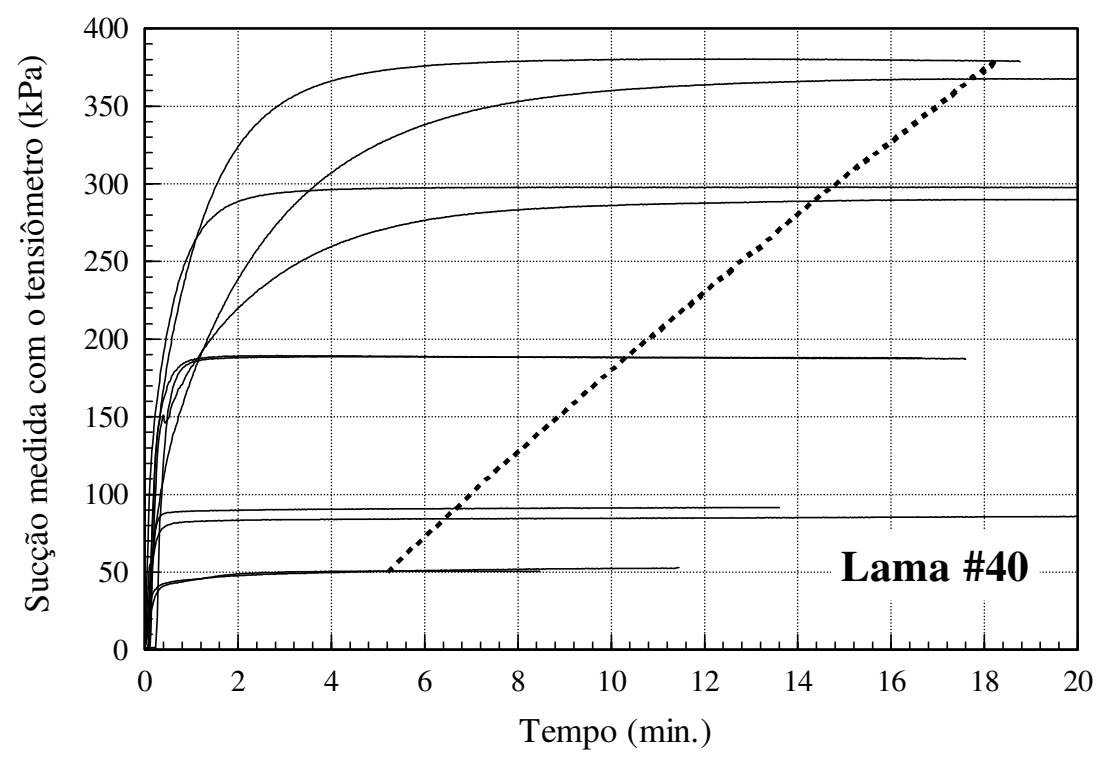

Figura 7.11 - Resultados das medições das sucções dos corpos de prova utilizados na determinação da curva de retenção da lama preparada com o solo que passa na peneira $\mathrm{n}^{\mathrm{o}} 40$.

Observando os resultados apresentados nas Figuras 7.7 a 7.11 constata-se que, para uma mesma condição de moldagem, os tempos de equilíbrio são maiores a medida 
em que aumenta o valor sucção do corpo de prova. As linhas do tempo de equilíbrio, representadas nas Figuras 7.7 a 7.11, foram reunidas em um único gráfico na Figura 7.12. Observa-se que para sucções dos corpos de prova próximas de $50 \mathrm{kPa}$ o tempo de equilíbrio é semelhante para as três condições de moldagem. Com o aumento do valor da sucção constata-se o aumento no tempo de equilíbrio, que passa a apresentar valores maiores para as condições de moldagem no ramo seco, seguida da moldagem na umidade ótima e no ramo úmido. Os menores tempos de equilíbrio para cada valor de sucção correspondem aos corpos de prova moldados com a consistência de lama. Segundo Ridley et al (2003), o tempo de equilíbrio pode ser influenciado pelo grau de saturação do corpo de prova, pelo tipo de solo e à qualidade do contato existente entre o corpo de prova e o tensiômetro.

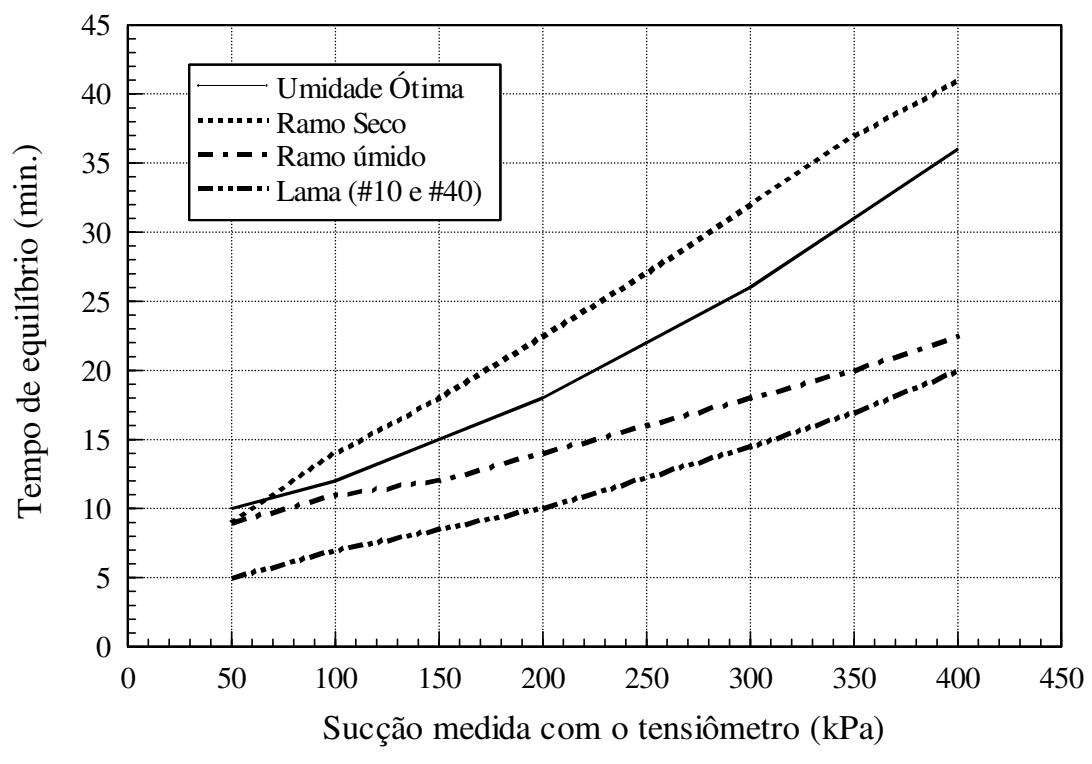

Figura 7.12 - Variação do tempo de equilíbrio das medições das sucções dos corpos de prova em função das condições de moldagem e do nível de sucção.

\section{3 - Determinação da equação de calibração do papel filtro}

As curvas de retenção, apresentadas nos itens 5.2.1 e 5.2.2, foram determinadas com a utilização da placa de sucção, placa de pressão e com a técnica do papel filtro. Ao se utilizar a equação proposta por Chandler et al (1992), observou-se que os resultados do papel filtro não definem a continuidade do trecho 
inicial da curva de retenção, obtido com a utilização das placas de sucção e de pressão. Com o objetivo de se esclarecer as diferenças destes resultados, optou-se por se determinar a equação da calibração do lote 920071 do papel filtro Whatman no ${ }^{0} 42$, utilizado nesta pesquisa.

Alguns fatores importantes a serem considerados na calibração do papel filtro foram apresentados no item 3.7.2. Para a obtenção desta calibração foi utilizada a placa de sucção, a placa de pressão e soluções de $\mathrm{NaCl}$ colocadas em dessecador. A molaridade destas soluções foram determinadas pela equação 3.2, proposta por Marinho (1994). Na Tabela 7.2 estão indicados os equipamentos utilizados e os valores das sucções aplicadas nos ensaios de calibração.

Tabela 7.2 - Equipamentos e sucções aplicadas na calibração do papel filtro.

\begin{tabular}{|l|l|}
\hline Equipamentos & Sucção $(\mathrm{kPa})$ \\
\hline Placa de sucção & 10,20 e 30 \\
\hline Placa de pressão & $70,100,200,300$ e 400 \\
\hline Solução de $\mathrm{NaCl}$ (dessecador) & $500,1000,2000,3000,4000$ e 5000 \\
\hline
\end{tabular}

Na placa de sucção e de pressão o papel filtro deve ser colocado diretamente sobre a pedra porosa que atua como fonte geradora de sucção. Em função do diâmetro da pedra porosa $(\cong 15 \mathrm{~cm})$ e do papel filtro $(\cong 7 \mathrm{~cm})$, em cada ensaio de calibração só é possível a utilização de apenas dois papeis filtro inteiros. De forma a se obter um maior número de resultados em cada valor de sucção aplicada por estes equipamentos, utilizou-se papel filtro inteiro e cortado com diâmetro de $3.5 \mathrm{~cm}$. Com este procedimento consegue-se, em cada ensaio da calibração, a obtenção de até 5 resultados. De acordo com os resultados encontrados, as umidades apresentadas pelos papéis não estão relacionadas às diferentes dimensões utilizadas. Durante a montagem dos ensaios de calibração com utilização da placa de pressão e de sucção, foram tomados os seguintes cuidados:

- A superfície da pedra porosa deve ser secada com um pano úmido de forma a se evitar que o papel filtro absorva inicialmente água em excesso, passando a perder água para atingir a sucção imposta no ensaio. 
- O papel filtro foi retirado diretamente de sua embalagem e colocado sobre a superfície da pedra porosa.

- Para melhorar o contato entre o papel filtro e a pedra porosa, foi colocado uma pequena sobrecarga $(\cong 0,1 \mathrm{kPa})$ sobre os mesmos. Esta sobrecarga consiste em uma tampa metálica contendo em seu interior algodão embebido em água.

- Não se procedeu a nenhum tratamento químico no papel.

- Não houve contato manual com o papel filtro, utilizando-se a pinça para o seu manuseio.

Após estes cuidados iniciais os equipamentos são fechados, sendo aplicadas, por um período mínimo de 7 dias, as sucções arbitradas para a calibração. Durante o procedimento de retirada do papel filtro da placa de sucção, a mesma deve ser mantida na altura utilizada no ensaio. Desta forma se evita que ocorram variações da sucção imposta por este equipamento. Após as retirada do recipiente plástico que fica sobre a placa (ver Figura 3.2), é feita a retirada da sobrecarga e com o auxílio de pinça o papel filtro é colocado em sacos auto selantes. Para a abertura da placa de pressão deve-se inicialmente fechar as conexões da pedra porosa com a bureta e com o sistema de circulação de água (ver Figura 3.3) e em seguida é feito o alívio da pressão de ar do interior da câmara. O equipamento é aberto e o papel filtro é retirado, de forma semelhante aos procedimentos utilizados da placa de sucção. Os procedimentos da obtenção da umidade do papel filtro estão descritos no item 4.8.4.

Para as sucções impostas com a utilização de soluções de $\mathrm{NaCl}$, foram utilizados dessecadores com capacidade de até 0.5 litro de solução e volume interno de ar de aproximadamente $500 \mathrm{~cm}^{3}$. Seguindo os mesmos procedimentos propostos por Marinho (1994), os papeis filtro foram mantidos na posição horizontal e a $1 \mathrm{~cm}$ acima da solução de $\mathrm{NaCl}$. Seguindo as recomendações da Tabela 3.2, os papeis filtros permaneceram no dessecador por um período que variou de 7 a 20 dias. 
Com o objetivo de se comparar a calibração para lotes diferentes, foram utilizados os papéis filtro cedidos pelas seguintes universidades:

- Whatman no 42 - Lote 920071 (Escola Politécnica - USP/SP)

- Whatman no 42 - Lote B939551 (Escola Politécnica - USP/SP)

- Whatman no 42 - Lote 46307 (PUC - RJ)

- Whatman no 42 - Lote 1442090 (UENF - RJ)

- Whatman no 42 - Lote A577070 (Imperial College - Inglaterra)

Os resultados das calibrações obtidas para lote 920071, utilizado nesta pesquisa, estão apresentados na Tabelas 7.3. Na Tabela 7.4 estão as calibrações de alguns pontos obtidos para os outros lotes. Nestas tabelas estão indicados os equipamentos utilizados para se impor a sucção ao papel filtro, o valor desta sucção, o tempo que permaneceram nestes equipamentos e a umidade do papel filtro após a realização dos ensaios. Na Figura 7.13 estão plotados os resultados das Tabelas 7.3 e 7.4. Em linha contínua esta a representação da equação de calibração encontrada para o lote 920071 (utilizado nesta pesquisa). Observa-se claramente que este lote apresenta, a partir de sucções superiores a $60 \mathrm{kPa}$, uma calibração diferente da equação obtida proposta por Chandler et al (1992). Os resultados dos outros lotes ficaram localizados entre estas duas calibrações, representadas pelas linhas contínuas e tracejadas.

Os resultados obtidos para os lotes B939551 (Poli), 46307 (PUC-RJ) e 1442090 (UENF-RJ) apresentaram resultados semelhantes à equação proposta por Chandler et al (1992) e os resultados obtidos para o lote A577070 (Imperial College) estão mais próximos da equação definida para o lote 920071. Desta forma, para os lotes 920071 (Poli) e o lote A577070 (Imperial College), a utilização da equação proposta por Chandler et al (1992) fornece valores de sucção maiores que os resultados encontrados nas Tabelas 7.3 e 7.4. 
Este fato sugere que ao se utilizar papel filtro seja obtida a calibração de apenas um valor de sucção. O confronto deste resultado com o valor da sucção obtida ao se utilizar a equação proposta por Chandler et al (1992), serve para constatar se a mesma pode ser utilizada sem fornecer grandes erros nos valores de sucção que se deseja medir. De acordo com os resultados da Figura 7.13, sugere-se que esta calibração seja feita para a sucção de $200 \mathrm{kPa}$. Para este valor de sucção tem-se a maior diferença no teor de umidade do papel ao se utilizar a calibração do lote 920071 e a equação proposta por Chandler et al (1992).

A calibração encontrada para o lote 920071(Poli), representada pela linha contínua na Figura 7.13, é dada por:

Para teor de umidade menor que 33\%:

Sucção $(\mathrm{kPa})=10^{(4.83-0.0839 \mathrm{w})}, \mathrm{r}^{2}=0.90$

Para teor de umidade maior ou igual a 33\%:

Sucção $(\mathrm{kPa})=10^{(2.57-0.0154 \mathrm{w})}, \mathrm{r}^{2}=0.89$

$r^{2}$ - Quadrado do coeficiente de correlação.

Para a determinação de $r^{2}$ foram obtidos inicialmente os valores médios dos teores de umidade dos papeis filtro para cada sucção aplicada nos ensaios de calibração. Com este teor de umidade obteve-se o valor sucção utilizando-se as equações 7.1 e 7.2. O valor de $r^{2}$ foi obtido pela correlação entre estes pares de valores de sucções.

Na Figura 7.14 está representada, em função do grau de saturação, a curva de retenção obtida do corpo de prova compactado estaticamente na umidade ótima. Nesta Figura estão indicados o trecho inicial da curva, obtido com a utilização das placas de sucção e de pressão, e o trecho final obtido com a utilização de papel filtro. Para este trecho foram utilizadas a calibração proposta por Chandler et al (1992) e a calibração obtida para o lote 920071, dadas pelas equações 7.1 e 7.2. Verifica-se que ao se utilizar a calibração proposta por Chandler et al (1992), o trecho obtido com o papel filtro fica deslocado para a direita do trecho inicial da curva. 
Com a utilização da equação obtida para lote 920071, este trecho passa a apresentar valores de sucção mais coerentes com o trecho obtido com as placas de sucção e de pressão. Em função desta significante diferença entre a equação de calibração encontrada para o lote 920071 e a equação de Chandler et al (1992), todos os resultados de sucção do papel filtro desta pesquisa foram obtidos utilizando-se as equações 7.1 e 7.2 .

Tabela 7.3 - Resultados das calibrações realizadas para o lote de papel utilizado nesta pesquisa.

\begin{tabular}{|c|c|c|c|c|c|c|c|}
\hline \multicolumn{8}{|c|}{ Papel Filtro Whatman no 42 - Lote 920071(Poli-USP) } \\
\hline Equip. & $\begin{array}{c}\text { Tempo } \\
\text { (dias) }\end{array}$ & \begin{tabular}{|c|} 
Sucção \\
$(\mathrm{kPa})$
\end{tabular} & $\begin{array}{c}\text { Umidade (\%) } \\
\text { papel Filtro }\end{array}$ & Equip. & $\begin{array}{c}\text { Tempo } \\
\text { (dias) }\end{array}$ & $\begin{array}{c}\text { Sucção } \\
(\mathrm{kPa})\end{array}$ & $\begin{array}{c}\text { Umidade (\%) } \\
\text { papel Filtro }\end{array}$ \\
\hline \multirow{9}{*}{ 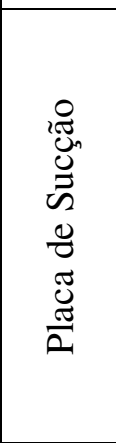 } & \multirow{2}{*}{7} & 10 & 105.43 & \multirow{12}{*}{ 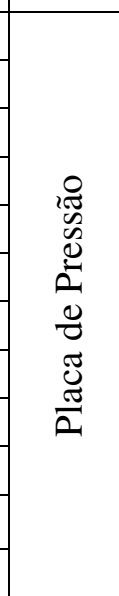 } & \multirow{3}{*}{7} & 200 & 30.64 \\
\hline & & 10 & 92.53 & & & 200 & 30.66 \\
\hline & \multirow{2}{*}{7} & 10 & 97.00 & & & 200 & 29.68 \\
\hline & & 10 & 103.92 & & \multirow{3}{*}{8} & 300 & 25.36 \\
\hline & \multirow{2}{*}{7} & 20 & 71.75 & & & 300 & 27.24 \\
\hline & & 20 & 73.21 & & & 300 & 24.73 \\
\hline & 7 & 30 & 71.40 & & \multirow{2}{*}{7} & 300 & 27.95 \\
\hline & \multirow{2}{*}{7} & 30 & 71.96 & & & 300 & 28.87 \\
\hline & & 30 & 75.31 & & \multirow{4}{*}{7} & 400 & 26.69 \\
\hline \multirow{20}{*}{ 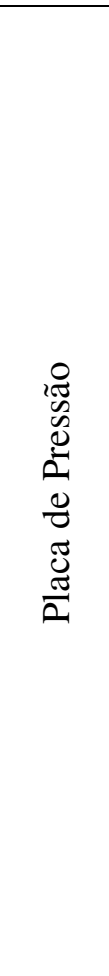 } & \multirow{2}{*}{7} & 50 & 49.68 & & & 400 & 24.81 \\
\hline & & 50 & 50.32 & & & 400 & 25.54 \\
\hline & \multirow{4}{*}{8} & 70 & 45.63 & & & 400 & 25.28 \\
\hline & & 70 & 43.48 & \multirow{17}{*}{ 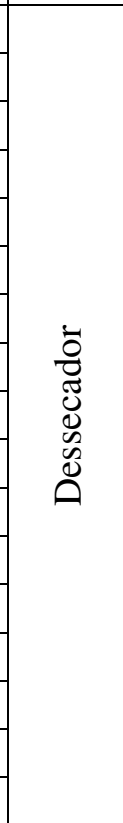 } & \multirow{2}{*}{21} & 500 & 24.11 \\
\hline & & 70 & 45.76 & & & 500 & 22.60 \\
\hline & & 70 & 50.30 & & \multirow{2}{*}{7} & 700 & 23.45 \\
\hline & \multirow{5}{*}{7} & 100 & 35.83 & & & 700 & 22.37 \\
\hline & & 100 & 32.62 & & 20 & 1000 & 21.01 \\
\hline & & 100 & 32.84 & & \multirow{2}{*}{20} & 2000 & 19.28 \\
\hline & & 100 & 33.10 & & & 2000 & 19.31 \\
\hline & & 100 & 31.65 & & \multirow{2}{*}{9} & 3000 & 15.10 \\
\hline & \multirow{2}{*}{7} & 100 & 47.85 & & & 3000 & 15.16 \\
\hline & & 100 & 40.41 & & \multirow{2}{*}{20} & 4000 & 16.59 \\
\hline & \multirow{3}{*}{9} & 150 & 34.87 & & & 4000 & 16.53 \\
\hline & & 150 & 37.45 & & \multirow{6}{*}{7} & 5000 & 12.32 \\
\hline & & 150 & 33.31 & & & 5000 & 13.66 \\
\hline & \multirow{2}{*}{7} & 200 & 33.22 & & & 5000 & 12.88 \\
\hline & & 200 & 32.80 & & & 5000 & 12.31 \\
\hline & \multirow{2}{*}{7} & 200 & 29.89 & & & 5000 & 11.79 \\
\hline & & 200 & 31.88 & & & & \\
\hline
\end{tabular}


Tabela 7.4 - Resultados das calibrações realizadas para os outros lotes.

\begin{tabular}{|c|c|c|c|c|c|c|c|}
\hline \multicolumn{8}{|c|}{$\begin{aligned} \text { Papel Filtro Whatman n⿳0 } 42 \\
\end{aligned}$} \\
\hline \multicolumn{4}{|c|}{ Lote B939551(Poli-USP) } & \multicolumn{4}{|c|}{ Cont...Lote 46307 (PUC-RJ) } \\
\hline Equip. & $\begin{array}{c}\text { Tempo } \\
\text { (dias) }\end{array}$ & \begin{tabular}{|c|} 
Sucção \\
$(\mathrm{kPa})$
\end{tabular} & $\begin{array}{c}\text { Umidade (\%) } \\
\text { papel Filtro }\end{array}$ & Equip. & $\begin{array}{c}\text { Tempo } \\
\text { (dias) }\end{array}$ & \begin{tabular}{|c|}
$\begin{array}{c}\text { Sucção } \\
(\mathrm{kPa})\end{array}$ \\
\end{tabular} & $\begin{array}{c}\text { Umidade (\%) } \\
\text { papel Filtro }\end{array}$ \\
\hline \multirow{2}{*}{ P.Sucção } & \multirow{2}{*}{7} & 20 & 86.29 & \multirow{2}{*}{ P. Pressão } & \multirow{2}{*}{9} & 3000 & 19.95 \\
\hline & & 20 & 85.09 & & & 3000 & 21.22 \\
\hline \multirow{16}{*}{ 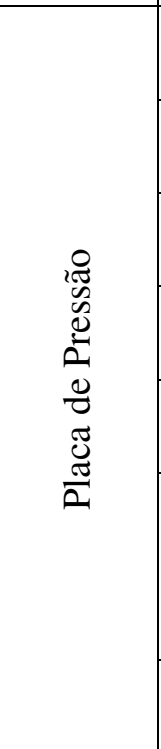 } & \multirow{2}{*}{7} & 50 & 47.01 & \multicolumn{4}{|c|}{ Lote A577070 (Imperial College) } \\
\hline & & 50 & 46.57 & \multirow{2}{*}{ Equip. } & \multirow{2}{*}{$\begin{array}{c}\text { Tempo } \\
\text { (dias) }\end{array}$} & \multirow{2}{*}{$\begin{array}{c}\text { Sucção } \\
(\mathrm{kPa})\end{array}$} & \multirow{2}{*}{$\begin{array}{c}\text { Umidade }(\%) \\
\text { papel Filtro }\end{array}$} \\
\hline & \multirow{2}{*}{7} & 100 & 46.87 & & & & \\
\hline & & 100 & 46.97 & \multirow{13}{*}{ 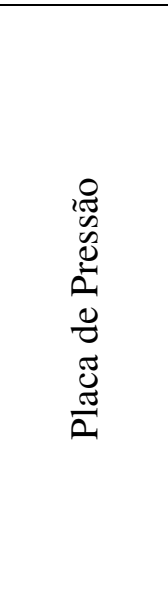 } & \multirow{2}{*}{16} & 50 & 61.57 \\
\hline & \multirow{2}{*}{9} & 150 & 40.67 & & & 50 & 58.74 \\
\hline & & 150 & 40.18 & & \multirow{3}{*}{8} & 100 & 42.79 \\
\hline & \multirow{2}{*}{7} & 200 & 36.62 & & & 100 & 42.42 \\
\hline & & 200 & 36.33 & & & 100 & 42.18 \\
\hline & \multirow{2}{*}{7} & 200 & 40.31 & & \multirow{2}{*}{13} & 200 & 35.09 \\
\hline & & 200 & 40.22 & & & 200 & 34.72 \\
\hline & \multirow{4}{*}{8} & 300 & 34.18 & & \multirow{2}{*}{7} & 300 & 32.54 \\
\hline & & 300 & 34.61 & & & 300 & 31.13 \\
\hline & & 300 & 33.99 & & \multirow{2}{*}{7} & 400 & 31.30 \\
\hline & & 300 & 34.68 & & & 400 & 30.57 \\
\hline & 7 & 300 & 34.78 & & 13 & 400 & 31.33 \\
\hline & 1 & 300 & 35.55 & & 13 & 400 & 31.32 \\
\hline & & 700 & 30.09 & Lot & e 14420 & 90 (UEI & NF-RJ) \\
\hline & 7 & 700 & 29.38 & Fouin & Tempo & Sucção & Umidade (\%) \\
\hline$\grave{o}$ & & 3000 & 20.76 & Equip. & (dias) & $(\mathrm{kPa})$ & papel Filtro \\
\hline శ్ర్ల & 9 & 3000 & 19.84 & & & 100 & 44.06 \\
\hline $\begin{array}{l}\infty \\
\infty \\
\infty\end{array}$ & & 5000 & 16.90 & & 12 & 100 & 45.89 \\
\hline อ๊ & 7 & 5000 & 16.18 & & 12 & 100 & 48.71 \\
\hline & 1 & 5000 & 18.45 & & & 100 & 48.92 \\
\hline & & 5000 & 17.98 & & & 200 & 37.55 \\
\hline & Lote 463 & 307 (PUC & C-RJ) & జి & 7 & 200 & 36.86 \\
\hline & Tempo & Sucção & Umidade (\%) & 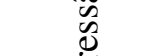 & 1 & 200 & 36.92 \\
\hline Equip. & (dias) & $(\mathrm{kPa})$ & papel Filtro & 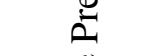 & & 200 & 37.69 \\
\hline P S & (1) & 20 & 78.45 & $\frac{\theta}{8}$ & & 300 & 34.34 \\
\hline P.Sucçao & 1 & 20 & 76.92 & $\tilde{\tilde{E}}$ & & 300 & 34.65 \\
\hline & 7 & 100 & 47.66 & $\frac{\pi}{2}$ & 11 & 300 & 37.74 \\
\hline in & 7 & 100 & 48.11 & & & 300 & 36.83 \\
\hline$D$ & & 300 & 34.62 & & & 400 & 33.01 \\
\hline 8 & 7 & 300 & 33.69 & & 10 & 400 & 32.77 \\
\hline త్ర్ర & 7 & 700 & 28.47 & & 10 & 400 & 32.72 \\
\hline$\frac{\pi}{\alpha}$ & 1 & 700 & 30.03 & & & 400 & 33.27 \\
\hline
\end{tabular}




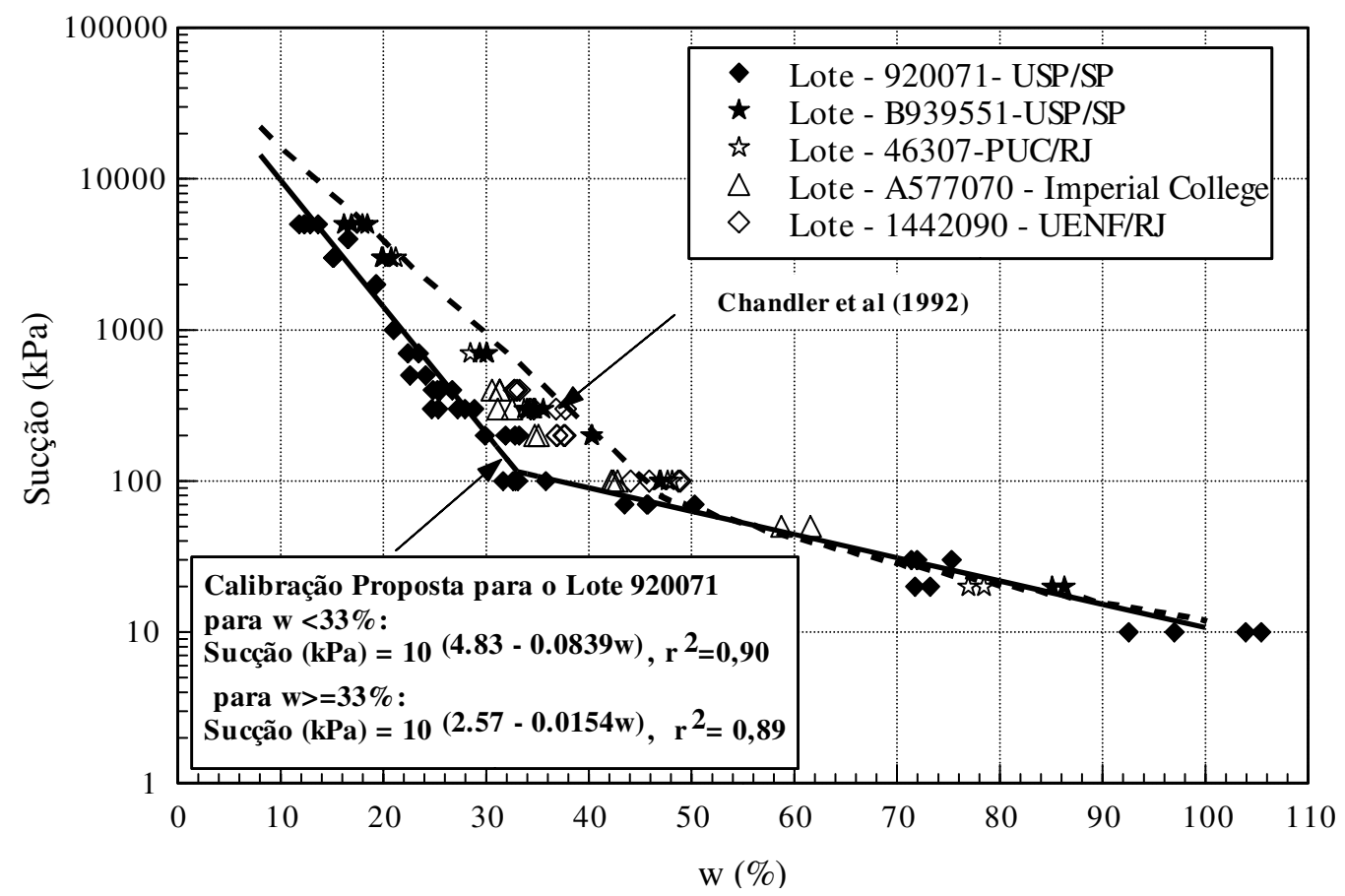

Figura 7.13 - Valores experimentais dos ensaios e representação da equação de calibração encontrada para o lote 920071.

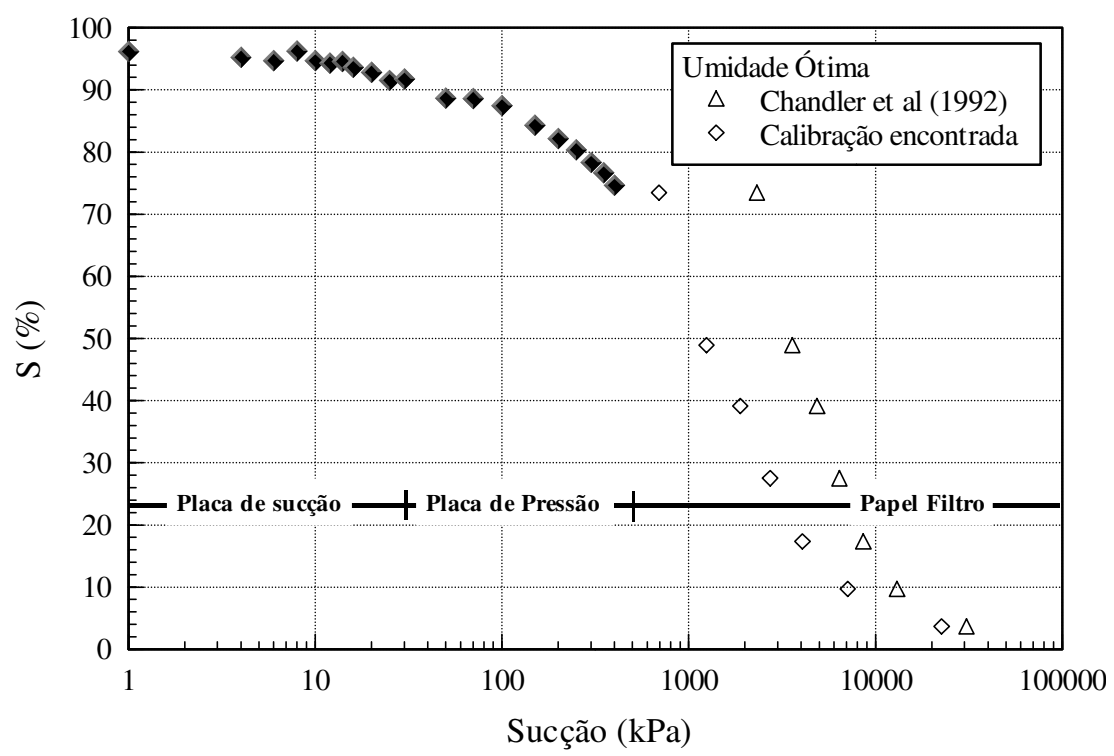

Figura 7.14 - Resultados experimentais da curva de retenção utilizando-se, para o trecho determinado com o papel filtro, a calibração obtida para lote 920071 e a equação proposta por Chandler et al (1992). 


\section{5 - Relação entre os valores das sucções determinadas com a placa de pressão, papel filtro e o tensiômetro}

Para quase todos os ensaios de resistência e para a curva de retenção da lama foram obtidas as sucções iniciais dos corpos de prova utilizando-se mais de uma técnica. Antes da realização dos ensaios de compressão simples, a sucção inicial de alguns corpos de prova foi determinada com o papel filtro e o tensiômetro. Nos ensaios triaxiais CW não saturados, antes da medição da sucção com o tensiômetro e o papel filtro, os corpos de prova também foram submetidos a diferentes valores de sucções na placa de pressão. Os corpos de prova utilizados para a determinação da curva de retenção da lama, ao serem retirados da placa de pressão tiveram as suas sucções determinadas com o tensiômetro. Os valores das sucções obtidas no início destes ensaios, utilizando-se diferentes técnicas, são analisados neste item. Na Tabela 7.5 estão apresentados os tipos de ensaios realizados, as técnicas utilizadas para a determinação das sucções iniciais dos corpos de prova, com suas respectivas condições de moldagem, e a numeração das tabelas e dos itens onde os mesmos podem ser encontrados.

Tabela 7.5 - Comparação das diferentes técnicas utilizadas na determinação das sucções iniciais dos corpos de prova.

\begin{tabular}{|c|c|c|c|c|}
\hline Tipo de Ensaio & $\begin{array}{c}\text { Comparação dos valores de } \\
\text { sucções iniciais obtidas por } \\
\text { diferentes técnicas. }\end{array}$ & $\begin{array}{c}\text { Condições } \\
\text { de } \\
\text { Moldagem }\end{array}$ & Tabela & Item \\
\hline $\begin{array}{c}\text { Compressão simples } \\
\text { (deformação controlada) }\end{array}$ & $\begin{array}{c}\text { P.F. versus Tensiômetro } \\
\text { (P.F. - Papel Filtro) }\end{array}$ & O, S e U & $\begin{array}{c}6.4, \\
6.5 \text { e } \\
6.6\end{array}$ & 6.1 .2 \\
\hline $\begin{array}{c}\text { Compressão simples } \\
\text { (carregamento } \\
\text { controlado) }\end{array}$ & P.F. versus Tensiômetro & O, S e U & $\begin{array}{c}6.7 \text { e } \\
6.8\end{array}$ & 6.1 .3 \\
\hline $\begin{array}{c}\text { Compressão simples } \\
\text { (estudo do efeito da } \\
\text { velocidade de } \\
\text { cisalhamento) }\end{array}$ & P.F. versus Tensiômetro & O & 6.9 & 6.1 .4 \\
\hline $\begin{array}{c}\text { Ensaios triaxiais não } \\
\text { saturados (CW) }\end{array}$ & P.F.versus Tensiômetro & Placa de pressão versus P.F. \\
versus Tensiômetro & O, S e U & $\begin{array}{c}6.13 \text { e } \\
6.14\end{array}$ & 6.3 \\
\hline $\begin{array}{c}\text { Curva de retenção da } \\
\text { lama }\end{array}$ & $\begin{array}{c}\text { Placa de Pressão versus } \\
\text { Tensiômetro }\end{array}$ & Lama & 5.4 & 5.2 .5 \\
\hline
\end{tabular}


Para a condição de moldagem na umidade ótima, foram obtidos mais alguns resultados com um corpo de prova moldado especificamente para este fim. Este corpo de prova foi obtido por compactação estática no molde tripartido, apresentando após moldagem diâmetro e altura iguais a $3.8 \mathrm{~cm}$. Em seguida foi preparado por umedecimento ou secagem de forma a apresentar diferentes teores de umidade. Após ficar em repouso por um período de 48 horas, foram colocados dois papéis filtros na sua superfície lateral, obtendo-se a sucção depois de 7 dias. Logo em seguida a sucção do corpo de prova foi determinada com o tensiômetro. Os resultados destes testes estão indicados na Tabela 7.6.

Tabela 7.6 - Resultados dos valores das sucções obtidas com o papel filtro e o tensiômetro, utilizando um corpo de prova moldado na umidade ótima.

\begin{tabular}{|c|c|c|c|}
\hline \multicolumn{4}{|c|}{ Umidade Ótima } \\
\hline $\begin{array}{c}\text { Sucção Tens. } \\
(\mathrm{kPa})\end{array}$ & $\begin{array}{c}\text { Sucção P.F. } \\
(\mathrm{kPa})\end{array}$ & $\begin{array}{c}\text { Sucção Tens. } \\
(\mathrm{kPa})\end{array}$ & $\begin{array}{c}\text { Sucção P.F. } \\
(\mathrm{kPa})\end{array}$ \\
\hline 487 & 898 & 153 & 660 \\
\hline 353 & 824 & 187 & 704 \\
\hline 104 & 404 & 276 & 782 \\
\hline 39 & 79 & 393 & 909 \\
\hline 55 & 100 & 366 & 870 \\
\hline 77 & 177 & 295 & 694 \\
\hline 126 & 446 & 407 & 748 \\
\hline 223 & 799 & 411 & 896 \\
\hline 79 & 226 & 451 & 884 \\
\hline 104 & 405 & 328 & 899 \\
\hline 134 & 521 & 407 & 949 \\
\hline 214 & 731 & 405 & 855 \\
\hline 319 & 1092 & 479 & 915 \\
\hline 141 & 575 & --- & --- \\
\hline
\end{tabular}

Na Figura 7.15 estão apresentados os resultados obtidos para os corpos de prova moldados na umidade ótima. A linha contínua desta figura representa o local onde as leituras dos equipamentos seriam iguais. No eixo das ordenadas estão os valores das sucções obtidas com o papel filtro e imposta aos corpos de prova na placa de pressão. Os valores das sucções obtidas com o tensiômetro estão representados no eixo das abscissas. 
Na Figura 7.15, a relação entre os valores das sucções obtidos com o papel filtro e o tensiômetro estão representados pelos losangos vazados e os impostos na placa de pressão e medidos com o tensiômetro estão representados pelos losangos pretos.

Observa-se na Figura 7.15 que os valores das sucções impostas nos corpos de prova pela placa de pressão apresentam uma boa correlação com os valores medidos pelo tensiômetro. Entretanto não se pode chegar à mesma conclusão ao ser verificar a relação entre a sucção do tensiômetro e do papel filtro. A correlação entre estes valores esta representada, na Figura 7.15, pela linha pontilhada. Observa-se que, a partir do valor de $50 \mathrm{kPa}$ no eixo das abscissas, o papel filtro passa a medir valores de sucção maiores. Esta diferença aumenta gradativamente até a sucção em torno de $150 \mathrm{kPa}$. No eixo das ordenadas este valor corresponde à sucção em torno de 600 $\mathrm{kPa}$. A partir deste ponto a relação entre as sucções medidas com o tensiômetro e o papel filtro (linha pontilhada) apresenta inclinação semelhante à linha contínua. Isto indica que as diferenças entre os valores de sucção desta correlação passam a ser constante e igual a aproximadamente $450 \mathrm{kPa}$.

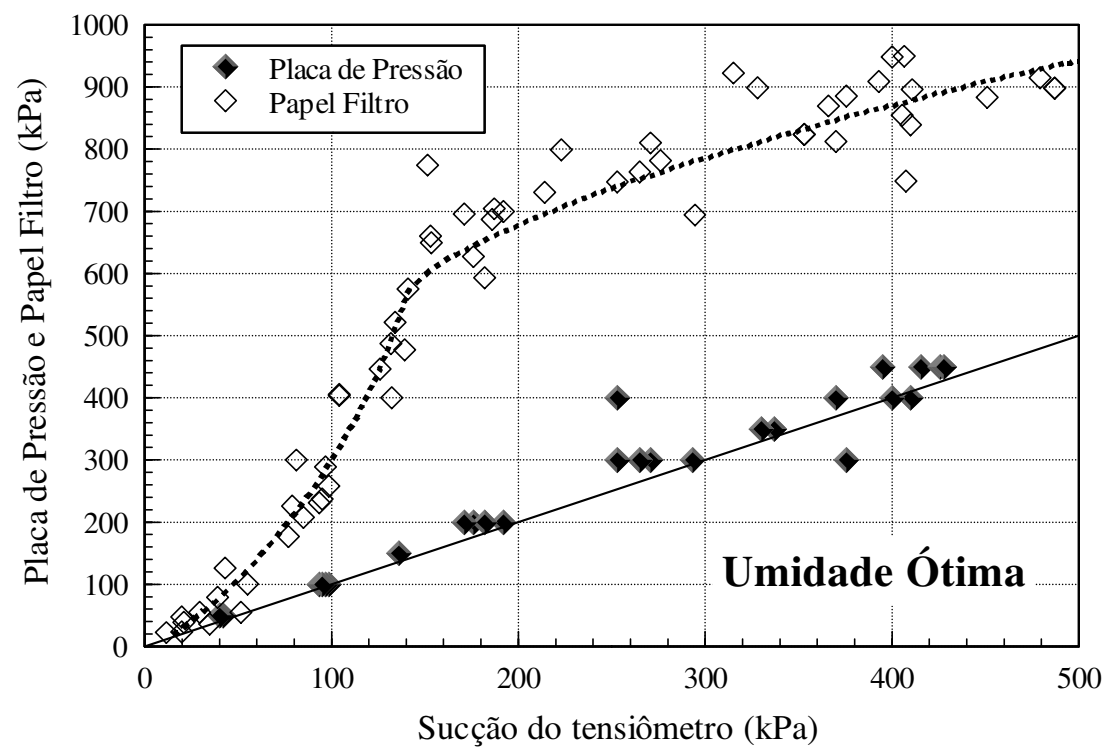

Figura 7.15 - Valores das sucções medidas com o tensiômetro em relação a sucção obtida com o papel filtro e a sucção imposta na placa de pressão (ponto O). 
Os resultados dos corpos de prova moldados no ramo seco e no ramo úmido estão apresentados nas Figuras 7.16 e 7.17. Em função da pequena quantidade de resultados, a correlação entre os valores de sucção medida pelo o tensiômetro e pelo papel filtro, não está tão bem definida quanto à obtida na umidade ótima (Figura 7.15). No entanto, observa-se nestas figuras que existe uma boa concordância entre os valores de sucção medidos pelo tensiômetro e os valores impostos na placa de pressão.

As relações entre as sucções da placa de pressão e medidas pelo tensiômetro, para os corpos de prova moldados na condição de lama, estão apresentadas na Figura 7.18. Para esta condição de moldagem, os valores da sucção obtidas no tensiômetro são inferiores às sucções aplicadas na placa de pressão. O uso da técnica da translação de eixos pode sobreestimar o valor da sucção do corpo de prova para os solos que apresentam uma certa quantidade de ar ocluso (Bocking e Fredlund, 1980).

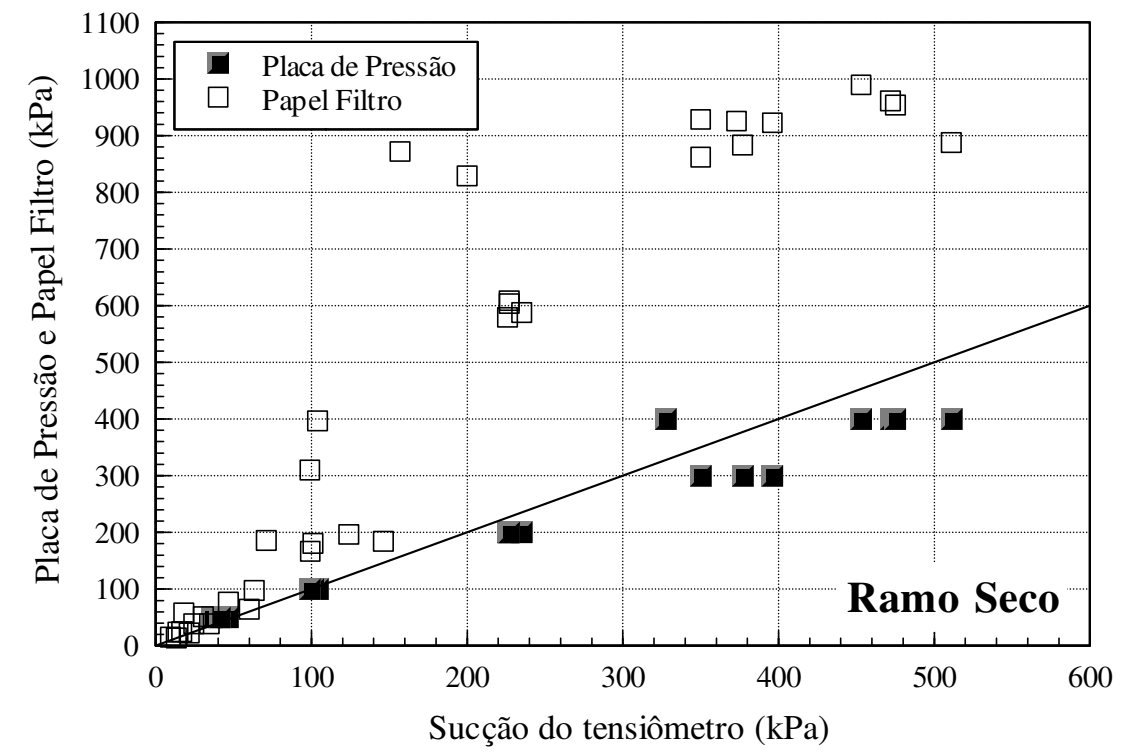

Figura 7.16 - Valores das sucções medidas com o tensiômetro em relação a sucção obtida com o papel filtro e imposta na placa de pressão (ponto S). 


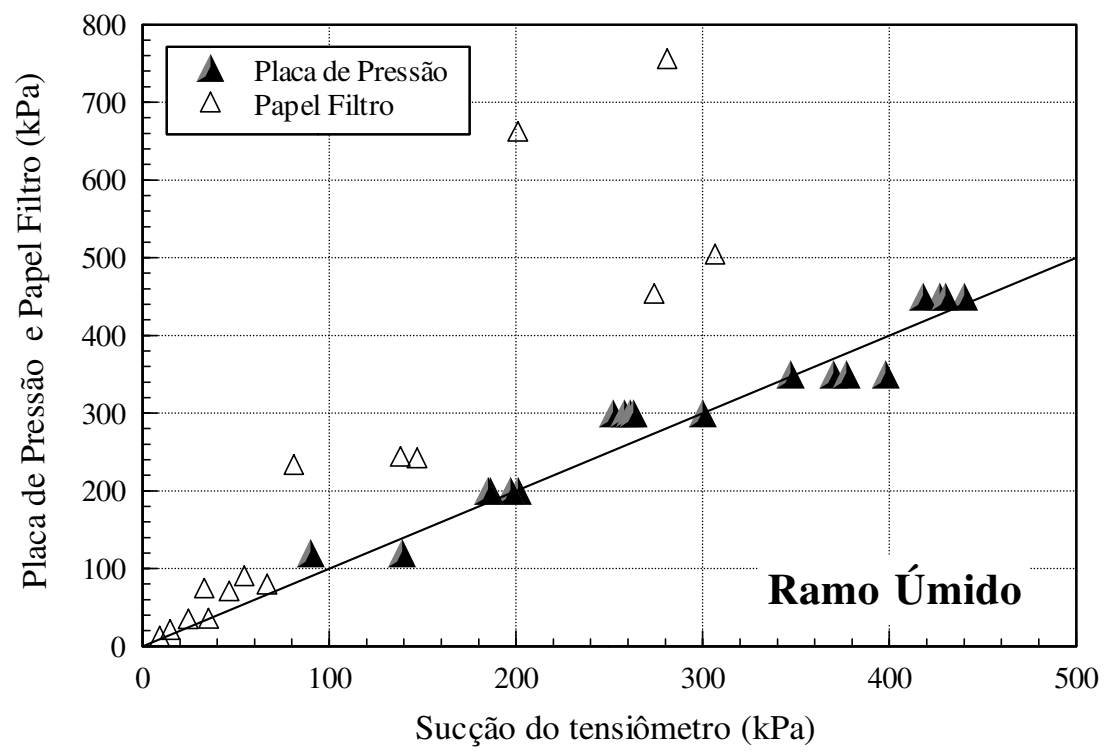

Figura 7.17 - Valores das sucções medidas com o tensiômetro em relação a sucção obtida com o papel filtro e imposta na placa de pressão (ponto U).

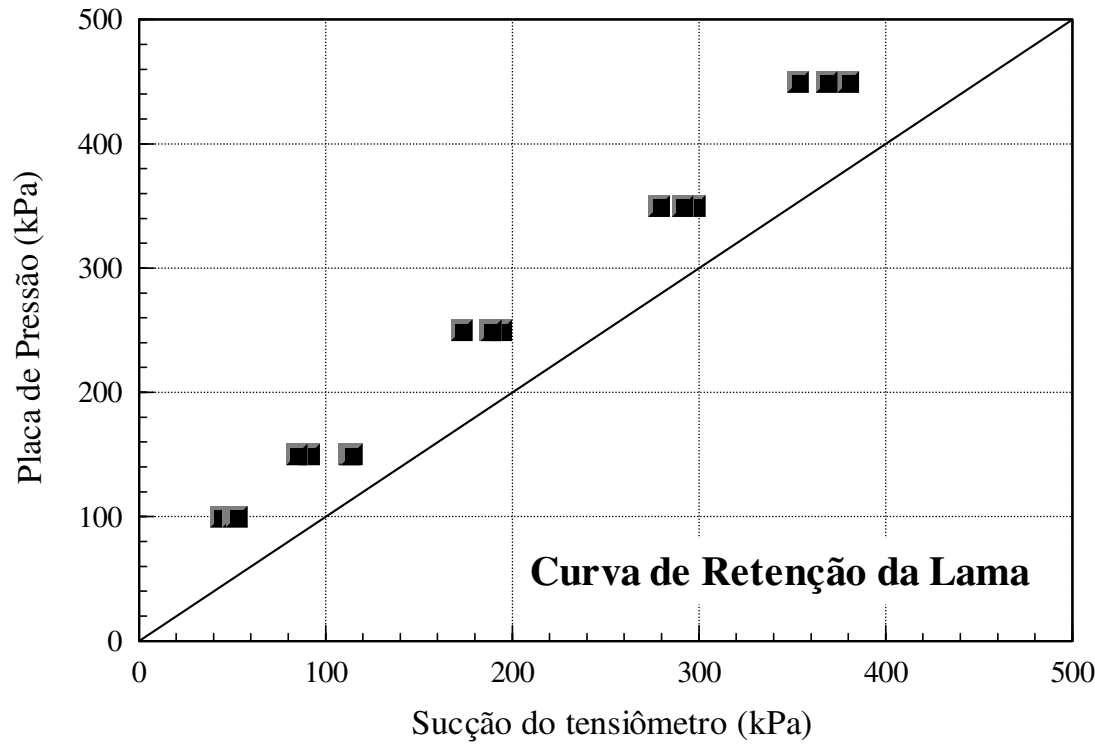

Figura 7.18 - Relação entre os valores das sucções impostas na placa de pressão e medida com o tensiômetro, utilizando os resultados da curva de retenção da lama. 
Todos os resultados apresentados anteriormente neste item estão reunidos na figura 7.19. Observa-se nesta figura que as correlações entre os valores das sucções obtidas com o papel filtro e imposta na placa de pressão, em relação aos valores medidos pelo tensiômetro, independem das condições de moldagem dos corpos de prova. No entanto fica difícil compreender que tipo de sucção está sendo obtido pelo papel filtro. Provavelmente tem-se que, a partir da sucção em tono de $50 \mathrm{kPa}$, o contato do papel filtro com a água do corpo de prova não seja suficiente para se obter a sucção matricial do corpo de prova em 7 dias. Desta forma o mesmo pode estar medindo um valor de sucção intermediário, maior que a matricial e menor que a total.

Marinho e Chandler (1994) afirmam que em função da redução do contanto entre o papel filtro e o corpo de prova, ao ser submetido à secagem, a transferência de água passa a ocorrer por fluxo capilar e pela fase de vapor. Sendo assim o papel filtro passa gradualmente a medir a sucção total. Deka et al (1995) sugerem um tempo de equilíbrio maior que 7 dias para se obter a sucção de um corpo de prova ao se aplicar a técnica do papel filtro. Ridley e Edenmosun (1999) constataram que o papel filtro Whatman $\mathrm{n}^{\mathrm{o}} 42$, sobreestima o valor da sucção do corpo de prova devido à presença de sais no interior do solo.

A explicação do tipo de correlação apresentada entre o papel filtro e o tensiômetro, requer uma investigação mais aprofundada e não faz parte dos objetivos desta pesquisa. Em função das incertezas nos valores das sucções obtidas com o papel filtro, as análises dos resultados de resistência ao cisalhamento serão realizadas apenas com os valores das sucções medidas pelo tensiômetro. 


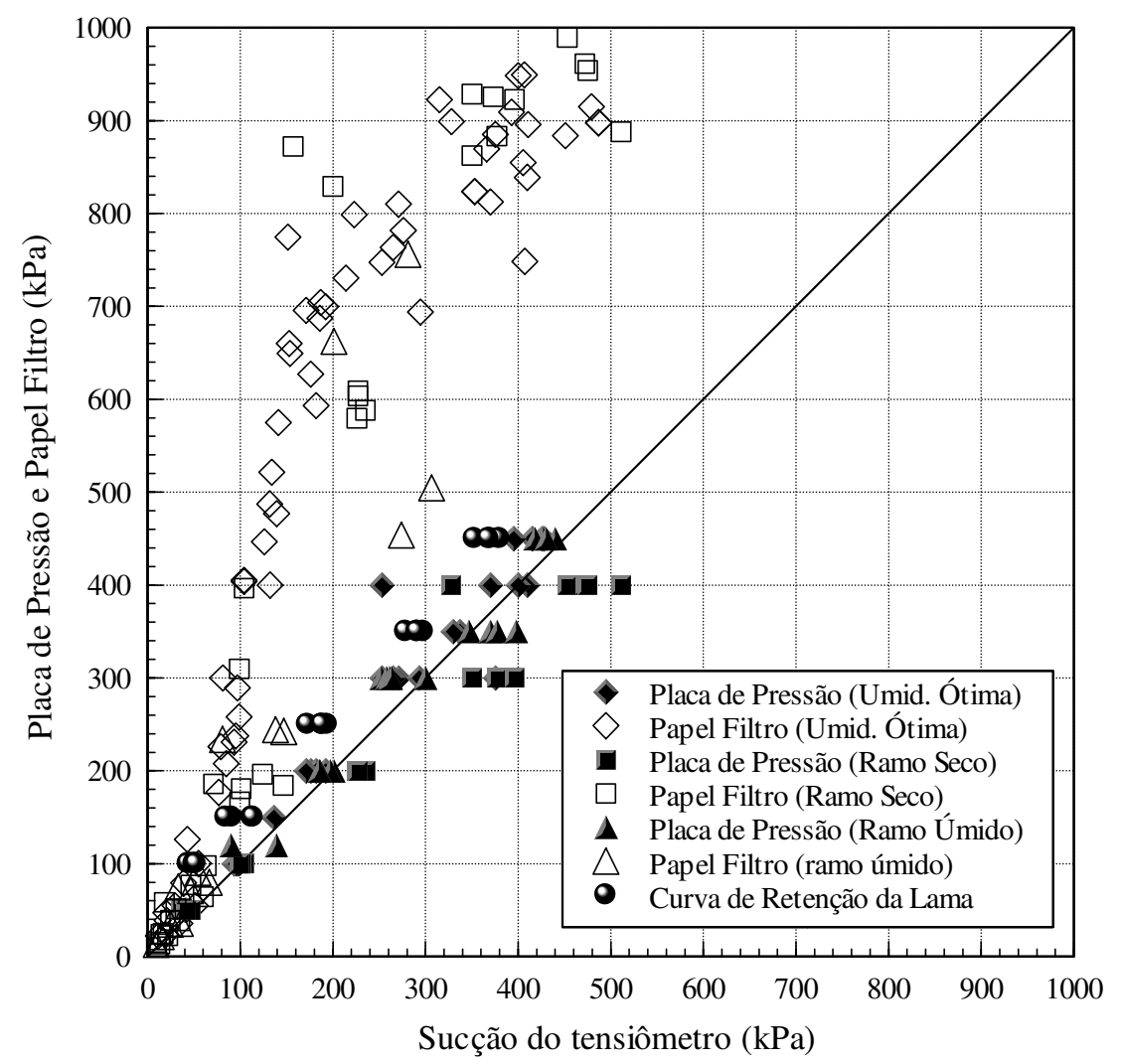

Figura 7.19 - Apresentação de todos os resultados experimentais das relações definidas entre os valores de sucção impostas na placa de pressão e medidas pelo tensiômetro e papel filtro. 


\section{8 - ANÁLISE DOS ENSAIOS DE RESISTÊNCIA}

Neste capítulo são analisados os resultados dos ensaios de resistência apresentados no Capítulo 6. Para os ensaios de compressão simples é investigada, nos valores de resistência ao cisalhamento, a influência das diferentes trajetórias de umidade impostas aos corpos de prova e dos tipos de carregamentos aplicados na etapa de cisalhamento. Para as trajetórias de tensões, correspondentes aos ensaios de compressão simples e triaxiais CW não saturados, são analisadas a influência da sucção inicial dos corpos e da pressão confinante. Utilizando-se os resultados destes ensaios é apresentada uma proposta de ajuste e obtenção das superfícies de ruptura para cada condição de moldagem. No final deste capítulo são aplicados os modelos de previsão da resistência propostos por Vanapalli et al (1996) e Khalili e Khabbaz (1998).

\section{1 - Análise dos ensaios de compressão simples}

Na Tabela 8.1 estão indicados, para cada condição de moldagem, os tipos de ensaios de compressão simples realizados nesta pesquisa e as respectivas tabelas onde se encontram os resultados analisados neste item. Para os diferentes tipos de ensaios serão comparadas, para cada condição de moldagem, as relações definidas entre o grau de saturação e a sucção dos corpos de prova, após a etapa de preparação, e as relações definidas pela umidade gravimétrica e a sucção na ruptura. As análises destas relações são utilizadas na interpretação dos valores de q versus sucção na ruptura. A etapa de preparação corresponde às diferentes trajetórias de umidade impostas aos corpos de prova após a moldagem.

Tabela 8.1 - Localização das tabelas e itens dos resultados dos ensaios de compressão simples.

\begin{tabular}{|c|c|c|c|}
\hline Tipo de Ensaio & Umidade Ótima & Ramo Seco & Ramo Úmido \\
\hline \multirow{2}{*}{ Deformação Controlada (Traj. 3 e 4 ) } & $\begin{array}{c}\text { Tabela 6.4 } \\
\text { (item 6.1.1) }\end{array}$ & $\begin{array}{c}\text { Tabela 6.4 } \\
\text { (item 6.1.2) }\end{array}$ & $\begin{array}{c}\text { Tabela 6.4 } \\
\text { (item 6.1.3) }\end{array}$ \\
\hline Deformação Controlada (Traj. 5) & $\begin{array}{c}\text { Tabela 6.7 } \\
\text { (item 6.1.2) }\end{array}$ & $\begin{array}{c}\text { Tabela 6.7 } \\
\text { (item 6.1.2) }\end{array}$ & $\begin{array}{c}\text { Tabela 6.7 } \\
\text { (item 6.1.2) }\end{array}$ \\
\hline Carregamento Controlado (traj. 3 e 4) & $\begin{array}{c}\text { Tabela 6.8 } \\
\text { (item 6.1.3) }\end{array}$ & $\begin{array}{c}\text { Tabela 6.8 } \\
\text { (item 6.1.3) }\end{array}$ & $\begin{array}{c}\text { Tabela 6.8 } \\
\text { item 6.1.3) }\end{array}$ \\
\hline
\end{tabular}




\subsection{1 - Considerações sobre as relações definidas pelo grau de saturação e a sucção dos corpos de prova após a etapa de preparação e na ruptura}

Nas Figuras 8.1, 8.2 e 8.3 estão representados, para os três tipos de ensaio de compressão simples, os dados iniciais dos corpos de prova após a etapa de preparação, plotados em termos de grau de saturação e sucção. Juntamente com estes valores estão representadas em linha contínua, as curvas de retenção obtidas sem confinamento, apresentadas na Figura 5.4 (item 5.2.1).

Para os corpos de prova moldados na umidade ótima (Figura 8.1) observa-se que, os que foram preparados seguindo a trajetória 5 (saturados e posteriormente submetidos à secagem) definem praticamente a mesma relação entre o grau de saturação e a sucção, quando comparados aos corpos de prova que foram umedecidos ou secados. Para as condições de moldagem no ramo úmido (Figura 8.3) também se observa a semelhança destas relações.

Resultado diferente foi encontrado para os corpos de prova moldados no ramo seco. Em função da sucção inicial de moldagem ser elevada ( $\cong 370 \mathrm{kPa})$, os corpos de prova foram submetidos apenas às trajetórias de umedecimento (Traj.3) e saturação e secagem (Traj.5). Dos resultados apresentados na Figura 8.2 observa-se que, a relação definida para os corpos de prova preparados pela trajetória 5 ficou acima da correspondente aos corpos de prova que foram apenas umedecidos, caracterizando assim uma histerese em relação às diferentes trajetórias de umidade. Salienta-se que estes pontos coincidem com a curva de retenção representada pela linha contínua, obtida em condições semelhantes. 


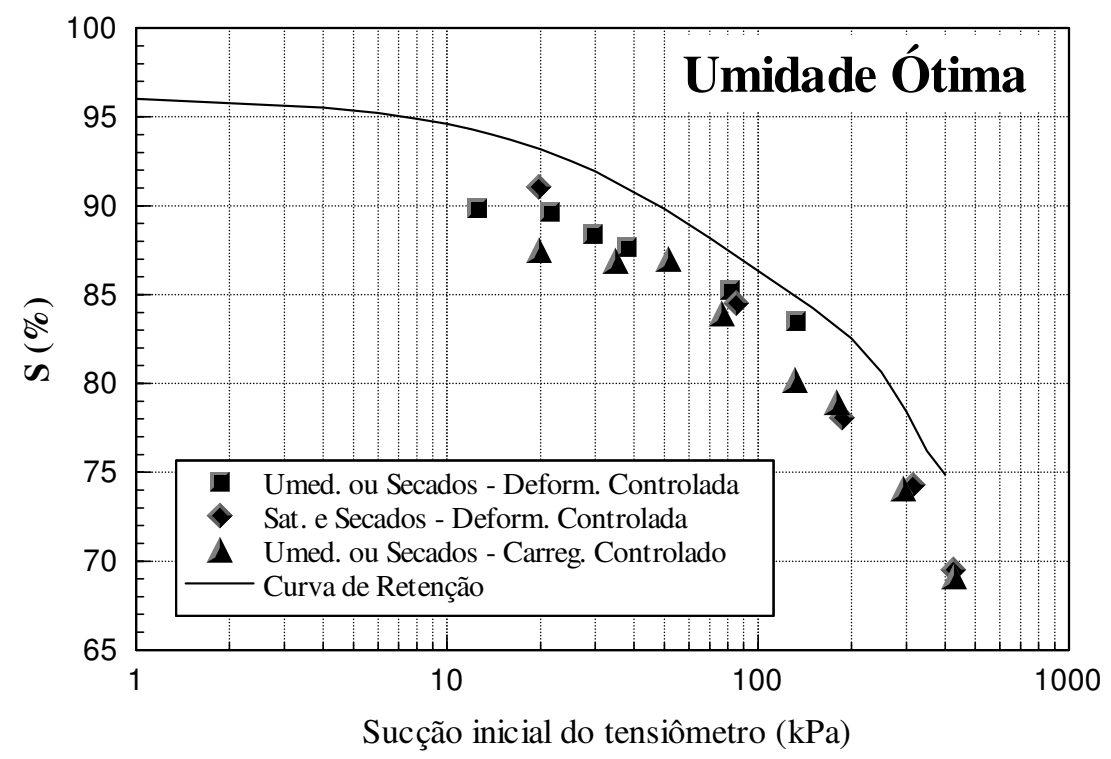

Figura 8.1 - Valores do grau de saturação e da sucção dos corpos de prova após a etapa de preparação para realização dos ensaios de compressão simples (Ponto O).

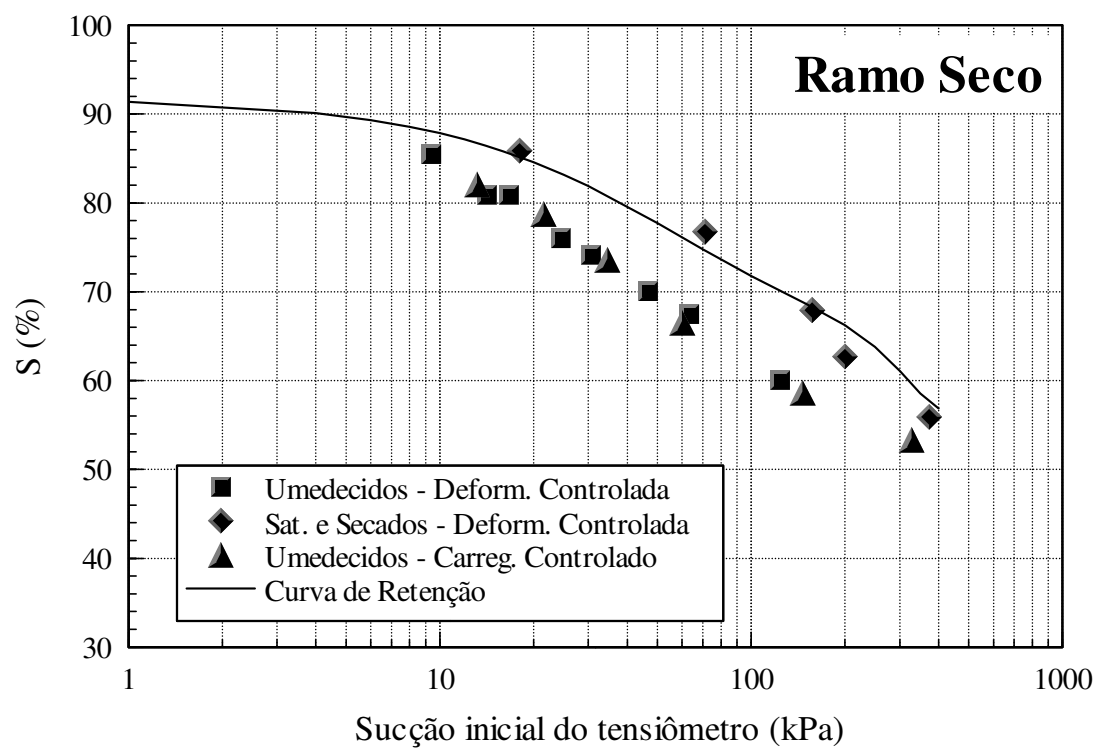

Figura 8.2 - Valores do grau de saturação e da sucção dos corpos de prova após a etapa de preparação para realização dos ensaios de compressão simples (Ponto S). 


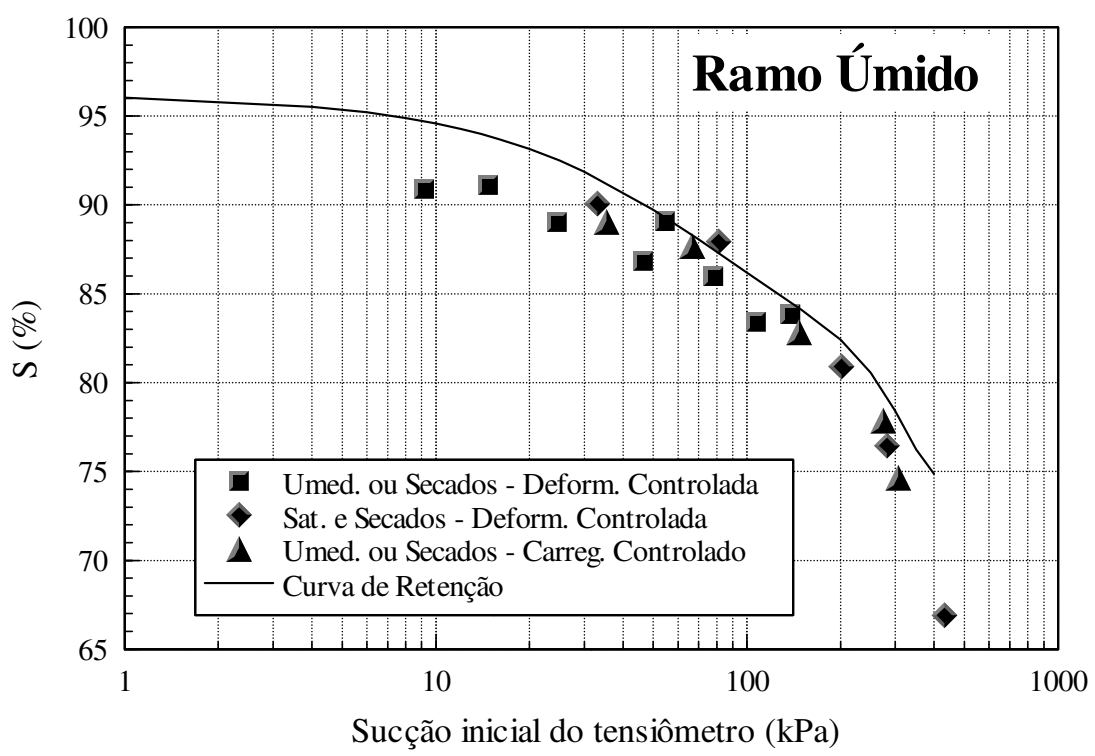

Figura 8.3 - Valores do grau de saturação e da sucção dos corpos de prova após a etapa de preparação para realização dos ensaios de compressão simples (Ponto U).

Os aspectos investigados neste item são importantes para a aplicação do modelo de previsão da resistência proposto por Vanapalli et al (1996). A relação definida pelo grau de saturação e a sucção inicial dos corpos de prova deve ser semelhante aos resultados da curva de retenção. Em função da proximidade destas relações, observadas nas Figuras 8.1, 8.2 e 8.3, os corpos de prova utilizados dos ensaios de compressão simples serão considerados como representativos das respectivas curvas de retenção.

Nos gráficos das Figuras 8.4, 8.5 e 8.6 estão representados os valores da umidade gravimétrica e da sucção inicial e na ruptura, obtidos dos ensaios de compressão simples realizados em corpos de prova moldados na umidade ótima, ramo seco e ramo úmido. Observa-se nestas figuras que a relação definida pelos copos de prova na ruptura, representados pelos símbolos vazados e pela linha tracejada, independem das diferentes trajetórias de umidade impostas em sua preparação. 


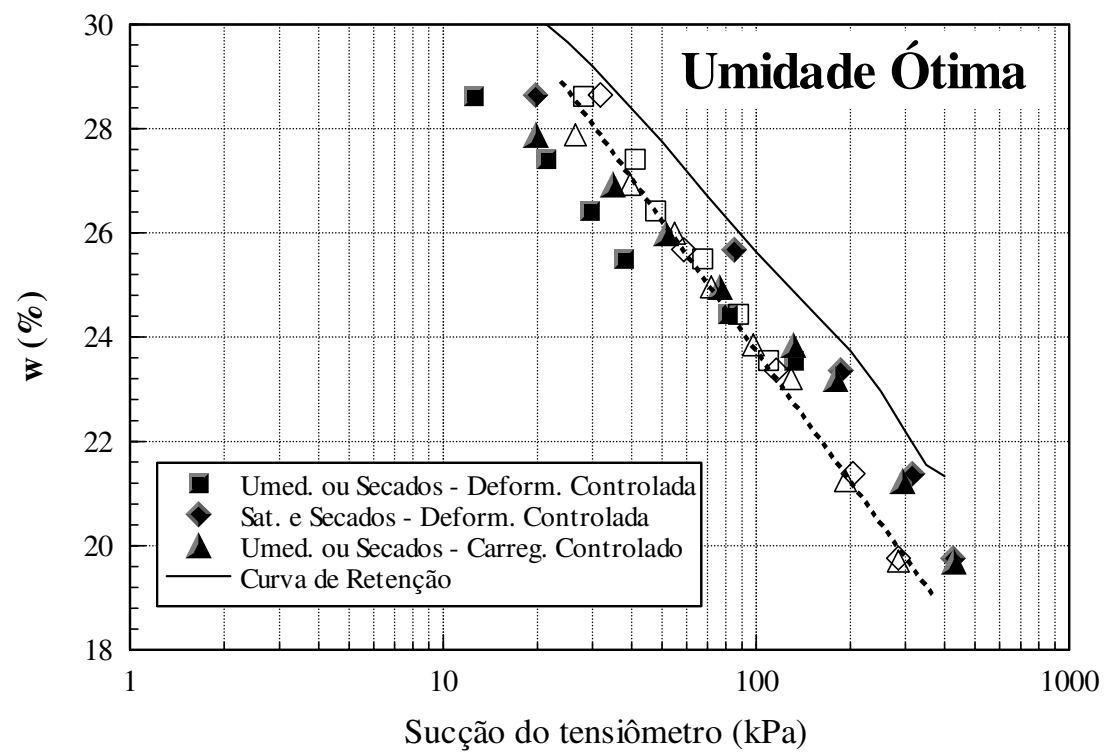

Figura 8.4 - Valores das sucções iniciais e na ruptura em função do teor de umidade obtidos dos corpos de prova moldados na umidade ótima e ensaiados em compressão simples (Ponto O).

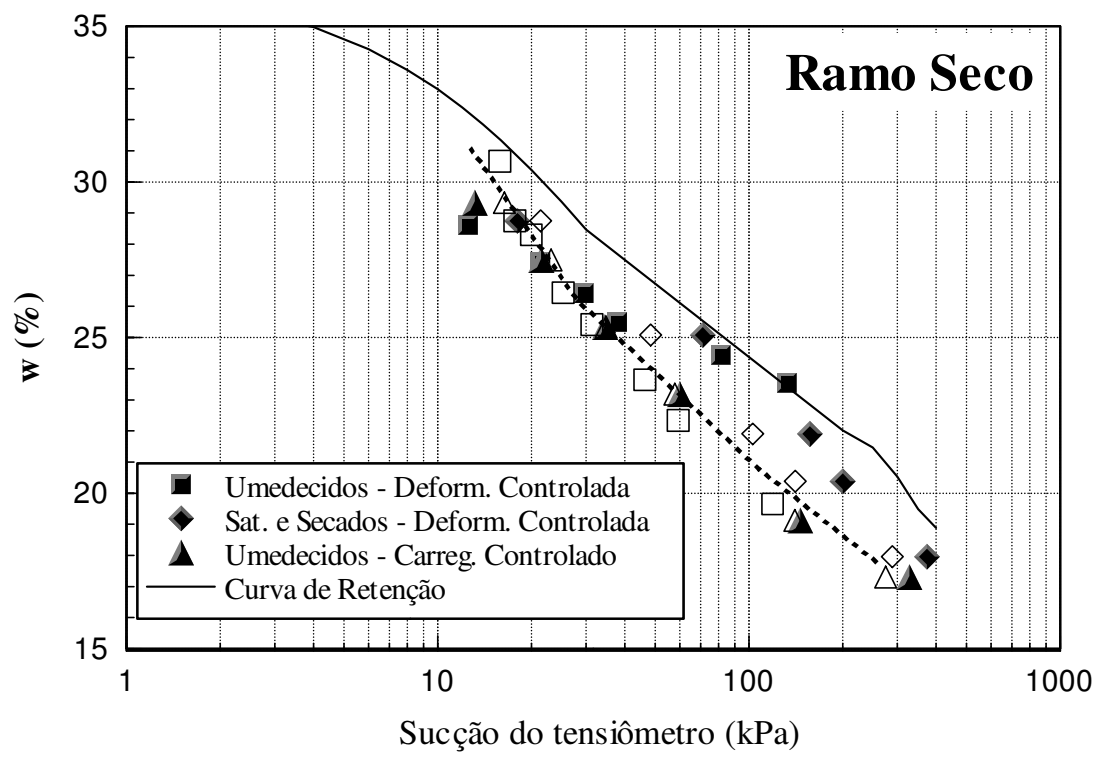

Figura 8.5 - Valores das sucções iniciais e na ruptura em função do teor de umidade obtidos dos corpos de prova moldados no ramo seco e ensaiados em compressão simples (Ponto $\mathrm{S}$ ). 


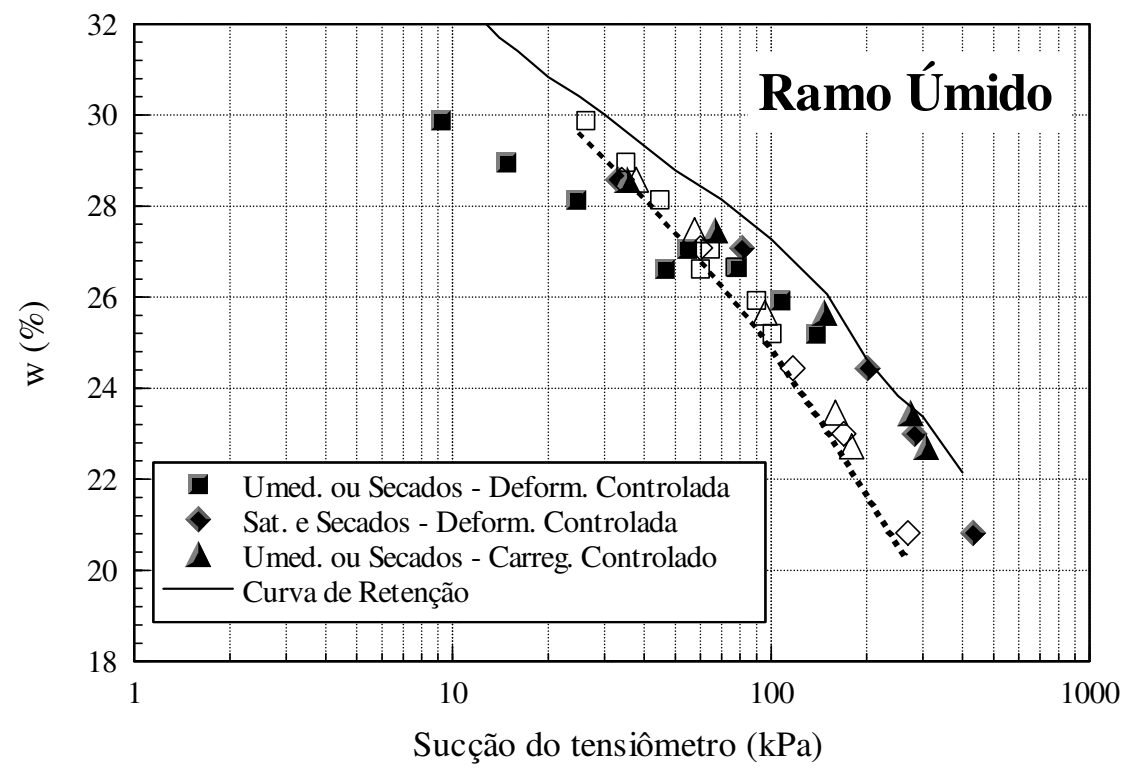

Figura 8.6 - Valores das sucções iniciais e na ruptura em função do teor de umidade obtidos dos corpos de prova moldados no ramo úmido e ensaiados em compressão simples (Ponto $\mathrm{U}$ ).

Croney (1977) apud Brady (1988) já havia constatado a definição de uma relação única para a sucção na ruptura em função do teor de umidade gravimétrico, para ensaios realizados com umidade constante. $\mathrm{O}$ encontro desta relação com a curva de retenção corresponderia ao teor de umidade do limite de plasticidade. Estas mesmas afirmações se aplicam aos resultados apresentados nas Figuras 8.4, 8.5 e 8.6. O prolongamento das linhas pontilhadas destas figuras, correspondentes as condições de ruptura, tendem a interceptar a curva de retenção para valores de umidade próximas do limite de liquidez $\left(\mathrm{w}_{1}=34 \%\right)$ do solo utilizado nesta pesquisa. Brady (1988) afirma que a relação definida entre o teor de umidade e a sucção dos corpos de prova na ruptura corresponde a uma linha de estado crítico.

\subsection{2 - Influência das trajetórias de umidade nos valores nos valores de resistência ao cisalhamento}

Para estas análises os resultados dos ensaios de resistência são apresentados pela relação entre q e o valor da sucção da ruptura. No entanto, estes resultados 
devem ser percebidos como pontos situados em um espaço tridimensional. Em um terceiro eixo, na direção perpendicular ao gráfico, estão os valores de p. Para uma melhor visualização destes resultados, a envoltória de ruptura está representada esquematicamente na Figura 8.7.

Na Figura 8.7a observa-se o desenvolvimento de uma possível trajetória de tensão até o momento da ruptura do corpo de prova. Após a etapa de preparação, o corpo de prova apresenta um determinado valor de sucção inicial, indicado pelo ponto A. Em seguida inicia-se a fase de cisalhamento, passando pelos círculos de Mohr intermediários (1, 2 e 3), atingindo a ruptura no ponto B (círculo 4). A linha que une o ponto A ao ponto B (Figura 8.7a), representa a trajetória de tensão deste ensaio, que neste caso rompeu com aumento de sucção.

Na Figura 8.7b estão representados os resultados de 4 ensaios de compressão simples e a envoltória de ruptura determinada pela união dos pontos finais de cada trajetória de tensão. A linha pontilhada $\mathrm{CD}$ representa a projeção desta envoltória sobre o plano $\mathrm{p}$ versus sucção. $\mathrm{O}$ formato desta linha indica que a envoltória de ruptura não é paralela a este plano (q versus sucção), o que evidentemente não se consegue perceber na apresentação dos resultados dos ensaios em termos de q versus $\mathrm{p}$.

Nas Figuras 8.8 a 8.13 estão apresentadas as relações entre q e a sucção, obtidas dos resultados dos ensaios de compressão de simples dos itens 6.1.1, 6.1.2 e 6.1.3. As linhas contínuas destas figuras representam as trajetórias de tensões dos corpos de prova durante a etapa de cisalhamento. Estas linhas iniciam sobre o eixo das abscissas com valores iguais às sucções apresentadas pelos corpos de prova após a etapa de preparação, ou seja, após serem submetidos as diferentes trajetórias de umidade indicadas na Figura 4.9.

Para uma melhor visualização das trajetórias de tensões dos ensaios realizados em corpos de prova que apresentam sucção inicial inferior a $150 \mathrm{kPa}$, os resultados das Figuras 8.8, 8.10 e 8.12 foram plotados, nas Figuras 8.9, 8.11 e 8.13, para um intervalo menor de sucção. 

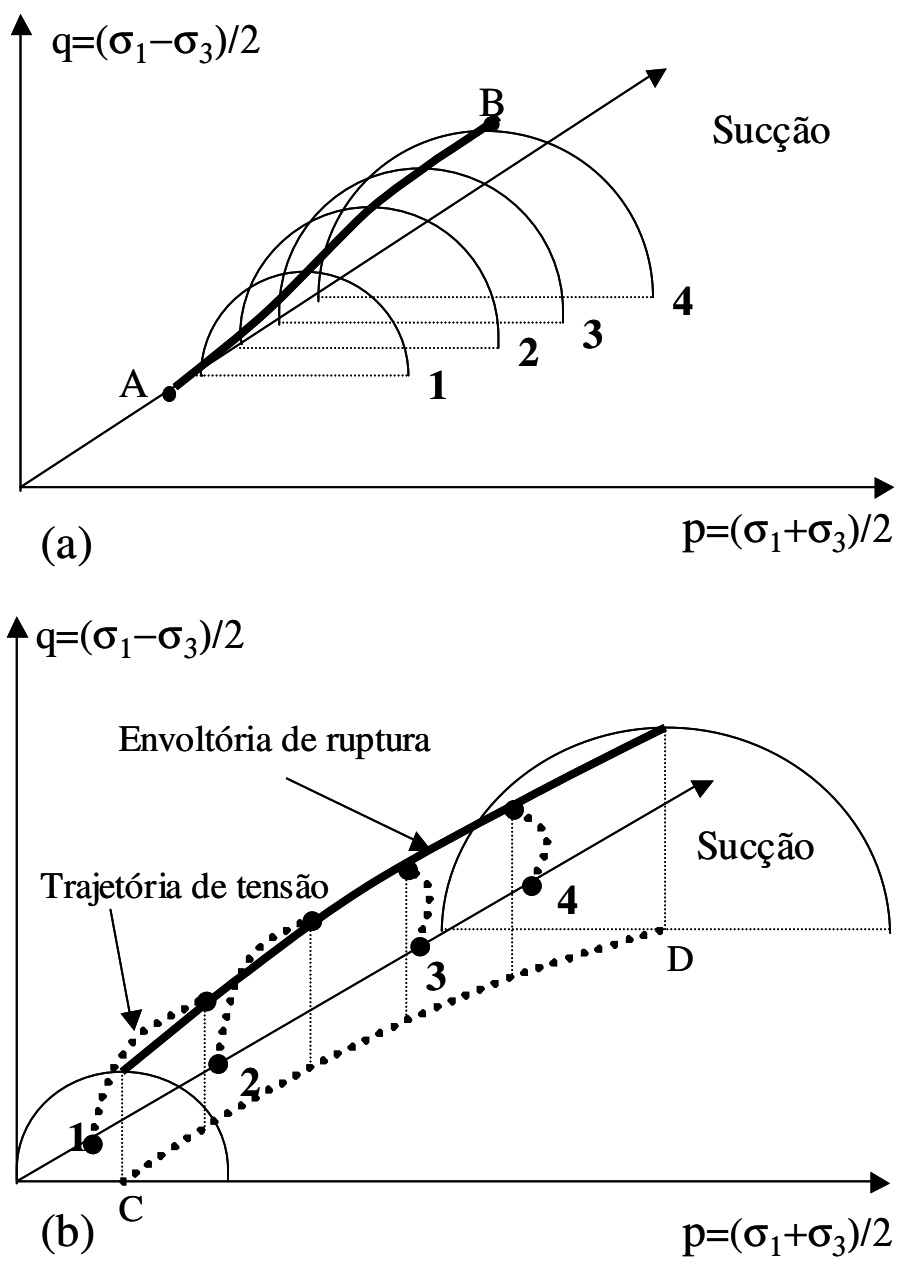

Figura 8.7 - (a) - Representação esquemática das trajetórias de tensão e (b) envoltória de ruptura dos ensaios de compressão simples. 


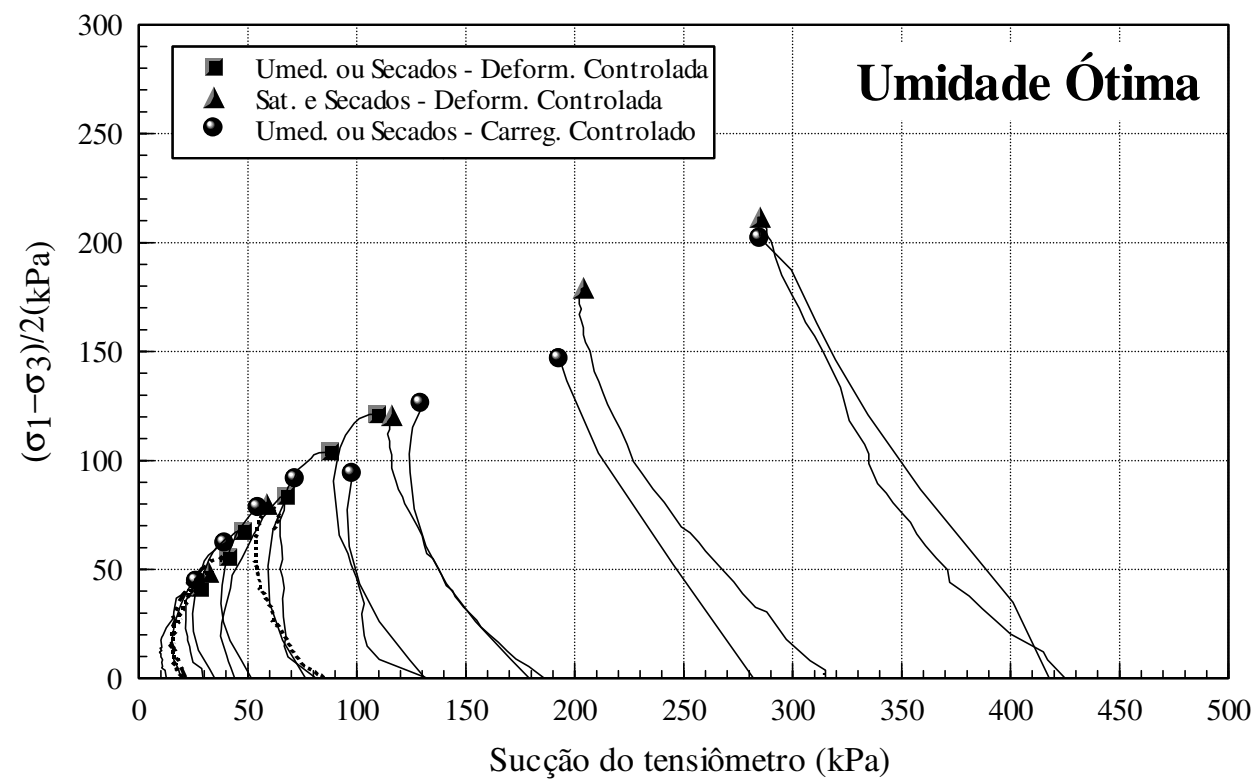

Figura 8.8 - Resultados dos ensaios de compressão simples realizados nos corpos de prova compactados na umidade ótima (ponto $\mathrm{O}$ ).

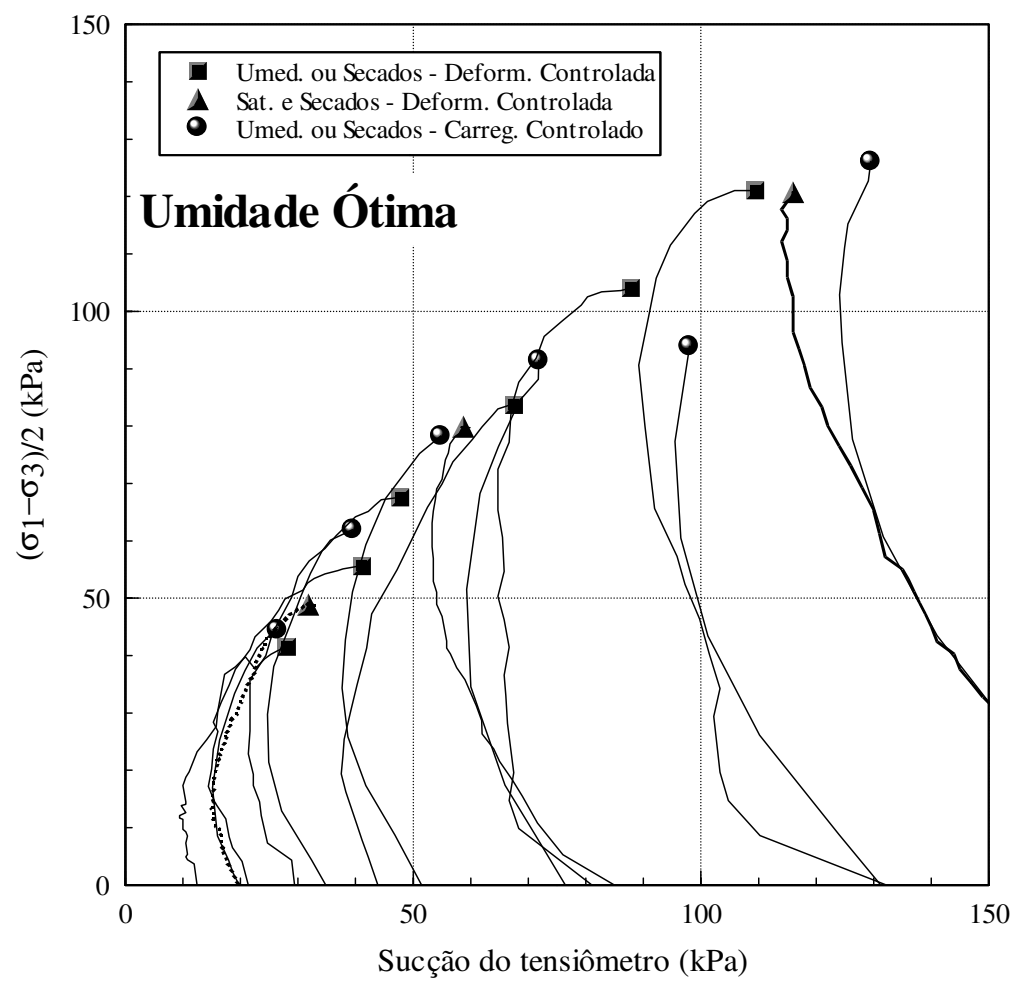

Figura 8.9 - Resultados dos ensaios de compressão simples realizados nos corpos de prova compactados na umidade ótima e com sucção inicial inferior a $150 \mathrm{kPa}$. 


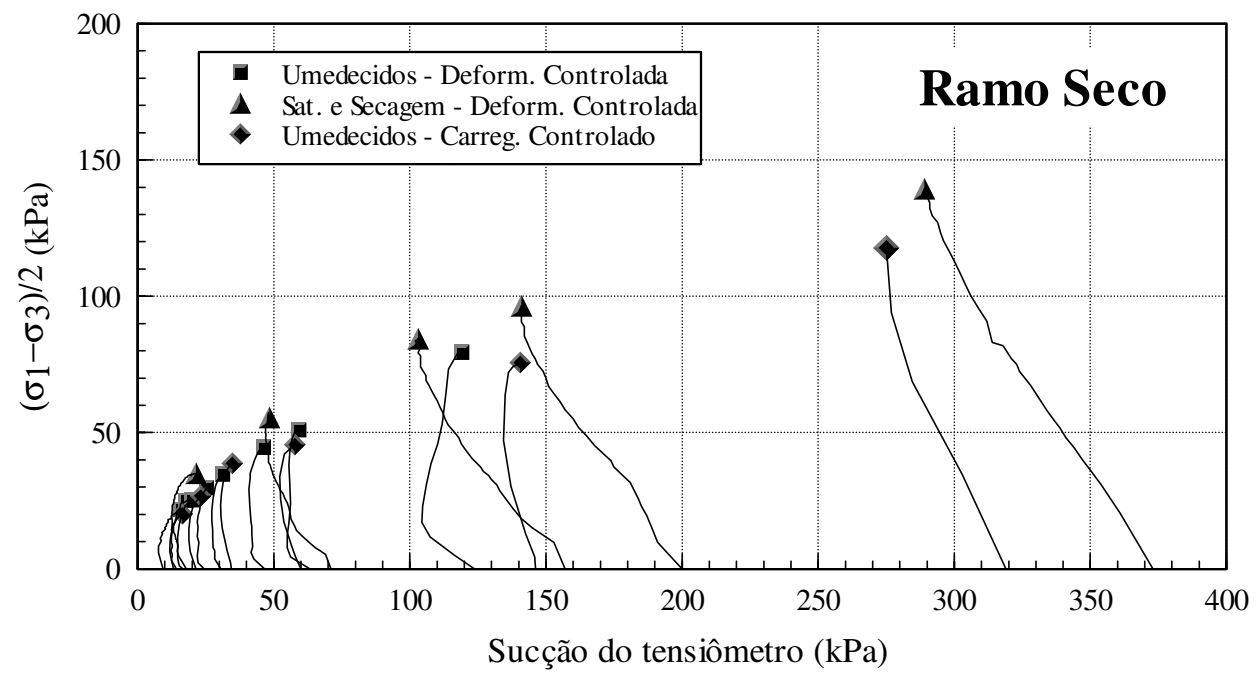

Figura 8.10 - Resultados dos ensaios de compressão simples realizados nos corpos de prova compactados no ramo seco (ponto $\mathrm{S}$ ).

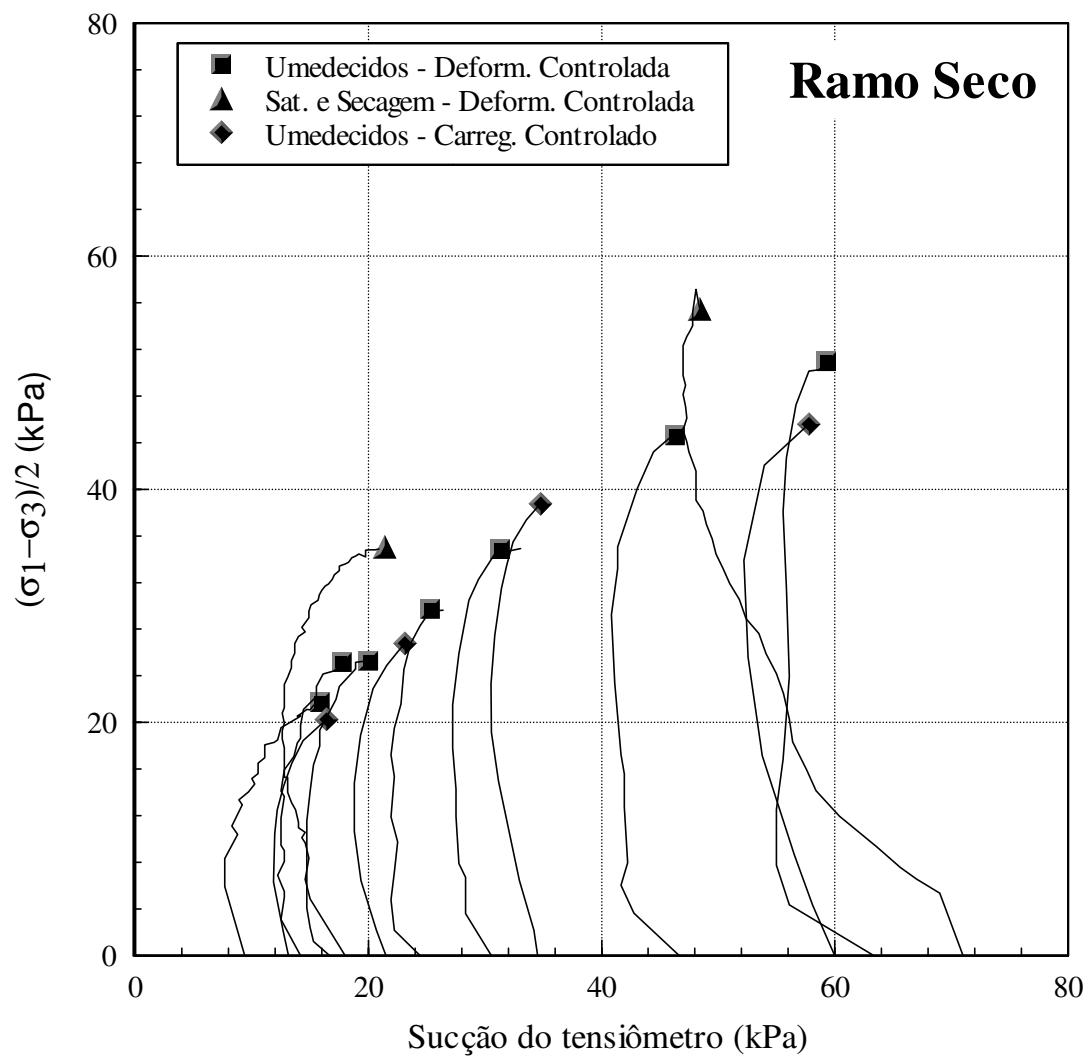

Figura 8.11 - Resultados dos ensaios de compressão simples realizados nos corpos de prova compactados no seco e com sucções iniciais inferiores a $100 \mathrm{kPa}$ (ponto S). 


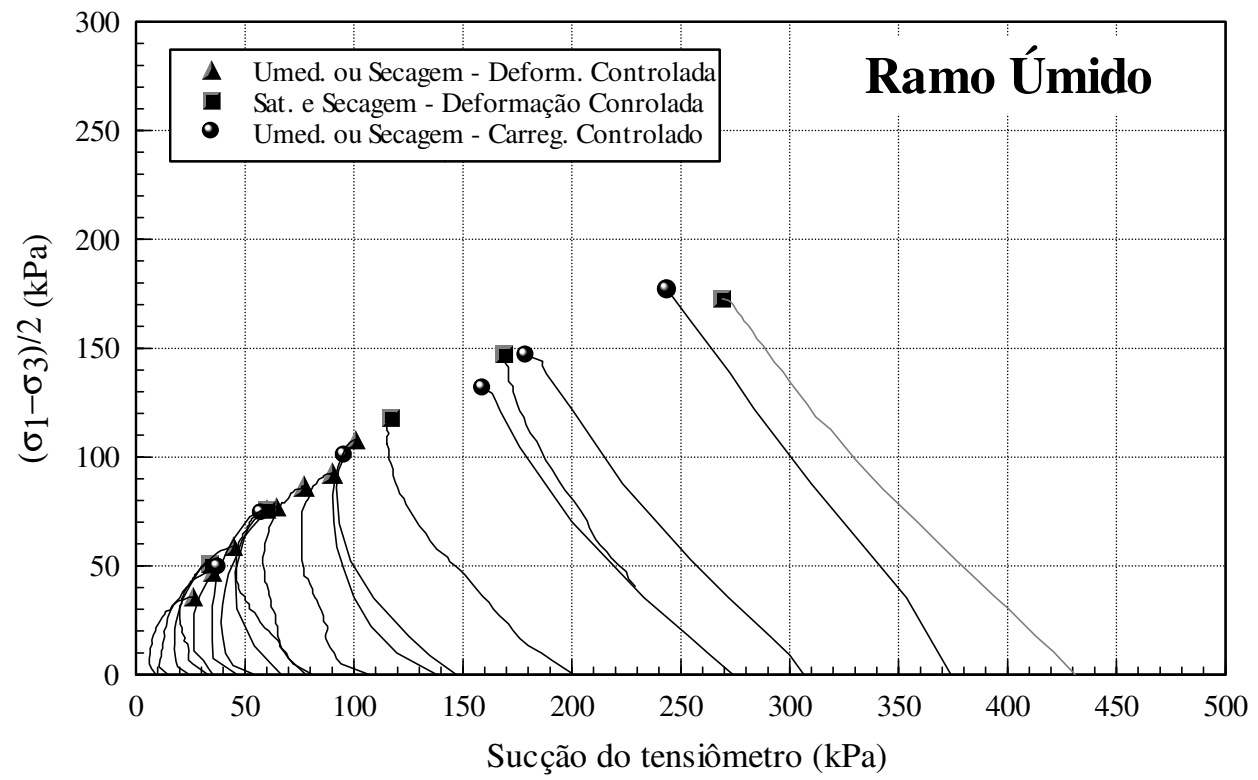

Figura 8.12 - Resultados dos ensaios de compressão simples realizados nos corpos de prova compactados no ramo úmido (ponto $\mathrm{U}$ ).

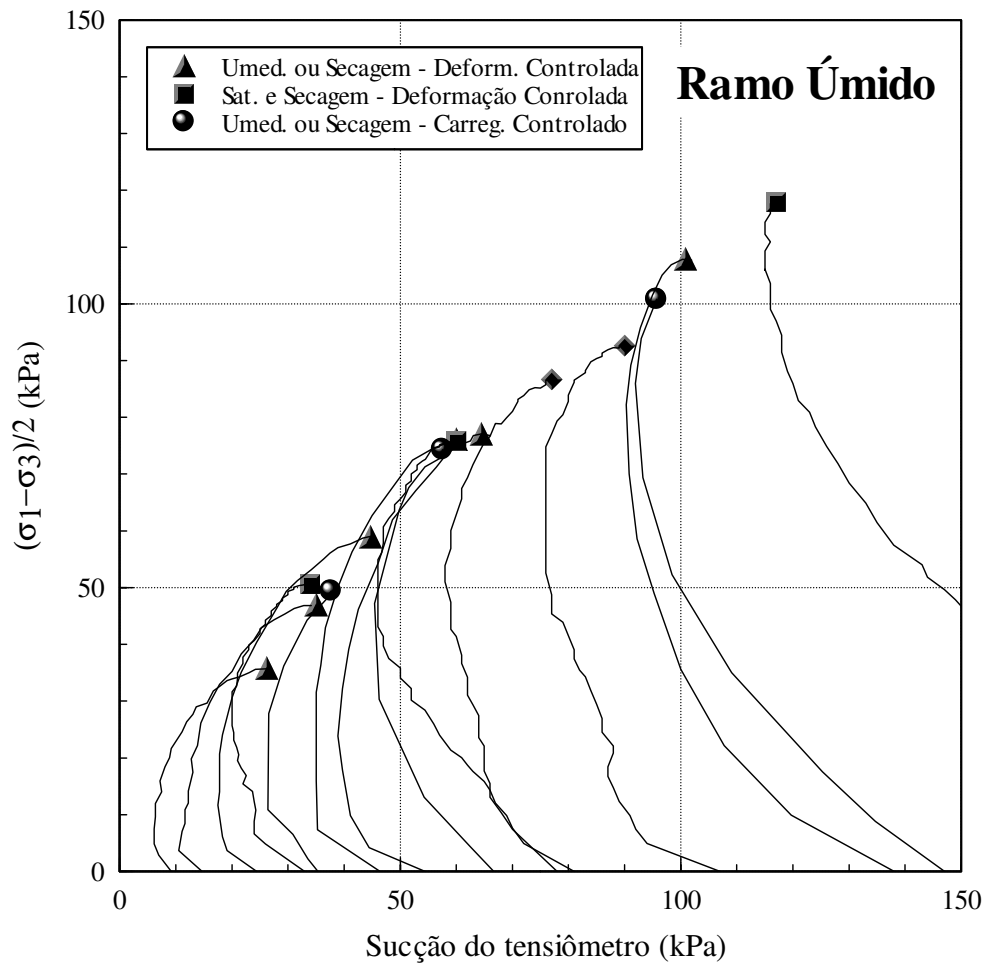

Figura 8.13 - Resultados dos ensaios de compressão simples realizados nos corpos de prova compactados no ramo úmido e com sucções iniciais inferiores a $150 \mathrm{kPa}$ (ponto U). 
Nas Figuras 8.8 a 8.13 constata-se que as relações definidas pelos valores de q em função da sucção na ruptura são independentes das trajetórias de umidade seguidas na etapa de preparação dos corpos de prova e do tipo de carregamento empregado na etapa de cisalhamento. Apenas os resultados do ensaio relacionados às condições de moldagem no ramo seco (Figuras 8.10 e 8.11), cujos corpos de prova foram saturados e secados (trajetória 5), apresentaram valores de resistência maiores que os outros dois tipos de ensaio. Esta diferença no valor de q é da ordem de $10 \mathrm{kPa}$, para qualquer valor de sucção. Na Figura 8.2 já havia sido constatada, para os corpos de prova preparados por esta trajetória de umidade, uma certa diferença em termos da relação determinada entre o grau de saturação inicial em função da sucção.

Nas Figuras 8.8, 8.10 e 8.12 observa-se que à medida que aumenta o valor da sucção inicial dos corpos de prova, as trajetórias de tensões passam a apresentarem redução da sua curvatura, com tendência a tornarem-se retilíneas para valores maiores de sucção. A curvatura das trajetórias de tensões esta associada a uma redução da sucção do corpo de prova no início do ensaio, seguida do aumento deste valor até se atingir a ruptura. Para os valores de sucção inferiores a 80,35 e $50 \mathrm{kPa}$, respectivamente para as condições de moldagem na umidade ótima, ramo seco e ramo úmido, os corpos de prova tendem a romper com aumento de sucção. Para sucções maiores que estas, independentemente das condições de moldagem, os corpos de prova atingem a ruptura com sucção menor que a inicial.

\section{2 - Análise dos resultados dos ensaios triaxiais não saturados}

Neste item são analisados os aspectos relacionados aos procedimentos de preparação dos corpos de prova e de aplicação da pressão confinante. Para os valores de q em função da sucção serão apresentadas as trajetórias de tensão de cada ensaio. Complementando as análises das trajetórias de tensões são comparados os valores das sucções dos corpos de prova no início do ensaio e na ruptura. 


\subsection{1 - Aspectos relacionados à etapa de preparação e confinamento dos corpos de prova.}

Na Figura 8.14 esta representada de forma esquemática, as etapas seguidas pelos corpos de prova nos ensaios triaxiais CW não saturados. A descrição dos aspectos desta figura são importantes para a compreensão dos resultados analisados posteriormente neste item. A sucção do corpo de prova correspondente as condições de moldagem esta representada pelo ponto A (Figura 8.14). Em seguida vem a etapa de preparação onde os corpos de prova podem ser submetidos a uma das cinco trajetórias de umidade descritas no item 4.11.1. No exemplo da Figura 8.14 o corpo de prova foi submetido a secagem (traj. 4), estando associado ao ponto B. A partir deste momento o mesmo é submetido à pressão confinante de ensaio. Ao final desta etapa o corpo de prova passa a ser representado pelo ponto C. A trajetória que une o ponto $\mathrm{C}$ ao ponto $\mathrm{D}$ corresponde a etapa de cisalhamento.

Nas Figuras 8.15, 8.16 e 8.17 estão apresentadas as etapas de preparação e aplicação da pressão de confinamento dos ensaios realizados em corpo de prova moldados nos três pontos de estudo. Estas duas etapas correspondem na Figura 8.14, às trajetórias dadas pelos seguimentos que unem os pontos $\mathrm{A}, \mathrm{B}$ e $\mathrm{C}$. $\mathrm{O}$ traço horizontal entre as duas setas (Figuras 8.15, 8.16 e 8.17), localizado próximo do eixo das ordenadas, indica o valor da sucção correspondente a condição de moldagem dos corpos de prova. A seta para cima corresponde aos que foram preparados por secagem e a seta para baixo os que foram preparados por umedecimento.

Os pontos localizados sobre o eixo das ordenadas e representados pelos mesmos símbolos (Figuras 8.15, 8.16 e 8.17), correspondem aos corpos de prova submetidos a um mesmo valor de sucção na placa de pressão (ver item 4.11.2, parte 3). A partir deste momento foram aplicadas diferentes pressões de confinamento para cada corpo de prova destes grupos. Para alguns corpos de prova, moldados na umidade ótima (Figura 8.15) e no ramo seco (Figura 8.16), foram definidas as variações da sucção com o aumento da pressão confinante, estando as mesmas representadas pelas linhas tracejadas. 


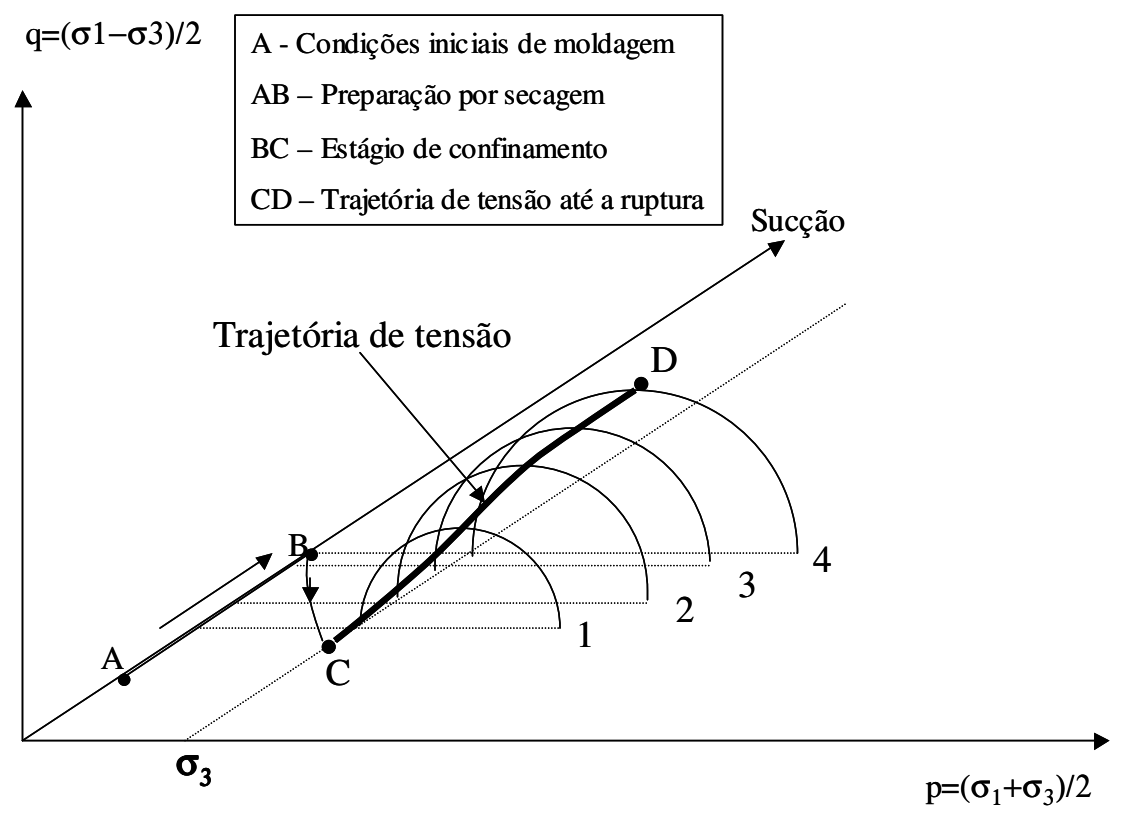

Figura 8.14 - Representação esquemática das etapas seguidas pelos corpos de prova nos ensaios triaxiais não saturados $(\mathrm{CW})$.

Para se obter estes resultados o valor da pressão confinante do ensaio foi aplicada de forma incremental, obtendo-se os respectivos valores de sucção. Em todos os corpos de prova, independentemente do nível de sucção e das condições iniciais de moldagem, ocorre redução da sucção após a etapa de confinamento. Quanto maior a pressão confinante aplicada, maiores foram as reduções apresentadas. As trajetórias seguidas pelos corpos de prova durante o confinamento, são aproximadamente paralelas entre si e tendem a tangenciar o eixo das abscissas. Resultados semelhantes a estes foram obtidos por Kuwajima (2000), utilizando o mesmo tipo de solo desta pesquisa, e por Lins e Sandroni (1994) utilizando um solo residual compactado no ramo seco e adensado isotropicamente com umidade constante.

O tensiômetro utilizado nesta pesquisa mede sucções de até $500 \mathrm{kPa}$. Portanto, após serem submetidos às diferentes trajetórias de umidade, as sucções dos corpos de prova não devem exceder este valor. Este fato associado às reduções da sucção, durante a etapa da aplicação da pressão de confinamento, impossibilita que se realizem ensaios com pressões confinantes e sucções elevadas. 
A linha contínua apresentada nas Figuras 8.15, 8.16 e 8.17, marca o limite onde existe a possibilidade da realização dos ensaios triaxiais $\mathrm{CW}$ não saturados. Desta forma, o intervalo de sucção onde é possível de se obter corpos de prova, após a etapa de preparação, diminui com o aumento da pressão de confinamento. Para se realizar ensaios em corpos de prova cujas condições, após a aplicação da pressão confinante estejam acima destas linhas, deve-se utilizar um tensiômetro com capacidade de medir sucções superiores a $500 \mathrm{kPa}$.

Os procedimentos de preparação e aplicação da pressão confinante foram programados de forma a se obter, para cada valor de pressão de confinamento, corpos de prova com sucção variando dentro de todo o intervalo delimitado pela linha contínua das Figuras 8.15, 8.16 e 8.17.

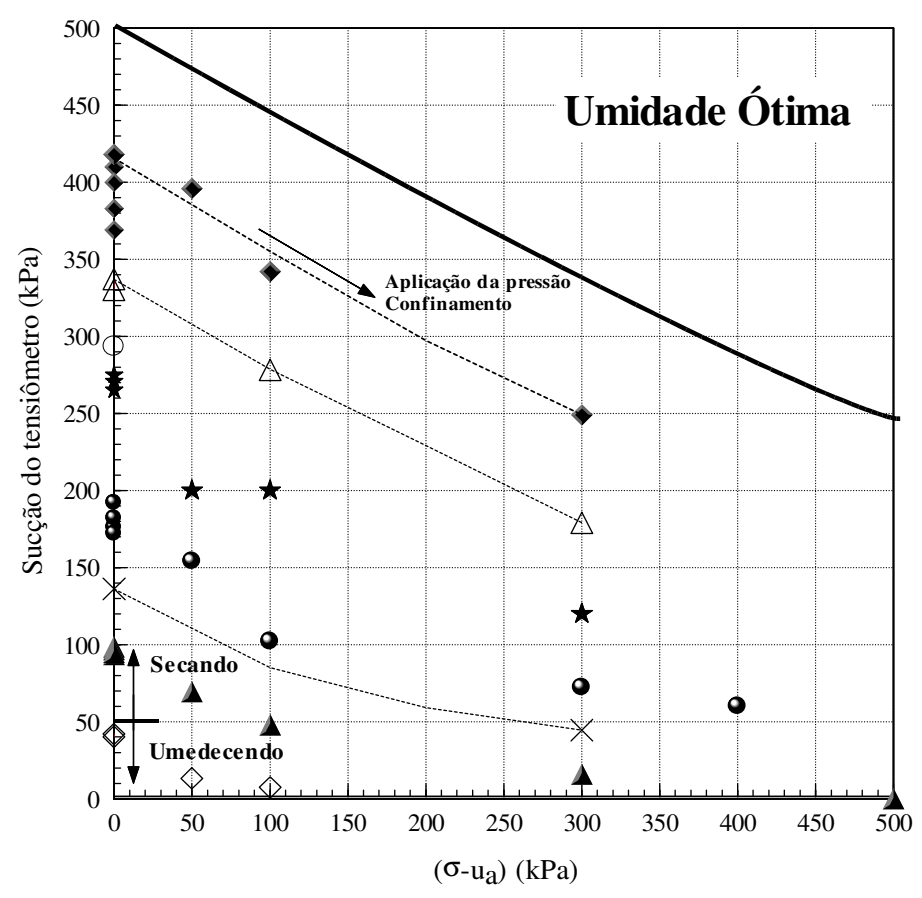

Figura 8.15 - Trajetória da variação da sucção durante a etapa de preparação e aplicação da pressão confinante dos corpos de prova utilizados nos ensaios triaxiais CW não saturados (ponto $\mathrm{O}$ ). 


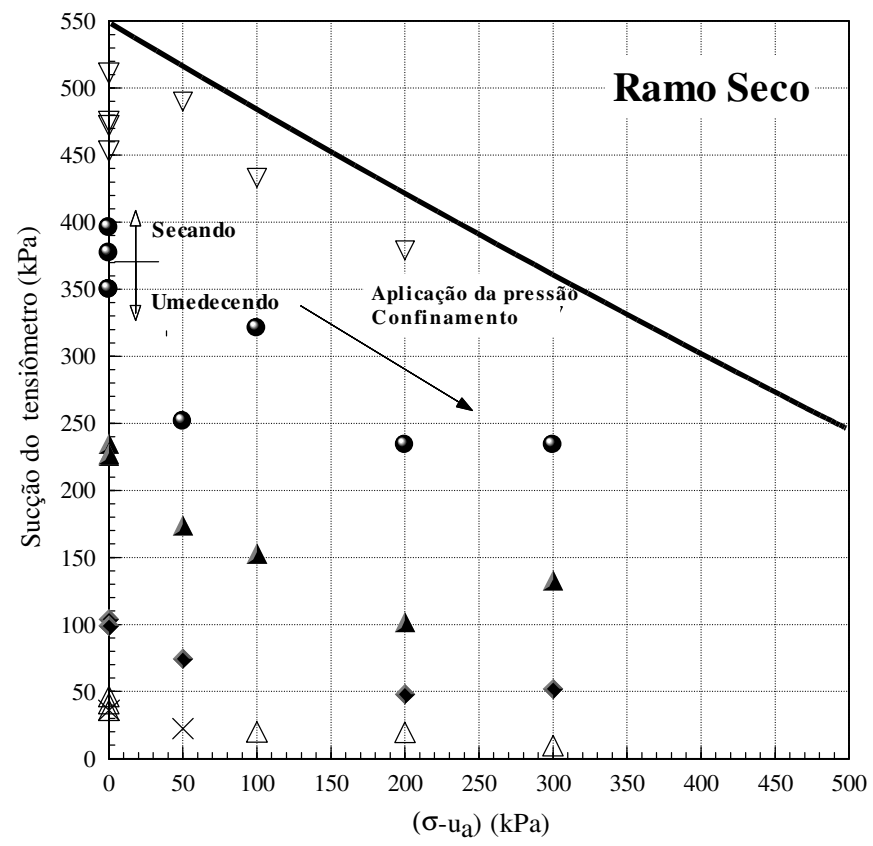

Figura 8.16 - Trajetória da variação da sucção durante a etapa de preparação e aplicação da pressão confinante dos corpos de prova utilizados nos ensaios triaxiais $\mathrm{CW}$ não saturados (ponto $\mathrm{S}$ ).

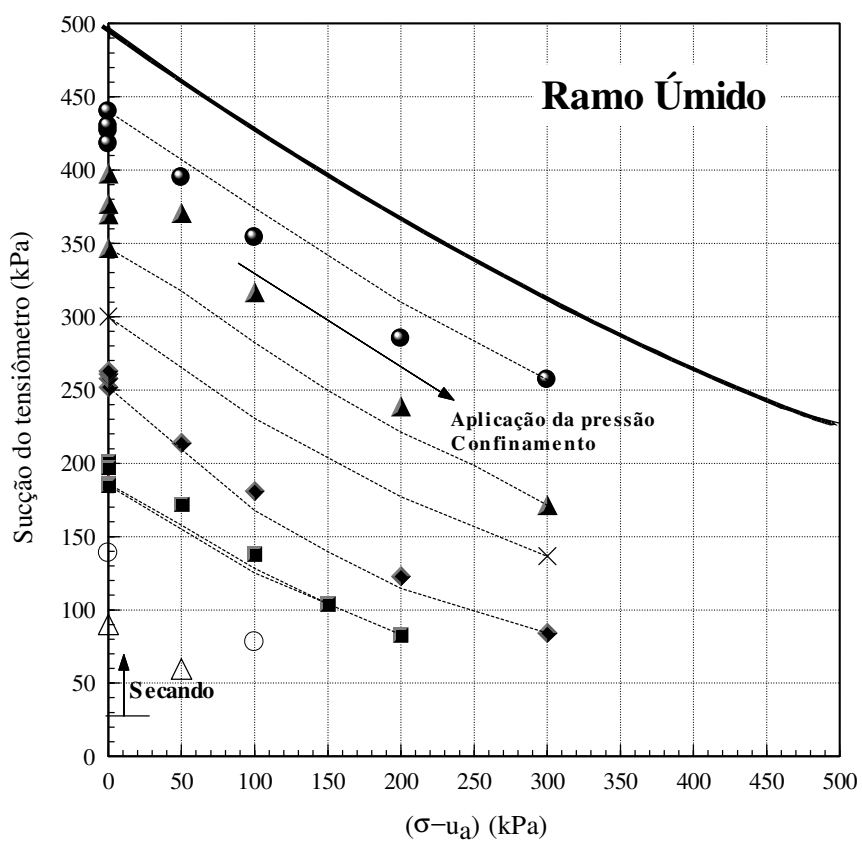

Figura 8.17 - Trajetória da variação da sucção durante a etapa de preparação e aplicação da pressão confinante dos corpos de prova utilizados nos ensaios triaxiais CW não saturados (ponto $\mathrm{U}$ ). 


\subsection{2 - Análise das trajetórias de tensões}

Nas Figuras 8.18, 8.19 e 8.20 estão apresentadas as trajetórias de tensões dos ensaios triaxiais CW não saturados, realizados nos três pontos de estudo, e dos ensaios de compressão simples (item 8.1.2). O início das trajetórias de tensão, localizado sobre o eixo das abscissas, corresponde ao valor da sucção dos corpos de prova após a aplicação da pressão confinante de ensaio. Nestas Figuras constata-se que existe uma tendência destas trajetórias se tornarem mais retilíneas à medida que aumenta a pressão de confinamento, estando este fato mais evidenciado para a moldagem na umidade ótima e no ramo úmido.

Em relação às outras duas condições de moldagem, os corpos de prova moldados no ramo seco apresentam trajetórias de tensão menos inclinadas, o que caracteriza menores variações de sucção durante a fase de cisalhamento. Para uma mesma pressão de confinamento, observa-se nas Figuras 8.18, 8.19 e 8.20 que as trajetórias de se tornam mais retilínea à medida que aumenta do valor da sucção do corpo de prova no início do ensaio.

Observa-se nas Figuras 8.18, 8.19 e 8.20 que com o aumento da pressão de confinamento os resultados dos ensaios estão limitados a um intervalo menor de sucção. Este fato está relacionado à redução do intervalo de sucção onde é possível a obtenção de corpos de prova após a aplicação da pressão confinante, descrita no item anterior. Estes intervalos de sucção estão limitados pelas linhas contínuas apresentadas nestas figuras. 


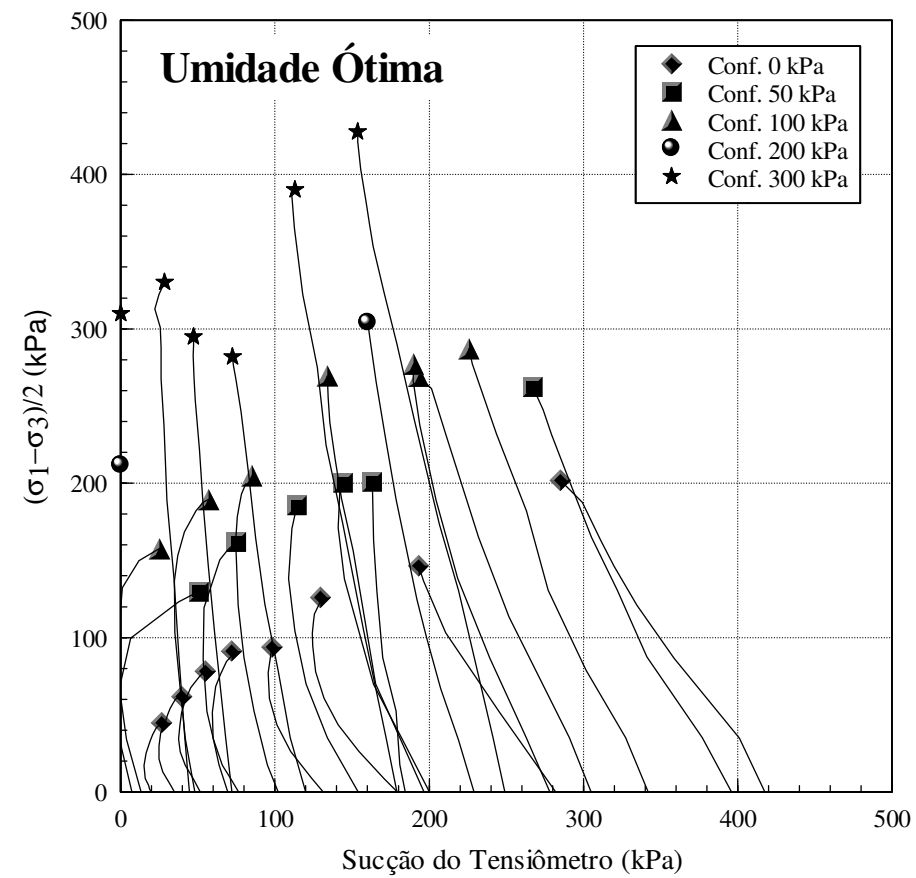

Figura 8.18 - Trajetórias de tensões dos ensaios triaxiais CW não saturados realizados em corpos de prova compactados na umidade ótima (Ponto O).

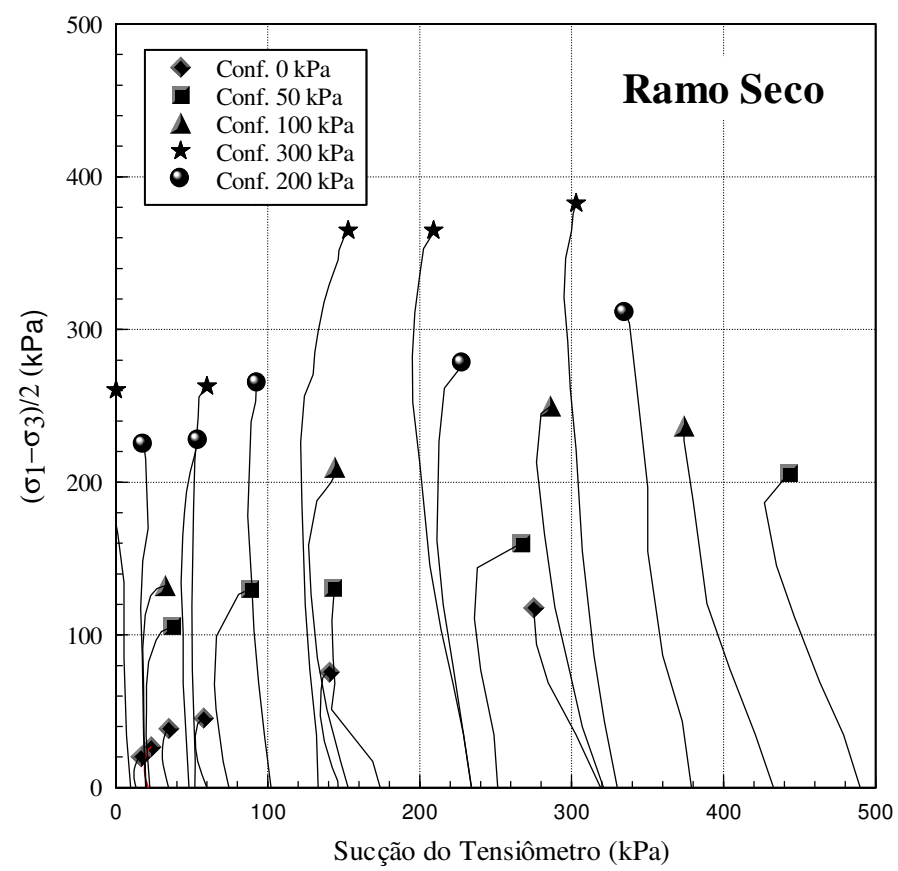

Figura 8.19 - Trajetórias de tensões dos ensaios triaxiais $\mathrm{CW}$ não saturados realizados em corpos de prova compactados no ramo seco (Ponto S). 


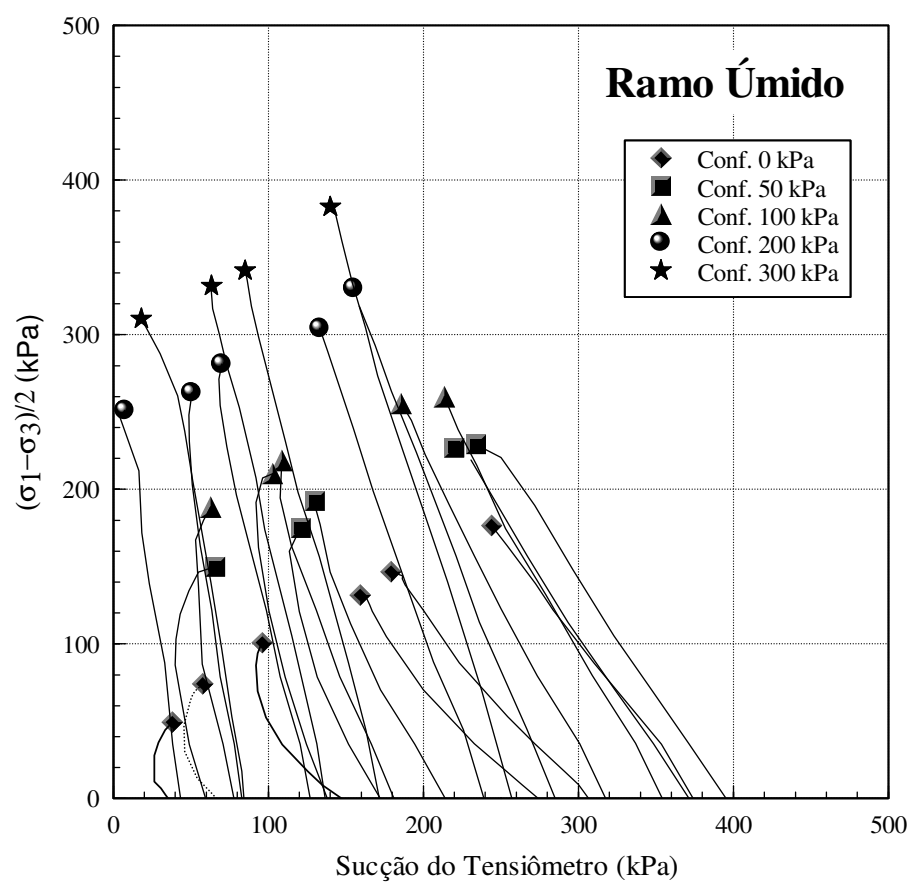

Figura 8.20 - Trajetórias de tensões dos ensaios triaxiais CW não saturados realizados em corpos de prova compactados no ramo úmido (Ponto $\mathrm{U}$ ).

\subsection{3 - Análise das variações de sucção dos corpos de prova durante a etapa de cisalhamento}

Em todos os ensaios triaxiais $\mathrm{CW}$ não saturados foram obtidos os valores da sucção dos corpos de prova após a aplicação da pressão confinante e na ruptura. Estes resultados estão apresentados nas Figuras 8.21, 8.22 e 8.23. Nestas figuras foram utilizados os resultados obtidos dos ensaios realizados com compressão simples e mais três valores de pressão de confinamento, para representarem a tendência das variações das sucções de cada condição de moldagem. Por serem ensaios realizados com umidade constante, para um mesmo teor de umidade tem-se o valor correspondente a sucção após confinamento e na ruptura do corpo de prova.

Para a moldagem na umidade ótima e no ramo úmido, apresentadas nas Figuras 8.21 e 8.23, observa-se que as linhas que definem as condições dos corpos de prova após confinamento se deslocam para a esquerda à medida que aumenta o valor da pressão 
confinante. Este comportamento está relacionado às linhas tracejadas das Figuras 8.15 e 8.17. O formato destas linhas indica que quanto maior o valor da pressão confinante aplicada maior será a redução da sucção do corpo de prova.

Na Figura 8.21 correspondente à umidade ótima, constata-se que nos resultados dos ensaios de compressão simples e submetidos às pressões confinantes de 50 e 100 $\mathrm{kPa}$, os corpos de prova rompem com aumento de sucção para teores de umidade menores que o correspondente as condições de moldagem $(\mathrm{w}=25 \%)$. Para os resultados dos corpos de prova moldados no ramo úmido, os corpos de prova rompem apenas com redução da sucção.

As linhas que definem a sucção da ruptura, para a moldagem na umidade ótima e ramo úmido (Figuras 8.21 e 8.23), também se deslocam para a esquerda com o aumento da pressão confinante. Os deslocamentos das linhas que definem as sucções após confinamento e na ruptura, observadas para estas duas condições de moldagem, fazem com que as tendências de variações da sucção sejam, de forma geral, independentes da pressão confinante aplicada. Para um mesmo valor de pressão confinante tem-se que quanto maior o valor da sucção inicial do corpo de prova, maior será a sua variação de sucção durante o ensaio.

Os resultados obtidos para os corpos de prova moldados no ramo seco apresentam, em relação às outras duas condições de moldagem, um comportamento diferente. As linhas que definem os valores das sucções iniciais e na ruptura apresentam pequenas variações com o aumenta da pressão confinante. Para valores de sucção de até 150 $\mathrm{kPa}$ os corpos de prova rompem praticamente com a mesma sucção, independentemente dos valores das pressões confinantes. A partir deste valor observam-se pequenas reduções das sucções dos corpos de prova no final do ensaio. 

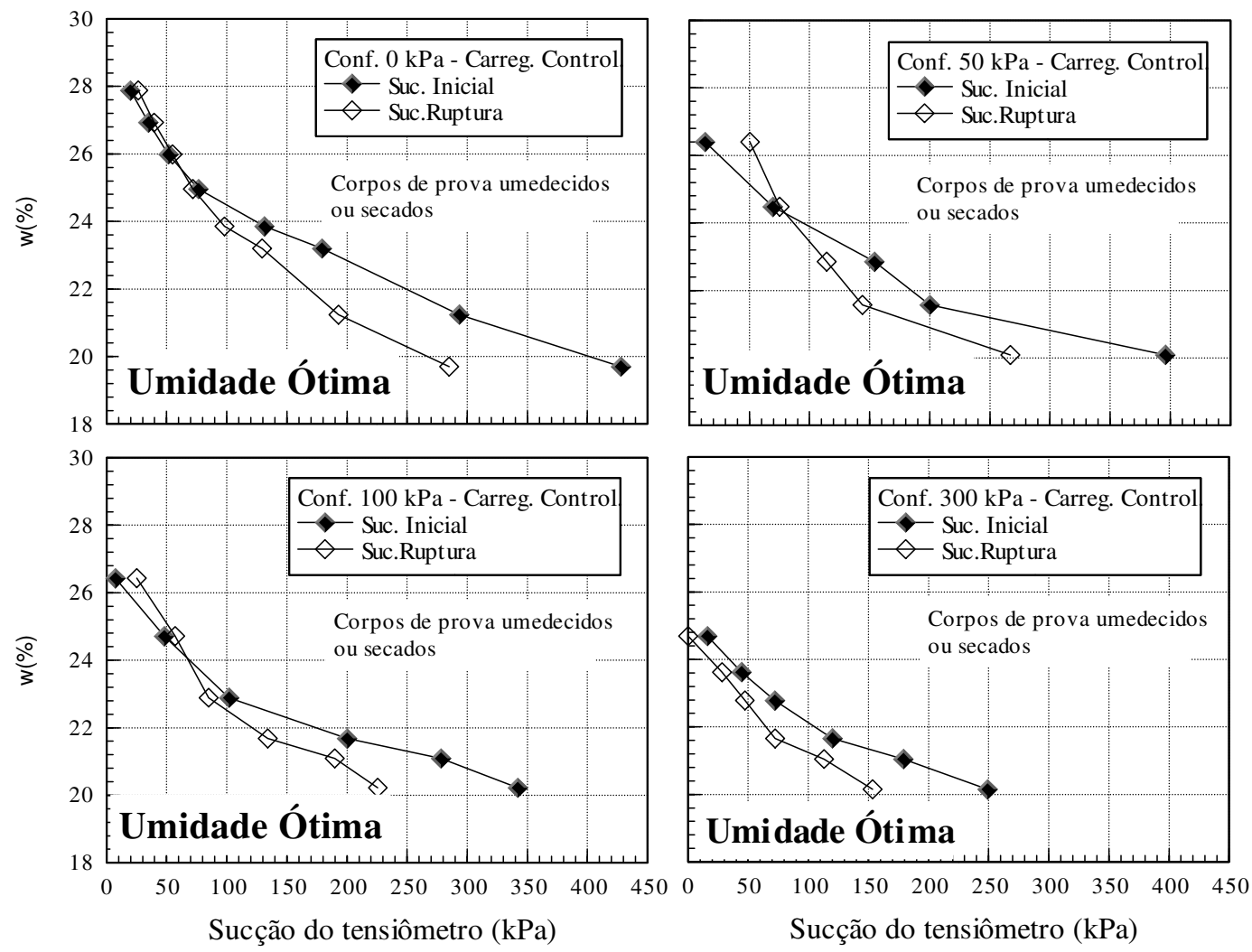

Figura 8.21 - Valores das sucções após confinamento e na ruptura obtidos dos ensaios triaxiais CW não saturados realizados em corpos de prova compactados na umidade ótima. 

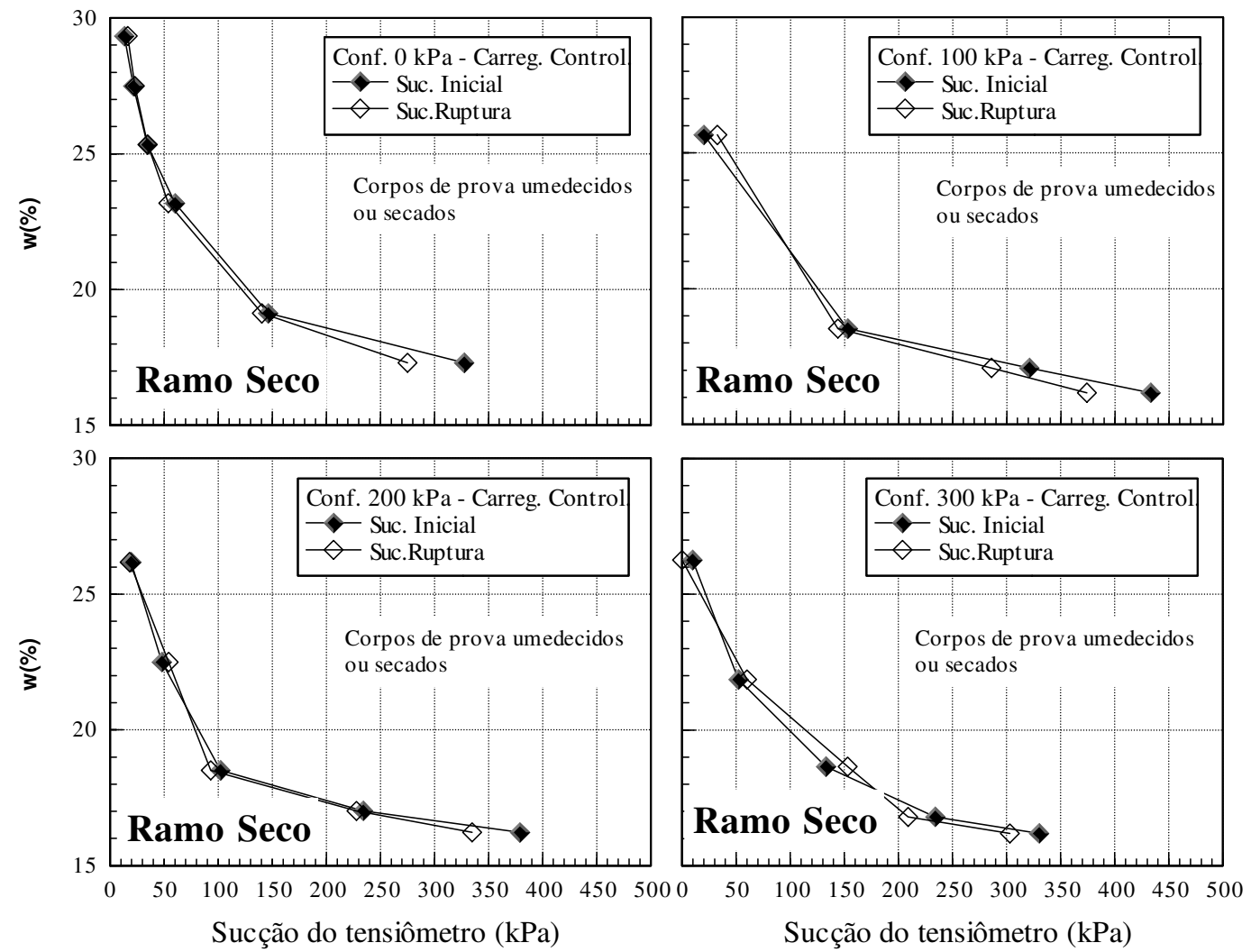

Figura 8.22 - Valores das sucções após confinamento e na ruptura obtidos dos ensaios triaxiais CW não saturados realizados em corpos de prova compactados no ramo seco. 

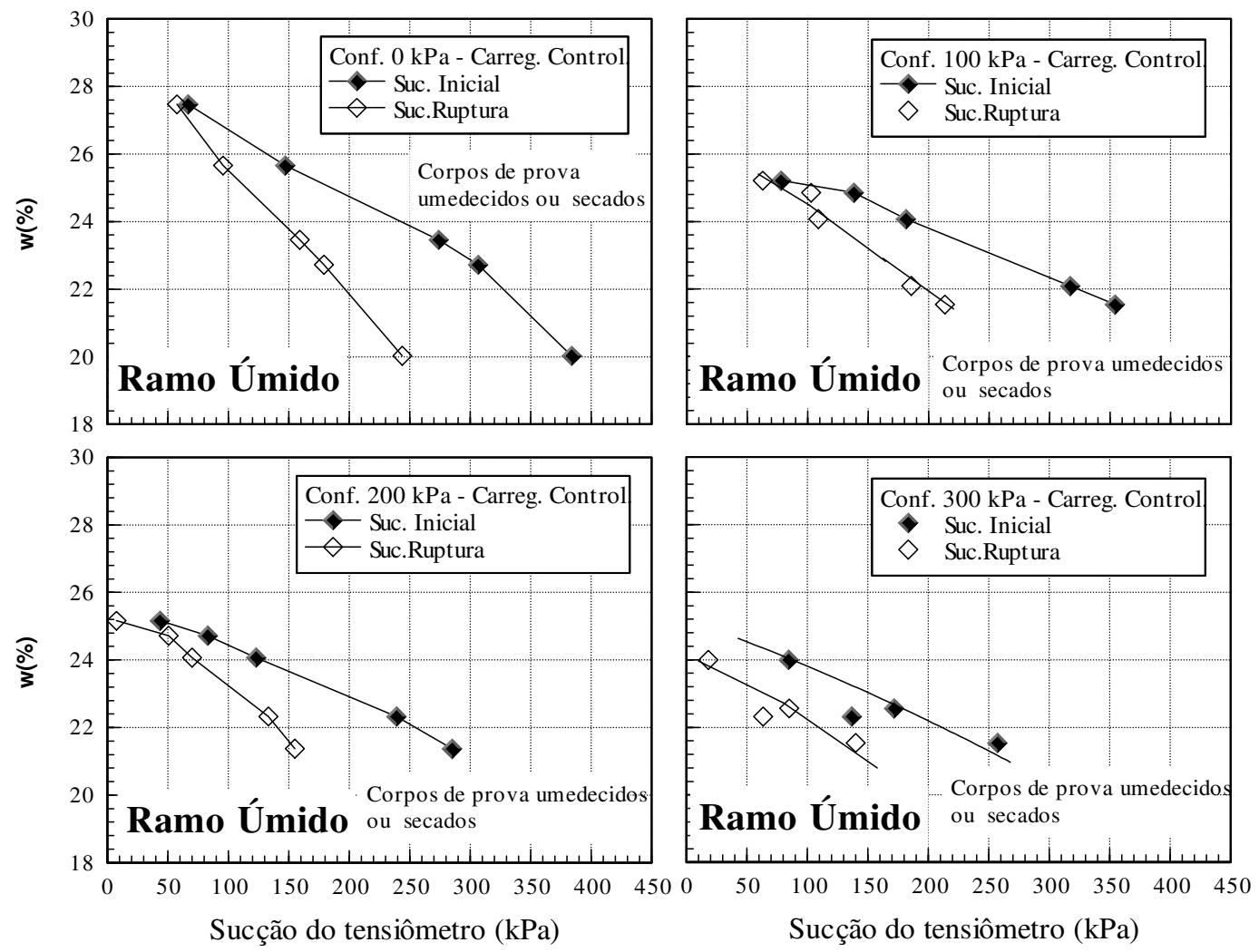

Figura 8.23 - Valores das sucções após confinamento e na ruptura obtidos dos ensaios triaxiais CW não saturados realizados em corpos de prova compactados no ramo úmido. 


\section{3 - Definição dos parâmetros efetivos obtidos dos ensaios triaxiais saturados}

Neste item serão definidos os parâmetros efetivos obtidos dos ensaios triaxiais saturados, cujos resultados foram apresentados no item 6.2. Foram realizados 3 ensaios CAU em cada ponto de estudo e 3 ensaios CD com os corpos de prova moldados nas condições da umidade ótima. A principal diferença entre estes dois tipos de ensaio, além da condição de drenagem, está relacionada aos procedimentos de preparação dos corpos de prova e ao tipo de carregamento utilizado durante a fase de cisalhamento, conforme descrito no item 4.11.2.

Nas Figuras 8.24, 8.26 a 8.28 estão apresentados, em termos de tensões efetivas, os círculos de Mohr dos ensaios CAU realizados em cada condição de moldagem. As envoltórias de ruptura foram obtidas por regressão linear, utilizando os pontos de máxima ordenada de cada círculo. Os valores do ângulo de atrito e da coesão efetiva, indicados nas legendas destas figuras, variaram de $30^{\circ}$ a $34^{\circ}$ e de 5 a $12 \mathrm{kPa}$. As trajetórias de tensões e as envoltórias de ruptura destes ensaios estão apresentas nas Figuras $8.25,8.27$ e 8.29 . Partindo da origem destes gráficos, inicia-se a etapa do adensamento anisotrópico que seguem até o ponto correspondente às pressões confinantes efetivas de cada ensaio (Pressão Conf. 30, 80 e $150 \mathrm{kPa}$ ).

Os resultados dos ensaios triaxiais CD, realizados com carregamento controlado, estão apresentados nas Figuras 8.30 e 8.31. Ao se aplicar uma regressão linear aos pontos de máxima ordenada de cada círculo de Mohr, constata-se uma certa dispersão nestes resultados. Desta forma, para este tipo de ajuste admitiu-se que o valor do intercepto de coesão é igual ao obtido no ensaio CAU para as condições de moldagem na umidade ótima. Com esta hipótese obteve-se uma coesão de $12 \mathrm{kPa}$ e ângulo de atrito igual a $30^{\circ}$. O coeficiente de correlação deste ajuste $\left(\mathrm{r}^{2}\right)$ é igual 0.99 . Os valores dos parâmetros efetivos obtidos nos ensaios CAU e CD estão indicados na Tabela 8.1 . 


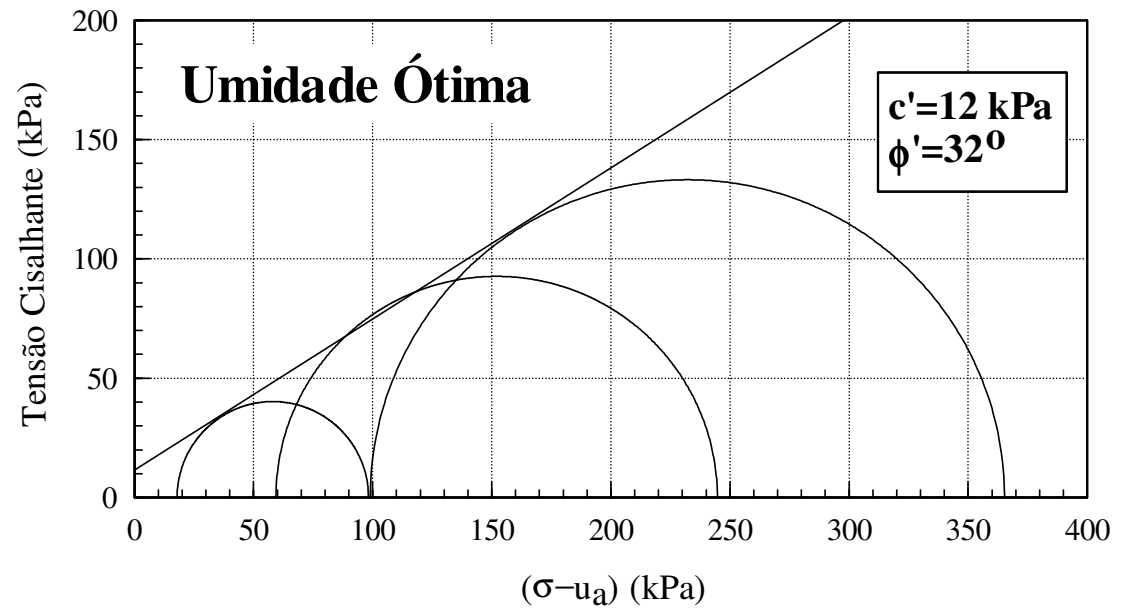

Figura 8.24 - Resultado dos ensaios triaxiais CAU realizados com tensão controlada utilizando corpos de prova compactados na umidade ótima (Ponto O).

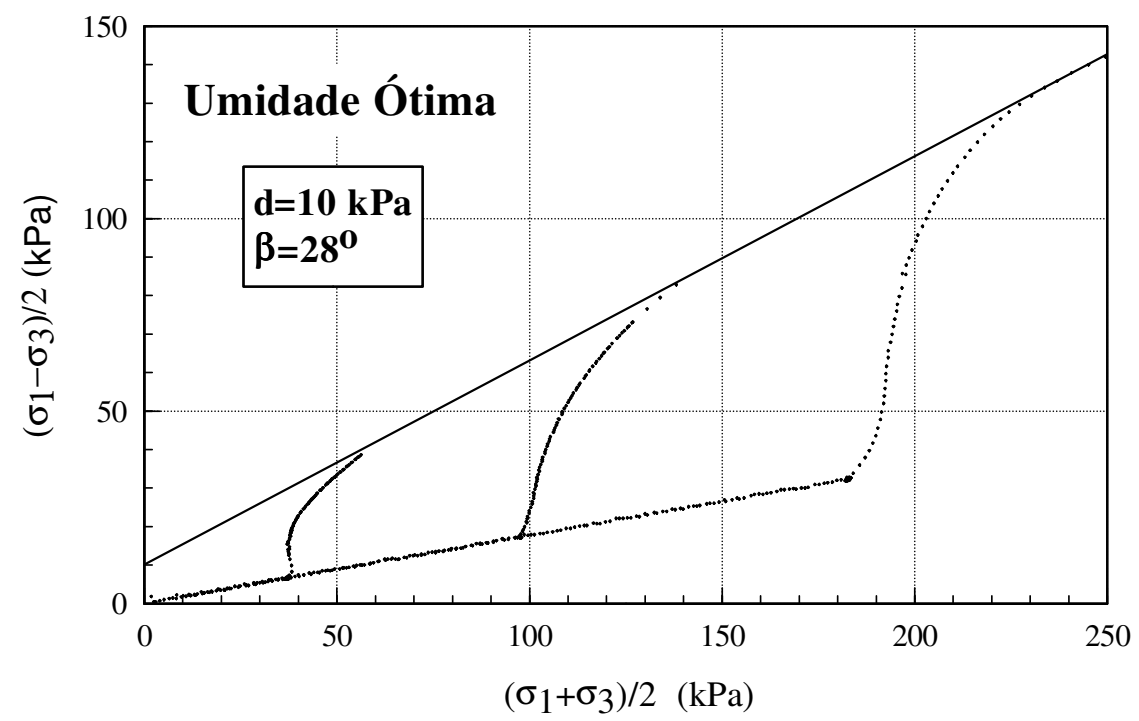

Figura 8.25 - Trajetórias de tensão dos ensaios triaxiais CAU realizados com tensão controlada utilizando corpos de prova compactados na umidade ótima (ponto $\mathrm{O}$ ). 


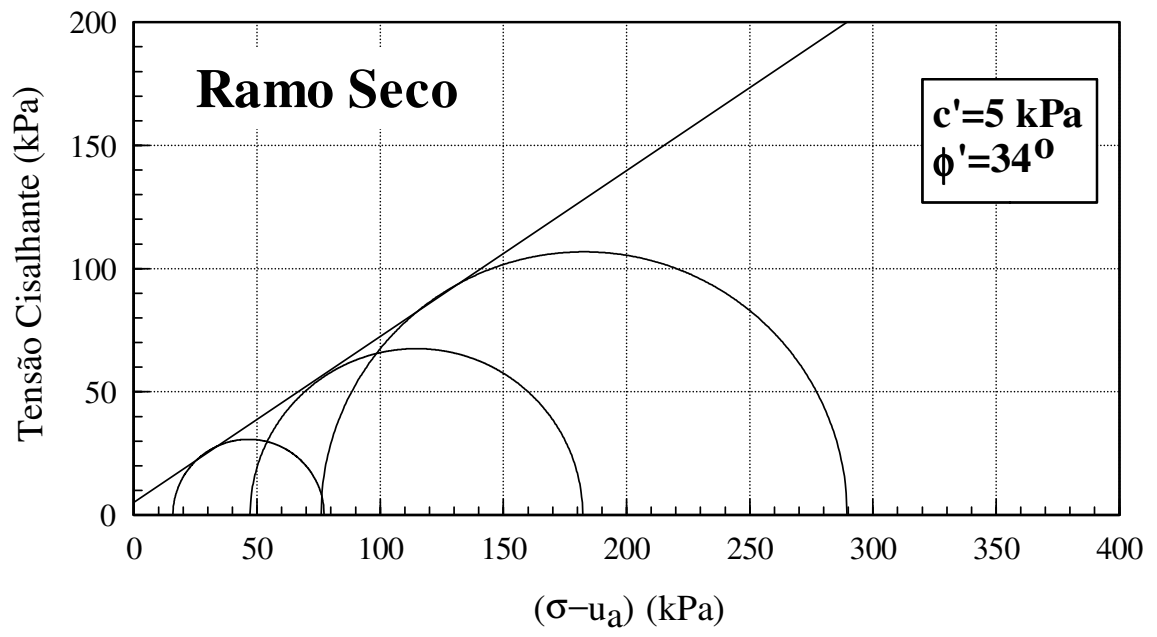

Figura 8.26 - Resultado dos ensaios triaxiais CAU realizados com tensão controlada utilizando corpos de prova compactados no ramo seco (ponto $\mathrm{S}$ ).

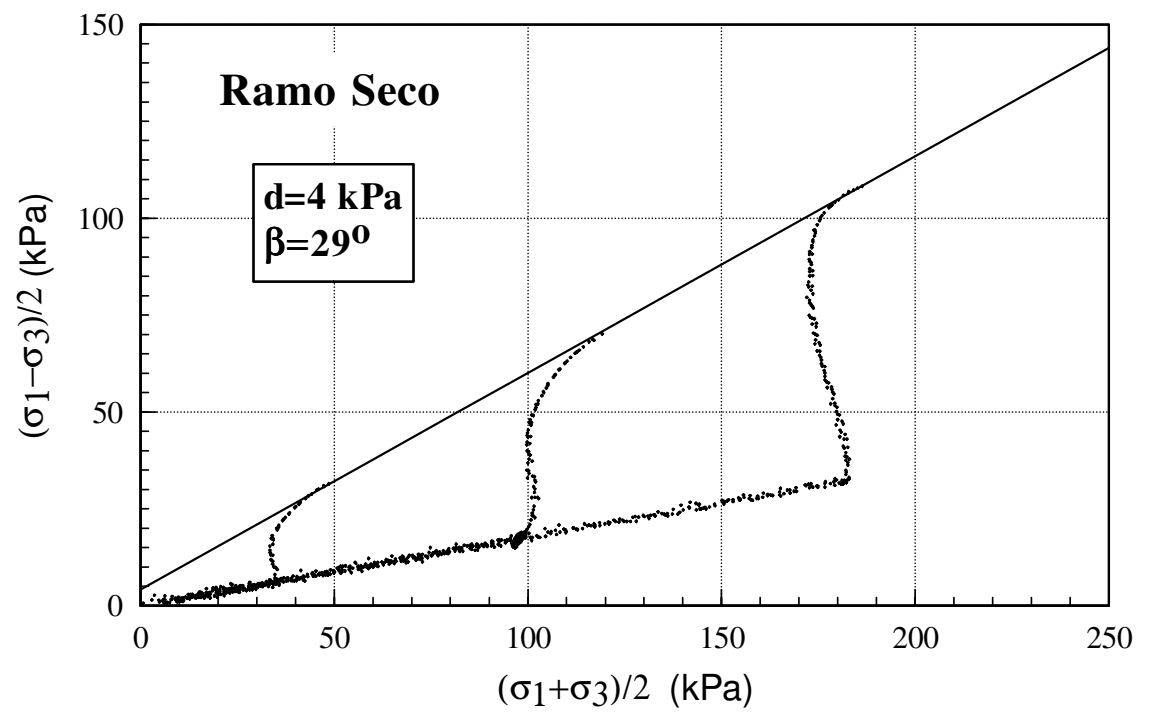

Figura 8.27 - Trajetórias de tensão dos ensaios triaxiais CAU realizados com tensão controlada utilizando corpos de prova compactados no ramo seco (ponto $\mathrm{S}$ ). 


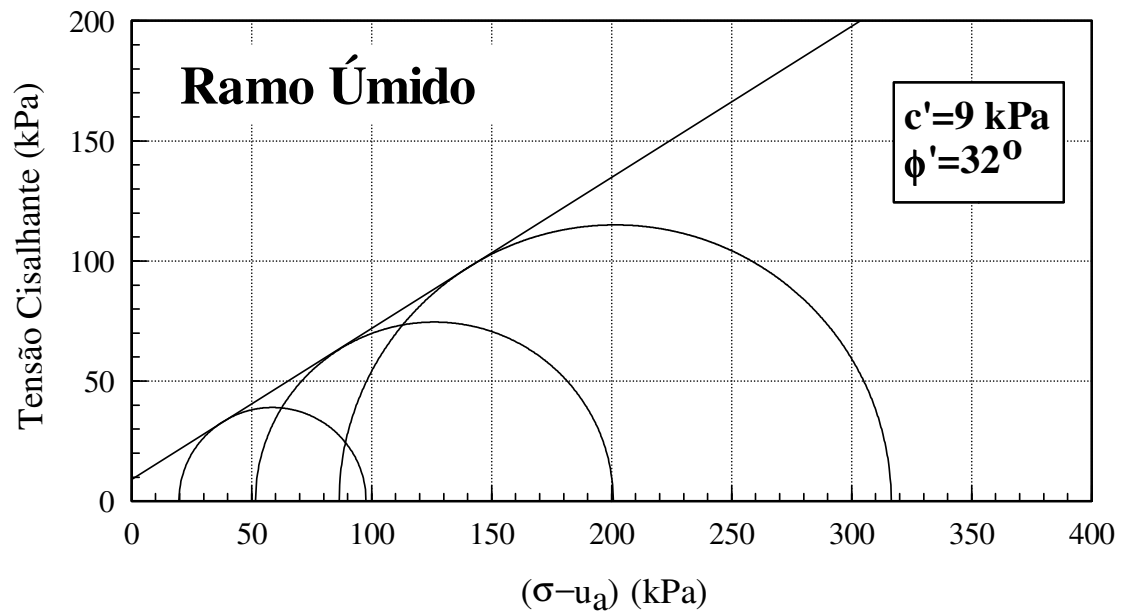

Figura 8.28 - Resultado dos ensaios triaxiais CAU realizados com tensão controlada utilizando corpos de prova compactados no ramo úmido (ponto $\mathrm{U}$ ).

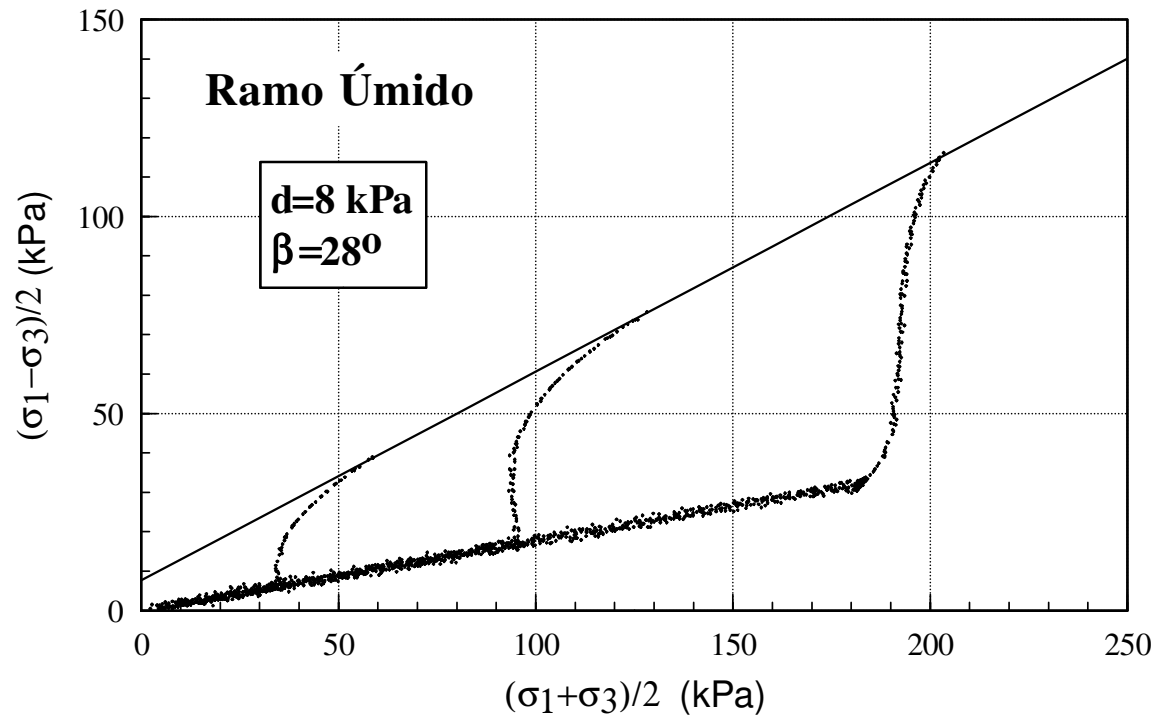

Figura 8.29 - Trajetórias de tensões dos ensaios triaxiais CAU realizados com tensão controlada utilizando corpos de prova compactados no ramo úmido (ponto U). 


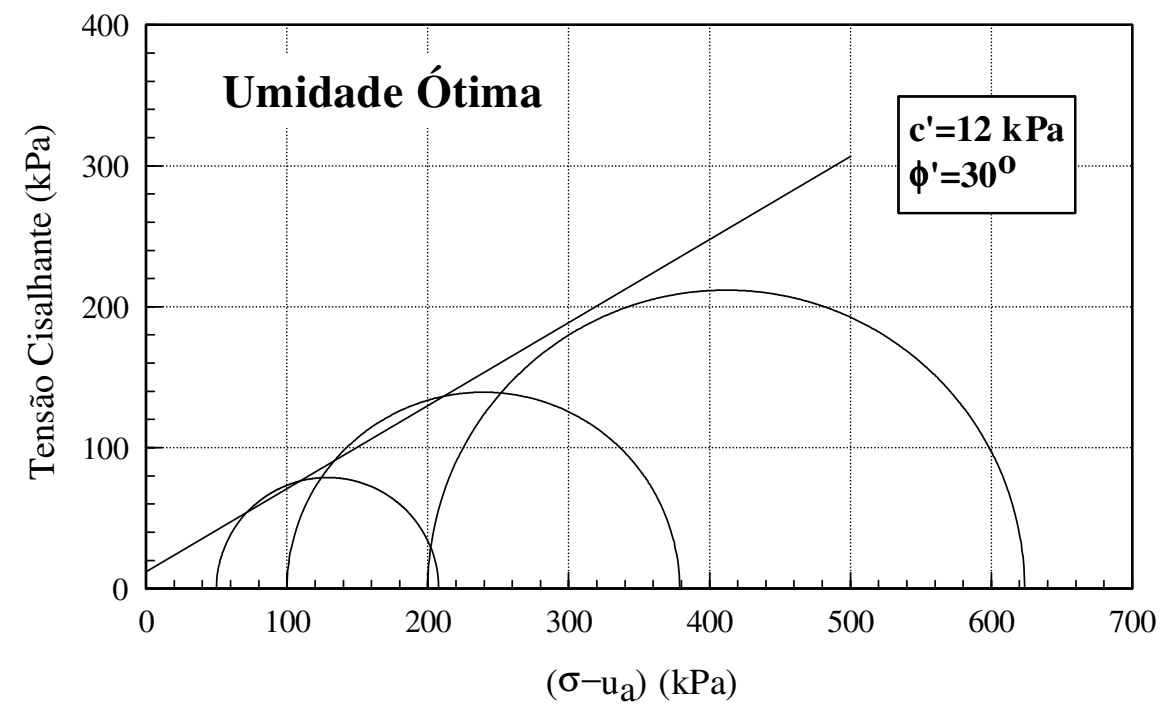

Figura 8.30 - Resultado dos ensaios triaxiais CD realizados com carregamento controlado utilizando corpos de prova compactados na umidade ótima (ponto $\mathrm{O}$ ).

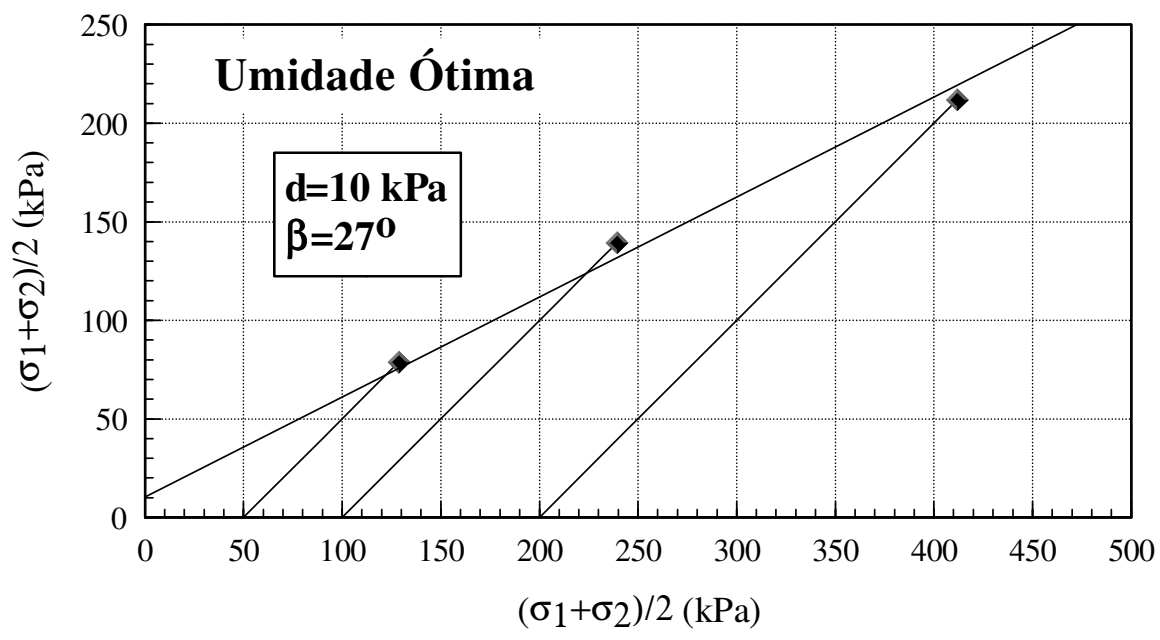

Figura 8.31 - Trajetórias de tensões dos ensaios triaxiais CD realizados com carregamento controlado utilizando corpos de prova compactados na umidade ótima (ponto O).

Tabela 8.2- Parâmetros efetivos obtidos dos ensaios triaxiais saturados.

\begin{tabular}{|c|c|c|c|c|}
\hline Tipo de Ensaio & Trajetória & Condição de Moldagem & $\mathrm{d}(\mathrm{kPa})$ & $\beta$ \\
\hline CAU & 1 & Umidade Ótma & 10 & $28^{\circ}$ \\
\hline CD & 2 & Umidade Ótima & 10 & $27^{\circ}$ \\
\hline CAU & 1 & Ramo Seco & 4 & $29^{\circ}$ \\
\hline CAU & 1 & Ramo Úmido & 8 & $28^{\circ}$ \\
\hline
\end{tabular}

Trajetória 1 - saturação sem expansão do C.P., trajetória 2- saturação com expansão livre. 
Os resultados dos ensaios CAU indicam que as diferentes condições de moldagem influenciam apenas nos valores de coesão, com os ângulos de atrito permanecendo praticamente constantes. Pinto (1971) também observou este tipo de comportamento, concluindo que a coesão depende praticamente da densidade de compactação.

Na Tabela 8.2 constata-se uma pequena diferença no valor do ângulo de atrito dos ensaios triaxiais CD e CAU, realizados para as condições de moldagem na umidade. O mesmo valor de coesão é função do critério de ajuste adotado para os ensaios CD. A justificativa deste critério deve-se a dispersão dos resultados ao se aplicar um ajuste linear para estes ensaios. Caso o mesmo não fosse adotado o valor da coesão seria de $25 \mathrm{kPa}$, superior ao obtido no ensaio CAU. No entanto os corpos de prova utilizados no ensaio $\mathrm{CD}$, saturados com expansão livre, apresentam maiores índices de vazios em relação aos que foram utilizados nos ensaios CAU, saturados por contrapressão. Com estes diferentes procedimentos de saturação dos corpos de prova, era de se esperar que os ensaios CD definissem valor de intercepto de coesão igual ou menor que o obtido para o ensaio CAU. A diferença entre o ângulo de atrito obtido nestes ensaios, provavelmente esteja relacionada às diferentes trajetórias de umidade utilizadas na preparação dos corpos de prova.

\section{4 - Obtenção das equações de ajuste para a relação definida entre q e a sucção do corpo de prova na ruptura}

Para a definição das superfícies de ruptura de cada condição de moldagem, foram obtidas inicialmente as equações de ajuste dos ensaios realizados com uma mesma pressão de confinamento (ver Figura 8.7b). Estes ajustes podem ser obtidos por diferentes tipos de equações, tais como, as exponenciais, lineares, hiperbólicas, logarítmicas, polinomiais e de potência. No entanto, nenhuma destas equações se ajusta satisfatoriamente para todo o conjunto de resultados experimentais obtidos nesta pesquisa. Desta forma, optou-se por se obter a envoltória de ruptura, correspondente a cada pressão de confinamento, aplicando-se uma equação linear

para o trecho inicial e um ajuste de potência $\left(\mathrm{y}=\mathrm{ax}{ }^{\mathrm{b}}\right)$ para o trecho final, correspondente a sucções de até $300 \mathrm{kPa}$. 
Na Figura 8.32 estão os ajustes obtidos para os resultados dos ensaios realizados em corpos de prova moldados na umidade ótima. Os valores experimentais, situados sobre o eixo das ordenadas, correspondem aos ensaios triaxiais CD saturados realizados com pressões confinantes iguais a 50,100 e $200 \mathrm{kPa}$. O resultado do ensaio realizado com pressão confinante de $300 \mathrm{kPa}$, localizado sobre este eixo, esta relacionado a um corpo de prova (CDO6) que atingiu a saturação durante a fase de cisalhamento.

De todos os ensaios realizados na umidade ótima, com exceção dos ensaios CD saturados, apenas cinco corpos de prova foram umedecidos durante os procedimentos de preparação. Os símbolos vazados (Figura 8.32) representam os corpos de prova que em sua preparação foram umedecidos e os símbolos cheios representam os que foram secados a partir das condições iniciais de moldagem. A intenção inicial era a de se analisar separadamente cada trajetória de umidade imposta aos corpos de prova. No entanto, na Figura 8.32 observa-se que existe uma continuidade da envoltória de ruptura, independentemente se os corpos de prova foram umedecidos ou secados.

De acordo com os resultados apresentados nas Figuras 8.8 a 8.13, a relação entre q e a sucção dos corpos de prova ensaiados com compressão simples, independe da trajetória de umidade imposta na etapa de preparação. Desta forma, a relação entre q e sucção, definida para os corpos de prova submetidos a secagem ou umedecimento, é semelhante à obtida para os corpos de prova preparados por uma única trajetória de umidade (saturado e secados). Este fato justifica a análise conjunta dos resultados dos corpos de prova preparados por secagem ou umedecimento, apresentados na Figura 8.32.

Para as condições de moldagem na umidade ótima, representada na Figura 8.32, o trecho retilíneo do ajuste dos ensaios de compressão simples se prolongou até à sucção de $56 \mathrm{kPa}$. Os resultados dos ensaios triaxiais CD saturados,. que estão sobre o eixo das ordenadas desta figura, foram utilizados como origem dos ajustes correspondentes às pressões confinantes de 50 e $100 \mathrm{kPa}$. O ajuste de potência é 
aplicado a partir do momento em que o ajuste linear passa a se afastar dos resultados experimentais. Em função dos ensaios realizados com pressão confinante de $300 \mathrm{kPa}$ apresentarem apenas dois corpos de prova para se aplicar o ajuste de potência, para este trecho foi feita a translação do ajuste obtido para os ensaios de compressão simples.

Na Figura 8.32, as setas localizadas sobre os ajustes obtidos, indicam o máximo valor da sucção correspondente ao trecho linear. A partir destes valores, que variaram entre 56 e $76 \mathrm{kPa}$, a sucção perde a sua efetividade em fornecer resistência aos corpos de prova e as envoltórias passam a apresentar uma tendência não linear. Observando os resultados das curvas de retenção definidas para diferentes pressões confinantes, apresentadas na Figura 5.38, as sucções indicadas pelas setas estão relacionadas ao início da entrada de ar e não a entrada de ar generalizada. O início da entrada de ar corresponde ao valor de sucção onde a curva de retenção começa a se afastar da reta horizontal traçada sobre a mesma (ver Figura 5.38). A entrada de ar generalizada corresponde à sucção onde uma pequena variação de sucção implica em uma considerável variação no grau de saturação. Marinho e Chandler (1994) apresentam graficamente a diferença entre estes valores de sucção de entrada de ar.

Os ajustes obtidos para os resultados dos corpos de prova moldados na umidade ótima (Figura 8.32), são praticamente paralelos entre si. Este fato indica que o valor do ângulo de atrito determinado no ensaio $\mathrm{CD}$, permanece constante para todo o intervalo de sucção. Um bom ajuste poderia ser obtido ao se transladar a envoltória de ruptura obtida do ajuste aos ensaios de compressão simples, para os resultados dos ensaios submetidos às diferentes pressões confinantes. As equações dos ajustes obtidos para as condições de moldagem na umidade ótima estão apresentadas na Tabela 8.3. Nesta tabela estão indicados para cada envoltória, a pressão confinante de ensaio, os intervalos de sucção de cada ajuste, as equações obtidas e os respectivos coeficientes de correlação $\left(\mathrm{r}^{2}\right)$. 


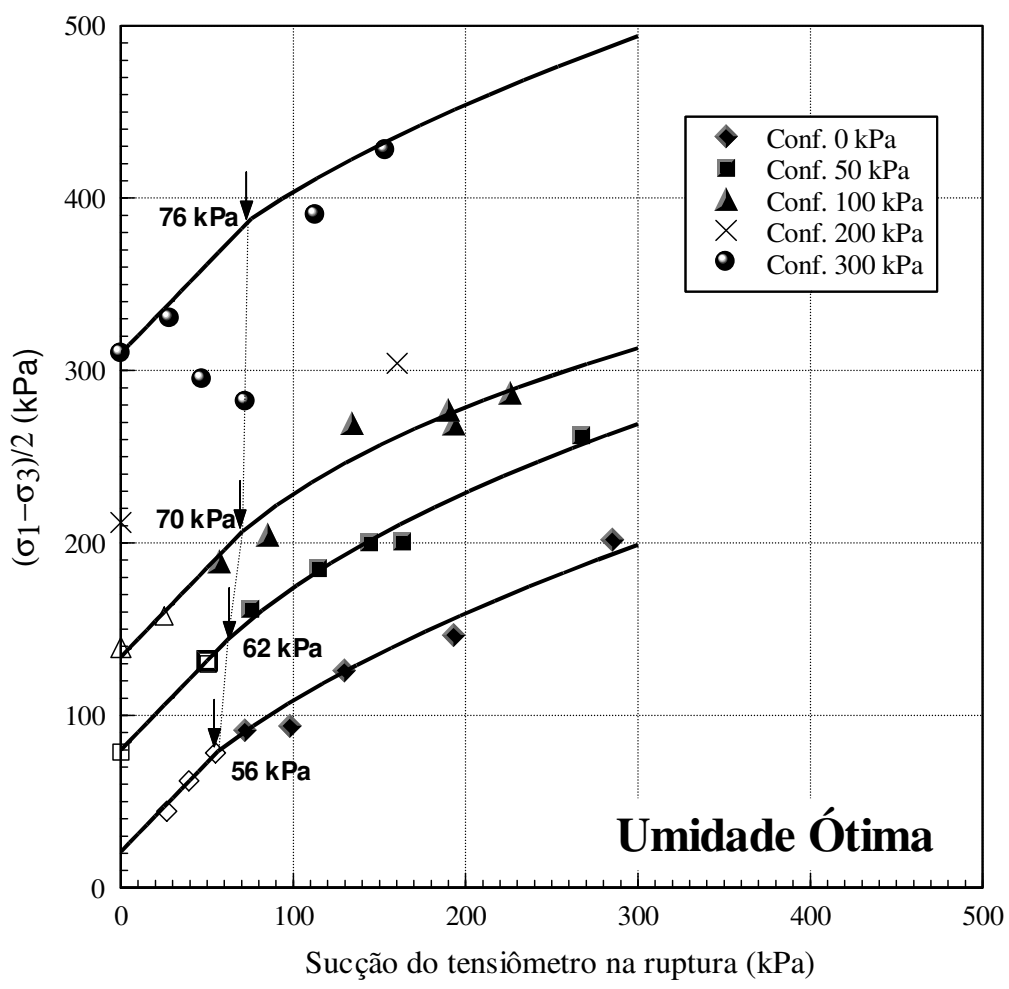

Figura 8.32 - Ajuste obtidos para os ensaios triaxiais saturados e não saturados realizados em corpos de prova compactados na umidade ótima (ponto $\mathrm{O}$ ).

Tabela 8.3 - Equações dos ajustes obtidos para os resultados dos ensaios triaxiais CW não saturados realizados em corpos de prova moldados na umidade ótima.

\begin{tabular}{|c|c|c|c|c|c|c|}
\hline \multirow{2}{*}{$\begin{array}{c}\text { Tens. Conf. } \\
(\mathrm{kPa})\end{array}$} & \multicolumn{3}{|c|}{$1^{\circ}$ trecho } & \multicolumn{3}{c|}{$2^{\circ}$ trecho } \\
\cline { 2 - 7 } & $\begin{array}{c}\text { Sucção } \\
\mathrm{kPa})\end{array}$ & $\begin{array}{c}\text { Equação } \\
(\text { Reta })\end{array}$ & $\begin{array}{c}\mathrm{r}^{2} \\
(\text { Reta) }\end{array}$ & $\begin{array}{c}\text { Sucção } \\
(\mathrm{kPa})\end{array}$ & $\begin{array}{c}\text { Equação } \\
\text { (Potência) }\end{array}$ & $\begin{array}{c}\mathrm{r}^{2} \\
\text { (Potência) }\end{array}$ \\
\hline 0 & $0-56.4$ & $\mathrm{q}=21+1.03 \Psi_{\mathrm{m}}$ & 0.99 & $>56.4$ & $\mathrm{q}=8.5786 \Psi_{\mathrm{m}}{ }^{0.5512}$ & 0.97 \\
\hline 50 & $0-62$ & $\mathrm{q}=80+1.03 \Psi_{\mathrm{m}}$ & 1 & $>62$ & $\mathrm{q}=28.004 \Psi_{\mathrm{m}}{ }^{0.3967}$ & 0.97 \\
\hline 100 & $0-70.5$ & $\mathrm{q}=134+1.03 \Psi_{\mathrm{m}}$ & 1 & $>70.5$ & $\mathrm{q}=61.103 \Psi_{\mathrm{m}}{ }^{0.2864}$ & 0.84 \\
\hline 300 & $0-75.8$ & $\mathrm{q}=310+1.03 \Psi_{\mathrm{m}}$ & --- & $>75.8$ & $\mathrm{q}=295+8.5786 \Psi_{\mathrm{m}}{ }^{0.5512}$ & --- \\
\hline
\end{tabular}

$\psi_{m}$ - valor da sucção matricial na ruptura, $r^{2}$ - Quadrado do coeficiente de correlação 
Na Figura 8.33 estão os resultados experimentais e os ajustes obtidos para os ensaios realizados em corpos de prova moldados no ramo seco. Os símbolos vazados correspondem aos corpos de prova preparados por umedecimento a partir das condições iniciais de moldagem. De forma semelhante as resultados da Figura 8.32, não se observa em função das trajetórias de umidade impostas na preparação dos corpos de prova, tendência a apresentarem envoltórias de ruptura diferentes, sendo assim os mesmos são analisados conjuntamente.

Para os ensaios de compressão simples o trecho retilíneo se prolonga até a sucção de $14 \mathrm{kPa}$, correspondendo ao primeiro ponto experimental. Para os valores de sucção superiores a este, foi aplicado um ajuste de potência. Em função da pequena quantidade de resultados para esta condição de moldagem e da semelhança das relações definidas entre os valores de q e a sucção na ruptura, optou-se por se transladar para as outras pressões confinantes, o ajuste encontrado para os ensaios de compressão simples. Estas equações estão apresentadas na Tabela 8.4. Observa-se nesta tabela que o procedimento de se transladar a equação de ajuste obtida para o ensaio de compressão simples, mostrou-se satisfatório em função dos coeficientes de correlação encontrados. Devido à inexistência de resultados experimentais os valores do coeficiente de correlação não foram determinados para o ajuste linear.

Os resultados dos ensaios triaxiais CW não saturados e os ajustes obtidos para as condições de moldagem no ramo úmido estão apresentados na Figura 8.34. Como os ensaios foram realizados com sucção inicial superior à de moldagem, todos os corpos de prova foram preparados por secagem. Os ajustes para estes resultados foram obtidos, de forma semelhante aos resultados dos ensaios no ramo seco, pela translação do ajuste determinado para os ensaios de compressão simples. O trecho inicial do ajuste linear se prolonga até o valor da sucção de $65 \mathrm{kPa}$. Para os outros resultados, com sucção na ruptura superior a este valor, foi aplicado um ajuste de potência. Na Tabela 8.5 estão apresentadas as equações que representam os resultados dos corpos de prova moldados no ramo úmido. Pelos coeficientes de correlação obtidos, o procedimento de se transladar o ajuste dos ensaios de compressão simples se mostrou satisfatório. 


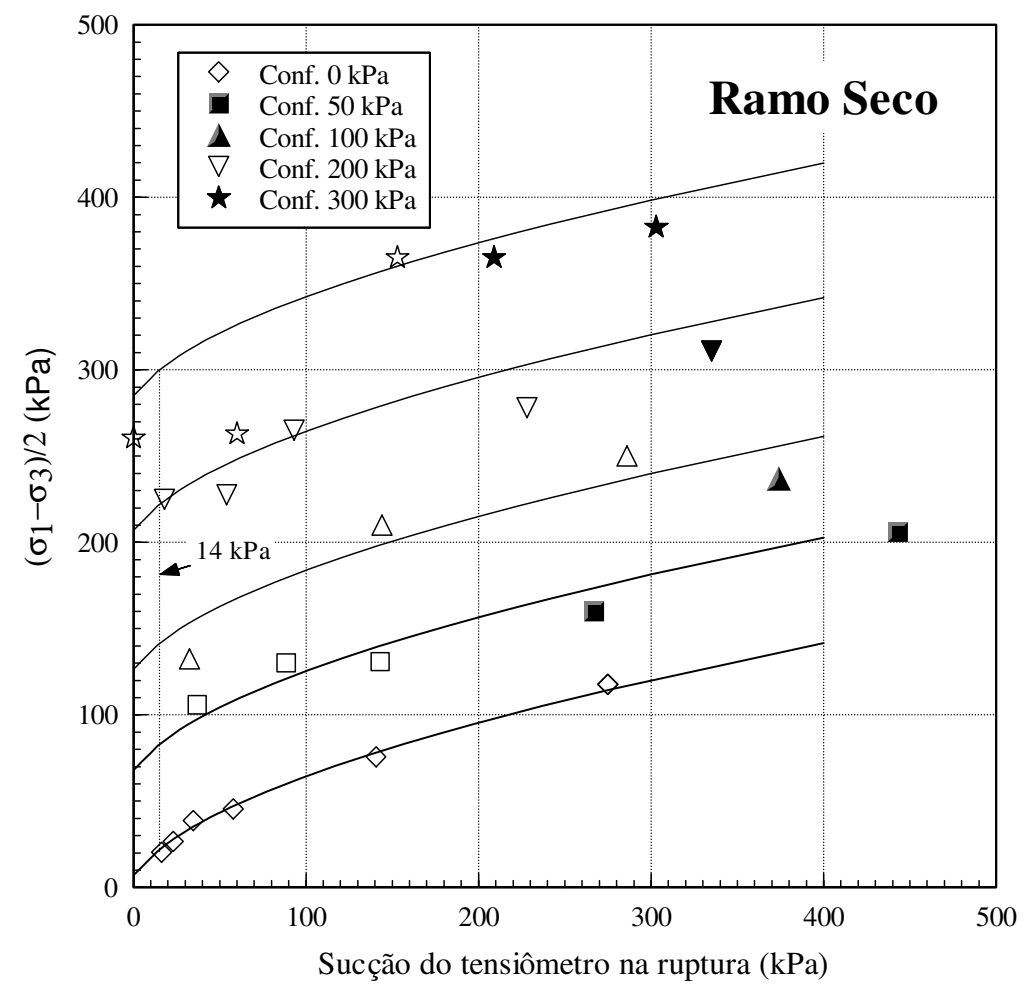

Figura 8.33 - Ajuste obtidos para os ensaios triaxiais não saturados realizados em corpos de prova compactados no ramo seco (ponto $\mathrm{S}$ ).

Tabela 8.4 - Equações dos ajustes obtidos para resultados dos ensaios triaxiais CW não saturados realizados em corpos de prova moldados no ramo seco.

\begin{tabular}{|c|c|c|c|c|c|}
\hline \multirow{2}{*}{$\begin{array}{c}\text { Tens. Conf. } \\
(\mathrm{kPa})\end{array}$} & \multicolumn{2}{|c|}{$1^{\circ}$ trecho } & \multicolumn{3}{|c|}{$2^{\circ}$ trecho } \\
\hline & $\begin{array}{c}\text { Sucção } \\
(\mathrm{kPa})\end{array}$ & $\begin{array}{c}\text { Equação } \\
\text { (Reta) }\end{array}$ & $\begin{array}{c}\text { Sucção } \\
(\mathrm{kPa})\end{array}$ & $\begin{array}{c}\text { Equação } \\
\text { (Potência) }\end{array}$ & $\begin{array}{c}\mathrm{r}^{2} \\
\text { (Potência) }\end{array}$ \\
\hline 0 & $0-14$ & $\mathrm{q}=7+\Psi_{\mathrm{m}}$ & $>14$ & $\mathrm{q}=4.6679 \Psi_{\mathrm{m}}^{0.5698}$ & 0.99 \\
\hline 50 & $0-14$ & $\mathrm{q}=68+\Psi_{\mathrm{m}}$ & $>14$ & $\mathrm{q}=61+4.6679 \Psi_{\mathrm{m}}^{0.5698}$ & 0.96 \\
\hline 100 & $0-14$ & $\mathrm{q}=126.5+\Psi_{\mathrm{m}}$ & $>14$ & $\mathrm{q}=119.5+4.6679 \Psi_{\mathrm{m}}^{0.5698}$ & 0.88 \\
\hline 200 & $0-14$ & $\mathrm{q}=207+\Psi_{\mathrm{m}}$ & $>14$ & $\mathrm{q}=200+4.6679 \Psi_{\mathrm{m}}^{0.5698}$ & 0.93 \\
\hline 300 & $0-14$ & $\mathrm{q}=285+\Psi_{\mathrm{m}}$ & $>14$ & $\mathrm{q}=278+4.6679 \Psi_{\mathrm{m}}^{0.5698}$ & 0.84 \\
\hline
\end{tabular}

$\psi_{\mathrm{m}}$ - Sucção matricial na ruptura, $\mathrm{r}^{2}-$ Quadrado do coeficiente de correlação 


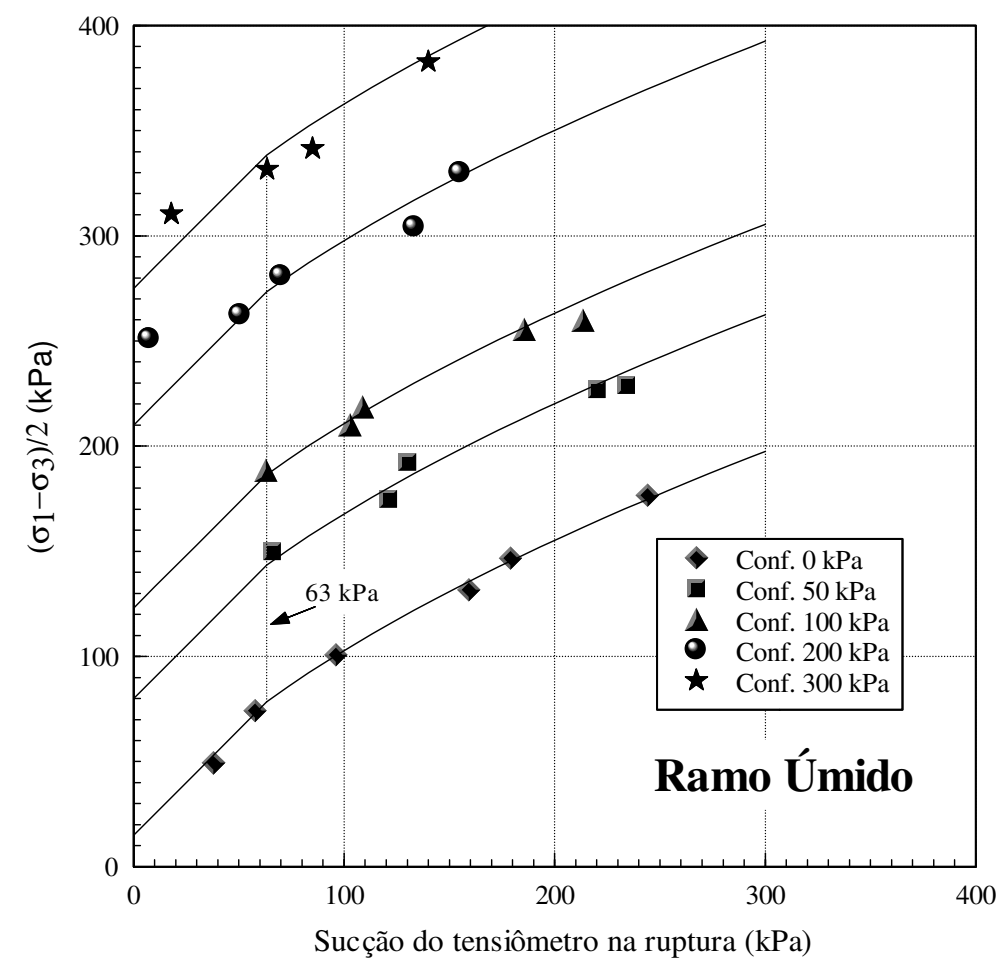

Figura 8.34 - Ajuste obtidos para os ensaios triaxiais não saturados realizados em corpos de prova compactados no ramo úmido (ponto $\mathrm{U}$ ).

Tabela 8.5 - Equações dos ajustes obtidos para os resultados dos ensaios triaxiais CW não saturados realizados em corpos de prova moldados no ramo úmido.

\begin{tabular}{|c|c|c|c|c|c|}
\hline \multirow{2}{*}{$\begin{array}{c}\text { Tens. Conf. } \\
(\mathrm{kPa})\end{array}$} & \multicolumn{2}{|c|}{$1^{\mathrm{o}}$ trecho } & \multicolumn{3}{c|}{$2^{\circ}$ trecho } \\
\cline { 2 - 6 } & $\begin{array}{c}\text { Sucção } \\
\mathrm{kPa})\end{array}$ & $\begin{array}{c}\text { Equação } \\
(\text { Reta })\end{array}$ & $\begin{array}{c}\text { Sucção } \\
(\mathrm{kPa})\end{array}$ & $\begin{array}{c}\text { Equação } \\
(\text { Potência) }\end{array}$ & $\begin{array}{c}\mathrm{r}^{2} \\
\text { (Potência) }\end{array}$ \\
\hline 0 & $0-63$ & $\mathrm{q}=15+\Psi_{\mathrm{m}}$ & $>63$ & $\mathrm{q}=6.644 \Psi_{\mathrm{m}}^{0.5947}$ & 0.99 \\
\hline 50 & $0-63$ & $\mathrm{q}=80+\Psi_{\mathrm{m}}$ & $>63$ & $\mathrm{q}=65+6.644 \Psi_{\mathrm{m}}^{0.5947}$ & 0.98 \\
\hline 100 & $0-63$ & $\mathrm{q}=123+\Psi_{\mathrm{m}}$ & $>63$ & $\mathrm{q}=108+6.644 \Psi_{\mathrm{m}}^{0.5947}$ & 0.99 \\
\hline 200 & $0-63$ & $\mathrm{q}=210+\Psi_{\mathrm{m}}$ & $>63$ & $\mathrm{q}=195+6.644 \Psi_{\mathrm{m}}^{0.5947}$ & 0.95 \\
\hline 300 & $0-63$ & $\mathrm{q}=275+\Psi_{\mathrm{m}}$ & $>63$ & $\mathrm{q}=260+6.644 \Psi_{\mathrm{m}}^{0.5947}$ & 0.98 \\
\hline
\end{tabular}

\footnotetext{
$\psi_{\mathrm{m}}$ - Sucção matricial na ruptura, $r^{2}-$ Quadrado do coeficiente de correlação
} 
Em função da inexistência de resultados para as pressões confinantes de 50 e 100 $\mathrm{kPa}$ e da pequena quantidade de resultados para os outros valores de pressão confinante, não foram obtidos, para a condição de moldagem no ramo úmido, os coeficientes de correlação das equações do trecho retilíneo.

Na Figura 8.35 estão os ajustes obtidos nas Figuras 8.32, 8.33 e 8.34, referentes às pressões confinantes de 0,50 e $100 \mathrm{kPa}$. Comparando estes resultados observa-se que para as condições de moldagem na umidade ótima e no ramo úmido os valores de q são semelhantes, para qualquer nível de sucção e de pressão de confinamento. Para os resultados obtidos com uma mesma pressão confinante, os ensaios realizados em corpos de prova moldados no ramo seco apresentam valores menores de resistência.

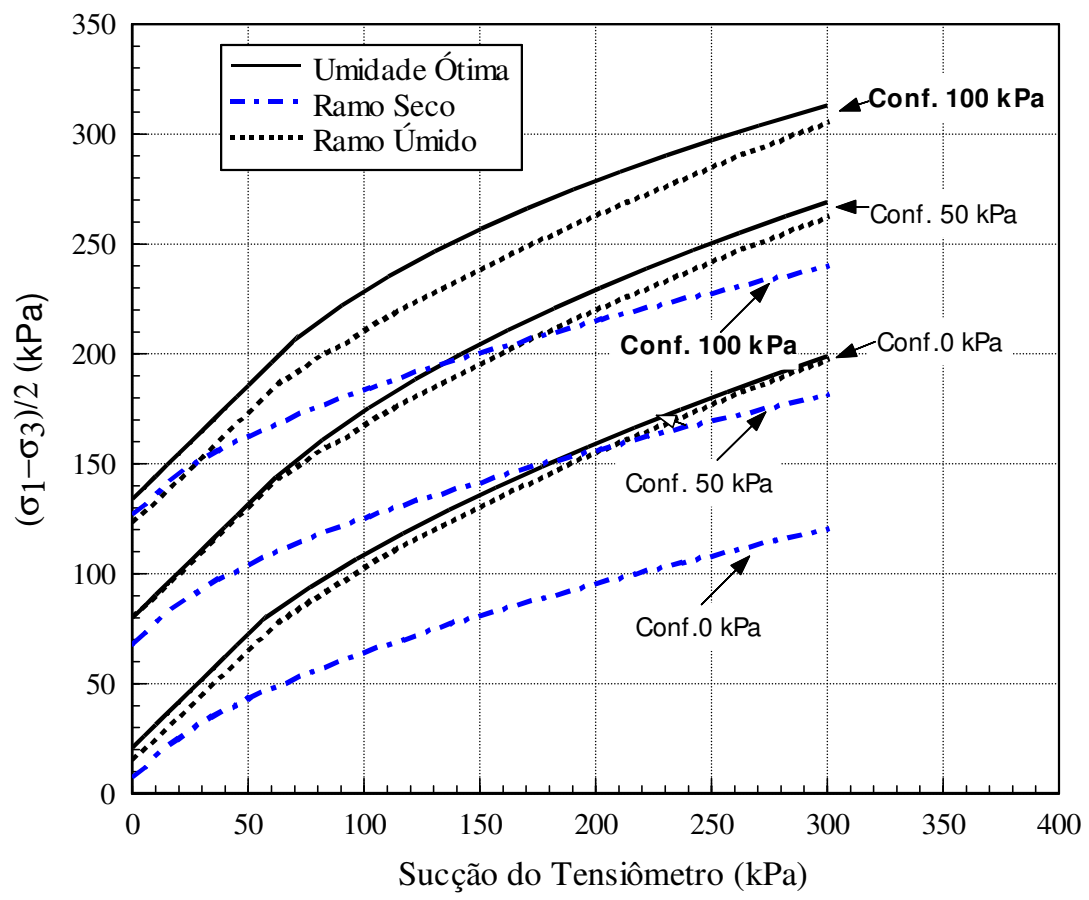

Figura 8.35 - Comparação dos ajustes obtidos para os resultados dos ensaios triaxiais CW não saturados realizados em corpos de prova compactados na umidade ótima, ramo seco e ramo úmido. 


\section{5 - Definição das equações das superfícies de ruptura}

Para a obtenção das equações que representam as superfícies de ruptura de cada condição de moldagem deve-se obter as equações da intercessão das mesmas com os planos $q$ versus $p$ e $q$ versus sucção. A intercessão com o plano q versus $p$ corresponde à envoltória de resistência obtida dos ensaios triaxiais saturados. Para se obter a intercessão da superfície de ruptura com o plano q versus sucção, obteve-se a projeção da envoltória de ruptura, correspondente aos ensaios de compressão simples, para o valor de p igual a zero. A obtenção da equação desta projeção esta esquematicamente ilustrada na Figura 8.36. Os pontos A, B e C, relacionados à máxima ordenada do círculo de Mohr, passam a corresponder aos pontos A', B' e C'. As retas que passam pelos pontos de máxima ordenada de cada círculo possuem inclinação igual ao ângulo de atrito correspondente ao valor de sucção do ensaio. A eqüidistância entre os ajustes para as diferentes pressões confinantes (ver Figuras $8.32,8.33$ e 8.34), indicam que o ângulo $\beta$ p permanece constante para qualquer valor de sucção. A envoltória de ruptura que passa pelos pontos A', B' e C' pode ser obtida pela seguinte expressão:

$q_{\text {proj. }}=q(1-\operatorname{tg} \beta)$

q- valor do resultado experimental

$\beta$-valor do ângulo de atrito

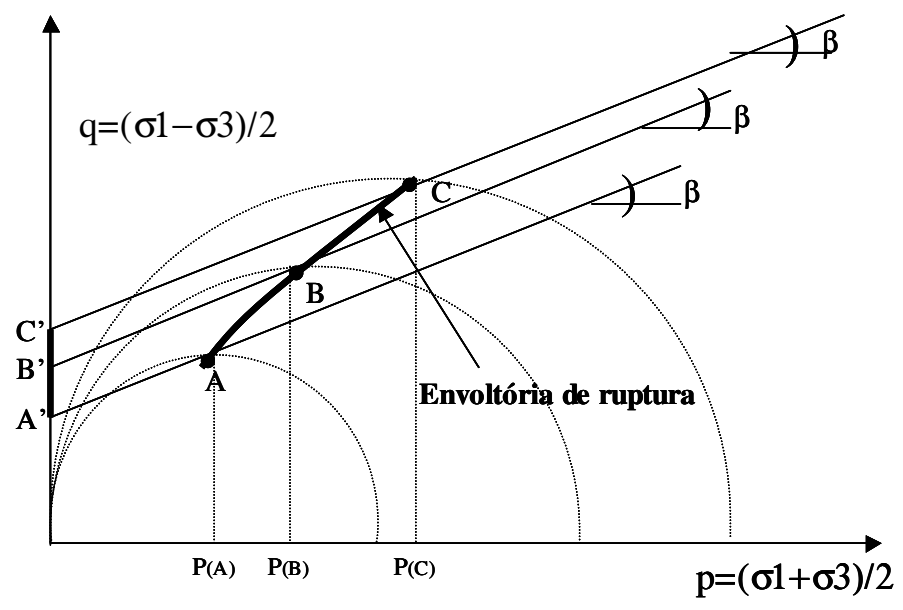

Figura 8.36 - Representação da projeção da envoltória dos ensaios de compressão simples para o valor de p igual a zero. 
Para os ajustes apresentados nas Figuras 8.32, 8.33 e 8.34, os valores de $\square$ podem ser determinados pelos valores q versus p, obtidos da intercessão dos ajustes lineares, correspondentes a cada pressão confinante, com o eixo das ordenadas. Para as condições da umidade ótima estes pontos foram obtidos experimentalmente e correspondem aos resultados dos ensaios CD saturados. Os valores de $\square$.para as condições de moldagem no ramo seco e ramo úmido, foram estimados pela aplicação de uma regressão linear aos valores de q versus p. Estes resultados estão apresentados na Tabela 8.6.

Os resultados dos ensaios apresentados nas Figuras 8.32, 8.33 e 8.34, foram obtidos em corpos de prova preparados por umedecimento ou secagem, sem impedimento das variações volumétricas associadas a estes procedimentos. A semelhança na preparação dos corpos de prova utilizados nos ensaios triaxiais CD, saturados com expansão livre, explica a boa correlação destes resultados com os ensaios triaxiais CW não saturados, apresentados na Figura 8.32. Os valores de $\square$ estimados dos ajustes apresentados nas Figuras 8.33 e 8.34, provavelmente correspondem ao resultado de ensaios triaxias CD saturados realizados em corpos de prova saturados com expansão livre.

Tabela 8.6 - Valores dos parâmetros efetivos correspondente aos ajustes dos resultados de ensaios CW não saturados.

\begin{tabular}{|c|c|c|c|c|}
\hline Moldagem & $\mathrm{d}(\mathrm{kPa})$ & $\beta\left(^{\circ}\right)$ & $\mathrm{r}^{2}$ & Observação \\
\hline Umidade Ótima & 10.3 & 27 & 0.99 & dados do ensaio CD \\
\hline Ramo Seco & 3.6 & 26 & 0.99 & estimados \\
\hline Ramo úmido & 7.7 & 26 & 0.99 & estimados \\
\hline
\end{tabular}

Utilizando a equação 8.1, as equações de ajuste obtidas para os ensaios de compressão simples (ver Tabelas 8.3, 8.4 e 8.5) e os valores de $\square$.. apresentados na Tabela 8.6, foram obtidas as equações que representam a intercessão da superfície de ruptura com o plano q versus sucção. Estes resultados estão apresentados na Tabela 8.7 . 
Tabela 8.7 - Intercessão das superfícies de ruptura com o plano definido por q versus sucção.

\begin{tabular}{|c|c|c|c|c|}
\hline \multirow{2}{*}{$\begin{array}{c}\text { Condição de } \\
\text { Moldagem }\end{array}$} & \multicolumn{2}{|c|}{ Ajuste linear } & \multicolumn{2}{c|}{ Ajuste de potência } \\
\cline { 2 - 5 } & $\begin{array}{c}\text { Sucção } \\
(\mathrm{kPa})\end{array}$ & $\begin{array}{c}\text { Equação } \\
\text { (Reta) }\end{array}$ & $\begin{array}{c}\text { Sucção } \\
(\mathrm{kPa})\end{array}$ & $\begin{array}{c}\text { Equação } \\
\text { (Potência) }\end{array}$ \\
\hline Umidade Ótima & $0-56.4$ & $\mathrm{q}=10.3+0.5057 \Psi_{\mathrm{m}}$ & $>56.4$ & $\mathrm{q}=4.2035 \Psi_{\mathrm{m}}{ }^{0.5512}$ \\
\hline Ramo Seco & $0-14$ & $\mathrm{q}=3.57+0.5100 \Psi_{\mathrm{m}}$ & $>14$ & $\mathrm{q}=2.3806 \Psi_{\mathrm{m}}{ }^{0.5698}$ \\
\hline Ramo Úmido & $0-63$ & $\mathrm{q}=7.65+0.5100 \Psi_{\mathrm{m}}$ & $>63$ & $\mathrm{q}=3.3884 \Psi_{\mathrm{m}}{ }^{0.5947}$ \\
\hline
\end{tabular}

$\psi_{\mathrm{m}}$ - Sucção matricial na ruptura

Na Figura 8.37 esta a representação esquemática das equações que devem ser obtidas para se determinar a superfície de ruptura. No plano q versus sucção esta a projeção da envoltória de ruptura correspondente aos ensaios de compressão simples (seguimento $\mathrm{ABC}$ ) e no plano q versus p está a envoltória de ruptura dos ensaios triaxiais saturados (seguimento $\mathrm{AD}$ ). É necessário conhecer a equação da reta que separa o trecho do ajuste linear do trecho de ajuste de potência, representado na Figura 8.37 pelo seguimento BE. Como o ângulo de atrito é constante e independe do valor da sucção, conforme verificado no item 8.4, a reta BE tem o mesmo coeficiente angular da envoltória do ensaio triaxial saturado. As equações para as três condições de moldagem, representadas na Figura 8.37 pelos seguimentos AB, BC, AD e BE, estão apresentadas na Tabela 8.8 .

$\mathrm{O}$ valor do ângulo definido pelo segmento $\mathrm{AB}$ da Figura 8.37 está relacionado ao coeficiente angular dos ajustes lineares apresentados na Tabela 8.7. Estes valores correspondem a um ângulo igual a $27^{\circ}$ para as três condições de moldagem. Comparando o valor deste ângulo com os resultados da Tabela 8.6, constata-se que a reta $\mathrm{AB}$ apresenta a mesma inclinação da reta $\mathrm{AD}$. Este fato indica que, para os valores de sucção correspondentes aos ajuste linear, o valor de $\square$ ' é igual ao valor dẹ $\square^{\mathrm{b}}$ para a análise em termos de resistência ao cisalhamentọ. 


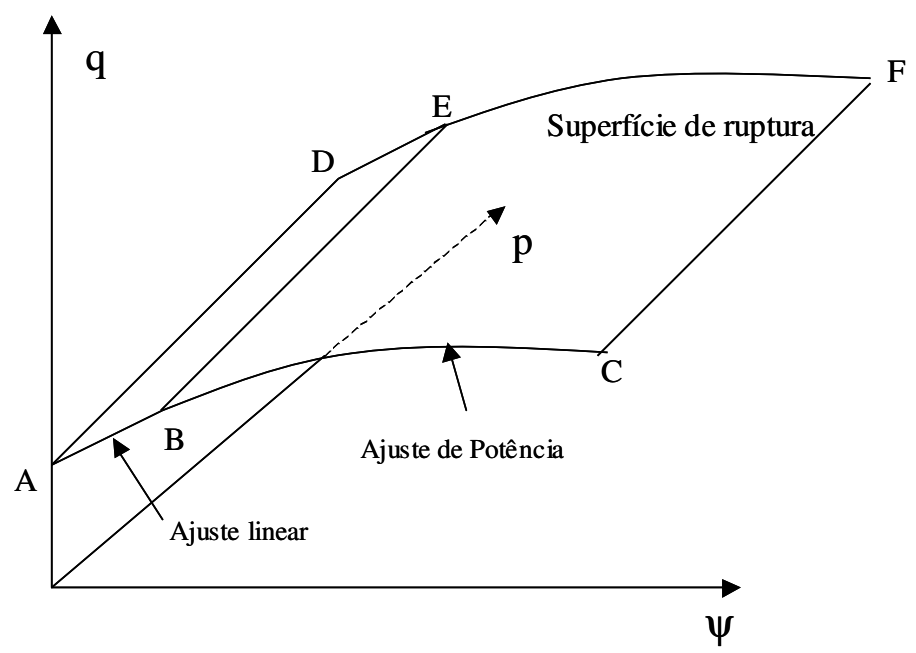

Figura 8.37 - Representação esquemática das equações utilizadas para a determinação das superfícies de ruptura

Tabela 8.8 - Equações utilizadas para a definição das superfícies de ruptura.

\begin{tabular}{|c|l|l|l|}
\hline Equação & \multicolumn{1}{|c|}{ Umidade Ótima } & \multicolumn{1}{|c|}{ Ramo Seco } & \multicolumn{1}{|c|}{ Ramo Úmido } \\
\hline $\mathrm{AB}$ & $\mathrm{q}=10.3+0.5057 \psi_{\mathrm{m}}$ & $\mathrm{q}=3.57+0.51 \psi_{\mathrm{m}}$ & $\mathrm{q}=7.65+0.51 \psi_{\mathrm{m}}$ \\
\hline $\mathrm{BC}$ & $\mathrm{q}=4.2035 \psi_{\mathrm{m}}^{0.5512}$ & $\mathrm{q}=2.3806 \psi_{\mathrm{m}}{ }^{.05698}$ & $\mathrm{q}=3.3806 \psi_{\mathrm{m}}^{0.5947}$ \\
\hline $\mathrm{AD}$ & $\mathrm{q}=10.3+0.5057 \mathrm{p}$ & $\mathrm{q}=3.57+0.51 \mathrm{p}$ & $\mathrm{q}=7.65+0.51 \mathrm{p}$ \\
\hline $\mathrm{BE}$ & $\mathrm{q}=38.82+0.5057 \mathrm{p}$ & $\mathrm{q}=10.71+0.51 \mathrm{p}$ & $\mathrm{q}=39.93+0.5095 \mathrm{p}$ \\
\hline
\end{tabular}

A equação da parte plana da superfície de ruptura, representada na Figura 8.37 por ABDE, é obtida pela combinação da equação $\mathrm{AB}$ com $\mathrm{AD}$. A região desta superfície onde foi aplicado o ajuste de potência, representada na Figura 8.37 por BCEF, é representada pela combinação das equações BE com BC. Utilizando os resultados Tabela 8.5 foram determinadas as superfícies de ruptura de cada condição de moldagem, sendo as mesmas representadas pelas seguintes equações:

\section{- Umidade Ótima}

Para $\Psi_{\mathrm{m}} \leq 56.4 \mathrm{kPa} \Rightarrow \mathrm{q}=10.3+0.5057\left(\mathrm{p}+\psi_{\mathrm{m}}\right)$

Para $\psi_{\mathrm{m}}>56.4 \mathrm{kPa} \Rightarrow \mathrm{q}=38.82+0.5057 \mathrm{p}+4.2035 \psi_{\mathrm{m}}^{0.5512}$ 
-Ramo Seco

Para $\Psi_{\mathrm{m}} \leq 14 \mathrm{kPa} \Rightarrow \mathrm{q}=3.57+0.51\left(\mathrm{p}+\psi_{\mathrm{m}}\right)$

$\operatorname{Para} \psi_{\mathrm{m}}>14 \mathrm{kPa} \Rightarrow \mathrm{q}=10.71+0.51 \mathrm{p}+2.3806 \psi_{\mathrm{m}}{ }^{0.5698}$

\section{•Ramo Úmido}

Para $\Psi_{\mathrm{m}} \leq 63.3 \mathrm{kPa} \Rightarrow \mathrm{q}=7.65+0.51\left(\mathrm{p}+\psi_{\mathrm{m}}\right)$

Para $\psi_{\mathrm{m}}>63.3 \mathrm{kPa} \Rightarrow \mathrm{q}=39.93+0.5095 \mathrm{p}+3.3806 \psi_{\mathrm{m}}^{0.5947}$

As superfícies determinadas pelas equações 8.2 a 8.7 estão representadas nas Figuras 8.38, 8.39 e 8.40. Estas representações tridimensionais servem apenas para ilustrar o formato destas superfícies, sendo inviável utiliza-las para obtenção das coordenadas de algum seus pontos.

O tempo para a realização de cada ensaio triaxial CD saturado e $\mathrm{CW}$ não saturado, desde a sua montagem até a ruptura, pode ser de até 4 horas. A superfície de ruptura pode ser determinada com a realização de 8 ensaios de compressão simples e quatro ensaios triaxiais saturados, que podem ser realizados em 6 dias. Considerando ainda o tempo necessário para a moldagem e preparação dos corpos de prova, a superfície de ruptura pode ser determinada em aproximadamente 10 dias. Cabe salientar que o ajuste obtido ao se transladar a envoltória de ruptura dos resultados de compressão simples se mostrou satisfatório para o caso particular do solo utilizado nesta pesquisa, para o tipo de moldagem e as condições específicas destes ensaios. A aplicação deste ajuste tem com hipótese que o valor de $\beta$ é constante e portanto independe da sucção. 


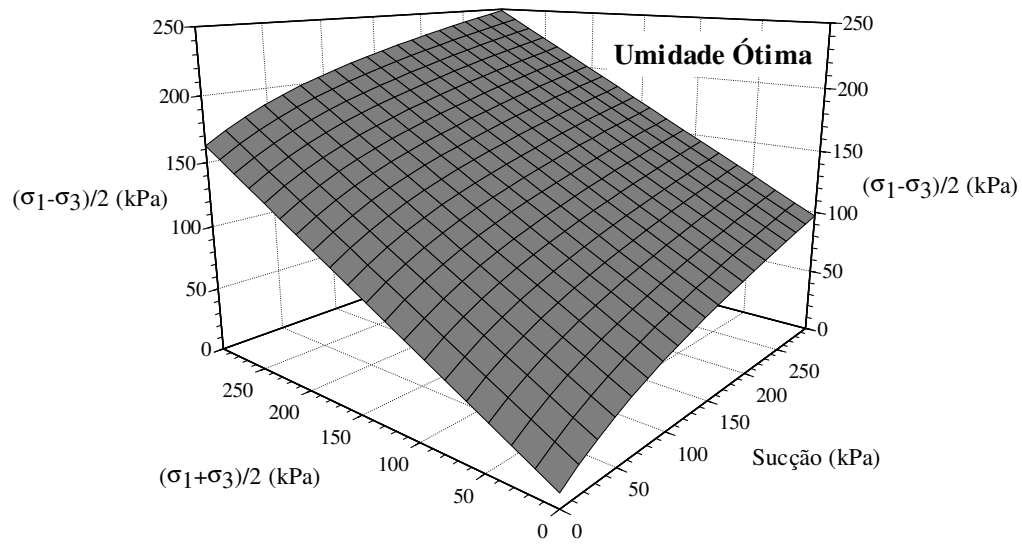

Figura 8.38 - Representação da superfície de ruptura correspondente às condições de moldagem na umidade ótima.

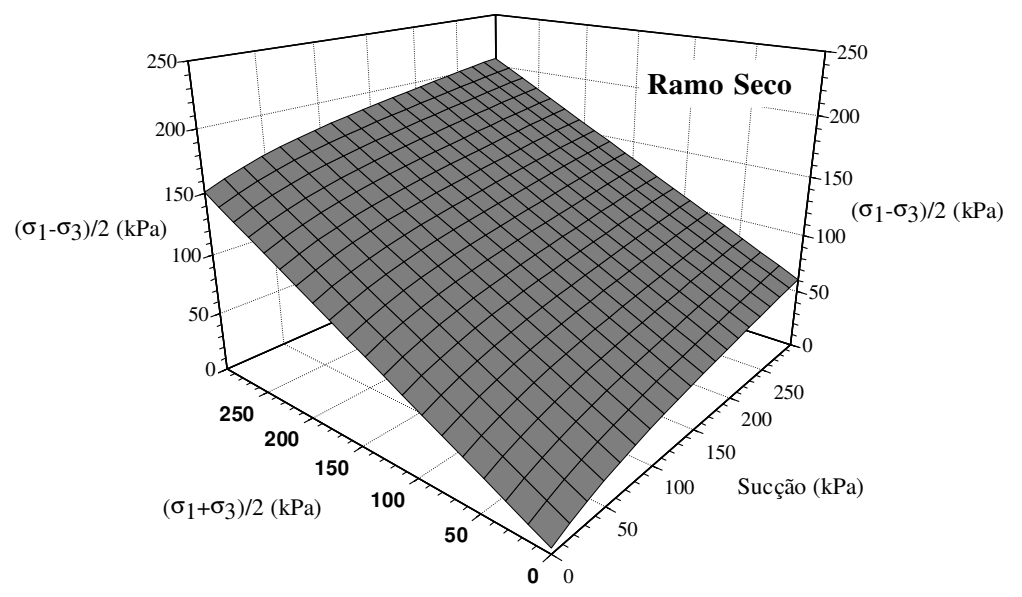

Figura 8.39 - Representação da superfície de ruptura correspondente às condições de moldagem no ramo seco.

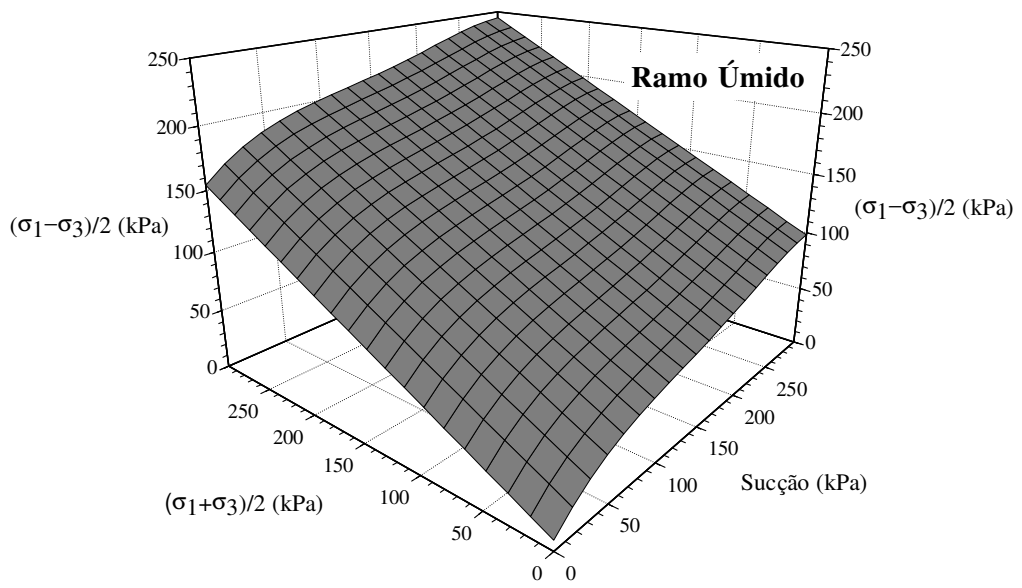

Figura 8.40 - Representação da superfície de ruptura correspondente às condições de moldagem ramo úmido. 


\section{6 - Aplicação dos modelos propostos por Vanapalli et al (1996) e Khalili e Khabbaz (1998)}

Neste item são utilizados os resultados dos ensaios triaxiais $\mathrm{CW}$ não saturados, apresentados nas Figuras 8.32, 8.33 e 8.34, para se avaliar a aplicabilidade dos modelos propostos por Vanapalli et al (1996) e Khalili e Khabbaz (1998). Além dos parâmetros efetivos do solo, obtidos de ensaios triaxiais saturados, o modelo proposto por Vanapalli et al (1996) utiliza toda a curva de retenção e o modelo proposto por Khalili e Khabbaz (1998) apenas o valor da sucção referente à entrada de ar. Estas curvas devem ser determinadas em corpos de prova submetidos às mesmas condições do solo que se deseja prever a resistência. Se este solo esta compactado e confinado, a curva de retenção deve ser determinada utilizando um corpo de prova compactado e submetido à mesma pressão de confinamento.

As curvas de retenção desta pesquisa foram obtidas sem confinamento (para as três condições de moldagem) e com confinamentos de 100, 200 e $300 \mathrm{kPa}$ (para a moldagem na umidade ótima). Utilizando estas curvas de retenção, os modelos de previsão da resistência serão aplicados aos resultados dos ensaios de compressão simples de cada condição de moldagem e para os ensaios com confinamento de 100 e $300 \mathrm{kPa}$, correspondente aos corpos de prova moldados na umidade ótima.

Estes modelos utilizam os valores das projeções dos resultados experimentais, conforme ilustrado esquematicamente na Figura 8.36. Para se obter a projeção destes resultados os valores de q, dados nas Tabelas 6.8 e 6.13 , foram multiplicados por (1$\operatorname{tg} \tilde{\dddot{i}}$ Nas Figuras 8.41, 8.42 e 8.43, estão os resultados das projeções dos ensaios, para a moldagem dos corpos de prova respectivamente na umidade ótima, ramo seco e ramo úmido e os ajustes do modelo proposto por Vanapalli et al (1996). Os resultados destes ensaios referem-se à sucção do corpo de prova na ruptura. $\mathrm{Na}$ equação 2.3, o valor da umidade volumétrica normalizado ( $\square$ foi substituída pelo grau de saturação. Como os resultados estão sendo analisados em termos de p e q, a equação deste modelo é dada por: 
$q=d+p \operatorname{tg} \beta+\left(u_{a}-u_{w}\right)(S)^{\kappa} \operatorname{tg} \beta$

O termo $\mathrm{d}+\mathrm{ptg} \beta$ corresponde à envoltória de ruptura dos ensaios triaxiais saturados (CD), cujos parâmetros estão apresentados na Tabela 8.6. Os valores de $\mathrm{S}$ e $\left(\mathrm{u}_{\mathrm{a}}-\mathrm{u}_{\mathrm{w}}\right)$ estão relacionados às coordenadas dos pontos da curva de retenção obtida para cada condição do ensaio. O melhor ajuste foi obtido para o valor de $\kappa$ igual a 2.2. O valor deste parâmetro se mostrou independente da condição de moldagem e da pressão de confinamento aplicada nos ensaios.

A relação entre o valor de $\kappa$ e o índice de plasticidade, proposta por Vanapalli e Fredlund (2000), esta apresentada na Figura 8.44 juntamente com o resultado obtido para o solo residual de gnaisse utilizado nesta pesquisa. Um dos resultados experimentais utilizados por Vanapalli e Fredlund (2000), para a definição da relação entre o valor de $\kappa$ e o IP, não corresponde ao obtido por Escário e Jucá (1989). Na Figura 8.44 estes resultados estão apresentados corretamente. Observa-se que ao se aplicar a relação da Figura 8.44, encontra-se para o $\mathrm{IP}=13 \%$, obtido para o solo utilizado nesta pesquisa, um valor de $\kappa$ igual a 2 . A semelhança entre os valores de $\square$ obtido experimentalmente e pela relação da Figura 8.44, permite concluir que a equação proposta por Vanapalli et al (1996) associada à relação entre $\kappa$ e o IP, sugerida por Vanapalli e Fredlund (2000), se aplica satisfatoriamente aos resultados dos ensaios realizados sob as condições específicas desta pesquisa.

Oliveira e Marinho (2002) e Oliveira e Marinho (2003) aplicaram o modelo proposto por Vanapalli et (1996) aos resultados dos ensaios de compressão simples realizados com deformação controlada, apresentados nas Tabelas 6.4, 6.5 e 6.6. No entanto, foram utilizados os valores da sucção inicial dos corpos de prova determinadas com o papel filtro. Na Figura 7.19 constatou-se que o papel filtro passa a fornecer, a partir de $50 \mathrm{kPa}$, valores de sucção superiores aos obtidos com o tensiômetro. Desta forma, a relação definida entre q e a sucção inicial determinada com o papel filtro fica abaixo da relação determinada ao se utilizar o valor da sucção na ruptura, obtida com o tensiômetro. 
Utilizando os resultados da sucção dos corpos de prova medida com o papel filtro no início do ensaio, Oliveira e Marinho (2002) e Oliveira e Marinho (2003) obtiveram valor de $\square$ igual a 3.5 , para as três condições de moldagem.

Ao se aplicar o modelo proposto por Vanapalli et al (1996) utilizando a sucção inicial obtida com o tensiômetro, os valores de $\kappa$ foram iguais a 2.9, para as condições de moldagem na umidade ótima e no ramo úmido, e 2.2 para as condições de moldagem no ramo seco. O valor de sucção do corpo de prova após o confinamento e na ruptura é igual a 2.2, devido às pequenas variações da sucção dos corpos de prova durante a realização destes ensaios (ver Figura 8.22). De acordo com estes resultados, a boa aplicabilidade do modelo proposto por Vanapalli et al (1996) foi constatada apenas para os valores da sucção medidas com o tensiômetro no momento da ruptura do corpo de prova.

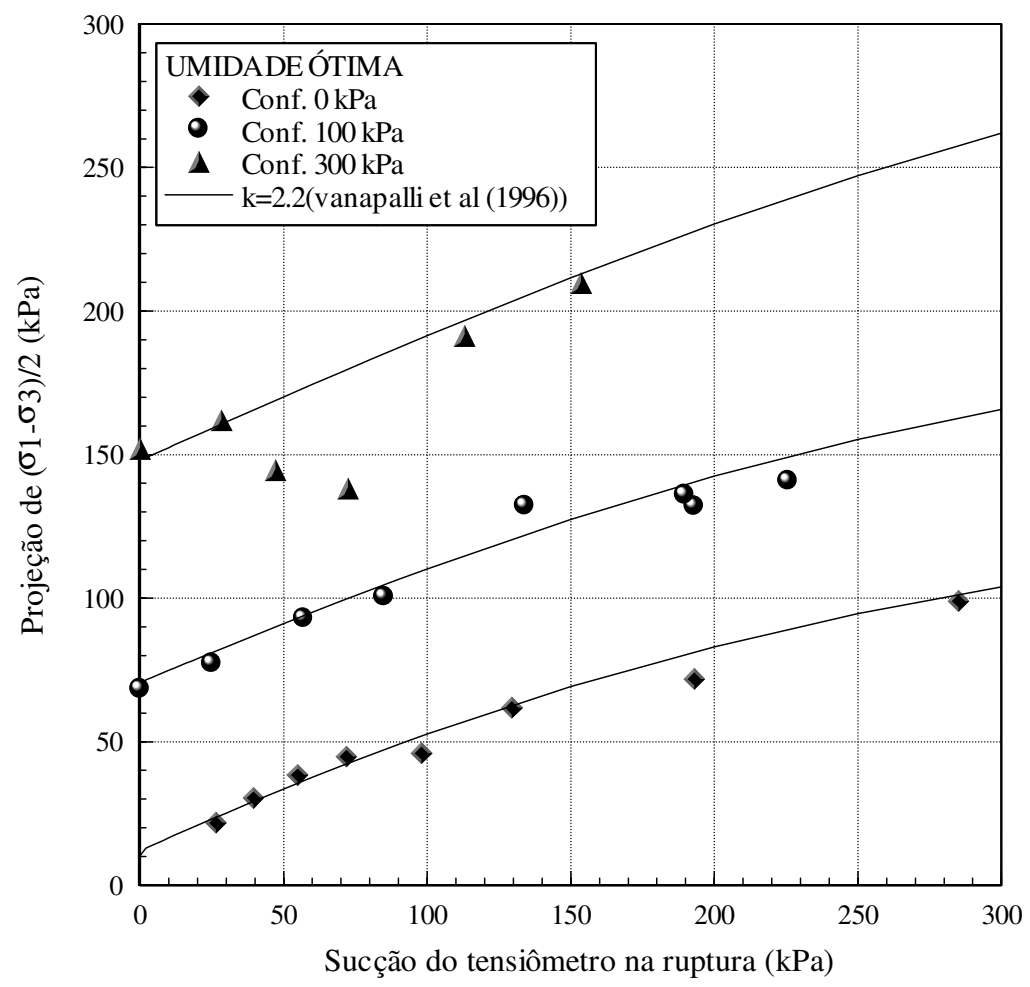

Figura 8.41 - Aplicação do modelo proposto por Vanapalli et al (1996) aos ensaios realizados na umidade ótima (Ponto $\mathrm{O}$ ). 


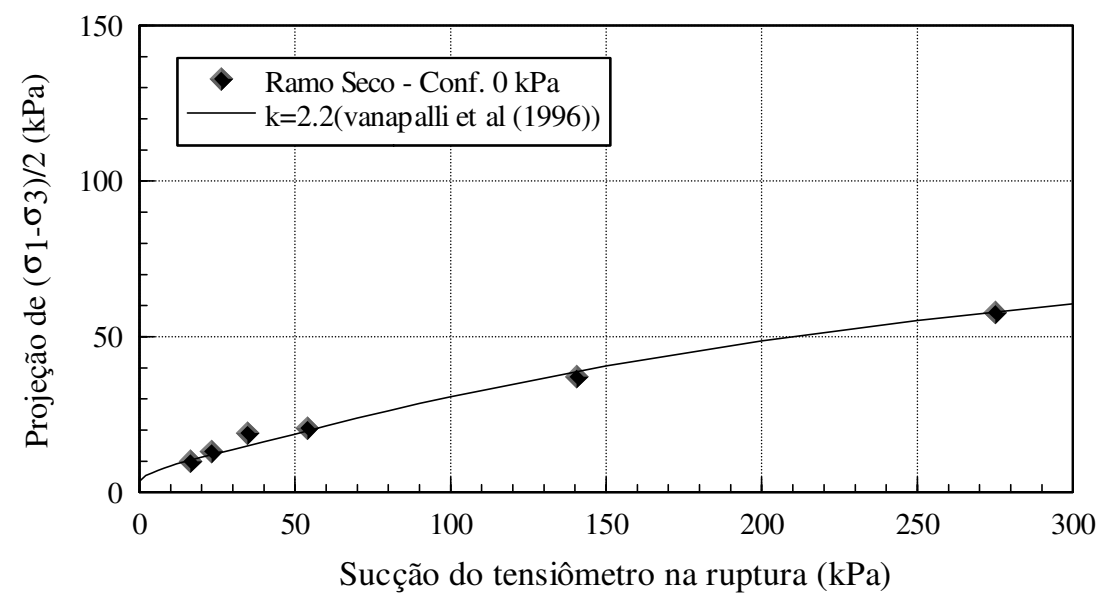

Figura 8.42 - Aplicação do modelo proposto por Vanapalli et al (1996) aos ensaios realizados no ramo seco (Ponto $\mathrm{S}$ ).

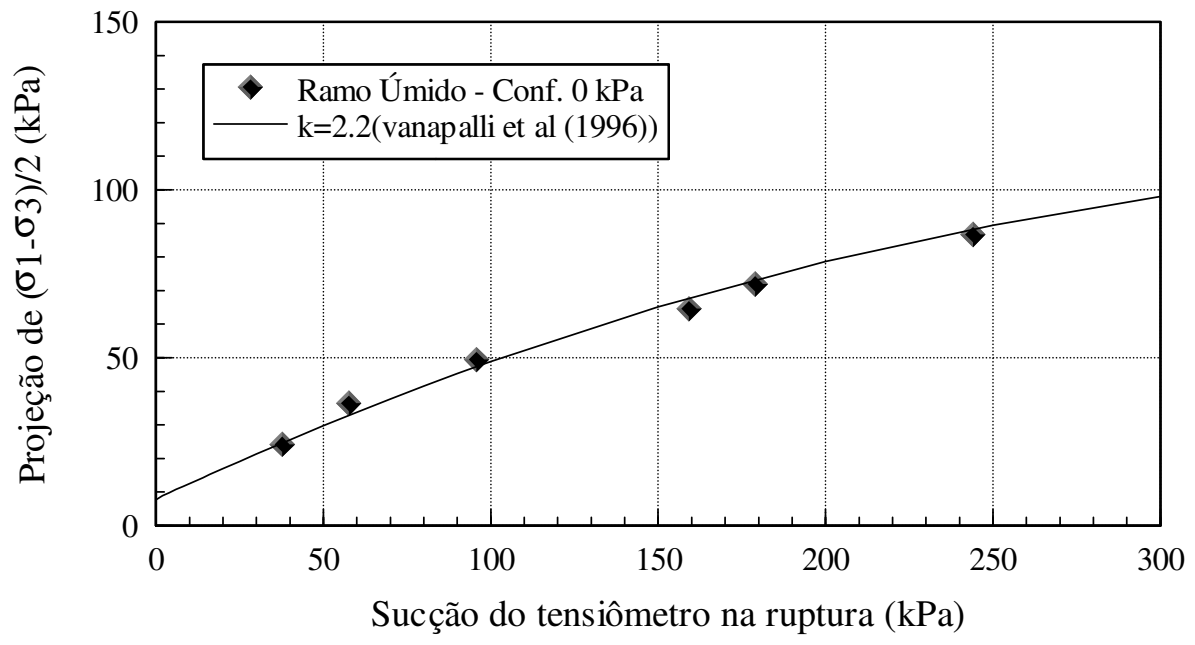

Figura 8.43 - Aplicação do modelo proposto por Vanapalli et al (1996) aos ensaios realizados no ramo úmido (Ponto $\mathrm{U}$ ). 


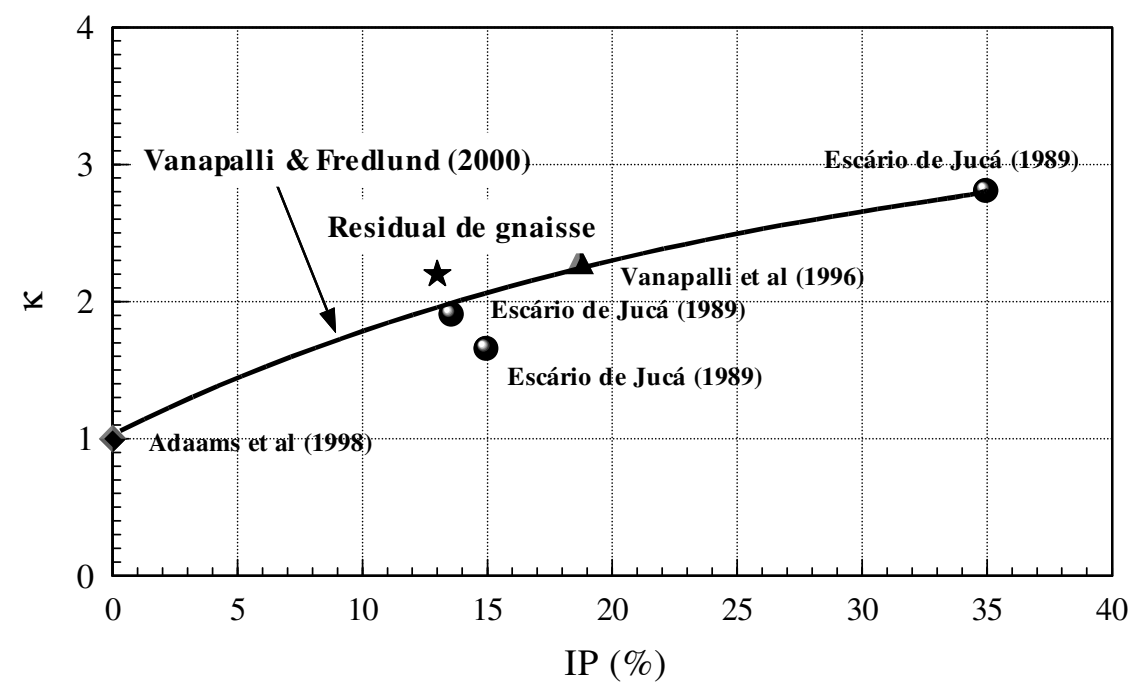

Figura 8.44 - Relação entre $\kappa$ e o valor do índice de plasticidade proposta por Vanapalli e Fredlund (2000).

Khalili e Kabbaz (1998), analisando resultados de ensaios de resistência realizados em solos de diferentes partes do mundo, chegaram a uma relação entre $\chi$ e a sucção correspondente à entrada de ar. Seguindo o mesmo tipo de análise destes autores (ver item 2.4.3), obteve-se esta relação para resultados dos ensaios de compressão simples e ensaios triaxiais CW não saturados apresentados respectivamente nas Tabelas $6.8 \mathrm{e}$ 6.13. De forma semelhante à aplicação do modelo proposto por Vanapalli et al (1996), são utilizadas as projeções dos resultados experimentais para um valor de $\mathrm{p}$ igual ao valor da pressão confinante (ver Figura 8.36).

Nas Figuras 8.45, 8.46 e 8.47 estão os valores das projeções dos resultados experimentais (Tabelas 6.8 e 6.13), a projeção dos ajustes apresentados nas Tabelas 8.3, 8.4 e 8.5 e os resultados dos ensaios triaxias CD saturados. Utilizando-se os resultados destas figuras e aplicando o procedimento indicado na Figura 2.52, as variações de $\chi$ em função da sucção estão apresentadas na Figura 8.48. 
Nas Figuras 8.45, 8.46 e 8.47, observa-se que as retas que representam os ensaios triaxiais saturados tangenciam as envoltórias de resistência dada por q em função da sucção. O ponto a partir do qual as duas não mais coincidem, esta relacionado à sucção onde se inicia a entrada de ar no corpo de prova e não à sucção referente a entrada de ar generalizada. Na Figura 8.48 estes valores correspondem a intersessão das relações do $\chi$ em função da sucção com a linha que representa o valor de $\chi$ igual a 1. Os valores das sucções assim obtidas estão apresentados na Tabela 8.9.

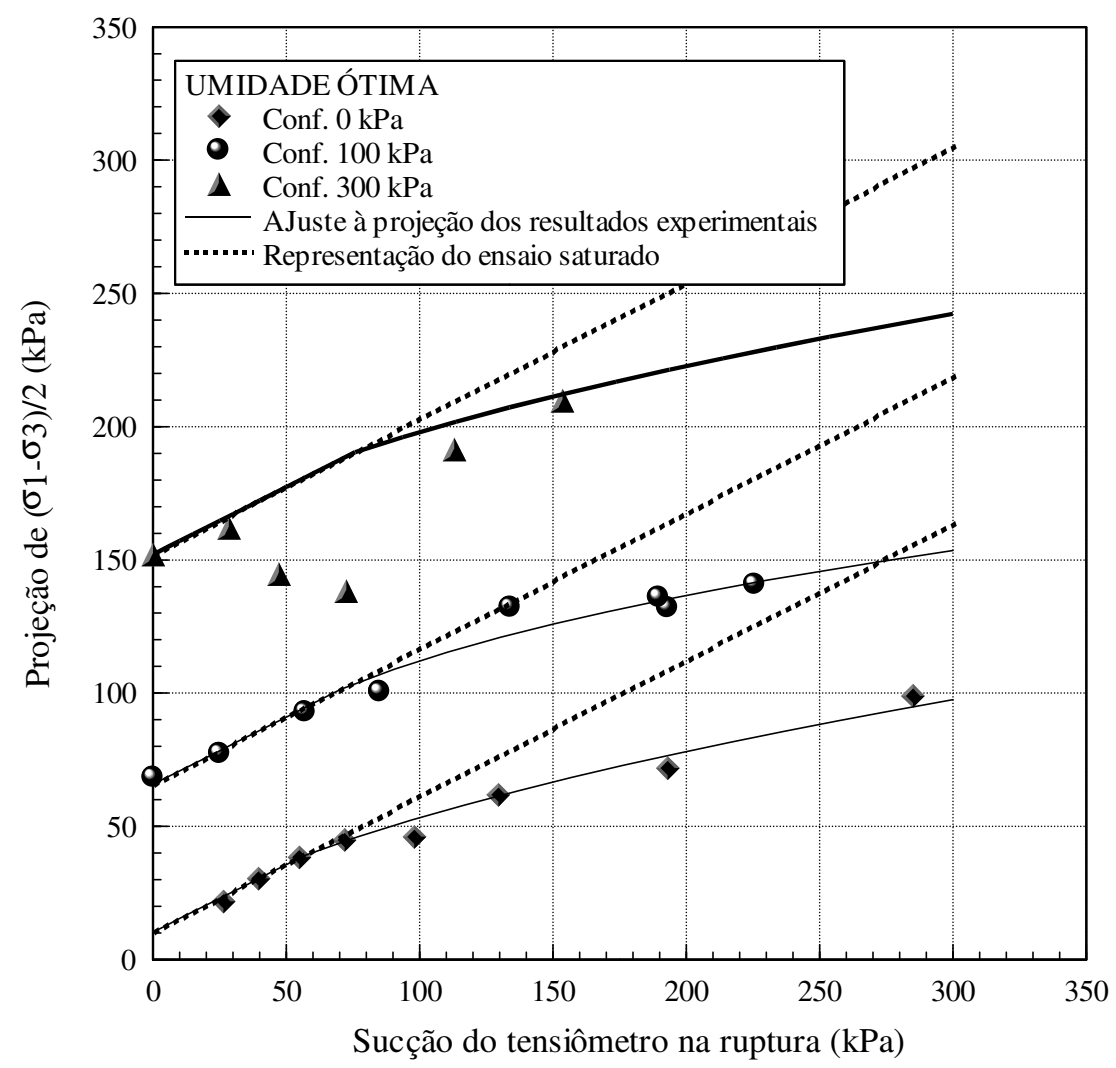

Figura 8.45 - Projeção dos ajustes e dos resultados experimentais juntamente com a envoltória de ruptura obtida dos ensaios triaxias saturados (ponto O) 


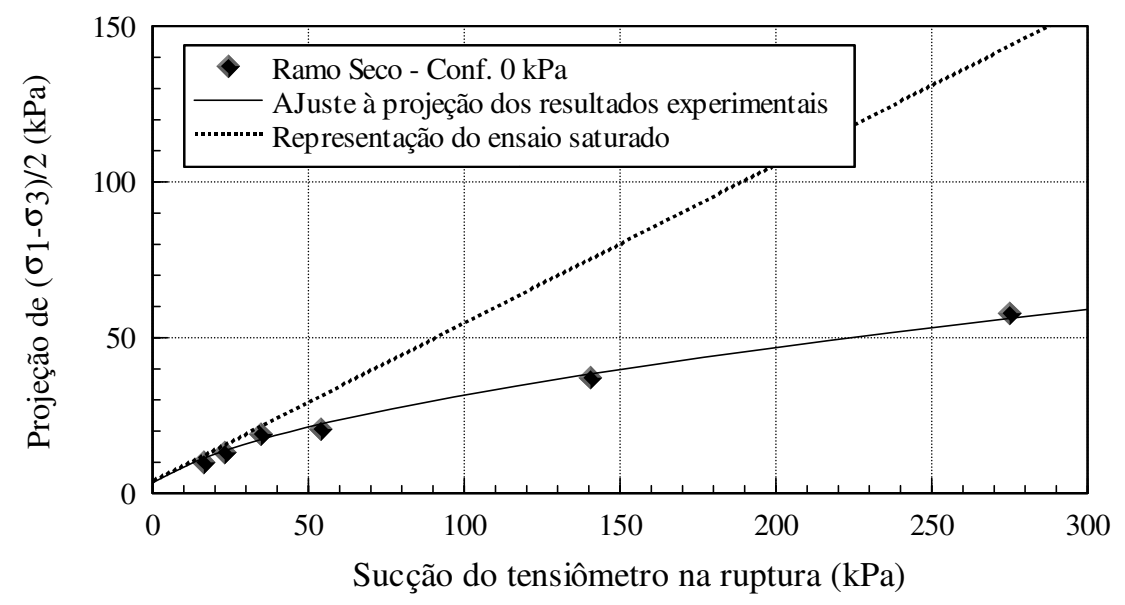

Figura 8.46 - Projeção dos ajustes e dos resultados experimentais juntamente com a envoltória de ruptura obtida dos ensaios triaxias saturados (ponto $\mathrm{S}$ ).

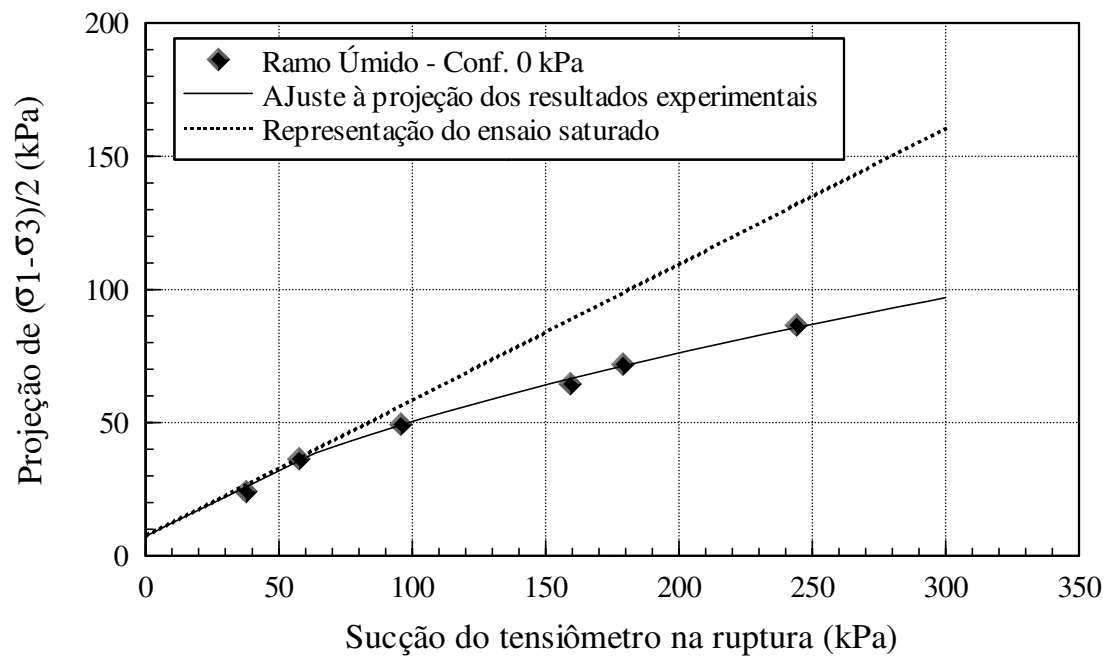

Figura 8.47 - Projeção dos ajustes e dos resultados experimentais juntamente com a envoltória de ruptura obtida dos ensaios triaxias saturados (ponto U). 


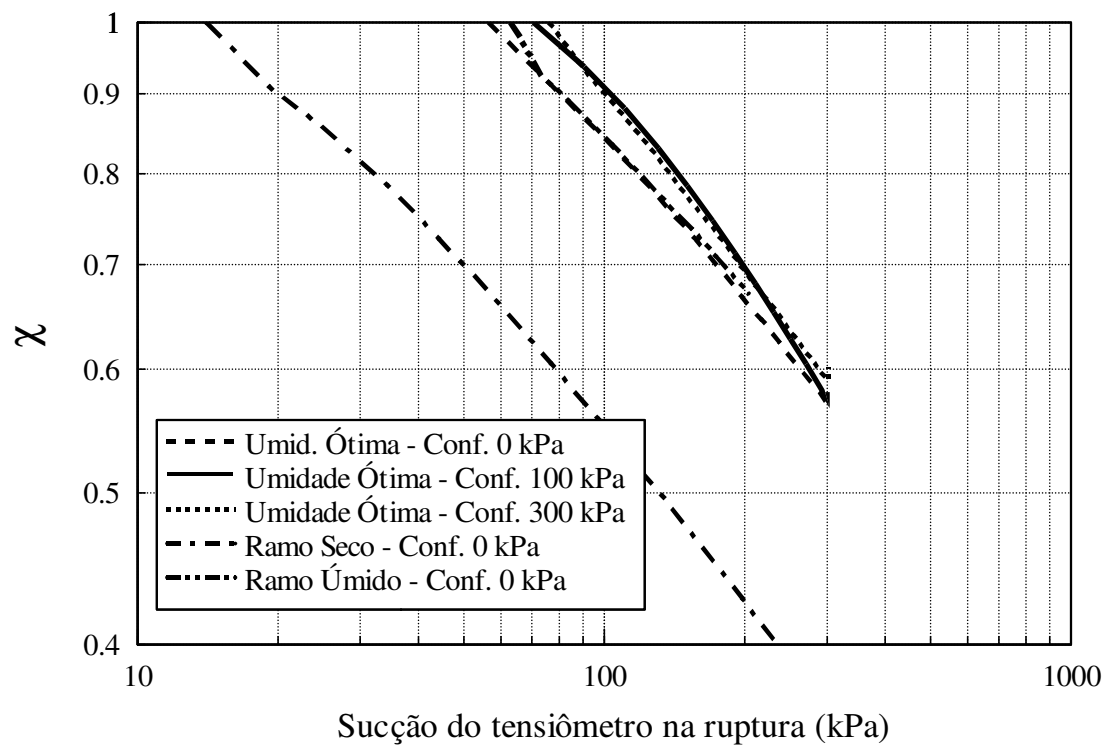

Figura 8.48 - Relação entre o parâmetro $\chi$ e a sucção do tensiômetro na ruptura.

Tabela 8.9 - Valores das sucções correspondentes ao início da entrada de ar em função da condição de moldagem e da tensão confinante aplicada nos ensaios.

\begin{tabular}{|c|c|c|}
\hline $\begin{array}{c}\text { Ponto de } \\
\text { Moldagem }\end{array}$ & $\begin{array}{c}\text { Tens. Conf. } \\
(\mathrm{kPa})\end{array}$ & $\begin{array}{c}\left(\mathrm{u}_{\mathrm{a}}-\mathrm{u}_{\mathrm{w}}\right)_{\mathrm{b}} \\
(\mathrm{kPa})\end{array}$ \\
\hline \multirow{3}{*}{ Umid. Ótima } & 0 & 56.4 \\
\cline { 2 - 3 } & 100 & 70.5 \\
\cline { 2 - 3 } & 300 & 75.8 \\
\hline Ramo Seco & 0 & 14 \\
\hline Ramo Úmido & 0 & 63.3 \\
\hline
\end{tabular}

Na Figura 8.49 estão apresentados os resultados da Figura 8.48, normalizados em relação às respectivas sucções de inicio de entrada de ar (Tabela 8.9). Juntamente com estes resultados estão os valores obtidos por Khalili e Khabbaz (1998). Observase na Figura 8.49 que os resultados obtidos nesta pesquisa ficaram acima da faixa de variação encontrada por estes pesquisadores, sendo os mesmos representados pela seguinte relação:

$\chi=\left[\left(\mathrm{u}_{\mathrm{a}}-\mathrm{u}_{\mathrm{w}}\right) /\left(\mathrm{u}_{\mathrm{a}}-\mathrm{u}_{\mathrm{w}}\right)_{\mathrm{b}}\right]^{-0.321}$ 
Nas Figuras 8.50, 8.51 e 8.52, o modelo de previsão da resistência proposto por Khalili e Khabbaz (1998) foi aplicado utilizando a relação entre $\chi$ e a sucção obtida em suas análises e a relação encontrada ao se utilizar os resultados desta pesquisa (equação 8.9). A equação deste modelo, em termos de q e p é dada por:

$\mathrm{q}=\mathrm{d}+\mathrm{ptg} \beta+\chi\left(\mathrm{u}_{\mathrm{a}}-\mathrm{u}_{\mathrm{w}}\right) \operatorname{tg} \beta$

$\mathrm{O}$ valor do termo $\mathrm{d}+\mathrm{ptg} \beta$ está relacionado à envoltória obtida dos ensaios triaxiais saturados. Observa-se nas Figuras 8.50, 8.51 e 8.52, que utilizando a relação do $\chi$ em função da sucção obtida por Khalili e Khabbaz (1998) os resultados dos ajustes de q em função da sucção ficaram abaixo das projeções dos resultados experimentais. Ao se aplicar a relação dada pela equação 8.9 , obtida para os resultados dos ensaios realizados nesta pesquisa, obteve-se um melhor ajuste. Desta forma, o modelo proposto originalmente por Khalili e Khabbaz (1998) não pode prever adequadamente os valores de resistência dos ensaios realizados nesta pesquisa.

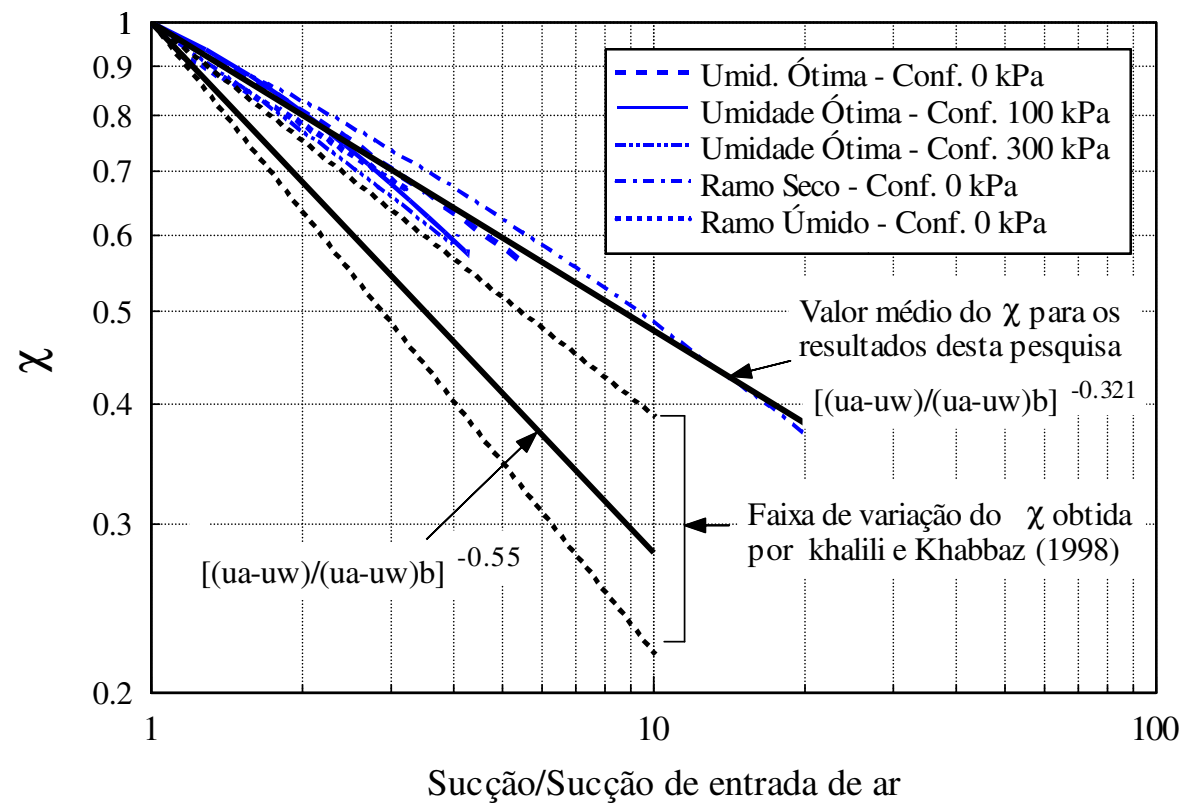

Figura 8.49 - Relação entre o parâmetro $\chi$ e a sucção do tensiômetro na ruptura normalizada em relação à sucção referente ao início da entrada de ar. 


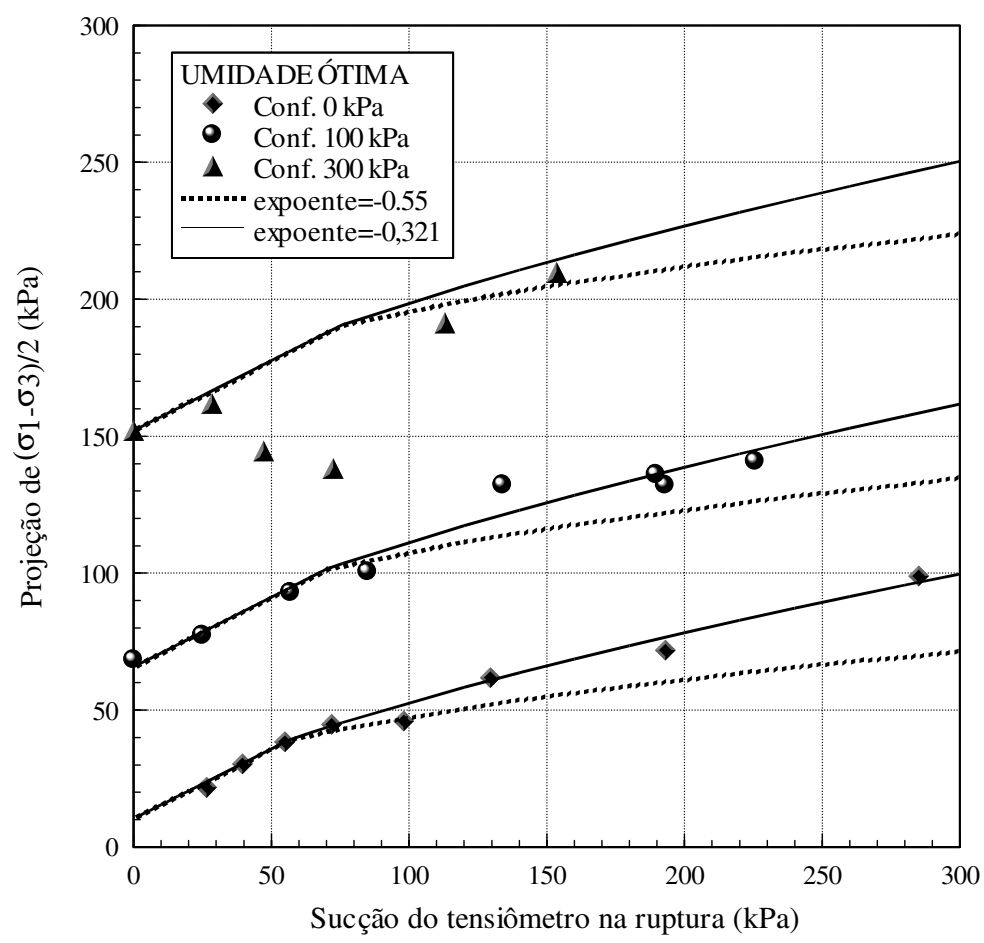

Figura 8.50 - Aplicação do modelo proposto por Khalili e Khabbaz (1998) utilizando diferentes relações entre o valor de $\chi$ e a sucção do corpo de prova (Ponto O).

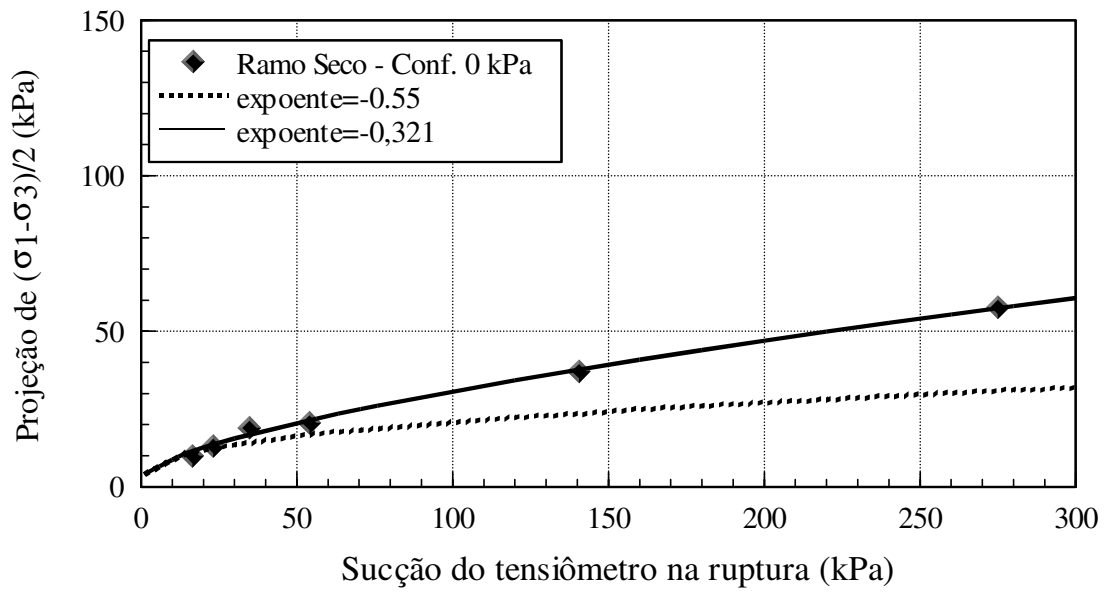

Figura 8.51 - Aplicação do modelo proposto por Khalili e Khabbaz (1998) utilizando diferentes relações entre o valor de $\chi$ e a sucção do corpo de prova (Ponto $S$ ). 


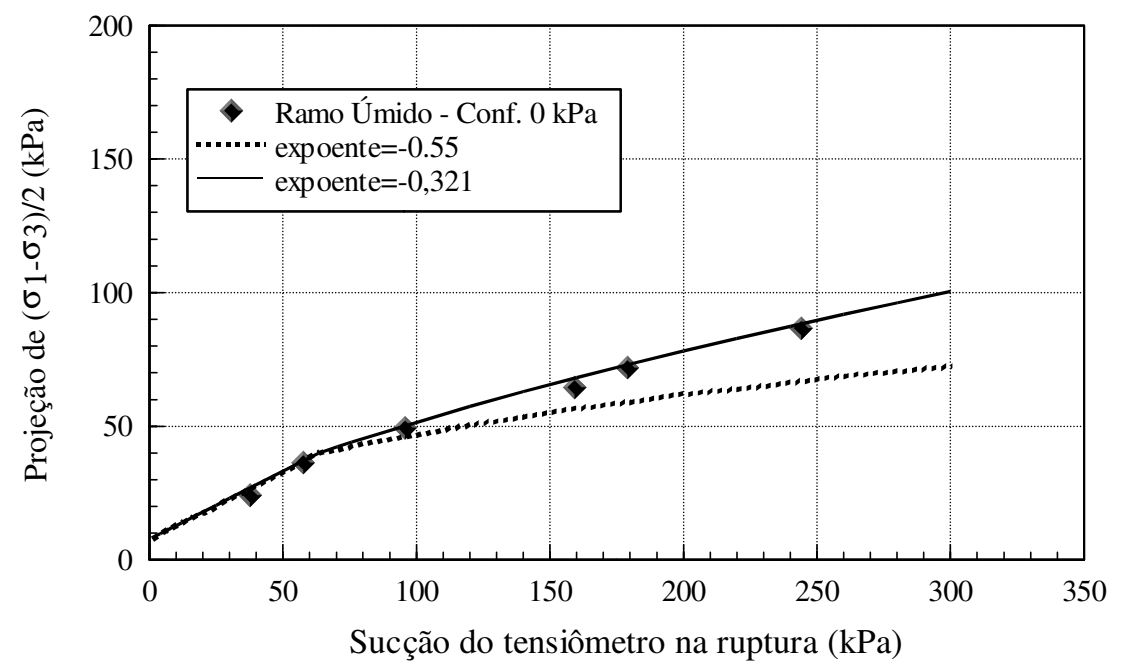

Figura 8.52 - Aplicação do modelo proposto por Khalili e Khabbaz (1998) utilizando diferentes relações entre o valor de $\chi$ e a sucção do corpo de prova (Ponto U). 


\section{9 - CONCLUSÕES E RECOMENDAÇÕES PARA FUTURAS PESQUISAS}

Nesta pesquisa foi utilizado um solo residual de gnaisse, retirado do campo experimental da USP, compactado estaticamente em três pontos da curva de compactação. Para estas condições de moldagem foram obtidas as respectivas curvas de retenção e realizados ensaios de resistência ao cisalhamento. O enfoque principal desta pesquisa foi direcionada para a obtenção das superfícies de ruptura correspondentes as condições de moldagem na umidade ótima, ramo seco e ramo úmido. Desta forma, foram realizados ensaios triaxiais CAU e CD saturados e ensaios triaxiais CW não saturados. As principais conclusões as quais se pode chegar, com os resultados obtidos nesta pesquisa, são abordadas separadamente para os aspectos relacionados às curvas de retenção e aos ensaios de resistência ao cisalhamento.

\section{1 - Aspectos relacionados às curvas de retenção}

Em relação aos resultados das curvas de retenção foram investigadas as influências das diferentes condições de moldagem, do tipo de compactação e da aplicação de pressão confinante. Com os resultados destas investigações obteve-se as seguintes conclusões:

\section{- Medição da sucção}

A determinação do tempo de equilíbrio, ao se utilizar a placa de pressão, deve ser acompanhada pela variação do teor de umidade dos corpos de prova com o tempo. O ideal é que na placa de pressão exista a possibilidade de se controlar a umidade relativa do ambiente interno da câmara, de forma a impor aos corpos de prova uma sucção igual à da pedra porosa. 
Em função dos resultados da calibração do lote de papel filtro Whatman $\mathrm{n}^{\mathrm{o}} 42$, utilizado nesta pesquisa, sugere-se que ao se utilizar esta técnica seja feita a calibração para a sucção de $200 \mathrm{kPa}$. Este resultado deve ser comparado com o valor de sucção obtido pela equação proposta por Chandler et al (1992).

\section{- Condições de moldagem}

As curvas de retenção obtidas dos corpos de prova moldados nas condições da umidade ótima e no ramo úmido são semelhantes entre si. Na curva de retenção determinada para as condições de moldagem no ramo seco constatou-se uma distribuição bimodal de poros, apresentando em relação às curvas anteriores um valor menor de sucção de entrada de ar generalizada.

\section{- Tipo de compactação}

Para o solo residual de gnaisse, utilizado nesta pesquisa, constatou-se que as curvas de retenção obtidas para as condições de moldagem na umidade ótima, ramo seco e ramo úmido, independem do tipo de compactação. Desta forma, pode-se concluir que a compactação estática e dinâmica produzem corpos de prova com estruturas de poros semelhantes.

\section{- Sucção de entrada de ar}

A aplicação de diferentes valores de pressão de confinamento, conforme sugerido por Vanapalli (1994), interferem no valor da sucção de entrada de ar das curvas de retenção obtidas para as condições de moldagem na umidade ótima. O aumento da pressão de confinamento faz com que ocorra o aumento da sucção de entrada de ar generalizada. 


\section{$\bullet$ Histerese}

Para as curvas de retenção obtidas por compactação estática, nas condições de moldagem referente à umidade ótima, ramo seco e ramo úmido, constatou-se uma pequena histerese ao serem obtidas por secagem ou umedecimento. As variações dos índices de vazios em função da umidade gravimétrica são semelhantes para estas duas trajetórias de umidade. Portanto, a pequena histerese deve-se a formação de bolhas de ar ocluso no interior da estrutura do corpo de prova durante o processo de umedecimento por aspersão.

\section{2 - Aspectos relacionados à resistência ao cisalhamento}

Para os resultados dos ensaios de resistência foram obtidas as seguintes conclusões:

\section{- Ensaios de compressão simples}

Os valores de q em função da sucção de ruptura, obtidos para os corpos de prova moldados na umidade ótima e no ramo úmido, independem das respectivas trajetórias de umidade seguidas na etapa de preparação. Uma pequena histerese nos valores de q foi observada para as condições de moldagem no ramo seco. Os corpos de prova moldados no ramo seco e submetidos à saturação e secagem apresentaram, para um mesmo valor de sucção, valores de q maiores que os submetidos à secagem ou umedecimento, sendo esta diferença menor que $10 \mathrm{kPa}$.

Apesar da constatação da compressibilidade da pasta de solo colocada sobre o tensiômetro, a semelhança das relações definidas entre q e a sucção e das trajetórias de tensões permitem concluir que os resultados dos ensaios de compressão simples independem do tipo de carregamento aplicado na fase de cisalhamento do corpo de prova. 
Em ensaios realizados em corpos de prova moldados e ensaiados nas condições da umidade ótima, não foram constatadas diferenças nos valores da tensão e da sucção em função da deformação axial, ao serem cisalhados com velocidades que variaram entre 0.03 e $0.5 \mathrm{~mm} / \mathrm{min}$.

\section{- Relação entre os valores das sucções iniciais dos corpos de prova obtidas com o tensiômetro e o papel filtro}

As sucções dos corpos de prova, medidas no início do ensaio, independem da consistência da pasta de solo colocada sobre o tensiômetro. O tempo de equilíbrio destas medições está relacionado às condições de moldagem e ao valor de sucção dos corpos de prova.

Quanto maior a sucção do corpo de prova maior será o valor do tempo de equilíbrio. Em relação às condições de moldagem, constatou-se que para um mesmo valor de sucção (>50 kPa), o maior tempo de equilíbrio corresponde à condição de moldagem no ramo seco, seguido da umidade ótima e ramo úmido.

A relação entre as sucções dos corpos de prova obtidas com o papel filtro e o tensiômetro são semelhantes para valores inferiores a $50 \mathrm{kPa}$. Para sucções superiores a este valor, o tipo de transferência de água do corpo de prova para o papel filtro faz com que o mesmo passe a fornecer um valor de sucção intermediária, maior que a matricial e menor que a total.

\section{- Ajuste obtido para os valores de q versus sucção}

Para os valores de q em função da sucção, obtidos para as diferentes condições de moldagem e pressões confinantes foi aplicado um ajuste linear e de potência. Os ajustes obtidos para os ensaios realizados para as condições de moldagem na umidade ótima, permitem concluir que a máxima sucção do ajuste linear corresponde ao inicio da desaturação dos corpos de prova e não a entrada de ar generalizada. 
A translação dos ajustes dos ensaios de compressão simples para os resultados dos ensaios realizados com diferentes pressões confinantes se mostrou satisfatório, ao se analisar os respectivos coeficientes de correlação. A eqüidistância entre os ajustes para as diferentes pressões de confinamento indica que o ângulo de atrito não varia em função do aumento da sucção.

A boa correlação proporcionada pela translação do ajuste obtido para os ensaios de compressão simples, possibilita que a superfície de ruptura seja definida pelas seguintes equações:

-Para o intervalo de sucção do ajuste linear:

$\mathrm{q}=\mathrm{d}+\left[\mathrm{p}+\left(\mathrm{u}_{\mathrm{a}}-\mathrm{u}_{\mathrm{w}}\right)\right] \operatorname{tg} \beta$

-Para sucções correspondentes ao ajuste de potência:

$\mathrm{q}=\mathrm{d}+\mathrm{ptg} \beta+\mathrm{a}\left(\mathrm{u}_{\mathrm{a}}-\mathrm{u}_{\mathrm{w}}\right)^{\mathrm{b}}$

Para o solo residual de gnaisse utilizado nesta pesquisa, a superfície de ruptura pode ser definida apenas com a realização de ensaios de compressão simples não saturados e de ensaios triaxiais saturados. Como os ensaios de compressão simples não saturados foram realizados com a medição da variação da sucção e não com a utilização da técnica de translação de eixos, os mesmos podem ser realizados em um tempo menor ( $\cong 4$ horas), possibilitando a obtenção da superfície de ruptura em aproximadamente 10 dias.

As superfícies de ruptura obtidas para as condições de moldagem na umidade ótima e no ramo úmido são semelhantes. Comparando os ajustes obtidos para os ensaios realizados nas diferentes condições de moldagem e submetidos a uma mesma pressão de confinamento, observa-se que a moldagem no ramo seco apresenta valores de resistência menores passando a aumentar esta diferença para valores maiores de sucção. 


\section{- Aplicação dos modelos propostos por Vanapalli et al (1996) e Khalili e Khabbaz (1998)}

A aplicação do modelo proposto por Vanapalli et al (1996) apresentou uma boa previsão dos valores de q versus a sucção do corpo de prova na ruptura. $\mathrm{O}$ valor do parâmetro $\kappa=2.2$, obtido nesta pesquisa, mostrou-se independente das condições de moldagem e da pressão de confinamento aplicada no ensaio. Ao se utilizar a relação entre o valor de $\kappa$ e o IP, proposto por Vanapalli e Fredlund (2000), obtêm-se para o solo utilizado nesta pesquisa um valor de $\kappa$ igual a 2, o que proporciona também um ajuste satisfatório.

Para o modelo proposto por Khalili e Khabbaz (1998) obteve-se uma outra relação para o valor de $\chi$. Como proposto originalmente por estes autores, a aplicação deste modelo não se mostrou satisfatória, afastando-se dos pontos experimentais na medida em que aumenta o valor da sucção. Para se obter uma melhor previsão dos valores de resistência a relação proposta para o valor de $\chi$ deve ser elevado ao expoente $-0.32 \mathrm{e}$ não a -0.55. Ao se estimar a sucção de entrada de ar para a aplicação deste modelo, deve-se obter o valor referente ao início da desaturação do corpo de prova e não a correspondente a entrada de ar generalizada.

\section{3 - Recomendações para futuras pesquisas}

Seria interessante confrontar os resultados dos ensaios realizados nessa pesquisa, com ensaios realizados utilizando a técnica da translação de eixos.

A relação do valor de $\chi$ com a sucção de entrada de ar obtida nesta pesquisa, ao se aplicar o modelo proposto por Khalili e Khabbaz (1998), deve ser verificada para outros tipos de solos residuais. 
A variação da sucção do corpo de prova durante a etapa de cisalhamento pode ser definida com maior precisão ao se utilizar dois tensiômetros. Além da medição da sucção na base do corpo de prova, um outro tensiômetro pode ser acoplado a um medidor de deformação axial colocado no meio do corpo de prova.

Deve ser verificada, para outros tipos de solo, a aplicabilidade do ajuste proposto nesta pesquisa para a relação entre q e a sucção correspondente a diferentes pressões confinantes. 


\section{0 - REFERÊNCIAS BIBLIOGRÁFICAS}

ABEF-Research on Foundation Engineering (1989). Publicado no XII ICMF.

ABRAMENTO, M. (1988). Resistência ao cisalhamento de Solos Não Saturados: Considerações Teóricas e Estudo Experimental Sobre Solo Coluvionar da Serra do Mar. Dissertação de Mestrado, Escola Politécnica da Universidade de São Paulo.

ABRAMENTO, M., PINTO, C. S. (1993). Resistência ao Cisalhamento de Solo Coluvionar Não Saturado das Encostas da Serra do Mar. Solos e Rochas. Vol. 16, no 3, pp. 145-158.

ADAMS, B. A., WULSOHN, D., FREDLUND, D. G. (1996). Application of Unsaturated Soil Mechanics for Agricultural Condition. Canadian Agricultural Engineering, vol. 38, n⿳ำ 3, pp. 131-181.

AITCHINSON, G. D. (1960). Relationships of Moisture Stress and Effective Stress Functions in Unsaturated Soils. Conference Pore Pressure and Suction in Soils. pp. 47-52. Butterworths, London.

AITCHINSON, G. D. (1973). The Quantitative Description of the StressDeformation Behavior of Expansive Soils, Vol. 2, pp. 79-82, Haifa, Israel.

Al-KHAFAF, S., HANKS, R. J. (1972). Evaluation of the Filter Paper Method for Estimating Soil Water Potential. Soil Science, Vol. 113, Nº 4, pp. 194-199.

CHANDLER, R. J., GUTIERREZ, C. I. (1986). The Filter Paper Method of Suction Measurement. Geotechnique, Vol. 36, $\mathrm{N}^{\mathrm{o}}$ 2, pp. 265-268.

AHMED, S., LOVELL1, C.W., DIAMOND, S. (1974). Pore Sizes and Strength of Compacted Clay. Journal of the Geotechnical Engineering Division. $N^{\mathrm{o}}$ GT4, Vol. 100, pp. 407-425. 
ATTOM, F. M ., ABU-ZREIG, M. M., OBAIDAT, M. T. (2001). Changes in Clay Swelling and Shear Strength Properties With Different Sample Preparation Techiniques. Geotechnical Testing Journal, Vol. 24, $\mathrm{n}^{\mathrm{o}}$ 2, pp. 157-163.

BARBOUR, S. L. (1998). Nineteenth Canadian Geotechnical Colloquion: The SoilWater Characteristic Curve: A Historical Perspective. Canadian Geotechnical Journal, Vol. 35, pp. 873-894.

BENGOCHEA, I. G., LOVELL, C. W., ALTSCHAEFFL, A. G. (1979). Pore Distribution and Permeability of Silty Clays. Journal of the Geotechnical Engineering Division, Vol. 105, N ${ }^{\mathrm{o}}$ GT7, pp. 839-856.

BISHOP, A. W. (1959). The Principle of Effective Stress. Publish in Teknisk Ukeblad, Vol. 106, № 39 , pp. 859-863.

BISHOP, A. W., ALPAN, J., BLIGHT, G. E, DONALD, I. B. (1960). Factors Controlling the Strength of Partly Saturated Cohesive Soils. Research Conference Shear Strength of Cohesive Soils, ASCE, pp. 503-532.

BISHOP, A. W., DONALD, B. (1961). The Experimental Study of Partly Saturated Soil in the Triaxial Apparatus. $5^{\text {th }}$ International Conference of Soi Mechanics and Foundation Engineering, vol. 1, pp. 13-21, Paris.

BISHOP, A. W., HENKEL, D. J. (1962). The Measurement of Soil Properties in the Triaxial Test. Second edition, printed in Great Britain by Spottiswoode Ballantyne Ltd.

BISHOP, A. W., BLIGHT, G. E. (1963). Some Aspects of Effective Stress in Saturated and Unsaturated Soils. Geotechnique, Vol. 13, № ${ }^{\mathrm{o}}$ 103, pp. 447-466. 
BLIGHT, G. E. (1967). Effective Stress Evaluation for Unsaturated Soils. Journal of the Soil Mechanics and Foundation Division. Proceedings ASCE, ${ }^{0}$ SM2, Vol. 93, pp. 125-148.

BOCKING, K. A., FREDLUND, D. G. (1980). Limitations of the Axis-Translation Technique. 4 th International Conference on Expansive Soils,Denver, Colorado, vol. 1, pp. 117-135.

BRACLEY, I. J. A (1973). Swell Pressure and Free Swell in a Compacted Clay. Proceeding $3^{\text {rd }}$ Int. Conf. Expansive Soils, Haifa, Vol. 1, pp. 169-176, Jerusalem: Academic Press.

BRADY, K. C. (1988). Soil Suction and the Critical State. Géotechnique, vol. 38, nº 1, pp. 117-120.

BROOKS, R. H., COREY, A. T. (1964). Hydraulic Properties of Porous Media. Colorado State Univ. Hydrol. Paper, n⿳⺈ 3, 27 pp.

BURLAND, J. B. (1965). Some Aspects of the Mechanical Behaviour of Partly Saturated Soils. In Moisture Equilibrium and Moisture Changes in Soils Beneath Covered Areas, Butterworth and Company Ltd, pp.270-278, Austrália.

CHANDLER R. J., GUTIERREZ, C.I. (1986). The Filter-Paper Method of Suction Measurement. Géotechnique, vol. 36, nº 2, pp. 265-268.

CHANDLER, R. J., CRILLY, M. S., MONTGOMERY-SMITH, G. (1992). A LowCost Method of Assessing Clay Desiccation for Low-Rise Buildings. Proceeding of the Institute of Civl Engineering, № ${ }^{\mathrm{o}}$, pp. 82-89. 
CHARLES, W.W., PANG, Y.W. (2000). Influence of Stress State on Soil-Water Characteristics and Slope Stability. Journal of Geoenvironmental Engineering. Vol. $126, \mathrm{n}^{\mathrm{o}} 2$, pp. $157-166$.

COLEMAN, J. D. (1962). Stress-Strain Relations for Partially Saturated Soils. Geotechnique, Vol.12, n⿳ำ 4, pp. 348-350.

COLMENARES, J. E., RIDLEY, A. M. (2002). Stress-Strain and Strength Relationships for a Reconstituted Clayey Silt. Proceeding of the Third International Conference on Unsaturated Soils. Vol.2, pp. 481-484, Recife, Brazil.

COREY, A T., BROOKS, R. H. (1997). The Brooks-Corey Relationships. International Workshop on Characterization and Measurement of the Hydraulic Properties of unsaturated Porous Media, Part. 1, Riverside, California.

CRONEY, D. (1952). The Movement and Distribution of Water in Soils. Geotechnique, Vol. 3, pp. 1-16.

CRONEY, D., COLEMAN, J. D., BLACK, P. M. (1958). Movement and Distribution of Water in Soil in Relation to Highway Design and Performance. Highway Research Board, Special Report, № 40, pp. 226-252, Washington.

CRONEY, D., COLEMAN, J.D. (1961). Pore Pressure and Suction in Soils. Proceeding of the Conference on Pore Pressure and Suction in Soils. Pp. 31-37. Butterworths, London.

CRUZ, P. T., FERREIRA, R.C. (1993). Aterros Compactados. Solos do Interior de São Paulo. pp. 277-313. ABMS, USP/SC. 
CUI, Y. J., LOISEAN, C., DELAGE, P. (2002). Microestructure Changes of a Confined Swelling Soil due to Suction Controlled Hydration. Proceeding of the Third International Conference on Unsaturated Soils. Vol. 2, pp. 593-598. Recife, Brazil.

DE CAMPOS, T. M. P. (1997). Resistência ao Cisalhamento de Solos Não Saturados. $3^{\circ}$ Simpósio Brasileiro de Solos Não Saturados, NSAT’97, Vol. 2, pp. 399-417. Rio de Janeiro.

DEKA, R. N., WAIRIU, M., MTAKWA, P. W., MULLINS, C. E., VEENENDALL, E. M., Townend, J. (1995). Use and Accuracy of the Filter Paper Technique for Measurement of the Soil Matric Potential. European journal of Soil Science, vol. 46, pp. 233-238.

DELAGE, P., AUDIGUIER, M, CUI, Y., HOWAT, M. D. (1996). Microstructure of a Compacted Silt. Canadian Geotechnical Journal, Vol. 33, pp. 150-158.

DINEEN, K., RIDLEY, A. M. (1999). The Soil Moisture Characteristics Curve the Influence of Hysteresis on its Measurement and Interpretation. XII Panamerican Conference on Soil Mechanics and Geotechnical Engineering, Vol. 2, pp. 1013-1018, Foz do Iguaçu, Brazil.

DONALD, I. B. (1960). Discussion - Proceedings of Conference on Pore Pressure and Suction in Soils. Butterworth, London.

D5298-92. STANDARD TEST METHOD FOR MEASUREMENT OF SOIL POTENTIAL (SUCTION) USING FILTER PAPER. Annual Book of ASTM Standards, Vol. 1509, pp. 1312-1316.

ESCÁRIO, V., SÁES, J. (1986). The Shear Strength of Partly Saturated Soils. Géotechnique, vol. 36, nº 13, pp. 453-456. 
ESCÁRIO, V., JUCÁ, J. F. T. (1989). Strength and Deformation of Partly Saturated Soil. Proceedings of the $12^{\text {th }}$ International Conference on Soil Mechanics and Foundation Engineering, Rio de Janeiro, Vol. 2, pp. $43-46$.

FAWCETT, R.G., COLLIS-GEORGE, N. (1967). A Filter-Paper Method for Determining the Moisture Characteristics of Soil. Australian Journal of Experimental Agriculture and Animal Husbandry, Vol. 7, pp. 162-167.

FLEUREAU, J-M,VERBRUGGE, J-M, HUERGO, P. J., CORREIA, A. G., KHEIRBEK-SAOUD, S. (2002). Aspects of the Behaviour of Compacted Clayey Soils on Drying and Wetting Paths. Canadian Geotechnical Journal, vol. 39, pp.1341-1357.

FREDLUND, D. G., MORGENSTERN, N. R. (1977). Stress State Variables for Unsaturated Soils. Journal of the Geotechnical Engineering Division, vol. 103, $\mathrm{n}^{\mathrm{o}}$ GT5, pp.447-466.

FREDLUND, D. G., MORGENSTERN, N. R., WIDGER, R. A (1978). The Shear Strength of Unsaturated Soils, Canadian Geotechnical Journal, Vol. 15, $\mathrm{N}^{\mathrm{o}} 3$, pp. 313-321.

FREDLUND, D. G., RAHARDJO, H., GAN, J. K. M. (1987). Non-Linearity of Strength Envelope for Unsaturated Soils. 6 th International Conference on Expansive Soils, vol. 1, pp. 49-54, New Delhi, Índia.

FREDLUND, D. G., RAHARDJO, H. (1993). Soil Mechanics for Unsaturated Soils. John Wiley \& Sons, INC, New York.

FREDLUND, D. G., XING, A. (1994). Equations for the Soil-Water Characteristic Curve. Canadian Geotechnical Journal, Vol. 31, pp.521-532. 
FREDLUND, D. J. (1998). Bringing Unsaturated Soil Mechanics into Engineering Practice. $2^{\text {nd }}$ International Conference on Unsaturated soil, Vol. 2, pp. 1-36, Beijing, China.

FREDLUND, D. G., VANAPAlli, S. K., XING, A , PUFAHL, D. E. (1995). Predicting the Shear Strength Function for Unsaturated Soils Using the Soil-Water Characteristic Curve. Proceeding of the First International Conference on Unsaturated Soil. Vol. 1, pp. 63-69. Paris, France.

GAN, J.K-M., FREDLUND, D. G. (1988). Multistage Direct Shear Testing of Unsaturated Soils. American Society for testing Materials, Geotechnical Testing Journal, vol. 11, n⿳丷ㅡ. 2, pp. 132-138.

GAN, J.K-M., FREDLUND, D. G. (1995). Shear Strength Behavior of Two Saprolitic Soils. $1^{\text {st }}$ International Conference on Unsaturated Soils, Vol. 1, pp. 71-76, Paris.

GERSCOVICH, D. M. S., SAYÃO, A. S. F. J. (2002). Evaluation of the Soil-Water Characteristic Curve Equations for Soils from Brazil. Proceeding of the Third International Conference on Unsaturated Soils. Vol.1, pp.2195-300. Recife, Brazil.

GREACEN, E. L., WALKER, G. R., COOK, P. G. (1987). Evaluation of the Filter Paper Method for Measurement Soils Water Suction. International Conference on Measurement of Soil and Plant Water Status, Logan, U.S.A., pp. 137-143.

GUAN, Y., FREDLUND, D.G. (1997). Use of the Tensile Strength of Water for the Direct Measurement of High Soil Suction. Canadian Geotechnical Journal, Vol. 34, pp.604-614.

HARVEY, E. N., BARNES, D. K., MCELROY, A. H., WHITELEY, A. H., PEASE, D. C., COOPER, K. W. (1994). Bubble Formation in Animals. 1. Physical Factors. Journal of Cellular and Comparative Physiology, vol.24, $\mathrm{n}^{\mathrm{o}} 1$. 
HAMBLIM, A. P. (1981). Filter-Paper Method for Routine Measurement of Field Water Potential. Journal of Hydrology, 53, pp. 355-360.

HILF, J. W. (1956). An Investigation of Pore-Water Pressure in Compacted Cohesive Soils. PhD Thesis, Denver, Colorado.

HOUSTON, S. L., HOUSTON, W. N, WAGNER, A. M. (1994). Laboratory Filter Paper Suction Measurements. Geotechinical Testing Journal, GTJODJ, Vol. 17, ${ }^{\mathrm{o}}$ 2, pp. 185-194.

JENNINGS, J. E. (1960). A Revised Effective Stress Law for Use en the Prediction of the Behaviour of Unsaturated Soils. Conference Pore Pressure and Suction in Soils, pp. 26-30. Butterworths, London.

JENNINGS, J. E. (1961). A Revised Effective Stress Law for Use in the Prediction of the Behavior of Unsaturated Soils. Conference Pore Pressure and Suction in Soils, pp. 26-32. Butterworths, London.

JENNINGS, J. E. B, BURLAND, J. B. (1962). Limitations to the Use of Effective Stresses in Partly Saturated Soils,.Geotechnique, Vol. 12, pp. 125-144.

KHALILI, N., KHABBAZ, M. H. (1998). A Unique Relationship for $\chi$ for the Determination of the Shear Strength of Unsaturated Soils. Geotechnique, Vol. 48, № 5, 681-687.

KHALILI, N. (2000). Application of the Effective Stress Principle to Volume Change in Unsaturates Soils. Unsaturated Soils for Asia, pp. 119-124.

KHATTAB, S. A. A., Al-MUKHATAR, M., FLEUREAU, J. M. (2002). Effect of Initial Suction on the Swelling Pressure and Porosity of Lime Stabilized Clays. Proceeding of the Third International Conference on Unsaturated Soils. Vol.2, pp. 605-609. Recife, Brazil. 
KUWAJIMA, R. M. (2000). Determinação da Sucção “in situ” em Solo Residual Compactado Utilizando-se o Parâmetro B e a Medição Direta da Sucção. Dissertação apresentada a Escola Politécnica da Universidade de São Paulo.

LAMBE, T.W. (1958). The Structure of Compacted Clay. Journal Soils Mechanics and Foundations Division, ASCE, Vol. 84, № SM2.

LEONG, E. C., HE, L., RAHARDJO, H. (2002). Factors Affecting the Filter Paper Method for Total and Matric Suction Measurements. Geotechnical Testing Journal, vol. $25, \mathrm{n}^{\mathrm{o}} 3$, pp. 1-12.

LINS, A. H. P., SANDRONI, S. S. (1994). The Development of Pore-Water Pressure in Compacted Soil. XIII ICSMF, Vol. 1, pp. 177-180, New Dheli, India.

MASSACHUSETTS INSTITUTE OF TECHNOLOGY (1963). Engineering Behavior of Partially Saturated Soils. Phase Report $n^{0} 1$ to U.S. Army Engineers Waterways Experimental Station, Vicksburg, Mississippi. The Soil Engineering Division, Departament of Civil Engineering, M.I.T.,Contract n⿳ํㅡㄹ-22-07-eng-288.

MARINHO, F. A. M., CHANDLER, R. J. (1994). Discussion: A New Instrument for the Measurement of Soil Moisture Suction. Géotechnique, 44(3), 551-556.

MARINHO, F. A. M., CHANDLER, R. J. (1994). On the Relationship Between Suction and Degree of Saturation of Soils. $2^{\underline{o}}$ Simpósio sobre solos não saturados, pp. 37-44, Recife-PE, Brazil.

MARINHO, F. A. M. (1994). Shrinkage Behavior of some Plastic Clays. PhD Thesis, Imperial College, University of London.

MARINHO, F. A. M., PINTO, C. S. (1997). Soil Suction Measurement Using a Tensiometer. International Symposium on Recent Developments in Soil and Pavement Mechanics, pp. 249-254, Rio de Janeiro, Brazil. 
MARINHO, F. A. M. (1998). Introdução ao Comportamento dos Solos Não Saturados. Mini curso ministrado durante o XI Congresso Brasileiro de Mecânica dos Solos, Brasília.

MARINHO, F. A. M., STUERMER, M. M (2000). The Influence of the Compaction on the SWCC of a Residual Soil. Advances in Unsaturated Geotechnics, publication $\mathrm{n}^{\circ}$ 99, pp.125-141. Denver, Colorado.

MATYAS, E. L., RADHAKRISHINA, H. S. (1968). Volume Change Characteristics of Partially Saturated Soils. Geotechnique, $N^{0} 18$, pp. 4332-448.

MEILANE, I., RAHARDJO, H., LEONG, E. C., FREDLUND, D. G. (2002). Mini suction Probe for Matric Suction Measurements. Canadian Geotechnical Journal, Vol. 39, pp. 1427-1432.

NISHIMURA, T., FREDLUND, D. G. (2002). Hysteresis Effects Resulting from Drying and Wetting Under Relatively Dry Conditions. Proceeding of the Third International Conference on Unsaturated Soils. Vol.1, pp. 301-305. Recife, Brazil.

OBERG, A. L., SALLFORS, G. (1995). A Rational Approach to the Determination od the Shear Strength Parameters of Unsturated Soils. $1^{\text {st }}$ International Conference on Unsaturated Soils, Vol. 1, pp. 151-158, Paris.

OLIVEIRA, O. M., MARINHO, F. A. M. (2003). Unsaturated Shear Strength Behavior of a Compacted Residual Soil. $2^{\text {nd }}$ Asian Conference on Unsaturated Soils, pp.237-242, Japan.

OLIVEIRA, O. M., MARINHO, F. A. M. (2002). Resistência não Saturada de um Solo Residual Compactado Avaliada em Ensaios de Compressão Simples. XII COBRANSEG - Congresso Brasileiro de Mecânica dos Solos e Engenharia Geotécnica, vol.1, pp. 507-518. 
OLSON, R. E., LANGFELDER, L. J. (1965). Pore Water Pressures in unsaturated Soils. Journal of the Soil Mechanics and Foundations Division. Proceeding ASCE, $\mathrm{N}^{\mathrm{o}}$ SM4, Vol. 91, pp. 127-150.

PINTO, C. S. (1971). Sobre as Especificações de Controle de Compactação das Barragens de Terra. VII Seminário Nacional de Grandes Barragens.

PUSH, R. (1982). Mineral-Water Interaction and their Influence on the Physical Behavior of Highly Compacted $\mathrm{Na}$ Bentonite. Canadian Geotechnical Journal, Vol.19, pp. 381-387.

RASSAM, D.W., WILLIAMS, D. J. (1999). A Relationship Describing the Shear Strength of Unsaturated Soils. Canadian Geotechnical journal, Vol. 36, nº 2, pp.363368 .

RICHARDS, B.G. (1966). The Significance of Moisture Flow and Equilibria in Unsaturated Soils in Relations to the Design of Engineering Structures Built on Shallow Foundations in Australia. Symposion on Permeability and Capillary, ASTM, Atlantic City, NJ.

RIDLEY, A. M., BURLAND, J. B. (1993). A New Instrument for the Measurement of Soil Moisture Suction. Géotechnique, 43(2), 321-324.

RIDLEY, A. M., EDENMOSUN, E. O. (1999). The Influence of Pore Water Salt Concentration on the Measurement of Soil Suction Using the Filter Paper Method. Geotechnics for Developing Africa, Rotterdam, Balkema.

RIDLEY, A. M., DINEEN, K., BURLAND, J. B., VAUGHAN, P.R. (2003). Soil Matrix Suction: Some Examples of its Mesasurement and Application in Geotechnical Engineering. Géotechnique, vol. 53, no 2, pp. 241-253. 
ROBINSON, R. A. (1945). The Vapour Pressures of Solutions of Potassium Chlorite and Sodium Chloride. Transactions of the Royal Society of New Zealand, Vo. 75, part.2, pp.203-217.

ROHM, S. A., VILAR, O. M. (1995). Shear Strength of na Unsaturated Sandy Soil. Proceeding of the First International Conference on Unsaturated Soil. Vol. 1, pp. 189-193. Paris, France.

SEED, H. B., CHAN, C. K. (1959). Structure and Strength Characteristic of Compacted Clays. Journal of the Soil Mechanics and Foundation Division. Proceedings ASCE, N ${ }^{0}$ SM5, Vol. 85, pp. 87-127.

SIMMS, P. H., YANFUL, E. K.(2001). Measurement and Estimation of Pore Shrinkage and Pore Distribution in a Clayey Till During Soil-Water Characteristic Curve Test. Canadian Geotechnical Journal, Vol.39, pp. 741-754.

SKEMPTON, A. W. (1960). Effective Stress in Soils, Concrete and Rocks. Conference Pore Pressure and Suction in Soils, pp. 277-313. Butterworths, London.

STUERMER, M. M. (1998). Estudo da Capacidade de Retenção de Água em um Solo Residual Compactado. Dissertação apresentada a Escola Politécnica da Universidade de São Paulo.

SURIOL, J., GENS, A., ALONSO, E. E. (2002). Volumetric Behavior of a Compacted Soil Upon Wetting. Proceeding of the Third International Conference on Unsaturated Soils. Vol. 2, pp. 619-623. Recife, Brazil.

TAKE, W. A., BOLTON, M. D. (2003). Tensiometer Saturation and the Reliable Measurement of Soil Suction. Géotechnique, vol. 53, nº 2, pp. 159-172.

TARANTINO, A., BOSCO, G., MONGIOVI, L. (2000). Response of the IC tensiometer whith Respect to Cavitation. Unsaturated Soils for Asia, pp. 309-314. 
TARANTINO, A., MONGIOVI, L. (2002). Calibration of Tensiometer for Direct Measurement of Matric Suction. Géotechnique, vol. 53, № 1, pp. 137-141.

TERZAGHI, K. (1936). The Shear Resistance of Saturated Soils. Proceeding International Conference Soils Mechanics Foundation Engineering. Vol. 1, pp. 5456.

TINJUM, J. M., BENSON, C. H., BLOTZ, L. R. (1997). Soil-Water Characteristic Curves for Compacted Clays. Journal of Geotechnical and Geoenvironmental Engineering, Vol.123, N ${ }^{\mathrm{O}} 11$, pp. 1060-1069.

TOLL, D. G. (1990). A Framework for Unsaturated Soil behavior. Geotechnique, Vol. 40, № 1 , pp. 31-44.

TOLL, D. G. (2000). The Influence of Fabric on Shear Behavior of Unsaturated Compacted Soils. Advances in Unsaturated Geotechnics, GEODENVER, pp. 223234.Denver, Colorado.

VANAPALLI, S. K. (1994). Simple Procedures and their Interpretation in Evaluating the Shear Strength an Unsaturated Soil. PhD Thesis, University of Saskatchevan, Canada.

VANAPAlli, S. K., FREDlund, D. G., PUFAHL, D. E., ClifTON, A W. (1996). Model for The Prediction of Shear Strength with Respect to Soil Suction. Canadian Geotechnical Journal, Vol.33, pp.379-392.

VANAPALLI, S. K., FREDLUND, D. G., PUFAHL, D. E. (1999). The Influence of Soil Structure and Stress History on the Soil-Water Characteristics of a Compacted Till. Geotechnique, Vol.49, № 2 , pp. 143-159. 
VANAPALLI, S. K. (2001). A Simple Experimental Procedure for Determining the Fitting Parameter $\kappa$ for Predicting the Shear Strength of an Unsaturated Soil. $54^{\text {th }}$ Canadian Geotechnical Conference, An Earth Odyssey, pp.622-629. Calgary, Canada.

VANAPALLI, S. K., FREDLUND, D. G. (2000). Comparison of Different Procedures to Predict Unsaturated Soil Shear Strength. Advances in Unsaturated Geotechnics, GEODENVER, pp. 195-209.Denver, Colorado.

VAN GENUCHTEN (1980). A Closed-Form Equation for Predicting the Hydraulic Conductivity of Unsaturated Soil. Soil Science Society of America Journal. Vol.44, № 5 , pp.893-898.

VIEIRA, A. M. (1999). Variação Sazonal da Sucção em um Talude de Solo Residual de Gnaisse. Dissertação apresentada a Escola Politécnica da Universidade de São Paulo.

WHITE, N. F., DUKE, H. R., SUNADA, D. K., COREY, A.T. (1970). Physics of Desaturation in Porous Materials. Journal of the Irrigation and Drainage Division, Proceedings ASCE, Vol. 96, N IR2, pp. 165-191.

WOLLE, C. M. (1988). Análise dos Escorregamentos Translacionais numa Região da Serra do Mar. Tese de Doutorado, EPUSP, São Paulo, 406 p..

ZEIN, A K. M. (1985). Swelling Characteristics and Microfabric of Compacted Black Cotton Soil. PhD Thesis, University of Stratchlyde, Glasgow. 


\begin{abstract}
ANEXO A
Variação da sucção em função do tempo obtida de ensaios de compressão simples não saturados realizados com carregamento controlado e com umidade constante
\end{abstract}


Em virtude da grande quantidade de ensaios realizados serão apresentados 2 resultados de cada condição de moldagem.

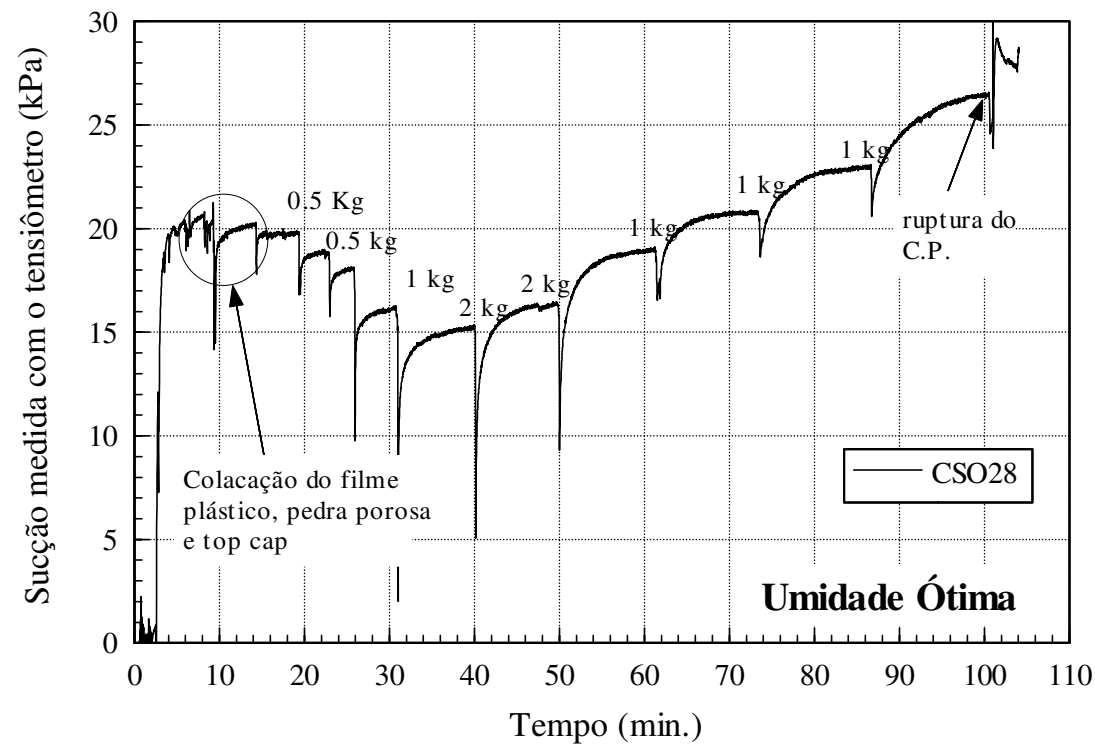

Figura A1 - Variação da sucção do corpo de prova CSO28 em função do tempo determinada em ensaio de compressão simples com carregamento controlado.

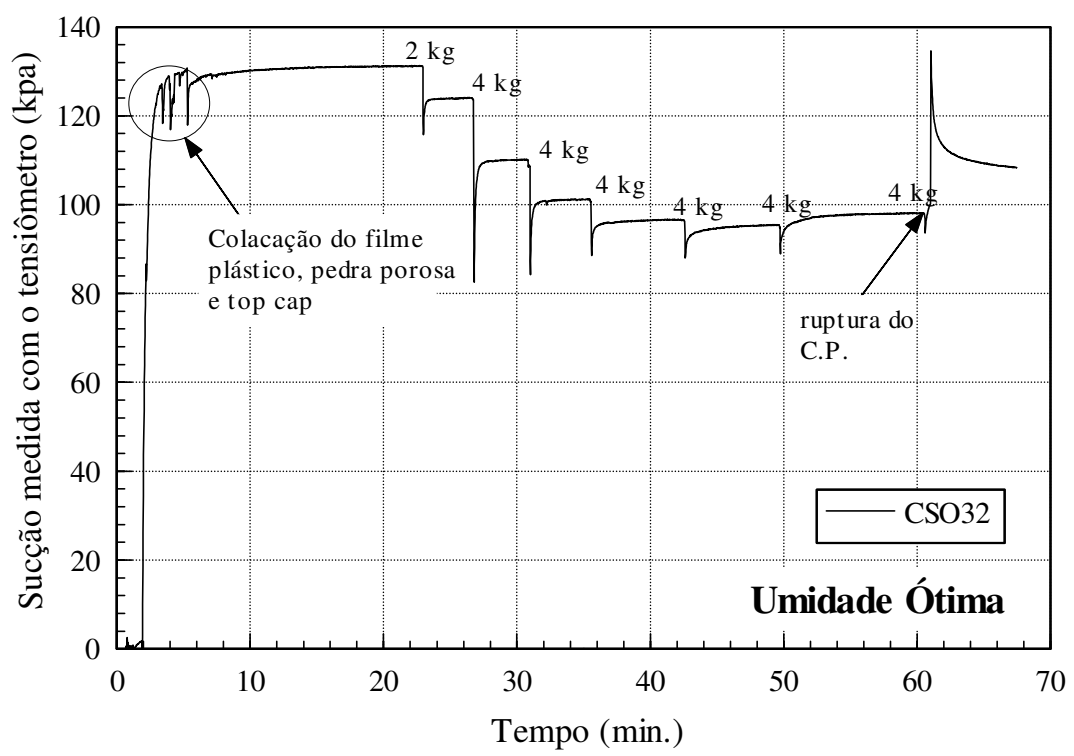

Figura A2 - Variação da sucção do corpo de prova CSO32 em função do tempo determinada em ensaio de compressão simples com carregamento controlado. 


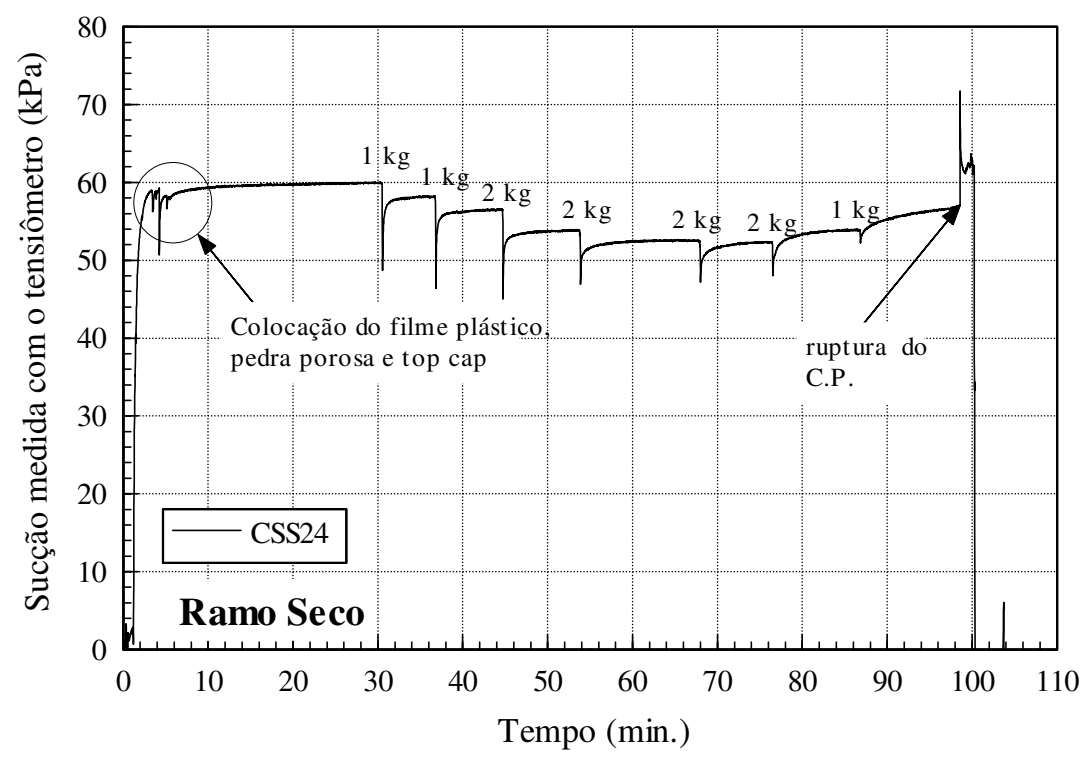

Figura A3 - Variação da sucção do corpo de prova CSS24 em função do tempo determinada em ensaio de compressão simples com carregamento controlado.

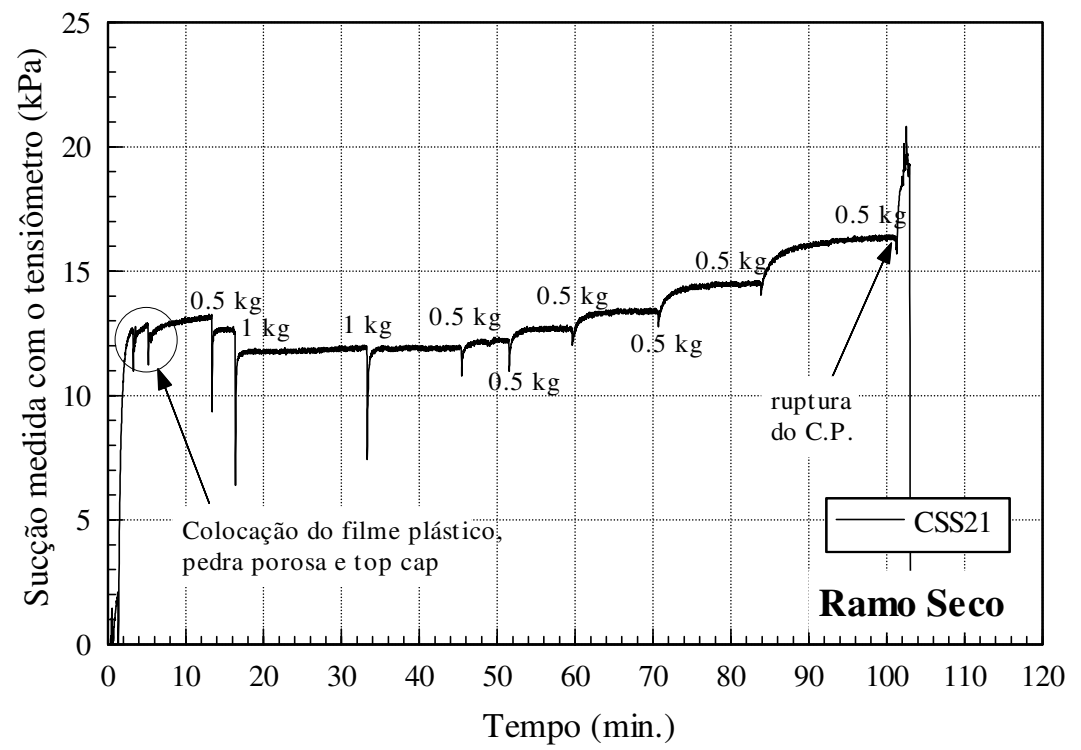

Figura A4 - Variação da sucção do corpo de prova CSS21 em função do tempo determinada em ensaio de compressão simples com carregamento controlado. 


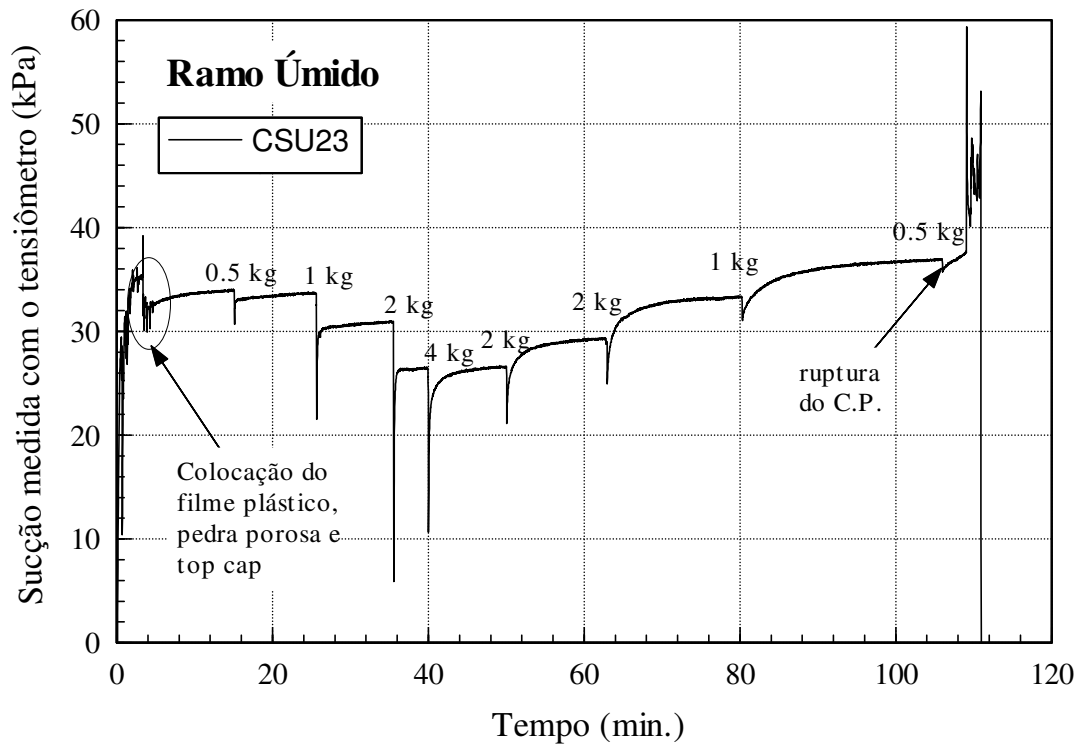

Figura A4 - Variação da sucção do corpo de prova CSU23 em função do tempo determinada em ensaio de compressão simples com carregamento controlado.

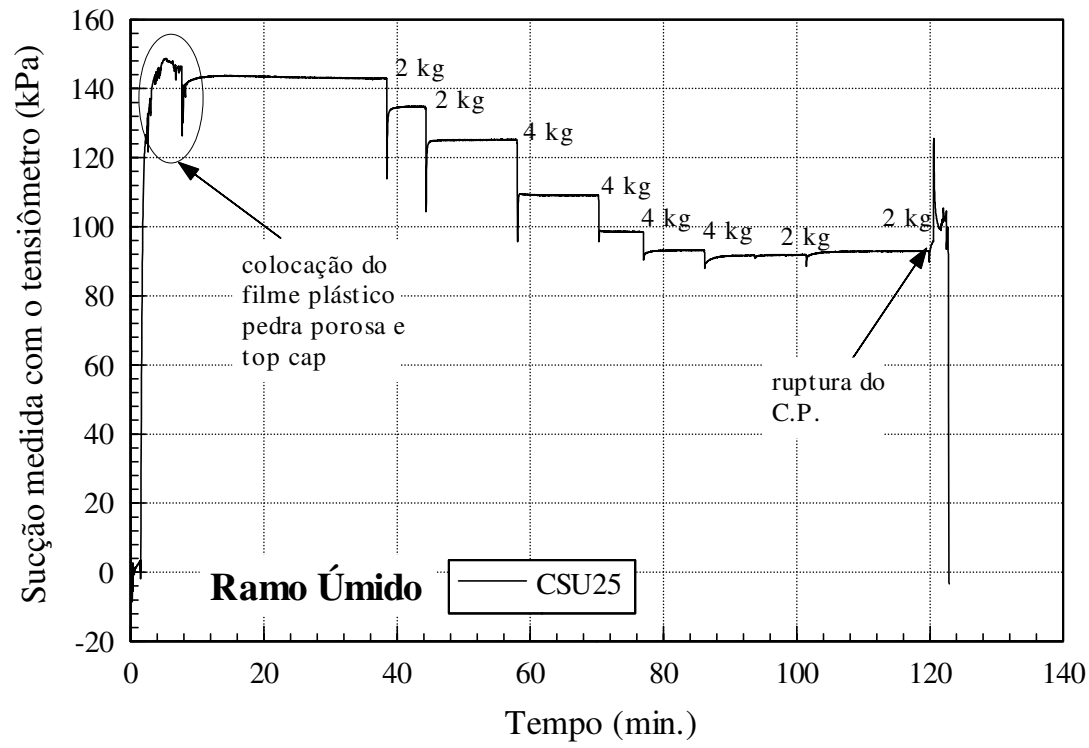

Figura A6 - Variação da sucção do corpo de prova CSU25 em função do tempo determinada em ensaio de compressão simples com carregamento controlado. 


\begin{abstract}
ANEXO B
Variação da sucção em função do tempo obtida de ensaios triaxiais CW não saturados realizados com carregamento controlado
\end{abstract}


Em virtude da quantidade de ensaios realizados serão apresentados 2 resultados para cada condição de moldagem.

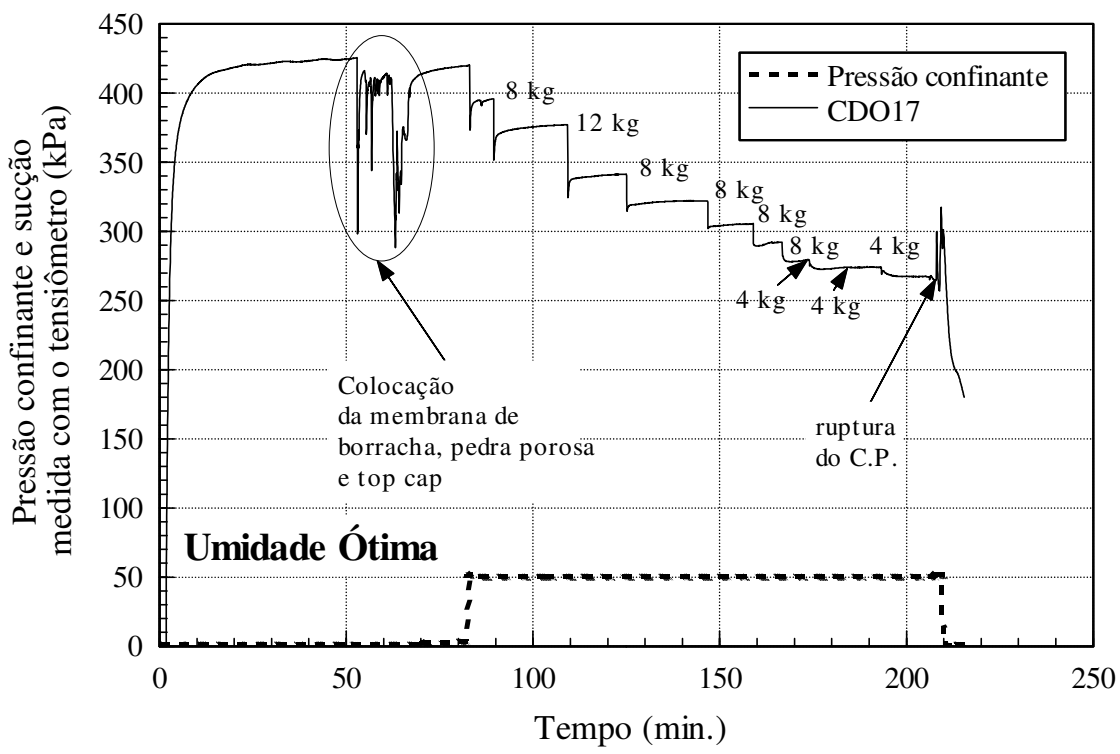

Figura B1 - Variação da sucção do corpo de prova CDO17 obtida de ensaio triaxial CW com carregamento controlado (pressão confinante de $50 \mathrm{kPa}$ ).

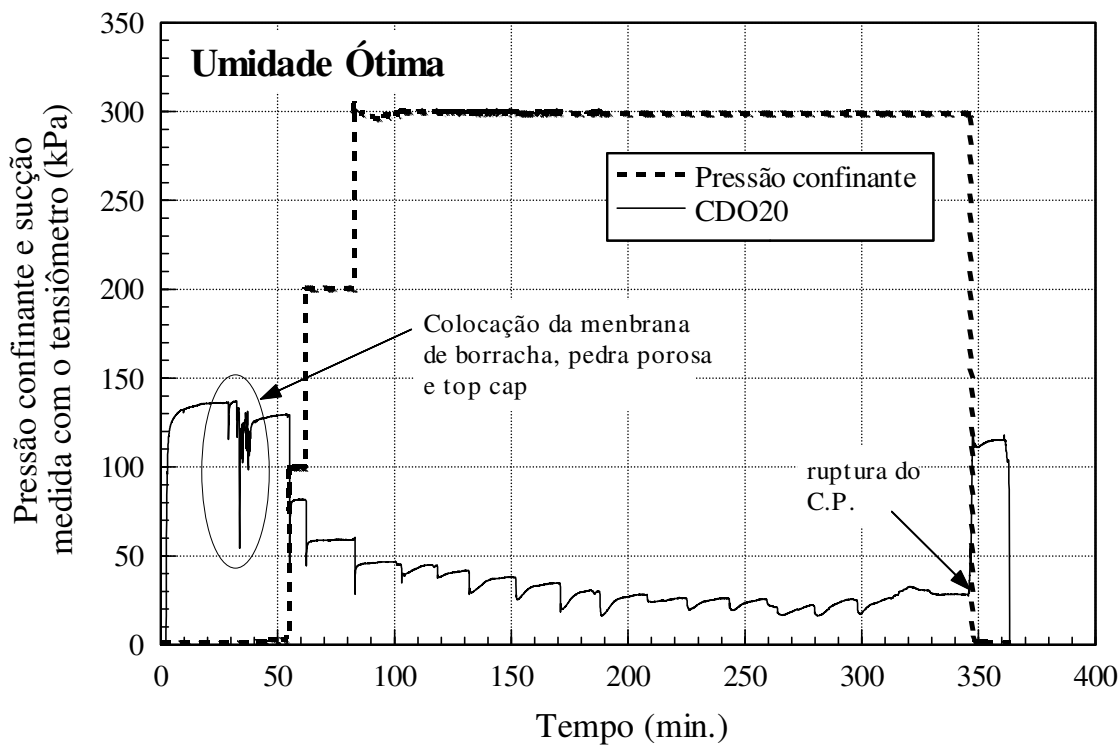

Figura B2 - Variação da sucção do corpo de prova CDO20 obtida de ensaio triaxial CW com carregamento controlado (pressão confinante de $300 \mathrm{kPa}$ ). 


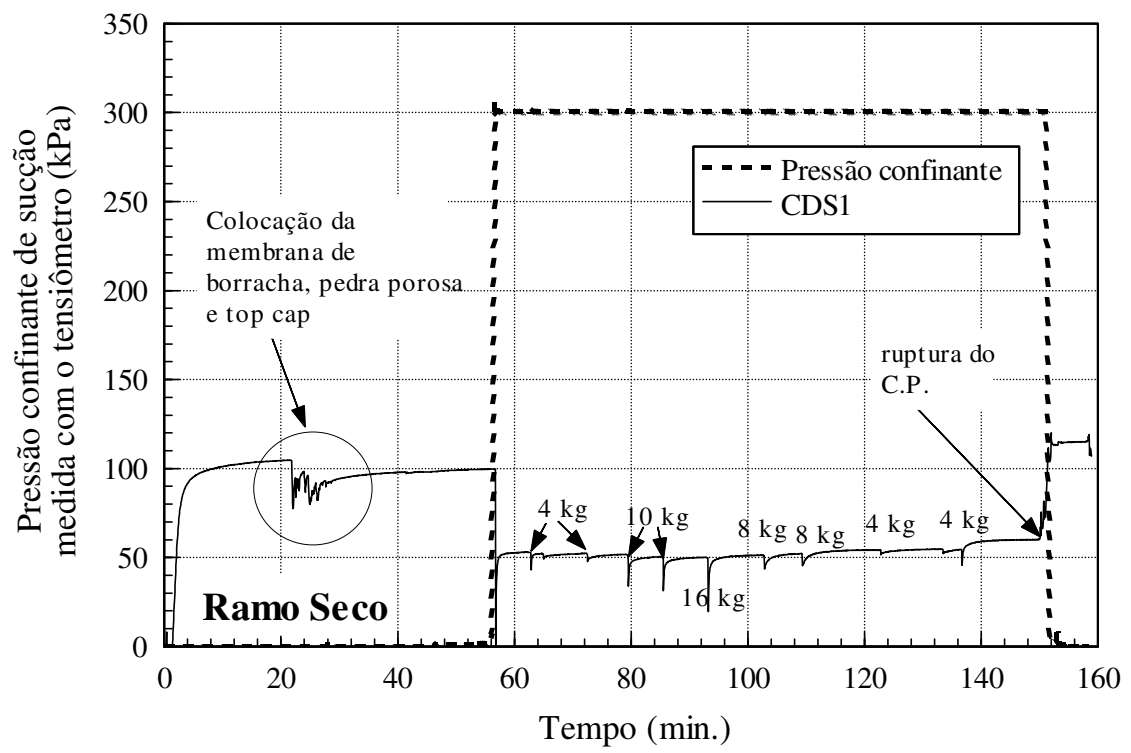

Figura B3 - Variação da sucção do corpo de prova CDS1 obtida de ensaio triaxial CW com carregamento controlado (pressão confinante de $300 \mathrm{kPa}$ ).

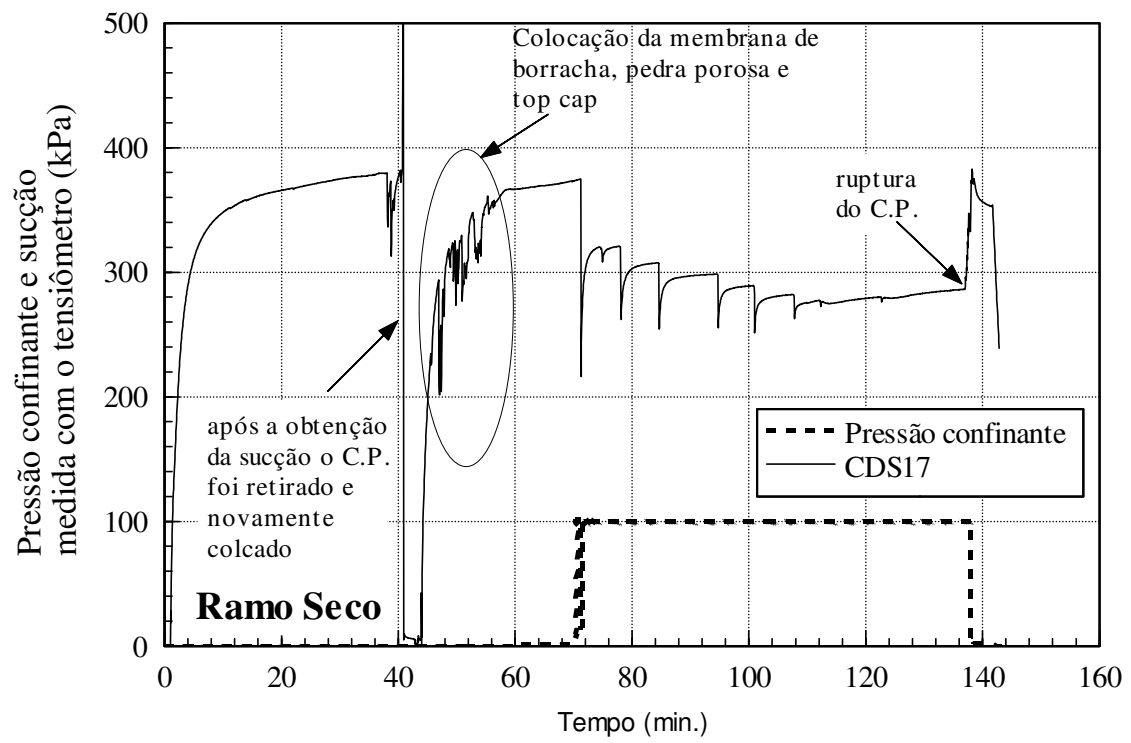

Figura B4 - Variação da sucção do corpo de prova CDS17 obtida de ensaio triaxial CW com carregamento controlado (pressão confinante de $100 \mathrm{kPa}$ ) 


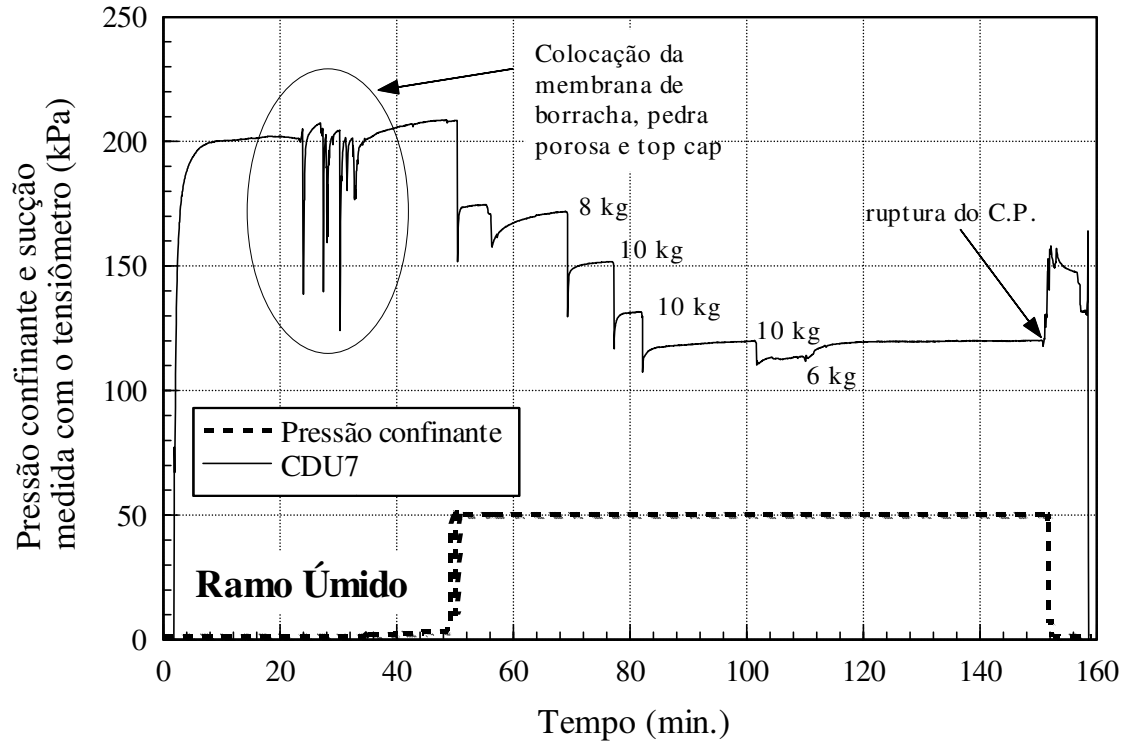

Figura B5 - Variação da sucção do corpo de prova CDU7 obtida de ensaio triaxial CW com carregamento controlado (pressão confinante de $50 \mathrm{kPa}$ ).

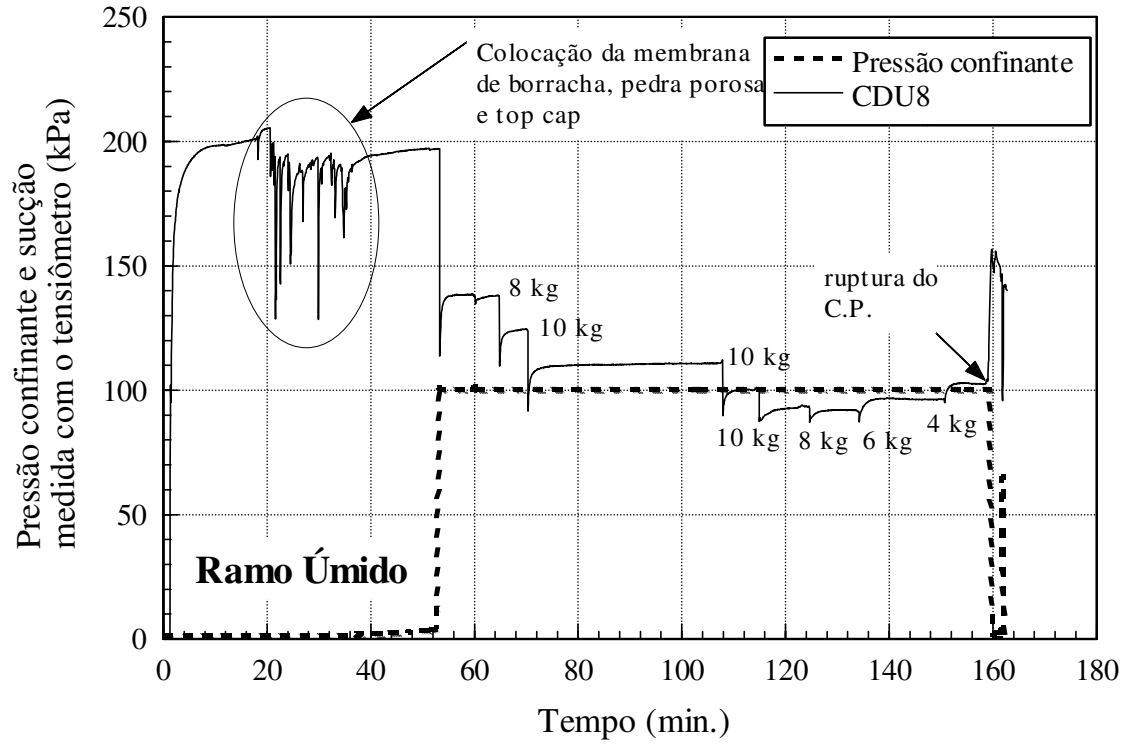

Figura B6 - Variação da sucção do corpo de prova CDU8 obtida de ensaio triaxial CW com carregamento controlado (pressão confinante de $100 \mathrm{kPa}$ ). 